\title{
HISPANIC NOTES
}

\& MONOGRAPHS

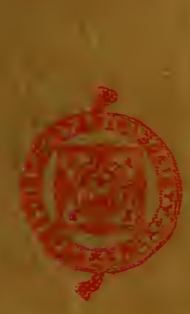



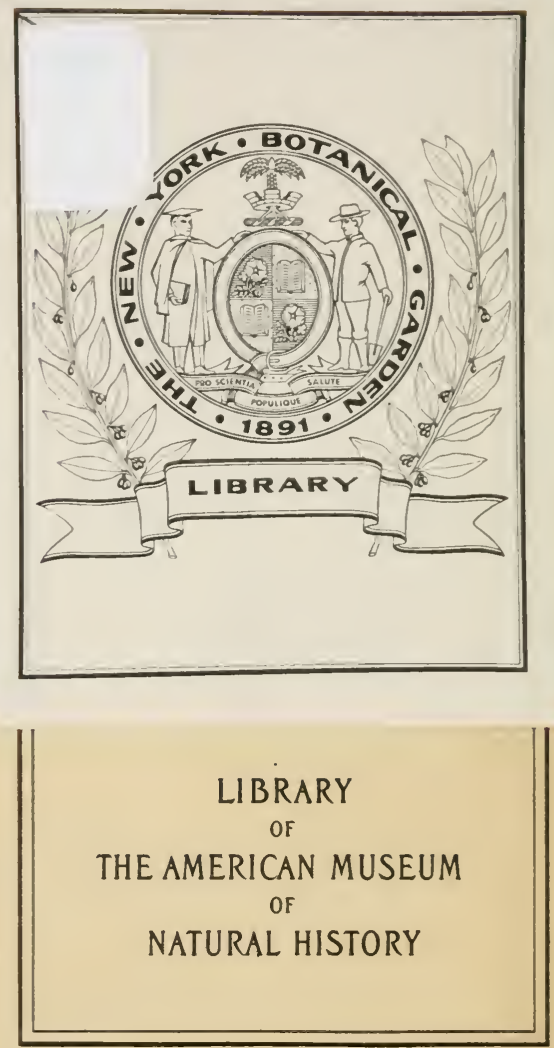

H IS P A N I C S O C I E T Y 
A M E R I A N SERIES

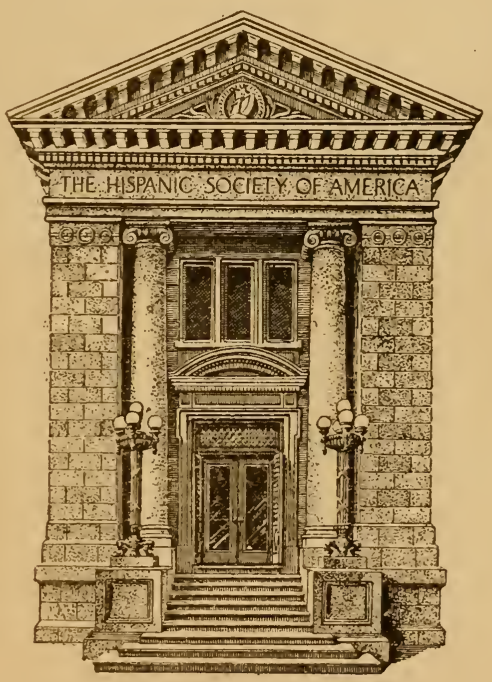

O F A M E R I C A 





\section{HISPANIC NOTES \& MONOGRAPHS}

ESSAYS, STUDIES, AND BRIEF BIOGRAPHIES ISSUED B Y THE HISPANIC SOCIETY OF AMERICA

I 



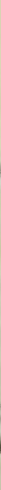

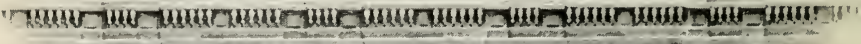

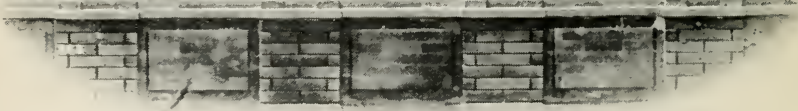

The Hispanic Society of America 


\section{GUB A N S $\mathrm{O} \mathrm{F}$}

T O - D A Y

EDITED BY

WILLIAM BELMONT PARKER

Corres. Memb. of the Hispanic Society of America

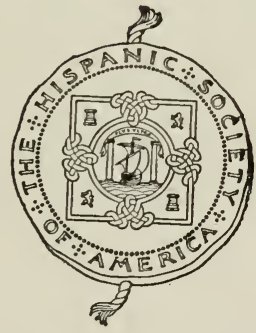

G. P. PUTNAM'S SONS NEW YORK AND LONDON 1919 
COPYRIGHT I919, BY

THE HISPANIC SOCIETY OF AMERICA

19.74703. Juen

Tbe 1knickerbocker Presg, \#ew Work 


\section{FOREWORD}

THE purpose of this book falls well within the scope of The Hispanic Society of America which embraces among its objects the "advancement of the study of the countries wherein Spanish and Portuguese are or have been spoken languages."

It aims to present to English readers some account of the living Cubans who have won distinction, and to make them better known and appreciated in English-speaking countries.

Those whose careers are here recorded may fairly be taken as representative of Cuba. They are drawn from every important field of the national life, as from every profession and calling; they include Artists, Authors, Churchmen, Diplomats, Journalists, Lawyers, Merchants, Officials, Orators, Poets, Soldiers, and Teachers. They are likewise drawn from every part

\section{H I S P A N I C NOTES}




\begin{tabular}{|c|c|}
\hline vi & C U B A N S O F T $-D A Y$ \\
\hline & $\begin{array}{l}\text { ot the Island; all six of the provinces and } \\
\text { almost every town in the Republic will } \\
\text { find their sons here, and if Havana scems } \\
\text { to have a disproportioned quota in the } \\
\text { list, this is due to the traditional disposi- } \\
\text { tion in Latin countries to make the capital } \\
\text { city the focus of the national life. } \\
\text { The biographies of the elder men reflect } \\
\text { the tremendous part which the struggle for } \\
\text { Independence played in their time and } \\
\text { show how military prestige overshadowed } \\
\text { for a time other kinds of distinction just } \\
\text { as the lives of the younger men disclose the } \\
\text { increasing value being attached to scien- } \\
\text { tific, commercial, literary, and scholastic } \\
\text { attainments. } \\
\text { Under the severe limitations of space } \\
\text { which the large number of studies inevit- } \\
\text { ably imposed, the aim has been kept } \\
\text { steadily in mind to write genuine "lives"; } \\
\text { and while avoiding bald summary and } \\
\text { mere eulogium alike, to produce miniature } \\
\text { but none the less veritable and, it may be } \\
\text { hoped, readable biographies. } \\
\text { The obligations which the editor has } \\
\text { incurred while preparing this book are too }\end{array}$ \\
\hline I & H I S P N I C NOTES \\
\hline
\end{tabular}




\section{F O R E W O R D}

many to be recounted, but it is impossible to omit paying his grateful acknowledgments for invaluable aid and counsel to his many friends; to Dr. Carlos de la Torre, Señor Carlos Trelles, Dr. Thomas Barbour, and Señor Luis M. Pérez for sound advice and suggestion; to Dr. Salvador Massip and Dr. Ernesto Dihigo for loyal and skillful assistance and to the whole company of the subjects of the biographies for their polite and friendly coöperation. He takes pleasure also in recording his sense of obligation to the members of the press of Havana and to the Library of Congress of Cuba for unwearied and gracious assistance, in accord with the best traditions of Hispanic courtesy.

$$
\text { W. B. P. }
$$

Westfield, N. J., May 20, I9I9.

\section{A N D MONOGRAPH S}





\section{TABLE OF CONTENTS}

Biographies marked with a star (*) are illustrated.

Mario G. Menocal*

PAGE

RAFAEl Montoro*

Alfredo Gonzalez Benard

Vicente Pardo SuÁRez*

José Manuel Cortina*

Fernando Figueredo y Socarras a 23

Charles Hernández*

José A. Valdés Anciano

Gustavo Pino .

Diego Tamayo y Figueredo

Emilio Martínez

Evelio Rodríguez Lendián*

Leonel Plasencia

Leopoldo Figueroa y Martí*

Julio Villoldo*

Carlos de Velasco y Pérez* ? 55

Alvaro de la Iglesia y Santos $\quad 59$

José Antonio Pichardo* . . 6 I

Jorge C. Milanés Figueredo* . 63

Marcelino Weiss . • 65

José A. Malberti* . . 67

Luis A. BARALt, JR. . . . $7 \mathrm{I}$

LEONARDO SORZANO-JORRÍN $\quad 73$ 
x TABLE OF CONTENTS

Nicolás Rivero* . . . . 75

Cosme de la TOR̈!lente* . . . 79

Arturo Betancourt Minidele 87

Domingo Figarola-Caneda . . 9I

Francisco de Arango* . . 95

Max HenríqueZ UREÑA . . . 97

Néstor Carbonell* . . IoI

Emeterio S. Santovenia . . 103

Jorge Navarro Faillace ? I05

Felipe González Sirrain . . IO7

Mariano Brull . . 109

Adolfo de Aragón . . I I I

Hubert de Blanck . I I 5

Antonio Rodríguez Morey . . I I 7

Jorge Le Roy Cassá • I I

Ramundo de Castro . 123

Antonio SÁNChez de Bustamante* I 27

José Miguel Gómez* . . I3I

Fernando Lles . . . 137

José Augusto Escoto . . . $\quad$ I39

Juan Santos Fernández*

Rafael Pérez Vento y Nin . . I 47

Alberto Barreras Fernández · 149

Tomás Juan de Jústiz Y del VAlle 153

Julio Blanco Herrera • • • 155

Mario Muñoz Bustamante* • . $\quad$ i 57

Rodolfo Rodríguez de Armas* . 159

Luis García Carbonell . . i6I 
Armando André Alvarado . . 163 Arturo R. DE Carricarte y de ARMAS . . . . . 165

Blanche Zacharie de Baralt . . 169

Modesto Morales Díaz . . . I7I

LEOFOLdo Romanach . . 175

Hugo Roberts* . . . I I77

Fernando Freyre de Andrade* . I 81

Sergio Cuevas Zequeira* . . 185

Luis A. Baralt y Peoli . . 189

Raimundo Cabrera* . . . 193

Enrique José Varona y Pera* . 199

Carlos M. Trelles* . . . 203

Lola Rodríguez y Ponce de León de

Tı́́ . . . . . . 209

Raul de Cárdenas y Echarte* . 2 I I

José Martí y Zayas Bazán • . 213

Francisco Domínguez Roldán* . 217

Carlos E. Finlay . . . . $22 \mathrm{I}$

José María Collantes · • . 223

Luis Marino Pérez · • . 227

Gustavo F. Arocha y Llaneras . $23 \mathrm{I}$

Miguel Garmendia y Rodríguez* . 233

Federico Edelmann y Pinto . . 235

VICTOR MUÑOZ* • • . . 237

Domingo F. Ramos y Delgado* . 239

Ezequiel García Enseñat* . . 243

Manuel Mencía y García . . 247 
Leandro González Alcorta

Luís Montané*

Manuel Pérez Beato* $25 \mathrm{I}$

Joaquín Chalons* 255

Aurelia Castillo de Gonsales* 259

Demetrio Castillo Duany* 263 Juan Guiteras* 267

Manuel Gutiérrez Quirós 271

José Manuel Carbonell

Emilio Alamilla Requeijo 277 279 283

Alfredo M. Aguayo 285

Guillermo de Montagú . 287

Pedro E. Betancourt* 291

Antonio Iraizoz y Del Villar* 295

Luis Ortega y Bolaños 297

José A. del Cueto* 299

Arturo García Casariego $30 \mathrm{I}$

Francisco Henares y Briega 303

Gabriel Casuso* 305

Enrique Saladrigas y Lunar . 307

Carlos Miguel de Céspedes* . 309

Gustavo Sánchez Galarraga 3I I

Manuel Sanguily* . 3I 3

Rafael Fernández de Castro . 317

Victorino Trelles Esturba* ? 321

Wifredo Fernández 323

Oscar Díaz Albertini*. . $\quad 325$

Miguel de Carrión y Cárdenas @ 327 
Domingo Hernando Seguí

Octavio Averhoff y Pla

Alfredo Rodríguez Morejón*

Ramiro Guerra y SÁNChez

José María Chacón y Calvo

335

Guillerio Patterson y Jáuregui*

José B. CoRnide

343

Alcides Betancourt

$3+5$

Gustavo G. Duplessis

$3+7$

Antonio Bravo Correoso

349

Ernesto A. de Aragón

Cristóbal de la Guardia*

Miguel Alonso Pujol*

Honoré F. LAINÉ

359

Manuel Ruiz y Rodríguez

36 I

Carmela Nieto de Herrera*

363

José M. Soler Fernández*

365

Arturo Montori de Céspedes .

367

Ernesto Asbert*

Fernando Ortiz y Fernández*

373

AlFREDO ZAYAS*

Francisco Carrera Jústiz

José Ramón Villalón y SÁnchez*

José Antonio Presno

Abraham PÉrez Miró

SAlvador SALAZAR .

Manuel Rafael Angulo.

Conrado Walter Massaguer y Díaz* 


\section{xiv TABLE OF CONTENTS}

José A. Rodríguez Gircía*

PAGE

José Comallonga y Mena*

407

Juan Manuel Menocal

4 II

Rodolfo Guiral

417

Francisco deL Rio

$+23$

Alejandro Ruiz Cadalso*

$+25$

Julio E. Brouwer .

427

Ricardo M. Alemán*

JUAN J. REMOS

+3 I

Pablo Desvernine*

$+35$

Joaquin N. Aramburu*

$+37$

Santiago García Cañizares 439

José G. VILLA

$+4^{1}$

Pablo Miguel y Merino

443

Temístocles Betancourt y Castillo* 445

Emilio de Bobadilla* . . . 449

Nemesio Busto y Delgado . . 453

Bonifacio Byrne . . . . . 455

Felix Callejas . . . . $4^{6 I}$

Felipe García Cañizares. . . $\$ 65$

Manuel Arteaga . . . . 467

Enrique Hernández Cartaya • 469

Armando Menocal . . . . 473

Enrique Collazo y TejadA* . . 475

Armando de Córdova y Quesada* . 479

Francisco de Paula Coronado Y Álvaro . . . . $48 \mathrm{I}$

Manuel Delfín . . . . 487 


\section{TABLE OF CONTENTS XV}

Miguel Espinosa y Hernández*

PAGE

Juan Miguel Dihigo*

491

Ricardo Dolz*

493

$50 \mathrm{I}$

Fernando Sánchez de Fuentes . 505

Juan Gualberto Gómez* · . 509

Pedro Mendoza Guerra . . 5I I

Gustavo Gutiérrez y Sánchez • 5I5

antonio Maria Valdés Dapena • 519

Gerardo Machado y Morales . 52I

Lorenzo Frau Marsal . . 523

Guillermo Fernández Mascaró ? 525

Carlos Mendieta* . . 529

Pedro Calvo y Castellanos $\quad 533$

Jesús María Barraqué y Adué @ 535

Arístides Mestre . . . 537

José Miro y Argenter · · 545

Manuel Rivero y Gandara • • 547

Rafael Montalyo . . . 549

Damaso Pasalodos . . . $55 \mathrm{I}$

José PEREdA · · · $\quad 555$

Carolina Poncet y de Cárdenas* . 559

Enrique Recio y Aguero · . $\quad 563$

Ramón García Mon . . $\quad 565$

Emilio Roig de Leuchsenting* ${ }^{*} \quad 5^{67}$

Alberto de Rojas y Cruzat • 569

Francisco Cabrera SaAvedra . $57 \mathrm{I}$

Enrique Roig y Fortesaavedra • 573

Luís de Sató Y SAgarRa . • 575 
Luís SANTAMARIA*

Manuel Márquez Sterling y Loret DE MOLA*

Antonio Pardo Suárez

José VARELA ZEQUeira

JOSÉ TARAFA

Manuel Villalón

RICARDO DE LA TORRIENTE

593

REgis DU REPAIRE DE TRUFFIX

595

JAme VAlle Y Diaz

597

Nicolás Alberdi*

599

Leopoldo CANCio y LunA*

601

Rafael Antonio Fernández*

605

Mariano Aramburo*

607

Arturo Hevia y Díaz

6 I I

Santiago de la Huerta.

6 I 3

Guillermo Domínguez Roldán*

Aurelio Hevia*

62 I

Julio de Cárdenas*

625

Maria de Los Angeles Landa Y

GONZALE

627

Manuel Herryman Gil

Mario G. Lebredo y Arango

José Antonio López Del Valle

EMilio NuÑEZ.

Benigno SouzA

Carlos M. de Rojas

Carlos Theye y Shoste 


\section{TABLE OF CONTENTS xvii}

PAGE

Carlos de la Torre* . . . 649

Andrés Segura y Cabrera . . 657

Eusebio Hernández* . . . 6 6

José López RodRIguez 665

Tomás V. Coronado* . . . 667

Rosendo Collazo y García* . . 675

INDEX - . . . . 679 




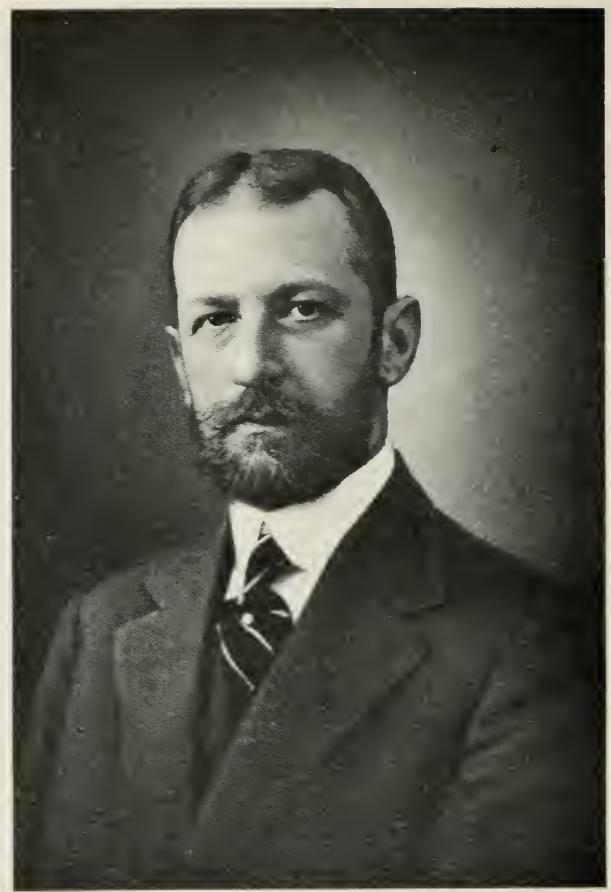

By permission of B. F. Buck \& Co., photographers (N. Y )

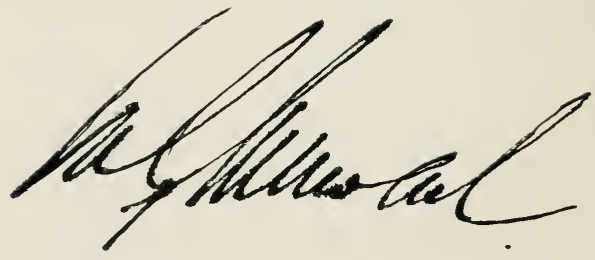




\section{MARIO G. MENOCAL}

Engineer, soldier, man of affairs, third President of the Republic of Cuba.

LIKE many of his compatriots of recent times President Menocal has spent much of his life away from his own country. His boyhood was passed largely in Mexico and his youth in the United States where he was educated.

Menocal was born in Hanábana, Province of Matanzas, on the seventeenth of December, 1866, the son of Don Gabriel G. Menocal, an experienced and skillful sugar planter who, when his son Mario was about two years old, had to flee from Cuba in consequence of his revolutionary activities. He went first to the United States and thence to Mexico where he settled down as a sugar planter at San

\section{H I S P A N C NOTES}




\begin{tabular}{|c|c|}
\hline $2 \cdot$ & C U B A N S O F T O-D A Y \\
\hline & $\begin{array}{l}\text { Juan Bautista, State of Tabasco. Here } \\
\text { the future President of Cuba spent his boy- } \\
\text { hood, but when he was thirteen he was } \\
\text { sent to school in the United States, first at } \\
\text { the Institute of Chappaqua, New York, and } \\
\text { later at the Maryland College of Agricul- } \\
\text { ture whence he passed in I } 884 \text { to Cornell } \\
\text { University where he was graduated in the } \\
\text { Engineering School in r } 888 \text {. } \\
\text { On finishing his University course Meno- } \\
\text { cal returned to Latin-America but not yet } \\
\text { to Cuba. He first associated himself with } \\
\text { his uncle Aniceto Menocal on the com- } \\
\text { mission for the study and construction of } \\
\text { the Nicaragua canal route, a task which } \\
\text { occupied the greater part of three years. } \\
\text { Then in I } 89 \text { I he returned to his native land, } \\
\text { which as yet he hardly knew. He was } \\
\text { employed for a time as Engineer for a } \\
\text { French Company owning salt works and } \\
\text { banana plantations on the Island of Cayo } \\
\text { Romano and later entered upon railway } \\
\text { construction work, having been employed } \\
\text { to carry the survey and location of the } \\
\text { proposed railway line from Camagüey to } \\
\text { Santa Cruz del Sur. }\end{array}$ \\
\hline I & H I P A N I C N T E S \\
\hline
\end{tabular}




\section{E N O C A L}

Here he soon found himself in the thick of revolutionary activities and when in I895 the War of Independence broke out he joined the forces under General Máximo Gómez, continuing to serve in the field until the final victory following the intervention of the United States in I898.

As a soldier Menocal exhibited talent for military affairs, and definite aptitude for strategy. He served under three famous chieftains, Generals Máximo Gómez, Mayía Rodríguez, and Calixto García, all of whom recognized his ability, and he won distinction in the battles of Yerba de Guinea, La Piedra, La Aguada, and also in the capture of the Fort Loma de Hierro.

In the capture of this fort he was mentioned as performing "gallant feats of valor" and given the rank of Colonel. Soon afterwards he took a very active part in the siege and capture of the town of Guáimaro in Camagüey for which he was made Brigadier General, but it was the battle of Victoria de las Tunas that marked the climax of his martial career. Here his engineering training stood him in good

\section{A N D M O N G R A P H S}




\begin{tabular}{|c|c|}
\hline 4 & C U B A N O F T O-D A Y \\
\hline & $\begin{array}{l}\text { stead. He made such skillful disposition } \\
\text { of men and guns that competent witnesses } \\
\text { have said that the conduct of this battle } \\
\text { stands out in the entire record of the Re- } \\
\text { volution as the one combat in which the } \\
\text { Cuban forces were disposed and directed } \\
\text { in accordance with the principles of mili- } \\
\text { tary science. Not only did General Meno- } \\
\text { cal direct the operations in pursuance of a } \\
\text { well-considered plan but he is said to have } \\
\text { led his soldiers in the assault with intrepid } \\
\text { courage. Victoria de las Tunas was the } \\
\text { crowning achievement of his military } \\
\text { career and gave him the rank of General } \\
\text { in the Cuban Army, but when war was } \\
\text { declared by the United States on Spain, } \\
\text { Menocal was appointed Commander of the } \\
5 \text { th Army Corps, comprising the Provinces } \\
\text { of Havana and Matanzas, where it was ex- } \\
\text { pected that American action would be more } \\
\text { concentrated. This appointment carried } \\
\text { his promotion to the rank of Major General. } \\
\text { On the return of peace General Ludlow } \\
\text { of the American Army of Intervention } \\
\text { made General Menocal Chief of Police of } \\
\text { Havana and in the same year he was ap- }\end{array}$ \\
\hline I & H I S P N I C NOTES \\
\hline
\end{tabular}




\section{E N O C A L}

pointed to organize the Lighthouse Service, a post which he held for a short time, but gave up to undertake an engineering commission of considerable importance and extent, namely, constructing for the Cuban American Sugar Company the factory at Chaparra, then said to be the largest sugar factory in the world. This task General Menocal fulfilled with credit and distinction.

Meantime the growth of his reputation had brought him within the field of politics. In 1908 he was nominated for the Presidency by the Conservative party but failed of election; in I9 2 he was again a candidate and was elected President of the Republic on the ticket of the same party. President Menocal's first term was characterized by a constructive policy including the following practical proposals:

(I) Administrative and financial reforms.

(2) Strengthening the relations with the United States.

(3) Strict regulation of the Public Treasury, liquidation and adjustment of all outstanding indebtedness, and reor-

A N D M ONOGRAPHS 


\section{C.U B A N S O F T O - D A Y}

ganization of taxation, in order to equalize, as far as possible, its incidence.

(4) Support of agriculture and development of immigration.

(5) Reorganization of the Army and Navy, in order to obtain efficiency.

Again in I9I 6 he received the nomination and was declared reëlected, but after a contest so close and so much disputed that the unsuccessful party fomented an armed uprising which for a time threatened to overturn the government and was only subdued after bloodshed and some destruction of property. During General Menocal's presidency the European War presented many problems of the utmost difficulty, some of which were solved and the quality of President Menocal's statesmanship shown, when, following the example of the United States, Cuba espoused the cause of the Allies and declared a state of war with Germany within twenty-four hours after the United States had done so.

In I9r 8 President Menocal was elected an Honorary Associate of the Hispanic Society of America.

H I S P A I C N O T E S 



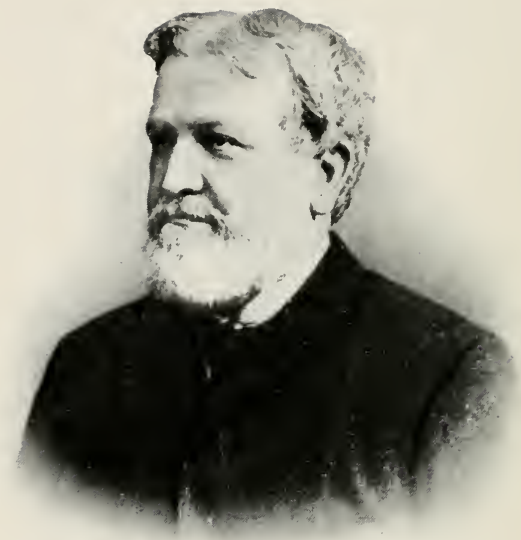

Rafael Montoro 


\section{O N T O R O}

\section{RAFAEL MONTORO}

Orator; publicist; diplomat; Secretary of the Presidency of Cuba.

Rafael Montoro was born in the city of Havana on the twenty-fourth of October, $185^{2}$, scion or an old family, whose ample means and close affiliations with Spain enabled him to pursue most of his studies in Madrid. There at the age of fifteen he began to study law, literature, and philosophy.

He began his literary career as editorialist and contributor to the Revista Europea and other publications including the $R e$ rista Contemporánea of which he was Chief Editor, taking an active part in the proceedings of the Atheneum of Madrid, having been elected Vice-president of its Political and Moral Sciences Section in I 877 ; also Second Secretary of the Association of Spanish Writers and Artists.

\section{A N D M O N O G R A P H S}




\begin{tabular}{|c|c|}
\hline 8 & C U B A N S O F T O-D A Y \\
\hline & $\begin{array}{l}\text { He returned to Cuba in I } 878 \text { just } \\
\text { prior to the termination of the Ten Years' } \\
\text { War, which ended with the Peace of } \\
\text { Zanjón. } \\
\text { Shortly after his arrival he joined a } \\
\text { party of friends in founding El Triunfo of } \\
\text { which he became one of the editors; he also } \\
\text { joined the Liberal Autonomist party, } \\
\text { devoted to the cause of Cuban autonomy. } \\
\text { The following year he was chosen as mem- } \\
\text { ber of the Central Committee of the party, } \\
\text { and likewise elected Deputy to the Spanish } \\
\text { Cortes representing the Province of Havana. } \\
\text { To this difficult post for which his senti- } \\
\text { mental regard for Spain and his familiarity } \\
\text { with Cuban affairs particularly fitted him, } \\
\text { Dr. Montoro was twice afterwards elected, } \\
\text { in I } 886 \text { and again in I } 893 \text { to represent the } \\
\text { Province of Puerto Principe. } \\
\text { From I } 883 \text { he practiced his profession as } \\
\text { a lawyer, having appeared in that capacity } \\
\text { before all the Courts. } \\
\text { A firm believer in political agitation and } \\
\text { discussion, a partisan of evolution rather } \\
\text { than revolution, Dr. Montoro took no part } \\
\text { in the bloody struggle of I } 895 \text { - } 98 \text {. He had }\end{array}$ \\
\hline I & H I S P A I C NOTES \\
\hline
\end{tabular}




\section{O N T O R O}

remained in Spain until 1895 , laboring to bring about autonomy for Cuba rather than final separation. When in 1897 in the midst of the final struggle for independence Spain granted autonomy and a new government was formed, Dr. Montoro accepted the post of Secretary of the Treasury. The solution came too late; the new government found no support and was lost in the intervention of the United States in 1898 . Thereupon Dr. Montoro retired from public office and also declined to continue filling the position of Professor of Philosophy and History of Philosophy, to which he had been appointed in the University of Havana and withdrew to complete obscurity. Notwithstanding, in 1902 he was appointed a member of the Tariff Commission, under the Presidency of the now General, Tasker H. Bliss. During the same year, I902, his talents and character were again requisitioned for the public service and he was appointed Envoy Extraordinary and Minister Plenipotentiary to England, to which office was added in 1904 that of Minister to Germany, and he held both

\section{A N D M O N O G R P H S}




\begin{tabular}{|l|l|}
\hline IO & \begin{tabular}{l} 
C U B A N S O F T O - D A Y \\
posts, residing alternately in London and \\
in Berlin. \\
In I906 he was appointed Delegate to \\
the Pan-American Conterence at Rio \\
Janeiro. The following year he took part \\
in the reorganization of the National Con- \\
servative party and was its first candidate \\
for the Vice-presidency in I9o8. Not- \\
withstanding his defeat in the elections he \\
resumed his position as Minister to London \\
and Berlin, at the request of the new \\
government, and remained in that position \\
until I9Io, when he was again elected to \\
represent Cuba at the Pan-American Con- \\
ference at Buenos Aires. On the success of \\
his party in the elections of I I 2 he was \\
made Secretary of the Presidency, which \\
position he still holds. \\
The place which Dr. Montoro has held \\
in the esteem and admiration of his fellow \\
countrymen, has been due in great meas- \\
ure to that gift of oratory which is so \\
brilliant a part of the Spanish heritage and \\
which he was enabled to cultivate to so \\
much advantage as member of the Cortes \\
of Spain. \\
\hline H I S P A N I C N O T E S
\end{tabular} \\
\hline I
\end{tabular}




\section{O N T O R O}

Dr. Montoro is a member and Director of the National Academy of Arts and Letters, a member of the Academy of History and various other literary corporations. He was also appointed a member of the Advisory Law Commission in 1906 by Governor Magoon.

Dr. Montoro's publications include: Discursos politicos y parlamentarios, informes y desertaciones, Philadelphia, I894; Principios de Moral e Instrucción Civica, Habana, I903: Nociones de Instrucción Moral y Civica, Habana, I 908. 



\section{B E N A R D}

\section{ALFREDO GONZALEZ BENARD}

Lawyer; public man.

Alfredo Gonzales Benard was born on the twenty-sixth of October, I87 I, in the city of Santiago de Cuba and received his early education in his native city. His more advanced studies he pursued in the University of Havana which he entered in I 888 and in which he obtained the degree of Licentiate in Law in 1893 and in 1897 that of Doctor of Laws.

Dr. Benard took up his residence in Cárdenas and entered upon the practice of his profession, becoming in due course Member of the Board of Education, Member of the Board of Patrons of the "Santa Isabel" Hospital, and legal representative of his party.

In November, I910, he was elected Representative in Congress for Matanzas, re-

\section{H I S P A I C N OTES}




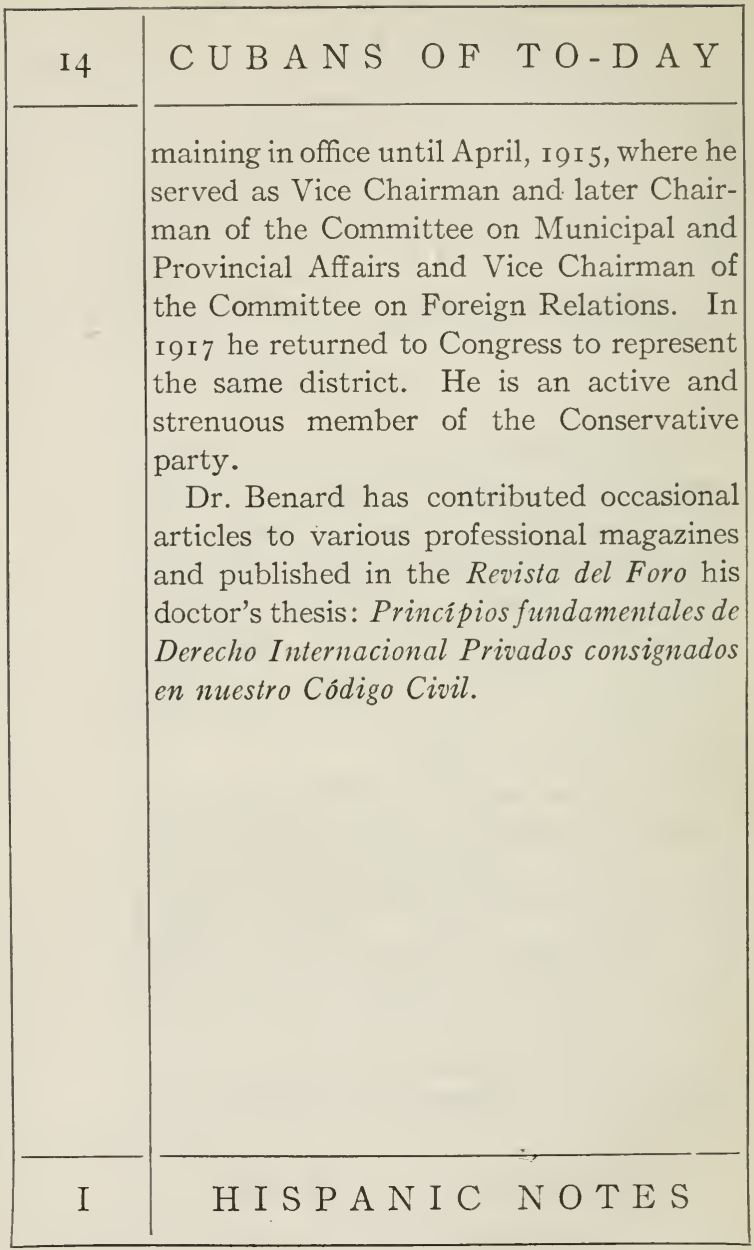





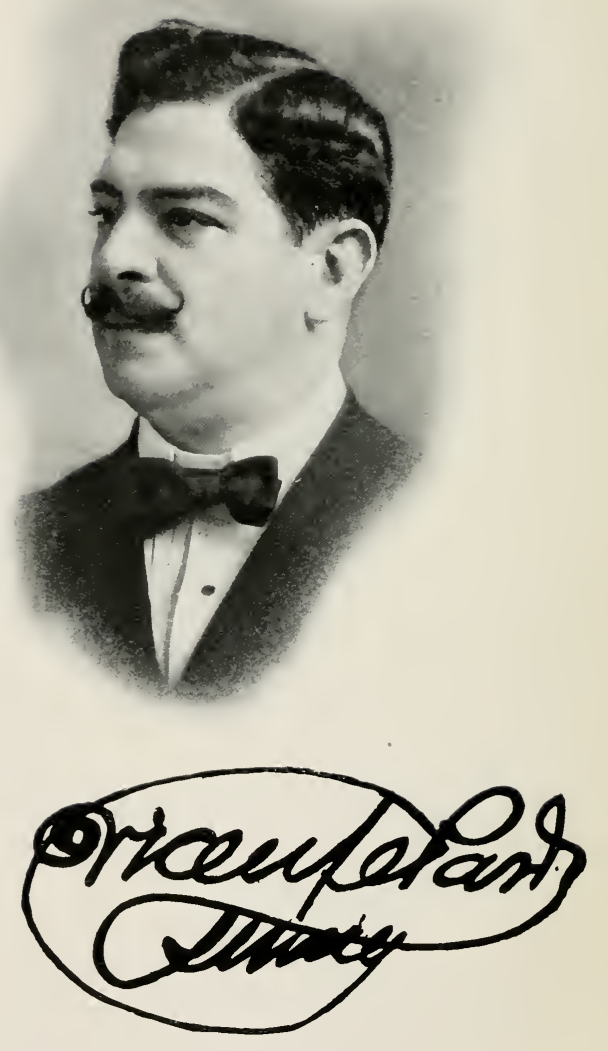




\section{P A R D O S U Á R E}

\section{VICENTE PARDO SUÁREZ}

Editor; official.

Vicente PaRdo SuÁREZ was born on the twenty-fifth of December, I870, in the city of Havana where he obtained his early education and completed the courses for the Bachelor's degree in the Colegio of San Francisco de Paula. At the age of fifteen he began to write in the Republican newspaper La Libertad which was published in Havana by Don Niceto Solá y Freixas. He wrote much also for the theater. In I 888 he founded $L a$ Republica, a newspaper in which he vigorously opposed the colonial administration and the unjust course of the Spanish authorities toward the legitimate aspirations of the Cubans; in consequence of which he underwent much persecution and many interruptions of his paper. In 1895 , after the begin-

\section{A N D M O N O G R A P H S}




\begin{tabular}{|l|l|}
\hline I6 & C U B A N S O F T O - D A Y \\
\hline $\begin{array}{l}\text { ning of the war of Independence, General } \\
\text { Valeriano Weyler suppressed the paper on } \\
\text { the ground that its title and ideals were } \\
\text { incompatible with the tranquillity of the } \\
\text { country and the sovereignty of Spain, sub- } \\
\text { sequently deporting its editor to Spain } \\
\text { where he was imprisoned in the castle of } \\
\text { Monjuitch in Barcelona and afterwards in } \\
\text { the prisons of Santander and Bilboa until } \\
\text { the thirteenth of August, I898, the day after } \\
\text { the Peace Protocol between Spain and the } \\
\text { United States was signed in Washington. } \\
\text { Onhis return to Cuba and on theorganiza- } \\
\text { tion of the first Board of Aldermen of Ha- } \\
\text { vana, Pardo Suárez was appointed, jointly } \\
\text { with Colonel Saturnino Lastra, to a position } \\
\text { of trust in the Administration of the Munici- } \\
\text { pal taxes. When those who had suffered } \\
\text { imprisonment, penalties, and deportation } \\
\text { formed an association for patriotic pur- } \\
\text { poses, he was elected Secretary; he also } \\
\text { became an honorary Member of the Pa- } \\
\text { triotic Committee of Havana of which Don } \\
\text { Salvador Cisneros Betancourt, who had } \\
\text { been President of the Republic in arms, was } \\
\text { Chairman. }\end{array}$ \\
\hline I & \begin{tabular}{l} 
H I S P A N I C N O T E S \\
\hline
\end{tabular} \\
\hline
\end{tabular}




\section{P A R D O S UÁR E Z}

When the Republic was constituted in 1902, Pardo Suárez was appointed Editor of the daily record of the House of Representatives (Diario de sesiones) a post which he resigned in 1904 on his election as Chief Clerk of the House. $\mathrm{He}$ has traveled widely, visiting the Parliaments of Washington, Toronto, Madrid, Paris, and Rome to study their methods of administration and to adopt such as seemed suitable and advantageous to the Cuban House.

By the law of the seventeenth of August, I9I 2, he was made Secretary of the Committee of the Cuban Congress to attend the Centenary of the Constitution of Cadiz, Spain, and in the same year he was elected a corresponding member of the Royal Hispano-American Academy of Arts and Sciences of Cadiz.

He was Secretary of the Anti-Germanic League, founded in Havana to lend aid to the Allies and to conduct propaganda in opposition to the German pretensions.

He has issued eight volumes of Records of the House of Representatives and three volumes of the Legislative Index; he is the

\section{A N D M O N O R A P H S}




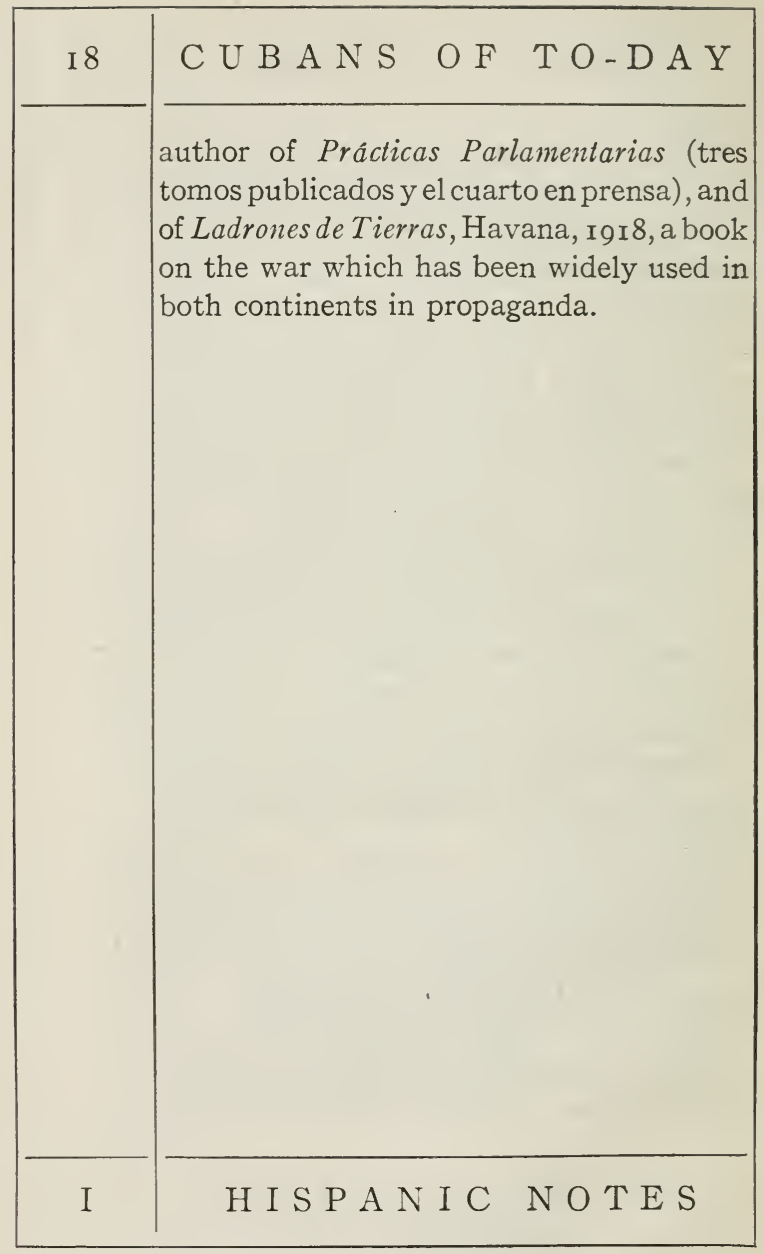





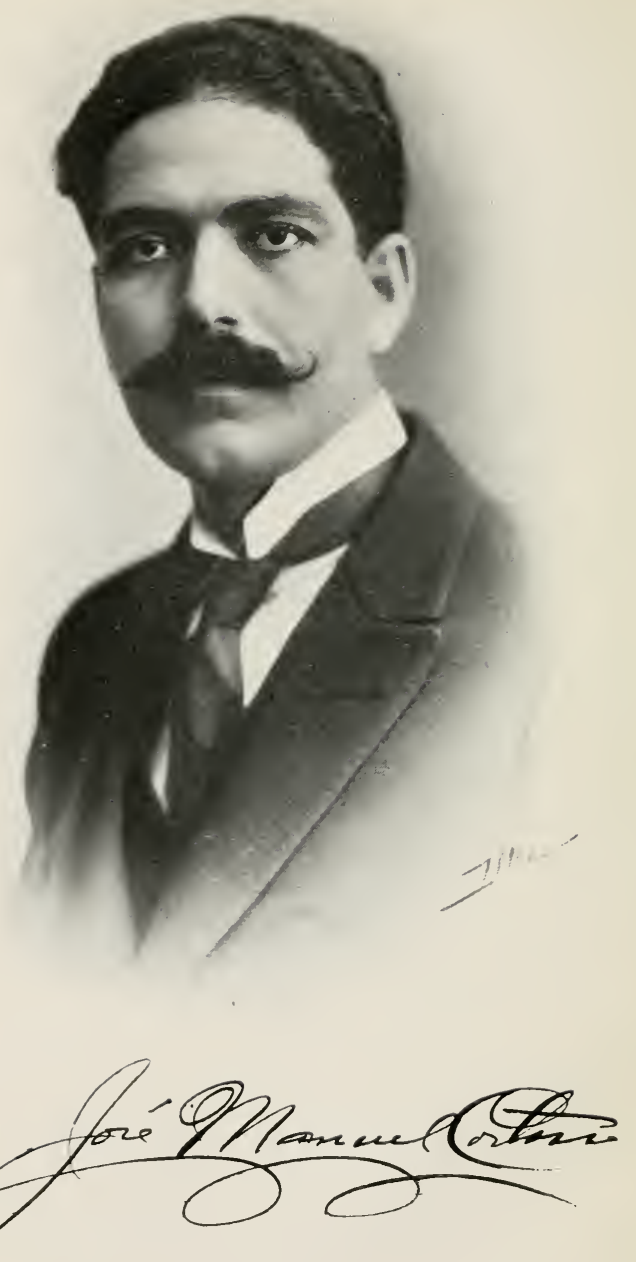




\section{O R T I N A}

\section{JOSÉ MANUEL CORTINA}

\section{Lawyer; legislator.}

José Manuel Cortina y García was born on the third of February, I880, in San Diego de Nuñez, Province of Pinar del Rio. He was educated in Havana, completing the courses for the Bachelor's degree in the Jesuits' Colegio of Belén and obtaining his degree of Doctor of Laws at the University in 1903 .

While he was an undergraduate he was elected President of the Federation of University Students, organized at the close of the Spanish sovereignty, and then gave signs of promise as an orator in the speech he made in salutation to General Máximo Gómez when he entered Havana at the head of the Army of Liberation in 1899 . He was still a student when he took an important part in the organization of the

\section{A N D M O N O G R A P S}




\begin{tabular}{|l|l|}
\hline C U B A N S O F T O - D A Y \\
$\begin{array}{l}\text { National Cuban Party, which had for one } \\
\text { of its chief aims to put an end to the Ameri- } \\
\text { can Intervention which followed upon the } \\
\text { withdrawal of Spain in I899. } \\
\text { Dr. Cortina has been active in journal- } \\
\text { ism. For two years he edited the news- } \\
\text { paper Democracia and was at one time or } \\
\text { another a member of the staffs of El Mundo, } \\
\text { La Lucha, and La Revista de derecho, besides } \\
\text { being a contributor to La Nacion and other } \\
\text { papers. } \\
\text { After the "Revolution of August" } \\
\text { (I9o6) which overthrew President Estrada } \\
\text { Palma, a division arose among the Liberals } \\
\text { who had made the revolution and Dr. Cor- } \\
\text { tina was chosen to bring about a reconcilia- } \\
\text { tion. His negotiations were successful and } \\
\text { resulted in the Liberal party coming into } \\
\text { power with the election of General José } \\
\text { Miguel Gómez as President. Again at a } \\
\text { later time when a fresh division occurred be- } \\
\text { tween the two wings of the party, under the } \\
\text { leadership of Dr. Alfredo Zayas and General } \\
\text { Gómez respectively, Dr. Cortina once more } \\
\text { acted as mediator and the party presented } \\
\text { a united front in the elections of I } 16 .\end{array}$ \\
\hline H I S P A N I C N O T E S
\end{tabular} \mid


He was elected Representative for $\mathrm{Ha}$ vana in I908 and reëlected in I9I 3 and I І 7. He has been the leader of the Liberals in the House and has been influential in legislation. $\mathrm{He}$ is the author of the Workmen's Accident Law now in force, and of Bills to regulate strikes, to establish a Court of Arbitration for labor disputes, to make compulsory the provision of hygienic dwellings for rural workers, to provide secretaries for the House of Representatives, etc., etc. $\mathrm{He}$ is Chairman of the Committee on Public Works.

Among the public offices with which Dr. Cortina has been honored are: Counsel to the Secretary of Public Instruction, and to the Board of Aldermen of Havana; member of the Board of Inspectors of the University, and member of the Special Committee of Congress to revise all the legislation in accord with the economic and social changes brought about by the World War.

\section{A N D M O N G R A P H S}





\section{F I G U E R E D O}

\section{FERNANDO FIGUEREDO Y SOCARRAS}

Soldier; engineer; official.

Fernando Figueredo y Socarras was born in Camagüey in the year 1847 and received his early education in Bayamo at the excellent training school "San José" then under the direction of Don José Maria Izaguirre. At the age of fifteen he passed on to Havana where he entered the preparatory school for special careers maintained by Colonel Eduardo Martín Pérez. In $186_{3}$, he proceeded to the United States and attended the Charlier French Institute. This was for a brief period, however, and in I 864 he entered the School of Engineers of Troy, New York, where he completed the course in Civil Engineering. Then he returned to Cuba to join the revolutionary forces organized by Carlos Manuel de

H I S PA N I NOTES 


\begin{tabular}{|c|c|}
\hline 24 & C U B A N O F TO-DA Y \\
\hline & $\begin{array}{l}\text { Céspedes after the call to arms (grito) of } \\
\text { Yara and the capture of Bayamo on the } \\
\text { eighteenth of October, I868, which began } \\
\text { the Ten Years' War. Figueredo fought } \\
\text { throughout the war, serving as soldier, } \\
\text { engineer, legislator, Chief of Staff, chief } \\
\text { of the revolutionary forces, and ended the } \\
\text { conflict as member of the Revolutionary } \\
\text { Government, being one of those who pro- } \\
\text { tested against signing the pact of peace of } \\
\text { Zanjón. During this historic period he } \\
\text { fought side by side with Maceo, and it was } \\
\text { not until the end of May, I } 878 \text {, that they } \\
\text { gave up fighting, and Figueredo left Cuba } \\
\text { with his wife and child. } \\
\text { He went first to Santo Domingo and } \\
\text { later to Florida where he held several offices } \\
\text { of trust under the American Government, } \\
\text { including Member of the Legislature of } \\
\text { Florida, Superintendent of Schools, and } \\
\text { Mayor of West Tampa. Throughout this } \\
\text { period he never ceased to serve the cause } \\
\text { of Cuba by every means in his power and } \\
\text { when the Revolution of I } 895 \text { broke out he } \\
\text { was appointed by Delegate José Martí } \\
\text { head of the movement for that district, and }\end{array}$ \\
\hline I & H I S A N I C N O T E \\
\hline
\end{tabular}




\section{F I G U E R E D O}

it is said that the group which lent the most valuable services to the cause was that under his direction.

After twenty years of exile he returned to Cuba in 1898 when the American flag was floating over the Island and soon afterwards was appointed by the American authorities Second Customs Officer at Cienfuegos. Later, in 1900 , he came to Havana to take the post of Sub-Secretary of State-a position which he occupied until the twentieth of May, I902, when President Tomás Estrada Palma appointed him Director General of Communications.

In 1906, he was made Interventor of State and in 1908 , on the death of General Roloff, he was appointed by Mr. Magoon (American Governor during Intervention) to succeed him as Treasurer General of the Republic-an office which he still holds.

\section{A N D M O NOG R A H S}





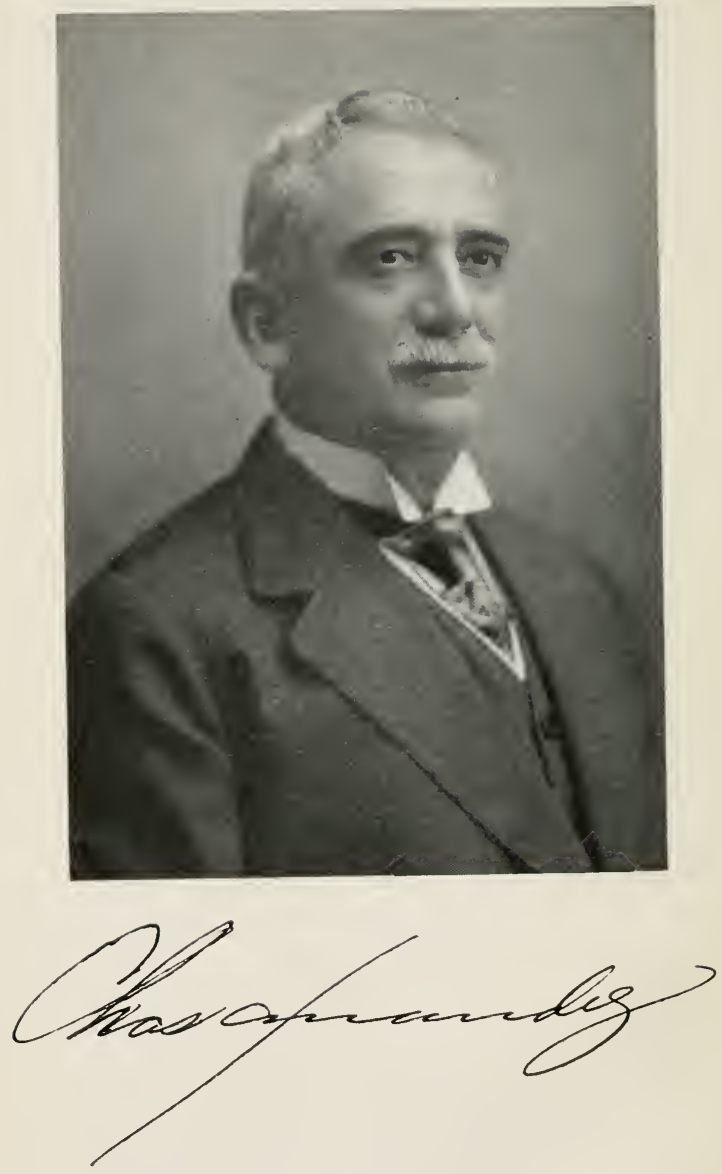


\section{H E R N Á N D E Z}

\section{CHARLES HERNÁNDEZ}

Soldier; official.

Charles Hernández y Sandrino was born on the sixth of May, 1867 , in Pinar del Rio and spent his youth partly in Cuba, partly in Santo Domingo, and partly in the United States where he obtained his education. Here also he gained his first military training, in the Massachusetts National Guard which he joined in 1887 . Later he went to Florida where he studied agriculture in general and especially tobacco culture.

Hernández enjoyed the confidence of José Martí, "the apostle of Cuban freedom," who commissioned him in 1894 to make preparations for the Revolution. $\mathrm{He}$ brought to Cuba the first orders of General Máximo Gómez, calling upon all the leaders of r868-78 (the Ten Years'

\section{H I S PA N I C NOTES}




\begin{tabular}{|c|c|}
\hline 28 & C U B A N S O F T O - D A Y \\
\hline 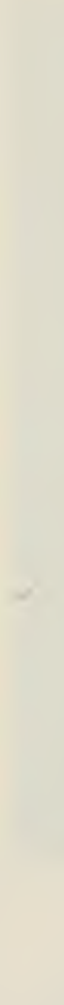 & $\begin{array}{l}\text { War) to place themselves at the command } \\
\text { of Hernández and Martí for the rising of } \\
\text { the twenty-fourth of February, I } 895 \text {. At } \\
\text { the outbreak of the war he was the first to } \\
\text { leave the coast of Florida in command of an } \\
\text { expedition with arms and supplies. Three } \\
\text { months later he returned with another ex- } \\
\text { pedition, running all manner of risks and } \\
\text { disembarking under the fire of the Spanish } \\
\text { guard in the harbor of Varaderode Cárdenas. } \\
\text { His knowledge of the topography, ge- } \\
\text { ology, and botany of the country served } \\
\text { him in good stead and was of great value } \\
\text { to the army. He placed the mines in the } \\
\text { River Cauto, entrance to the Bay of Puerto } \\
\text { Padre, and in various other places of special } \\
\text { peril and observed, hidden along the shore, } \\
\text { the Spanish gun-boats escorting troops and } \\
\text { supplies. } \\
\text { He won the rank of Major by gallantry } \\
\text { in the face of the enemy in the attack of } \\
\text { Guáimaro and that of Lieutenant Colonel } \\
\text { in the famous battle of Jiguani, and General } \\
\text { Funston said of him that he was one of the } \\
\text { bravest and most skillful of the Cuban } \\
\text { officers. }\end{array}$ \\
\hline I & H I P A N I N O TES \\
\hline
\end{tabular}




\section{H E R N Á N D E Z}

Early in May, I898, he was commissioned by General Calixto García to accompany Lieutenant Colonel Andrew Rown of the American Army to Washington and to set forth to the Secretary of War the situation of the Cuban Army in the eastern end of the island; after which he returned, at the request of General García, to assist in taking the city of Santiago de Cuba. At the siege of this city he won the rank of Colonel.

At the close of the war he turned enthusiastically to the task of organizing the Republic, laboring first in developing the national police, and later in the postal service where he continues to serve as Director General of Communications.

\section{A N D M O NOGRAPHS}





\section{A L D É A N C I A N O}

JOSÉ A. VALDÉS ANCIANO

Physician; teacher.

José A. Valdés Anciano was born on the twenty-first of March, 1869 , in the city of Matanzas and there obtained his early education, completing the courses for the Bachelor's degree. Thereafter he entered the University of Havana where he devoted himself to the study of Medicine and gained the degree of Licentiate and later that of Doctor.

He entered upon the practice of his profession in Havana and in I906 obtained by competitive examination the Chair of Nervous and Mental Ailments in the School of Medicine in the University.

$\mathrm{He}$ has filled various positions related to his profession and has contributed articles, dealing with medical subjects, to various reviews and journals, Cuban and foreign.

\section{H I S PA N C NOTES}




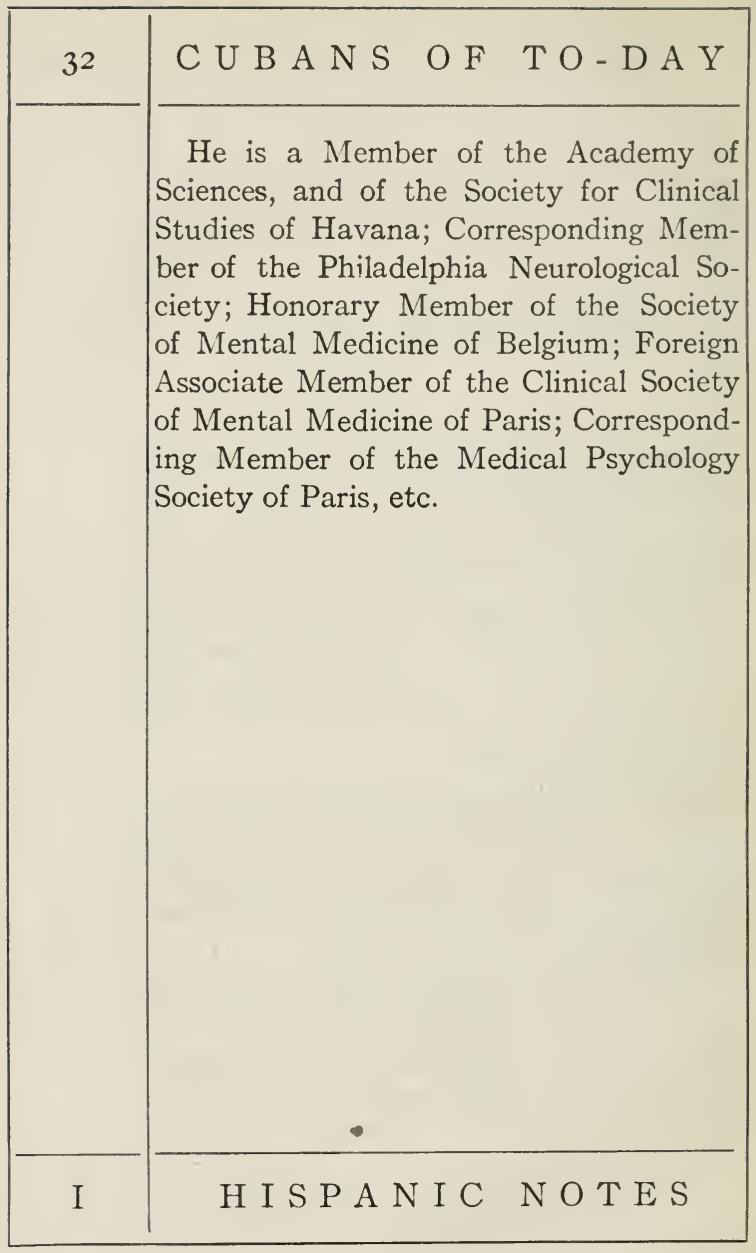




\section{GUSTAVO PINO}

Lawyer; magistrate; legislator.

Gustavo Pino was born in Havana on the twenty-fifth of June, I877. After completing the courses required for the Bachelor's degree in the Colegio of Belén he went to New York to continue his studies at Fordham University, but returned to Cuba to fulfill the requirements of the legal profession in the University of Havana where he obtained the degree of the Doctor of Laws in 1898 .

In 1902 , he was appointed Judge of the primary Court of Cienfuegos; in 1904 he was transferred to a corresponding post at Cárdenas; in r9o6, he was made Assistant Prosecuting Attorney of the lower courts of Matanzas, and in 1908 Counsel to the Prosecuting Attorney of the lower courts of Havana.

\section{A N D $\mathrm{MONO}$ G R A P H S}




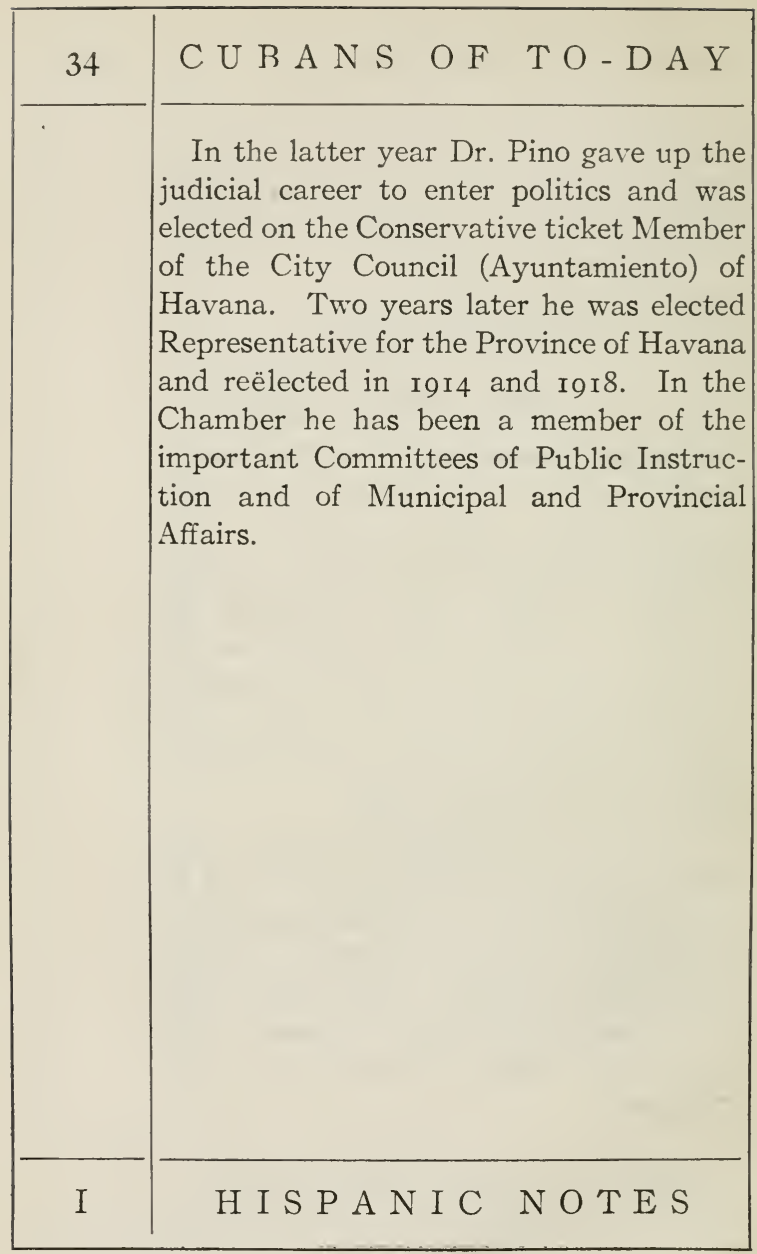




\section{T A M A Y O}

DIEGO TAMAYO Y FIGUEREDO

Soldier; physician; teacher.

Diego Tamayo y Figueredo was born in Bayamo on the twelfth of October, $\mathrm{I}_{53}$, and was educated in the Colegio of Belén in Havana where he obtained the Bachelor's degree in I868. A few months later the Ten Years' War broke out and Tamayo was one of those who joined the Cuban colors at Demajagua on the tenth of October of that year, being then fifteen years old, the youngest in the ranks. He took an active part in the war, being on the Staff of General Carlos M. de Céspedes until I 872, when, incapacitated by malaria, he was taken prisoner and expatriated.

Transported to Spain he there entered the University of Barcelona and obtained the degree of Doctor of Medicine in 1878 . Soon after this the Peace of Zanjón was

\section{A N D M O N O G R A P H S}




\begin{tabular}{|c|c|}
\hline 36 & C U B A N O F T O - D A Y \\
\hline$r$ & $\begin{array}{l}\text { signed and he returned to Cuba to enter } \\
\text { upon his profession, which he practiced, } \\
\text { first at Manzanillo and later at Havana } \\
\text { where he set up an academy to prepare } \\
\text { medical students for their examinations. } \\
\text { On the outbreak of the Revolutionary } \\
\text { War in I } 895 \text { he took part in the propaganda } \\
\text { and expeditionary activities carried on } \\
\text { from New York where he was President } \\
\text { of the Revolutionary Council. He was } \\
\text { also Vice-president of the Assembly of } \\
\text { Santa Cruz and member of the Constitu- } \\
\text { ent Assembly. Under the American Inter- } \\
\text { vention he was Secretary of Gobernació } \\
\text { and held the same office under President } \\
\text { Estrada Palma. In I905, he was elected } \\
\text { Senator for the Province of Havana. He } \\
\text { has been deeply engaged in politics, first } \\
\text { in the Autonomist party, in which he was } \\
\text { a member of the Central Committee until } \\
\text { I895; then in the National party of which } \\
\text { he was one of the founders, and later in the } \\
\text { Conservative party which he aided in } \\
\text { founding. } \\
\text { His professional activities have been } \\
\text { numerous and varied. He was the Presi- }\end{array}$ \\
\hline I & H I S A N I C N O T E S \\
\hline
\end{tabular}




\section{T A M A Y O}

dent of the first Medical Congress of the Island of Cuba in I890; joint founder with Dr. Juan Santos Fernández of the first bacteriological laboratory in $\mathrm{Cuba}$; he was the first to teach Bacteriology in Cuba and in union with Dr. Vildósola to use the Pasteur treatment. For a number of years he has been Editorial Secretary of the Crónica Médico Quirúrgica of Havana and is the publisher of Vida Nueva, a magazine of Hygiene and Social Science. He is also the founder and director of the "Tamayo Dispensary" which is a school for specialists. He has held office as Secretary of the Municipal Board of Health and Secretary pro tem of the General Board of Health.

$\mathrm{He}$ is President of all the Medical Corporations and has been four times President of the Mutual Aid Society of the Physicians of Cuba. He is also President of the National Health Commission, Professor of Medical Pathology, and Dean of the Faculty of Medicine and Pharmacy in the University.

He was Delegate from Cuba to the Antituberculosis Congress held in Washington

A N D M O N O G A P H S 


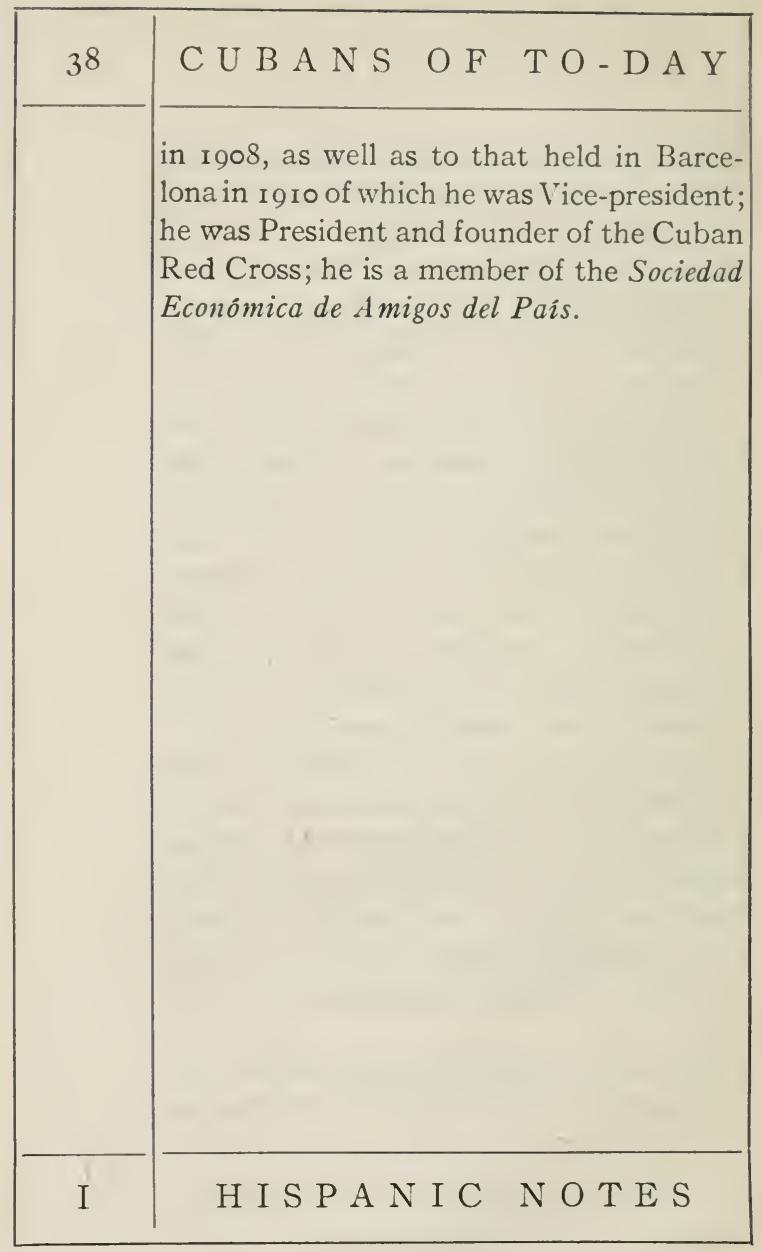




\section{A R T Í N E Z}

\section{EMILIO MARTÍNEZ}

\section{Physician; laryngologist.}

Emilio Martínez was born in Havana on the thirteenth of April, I864. His father, a political refugee, went to Baltimore during the Ten Years' War and for this reason he took his preliminary education at the public schools of that city; after the war he returned to his native city and entered the University of Havana where he graduated as Doctor in Medicine in I888. From I 889 to 1890 he was engaged by General (then Major) George M. Sternberg as laboratory assistant of his commission for the investigation of yellow fever, finishing this work in the Laboratories of the Johns Hopkins University, Baltimore. This visit to Johns Hopkins, where he studied pathology and laryngology (post-graduate course) determined his

\section{A N D M O N O G R A P H S}




\begin{tabular}{|c|c|}
\hline 40 & C U B A N O F TO-D A Y \\
\hline & $\begin{array}{l}\text { future career as laryngologist and sani- } \\
\text { tarian. } \\
\text { As a laryngologist he established his } \\
\text { practice in Havana and organized the } \\
\text { Throat department in the Tamayo Dis- } \\
\text { pensary and La Policlinica. He cultivated } \\
\text { this specialty thoroughly in various visits } \\
\text { to the New York Polyclinic and the Post- } \\
\text { graduate School, New York, and later on in } \\
\text { Vienna, at the Poliklinic Generale. His } \\
\text { experience of six years as general surgeon } \\
\text { to the Havana emergency stations (Casas } \\
\text { de Socorro) helped him greatly in the } \\
\text { specialty. In I9o6 he was appointed, by } \\
\text { competition, Professor of Clinical Micro- } \\
\text { scopy in the University of Havana, a chair } \\
\text { which he resigned later to occupy that of } \\
\text { Laryngologist. He is at present Senior Pro- } \\
\text { fessor of Laryngology, Rhinology, and Otol- } \\
\text { ogy in the University and is also in charge } \\
\text { of this Department at the General Calixto } \\
\text { García Hospital. He is a Member of the } \\
\text { American Laryngological, Rhinological, and } \\
\text { OtologicalSociety; and passed the examina- } \\
\text { tions at the University of New York admit- } \\
\text { ting him to practice medicine in that State. }\end{array}$ \\
\hline I & H I S P N I C NOTES \\
\hline
\end{tabular}




\section{A R T Í N E Z}

As a sanitarian Dr. Martínez was appointed a Member of the Commission for Infectious Diseases by President Palma and is now President of this Commission and ex-officio a Member of the National Board of Health and Charities. $\mathrm{He}$ attended the Pan-American Medical Congress at Panama, being sent by President Palma, at the request of General Gorgas, to expound to the medical men of Panama in their own language the new methods employed in the sanitation of Cuba. One of the principal works of Dr. Martínez was the active part he took trying to continue the work of the Intervention Government in the Department of Charities. Being a member of the National Board of Charities and Correction he attended, with other Directors of Hospitals of Cuba, the 28th National Conference of Charities and Correction at Washington and learned there the modern principles of Charities and Correction with $\mathrm{Mr}$. Homer Folks and Mr. Devine. On his return to Havana he organized Las Conferencias Nacionales de Beneficencia y Corrección with such success

\section{A N D M O N O G R A H S}




\begin{tabular}{|l|l|}
\hline 42 & $\begin{array}{l}\text { C U B A N S O F T O - D A Y } \\
\text { that they were held regularly for seven } \\
\text { years in different cities of Cuba. The } \\
\text { purpose of these Conferences was to de- } \\
\text { velop modern charities under the control } \\
\text { of the people. The political machine } \\
\text { gradually invaded this Department of } \\
\text { Charities and made useless all future work } \\
\text { in this line. } \\
\text { Dr. Martínez has taken an active part } \\
\text { in the medical press. He has been Co- } \\
\text { editor of La Revista de Ciencias Médicas, of } \\
\text { Los Archivos de la Policlinica, of La Revista } \\
\text { de Medicina Tropical, and has published } \\
\text { over one hundred articles on Laryngology } \\
\text { and Sanitary matters. He is the author of } \\
\text { Manual de Microscopia y Quimica Clinica } \\
\text { and an active member of La Sociedad de } \\
\text { Estudios Clinicos. }\end{array}$ \\
\hline H I S P A N I C N T E S \\
\hline \\
\hline
\end{tabular}




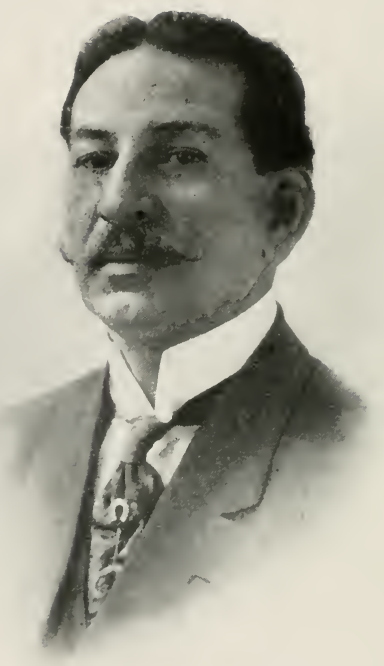

Evilio R. Lendián 


\section{E N D I Á N}

\section{EVELIO RODRIGUEZ LENDIÁN}

Scholar; teacher; author.

Evelio Rodríguer. Lendián was born on the eighteenth of November, I860, in Guanabacoa and there obtained his early education. He was enabled to pursue his studies and obtain the Bachelor's degree by means of a scholarship which carried the condition that he should obtain the highest rank in his classes. By fulfilling a similar condition he was able to continue his course into the University where in $188_{3}$ he gained the degree of Licentiate in Philosophy and Letters, winning at the same time the prize for distinction.

The same year he was appointed Auxiliary Professor in the Institute of Matanzas. In 1884 he obtained the degree of Licentiate in Civil and Canon Law, once more winning the prize for special distinction.

\section{A N D M O N O R A P H S}




\begin{tabular}{|c|c|}
\hline 44 & C U B A N O F TO-DAY \\
\hline • & $\begin{array}{l}\text { In this year also he gained the degree of } \\
\text { Doctor of Philosophy and Letters and was } \\
\text { appointed Auxiliary Professor in the Uni- } \\
\text { versity of which he served as Secretary for } \\
\text { a time. } \\
\text { In I } 889 \text { he went as a member of a Com- } \\
\text { mission of professors to examine the stu- } \\
\text { dents of the College El Ateneo of Porto } \\
\text { Rico. In I } 893 \text { he won in competitive } \\
\text { examination the chair of Universal History } \\
\text { and in I } 898 \text { he was elected Dean of the } \\
\text { Faculty of Philosophy and Letters. He } \\
\text { formed part of the Commission appointed } \\
\text { in I } 899 \text { for the reform and reorganization } \\
\text { of the University Professorships. } \\
\text { When General Weyler became Governor } \\
\text { General, Professor Lendián found himself } \\
\text { obliged, on account of his opinions, to leave } \\
\text { Cuba and coöperated with the Revolu- } \\
\text { tionary Committee in New York in active } \\
\text { propaganda against the Spanish régime. } \\
\text { At the close of the war he joined the Patri- } \\
\text { otic Committee which was organized in } \\
\text { Havana, contributed to the formation of } \\
\text { the first political party-the National } \\
\text { party-and drew up the Manifesto which }\end{array}$ \\
\hline I & H I S P A I C NOTES \\
\hline
\end{tabular}




\section{E N D I Á N}

the party addressed to the country in I899.

In rgro he went to Mexico as one of the Envoys Extraordinary to attend the Centenary of Mexican independence and to bear the greetings of the University of Havana to the University of Mexico. Dr. Lendián has served as Magistrate of the Provincial Courts of Havana, Secretary of the College of Advocates, Director of the Society of Conferences, President of the Association of Doctors in Philosophy and Letters, Dean of the Faculty of Letters and Sciences, Editor of the Magazine published by the Faculty, Member of the Sociedad Económica, Member of the Anthropological Society and temporary Rector of the University.

$\mathrm{He}$ is professor of the History of America and of Modern History for the rest of the world; Honorary President of the Society Teatro Cubano; President of the Ateneo of Havana and also of the Academy of History; Member of the Cuban Society of International Law and Charter Member of the Cuban Red Cross.

\section{A N D M O N O R A P H S}




\begin{tabular}{|c|c|}
\hline 46 & C U B A N S O F T - D A Y \\
\hline & 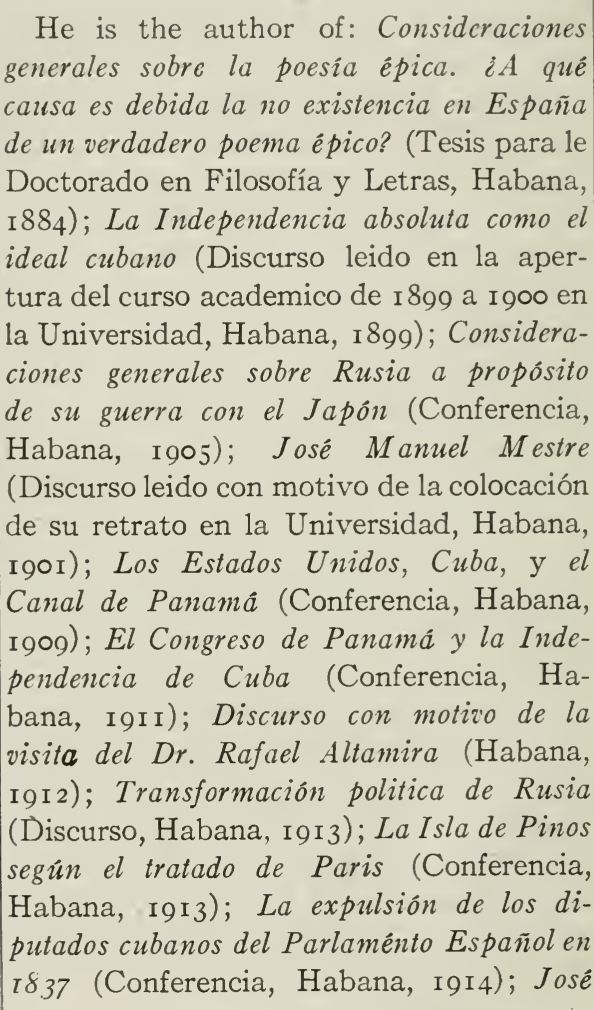 \\
\hline I & H I S P N I C NOTES \\
\hline
\end{tabular}




\section{E N D I Á N}

Antonio Saco (Conferencia, Habana, I914); Elogio del Dr. Ramón Meza y Suárez Inclan (Discurso leido en la Academia de la Historia, Habana, I915); La Interpretación de la Enmienda Platt (Discurso pronunciado en el congreso de Derecho Internacional, Habana, I9I7). 



\section{P L A S E N C I A}

\section{LEONEL PLASENCIA}

\section{Physician.}

Leonel Plasencia y Montes was born in Madruga, Province of Havana, in the year 1877 . His early studies were taken at the church school at Guanabacoa. Later he went abroad and studied at the Central University of Madrid, whence he returned to continue his studies at the University of Havana and there obtained the degree of Doctor in Medicine and Surgery.

$\mathrm{He}$ has served as Honorary Physician of the Hospital of Our Lady of Mercy and in 1906 became Anciliary Professor of the School of Medicine in the University. $\mathrm{He}$ is a member of the Academy of Sciences and Director of the Clinical Laboratory which bears his name.

Besides numerous monographs of a

H I S P A I C NOTES 


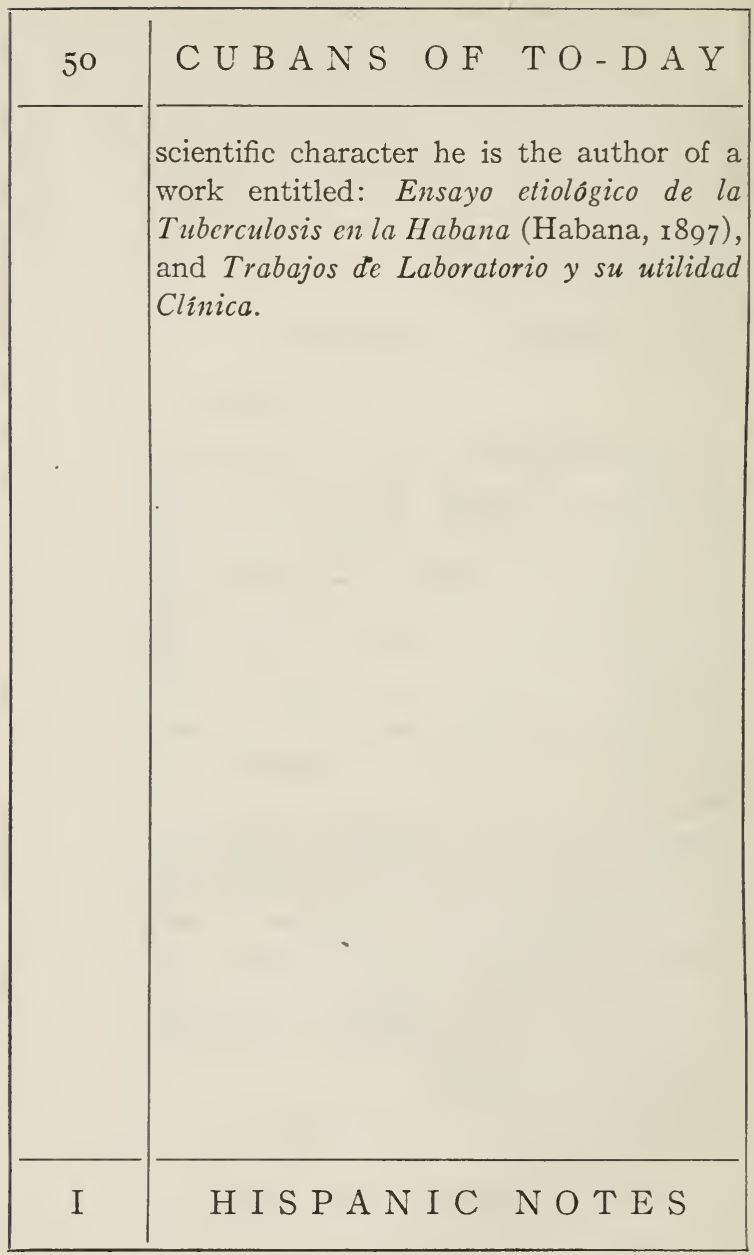



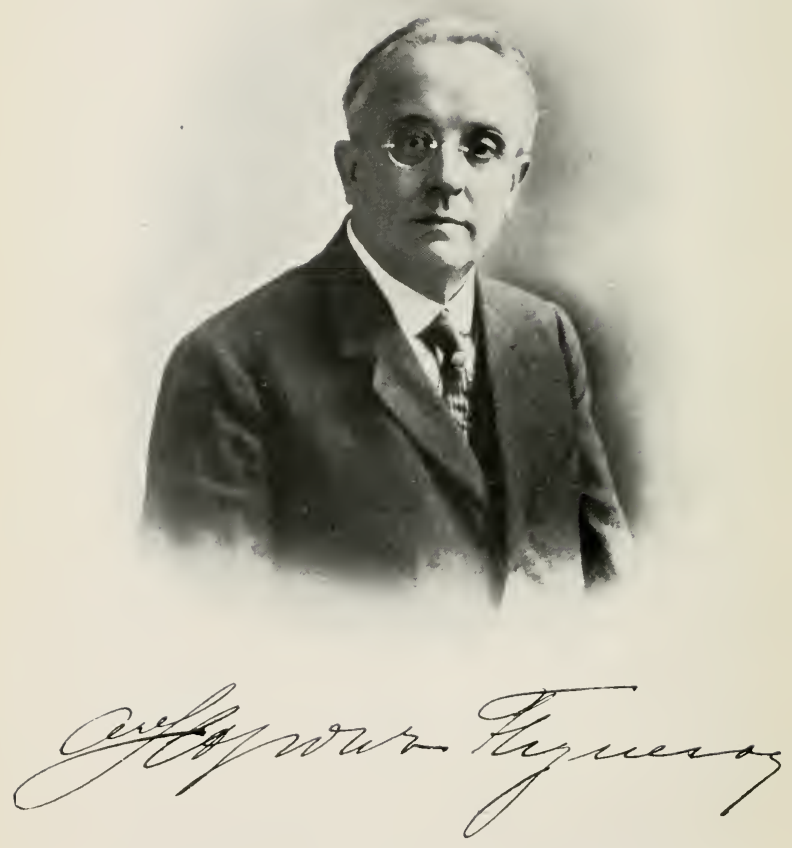


\section{F I G U E R O A}

LEOPOLDO FIGUEROA Y MARTÍ

Physician; public man.

Leopoldo Figueroa y Martí was born on the ninth of October, 1858 , in Santa Isabel de las Lajas, Province of Santa Clara. He was educated in Spain whither his father had been deported for political reasons and where, after completing the courses leading to the Bachelor's degree, he pursued the studies in the Faculty of Medicine for the degree of Doctor in Pharmacy which was granted him in $\mathrm{r} 88 \mathrm{r}$. $\mathrm{He}$ then returned to $\mathrm{Cuba}$ and established him. self first in Cárdenas and later at Cienfuegos.

Early in 1896 he joined the Revolution, taking part in the expedition of Colonel Arteaga and thereafter serving until the end of the war under the command of General José Miguel Gómez where he rose to the rank of LieutenantColonel. During

\section{A N D M O N O R A P H S}




\begin{tabular}{|l|l|}
\hline 52 & $\begin{array}{l}\text { C U B A N S O F T O - D A Y } \\
\text { the First American Intervention General } \\
\text { Wood appointed Figueroa Alcalde of Cien- } \\
\text { fuegos, an appointment which was ratified } \\
\text { by the public in the first elections held under } \\
\text { the Republic and by his reëlection in I go8. } \\
\text { In November of the same year he was } \\
\text { elected Senator for the Province of Santa } \\
\text { Clara to which office he has been reëlected } \\
\text { and which he now holds. He has served } \\
\text { on the following Committees of the Senate: } \\
\text { Health and Charities; Tariff Local Gov- } \\
\text { ernment, and Public Works of which last } \\
\text { he is the Chairman. Among the principal } \\
\text { laws proposed by Senator Figueroa are: } \\
\text { An Act to regulate the practice of Phar- } \\
\text { macy; An Act to remit the payment by the } \\
\text { city of Cienfuegos of a million pesos besides } \\
\text { the two fifths from which it was released } \\
\text { by Decree No. 8I3 of Governor Magoon } \\
\text { for the Aqueduct of Cienfuegos; An Act } \\
\text { revising the studies of the Faculty of } \\
\text { Pharmacy and of the School of Agronomi- } \\
\text { cal Engineers. } \\
\text { Senator Figueroa is a member of the } \\
\text { Liberal party and President of the party } \\
\text { in the Province of Las Villas. }\end{array}$ \\
\hline H I S P A N I C N O T E S \\
\hline I
\end{tabular} \mid





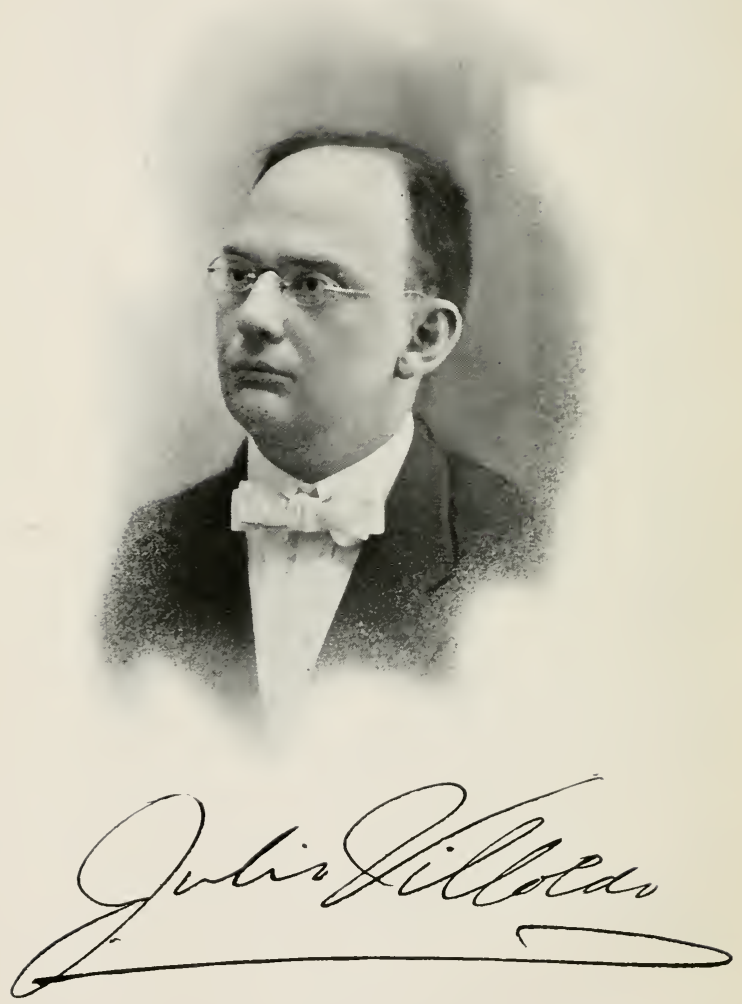




\section{I L L O L D O}

JULIO VILLOLDO

Author; editor.

Julio VILloldo y Bertrán was born in Havana on the eleventh of October, I88I, and obtained his early education partly in Cuba, and partly in the United States where he spent a portion of his youth. On returning to Cuba he entered the University of Havana to pursue the career of the law and won the degree of Doctor of Civil Law in 1907. But the call of journalism was stronger than that of the law and he devoted himself to writing. He became one of the editors of La Discusion, in which he established and, with the collaboration of associates, maintained for several years a special section called Ornato Público dedicated to the embellishment and adornment of the city.

In I9I 2 he was made a member of the

A N D M O N O G R A P H 


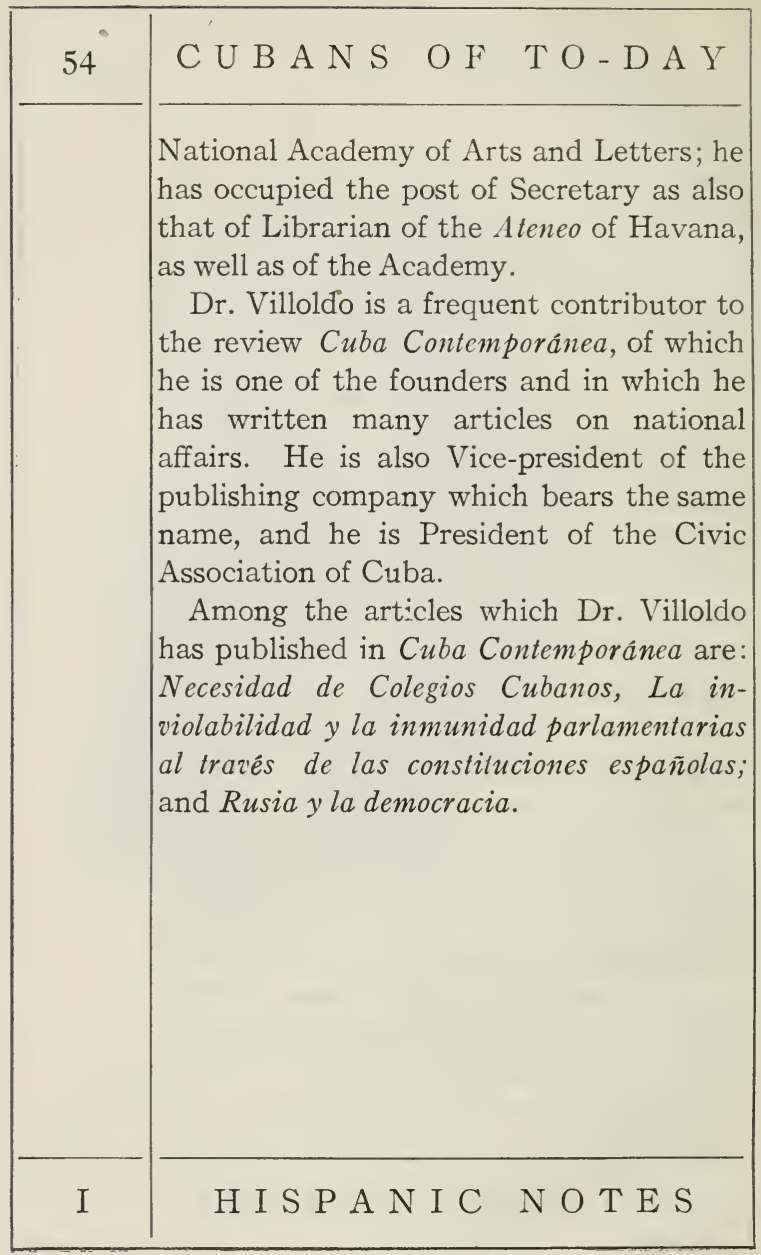




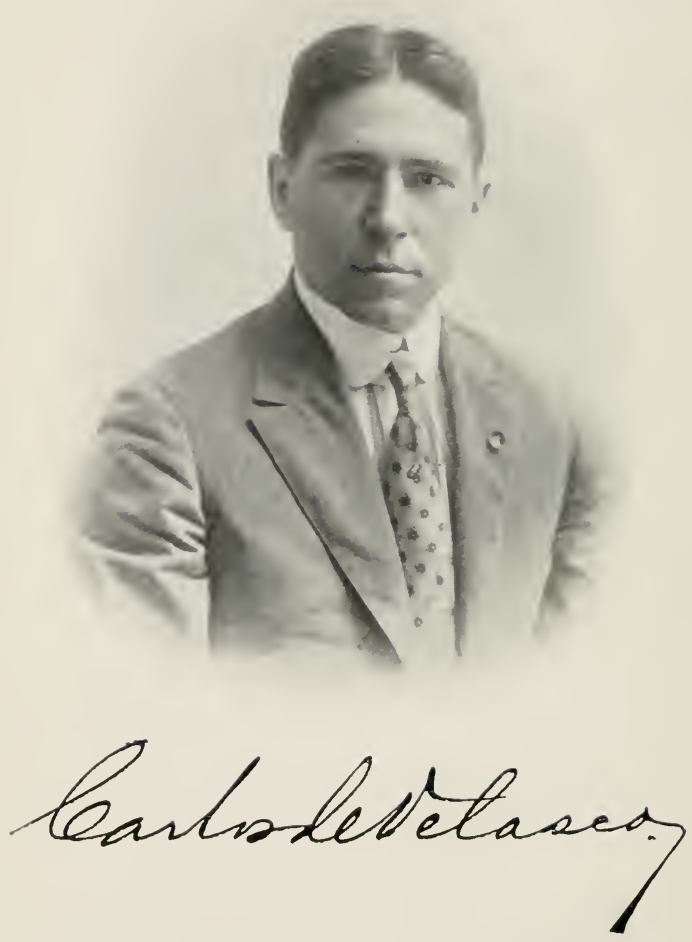


\section{CARLOS DE VELASCO Y PÉREZ}

Author; editor.

Carlos deVelasco y PÉREZ was born on the fourteenth of August, I884, in the city of Santa Clara and there, in the Colegio of "Santa Ana," he received his early instruction, but in 1900 his family removed to Havana where he completed his formal education in the Institute. At an early age he became associated with public men and affairs; first, while he was still a boy, with President Estrada Palma, and later with President Menocal, in both of whose administrations he served as Private Secretary to the Secretary of Gobernacion with the title of Chief of Administration.

Having chosen literature as his field of work, he became one of the founders and first editors of the newspaper La Prensa, later a member of the staff of $L a$ Discusion,

\section{A N D M O N O G R A P S}




\begin{tabular}{|c|c|}
\hline 56 & C U B A N O F TO-D A Y \\
\hline & $\begin{array}{l}\text { and in I9I3, with the coöperation of a } \\
\text { group of writers-Dr. José S. De Sola, Dr. } \\
\text { Julio Villoldo, Dr. Ricardo Sarabasa, Dr. } \\
\text { Max H. Urena, and Sr. Mario Guiral-he } \\
\text { founded the monthly review Cuba Con- } \\
\text { temporanea, which he has since edited and } \\
\text { which has made for itself a place in the } \\
\text { front rank of journals issued in Spanish on } \\
\text { this continent, numbering among its con- } \\
\text { tributors the most notable authors of Latin- } \\
\text { America. } \\
\text { Sr. Velasco has filled a number of posts } \\
\text { of a public character: in I I I he was Secre- } \\
\text { tary of the Ateneo of Havana; he served as } \\
\text { Secretary of the National Popular Com- } \\
\text { mission to erect a monument in honor of } \\
\text { General Máximo Gómez, Commander of } \\
\text { the Army of Liberation, and of the com- } \\
\text { mittee to celebrate the centenary of the } \\
\text { Cuban poetess G. G. de'Avellaneda, which } \\
\text { has prepared a definitive edition of her } \\
\text { works. He is a Member of the Academy of } \\
\text { History, Member of the National Academy } \\
\text { of Arts and Letters, Honorary Member of } \\
\text { the Royal Hispano-American Academy of } \\
\text { Science and Art of Cadiz (Spain), and he }\end{array}$ \\
\hline $\mathrm{I}$ & H I S P N I C NOTES \\
\hline
\end{tabular}




\section{E L A S C O}

holds the Order of the Liberator granted him by the Government of Venezuela. In I9I 5 the Municipal Council of his native city-Santa Clara-by a unanimous vote honored him with the title of "Distinguished Son."

He has written much and widely, being a contributor to the leading periodicals ànd magazines of Cuba and other LatinAmerican countries. He is the author of: Honrando al caido: Palabras de Estrada Palma (г gro); La Academia de la Historia de Cuba: Los Académicos de número (r910); Estrada Palma: Contribución histórica (rgII); Aspectos nacionales (I9r5); José Sixto de Sola (19r7). He has published also, with Introduction and Notes, the following books: Cartas Amatorias de la Avellaneda (Igrr); Pensando en Cuba (I9I7), a posthumous work of Dr. José S. de Sola; Desde el Castillo de Figueras (I918), letters of Estrada Palma. He is now preparing a study on the Cuban historian Pedro José Guiteras, and a translation from the Portuguese, Cartas Familiares y Billetes de Paris, de Eça de Queiroz. Finally,

\section{A N D $\mathrm{M} \mathrm{ONOGRAPH} \mathrm{S}$}




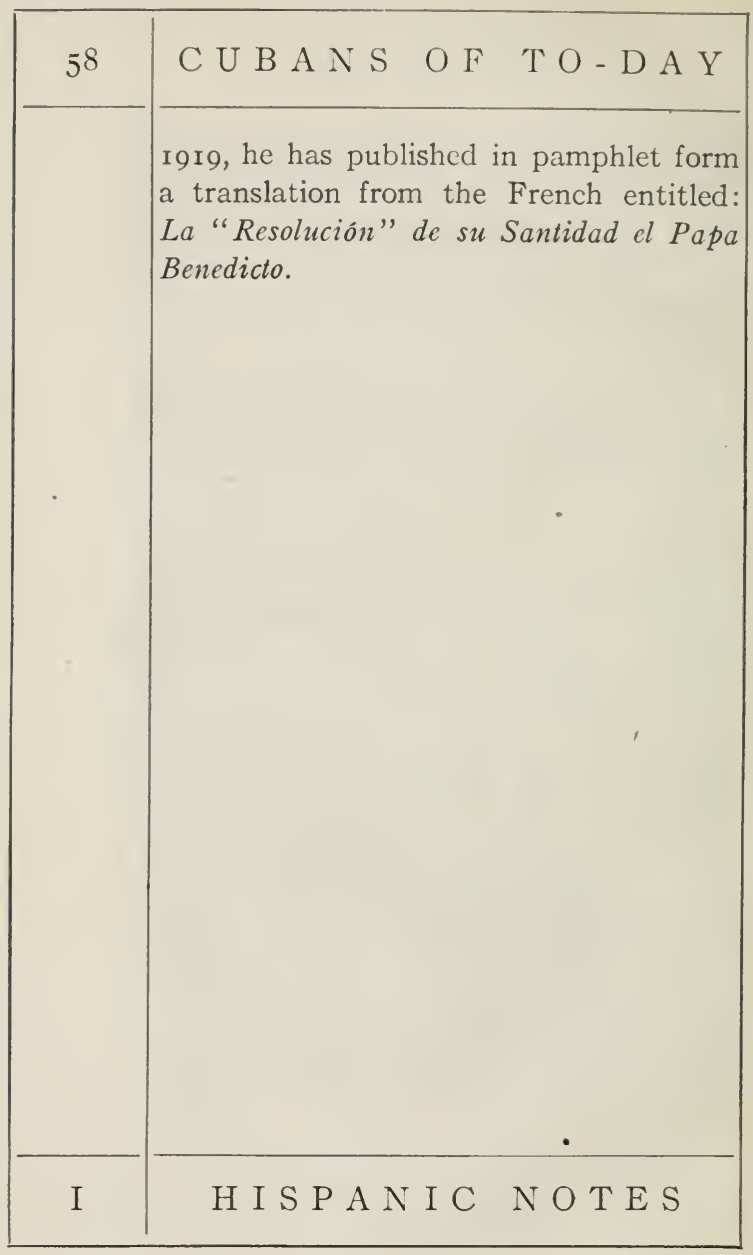




\section{G L E S I A}

\section{ALVARO DE LA IGLESIA Y SANTOS}

\section{Journalist; author.}

Alvaro de la Iglesia y Santos was born in la Coruña, Spain, on the fifth of April, 1859, and came to Cuba in 1874 , where for thirty-eight years he has lived the life of an active journalist, having served as editor or contributor on all the leading papers in Havana.

He founded $E l M$ Mndo, one of the most influential of Cuban newspapers, and is the dean of its editorial staff: he is also one of the editors of La Discusion on which he has served since before the War of Independence. He was editor-in-chief of La Época of Havana and of La Región of Matanzas. He was also the founder of La Familia Cristiana of Havana which he published for two years.

He has never held public office.

\section{A N D M O N O G R A P S}




\begin{tabular}{|c|c|}
\hline 60 & C U B A N S O F T O - D A Y \\
\hline & 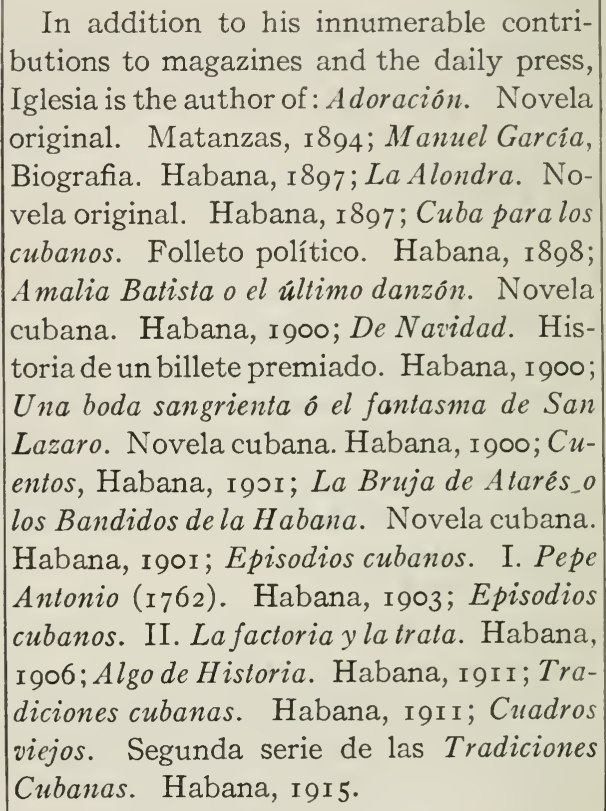 \\
\hline I & H I P A N I C N T E S \\
\hline
\end{tabular}





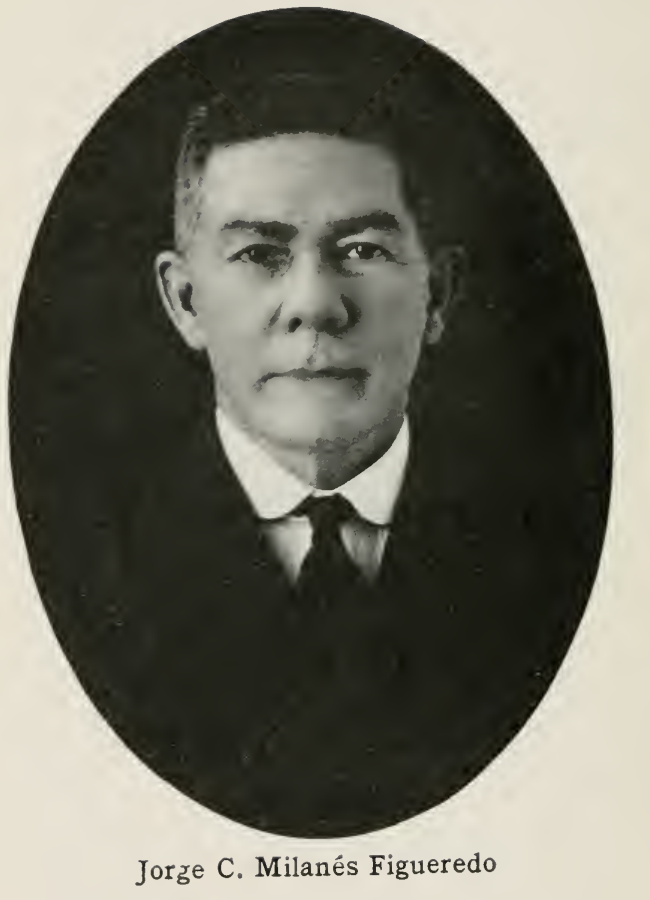




\section{I L A N É S}

\section{3}

\section{JORGE C. MILANÉS}

Lawyer; public man.

Jorge C. Milanés y Figueredo was born in the year 1859 in the town of $\mathrm{Ba}-$ yamo and there began his education. In I 868 his father took him to the revolutionary camp and in $\mathrm{r} 87 \mathrm{I}$ he was taken prisoner with all his family, except only his father, and obliged to leave Cuba. He went to Jamaica and later to Costa Rica where he completed his studies with the degree of Doctor of Laws granted by the University of St. Thomas.

In $188 \mathrm{I}$ he returned to Santiago de Cuba and in the following year, having obtained the validation of his degree at the University of Havana, entered upon the practice of his profession, first at Santiago de Cuba and later at Manzanillo.

When the War of Independence broke

\section{A N D M O N O R A P H S}




\begin{tabular}{|l|l|}
\hline C U B A N S O F T O - D A Y \\
\hline out in I895 he again withdrew to Costa \\
Rica, of which he had become a citizen, \\
and there for three years fulfilled the duties \\
of the office of Prosecuting Attorney of the \\
Provincial Court, meanwhile practicing his \\
profession. In November, I898, the war \\
being over, he returned again to Santiago \\
de Cuba, renounced his Costa Rican citi- \\
zenship to secure that of a Cuban and \\
was appointed Magistrate of the Provincial \\
Court in that city. \\
In January, I9oo, he was transferred to \\
Camagūey where he held the same office \\
and later he fulfilled similar duties in Pinar \\
del Rio and Santa Clara, finally being re- \\
turned to Santiago de Cuba. In I905 he \\
was appointed Presiding Judge of the Pro- \\
vincial Court of Santiago de Cuba. In \\
March, I9I8, he was appointed Presiding \\
Judge of the Civil Section of the Provincial \\
Court of Havana in which post he con- \\
tinues.
\end{tabular} \mid \begin{tabular}{l} 
H I S P A N I C N O T E S \\
\hline
\end{tabular}




\section{W E I S S}

\section{MARCELINO WEISS}

Dentist; soldier; teacher.

Marcelino Weiss was born in the ancient town of Sancti Spiritus on the ninth of June, 1877 . After receiving his early education in his native place and fulfilling the requirements for the Bachelor's degree in the Institute of Santa Clara, he went on in $\mathrm{r} 892$ to the University of $\mathrm{Ha}$ vana where he won the degree of Doctor of Dental Surgery in the year 1895 .

On the outbreak of the war (r895) he emigrated to the United States, there placing himself under the command of General Emilio Nuñez with whose forces he disembarked at Palo Alto. Later he was enrolled under the flag of José Miguel Gómez where his brothers were fighting and served as Secretary of the Army Corps, with the rank of Lieutenant.

\section{A N D M O N O G R P H S}




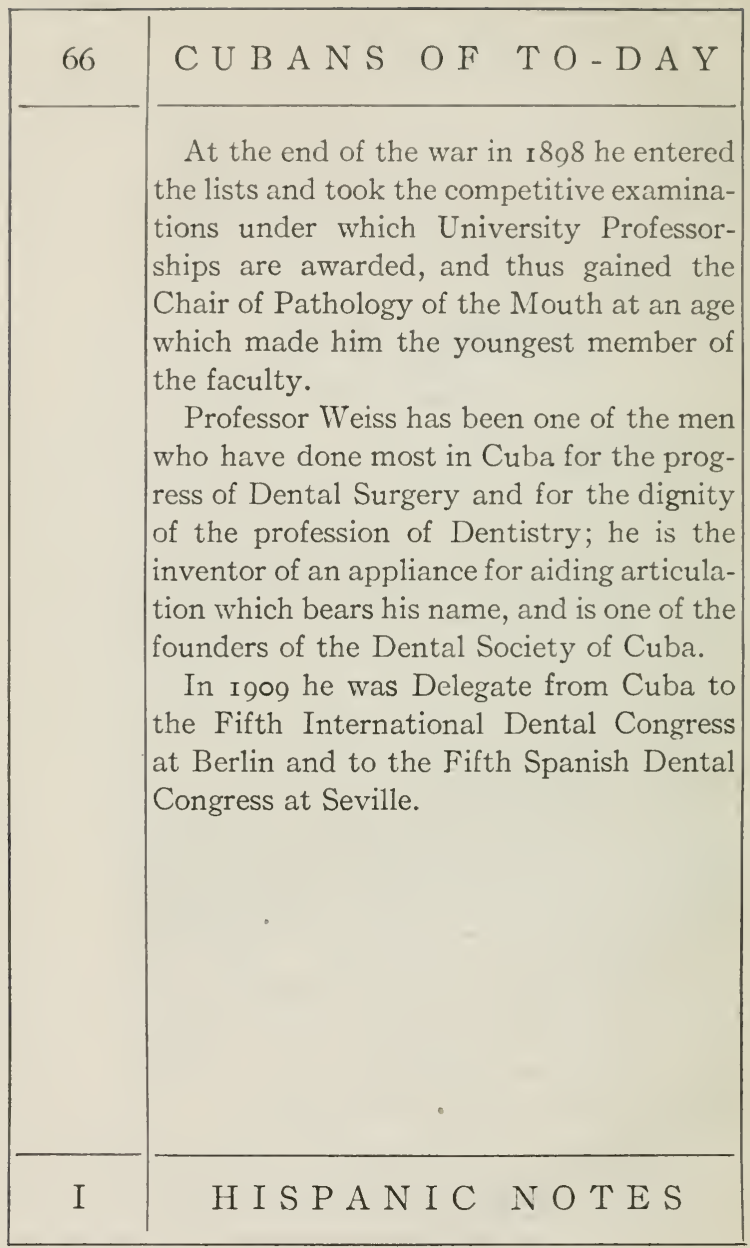





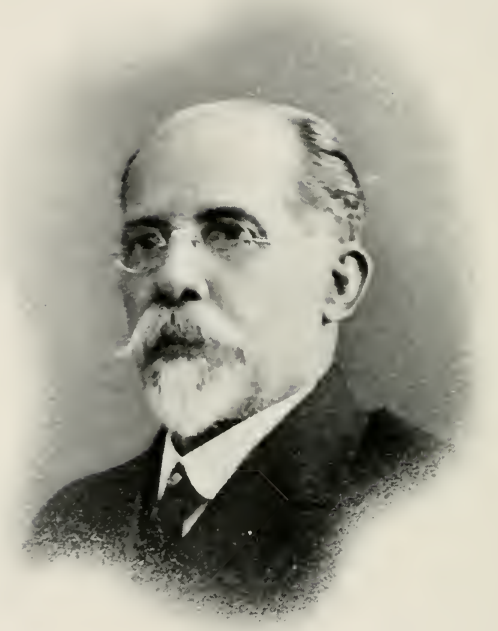

José Angel Malberti y Delgado 


\section{JOSÉ A. MALBERTI}

\section{Physician; patriot; alienist.}

José A. Malberti was born on the fourth of July, 1854 , in Baracoa where he began his studies which he afterwards continued in Spain at the University of Barcelona and there, in 1875 , obtained the degree of Doctor of Medicine. After further studies in Paris, Dr. Malberti returned to Cuba and entered on the practice of his profession in his native town of Baracoa. There, however, he became involved in the revolutionary movement of 1879 and was obliged to take refuge in an American schooner bound for New York.

In $\mathrm{I} 880$ he again returned to Cuba and settled in Havana where he was appointed physician to the Asylum for the Insane (Casa de Enajenados). Here he devoted all his time and energy to the study of

\section{A N D M O N O G R A P H S}




\begin{tabular}{|c|c|}
\hline 68 & C U B A N O F TO-D A Y \\
\hline & $\begin{array}{l}\text { mental ailments and became a skillful } \\
\text { alienist, rising step by step in the Asylum } \\
\text { staff until he became Director, a position } \\
\text { which he filled for sixteen years. } \\
\text { He became involved again in the revolu- } \\
\text { tionary movement-that of I } 895 \text {-and was } \\
\text { forced to flee to Mexico where he continued } \\
\text { the practice of medicine and became a } \\
\text { member of the faculty of the University } \\
\text { of Mexico, meantime conspiring actively } \\
\text { and at much cost to himself against the } \\
\text { Spanish rule by establishing political clubs } \\
\text { which maintained a constant propaganda } \\
\text { in support of Cuban liberty and of the } \\
\text { Revolution as a means thereto. } \\
\text { At the end of the war (I } 898 \text { ) Malberti } \\
\text { came back to Cuba to accept the post of } \\
\text { President of the Board of Managers of the } \\
\text { Hospital for the Insane. In I } 902 \text { he was } \\
\text { elected Representative on the Liberal ticket } \\
\text { and chosen Vice-president in two Con- } \\
\text { gresses and President in one. During his } \\
\text { period of service in the Legislature he was } \\
\text { author of no fewer than eighteen bills affect- } \\
\text { ing the public health and the organization } \\
\text { of sanitary service. }\end{array}$ \\
\hline $\mathrm{I}$ & H I S P A I C NOTES \\
\hline
\end{tabular}




\section{A L B E R T I}

In I906 Dr. Malberti founded a private hospital for mental ailments. He is editor of the Archivos de Medicina Mental and author of Tratamiento sugestivo de la locura, I 896 .

A N D M Ọ N O G A P H S I 



\section{B A R A L T, J R.}

LUIS A. BARALT, JR.

Lawyer; teacher.

Luis A. Baralt, JR., was born on the twelfth of April, 1892, in New York, where he lived until I900. At that time his parents established themselves in Havana, $\mathrm{Cuba}$, and there he has resided ever since. His father (q.v.) is a distinguished educator, lecturer, and diplomat. His mother, Blanche Z. de Baralt (q.v.), is well known in Cuba and in the United States as a lecturer and writer.

Dr. Baralt received his college education at the University of Havana, where he obtained the degrees of Doctor of Laws and Doctor of Philosophy and Letters. For his scholarship in the Faculty of Letters and Sciences, he was awarded the high distinction of "alumno eminente de la Universidad," which honor he won in competition.

\section{H I S P A N I C N O T E S}




\begin{tabular}{|c|c|}
\hline 72 & C U B A N S O F T $-\mathrm{DAY}$ \\
\hline & $\begin{array}{l}\text { He was also awarded a traveling fellowship } \\
\text { which allowed him to study at Harvard and } \\
\text { Columbia Universities for two years. At } \\
\text { Harvard he studied Experimental Psy- } \\
\text { chology under Munsterberg and conducted } \\
\text { original investigations. There he took the } \\
\text { degree of A.M. } \\
\text { He is now engaged in the practice of law } \\
\text { at Havana and, besides, is Professor of Eng- } \\
\text { lish at the Institute of Havana. } \\
\text { He has published his doctorate thesis on } \\
\text { "The Relations between Ethics and Re- } \\
\text { ligion" and a number of essays on philo- } \\
\text { sophical and literary subjects which have } \\
\text { not been collected. } \\
\text { He is a member of the Sociedad Cubana } \\
\text { de Derecho Internacional, in whose work } \\
\text { he has taken an active part since its foun- } \\
\text { dation. At its annual meeting, I } 9 \text { I9, he } \\
\text { read a paper on "The International Sig- } \\
\text { nificance of the Russian Revolution." }\end{array}$ \\
\hline I & H I S P N I C NOTES \\
\hline
\end{tabular}




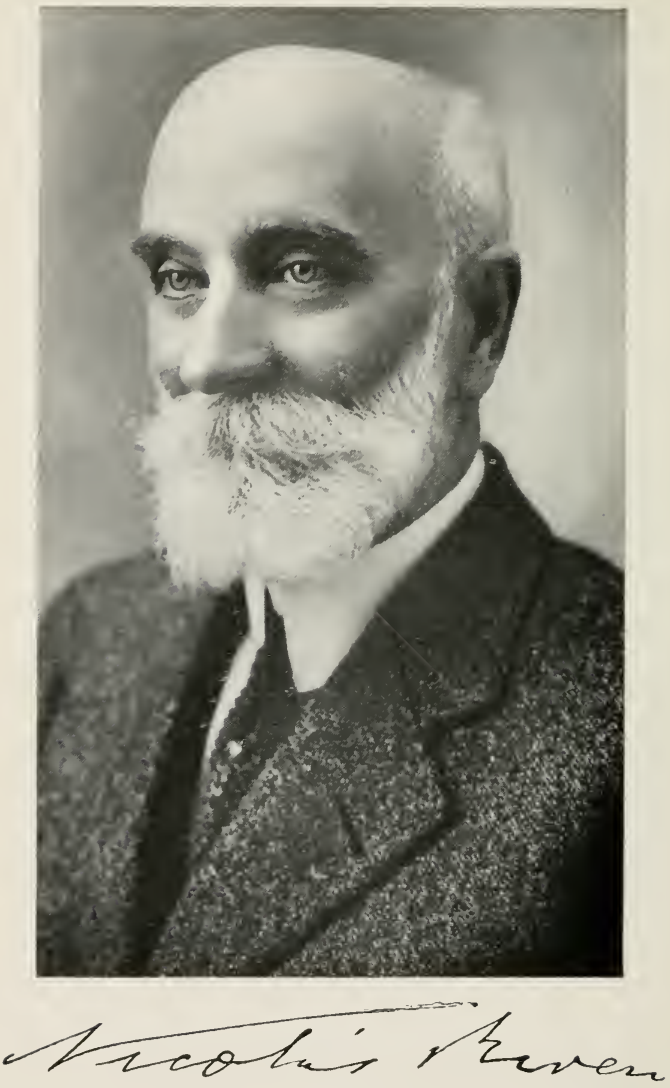


\section{J O R R Í N}

\section{LEONARDO SORZANO-JORRÍN}

Teacher; writer.

LEONARDO SORZANO-JORRÍN was born in Paris, during the voluntary exile of his grandfather, José Silverio Jorrín, and his family, at the time of the Ten Years' War. Educated in the United States, he received his A.B. degree at Georgetown University in 1899 and thence proceeded to Havana, where he studied law at the University of Havana and was admitted to the bar in I9II, being now a practicing lawyer and notary public.

In 1900 he won, through competitive examination, a life professorship of the English Language in the Institute of $\mathrm{Ha}-$ vana where he is still lecturing. He has written two elementary school books for the teaching of English, which have run into many editions, entitled Libro Pri-

\section{A N D M O N O R A P H S}




\section{4 \\ C U B A N S OF TO-D A Y}

mero de Inglés and Libro Segundo de Inglés and an Elementary Phonetics now in the press, and is an enthusiastic student of phonetics, being a member of long standing of the International Phonetic Association and of the Société de Dialetologie Romaine.

Mr. Sorzano-Jorrín was one of the founders and for many years a member of the Board of Directors of the Vedado Tennis Club, and materially helped to introduce and popularize the games of lawn-tennis and squash and the sport of rowing in Cuba.

He is the head of the Knights of Columbus in Cuba. 


\section{NICOLÁS RIVERO}

Journalist; author; publicist.

Nicolás Rivero was born on the twenty-third of September, I849, in VillaViciosa de Asturias in Spain, and there received his early education, but in 1858 entered the Seminary of Oviedo to be prepared for a career in the Church. In I872, at the age of twenty-three, when he was about to be ordained, he fled the Seminary to go and fight on the side of Don Carlos of Bourbon, the Pretender to the Spanish Crown. In this struggle he was taken prisoner and imprisoned first in one Spanish jail and then in another and finally exiled to the Canary Islands. There he plotted an uprising to seize a warship but the plan was discovered, and Rivero was transported to Cuba with four hundred other political prisoners to fill the ranks of

\section{A N D MONOGRAPHS}




\begin{tabular}{|c|c|}
\hline 76 & $\mathrm{C} U \mathrm{BANS} O \mathrm{OF}$ T O - D A Y \\
\hline * & $\begin{array}{l}\text { the Spanish regiments fighting to suppress } \\
\text { the Cuban insurgents. } \\
\text { After three months Rivero escaped to } \\
\text { Spain on the steamer Castilla and rejoined } \\
\text { the Carlist forces. With them he took part } \\
\text { in the battle of Montejura and continued } \\
\text { steadily fighting from I } 873 \text { to I } 875 \text {, during } \\
\text { which period he rose by his service in the } \\
\text { field to the rank of Major. At the end of } \\
\text { the war he took refuge in France, but in } \\
\text { I } 876 \text { an armistice permitted him to return } \\
\text { to Spain where he settled in Oviedo and } \\
\text { took up the practice of a notary. } \\
\text { In I } 880 \text { he returned to Cuba and de- } \\
\text { voted himself completely to journalism as } \\
\text { a strenuous defender of the sovereignty } \\
\text { of Spain. Settling in Havana he edited } \\
\text { El Relampago until, in consequence of its } \\
\text { severe attacks upon the Spanish Captain } \\
\text { General, it was suppressed. Then he pub- } \\
\text { lished El Rayo and, later, La Centella, both } \\
\text { of which came under the ban. His attacks } \\
\text { upon the Spanish authorities led General } \\
\text { Blanco to deport him to Spain, but in two } \\
\text { months the unyielding journalist was on } \\
\text { his way back to Cuba. In I } 883 \text { he founded }\end{array}$ \\
\hline I & H I S P A I C N O T E S \\
\hline
\end{tabular}




\section{R I V E R O}

the newspaper called El General Tacón; it was suspended. He founded $\mathrm{El}$ Español; it met the same fate: then El Pensamiento Español which was likewise suppressed.

In 1893 Rivero joined the staff of the Diario de la Marina and, in 1895 , when the War of Independence was raging, became its editor. The period was a very difficult one for the paper because it stood for the Spanish cause, and the triumph of the Revolution left it in an unfortunate position. But Rivero had maintained strong relations with the Autonomist party which now stood him in good stead and enabled him to make headway under the new conditions.

The war over, he adopted a discreet political course, urging reconciliation between Spaniards and Cubans and forgetfulness of past differences in a joint effort to make Cuba prosperous. His services in this direction were recognized by the Spanish Government which honored him in I 902 with the Cross of Alfonso XII, and he has continued to uphold the interests of the Spaniards in Cuba, supporting a political course of moderation and security.

\section{A N D M O N O R A P H S}




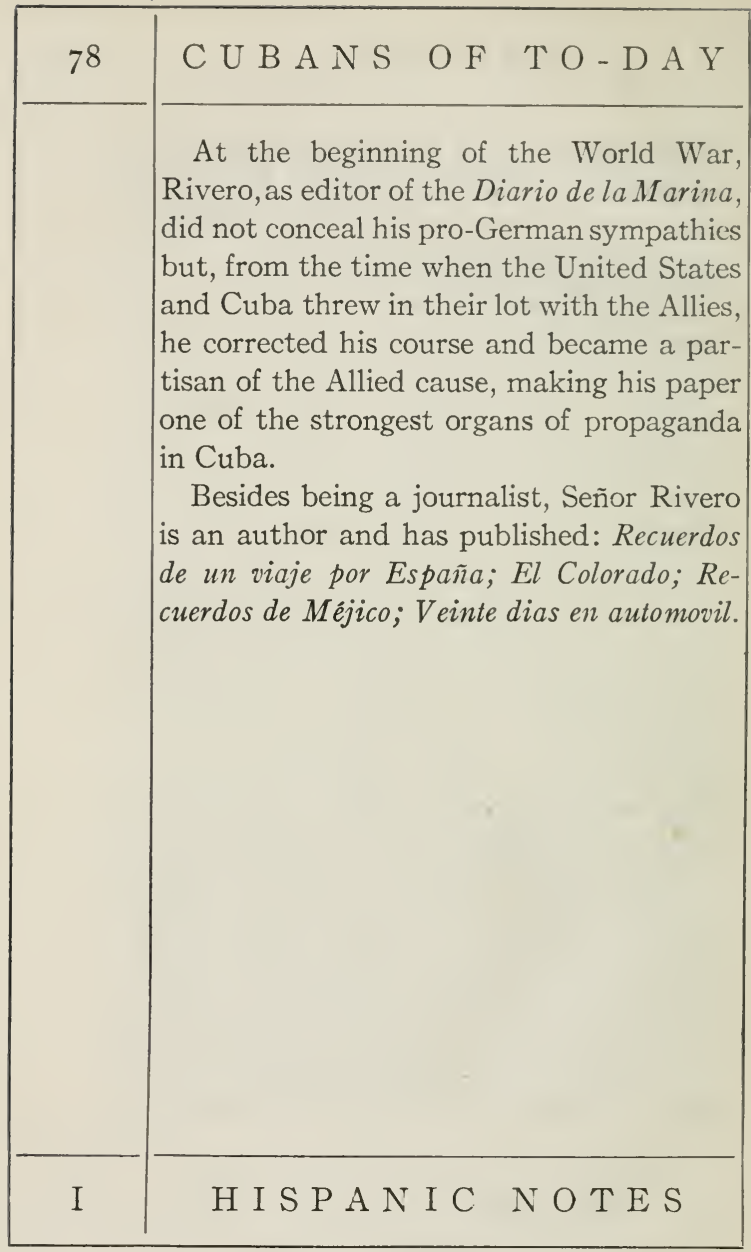




$$
8
$$




\section{T O R R I E N T E}

COSME DE LA TORRIENTE

Soldier; diplomat; lawyer; statesman.

Cosme de la Torriente y Peraza (son of Leandro and Maria Ignacia) was born on the estate of his father, "La Isabel," near Jovellanos in the Province of Matanzas on the twenty-seventh of June, I872. $\mathrm{He}$ was educated in the Institute of $\mathrm{Ma}$ tanzas where he completed the course for the Bachelor's degree and at the University of Havana, where he pursued the studies for the law until I 895 when he joined the Revolution which broke out on the twenty-fourth of February of that year. He had obtained the degree of Licentiate in Philosophy and Letters in 1892 , for he had pursued this course simultaneously with that of law, and he obtained the degree of Licentiate in Law on his return from the battlefield at the close of 1898 .

\section{A N D M O N O G R P H S}




\begin{tabular}{|c|c|}
\hline 80 & C U B A N S F T O - D A Y \\
\hline ' & $\begin{array}{l}\text { When the Revolution began in I } 895 \\
\text { Torriente was active in the revolutionary } \\
\text { clubs of Matanzas, and in March of that } \\
\text { year he embarked for the United States } \\
\text { to take part in the filibustering expeditions } \\
\text { there being organized. He was a partici- } \\
\text { pant in several of those which were cap- } \\
\text { tured and in consequence was imprisoned } \\
\text { at different times, at Washington, Dela- } \\
\text { ware, at Nassau in the Bahamas, and at } \\
\text { New York. Finally he joined the famous } \\
\text { expedition in the steamer Bermuda under } \\
\text { the command of General Calixto García } \\
\text { which landed successfully in Baracoa, and } \\
\text { he served throughout the rest of the war } \\
\text { under Generals Máximo Gómez, Calixto } \\
\text { García, José Maria Rodriguez, Francisco } \\
\text { Carrillo, and José Manuel Capote. He } \\
\text { served as Representative for Pinar del } \\
\text { Rio in the Constituent Assembly of Yaya, } \\
\text { Camagüey, returning to the field on its } \\
\text { dissolution. When the war closed he had } \\
\text { gained the rank of Colonel on the General } \\
\text { Staff, having taken part in the attack and } \\
\text { siege of Santiago de Cuba as Chief of Staff } \\
\text { in the Division commanded by Major }\end{array}$ \\
\hline I & H I S P A I C N O T E S \\
\hline
\end{tabular}




\section{T O R R I E N T E}

General José Manuel Capote. He took part also in the fighting along the GibaraHolguin line between the forces of General Calixto García and the Spanish General Luque, which continued until August seventeenth because the opposing forces were not aware that the Peace Protocol had been signed in Washington on the twelfth.

When the Spanish sovereignty ceased General Ludlow, the Military Governor of Havana, appointed Torriente Secretary of the Civil Government and later Acting Governor of the Province. In August, I899, he was appointed Magistrate of the Provincial Courts (Court of Appeals) of Santa Clara and in 1900 he assumed similar duties in Matanzas, his native Province. There he remained until 1903 when President Estrada Palma appointed him Secretary of Legation at Madrid, where he served as Chargé d'Affaires until some time later when he was appointed Minister, and also Envoy Extraordinary, to represent the Republic of Cuba at the wedding of King Alfonso who conferred upon him on that

\section{A N D M O N O G R A P S}




\begin{tabular}{|l|l|}
\hline C U B A N S O F T O - D A Y \\
\hline $\begin{array}{l}\text { Occasion the Grand Cross of Isabel the } \\
\text { Catholic. When the anarchist attempt } \\
\text { then made upon the lives of King Alfonso } \\
\text { and his bride occurred, the Cuban envoy } \\
\text { and his wife were among those nearest to } \\
\text { the royal pair and like them escaped un- } \\
\text { hurt although about a hundred people were } \\
\text { killed or wounded. } \\
\text { In I9o6 when the revolution broke out } \\
\text { against President Estrada Palma, and an } \\
\text { American Interventional government took } \\
\text { charge of the country, Torriente resigned } \\
\text { his charge although he was the only Cuban } \\
\text { diplomat who did so, preferring not to act } \\
\text { as foreign representative of the provisional } \\
\text { government. The first and only Treaty } \\
\text { ever made between Cuba and Spain-that } \\
\text { is to say between the former Colony and } \\
\text { her former sovereign-the Treaty of Ex- } \\
\text { tradition now in force, was negotiated by } \\
\text { Torriente and bears his signature. } \\
\text { Since I } 906 \text { he has devoted himself to } \\
\text { the practice of the legal profession and to } \\
\text { public affairs. During the administration } \\
\text { of President Gómez he held for a time the } \\
\text { office of Civil Service Commissioner, the }\end{array}$ \\
\hline H I S P A N I C N O T E S
\end{tabular} \mid




\section{T O R R I E N T E}

Commission consisting then of three members, two of the places being held by Liberals and one by a Conservative, Torriente, until the beginning of I9I 2 when he resigned. On his return from Spain he was one of those who founded and organized the National Conservative party which he served for some years as General Secretary, later as Vice-president, and finally as President which honor he laid down at the end of I9I4, but still continues to be Honorary President of the party.

In 1908 he was candidate for Senator from his native province and in I9ro for Representative and was later elected Senator for the term of eight years beginning in April, I9I8. He was the first Secretary of State in President Menocal's administration. Among matters of international importance which came under his charge, and were determined in accordance with his opinion and counsel, was the question of claims made by England, France, and Germany for damages suffered by their subjects during the War of Independence

\section{A N D M O N O G A P H S}




\begin{tabular}{|c|c|}
\hline 84 & C U B A N S O F T O - D A Y \\
\hline & $\begin{array}{l}\text { and known as the "Tripartite Claims, "and } \\
\text { the case, no less famous, of the Ports } \\
\text { Company of Cuba, known as the "Com- } \\
\text { pañia del Dragado." In regard to the } \\
\text { latter question it was the judgment of the } \\
\text { Cuban Government, sanctioned without } \\
\text { dissent by the Supreme Court of Cuba, that } \\
\text { it was the most important case of its kind } \\
\text { that had arisen in Cuba and possibly in any } \\
\text { country in America and offered more } \\
\text { difficulties than any other in its study and } \\
\text { solution. } \\
\text { Señor Torriente is the first Vice-presi- } \\
\text { dent of the Association and also of the } \\
\text { National Council of Veterans of the War } \\
\text { of Independence; Vice-president of the } \\
\text { Cuban Society of International Law, and } \\
\text { one of the four members for Cuba in The } \\
\text { Hague Tribunal of Arbitration; he is a } \\
\text { member also of the High International } \\
\text { Commission for Uniform Legislation which } \\
\text { holds its sessions in Washington. He is } \\
\text { the Chairman of the Committee on For- } \\
\text { eign Affairs in the Senate of Cuba. } \\
\text { On the declaration of war by Cuba upon } \\
\text { the Imperial Governments of Germany and }\end{array}$ \\
\hline $\mathrm{I}$ & H I P A N I N O T E S \\
\hline
\end{tabular}




\section{T O R R I E N T E}

Austria, Senator Torriente took an active part in presenting and urging the principal laws dealing with the war, among them the act for Aid to the Allies which was due to his initiative and became law on the fifteenth of May, r9r8. By this there was granted a credit of $\$ 2,400,000$ annually, to support the civil populations in the war zones of Europe and to succor the soldiers who were victims of the war, and their families. He was President of the Cuban National Committee created by the law of Propaganda for the war and of Aid to its Victims. In recognition of his labors and efforts the French Republic has conferred upon him the decoration of an Officer of the Legion of Honor and he has received the thanks of the Government of Great Britain.

Senator Torriente is a Member by Merit as also Corresponding Member of the Royal Hispanic-American Academy of Science and Art of Madrid: Honorary Member of the Faculty of Political and Administrative Science of the University of St. Mark of Lima, Honorary Corresponding Member

\section{A N D M O N O G R P H S}




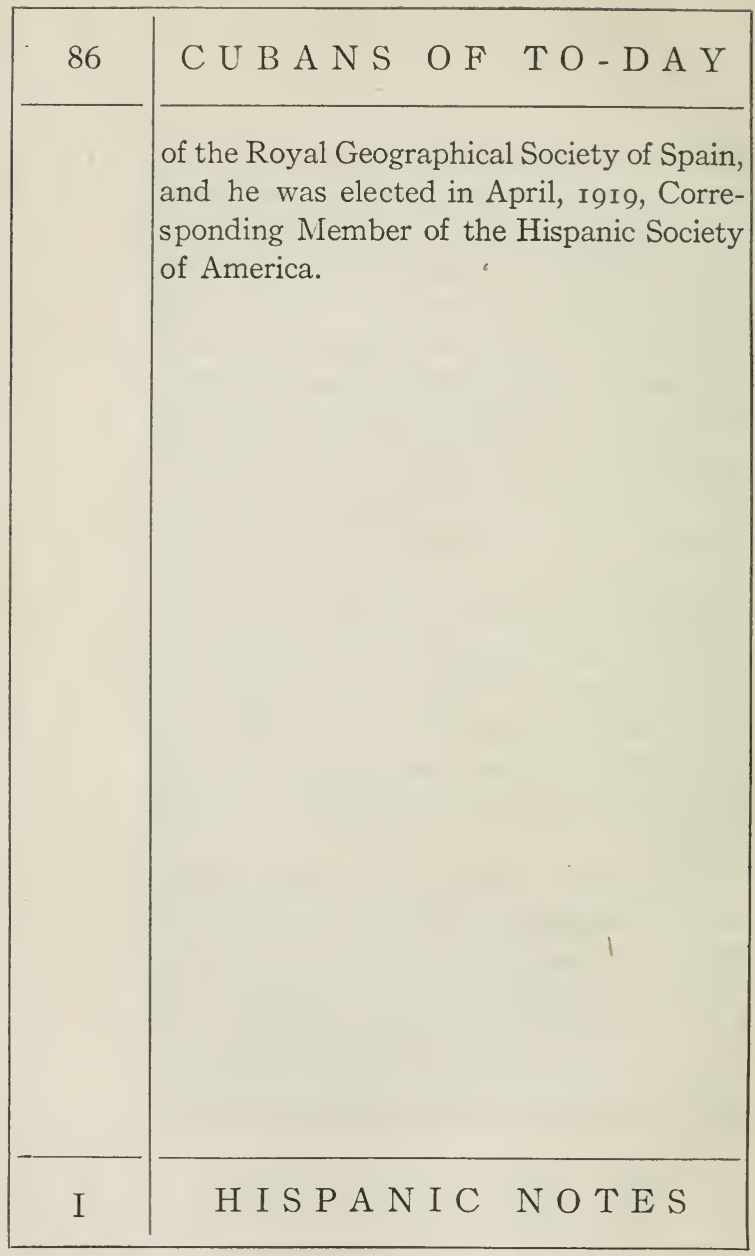




\section{B E T A N C O U R T}

ARTURO BETANCOURT MANDULEY

Lawyer; public man.

Arturo Betancourt Manduley was born in the town of Holguin, Province of Oriente, Cuba, on the third of August, I870. His formal education was interrupted in his youth and was not resumed until much later.

When the War of Independence broke out in 1895 he was deported from the city of Santiago and withdrew to the state of Yucatan, Mexico, where he continued active in the cause of the Revolution until opportunity offered to return and join the Cuban forces in the field. Disembarking in the Province of Santa Clara he served with the rank of Lieutenant under the command of Major General Máximo Gómez.

Some years later he returned to his 


\begin{tabular}{|c|c|}
\hline 88 & C UBANS OF TO-DAY \\
\hline & $\begin{array}{l}\text { studies; he completed the courses for the } \\
\text { Bachelor's degree at the Institute of San- } \\
\text { tiago de Cuba in I909; in I9I I he took the } \\
\text { Civil Service Examinations for administra- } \\
\text { tive service; in I9I } 2 \text { he took the examina- } \\
\text { tions for Procurator before the provincial } \\
\text { court of Oriente and in I9I } 4 \text { he obtained } \\
\text { the degree of Doctor of Civil Laws in the } \\
\text { University. In I9I6 he was appointed } \\
\text { Notary Public for the Municipal district } \\
\text { of Cobre, Oriente, and practices the pro- } \\
\text { fession of law in Santiago de Cuba and } \\
\text { Havana. } \\
\text { He has taken an active part in politics. } \\
\text { For three and a half years he served as } \\
\text { Private Secretary to the Governor of } \\
\text { Oriente. In the general elections of I9I } 2 \\
\text { he was elected Representative from the } \\
\text { Province of Oriente on the Liberal ticket } \\
\text { and was reëlected in I } 16 \text {. In the House } \\
\text { of Representative he has been Secretary of } \\
\text { the House; Vice-president of the Committee } \\
\text { on Foreign Relations, Member of the Com- } \\
\text { mittee on Justice and Codes, and President } \\
\text { of the Committee on Petitions and Con- } \\
\text { cessions. }\end{array}$ \\
\hline I & H I S P N I C NOTES \\
\hline
\end{tabular}




\section{B E T A N C O R T}

From the year r 9 ro he has been General Secretary of the Liberal party in the Province of Oriente.

He took an active part in the Revolution of 1917 and was appointed Legal Adviser to the Provincial Government of Oriente, President of the Committee on Banks, and Colonel in the Legal Staff of the Revolutionary army.

$\mathrm{He}$ is the author of many laws to improve the condition of labor and of public roads. 



\section{F I G A R O L A}

\section{I}

\section{DOMINGO FIGAROLA-CANEDA}

Librarian; editor; author.

Domingo Figarola-Caneda was born in Havana on the seventeenth of January, I 852 . He completed the courses leading to the Bachelor's degree and at an early age entered upon a literary career, working as a journalist-contributor, editor, and correspondent-on various newspapers among them El Triunfo, El Pä̈s, and La Lucha.

In 1876 he founded, in Havana, El Mercurio which he published until the following year. In $\mathrm{I}_{883}$ he founded $\mathrm{El} \mathrm{Argumento}$ which had a brief career in Havana. In I 885 he founded La Ilustración Cubana in Barcelona and directed it until $I 887$. In Paris he founded and published $L a$ Repüblica Cubana, I896-I897. Finally he founded $\mathrm{La}$ Revista de la Biblioteca $N$ acional in Havana.

\section{H I S P A I C NOTE S}




\begin{tabular}{|c|c|}
\hline 92 & C U B A N O F TO-DAY \\
\hline & $\begin{array}{l}\text { Señor Figarola is a member and one of } \\
\text { the founders of the Academy of History } \\
\text { and is keeper of its Annals. He is also a } \\
\text { consulting member of the Permanent } \\
\text { Council of the American Congress of Bib- } \\
\text { liography and History of Buenos Aires. } \\
\text { He is the author of the following works: } \\
\text { Biografia de don Saturnino Valverde (Ha- } \\
\text { bana, I88o); Guia Oficial de la Exposición } \\
\text { de Matanzas (Matanzas, r88I); Biblio- } \\
\text { grafia de Rafael Merchán (Habana, I9o5); } \\
\text { El Dr. Ramón Meza y Suárez Inclan, } \\
\text { noticia bibliográfica (Habana, roog), and } \\
\text { Curtografía cubana del British Museum, a } \\
\text { chronological catalogue of charts, plans, } \\
\text { and maps from the sixteenth to the nine- } \\
\text { teenth century. He collaborated upon the } \\
\text { Diccionario Biográfico cubano, de Cal- } \\
\text { cagno (New York-Habana, I878-86); he } \\
\text { arranged the materials of the Obras de Rosa } \\
\text { Kruger (T. I. Habana, I883), and as part } \\
\text { of the Biblioteca de La Ilustración cubana } \\
\text { published the Poesias de Julia Pérez de } \\
\text { Montes de Oca (Barcelona [r887]); Los } \\
\text { negros, de Antonio Bachiller y Morales } \\
\text { (Barcelona [r887]); Seis conferencias, de }\end{array}$ \\
\hline I & H I P A N I C N O TES \\
\hline
\end{tabular}




\section{F I G A R O L A}

Enrique José Varona (Barcelona [I887]) and Dos Amores, de Cirilo Villaverde (Barcelona, I 887).

In addition to these books, Figarola has published the following of which also he is the author:

Escudos primitivos de Cuba (Habana, I9г3); Memorias inéditas de la Avellaneda (anotadas, Habana, I9I4); Milanés y Plácido (Habana, I9I4); Bibliografía de Luz y Caballero (Habana, I9I 5). 




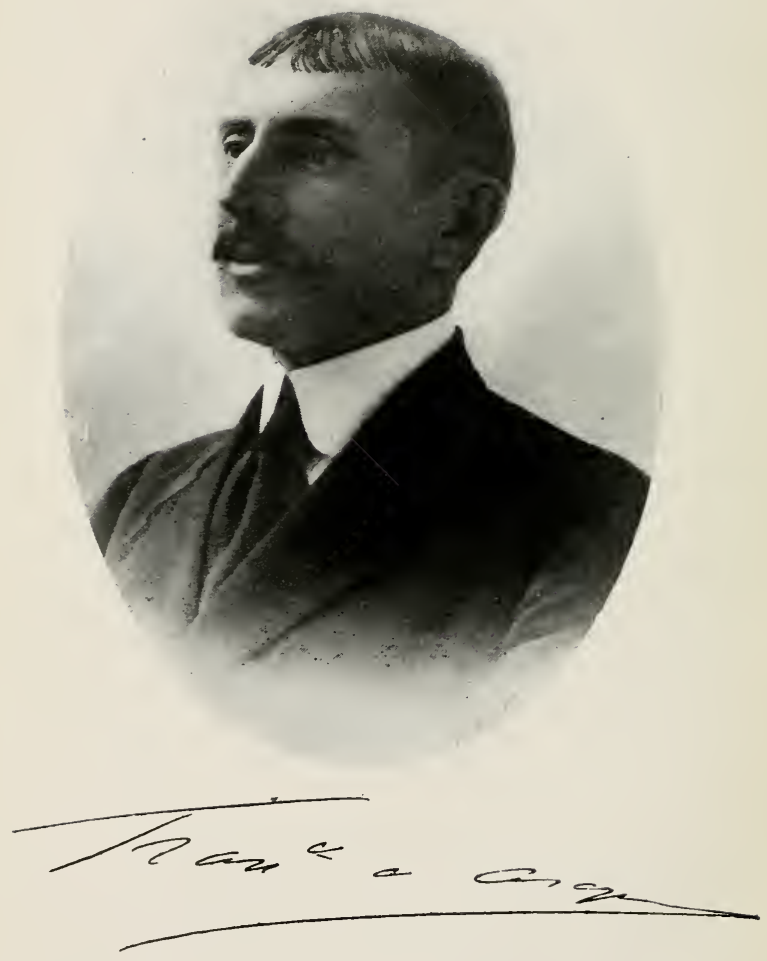




\section{E A R A N G O}

\section{FRANCISCO DE ARANGO}

\section{Official; man of affairs.}

Francisco de Arango y Mantilla is a scion of one of the most distinguished Cuban families, grandson of the eminent don Francisco de Arango y Parreño whose services to his country were so numerous and so conspicuous that on the petition of the Ayuntamiento of Havana the Spanish Government granted him the title of "Marques de la Gratitud." Arango was born at Guanabacoa, and entered the University of Havana where in the years $1884^{-1} 885$ he gained the degrees of Doctor of Civil and Canon Laws and Doctor of Philosophy and Letters.

In 1885 Dr. Arango was made Assistant Professor in the Faculty of Philosophy and Letters and in the same year began the practice of his profession, but the death of his parents in $r 889$ compelled him to aban-

H I S P A N I NOTES 


\begin{tabular}{|l|l|}
\hline C U B A N S O F T O - D A Y \\
\hline $\begin{array}{l}\text { don his hopes of a professional and aca- } \\
\text { demic career and to devote himself to the } \\
\text { care of his properties. In consequence of } \\
\text { the Revolutionary War and the destruc- } \\
\text { tion of his properties, he was obliged in } \\
\text { I } 89 \text { to go to Europe and later to Puerto } \\
\text { Rico where he was appointed Judge of the } \\
\text { Lower Courts. With the end of the war } \\
\text { in I898 Arango was able to return to his } \\
\text { country and give his attention to restoring } \\
\text { what had been destroyed in the war. He } \\
\text { took no part in politics until his friend } \\
\text { General José Miguel Gómez was nomi- } \\
\text { nated for the Presidency when he entered } \\
\text { the lists in his behalf. On the election of } \\
\text { General Gómez in I9o8, Dr. Arango was } \\
\text { appointed Assistant Secretary of Govern- } \\
\text { ment (Gobernación), in I9Io he was made } \\
\text { Assistant Secretary of Justice, and in I9I I } \\
\text { Inspector General of Agricultural Schools. } \\
\text { In I9I 2, at the end of General Gómez's } \\
\text { term of office, Señor Arango resigned and } \\
\text { turned his attention to practical affairs- } \\
\text { particularly to developing new resources } \\
\text { and new agricultural products, for which } \\
\text { the fields of Cuba offer specialopportunities. }\end{array}$ \\
\hline H I S P A N I C N O T E S
\end{tabular} \mid




\section{H E N R Í Q U, E Z U R E Ñ A}

MAX HENRÍQUEZ UREÑA

Author; musician; critic; teacher.

Max Henríquez Ureña was born in Santo Domingo on the six teenth of November, 1885 . He was educated in his native place and at an early age entered upon the literary career, being dramatic critic of La Lucha of Santo Domingo when he was fifteen. In I90 I he was granted a pension by the Dominican Government to enable him to go abroad to study music and he began to develop his aptitude for this art in the New York College of Music. Very soon, however, he abandoned his musical studies and though, to be sure, he produced some few compositions, he found his real vocation in literature to which he devoted himself. In I903 he settled in Cuba and there in Santiago de Cuba founded, and during two years published, the magazine

\section{A N D M O N O R A P H S}




\begin{tabular}{|c|c|}
\hline 98 & C U B A N S O F T O - D A Y \\
\hline & $\begin{array}{l}\text { Cuba Literaria. Later in Havana he served } \\
\text { as editor of La Discusión, El Figaro, and } \\
\text { La Lucha. } \\
\text { In I } 907 \text { Henríquez removed to Mexico } \\
\text { where he remained a year, living an active } \\
\text { editorial life as editor of El Diario in } \\
\text { Mexico City, of La Gaceta in Guadalajara } \\
\text { and of The Monterrey News of Monterrey. } \\
\text { During this year he also founded La Socie- } \\
\text { dad de Conferencias de Mexico. } \\
\text { In I } 908 \text { he returned to Havana and there } \\
\text { continued his literary labors. In associa- } \\
\text { tion with Jesís Castellanos he founded } \\
\text { La Sociedad de Confercncias de la Habana } \\
\text { in which he delivered a number of addresses } \\
\text { including: Grieg y la música del Norte, } \\
\text { Georges Rodenbach, Tolstoi y la novela real- } \\
\text { ista, Jesús Castellanos; su vida y su obra } \\
\text { and Marti en Santo Domingo. } \\
\text { Henríquez also delivered notable ad- } \\
\text { dresses in the Ateneo of Havana, as Ibsen } \\
y \text { el teátro contemporáneo, Heredia y la } \\
\text { poesía parnasiana, and Los fundamentos } \\
\text { del bien y del mal. In the Academia Na- } \\
\text { cional of Arts and Letters he has spoken on } \\
\text { Hauptmann. }\end{array}$ \\
\hline I & H I S A N I C NOTES \\
\hline
\end{tabular}




\section{H E N R Í U E Z U R E Ñ A}

In I 9 I 2 he received the title of Doctor of Civil Laws in the University and in r9r6 that of Doctor in Philosophy and Letters. In I9I 7 he gained in competitive examination the Chair of Grammar and Literature in the Normal School of Santiago de Cuba and in I9r 8 he was appointed Director of the School.

He was Director of the Ateneo of Havana. In I9I4 he founded the Atcneo of Santiago de Cuba in which he has given lectures on Schumann, José Enrique Rodó, and others. In I9I 5 he founded an Academy for higher studies in language and literature under the title "Academia Domingo Delmonte" in which he has given courses in Spanish and Cuban literature.

He has published: Whistler y Rodin, conferencia (I906); Anforas, poesías (I9I4); Tres poetas de la música (I9I5); La Combinación diplomática, juguete cómico (г16); Rodó y Rubén Dario (I9I8) and El ocaso del dogmatismo literario (I9r9). He has in preparation a study on the Teátro contemporáneo (I850-I9I8). He has translated into Spanish Los Trofeos de José María Heredia.

\section{A N D M O N O R A P H S}





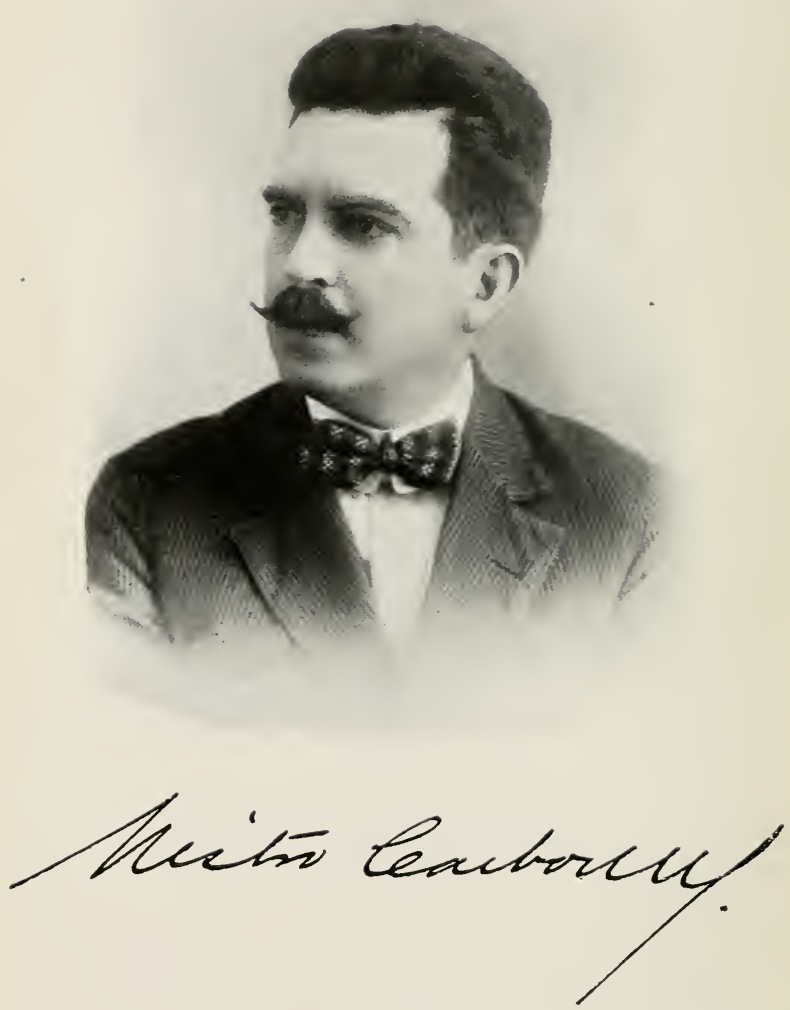


\section{A R B O N E L L}

\section{NÉSTOR CARBONELL}

\section{Journalist.}

Néstor Carbonell y Rivero was born on the fourth of May, $188_{3}$, in the town of Alquízar, Province of Havana. When he was four years old his family emigrated and for this and other causes his father was his sole instructor until he was sixteen. Although his family returned to Cuba in I 889 he was not able to follow the usual course of education on account of the necessity to assist in the family support. He obtained somewhat later than usual the degree of Bachelor of Arts in the Institute of Pinar del Rio.

He took part in the Revolution of 1906 , directed against the government of President Tomás Estrada Palma, and held the rank of Colonel.

Carbonell has been an active journalist

\section{H I S P A N I N O T ES}




\begin{tabular}{|c|c|}
\hline 102 & C U B A N O F T O - D A Y. \\
\hline & $\begin{array}{l}\text { and has founded the following magazines: } \\
\text { Letras in I9o6, Bibliotéca Cuba in I9I4, } \\
\text { Don Pepe (devoted to boys and girls) in } \\
\text { I9I7. } \\
\text { In I909 he was made Special Inspector } \\
\text { in the Department of Public Instruction } \\
\text { and, in the same year, Chief Secretary to } \\
\text { the Police Force of Havana. } \\
\text { Carbonell is the author of many articles } \\
\text { in the press and in various magazines and } \\
\text { has given special study to Cuban biog- } \\
\text { raphy, a field in which he has written much } \\
\text { and in which he has a volume in prepara- } \\
\text { tion: Los Próceres; ensayos biográficos de } \\
\text { cubanos ilustres. In particular he has } \\
\text { made a special study of the career of Martí } \\
\text { whose works are now appearing under his } \\
\text { direction in La Prensa, and whose person- } \\
\text { ality has formed the subject of various } \\
\text { addresses by Carbonell, particularly that } \\
\text { given on his election in I9I to member- } \\
\text { ship in the Academia Nacional de Artes y } \\
\text { Letras. }\end{array}$ \\
\hline I & H I S P A N I N O T E S \\
\hline
\end{tabular}




\section{S A N T O V E N I A}

\section{EMETERIO S. SANTOVENIA}

Journalist; author; historian.

Emeterio S. Santovenia y Echaide was born on the twenty-third of May, I889, in the village of Mantua, Pinar del Rio, and there pursued his early studies, afterward continuing in the Institute of Pinar del Rio, where he obtained the degree of Bachelor of Letters and Sciences, and at the University of Havana where he pursued the courses for the degree of Doctor of Civil Law. He was made Professor of Public Instruction but pursued the vocation only one year, devoting himself to literary pursuits, both as journalist and as author. As journalist he has contributed extensively to most of the leading papers and magazines of Havana including Diario de la Marina, El Comercio, El Triunfo, La Prensa, Heraldo de Cuba, La Nación,

\section{A N D M O N O G R P H S}




\begin{tabular}{|c|c|}
\hline IOt & C U B A N O F TO-D A Y \\
\hline & 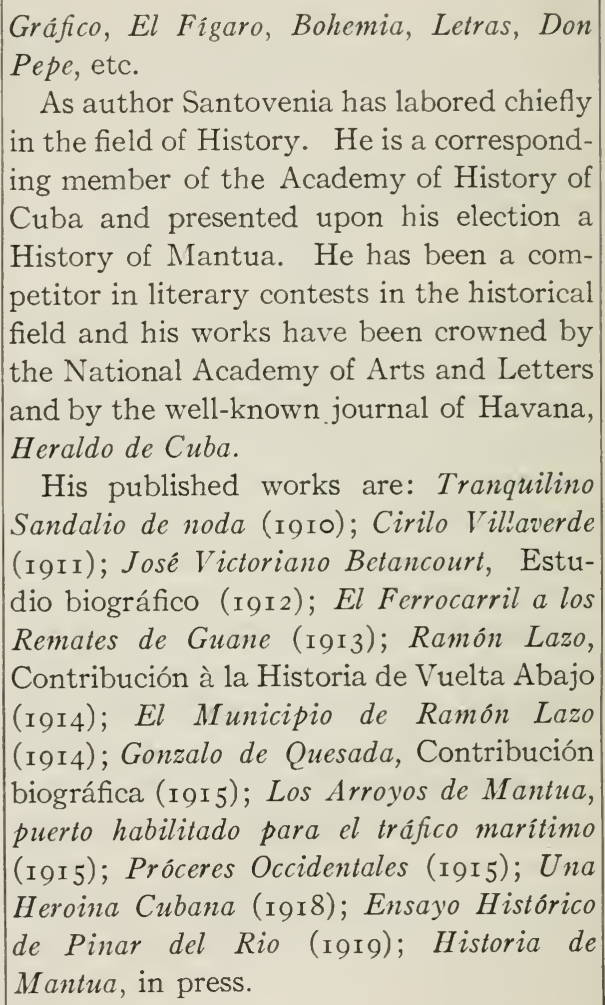 \\
\hline I & H I S P N I C NOTES \\
\hline
\end{tabular}




\section{F A I L L A C Q}

\section{JORGE NAVARRO FAILLACQ}

\section{Teacher; bacteriologist.}

Jorge Navarro FaillacQ was born on the twelfth of May, I888, in the city of Cienfuegos and there in the Colegio of the Jesuit Fathers gained his early education. Having obtained the Bachelor's degree in I 905 he continued his studies at the University of Havana where he won the degree of Engineer of Agronomy in roro and that of Civil Engineer in ror r.

From I908 until I9I he occupied the position of Assistant in the School of Sciences in the University. From rgi to I9I 2 he was Chief Engineer in the office of Plans and Projects of the Department of Agricuiture. In IgI 2 he won, in competitive examination, Chair " $\mathrm{H}$ " in the Agricultural School of Matanzas and was the first Director until IgI4. In IgI5 he ob-

\section{A N D M O N O G R A H S}




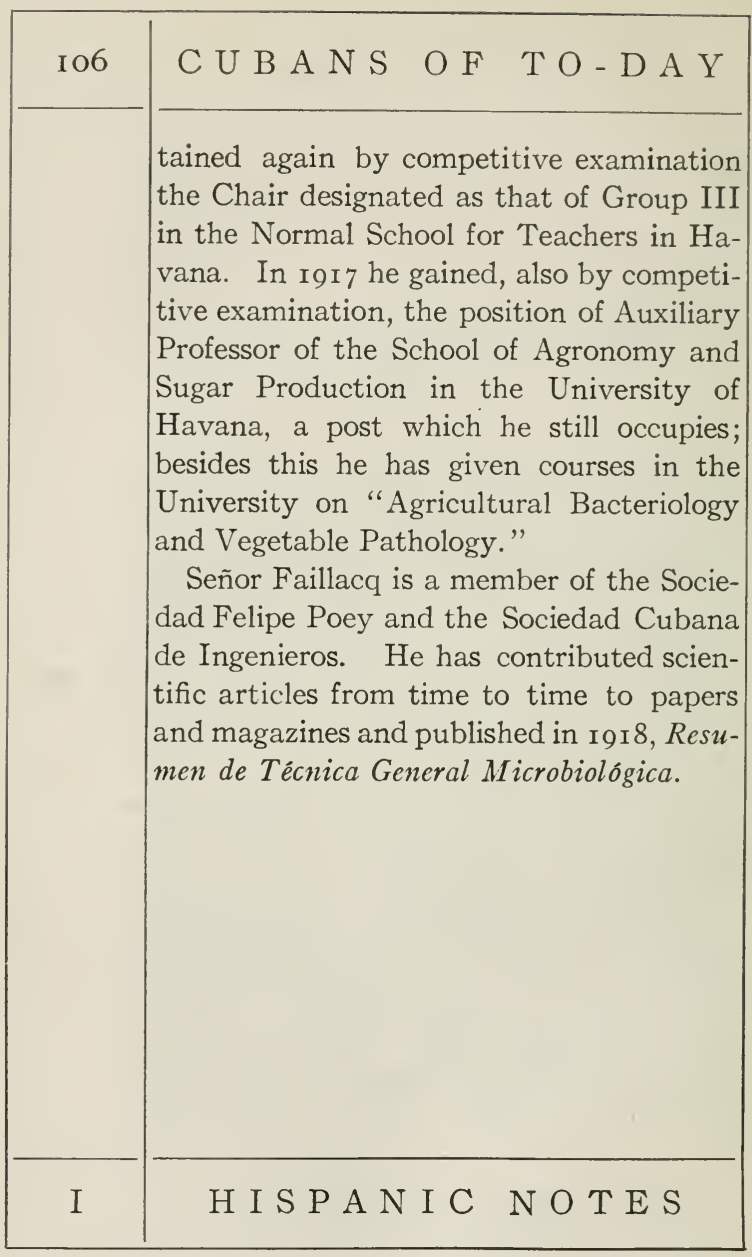




\section{S A R R A I N}

\section{FELIPE GONZÁLEZ SARRAIN}

Lawyer; legislator; parliamentarian.

Felipe González Sarrain was born in Havana on the first of May, I868. He was educated at the Colegio of Belén where, in $188_{3}$, he completed the courses leading to the Bachelor's degree, passing thence to the University where he pursued the study of law, obtaining the degree of Licentiate in 1887 and that of Doctor in 1893 .

During the first American Intervention he was a member of the City Council of Havana and later was Counsel to that body. He was one of the founders of the Liberal party under which he was elected Representative for the Province of Havana in I 902 and reëlected in I904. During the second American Intervention he was a member of the Consultative Commission organized by Governor Magoon and had a

\section{A N D M O N O R A P H S}




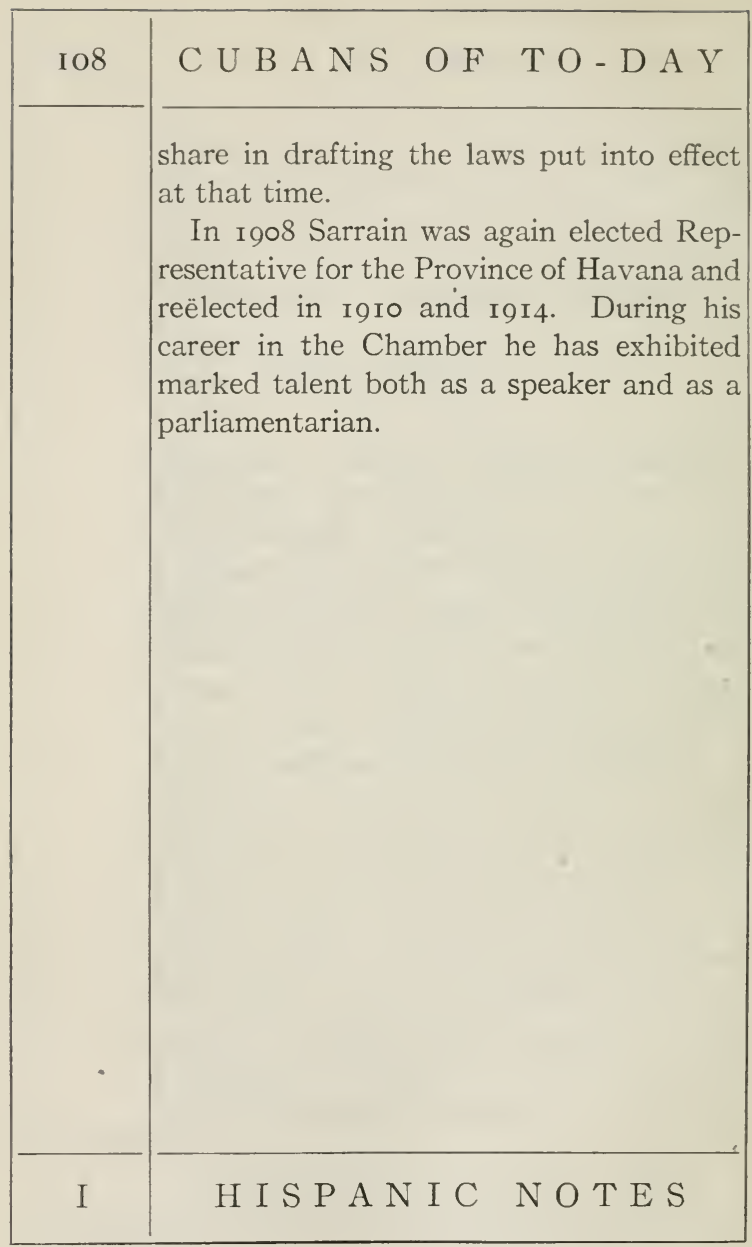




\section{B R U L L}

\section{MARIANO BRULL}

\section{Poet; diplomat.}

Mariano Brull was born in the city of Camagüey, Cuba, on the twenty-fourth of February, r89I. At the age of two his parents took him to Spain, where he lived in Andalucía for about nine years, then returning to Cuba. He received his degree of Bachelor of Science and Arts in the city of Camagüey in 1908, and graduated as Doctor of Law at the University of Havana in r9r3. He practiced as Attorney at Law in that city almost four years, leaving that profession to enter the Diplomatic Career as Second Secretary of the Cuban Legation at Washington, D. C., in I9I 7 .

During his several years as student in Camagüey, Brull made his first essays as prose and poetry writer. Together with other schoolmates he founded and edited

A N D M ONOGR A P H S 


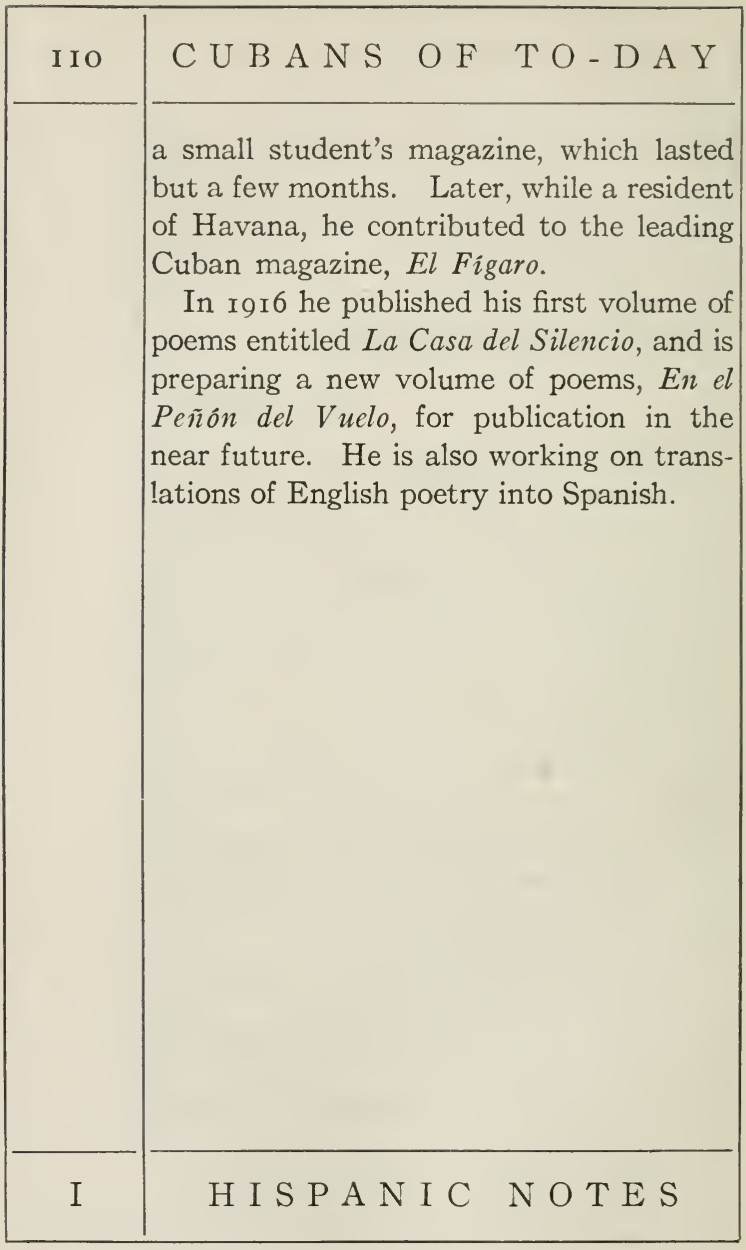




\section{E A R A G Ó N}

\section{ADOLFO DE ARAGÓN}

Scholar; teacher; author.

Adolfo de ARAgón was born on the twenty-fourth of March, I864, in Havana and has lived almost all his life in his native city. There he obtained his education, gaining his degree as Bachelor of Arts in the Institute in 1878 ; that of Licentiate in Philosophy and Letters at the University in 1882 ; and likewise that of Licentiate in Civil and Canon Law in 1883 . There also he has taught, with the exception of a brief period at the Institute of the neighboring Province of Pinar del Rio where he was Professor of Latin and Spanish in 1883-84. In the latter year he received the investiture of Doctor of Philosophy and Letters and was made Auxiliary Professor, occupying temporarily the chairs of Greek and Latin Literature and Metaphysics.

\section{A N D M O N O G R A P H S}




\begin{tabular}{|c|c|}
\hline I I 2 & C U B A N S F TO-DA Y \\
\hline & $\begin{array}{l}\text { In I } 896 \text { Dr. Aragón was obliged to leave } \\
\text { Havana and Cuba on account of his po- } \\
\text { litical opinions which were emphatically } \\
\text { Separatist, and he removed to the United } \\
\text { States where he joined himself to the re } \\
\text { volutionists acting with them in the politi- } \\
\text { cal clubs "Oscar Primelles" and "Patria" } \\
\text { of New York and "Tunas de Calixto" of } \\
\text { Jacksonville. } \\
\text { In I } 897 \text { his Chair at the University was } \\
\text { declared vacant for the reason that Gen- } \\
\text { eral Weyler had commanded him to return } \\
\text { and he had not done so, but on the contrary } \\
\text { had continued his revolutionary activities } \\
\text { abroad. } \\
\text { In I } 898 \text { when the War of Independence } \\
\text { was won, Dr. Aragón was reinstated in his } \\
\text { position as Auxiliary Professor by the } \\
\text { Government. On May first, I } 900 \text {, he was } \\
\text { appointed to the Chair of History of Classi- } \\
\text { cal Literature and in September of that } \\
\text { year he gained, in competitive examination, } \\
\text { the post of Professor of Latin Language } \\
\text { and Literature which he has continued to } \\
\text { occupy. } \\
\text { In I } 900 \text { Professor Aragón was elected a }\end{array}$ \\
\hline I & H I S A N I C NOTES \\
\hline
\end{tabular}




\section{E A R A G Ó N}

member of the Board of Education of $\mathrm{Ha}$ vana which office he filled until r9i6 and was President of the Board from I9I4 to I9 6 during a period of important changes in the educational system. In r9r6 he was elected Dean of the Faculty of Letters and Science for the period I9I6 to I9I9.

Dr. Aragón has published Los Dramas de Esquilo (Conferencia, I916); Aristofanes y la antigua comedia griega, Conferencia, I9I4. 



\section{E B L A N C K}

\section{HUBERT DE BLANCK}

Musician; composer.

Hubert de Blanck was born on the eleventh of July, I 856 , in Utrecht, Holland. $\mathrm{He}$ received his first instruction from his father and continued his studies in the Conservatory at Liége under Professors Dupuy and Le Dent, where he won the second prize for proficiency at the piano and gained a subvention from the government. In 1873 when he was only sixteen he made a tour of the cities of Russia, and in 1875 , being then director of the orchestra at the theater "El Dorado" in Warsaw, he made a joint tour with the violinist Dangremont through Germany and Denmark which was attended with marked success. Following this tour the two musicians sailed for South America where they gave several concerts at the court of Don

\section{H I S P A N I C N O T E S}




\begin{tabular}{|c|c|}
\hline 116 & C U B A N OF TO-DAY \\
\hline & $\begin{array}{l}\text { Pedro II. In the same year Blanck re- } \\
\text { turned to Europe and took part in a musi- } \\
\text { cal festival at the palace of the King } \\
\text { of Saxony. Later he embarked for the } \\
\text { United States where he was appointed } \\
\text { Professor of the Piano in the College of } \\
\text { Music in New York. } \\
\text { In I } 88 \text { B Blanck visited Cuba and gave } \\
\text { several concerts which were crowned with } \\
\text { success, and in the following year returned } \\
\text { to Havana where he settled and in I } 885 \\
\text { established a Conservatory of Music. } \\
\text { In I } 896 \text { he was imprisoned for belonging } \\
\text { to the Revolutionary Committee of Ha- } \\
\text { vana, and soon afterwards, on the order of } \\
\text { General Weyler, expelled from the coun- } \\
\text { try. On his return after the defeat of Spain, } \\
\text { he reopened the Conservatory of Music, } \\
\text { which he had founded in I } 885 \text {, giving it } \\
\text { the title Conservatorio Nacional to signify } \\
\text { that it was the center of musical education } \\
\text { in Cuba. } \\
\text { Hubert de Blanck is not only a pianist } \\
\text { but also a composer, and has had an in- } \\
\text { fluence in both fields upon the develop- } \\
\text { ment of music in Cuba. }\end{array}$ \\
\hline I & H I S A N I C NOTES \\
\hline
\end{tabular}




\section{ANTONIO RODRÍGUEZ MOREY}

Painter; director, and teacher of Art.

Antonio Rodríguez Morey was born on the fourth of March, 1874 , in Havana and there in his native city he gained his first instruction in the art of painting to which he has devoted himself. His early studies in design were made in the Academy of San Alejandro de la Habana, and those in painting under the Cuban painters: Juan Ruiz and Miguel Arias. For further instruction he sailed in $189 \mathrm{I}$ to Italy and continued his work in scenic painting and perspective under the celebrated painter Giovanni Lessi. In 1892 , with the advice of Lessi, he entered the Scuola Professionale delli Arti Decorative where he won several prizes and the title Pintor escenógrafo. In I 895 Morey passed on to Rome where he entered the examinations and won one of

\section{A N D M O N O R A P H S}




\begin{tabular}{|c|c|}
\hline I I 8 & C U B A N O F T O - D A Y \\
\hline & $\begin{array}{l}\text { the free posts in the Academy of Painting } \\
\text { for the study of anatomy and the nude. } \\
\text { At the same time he worked in the studio } \\
\text { of the famous Spanish painter Salvador } \\
\text { Viniegra and collaborated with the paint- } \\
\text { ers Serra and Carrodi. He became Pro- } \\
\text { fessor of Design and Painting in the Colegio } \\
\text { of Santa del Monti and later, after a tour } \\
\text { through the principal art centers ot Europe, } \\
\text { returned to Cuba. } \\
\text { On his return he was appointed Pro- } \\
\text { fessor of Anatomy, Perspective, and the } \\
\text { History of Art in the Academy of Painting } \\
\text { and Sculpture of Havana. He has been } \\
\text { awarded medals and diplomas in many } \\
\text { expositions both in Europe and America. } \\
\text { He is a member of the National Academy } \\
\text { of Arts and Letters and Art Director of } \\
\text { the magazine Bohemia. } \\
\text { Among Morey's most notable works are: } \\
\text { Demasiado tarde, Triste jornada, and El } \\
\text { otoño en la montaña. }\end{array}$ \\
\hline I & H I S A N I C NOTES \\
\hline
\end{tabular}




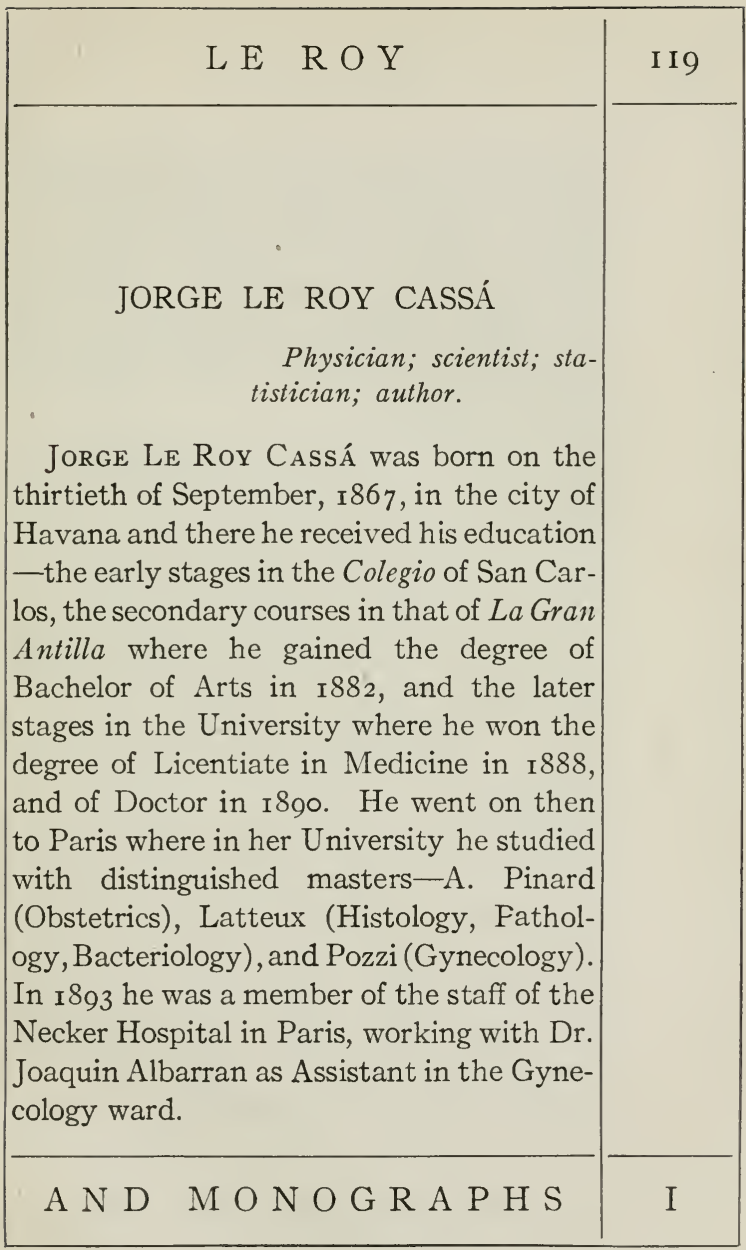




\begin{tabular}{|c|c|}
\hline 120 & C U B A N S O F T O - D A Y \\
\hline & $\begin{array}{l}\text { On his return to Cuba Dr. Le Roy taught } \\
\text { in the University where, in the absence of } \\
\text { their holders, he filled various chairs in- } \\
\text { cluding those of Anatomy, Pathology, } \\
\text { Histology, Diseases of Infancy, and Clinical } \\
\text { Obstetrics. In I } 897 \text { he was appointed } \\
\text { Professor pro tempore of Legal Medicine } \\
\text { and Toxicology. } \\
\text { In I90I, Dr. Le Roy was appointed by } \\
\text { General Wood, Secretary of the Yellow } \\
\text { Fever Commission; in I } 903 \text { he was ap- } \\
\text { pointed Chief Statistician of Cuba and } \\
\text { from this date he entered upon a new } \\
\text { phase in his career which has been marked } \\
\text { by notable success. In I } 907 \text { he was made } \\
\text { Chief Statistician of Health and Demog- } \\
\text { raphy in the Deparment of Health and } \\
\text { Charity. In I } 909 \text { he was designated to } \\
\text { prepare a statistical report upon the moral } \\
\text { condition of Cuba (crime, suicide, insanity, } \\
\text { alcoholism, prostitution, illiteracy, etc., } \\
\text { etc.). In I } 9 \text { Io he was appointed, together } \\
\text { with three other distinguished physicians, } \\
\text { to collect, edit, select, and publish the } \\
\text { works of Dr. Carlos T. Finlay. } \\
\text { Dr. Le Roy is a member of the Com- }\end{array}$ \\
\hline I & H I S P N I C N O T E S \\
\hline
\end{tabular}




\section{E R O Y}

mission appointed to issue the National Pharmacopia and of the Academy of Medical, Physical, and Natural Sciences whose Annals he has had charge of since I902, and of which he has been Secretary since 1907 . He was a member or the delegation which represented $\mathrm{Cuba}$ in the Second LatinAmerican Congress held in Buenos Aires in 1904; he was Vice-president of the Section of Vital Statistics of the American Public Health Association in r9r r, and was a delegate of the Association to the Twentieth Congress of Hygiene and Demography held in Washington in r9r 2.

Dr. Le Roy is the author of numerous scientific works among which are:

A puntes para la Historia de la Obstetricia en Cuba, rgo3; Historia de la Academia de Ciencias de la Habana; Consideraciones sobre la Prensa Médica de Cuba, I9r3; La Prensa y la Bibliografía Médicas cubanas, r9r4; La Historia y la Prensa Médica de Cuba, r9r7; La Prensa Médica y la Estadistica; Sobre las funciones sexuales en la mujer cubana; Nota de ginecomastia, I9r3; Higiene Pública, I888; Progreso

\section{A N D M O N O G R A P H S}




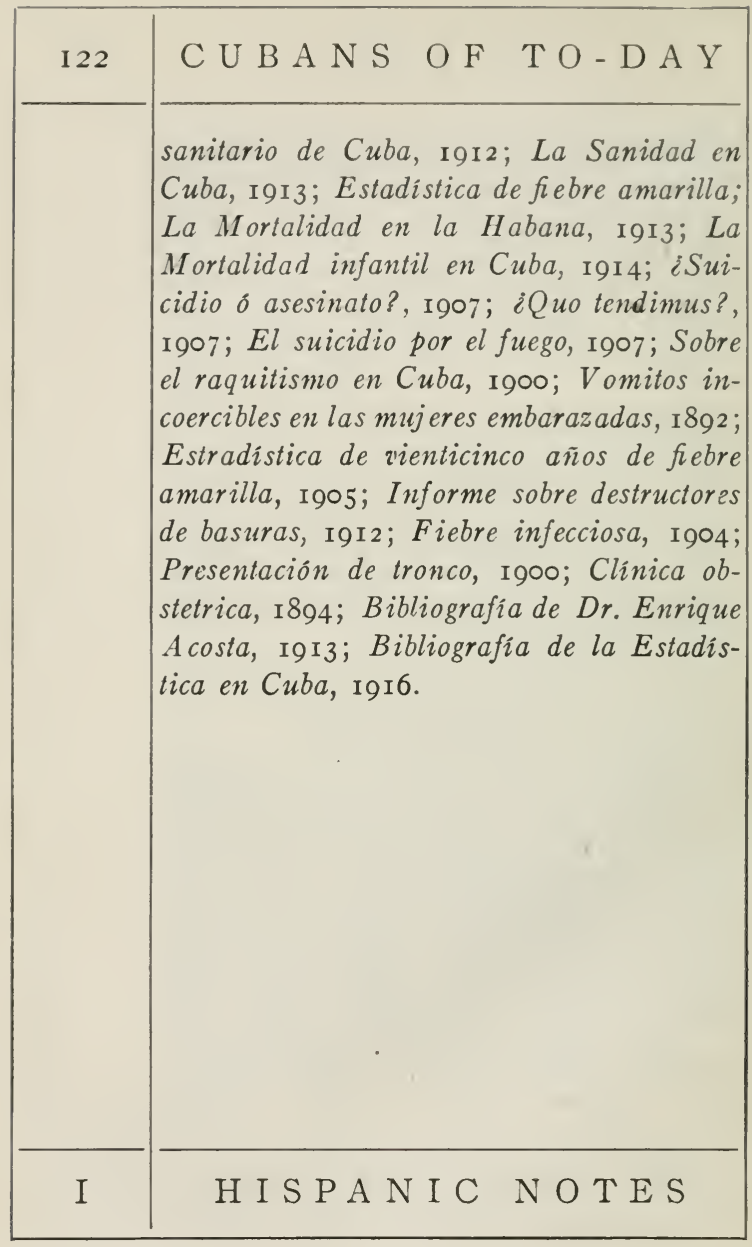




\section{RAIMUNDO DE CASTRO}

Physician; teacher; author.

Raimundo de Castro y Bachiller was born on the sixth of March, I878, in the city of New York where his parents were sojourning, and where he gained his early education under the private tutelage of Dr. Valdés Ragues. When his parents returned to Cuba he continued his studies in the Institute of Havana and there obtained the degree of Bachelor of Arts in r894. He began the study of Medicine in the University of Havana, but after two years went to New York where he completed the course and gained his degree at Columbia University in rgor. In the same year the degree of Doctor of Medicine was conferred upon him by the University of Havana.

He became Assistant in the Laboratory

\section{A N D M O N O G R A P H S}




\begin{tabular}{|c|c|}
\hline 124 & C U B A N S O F T O - D A Y \\
\hline & $\begin{array}{l}\text { of Medical Hygiene in the University in } \\
\text { I } 902 \text { and retained the post until I9I } 7 \text { when } \\
\text { he became Assistant Professor of Legal } \\
\text { Medicine and Toxicology. He is a Mem- } \\
\text { ber of the Liga contra la Tuberculosis de } \\
\text { Cuba, Medical Advisor of the Compañia } \\
\text { Nacional de Seguros, the "Confederation } \\
\text { Life Insurance Co," and of the "Pan- } \\
\text { American Co."; Medical Inspector of the } \\
\text { "Peninsular and Occidental S. S. Co." and } \\
\text { of the "Southern Pacific S. S. Co." } \\
\text { Dr. de Castro is also Titular Associate } \\
\text { of Clinical Studies; Charter member of the } \\
\text { Sociedad de Medicina Tropical de Cuba; } \\
\text { Honorary Physician of the Hospital de } \\
\text { San Francisco de Paula; Socio Protector } \\
\text { del Coiegio Médico de Cuba; Miembro de } \\
\text { los cuatro Congresos Nacionales de Cuba, } \\
\text { Miembro de la Asociación de Salud Pubblica } \\
\text { Americana, Delegado al Congreso Inter- } \\
\text { nacional de Higiene y Demografia in Wash- } \\
\text { ington, Associate Fellow of the American } \\
\text { Medical Association, Member of the } \\
\text { Columbia University Alumni Association } \\
\text { in Cuba. } \\
\text { Author of: Cuadros sinopticos del trata- }\end{array}$ \\
\hline I & H I S P A I C NOTES \\
\hline
\end{tabular}




\section{E C A S T R O}

miento de las intoxicaciones y envenenamientos; Análisis Hidrotimétrico en el Laboratorio de Higiene de la Facultad de Medicina de la Universidad de la Habana; Estado del Sueño y sus funciones anti-tóxicas, Contribución al estudio del envenenamiento agudo por el colodion; Negando la teoria de Koch (translation from the English), La Criminologia ante la Medicina Legal, Intoxicaciones industriales debida a las fabricaciones de los explosivos, Una observación clinica curiosa; Elogio del Dr. Miguel Sánchez Toledo.

\section{$\begin{array}{llll}\text { A N D } & \text { M O NOGRA P H S I }\end{array}$}




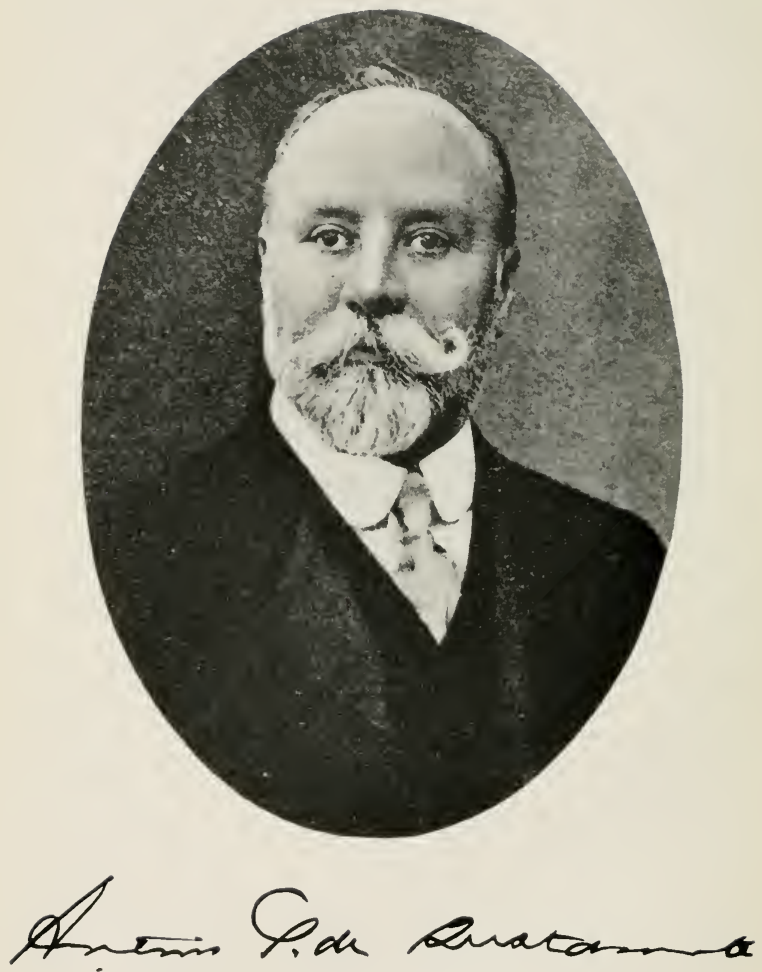


\section{B U S T A M A T E}

\section{ANTONIO SÁNCHEZ DE BUSTAMANTE}

Lawyer; professor; publicist; statesman; orator.

Dr. Bustamante's life possesses that unity and continuity which belongs peculiarly to one whose days are spent in the city of his birth, and where his family has lived before him. Antonio Sánchez de Bustamante was born in Havana on the thirteenth of April, I865, son of another Dr. Bustamante, who was Professor and Dean of the Faculty of Medicine in the University of Havana. The boy began his studies in the famous Colegio of Belén where he completed the course for the Bachelor's degree, going thence to Spain, as was long the custom with Cuban youth, to begin his legal studies at the Central University of Madrid, but returning to the University of Havana to complete his 


\begin{tabular}{|c|c|}
\hline I 28 & $\mathrm{CUBANS}$ O F TO-D A Y \\
\hline & $\begin{array}{l}\text { course and obtain his title of Advocate } \\
\text { (Abogado). } \\
\text { In } 1884 \text {, before he was yet twenty, he } \\
\text { began the profession of the law and gained } \\
\text { by the customary contest of public com- } \\
\text { petitive examination the chair of Inter- } \\
\text { national Law in the University which he } \\
\text { has occupied from that date. } \\
\text { In r902, when the Republic of Cuba } \\
\text { was constituted, he was elected Senator } \\
\text { for the Province of Pinar del Rio and } \\
\text { was reëlected in I9o9 to represent } \\
\text { Havana. } \\
\text { In I895 he was made Member of the } \\
\text { Institute of International Law, the only } \\
\text { Cuban who has gained that distinction, and } \\
\text { in r9o7 he was selected as Delegate Pleni- } \\
\text { potentiary of Cuba to the Second Peace } \\
\text { Conference at The Hague. He is Dean of } \\
\text { the Faculty of Law at Havana University, } \\
\text { President of the Academy of Arts and } \\
\text { Letters; President of the Proprietors' Club } \\
\text { (Centro de Propietarios) of Havana, over } \\
\text { which he has presided for twenty years; } \\
\text { Dean of the Havana Bar; Member of the } \\
\text { Permanent Arbitration Tribunal of The }\end{array}$ \\
\hline I & H I S P A I C NOTES \\
\hline
\end{tabular}




\section{B U S T A M A N T E}

Hague; Custodian of Alien Enemy Property, I9I8; Delegate from Cuba to the Peace Conference, I9r8; Corresponding Member of the Hispanic Society of America, I9r8.

Dr. Bustamante is a contributor to reviews and magazines, chiefly on subjects connected with International Law, and is the author of: Tratado de Derecho Internacional Privado, Havana, I896. Printed by the University. Informe relativo a la Segunda Conferencia Internacional de la Paz, Havana, I908. Programa de las A signaturas de Derecho Internacional Público y Derecho Internacional Privado. Madrid, r89г. El Orden Público. Estudio de Derecho Internacional Privado, Habana, 1893. Le Canal de Panama et le Droit International. Bruxelles, I895. La Segunda Conferencia de la Paz. Madrid, igo8. La Seconde Conférence de la Paix. Translated into French by George Seelle. Paris, I909. La Autarquia Personal. A study of International Private Law. Havana, I9I4. Discursos. 3 vols. published and two in press.

\section{A N D M O N O G A P H S}






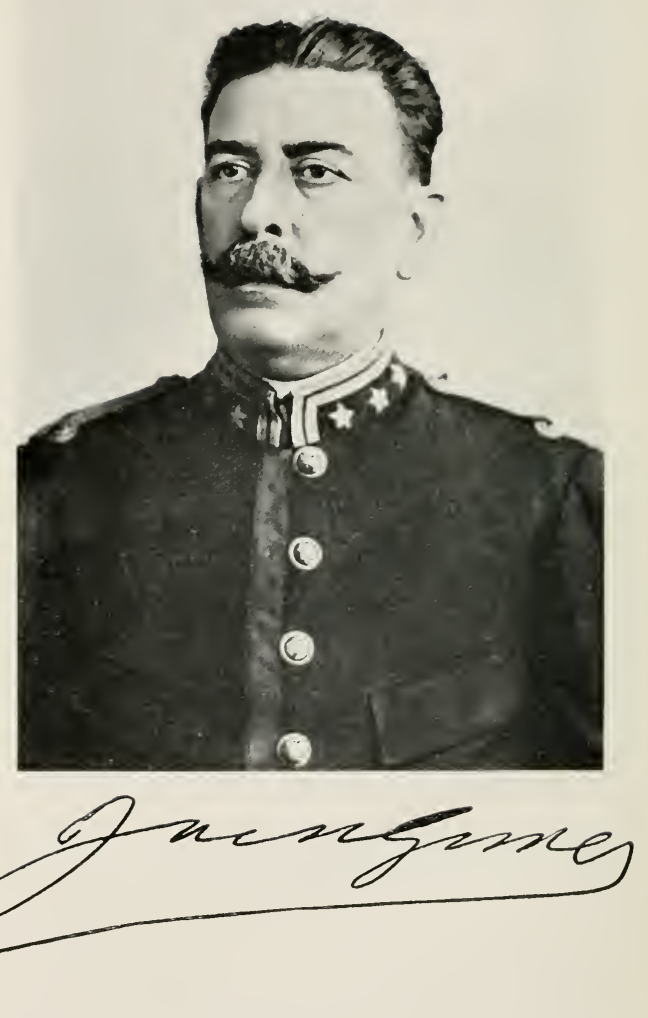




\section{G Ó M E Z}

\section{JOSÉ MIGUEL GÓMEZ}

Soldier; man of affairs; statesman; ex-President of the Republic of Cuba.

José Miguel Gómez was born in the year $185^{8}$ in the ancient town of Sancti Spiritus and here, in a Colegio maintained by the Society of Jesus, he obtained his early education. After some years he proceeded to Havana and entered the Institute there. Meantime the Ten Years' War which disturbed the country from I 868 to 1878 was raging and at last the call to arms became too urgent for young Gómez to resist and, in 1876 , only a short time before his graduation from the Institute, he joined the forces in the field and fought to the end of the war in Sancti Spiritus.

From this time on he has taken part in nearly every political movement in Cuba. $\mathrm{He}$ had a prominent and not inglorious 


\begin{tabular}{|c|c|}
\hline I 32 & C U B A N S O F T O - D A Y \\
\hline$\cdot$ & $\begin{array}{l}\text { share in the War of Independence, joining } \\
\text { the forces of General Serafin Sánchez in } \\
\text { the early conflict and continuing in arms } \\
\text { until the close. He was made Lieutenant } \\
\text { Colonel in command of the "Máximo } \\
\text { Gomez" regiment and rose from rank to } \\
\text { rank by valor in the field, becoming Col- } \\
\text { onel by reason of the battle of Palo Prieto } \\
\text {-one of the most important battles of the } \\
\text { war, becoming Brigadier General by the } \\
\text { battle of Santa Teresa-where he was } \\
\text { wounded-and finally winning the rank of } \\
\text { Major General by valor in the field at } \\
\text { Gíbaro and Arroyo Blanco. } \\
\text { General Gómez enjoyed the special con- } \\
\text { fidence and regard of the Commander-in- } \\
\text { Chief Máximo Gómez, to such a degree } \\
\text { that when Maceo was killed, he was se- } \\
\text { lected to take Maceo's place in command } \\
\text { of the forces in the West. For this duty } \\
\text { Gómez began to organize a force of volun- } \\
\text { teers, but so numerous were these that the } \\
\text { mandate was recalled, the Commander-in- } \\
\text { Chief fearing that his army would be } \\
\text { weakened and he himself be deprived of } \\
\text { an indispensable associate. During these }\end{array}$ \\
\hline $\mathrm{I}$ & H I S P A I C N O T E S \\
\hline
\end{tabular}




\section{G Ó M E Z}

strenuous times Gómez lived a life of incessant toil and combat-at one period, during General Weyler's campaign in the Sancti Spiritus region, fighting no fewer than seventeen minor engagements in one day.

It was General Gomez' good fortune in all these combats, great and small, never to have been defeated, though often engaged with much superior forces of the enemy and on one occasion, when the force at his command amounted only to seventy men, taking captive no fewer than two hundred Spanish cavalry, men, horses, and equipment.

At the close of the war, General Gómez was elected Representative to the famous Last Assembly of the Revolution which met first in Santa Cruz del Sur and later in the Cerro at Havana. He was also a member of the commission which was sent to Washington to obtain a settlement of the soldiers' claims for back pay, his associates being Generals Calixto García, González Lanuza, Villalón and Sanguily. In I 898 he was appointed Governor of Las

\section{A N D M O N O G R A H S}




\begin{tabular}{|c|c|}
\hline I34 & C U BA N S OF TO-DAY \\
\hline & $\begin{array}{l}\text { Villas, under the American Intervention, } \\
\text { and was continued in the same office by } \\
\text { the votes of his fellow-citizens at the elec- } \\
\text { tion of I90I. In I } 905 \text { he was the candidate } \\
\text { of the Liberal party for the Presidency of } \\
\text { the Republic but failed of election. Where- } \\
\text { upon, after a visit to the United States, he } \\
\text { devoted himself for a time to business in- } \\
\text { terests, acting as head of the Silveira Sugar } \\
\text { Co. } \\
\text { When the Revolution of I9o6 occurred } \\
\text { Gómez was arrested and placed under in- } \\
\text { dictment, but was released at the order of } \\
\text { the American Commissioners, Taft and } \\
\text { Bacon. General Gómez now devoted him- } \\
\text { self to politics; he was again nominated } \\
\text { for the Presidency by the Liberal-Historical } \\
\text { party which fused with the old Liberal } \\
\text { party and elected its candidate in I9o8. } \\
\text { The administration of General Gómez } \\
\text { (I9o9-I9I3) was marked by many achieve- } \\
\text { ments, among which was the reorganization } \\
\text { of the army, the increase of the national } \\
\text { marine, the improvement of the ports, } \\
\text { roads, and bridges, the construction of rail- } \\
\text { ways, the improvement of the condition of }\end{array}$ \\
\hline I & H I S A N I C NOTES \\
\hline
\end{tabular}




\section{GÓ M E Z}

the workingmen, and the enlargement of the public schools.

Following the election in I9I 2 of General Menocal, candidate of the Conservative party, General Gómez made an extended visit to Europe, and on his return abstained from politics until the Presidential election of 19 I 6 when he gave his utmost efforts to secure the election of Alfredo Zayas. On the defeat of Zayas in a disputed election, there were various disorders which grew to the proportions of a revolution in which General Gómez became involved and in February, I9I7, he was seized and imprisoned for a brief period after which he retired to the United States. 



\section{L E S}

\section{FERNANDO LLES}

Writer; editor; poet.

Fernando Lles was born in Ceiba Mocha, Province of Matanzas, on the thirty-first of August, I882, but received his early education in Spain where he was taken by his parents when he was only four years old. When he was twelve he returned to Cuba and set to work to gain an education which should be broad and sound in spite of its irregularity of method. Resolving to remedy the casual nature of his educational training by sustained methodical study, Lles obtained in I9I 8 the Bachelor's degree in the Institute of Matanzas.

From a very early age Lles felt drawn to letters and particularly to poetry. $\mathrm{He}$ founded and edited two magazines, Alma Latina and Matanzas, both of which had an interesting though brief career. In 1909

H I S A N I C N T E S 


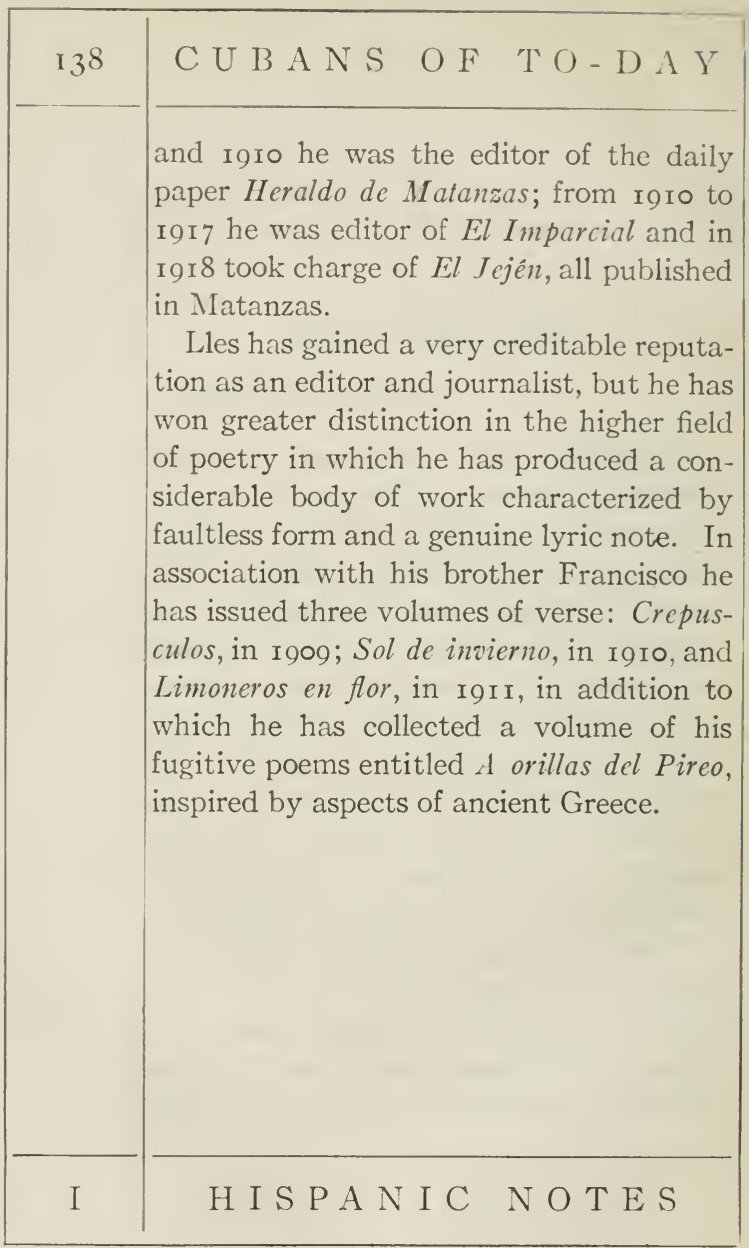




\section{E S C O T O}

\section{JOSÉ AUGUSTO ESCOTO}

\section{Librarian; writer; editor.}

José Augusto Escoto was born on the twenty-fourth of January, I864, in Matanzas, and gained his early education in his native town where he pursued the studies leading to the Bachelor's degree, but failed to obtain it there, because the Institute of Matanzas like others throughout the Island had been suppressed by the Spanish authorities; but he received the degree in I880 from the Institute of Havana. In the same year he entered upon the study of Medicine but soon abandoned it to follow the stronger interest in literature and criticism.

The twenty years between I880 and I 900 Escoto devoted to research-investigating and accumulating material on the history and literature of Cuba, coöperating

\section{A N D M O N O G R P H S}




\begin{tabular}{|c|c|}
\hline 140 & C U B A N O F TO-DAY \\
\hline & $\begin{array}{l}\text { in his labors with the distinguished Cuban } \\
\text { scholars, José Silverio Jorrín, Vidal Morales, } \\
\text { and Manuel Villanueva. } \\
\text { In I900 he succeeded Carlos M. Trelles } \\
\text { as Librarian of the Public Library of Ma- } \\
\text { tanzas and has continued in that post until } \\
\text { to-day. During this period, the second } \\
\text { epoch of his life, Escoto has brought to } \\
\text { fruition the results of his research in the } \\
\text { earlier years and has published numerous } \\
\text { articles and pamphlets in the field of Cuban } \\
\text { history. In I I I he produced an extensive } \\
\text { biography of the famous Cuban poetess, de } \\
\text { Avellaneda- entitled Gertrudis Gómez de } \\
\text { Avellaneda: cartas inéditas } y \text { documentos, } \\
\text { I859 a I864. } \\
\text { In I9I6 Escoto began to issue his maga- } \\
\text { zine Revista histórica, critica y bibliografica } \\
\text { de la literatura cubana, which, though only } \\
\text { four numbers appeared, constituted a } \\
\text { positive contribution to Cuban history } \\
\text { and letters. } \\
\text { In I I } 7 \text { Escoto was awarded the prize } \\
\text { offered by the Franciscan Order in Cuba } \\
\text { in a literary contest with his essay entitled } \\
\text { Contribución al estudio de la Primera Orden }\end{array}$ \\
\hline I & H I S P A I C NOTES \\
\hline
\end{tabular}




\section{E S C O T O}

Franciscana en Cuba. And he is at present bringing to completion the critical edition of the works of the poet José Jacinto Milanés which is being published in accordance with the vote of the Congress of Cuba. 



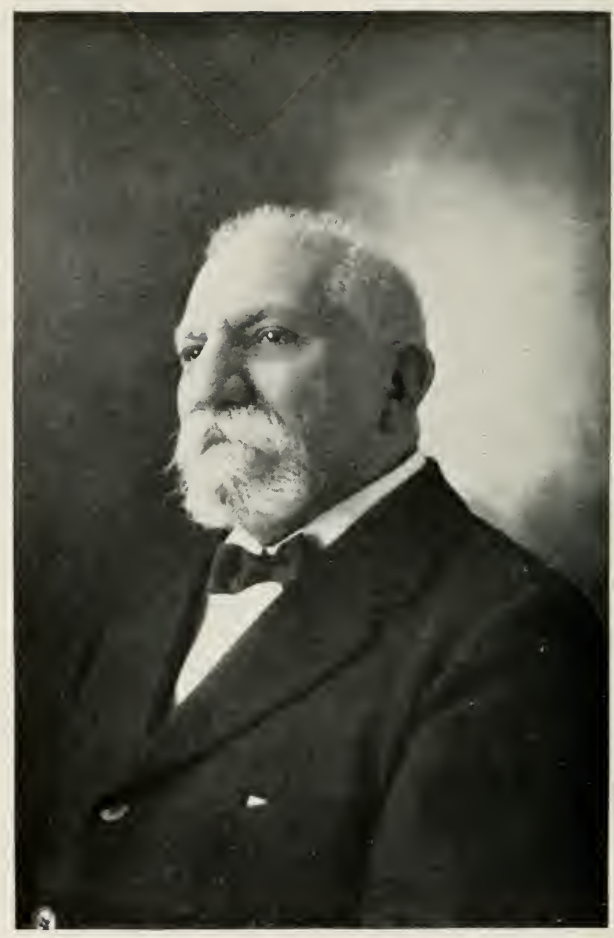

Juan Santos Fernandez 


\section{SANTOS FER ÁN DEZ}

\section{JUAN SANTOS FERNÁNDEZ}

Physician; ophthalmologist; publicist.

Juan Santos Fernández was born on the twenty-second of June, I847, at "Atrevido" the estate of his maternal grandfather in the town of Alacranes, Province of Matanzas.

He began his studies at the Colegio of Belén in Havana where he gained the Bachelor's degree and entered the University of Havana. He remained there, however, only two years, passing to Madrid where, in June, 1872 , he received the degree of Licentiate in Medicine and two years later at Barcelona that of Doctor.

His devotion to Ophthalmology was apparent during his university days and has remained the central interest in his life. From Spain he went to Paris where he gave special study to his chosen subject

H I S P A N I C N O T E S 


\begin{tabular}{|c|c|}
\hline 144 & C U B A N O F T O-D A Y \\
\hline & $\begin{array}{l}\text { until I } 875 \text { in Dr. Xavier Galezowski's } \\
\text { clinic for diseases of the eye. In I } 875 \text { he } \\
\text { established himself in Havana and founded } \\
\text { the Crónica Médico-Quirurgica de la Habana } \\
\text { which is the oldest magazine of the city. } \\
\text { In I } 887 \text { with the aid of colleagues he } \\
\text { founded the Laboratorio Histo-Bacterio- } \\
\text { lógico y de Vacunación Antirrabica which } \\
\text { has rendered important scientific service } \\
\text { and has passed its twenty-fifth year, which } \\
\text { was celebrated in a special number of the } \\
\text { Crónica Médico-Quirurgica de la Habana. } \\
\text { Dr. Fernández has devoted his energies } \\
\text { to the medical Press and the Academies. } \\
\text { His publications have been very numerous. } \\
\text { More than sixteen hundred contributions, } \\
\text { containing many annotations and descrip- } \\
\text { tions, constitute the record and these con- } \\
\text { tain details of no fewer than sixty thousand } \\
\text { cases, } i \text {. e., clinical histories of individuals. } \\
\text { So that it might be said that no physician } \\
\text { has published more cases in Spanish. } \\
\text { In October, I9o9, Dr. Fernández was } \\
\text { invited by the American Academy of } \\
\text { Ophthalmology to read a paper on his } \\
\text { specialty and to receive the title of Honor- }\end{array}$ \\
\hline I & H I P A N I N O T E S \\
\hline
\end{tabular}


ary Member. On his return to Cuba the Academy of Sciences of Havana, as a sign of its admiration and esteem, devoted a special session to his honor and placed his portrait in its halls.

In I9I 2 he was chosen to preside at the Pan-American Congress held at Havana; he is President of the Academy of Sciences and also of the Ateneo y Circulo of Havana. 



\section{E N T O}

RAFAEL PEREZ VENTO Y NIN

Physician; teacher; writer.

Rafael Pérez Vento y Nin was born on the twenty-first of October, I875, in the town of Guanabacoa. His education was gained partly in Havana, partly in Madrid, and partly in Paris, and he holds the degree of Doctor in Medicine and Surgery.

He served for a time as Physician of the Hospital of Mercedes and Number One. $\mathrm{He}$ won in competitive examination the post of Professor of Physiology, etc., in the Faculty of Medicine of the University of Havana and has continued to occupy it. Meantime he has contributed many articles on his special subject to professional journals and has published: Hojas Fisiológicas, I9I4; Hojas Neurológicas y Mentales, I9r6.

\section{H I S P A N I C N T E S}



ALBERTO BARRERAS FERNÁNDEZ Soldier; educator; administrator.

Alberto Barreras Fernández was born on the twenty-seventh of February, I870, in Havana and there obtained his education, pursuing the courses leading to the Bachelor's degree in the Jesuit Colegio of Belén and continuing the study of law, though not completing the course, in the University.

During the War of Independence he was imprisoned for conspiring against the Spanish rule and in favor of Cuban liberty, and was later expelled from Cuba. Whereupon he gave himself to organizing revolutionary clubs in the United States and Mexico, devoting his energy particularly to providing resources for the Cuban army and to the propaganda of emancipation.

In 1897 he joined a military expedition

\section{H I S P N I C N O T E S}




\begin{tabular}{|c|c|}
\hline I 50 & $\mathrm{C} U \mathrm{~B}$ A N S O F TO-D A Y \\
\hline & $\begin{array}{l}\text { which reached the coast of Cuba on the } \\
\text { ship Dauntless and disembarked there } \\
\text { under the command of Major Luis Rodolfo } \\
\text { Miranda. His services in the war gained } \\
\text { him the rank of Major. } \\
\text { At the close of the war he continued in } \\
\text { government service and on the third of } \\
\text { January, I899, was appointed Secretary } \\
\text { of the Board of Education for Havana. } \\
\text { His duties began with the organization of } \\
\text { education in Cuba, and he had a share in } \\
\text { all the early stages, being entrusted with } \\
\text { special duties of importance. This post he } \\
\text { held until the eighth of October, I908, when } \\
\text { he was appointed Secretary of the Govern- } \\
\text { ment of the Province of Havana under } \\
\text { Governor Asbert, and filled the duties of } \\
\text { this office until the sixth of April, I } 913 . \\
\text { Meantime in the elections of the first of } \\
\text { November, I9I2, he had been chosen Repre- } \\
\text { sentative from the Province of Havana } \\
\text { and he entered upon the duties of his new } \\
\text { office on the seventh of April, I9I3. In the } \\
\text { House of Representatives he was elected } \\
\text { Secretary of the House and held this posi- } \\
\text { tion until the twenty-ninth of July, I9I4, }\end{array}$ \\
\hline I & H I S P A N C N O T E S \\
\hline
\end{tabular}




\section{B A R R E R A S}

continuing as Representative until the first of April, I9I 7.

In November, r9r6, he was the Liberal Candidate for Governor of the Province of Havana, and is said to have been elected by a great majority. Under the law the successful candidate should have taken possession of his office on the twentyfourth of February, I9I 7 , but the government then in power, belonging to the party to which Barreras had been opposed in the elections, prevented him from doing so and imprisoned him until the thirtieth of June, and then, on setting him at liberty, under a fine of $\$ 10,000$, charged that he had in effect resigned his office by not taking possession of it at the time designated-at which time he was in jail, imprisoned in the cells of the Cabaña. In the spring of I9I9, under authorization of the Courts, he entered into his office of Governor.

\section{A N D M O NOG R P H S}





\section{E J Ú S T I Z}

TOMÁS JUAN DE JÚSTIZ Y DEL VALLE

\section{Teacher; writer.}

Tomás JuAN DE JÚSTIZ y del VALle was born in Santiago de Cuba on the twelfth of July, I87r.

He gained his degree of Doctor in Philosophy and Letters and the secondary degree of Licentiate in Law at the University of Havana where he taught for a time as auxiliary Professor of Universal History. $\mathrm{He}$ is now Professor of Geography and Universal History in the Institute of $\mathrm{Ha}$ vana. In the Summer Sessions he has been Lecturer on the History of Cuba, and General Geography.

He has been active as a journalist as well as a teacher, serving as editor and contributor to various papers, and is now one of the editors of La Noche.

H I S P A I C N O T E S 


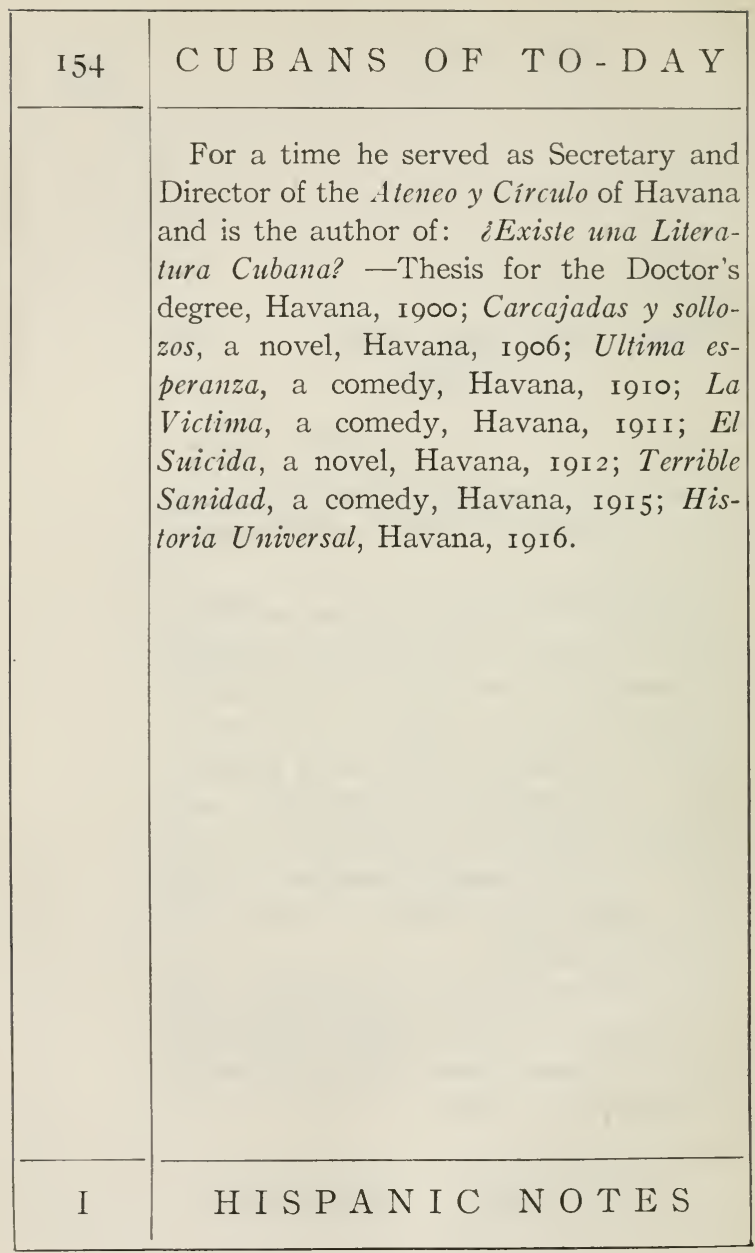




\section{JULIO BLANCO HERRERA}

Man of affairs.

Julio Blanco Herrera was born on the twentieth of December, $\mathbf{1} 88 \mathrm{I}$, in Havana. His early education he gained at the church schools of Guanabacoa, and later went to France where he entered the School of Commerce of Paris.

On returning to $\mathrm{Cuba}$ he entered the commercial field, joining the staff of the firm of ship-owners Empresa Naviera de Sobrinos de Herrera, of which his father was the manager. In 1903 he became head of the firm, and remained in charge until 19I4 when he became head of the Nueva Fábrica de Hielo, S. A.

Señor Herrera has traveled widely and in I9 I made a tour of the world.

$\mathrm{He}$ is prominent in Havana Society, being a member of many clubs, and is one of the Directors of the Chamber of Commerce, Industry, and Navigation.

\section{A N D M O N G R A P S}






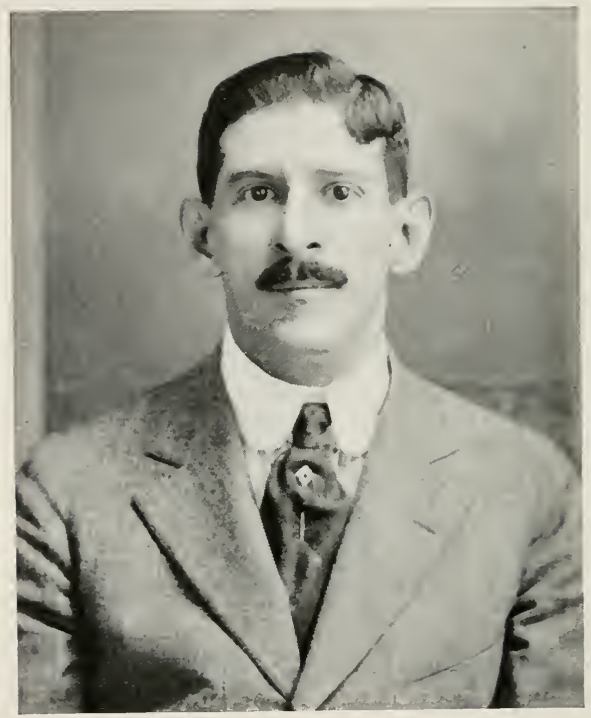

Narro Muing Prus tamante 


\section{MARIO MUÑOZ BUSTAMAN'TE}

Writer; official.

Mario Muñoz Bustamante y Medina was born in Havana on the third of July, I88I. He gained his education by his personal efforts without attending college or university.

He has an official position as Chief Clerk of the Republic of Cuba. But his active career has been that of a writer, first in journalism where he has served as editor or contributor to nearly all the papers and periodicals of Havana, and later in more sustained efforts in biography and fiction.

He is the author of: Crónicas Humanas, Habana, I905; El Pantano, Satire. Habana, I905; Ideas y Colores, Habana, I907; El General Mario G. Menocal, tercer Presidente de la República de Cuba, Habana, I9r3; Rimas de Gozo, Habana, I9r5.

\section{H I S P A N I C N O T E S}




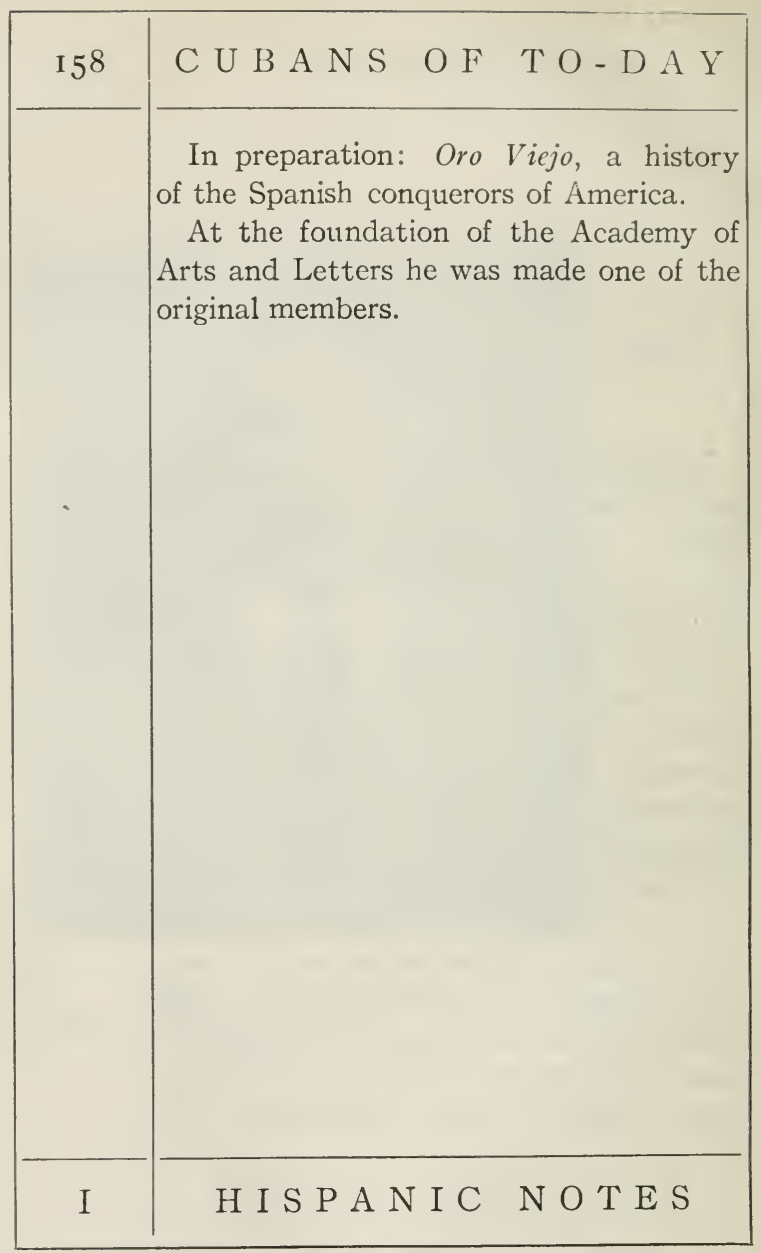





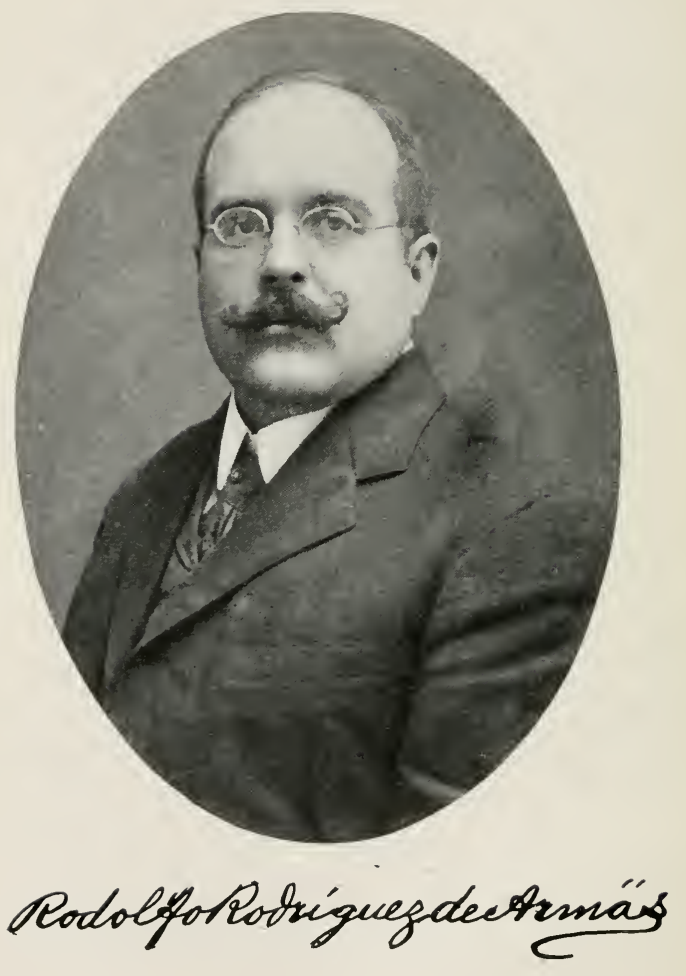




\section{E A R M A S}

RODOLFO RODRÍGUEZ DE ARMAS

Scholar; teacher; publicist.

Rodolfo Rodríguez de Armas was born on the fourth of February, I874, in Havana, and gained part of his education in the city of his birth. In the year r89 I he became editor of the Revista Universitaria, and in the following year edited also El Centenario en la Habana. He served for a time as Professor of Latin Grammar and of Spanish Grammar and Literature in the Institute of Pinar del Rio, and won the following degrees-Doctor in Philosophy and Letters and Licentiate in Law.

In 1898 he went as Deputy for Havana to the Spanish Cortes where he urged that a sweeping autonomy be granted to $\mathrm{Cuba}$, and later besought the Spanish government to authorizethe execution of the Treaty of Paris with the United States, maintaining that it was the duty of Spain to assure the recognition of Cuba as an independent nation.

\section{A N D M O N O G R A P H S}




\begin{tabular}{|c|c|}
\hline 160 & C U B A N O F T O - D A Y \\
\hline & $\begin{array}{l}\text { In I900 he edited La Unión Democrática } \\
\text { in Pinar del Rio. } \\
\text { In I } 909 \text { he was official Delegate of Cuba } \\
\text { in the Third International Conference on } \\
\text { Maritime Law at Brussels where he con- } \\
\text { tributed to the discussion of the rules upon } \\
\text { Boarding, Salvage, and Responsibility, the } \\
\text { application of which might be of great } \\
\text { benefit by preventing much litigation. } \\
\text { He is Professor of Geography and Uni- } \\
\text { versal History in the Institute of Havana; } \\
\text { President of the Section of History in the } \\
\text { Sociedad Económica de Amigos del Pais; } \\
\text { Member of the Academy of History of } \\
\text { Cuba and also Librarian. } \\
\text { He has published: Las hermanas Rossell, } \\
\text { novela, Habana, I9o8; La revolucion re- } \\
\text { ligiosa del siglo XVI, Habana, I9o9; La } \\
\text { Tercera Conferencia Internacional de De- } \\
\text { recho Maritimo, Habana, I9Io; Maria } \\
\text { Juana, drama, Habana, I9Io; Curso de } \\
\text { Historia Universal. } 3 \text { vols. Habana, I9I5; } \\
\text { Salvada del abismo, drama, Habana, I9I6. } \\
\text { In preparation: Critica literaria; Es- } \\
\text { tudios históricos; Discursos y conferencias. }\end{array}$ \\
\hline I & H I S A N I C NOTES \\
\hline
\end{tabular}




\section{A R B O N E L L}

\section{LUIS GARCIA CARBONELL}

\section{Meteorologist.}

Luis Garcia Carbonell was born in Los Palos, Province of Havana, on the tenth of October, I840. He took his early studies in the Colégio of Don Joaquin Andrés de Dueñas in Havana, but while still very young went to Spain to fit himself for a naval career. There he entered the Naval School of San Fernando in Cadiz where he graduated in 1857 as a Marine guard.

He sailed until 1875 on various ships and on many seas, being in charge of navigation or actually navigating officer of several vessels. From 1875 until I893, when he requested and obtained his discharge from the service, he was employed in the Captaincy of the Port of Havana and in the Naval Station.

In the year 1899 he established for the

\section{A N D M O N O G A P H S}




\begin{tabular}{|c|c|}
\hline 162 & C U B A N S OF TO-D A Y \\
\hline & $\begin{array}{l}\text { Spanish Marine the meteorological service } \\
\text { of the Antilles by which he gained the rank } \\
\text { of Frigate Captain with which he retired. } \\
\text { When the Spanish rule in Cuba ceased, } \\
\text { Carbonell was appointed by the U. S. } \\
\text { Government, Assistant in the Weather } \\
\text { Bureau of the Antilles, with headquarters } \\
\text { at Havana. On the establishment of the } \\
\text { Republic in I } 902 \text {, he was called upon by the } \\
\text { Secretary of Agriculture to take charge of } \\
\text { the service of climatology and crops which } \\
\text { the Intervention government handed over } \\
\text { to Cuba. } \\
\text { In I90 } 5 \text { he was placed in charge of the } \\
\text { Meteorological Service by which he became } \\
\text { Director of the National Observatory, and } \\
\text { this he inaugurated on the spot which it } \\
\text { now occupies in the Loma de Casa Blanca, } \\
\text { of which the exact geographical position } \\
\text { is: Latitude } 20^{\circ} \text {, } 9^{\prime} \text { N. Y.; Longitude } 5 \text { h. } \\
29 \text { m } 23.4 \text { sec. W. of the Meridian of } \\
\text { Greenwich. }\end{array}$ \\
\hline I & H I S P A N I C \\
\hline
\end{tabular}




\section{A. N D R É}

\section{ARMANDO ANDRÉ ALVARADO}

Soldier; official; Director of Subsistence.

Armando André Alvarado was born in Key West, Florida, on the first of May, I872. In 1892 , when he was twenty years old, he joined the Cuban revolution in the Province of Matanzas, attaching himself to. the staff of General Antonio Maceo. Under the orders of General Maceo he came to Havana and carried out daring projects including a visitation on General Valeriano Weyler in the very palace in the Plaza de Armas which is now occupied by the President of the Republic. He operated later in the Province of Havana with Generals Delgado and Castillo.

In 1892 he was sent to the United States under orders from General Castillo to conduct an expedition and obtain materials of war. This commission he fulfilled within a

\section{A N D M O N O G R A P H S}




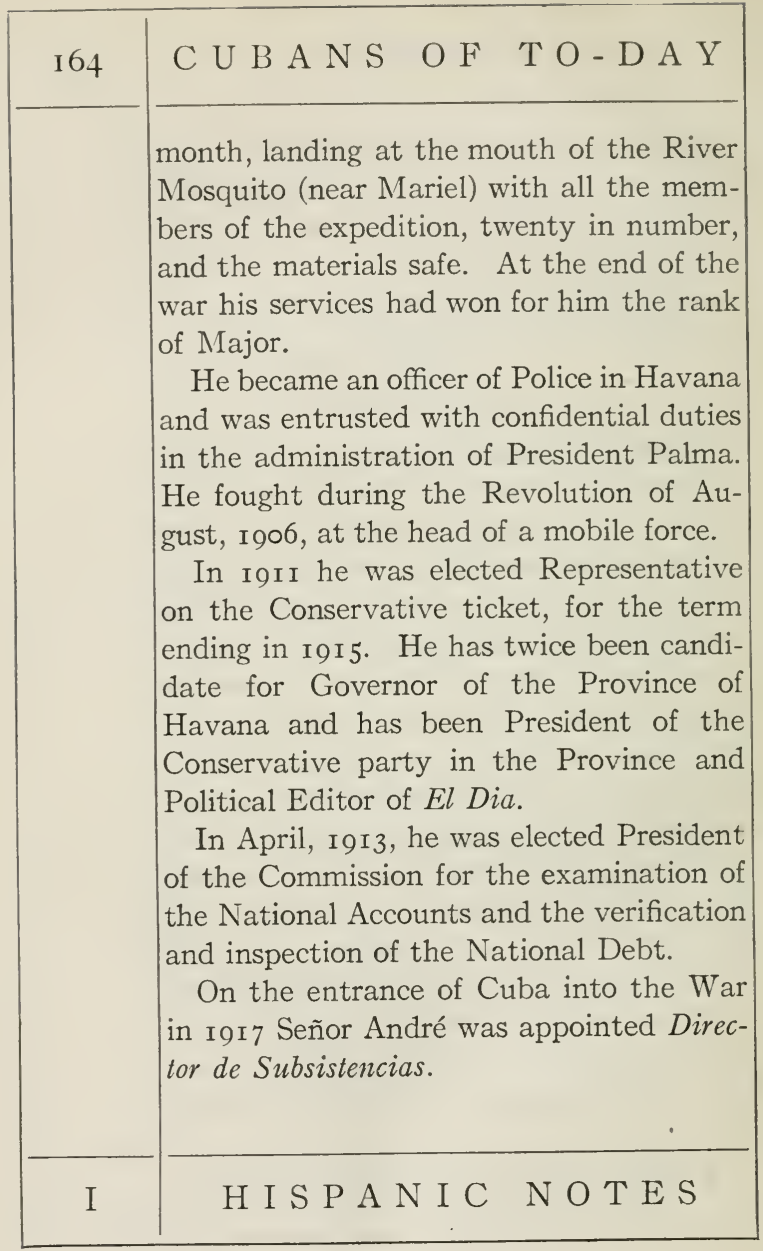


ARTURO R. DE CARRICARTE Y DE ARMAS

Editor; author; official.

Arturo R. De Carricarte y de Armas was born on the sixth of November, I880, in Havana and received his early education at home under the instruction of a noted teacher and writer, Doctor Esteban Borrero Echevarría. In I894 he gained the degree of Bachelor of Science and Letters and thereafter pursued for three years the Medical course. In I 900 he won the rank of Professor in competitive examination, being one of eleven successful out of a total number of a hundred and five competitors.

In 1902 he resigned his professorship and went to Mexico where he engaged in literary work which occupied him either in Cuba or in Mexico until Igog when he

\section{A N D M O N O G R P H S}




\begin{tabular}{|c|c|}
\hline I66 & C U B A N S O F T O - D A Y \\
\hline & $\begin{array}{l}\text { entered the Consular service and was } \\
\text { stationed at Montevideo, Uruguay. } \\
\text { In I9I I he resigned his consulship at } \\
\text { Montevideo and was appointed Chief } \\
\text { Clerk to the Secretary of Gobernacion from } \\
\text { which post he resigned in I9I3. In I9r6 } \\
\text { he was appointed Chief Clerk of the Senate } \\
\text { where he continues. } \\
\text { Señor Carricarte's life has been chiefly } \\
\text { lived in his literary work which he began } \\
\text { at an early age, having founded when he } \\
\text { was sixteen the Revista Habanera a stu- } \\
\text { dents' magazine. In I9o4 he founded the } \\
\text { weekly journal Helios at Marianao and in } \\
\text { I } 906 \text { in Vera Cruz, Mexico, the Revista } \\
\text { Critica. } \\
\text { In I9o7 he served as city Editor of the } \\
\text { Spanish edition of the Havana Post and also } \\
\text { edited the art journal El Mundo Artistico. } \\
\text { He has been a member of the staff of Azul } \\
\text { y Rojo, El Figaro, and El Triunfo of which } \\
\text { last he has been editorial writer for eight } \\
\text { years. He has also contributed to the } \\
\text { principal magazines of Cuba and written } \\
\text { reviews for the Diario de la Marina. } \\
\text { In I } 906 \text { he founded the Asociacion }\end{array}$ \\
\hline I & H I P A N I C NOTES \\
\hline
\end{tabular}




\section{A R R I C A R T E}

\section{67}

Literaria Internacional Americana which he served as President and which included among its members, Jesús Castellanos, Miguel de Carrión, Max Henriquez Ureña, etc. In 1908 he was crowned in the Ateneo of Havana for his critical study on the Caracteres predominantes de la actual lirica Castellana. $\mathrm{He}$ is an Honorary Member of the Ateneo of Salvador, and a Corresponding Member of the Academias de Ciencia, Letras y Artes of Salvador, of the Academia Emilio Castelar of Mexico, of the Sociedad de Escritores y Artistas of Porto Rico, etc.

He is the author of: Siluetas Pedagogicas, Habana, I903; Noche Trágica, novela, Habana, I903; La Novela en Cuba, artículo, Febrero, I907; El nacionalismo en América, artículo, Montevideo, I909; Un Centenario, Habana, I9I4; Historia de un vencido, novela, Habana, I9I4; La Novela en Cuba, two vols.; Balance Literario de Cuba en I9I5, I9I6.

\section{A N D M O N O G R A P H S}





\section{BLANCHE ZACHARIE DE BARALT}

\section{Lecturer; writer.}

Blanche Zacharie was born in New York on the seventeenth of March, I866, but spent most of her childhood in Paris where she obtained her early education. On returning to the United States, she entered the Packer Collegiate Institute of Brooklyn where she graduated and afterwards continued her studies, particularly in music, which she pursued under the best masters for several years.

After her marriage to Dr. Baralt (q. v.) she continued to live in New York, occupied chiefly in literary work, until r 900 when her husband fixed his residence in Havana and where husband and wife have had an active literary career. In I 902 she obtained the degree of Doctora in Philosophy and Letters.

H I S P A N C N O T E S 


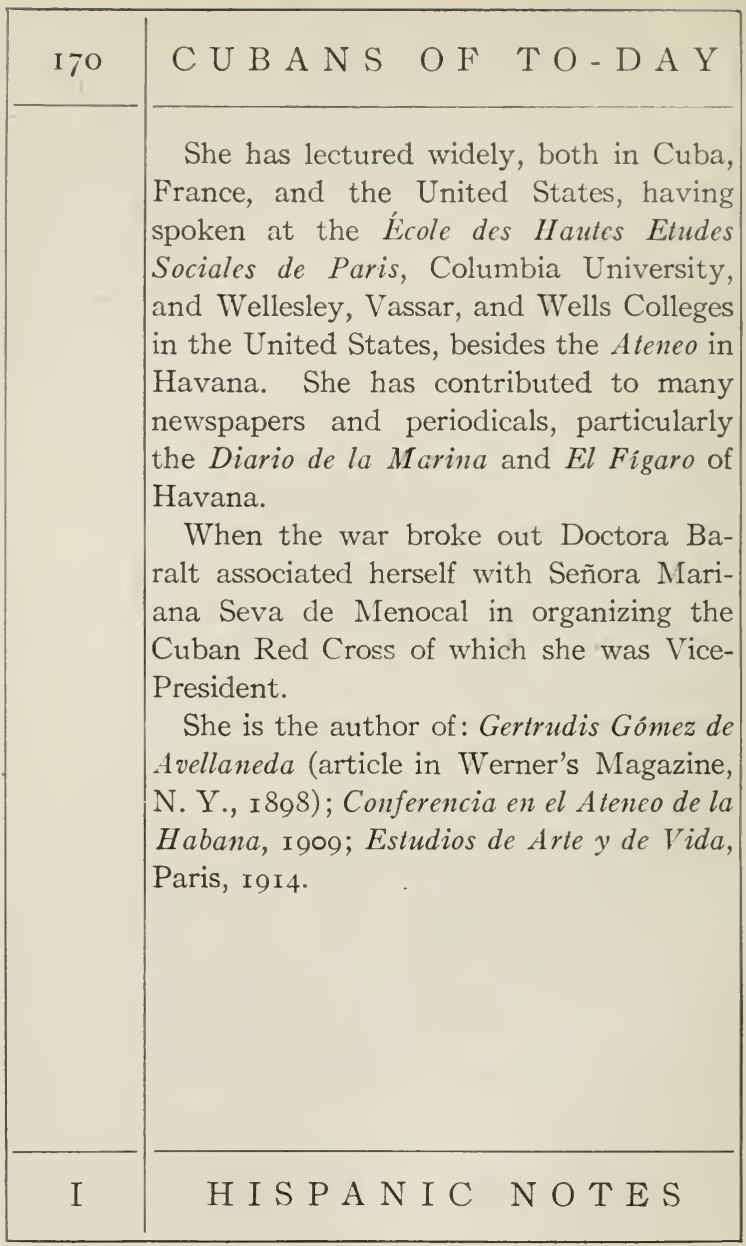




\section{O R A L E S}

\section{MODESTO MORALES DÍAZ}

\section{Journalist.}

Modesto Morales Diaz was born in the city of Sancti Spiritus, Province of Santa Clara, on the twentieth of April, I87 I, while the Ten Years' War was still raging. He obtained his education in his native place, which at that time possessed excellent primary and secondary schools, and entered at an early age upon the journalistic profession to which he has devoted himself. His first work was done on the staff of $E l$ Fenix, the oldest newspaper of the province, which he served first as reporter and later as editor and to which he has continued to contribute.

In his youth he took an active part in the Autonomist party and was zealous in organizing the Young Liberals. When the

\section{A N D M O N O G R A P H S}




\begin{tabular}{|c|c|}
\hline 172 & C U B A N S O F T O - D A Y \\
\hline & $\begin{array}{l}\text { Revolution broke out in } 1895 \text { he was an } \\
\text { energetic agent in the revolutionary or- } \\
\text { ganization, while acting at the same time } \\
\text { as a correspondent of } L a \text { Discusion (of } \\
\text { Havana), and was deported from Sancti } \\
\text { Spiritus, in company with other ardent } \\
\text { Cubans of the town, by the Spanish Gen- } \\
\text { eral Pin. Whereupon he took up his resi- } \\
\text { dence in Havana and joined the staff } \\
\text { of } L a \text { Discusion on which he continued } \\
\text { until it was suppressed by the Spanish } \\
\text { authorities. } \\
\text { On the foundation of the Republic (in } \\
\text { I9o2) he became one of the editors of } L \text { a } \\
\text { Lucha and remained on its staff until igo7 } \\
\text { when he coöperated with General José } \\
\text { Miguel Gómez in founding the newspaper } \\
\text { El Triunfo, of which he is now the sole } \\
\text { proprietor and in which he maintains the } \\
\text { lofty ideals and democratic principles of } \\
\text { the Liberal party. } \\
\text { Although he has had a prominent part } \\
\text { in political affairs, being one of the original } \\
\text { organizers of the National party in Cuba } \\
\text { and active later in uniting the elements } \\
\text { which supported and elected General }\end{array}$ \\
\hline I & H I P A N I C N O T E S \\
\hline
\end{tabular}




\section{O R A L E S}

Gómez, Sr. Díaz has never held office, either National, Provincial, or Municipal. His sole ambition is centered in the ideals of journalism. 



\section{R O M A N A C H}

\section{LEOPOLDO ROMANACH}

\section{Painter.}

LeOpoldo Romanach was born in I 869 in Sierra Morena, Province of Santa Clara, but was educated in Spain, whence he returned as a youth, resolved to be a painter. and began to paint without instruction.

Sometime later the Provincial Assembly of Santa Clara granted him a pension to enable him to go to Italy to study. There he remained five years and received much instruction from the distinguished master, Professor Filippi Prosperi, Director of the Institute of Fine Arts of Rome.

At the outbreak of the War of Independence in 1895 he lost his pension and went then to the United States where he lived by his brush until I 900 in which year he returned to Havana. His return was signalized by an exhibition of his paintings

\section{H I S P A I C NOTES}




\begin{tabular}{|c|c|}
\hline 176 & C U B A N S O F T O - D A Y \\
\hline & $\begin{array}{l}\text { and his appointment as Professor of Color } \\
\text { in the Academy of Havana, a post which } \\
\text { he still holds. } \\
\text { Sr. Romanach has exhibited at the } \\
\text { World's Fairs of Paris in I902, of Buffalo } \\
\text { in I903, of Charleston in the same year, of } \\
\text { St. Louis in I904, of Havana in I9I I, and } \\
\text { of San Francisco in I9I6. In the Havana } \\
\text { Exposition he was awarded the First Prize } \\
\text { (Gran Premio) and in that of San Fran- } \\
\text { cisco a Medal of Honor. In the earlier } \\
\text { Expositions he was awarded two gold } \\
\text { medals, one of silver, and one of bronze. } \\
\text { Among Sr. Romanach's works are: } \\
\text { Convaleciente, Abandonada, Un nido de } \\
\text { miseria, La promesa, Cumpliendo cl voto, } \\
\text { Juventud, Mis modelos, Rincón de estudios, } \\
\text { Segoviana, Viejo rezando, Segadora, Vende- } \\
\text { dora de naranjas, Luisete, Viejo fumamdo, } \\
\text { Gitana, Madrileña, Sonadora, Contraste. } \\
\text { In addition to these he has produced } \\
\text { various decorative panels, a triptich repre- } \\
\text { senting Agriculture, and a historical paint- } \\
\text { ing El Toso de los Laureles y la Ultima } \\
\text { Prenda which obtained the Medal of Honor } \\
\text { at the San Francisco Exposition. }\end{array}$ \\
\hline I & H I S P A I C N O T E S \\
\hline
\end{tabular}





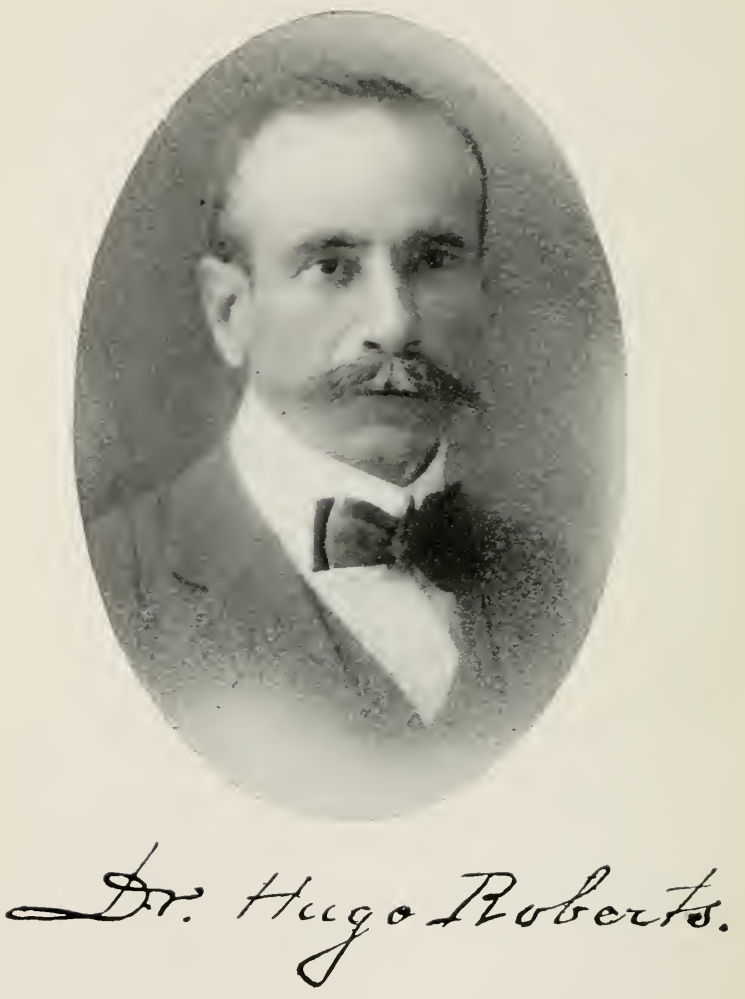




\section{R O B E R T S}

\section{HUGO ROBERTS}

Doctor; soldier; scientist; administrator.

Hugo Roberts was born in Trinidad on the twentieth of July, I868. He received his early education in Madrid but later came to Havana where he completed the studies for the Bachelor's degree in the Institute and, proceeding to the University, obtained the degree of Doctor of Medicine in I89I.

$\mathrm{He}$ was occupied in the practice of his profession and as Medical Advisor of the Compañía Transatlántica Española until the year I 895 when, on the outbreak of the War of Independence, he threw himself into the struggle and joined the forces of General Antonio Maceo under whom he served and who made him Surgeon at his Headquarters. When Generals Gómez and Maceo organized the column of invasion in

\section{A N D M O N O G R A H S}




\begin{tabular}{|c|c|}
\hline 178 & C U B A N S O F TO-DAY \\
\hline & $\begin{array}{l}\text { the Eastern provinces to carry the war into } \\
\text { the western part of the Island, Dr. Roberts } \\
\text { was made Surgeon General of the invading } \\
\text { forces, a difficult and dangerous post which } \\
\text { put to the test at once his personal valor, } \\
\text { his patriotism, his energy, and his quality } \\
\text { as a man of science. In the course of duty } \\
\text { he was severely wounded in the battle of } \\
\text { San Gabriel de Lombillo; nevertheless he } \\
\text { finished the campaign, gaining promotion } \\
\text { from rank to rank solely by his personal } \\
\text { merits and ended the war with the rank of } \\
\text { Brigadier General. } \\
\text { In I } 898 \text { he was delegated from the Sixth } \\
\text { Corps of the Army to the Assembly of } \\
\text { Santa Cruz del Sur, and in I } 90 \text { I he served } \\
\text { as Alternate in the Constitutional Con- } \\
\text { vention which drew up the fundamental } \\
\text { code of the Republic. } \\
\text { During the first American Intervention } \\
\text { Dr. Roberts was appointed Surgeon to the } \\
\text { Havana Police force; later he was made } \\
\text { first surgeon of the Port of Havana and } \\
\text { on September I, I9o2, he was named Chief } \\
\text { of the Quarantine service- a post which he } \\
\text { still occupies. }\end{array}$ \\
\hline I & H I S P N I C N O T E S \\
\hline
\end{tabular}




\section{R O B E R T S}

Along with Doctors Guiteras, Agramonte, Barnet, and López del Valle, Doctor Roberts was one of the most effective co-laborers in the work initiated under the American Intervention for the public health of Cuba, as he has been one of the ablest of those who have maintained the sanitary policy then adopted.

Dr. Roberts was Delegate of the Cuban Government to the Exposition in St. Louis (I904) and to the Pan-American Health Conventions in Mexico (I907), Costa Rica (I909), and Santiago de Chile (I9II).

$\mathrm{He}$ was also Acting President of the National Red Cross Society of Cuba; and at present is a Member of the National Board of Health; Member of Special Commission of Infectious Diseases and also Member of the Bureau of American Republics in Washington.

$\mathrm{He}$ is author of several scientific works on Medical and Sanitary matters and also inventor of an apparatus for generating and injecting hydrocyanic acid gas, which is employed to advantage by the Sanitary Department for the destruction of all kinds

A N D M O N G R A P S 


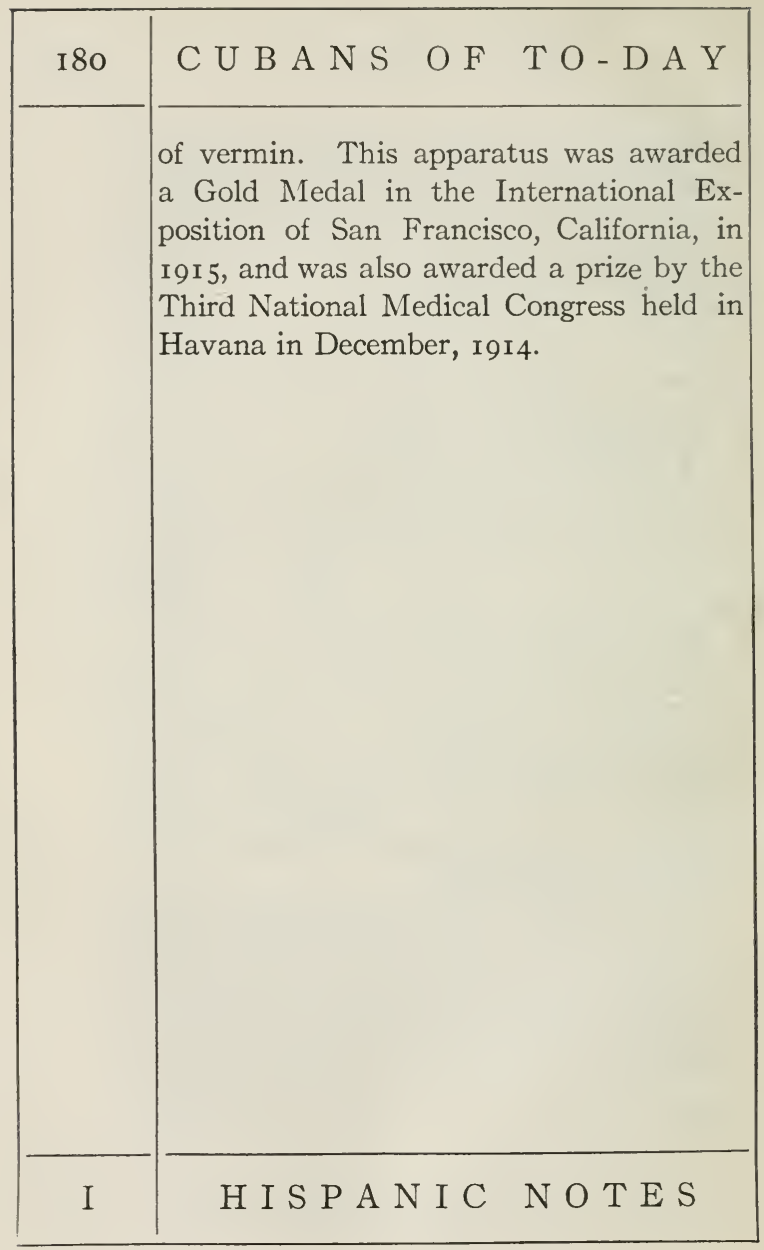





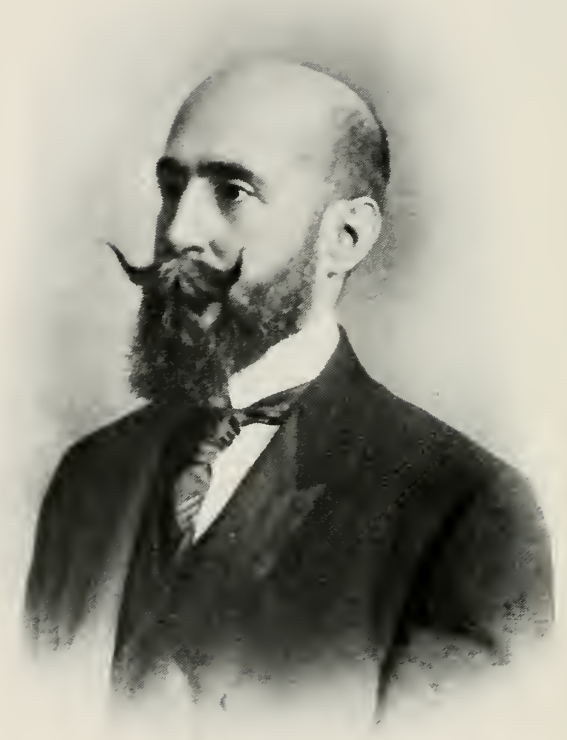

Fernando Freyre de Andrade 
FERNANDO FREYRE DE ANDRADE

Lawyer; soldier; magistrate; administrator.

SEÑor Freyre dE ANDRAdE was born in the city of Havana on the tenth of September, I863. His early studies were pursued in Havana in the Colegios of Carcasés and of Don José Alonso Delgado, where he completed the courses leading to the Bachelor's degree, going thence to the Universities of Havana and Madrid to continue his studies in the Law in which he graduated from Havana in $\mathrm{I}_{8} 8$.

In 1890 he was made substitute Prosecuting Attorney of the Audiencia of Havana, in 1894 he was made substitute Magistrate, and during the same period he acted as Secretary and Counsel of the Casa de Beneficencia y Maternidad.

When the War of Independence broke

\section{A N D M O N O R A P H S}




\begin{tabular}{|c|c|}
\hline I 82 & C U B A N O F T O-D A Y \\
\hline & $\begin{array}{l}\text { out Señor Freyre de Andrade left Cuba and } \\
\text { went to the United States where in due } \\
\text { course he placed himself under the direc- } \\
\text { tion of Tomás Estrada Palma who was } \\
\text { guiding the Revolutionary forces in New } \\
\text { York. He embarked on the third expedi- } \\
\text { tion of the Dauntless landing in Rio Hondo } \\
\text { de San Juan on the thirteenth of October, } \\
\text { I } 896 \text {. He then served under General } \\
\text { Máximo Gómez who placed him in com- } \\
\text { mand of his Cavalry. In the same year } \\
\text { the Council of Government named him } \\
\text { Auditor General of the Army Legal Staff } \\
\text { attached to General Headquarters. In } \\
\text { September, I897, he was elected Represen- } \\
\text { tative of the Fifth Army Corps in the } \\
\text { Second Legislative Assembly of the Rev- } \\
\text { olution which met at Yaya, Camagüey. } \\
\text { At the close of the Assembly the Council } \\
\text { appointed him chief of the Military Legal } \\
\text { Staff with the rank of Brigadier General, } \\
\text { and at the end of the war he was elected } \\
\text { to represent the Fifth Army Corps in the } \\
\text { last Assembly of the Revolution which } \\
\text { met, first in Santa Cruz del Sur and later } \\
\text { in Cerro in Havana-of which Assembly }\end{array}$ \\
\hline I & H I S P A N I N O T E S \\
\hline
\end{tabular}




\section{FREYRE DE A N D R D E}

he was elected alternate President with General Capote.

When the legal division of the Government was organized under the American Intervention, Freyre de Andrade was made Magistrate of the Audiencia of Havana. Later General Wood appointed him Prosecuting Attorney (Fiscal) of the Audiencia, and when the Republic was constituted President Palma appointed him Fiscal of the Supreme Court. This office he resigned to become Secretary of Gobernación in 1905. In the same year he was elected Representative and was also chosen President of the House of Representatives where he continued until Governor Magoon, at the second American Intervention, suspended the functions of Congress.

General Freyre de Andrade was one of the founders of the Republican party. For a period he abstained from politics on account of his duties as Magistrate, but after becoming Secretary of Gobernación he took part in the activities of the Moderate party as long as it survived, whereupon he shared in organizing the

A N D M O N G R A P H S 


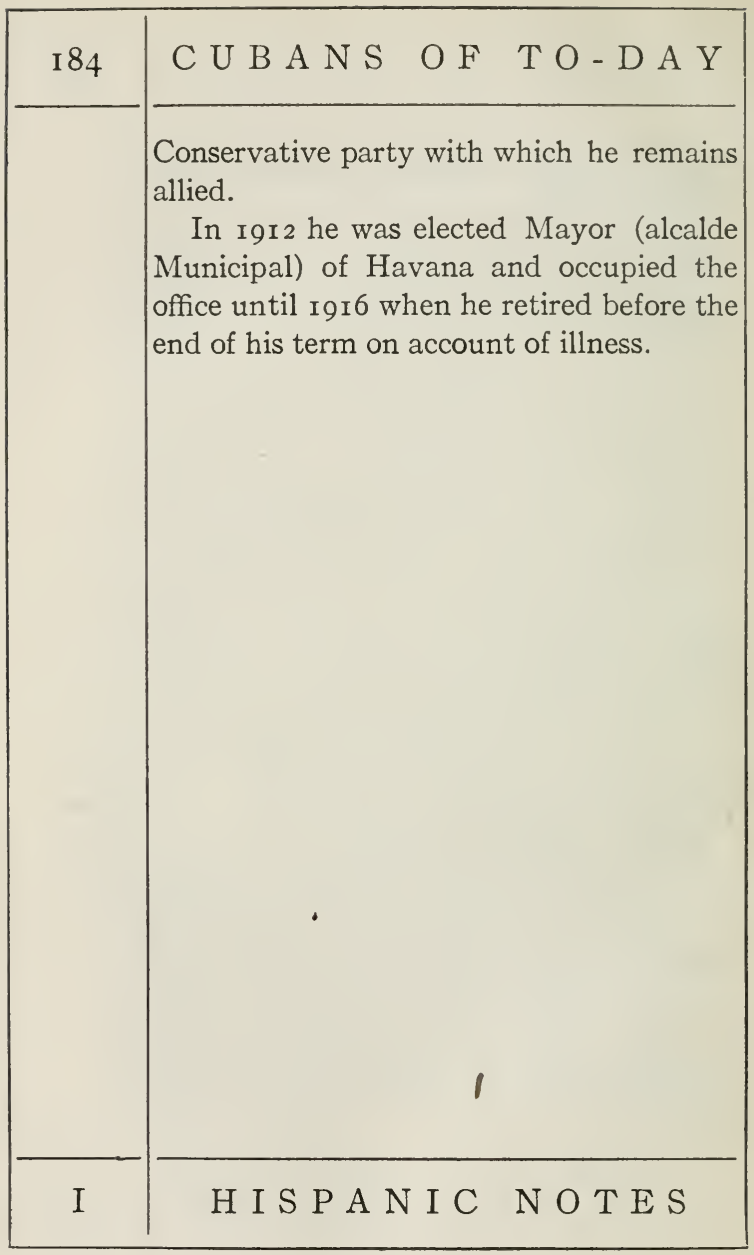





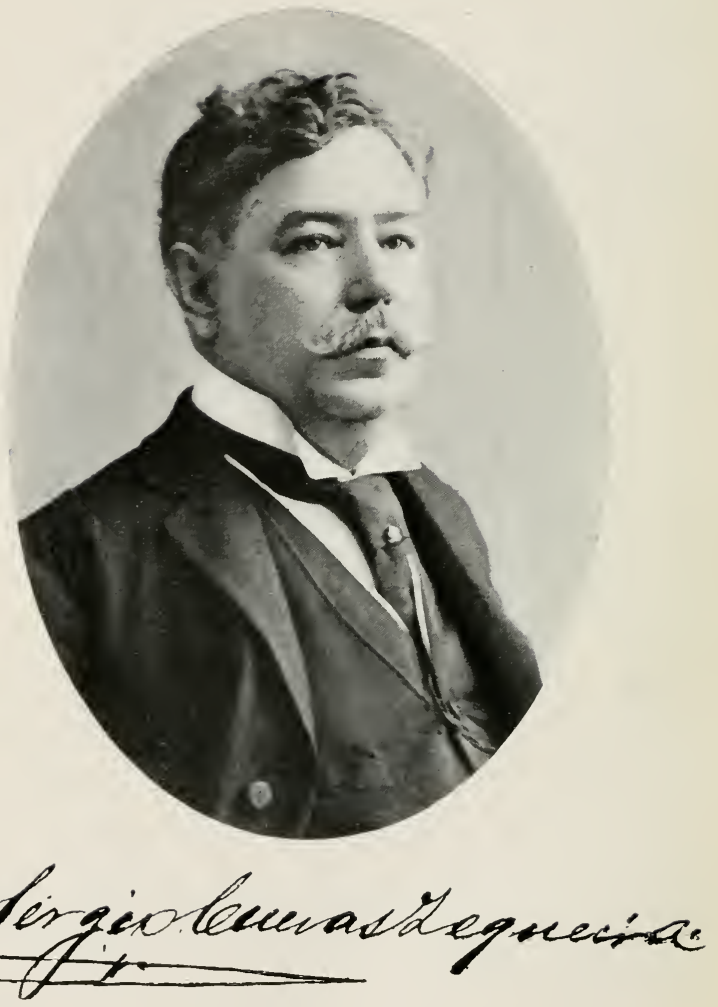




\section{Z E Q U E I R A}

SERGIO CUEVAS ZEQUEIRA

Teacher; orator; publicist.

Sergio Cuevas Zequeira was born on the thirty-first of January, 1863 , in the city of San Juan de Puerto Rico (Puerto Rico), and there, in the Colegio of the Society of Jesus, he obtained his early education and received the Bachelor's degree. He then devoted himself to the teaching profession and by competitive examination gained a position in the city schools of Ponce (Puerto Rico). In I887 the Spanish Governor General, D. Romualdo Palacios, threatened him with deprivation of office unless he would renounce his Autonomist opinions. Thereupon Cuevas Zequeira resigned his post, left Ponce and went to Mayagüez where the Society for the Propagation of the Faith entrusted him with the charge of $E l$ Liceo, a school of primary and second-

\section{A N D M O N O G R P H S}




\begin{tabular}{|c|c|}
\hline I 86 & C U B A N S O F T - D A Y \\
\hline & $\begin{array}{l}\text { ary education where he continued for three } \\
\text { years. } \\
\text { Stirred by the spirit of enterprise he left } \\
\text { his native country and set off to make a } \\
\text { career in Cuba. Going to Havana he } \\
\text { entered the University and there, having } \\
\text { gained the degree of Doctor in Philosophy } \\
\text { and Letters, he obtained the position of } \\
\text { acting-Professor of the History of Spain. } \\
\text { At the close of the Spanish-American War } \\
\text { he returned to Puerto Rico to accept the } \\
\text { post of Professor of Philosophy, Logic, and } \\
\text { Ethics in the Provincial Institute there. } \\
\text { In I9oo he returned to Cuba, seeking } \\
\text { an ampler field for his energies than he } \\
\text { could find in his native island, and entering } \\
\text { the competitive examination, he won, by } \\
\text { the unanimous vote of the committee of } \\
\text { judges, an Auxiliary Professorship in the } \\
\text { school of Philosophy and Letters in the } \\
\text { University. In fulfillment of this appoint- } \\
\text { ment he acted as substitute for Dr. En- } \\
\text { rique José Varonain the chair of Psychology, } \\
\text { Morals, and Sociology while this distin- } \\
\text { guished scholar was occupying the post } \\
\text { of Secretary of Public Instruction in the }\end{array}$ \\
\hline I & H I S A N I C NOTES \\
\hline
\end{tabular}




\section{Z E Q U E I R A}

Cabinet. Later he had the chair of History of Philosophy and has now been promoted to act definitively as Substitute Professor in the chair of Dr. Varona.

Dr. Cuevas Zequeira has won distinction in other fields - those of oratory and journalism. As an orator he became widely known in Puerto Rico, not only for political addresses but as a speaker in support of various good causes affecting patriotism and education. In Cuba he is President of the Society for advancing the Cuban Theater and is sought as a public speaker.

Both in Puerto Rico and in Cuba Dr. Cuevas Zequeira has had an active journalistic career. In Puerto Rico he founded and edited El Liceo and served on the editorial staffs of El Liberal, El Territorio and El Diario de Puerto Rico; in Cuba he has been an editor of $E l$ Mundo, La Republica Cubana, La Opinión Nacional and La Instrucción Primaria. He has served also as a member of the Provincial Council of Havana.

Besides being a frequent contributor to periodicals, Dr. Cuevas Zequeira is the

\section{A N D M O N O G R A P H S}




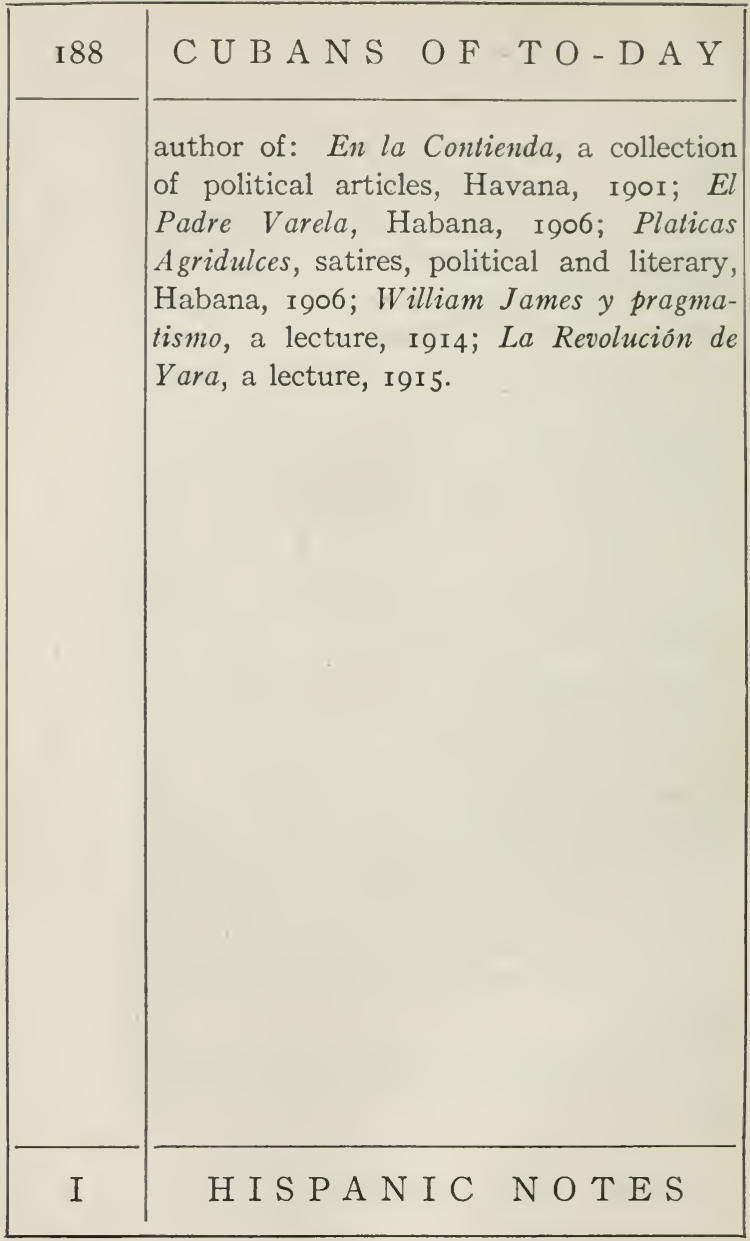




\section{B A R A L T}

LUIS A. BARALT Y PEOLI

Educator; writer; lecturer; physician; diplomat.

Luis A. Baralt y Peoli was born in Santiago de Cuba, on the first of October, I 849. Having received his early education there, he soon went to Matanzas where he continued his studies at "La Empresa," Antonio Guiteras's famous school. Having returned to Santiago de Cuba, he studied at the Institute of that City.

During his five years at this institution, from which he graduated a Bachelor, he earned his tuition by scholarships awarded for excellence in his work. In his eighteenth year he set sail from Santiago de Cuba to New York where he studied at Bellevue Hospital, and became a Doctor in Medicine. He practiced this profession for several years with success, but for

\section{A N D M O N O G R A P H S}




\begin{tabular}{|l|l|}
\hline C U B A N S O F T O - D A Y \\
\hline $\begin{array}{l}\text { vocational reasons discontinued his prac- } \\
\text { tice and devoted his attention to journalism, } \\
\text { art, and education. He was for severalyears } \\
\text { special dramatic critic for The World of } \\
\text { New York. In the eighties Doctor Baralt } \\
\text { became the center of an artistic and literary } \\
\text { movement, which took concrete form in } \\
\text { the "Society for Harmonious Culture," } \\
\text { of which he was founder and President. } \\
\text { At the time of the Cuban War of Inde- } \\
\text { pendence Doctor Baralt collaborated suc- } \\
\text { cessfully with the Revolutionary Junta } \\
\text { of New York in the work of raising funds } \\
\text { for the cause of Cuban freedom. } \\
\text { He was for some time Professor of Span- } \\
\text { ish at Columbia University and for fifteen } \\
\text { years Special Instructor in the same subject } \\
\text { at the College of the City of New York. } \\
\text { When the Spanish domination ceased, } \\
\text { he immediately returned to his native land } \\
\text { where he soon after won by competition a } \\
\text { chair at the Institute of Havana as Pro- } \\
\text { fessor of English. } \\
\text { Since returning to Cuba, Doctor Baralt } \\
\text { has devoted most of his time and efforts } \\
\text { to the study of Education; has been the }\end{array}$ \\
\hline H I S P A N I C N O T E S \\
\hline I
\end{tabular}




\section{B A R A L T}

leader or inspirer of several movements for the betterment of public instruction in Cuba, and on two occasions has been sent to Europe to study educational methods there. The first time, in 1907 , he traveled extensively through Europe and submitted to the government, on his return, an important report on his investigations. The second time, in I9 2 , he was a delegate of Cuba at the Pedological Congress held at Brussels.

Besides innumerable articles, lectures, reports, etc., which Dr. Baralt has published in various periodicals, he is the author of two textbooks for the study of English and one for the study of Spanish, and also of a translation into Spanish verse and prose of Shakespeare's Hamlet.

At present Dr. Baralt is Minister Plenipotentiary and Envoy Extraordinary of Cuba at Lima, Peru.

Publication: The Harmonic Method for Learning Spanish, New York, I896.

A N D M O N O G R A P H S 




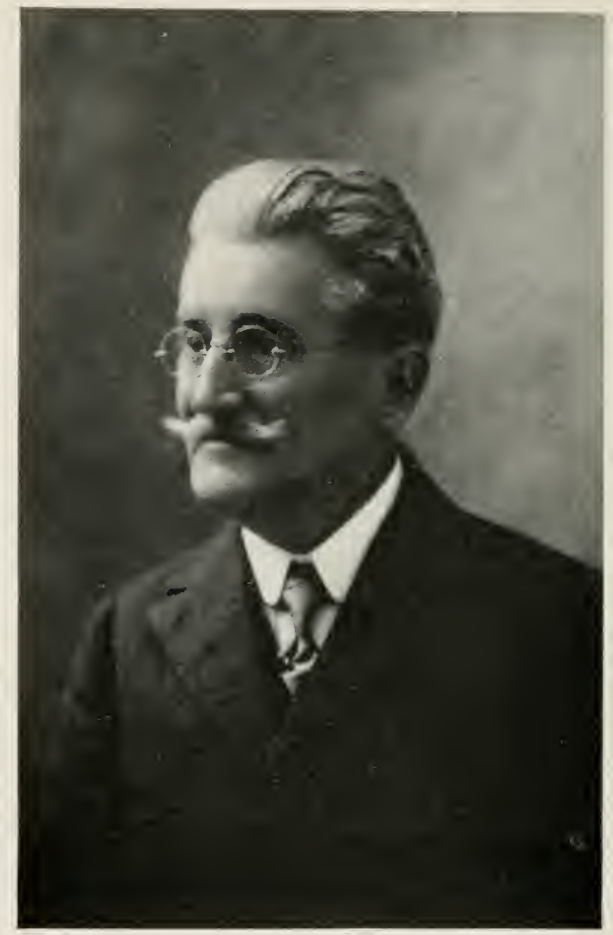

By permission of Sol Young," photographer (N. Y.)

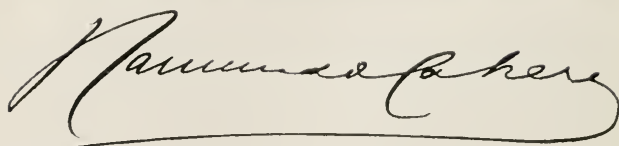




\begin{tabular}{|l|}
\hline C A B R E R A \\
\hline RAIMUNDO CABRERA \\
$\qquad$\begin{tabular}{l} 
Lawyer; editor; author. \\
RAIMvNo CABRERA was born in Ha- \\
vana on the ninth of March, I852, and \\
received his early education in the schools \\
for the poor in the town of Güines whence \\
he passed, as a gratuitous pupil, to the \\
Colegio of San Francisco of Asis completing \\
there his course for the Bachelor's degree. \\
From his boyhood he was involved in \\
revolutionary activities against the Spanish \\
rule and in I869 he was indicted, con- \\
demned, and confined upon the Isleof Pines. \\
In I 872 he obtained permission from the \\
Spanish authorities to be transferred to \\
Seville where he was permitted to resume \\
his studies at the University and obtained \\
the degree of Licentiate and was admitted \\
to practice in I873. In the same year he \\
returned to Cuba and entered upon the \\
\hline H I S P A N I C N O T E S
\end{tabular} \mid I \\
\hline
\end{tabular}




\begin{tabular}{|c|c|}
\hline I 94 & C U B A N S O F T - D A Y \\
\hline & $\begin{array}{l}\text { practice of the law in Havana where he won } \\
\text { early and notable success. } \\
\text { When the Ten Years' War closed in I } 878 \\
\text { and the Autonomist party was formed } \\
\text { Cabrera was one of its founders, organizing } \\
\text { the local section in Güines. In I } 879 \text { the } \\
\text { party elected him Provincial Deputy and } \\
\text { at the same time made him Secretary of } \\
\text { the Provincial Deputation of Havana, to } \\
\text { both of which offices he was reëlected in } \\
\text { I } 883 \text {. } \\
\text { In Güines he founded the newspaper } \\
\text { La Union which always maintained a high } \\
\text { reputation and under the inspiration of } \\
\text { Cabrera kept alive the fires of enthusiasm } \\
\text { for liberal ideas. } \\
\text { In I } 89 \text { the Central Board of the Autono- } \\
\text { mist party presented him as a candidate } \\
\text { for the office of Deputy in the Spanish } \\
\text { Cortes and although he gained the majority } \\
\text { of votes he was defeated through the high- } \\
\text { handed procedures of the Spanish party. } \\
\text { He never again sought public office. He } \\
\text { had already lost confidence in any peaceful } \\
\text { development of Cuba under the sover- } \\
\text { eignty of Spain and when the Autonomist }\end{array}$ \\
\hline I & H I P A N I N O T E S \\
\hline
\end{tabular}




\section{A B R E R A}

party ceased to be the genuine representative of the movement of protest against the oppression, Cabrera abandoned its ranks and withdrew from political life in I893.

A few years earlier, in 1887 , he had written, as a result of a controversy, a book which embodied the history and aspirations of the Cuban people of that time. Cuba y sus Jueces was the title of the work which ran through nine editions in a short time and was translated into English where it appeared as Cuba and the Cubans.

At the beginning of the War of Independence in $\mathrm{I} 895$, Cabrera emigrated to New York and founded the illustrated magazine $C u b a$ and America.

This magazine, which is still alive, soon gained a wide circulation and was the channel of a fearless campaign in support of the independence of Cuba. When peace was made Cabrera returned to Havana where, instead of seeking political office, to which both his deserts and his talents gave him high claims, he immersed himself in the practice of his profession as advocate.

\section{A N D M O N O G R P H S}




\begin{tabular}{|c|c|}
\hline 196 & C U B A N S O F T O - D A Y \\
\hline & $\begin{array}{l}\text { On his return from New York he had } \\
\text { continued publishing his magazine Cuba } \\
\text { and America which has always been his } \\
\text { pulpit from which he has made his in- } \\
\text { fluence felt in the intellectual and political } \\
\text { life of Cuba. } \\
\text { The only public offices which Cabrera } \\
\text { has held have been honorary. He has been: } \\
\text { Member of the Local Board of Health; } \\
\text { Member of the Provincial Board of Agri- } \\
\text { cultural Industry and Commerce of Ha- } \\
\text { vana; Vice-president of the Patrons of the } \\
\text { Home for Relief and Maternity (Casa de } \\
\text { Beneficencia y Mater nidad). } \\
\text { A great part of his life Cabrera is bound } \\
\text { up with the Economic Society of the Friends } \\
\text { of the Country (Socieded Economica de } \\
\text { A migos del Pais) which he served as Presi- } \\
\text { dent of the Section of Education from I } 898 \\
\text { to I9Io and of which he has been President } \\
\text { since I9Io. } \\
\text { In addition to Cuba y sus Jueces pub- } \\
\text { lished in I } 896 \text { he is the author of a number } \\
\text { of books among which are: Cuentos mios, } \\
\text { Havana, I9o4; Cartas a Estevez, Havana, } \\
\text { I } 906 \text {; La Casa de Beneficencia y la Sociedad }\end{array}$ \\
\hline I & H I S P N I C N O T E S \\
\hline
\end{tabular}




\section{A B R E R A}

Económica, Havana, I9I4; Los Partidos Coloniales, Havana, r9ı4; Desde mi Sitio, I9r г; Episodios de la Guerra, Phila., I 898; Los Estados Unidos, I89o; Cartas a Govin, I892; La Exposición de Chicago, I893; Juveniles, Poesias, I907; Borrador de Viaje, r9ı; Mediro Sigto, stories and a novel, I9I3; Sombras que Pasan, a political novel, r9r6; Ideales, sequel to the foregoing, I9I7; Sombra Eternas, sequel to the foregoing, r918; M is buenos Tiempos, I891. 




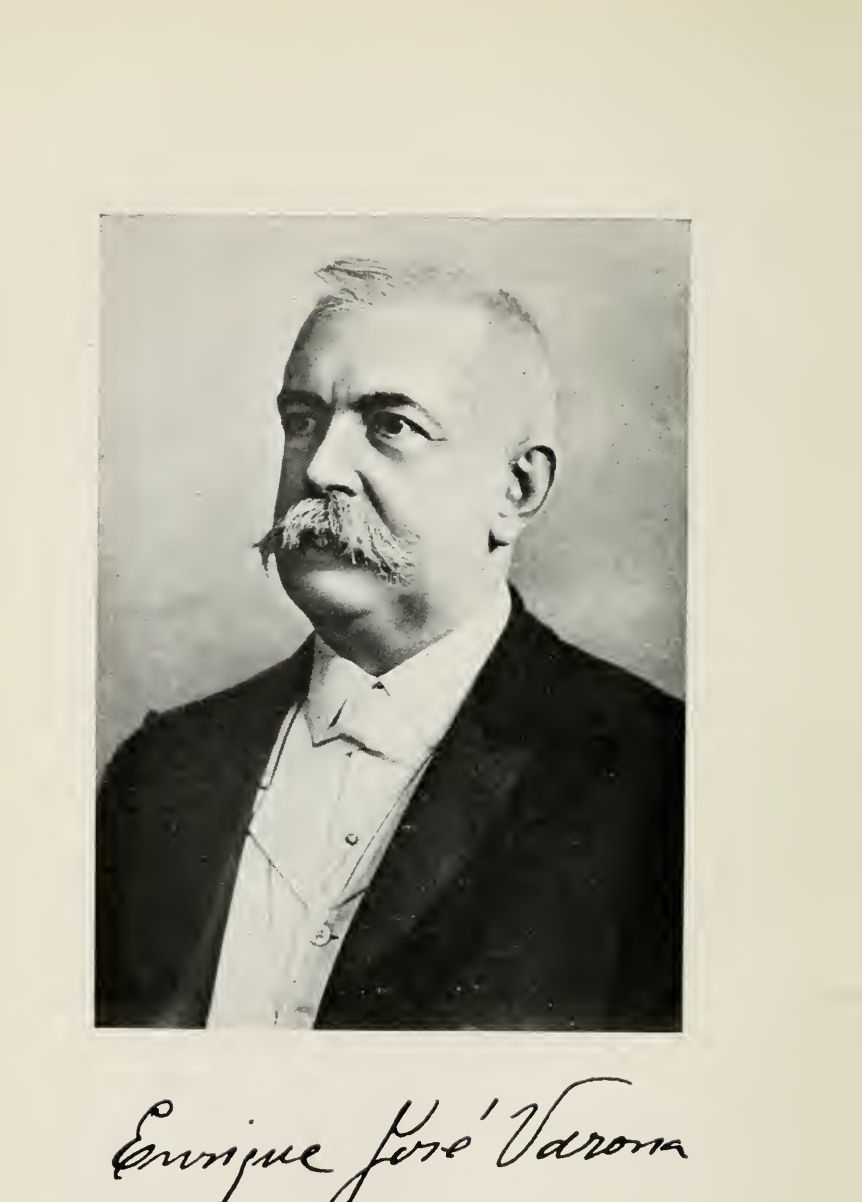




\section{A R O N A}

ENRIQUE JOSÉ VARONA Y PERA Man of letters; scholar; teacher; statesman.

Enrique José Varona y Pera was born on the thirteenth of April, I849, in Camagüey, and there obtained his early education, later going on to Havana where he graduated from the University with the degree of Doctor of Philosophy and Letters. He embodied for his generation in Cuba the ideals and attainments of the classic type of the parent race. A poet in his youth, producing before he was yet twenty odes and lyrics of marked promise, he went on to achieve a notable place in the fields of scholarship, letters, and public affairsthe arenas in which the men of earlier generations in Spain were used to test their powers and to exhibit their inheritance of the Roman tradition.

In all these fields Varona won distinc-

H I P A N I C N T E S 


\begin{tabular}{|c|c|}
\hline 200 & $\mathrm{C} U \mathrm{BANS}$ O F T $\mathrm{T}-\mathrm{DA} \mathrm{Y}$ \\
\hline & $\begin{array}{l}\text { tion. The list of his published works is } \\
\text { long and varied. He had written a volume } \\
\text { of Anacreontic Odes before he was nineteen, } \\
\text { ten years later he published a survey of the } \\
\text { intellectual movement in America; in the } \\
\text { following decade he was publishing philo- } \\
\text { sophical studies; in the forties he was } \\
\text { writing political tracts and later turned his } \\
\text { attention to problems of education. } \\
\text { The public life of Dr. Varona has been } \\
\text { in entire accord with the best traditions of } \\
\text { a University professor and a man of letters. } \\
\text { For many years he has held the chair of } \\
\text { Psychology, Moral Philosophy, and Sociol- } \\
\text { ogy in the University. } \\
\text { For a brief period he was one of the } \\
\text { Cuban Deputies in the Spanish Cortes, } \\
\text { and for more than two years he held office } \\
\text { first as Secretary of Finance and after- } \\
\text { wards as Secretary of Public Instruction } \\
\text { during the first American Intervention. } \\
\text { He was elected in I9I } 2 \text { Vice-president of } \\
\text { the Republic but at the end of his term } \\
\text { retired to the academic and literary life } \\
\text { which was more to his liking. He was } \\
\text { President of the Anthropological Society }\end{array}$ \\
\hline I & H I S P A N I C N O T E S \\
\hline
\end{tabular}




\section{A R O N A}

of Cuba and Vice-president of the Ateneo y Circulo of Havana.

Dr. Varona was the editor of the Revista Cubana from $\mathrm{I} 885$ to $\mathrm{I} 895$ and later directed Patria the organ of the Revolutionary party. Among his works are: Odas Anacreónticas (1868), Poesías (1878), Paisajes Cubanos (1879), La Metafísica en la Universidad de la Habana (I880), Estudios Literarios y Filosóficos (I883), Los Cubanos en Cuba (I891), Cuba contra España (1895), (translated into English, French, and Italian). Las Reformas de la Enseñanza Superior (1904), La Instrucción Pública en Cuba (Igor), Nociones de Lógica (I902), Curso de Psicología (1905-1908), Desde mi Belvadere (1907), Mirando en Torno (I910), Seis Conferencias (1885), Conferencias sobre la Lógica (1889), El Fundamento de la Moral (1903), Artículos y Discursos (1891), Violetas y Ortigas (I9I7), Por Cuba, Discursos (I9I8).

\section{A N D $\cdot$ M O N O G R A P H S}





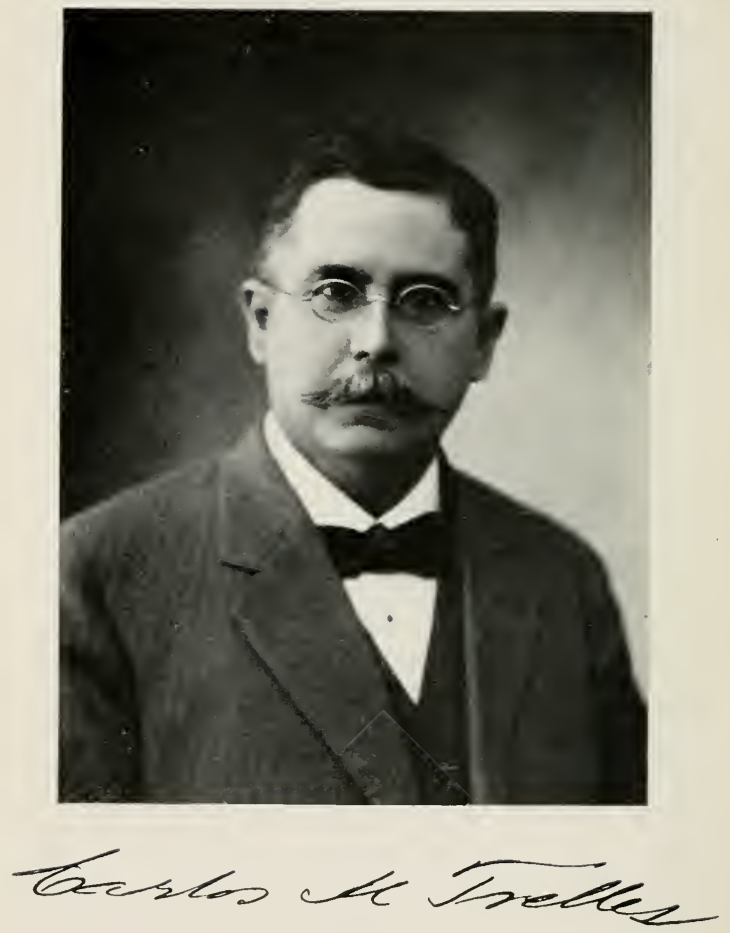




\section{T R E L L E S}

CARLOS M. TRELLES

Scholar; bibliographer; patriot; man of letters.

Carlos M. Trelles was born on the fifteenth of February, I866, in the city of Matanzas, "the Athens of Cuba," where he received his early education in Los Normales and La Unión schools in which he came under the influence of the distinguished scholar Dr. Carlos de la Torre. For his degree of Bachelor it was necessary for him to attend the Institute of Havana because the Spanish authorities had closed the doors of the Institute at Matanzas.

In the same year in which he graduated (I880) he began the study of Medicine but four years later gave it up to enter a commercial career, which did not prevent him, however, from continuing in his devotion to Letters. By the year 1887 he began to

\section{H I S P A N I C N O T E S}




\begin{tabular}{|c|c|}
\hline 204 & C U B A N S O F T O-D A Y \\
\hline & $\begin{array}{l}\text { be recognized as a rising journalist; in } \\
\text { I } 892 \text { he was one of the influential writers } \\
\text { in the Revista Cubana, then edited by Dr. } \\
\text { Enrique José Varona, to which he contri- } \\
\text { buted a series of articles on the United } \\
\text { States as an intellectual power. } \\
\text { In I } 895 \text { he issued a pamphlet widely } \\
\text { read at the time, Cuba and America, in } \\
\text { which he disclosed his separatist tendencies, } \\
\text { and on the outbreak of the War of In- } \\
\text { dependence Trelles began to take an active } \\
\text { part in it, laboring to arouse the spirit of } \\
\text { patriotism in Matanzas which had been } \\
\text { beaten down in the disaster of Ibarra (Feb- } \\
\text { ruary } 24 \text {, I } 895 \text { ). So successful were his } \\
\text { efforts that Estrada Palma, then directing } \\
\text { the revolutionary propaganda from New } \\
\text { York, designated him, together with other } \\
\text { patriots, to form the Revolutionary Com- } \\
\text { mittee of Matanzas, of which he continued } \\
\text { to be the life and soul. } \\
\text { In spite of the vigilance and persecuting } \\
\text { zeal of the Spanish authorities, Trelles } \\
\text { escaped to Tampa early in } 896 \text { where he } \\
\text { pursued his activities for the Revolution. } \\
\text { He became a regular contributor to Patria, }\end{array}$ \\
\hline I & H I S P A I C NOTES \\
\hline
\end{tabular}




\section{T R E L L E S}

the newspaper organ of the revolutionists then published in New York, contributing to its columns between eighty and a hundred propagandist articles, not ceasing meantime to contribute regularly to the pages of Cuba y America, the magazine which his compatriot Raimundo Cabrera was publishing in the same cause in the same city.

In 1898 , at the close of the war, Trelles returned to $\mathrm{Cuba}$ and organized in his native town the Public Library of Matanzas of which he was the first librarian. It began with two thousand volumes and he was able when, at the end of ten months, he turned it over to his successor to deliver thirteen thousand volumes-a thing without parallel in the history of Cuban libraries.

In 1900 he was selected to collect and organize the products and characteristic objects of the Province of Matanzas for exhibition at the Paris Exposition. $\mathrm{He}$ met with such a measure of success in this that he was commissioned to organize the Cuban section in the Exposition and was

\section{A N D M O N O G R A P H S}




\begin{tabular}{|c|c|}
\hline 206 & C U B A N O F T O - D A Y \\
\hline & $\begin{array}{l}\text { later designated to write the official report } \\
\text { on "Sugar and Tobacco at the Paris Ex- } \\
\text { position" which appeared in I9oI. } \\
\text { On his return to Cuba, Trelles was } \\
\text { elected Member of the Council of Ma- } \\
\text { tanzas, but he soon discovered that he } \\
\text { had no calling for politics and at the end } \\
\text { of three months retired in disgust. } \\
\text { In I9oo he had begun to collect the } \\
\text { materials for his great work Bibliografia } \\
\text { Cubana, on which he was continuously } \\
\text { occupied for sixteen years. In I9o7 he } \\
\text { began its publication in parts and com- } \\
\text { pleted the issue of the twelfth and conclud- } \\
\text { ing volume in I9I } 7 \text {. The bibliography } \\
\text { includes thirty-three thousand books and } \\
\text { pamphlets by nine thousand authors and } \\
\text { is the only work of its kind hitherto com- } \\
\text { pleted in any country of America-an } \\
\text { achievement due solely to the energy and } \\
\text { sacrifice of the author; for no aid of any } \\
\text { sort was supplied him by the government. } \\
\text { In I9I } 8 \text { he began a new series of bib- } \\
\text { liographical publications, the Biblioteca } \\
\text { cientifica cubuna of which the first volume } \\
\text { has already appeared and the second is in }\end{array}$ \\
\hline I & H I S P A I C N OTE S \\
\hline
\end{tabular}




\section{T R E L L E S}

the press-in reality a revision and supplement of his Bibliografia. These will be followed by Bibliotecas, Geografica, Histórica, Literaria, etc.

Trelles is also the author of Los ciento cincuenta libros más notables que los cubanos han escrito (The Hundred and Fifty Best Books Written by Cubans).

$\mathrm{He}$ is a Member of the Academy of Arts and Letters and that of History, and an Honorary Member of the Economic Society of Friends of the Country. On the occasion of his installation in the Academy of History, Trelles produced a study on The British Rule in Cuba (La dominación británica en Cuba) based upon documents hitherto unknown. In I9I 8 he was elected Corresponding Member of the Hispanic Society of America.

$\mathrm{He}$ is now engaged upon a new edition of his work on America as an Intellectual Power.

\section{A N D M O N O G A P H S}





\section{O L A D E T I Ó}

LOLA RODRÍGUEZ Y PONCE DE LEÓN DE TIÓ

Poet; authoress.

Lola Rodríguez y Ponce de León de Tió was born in the town of San Germán (Puerto Rico), the daughter of Dr. Sebastian Rodríguez de Astudillo and Doña Cármen Ponce de León.

From her early youth Señora Tió showed a marked talent for writing, and her disposition was developed by a stormy and eventful life marked by a period of exile for political reasons and much travel. She took as active a part as possible in the political struggles of Puerto Rico and, on taking up her residence in Cuba, gave similar devotion and zeal to her adopted country, becoming the enthusiastic admirer of General Máximo Gómez and the men who surrounded him in the Cuban Army of Liberation.

\section{H I S P A N I C N T E S}




\begin{tabular}{|c|c|}
\hline 210 & C U B A N S O F T O - D A Y \\
\hline & $\begin{array}{l}\text { In I } 892 \text { Señora Tió was distinguished } \\
\text { by her native town by being made an } \\
\text { Honorary Member of the Circulo Sanger- } \\
\text { meño. } \\
\text { In I } 896 \text { she was unanimously elected } \\
\text { Honorary President of the Political Club } \\
\text { Rius Rivera founded in New York by } \\
\text { those who emigrated from Cuba during } \\
\text { the War of Independence. } \\
\text { In I } 9 \text { Io she was made Honorary Member } \\
\text { of the Society of Authors and Artists of } \\
\text { Puerto Rico. In the same year, she was } \\
\text { elected a Member of the Academy of Arts } \\
\text { and Letters of Havana. } \\
\text { In I9I I she was honored with the title of } \\
\text { Socio Bienhacher, in the Benevolent Society } \\
\text { of the natives of Galicia. She has also } \\
\text { been decorated by the Government of } \\
\text { Venezuela with the Order of the Liberator } \\
\text { Bolivar. } \\
\text { Señora Tió has written much both in } \\
\text { verse and prose but her best known books } \\
\text { are three volumes of poems: Mis Cantares, } \\
\text { Claros } y \text { Nieblas, and Mi Libro de Cuba. }\end{array}$ \\
\hline I & H I S P N I C NOTES \\
\hline
\end{tabular}





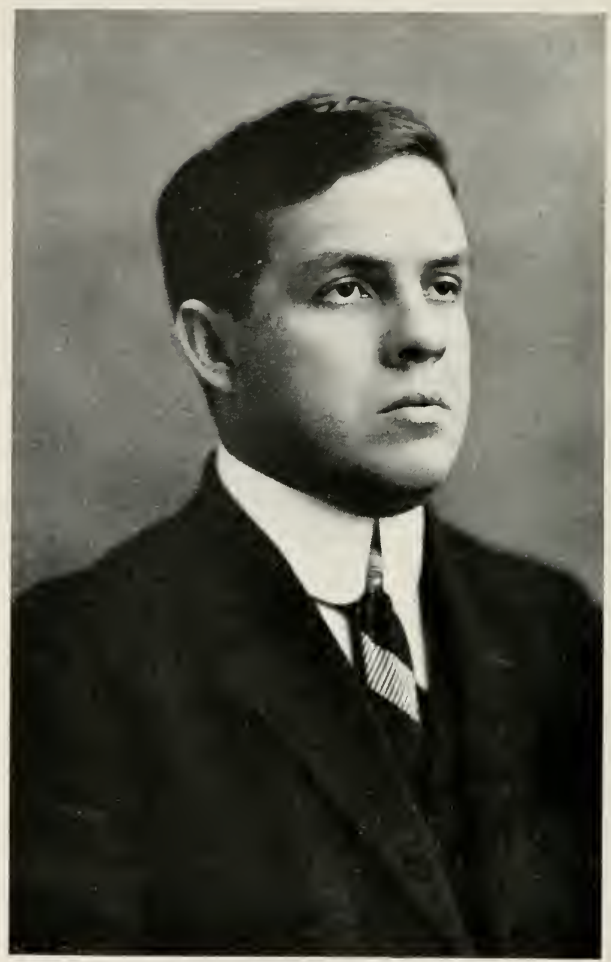

Raúl de Cárdenas y Echarte 


\section{C Á R D E N A S}

RAUL DE CÁRDENAS Y ECHARTE

\section{Lawyer; writer.}

Raul de CÁRdenas y Echarté was born on the twenty-fourth of December, I 884, in Havana, where he was educated, passing through the successive stages of primary school, the Institute where he gained the degree of Bachelor of Arts, and the University where in 1905 he was made Doctor of Laws.

He entered at once on the practice of his profession. In November, I9I0, he was elected Representative for the Province of Havana for the term ending in I9I 5 , and in I9I4 reëlected for the term ending in I9I9. In the same year he was chosen Secretary of the House of Representatives and reëlected to this office also in I 915 .

Dr. Cárdenas has written various papers of a legal character, among them, $E l R e$ -

\section{A N D M O N O G R P H S}




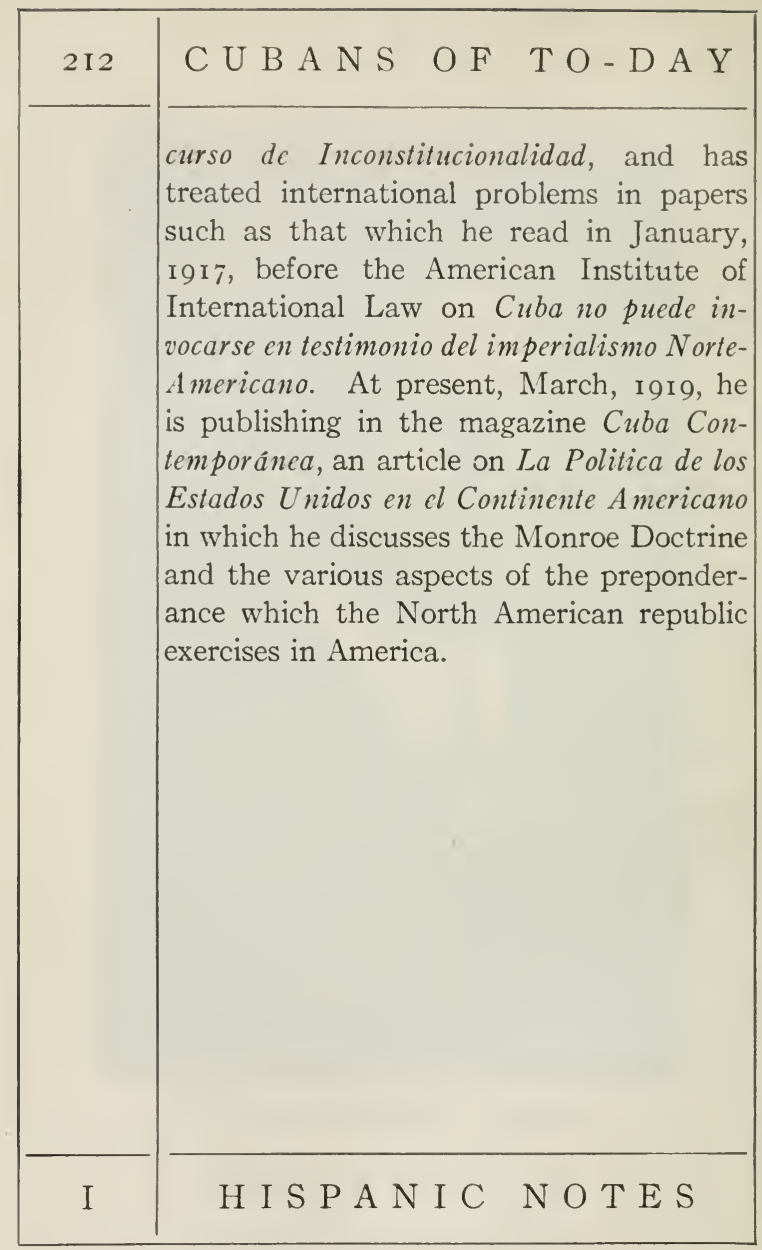




\section{A R T Í}

JOSE MARTÍ Y ZAYAS BAZÁN

Soldier; official.

José Martí y Zayas BazÁn, son of the famous Cuban patriot and apostle of independence, was born in Havana on the twenty-second of November, I878. There he was also educated, following the usual courses of study while his father in exile prosecuted in other lands the propaganda of Cuban liberty.

$\mathrm{He}$ was graduated at the Institute, Bachelor of Arts and Sciences, and had begun to study law at the University of Havana when the War of Independence broke out.

Being unable on account of the vigilance of the Spanish authorities to join the Cuban Army from Havana, he went with some of his student friends to the United States and tried to join from that point.

\section{A N D M O N O G R A P H S}




\begin{tabular}{|c|c|}
\hline $2 \mathrm{I} 4$ & C U B A N O F T O-D A Y \\
\hline & $\begin{array}{l}\text { For some time he was prevented from so } \\
\text { doing by his father's friends who con- } \\
\text { sidered him too young to enter the war. } \\
\text { But he was finally allowed to enlist as a } \\
\text { soldier, which he did in October, I } 896 \text {, and, } \\
\text { after some months of training and waiting, } \\
\text { landed in Cuba in February, I } 897 \text {. } \\
\text { He was promoted a month later to the } \\
\text { rank of Second Lieutenant, on account of } \\
\text { his being a Bachelor of Arts, and was ap- } \\
\text { pointed Aide-de-Camp to General Calixto } \\
\text { García on whose Staff he served until the } \\
\text { end of the war. } \\
\text { He volunteered for service with the } \\
\text { dynamite gun and served this weapon } \\
\text { during the siege and attack of Victoria de } \\
\text { las Tunas and Guisa, both great victories } \\
\text { for the Cuban Army. In the former fight } \\
\text { he was promoted to be First Lieutenant } \\
\text { for gallantry in action on the battlefield. } \\
\text { He took part in all the operations in Oriente } \\
\text { led by General García and finally was } \\
\text { present at the landing of the American } \\
\text { forces and the attack and siege of Santiago. } \\
\text { At the end of the war, when he was a } \\
\text { Captain, he was sent on an official mission }\end{array}$ \\
\hline I & H I S P•A N I C N O T E S \\
\hline
\end{tabular}




\section{A R T Í}

from General García to the Cuban Delegate in the United States, Tomás Estrada Palma. In I902, after a competitive examination for appointment of Officers to the Cuban Artillery forces organized at the time, he was appointed Captain, ranking first, and consequently took command of the battalion. In I 906 he was appointed Aide-de-Camp to Secretary William H. Taft and afterwards remained in the same capacity with Governor Magoon. In 1907 he was promoted by seniority to the rank of Major, in 1909 to that of Lieutenant Colonel and, on the reorganization and increase of the Army, to Colonel and appointed Chief of Staff of the Army. In I9ro he was appointed to the command of a Brigade of Infantry and in I9I 3 he was appointed to temporary command of the Army.

In I9I5, after the reorganization of the Army, a work he undertook by special instructions from the President of the Republic, General Menocal, he was appointed Assistant Chief of Staff with the rank of Brigadier General, and later in the

A N D M O NOGR A P H S 


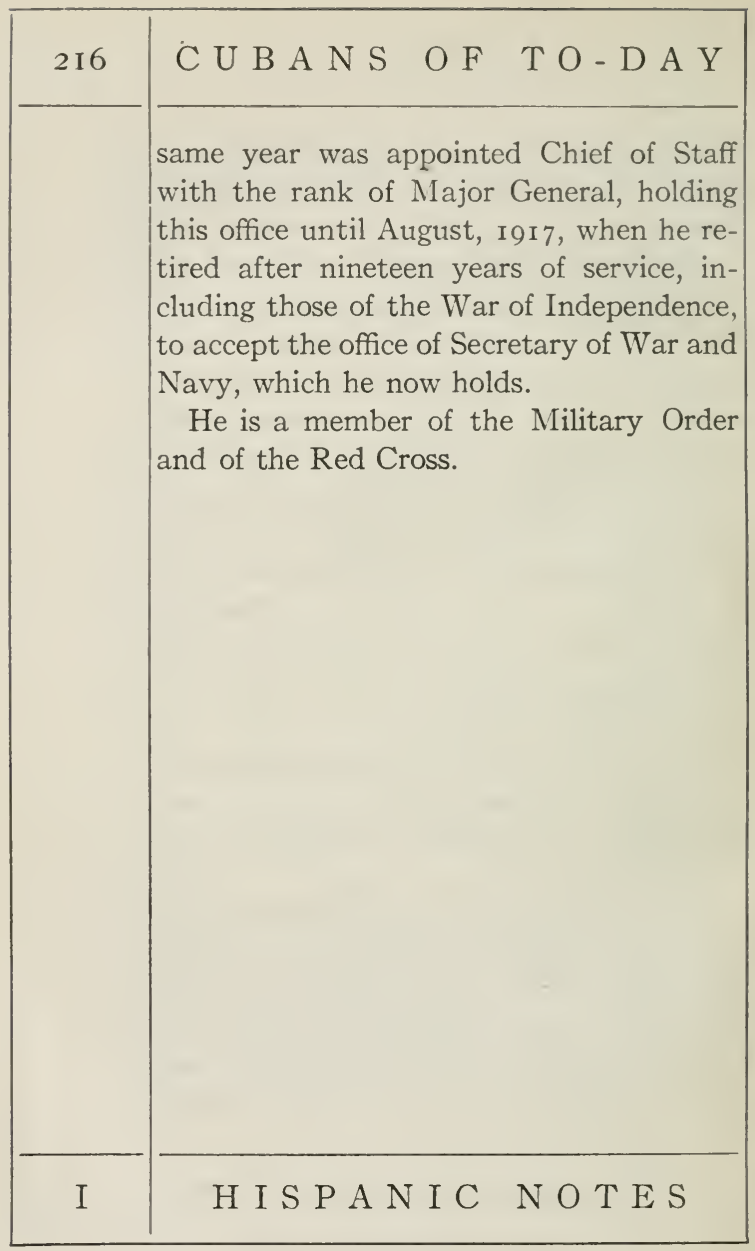





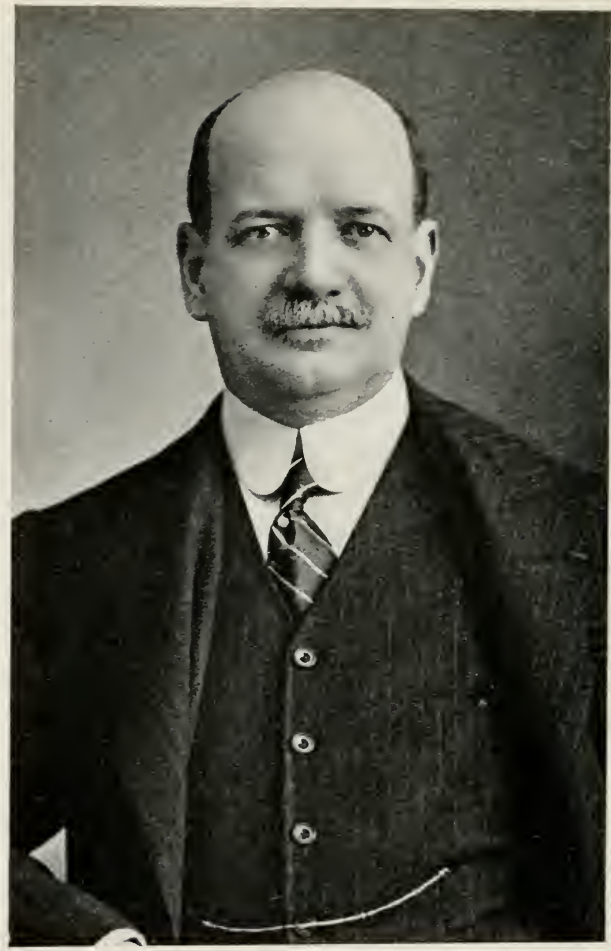

By permission of Sarony, photographer (N. Y.)

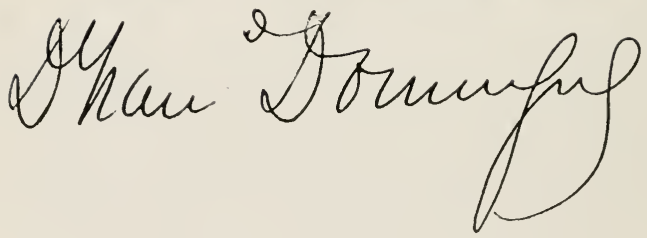




\section{O M Í N G U E Z}

FRANCISCO DOMÍNGUEZ ROLDÁN

Physician; soldier; teacher; Secretary of Education for Cuba, I9I7.

Francisco Domínguez Roldán was born in Havana on the fifteenth of February, I864. His early studies indicated his native bent, for he studied first in the Colegio of Esculapius in Guanabacoa, later going to the University of Havana where in 1884 he obtained the degree of Licentiate in Medicine and from there went to Madrid to obtain the degree of Doctor in the University.

From Madrid he journeyed to Paris and there won his Doctor's degree in 1888 . There also he won a place on the Hospital staff where he served as interne and externe for a period ot four years, and gained at the close of his service the Bronze Medal of the Asistencia Pública of Paris.

\section{A N D $\cdot$ M O N O G R A P H S}




\begin{tabular}{|c|c|}
\hline 2 I 8 & C U B A N S O F T O - D A Y \\
\hline & $\begin{array}{l}\text { In I } 892 \text { he returned to Cuba and exer- } \\
\text { cised his profession in Havana until I } 895 \\
\text { when, at the outbreak of the War of In- } \\
\text { dependence, he left his brilliant prospects } \\
\text { to take part in the Revolution. He served } \\
\text { throughout the campaign in the provinces } \\
\text { of Havana and Matanzas, rising to the rank } \\
\text { of Colonel in the Medical Service. At the } \\
\text { end of the war he returned to Havana and } \\
\text { took up again the practice of his profession. } \\
\text { In I } 899 \text { he assisted General Wood in re- } \\
\text { crganizing the School of Medicine and was } \\
\text { appointed Professor of Topographical Ana- } \\
\text { tomy. Since the year I } 903 \text { he has devoted } \\
\text { himself to the study of the X-ray in which } \\
\text { he has become an authority. In r } 905 \text { he } \\
\text { was commissioned by the government to } \\
\text { visit Europe to study radiography-a com- } \\
\text { mission which he fulfilled with great suc- } \\
\text { cess, visiting England, France, Germany, } \\
\text { and Denmark. In I9o7 he was honored } \\
\text { by the French Government with the order } \\
\text { of the Legion of Honor, and in I } 9 \text { Io he was } \\
\text { sent as delegate from Cuba to the Inter- } \\
\text { national Congress of Radiology held in } \\
\text { Barcelona. }\end{array}$ \\
\hline I & H I S P A N I C N $\odot$ T E S \\
\hline
\end{tabular}




\section{O M Í N G U E Z}

In I9r6 Dr. Roldán was elected Dean of the Faculty of Medicine and in I9I 7 he was appointed, by President Menocal, Secretary of Education and Art, in which position he has had opportunity to put into effect views of education which have been of great benefit to Cuban culture, giving vigorous impulse to all branches of education and calling to her shores distinguished educators from abroad.

Among his published works are: El tórax y sus regiones (I 895); Procedimientos operatorios (I 904$)$; Lecciones de cirugia de urgencia (1905); Lecciones de anatomía topogrâfica (1905 y 1906); Rayos Finsen, Rayos Rontgen, Radio (I 906); Radio, Radiologia y Electricidad Médicas (I9II); Anatomía topográfica y operaciones de urgencia del tórax (I9I4).

\section{$\mathrm{A} \cdot \mathrm{N} D \quad \mathrm{MONO}$ G R A P H S}





\section{CARLOS E. FINLAY}

Physician; teacher; specialist.

Carlos E. Finlay, son of the famous discoverer of the transmission of yellow fever by the Stegomyia mosquito, was born in Havana on the fifteenth of July, I868. His early studies were made at the Colegio of Belén, where he completed the courses leading to the Bachelor's degree, after which he went to the United States, entered Columbia University, and obtained his degree in Medicine in $\mathrm{I} 889$. He then joined the staff of the New York Ophthalmic and Aural Institute, serving as Clinical Assistant and Interne until I 892 when he returned to Havana and began the practice of his profession as eye and ear specialist. In 1905 Dr. Finlay was appointed Professor of Ophthalmology in

\section{H I S P A N I C N T E S}




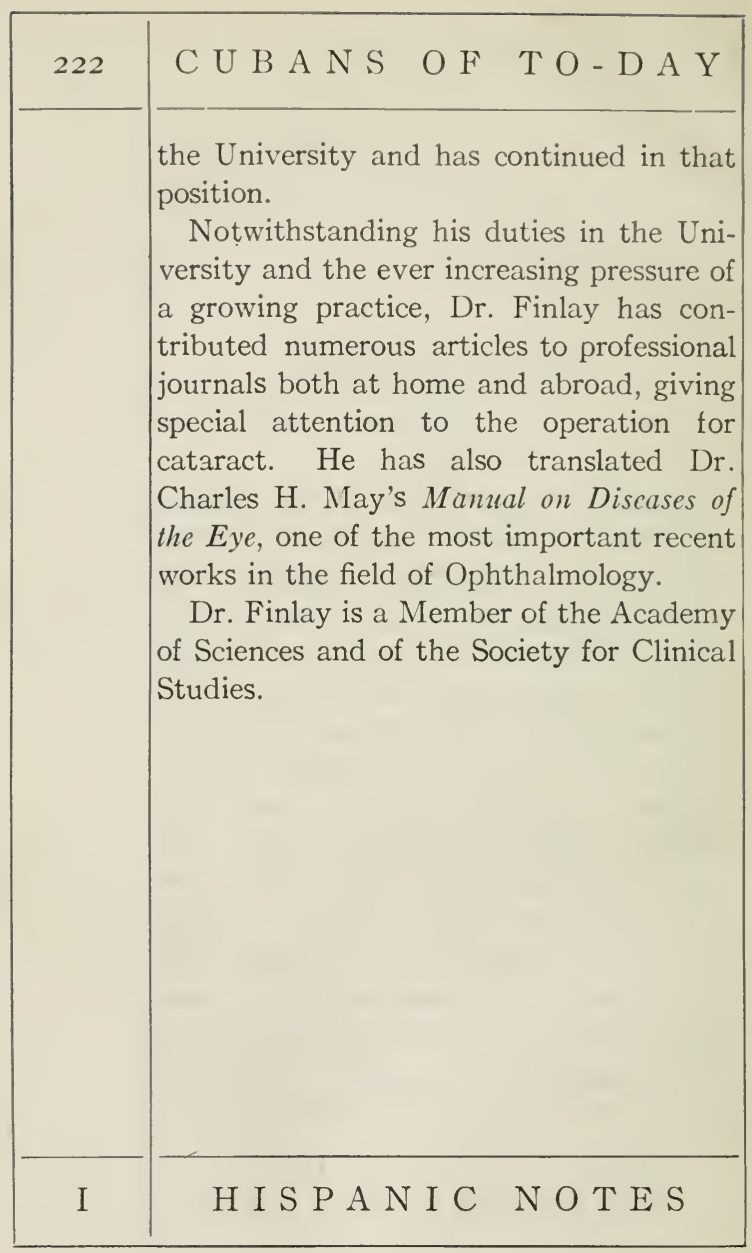




\section{JOSÉ MARÍA COLLANTES}

Lawyer: poet; official; Member of Congress of Cuba.

José María Collantes was born in San Cristóbal, Province of Pinar del Rio, on the thirteenth of November, 1877 , and received his early education in his native town. His later education he obtained in Havana where he studied at "La Gran Antilla" Colegio and gained the Bachelor's degree in the Institute of Havana in 1893.

Having elected to enter the legal profession, Collantes pursued the law course and obtained his degree as Licentiate in I 898. In the following year he was appointed Municipal Judge of the Vedado (Havana), and in I9oo designated as member, and Secretary, of the Tripartite Commission of Charities for the Island of Cuba,

\section{A N D M O N O G R A H S}




\begin{tabular}{|c|c|}
\hline 224 & C U B A N S O F T O - D A Y \\
\hline & 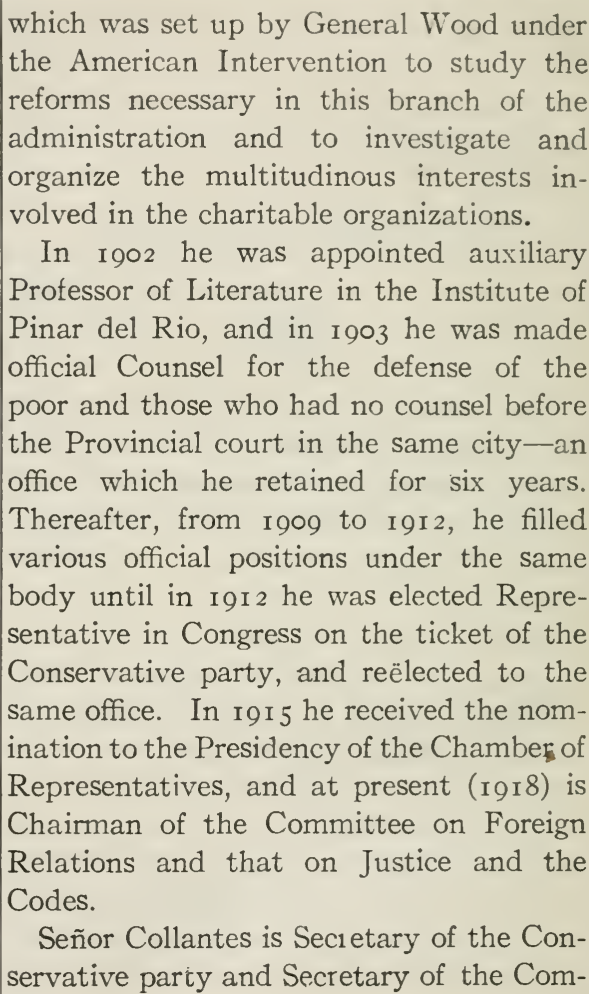 \\
\hline I & H I S P A N I N O T ES \\
\hline
\end{tabular}


mission on Propaganda for the War and for the Relief of its Victims.

Señor Collantes has distinguished himself also as a poet and is counted among the most effective orators of his party.

Among his published works are: Rojas y Pálidas, poems, I900; Un vueltabajero ilustre, Tranquilino Sandalio de Noda, I901; La casa del pobre, I903; Sistemas penitenciarios, I904; Discurso sobre Maceo, I9I4.

\section{A N D M O N O G A P H S}





\section{P É R E Z}

\section{LUIS MARINO PÉREZ}

\section{Librarian.}

Luis Marino PÉREZ was born on the twelfth of July, r882, at Kingston, Jamaica (B. W. I.). H is parents were among those Cubans who preterred to reside in a foreign country than to suffer the oppression of the Spanish government in Cuba. His father, José Francisco Pérez, had joined the Revolution in 1869 and was, during all his life, a staunch supporter of the movements for Cuban independence.

Pérez's education, begun in the Jamaica schools, was continued in the United States, where he studied successively at Alma Academy (Michigan), completing the Scientific course in June, rgor, and at the University of Michigan, obtaining the degrees of A.B. (1903) and A.M. (I904). He there studied principally philosophy, 


\begin{tabular}{|c|c|}
\hline 228 & C U B A N S O F T - D A Y \\
\hline & $\begin{array}{l}\text { sociology, and history; was a member of } \\
\text { the Quadrangle Club, and in I9o9 was } \\
\text { elected to the Michigan Chapter of the } \\
\text { Phi Beta Kappa Society. During his last } \\
\text { year in the University (I904) he was ap- } \\
\text { pointed Assistant in European history. } \\
\text { He has served in the following positions: } \\
\text { with the Department of historical research } \\
\text { of the Carnegie Institution, Washington, } \\
\text { D. C., for which he prepared, first, a report } \\
\text { on the materials for American history in } \\
\text { Cuban archives (I905) and, later (I9I6), or1 } \\
\text { the archives of Jamaica; in the Library of } \\
\text { Congress, Washington, D. C. (I9o6); } \\
\text { translator in various departments of the } \\
\text { Cuban government; and head Librarian of } \\
\text { the House of Representatives of Cuba } \\
\text { since I9I2. He was appointed in I9I } 4 \\
\text { to assist the Commission created by pres- } \\
\text { idential decree, No. } 659 \text { of I9I4, for the } \\
\text { study of the budget system of Cuba, and, } \\
\text { in I9I8, Chief Clerk of the National Com- } \\
\text { mission for war propaganda and for the } \\
\text { distribution of Cuban government funds } \\
\text { in aid of the soldiers and war victims of the } \\
\text { Allies. At the request of the Department }\end{array}$ \\
\hline I & H I S P A I C N O T E S \\
\hline
\end{tabular}




\section{P É R E Z}

of Public Instruction he has recently undertaken the work of organizing the classification and cataloguing of the National Library of Cuba.

$\mathrm{He}$ has contributed articles on historical, social, and political questions to the $P u b$ lications of the Southern History A ssociation, Washington, I907; Pro-Cuba, Havana, May and June, I9I I (only issues published); La Reforma Social, Cuba Contemporanea, El Fígaro, and others. At the annual meetings of the Cuban society of international law, г9г 7 , I9I8, and I9I9, he has read papers on the Sovereignty of Cuba, Justice as a Principle of International Law, and the Self-determination of the Small Nationalities, respectively.

$\mathrm{He}$ was one of the organizers of the "Fundación Luz Caballero," an influential educational and patriotic association, and of the Pure Suffrage League ("Liga protectora del sufragio"). He was the chief initiator, in I9I 7 , of the Liga nacional de propaganda económica, which, after a short agitation in favor of thedomestic production of all necessary foocistuffs, discontinued its labors.

\section{A N D M O N O G R A P H S}




\begin{tabular}{|c|c|}
\hline 230 & C U B A N S F T O - D A Y \\
\hline & $\begin{array}{l}\text { He has published the following books } \\
\text { and pamphlets: A puntes de libros y folletos } \\
\text {. . que tratan de Cuba, desde principios } \\
\text { del siglo XVII hasta I9I2, Havana, I907. } \\
\text { Guide to the Materials for American His- } \\
\text { tory in Cuban Archives, Washington, I907. } \\
\text { Estudio sobre las ideas politicas de José } \\
\text { Antonio Saco, Havana, I9o8. Bibliografia } \\
\text { de la Revolución de Yara-Cuaderno I, Ha- } \\
\text { vana, I9o8. Biografia de Miguel Jerónimo } \\
\text { Gutiérrez, revolucionario y pocta cubano, } \\
\text { Havana, I9I2; and, with Orestes Ferrara } \\
\text { and others, Anuario estadistico de la Re- } \\
\text { püblica de Cuba: Ano I, I9I4, Havana, } \\
\text { I9I5. In I9o9 he published a magazine } \\
\text { in Spanish and English entitled Cuban } \\
\text { Opinion (La Opinión cubana), of which } \\
\text { only six numbers were issued, and in I9I6, } \\
\text { with Federico Córdova, the Revista de his- } \\
\text { toria cubana y americana, of which five } \\
\text { numbers have been issued. He has edited, } \\
\text { with Vicente Pardo Suárez, Trabajos par- } \\
\text { lamentarios de José A. González Lanuza, } \\
\text { Havana, I9I9. }\end{array}$ \\
\hline I & H I S P A N I N O T E S \\
\hline
\end{tabular}




\section{A R O C H A}

GUSTAVO F. AROCHA Y LLANERAS

\section{Lawyer; magistrate.}

Gustavo F. Arocha y Llaneras was born on the first of May, I864, at the Villa of Guanajay, in the Province of Pinar del Rio. He was educated under the direction of F. B. Ramos, at the Colegio of San José de Calasanz. After studying at the Jesuit College of Belén he received the degree of Bachelor of Arts in 1879 and then took up the study of civil and canon law at the University of Havana. After six years' study he was admitted to practice in both these faculties. While at the university he worked in a law office and was admitted to the bar in Havana, where he exercised his profession from $\mathrm{I}_{8} 8$ to $\mathrm{I} 899$. At this last date the first American Government of Intervention nominated him for Judge of the First Instance and Instruc- 


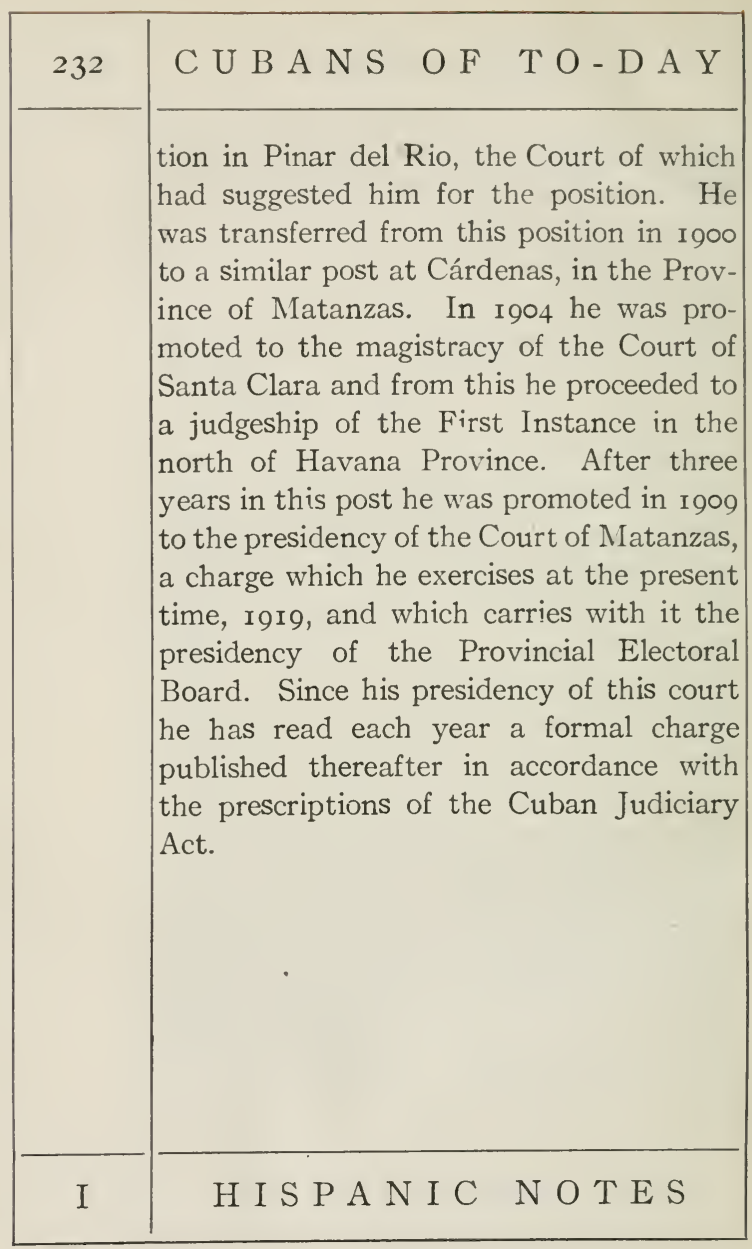





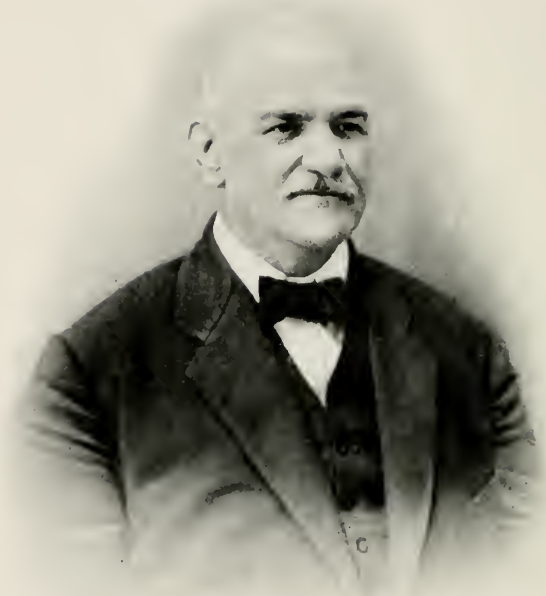

Miguel Garmendia y Rodríguez 


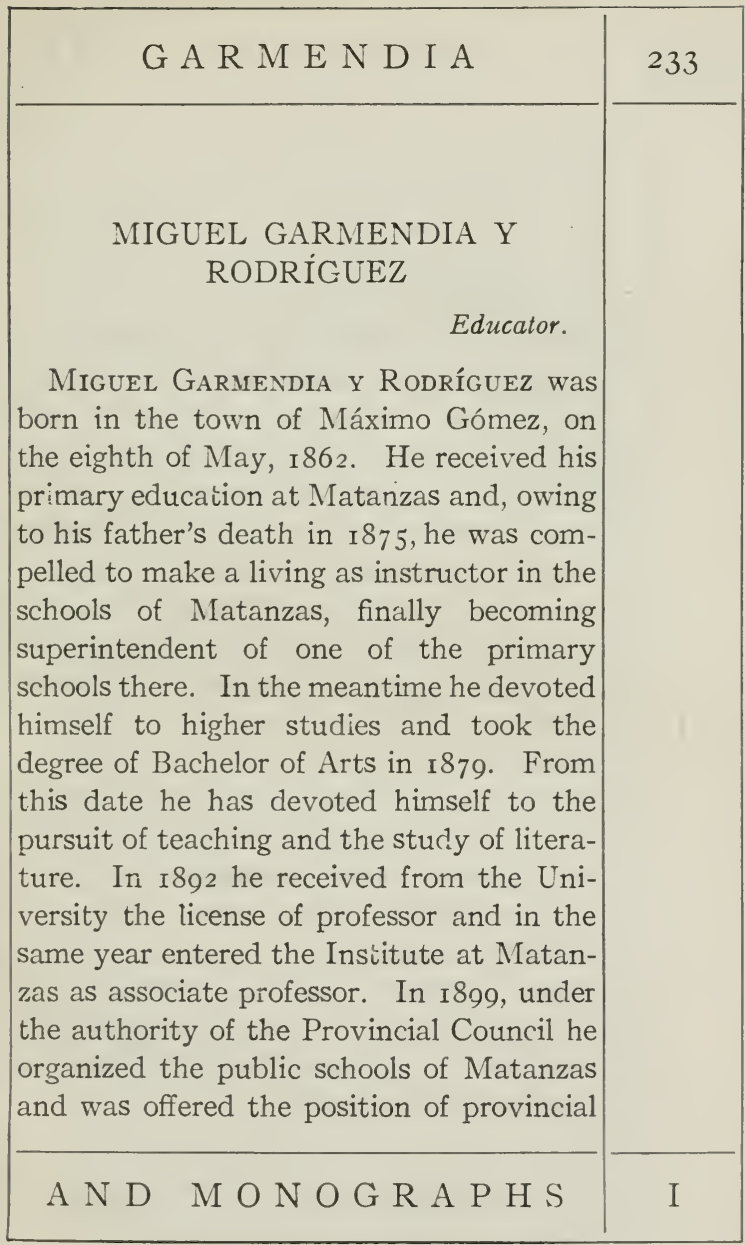




\begin{tabular}{|c|c|}
\hline 234 & C U B A N O F T O - D A Y \\
\hline & $\begin{array}{l}\text { school inspector by Mr. A. E. Frye, but he } \\
\text { preferred to remain in his teaching posi- } \\
\text { tion. In I } 899 \text { also he was authorized by } \\
\text { the American Intervention Government to } \\
\text { hold classes in Spanish for the officers of } \\
\text { the American Army stationed at Matanzas. } \\
\text { In I } 900 \text { he was appointed professor, after } \\
\text { competition, to the chair of grammar and } \\
\text { literature in the Institute of Matanzas. } \\
\text { In I9o2 he was nominated provincial } \\
\text { superintendent of the schools of Havana; } \\
\text { in I9o4 he accepted the position of general } \\
\text { superintendent of the schools in Cuba, and } \\
\text { took part in the arrangement of the courses } \\
\text { of study applied throughout the Island } \\
\text { until I9I4. In I905 he withdrew trom his } \\
\text { position, during the presidency of President } \\
\text { Palma, and resumed his chair at Matanzas. } \\
\text { In I9 } 6 \text { he was elected a member of the } \\
\text { educational board of Matanzas, over which } \\
\text { he presided for three years. Among his } \\
\text { published works may be named two novels: } \\
\text { Almas Perdidas, Cursa de Gramática, Sol } \\
\text { de A utuño, I } 882 \text {. His educational pub- } \\
\text { lications are: Libro de Lectura, I } 885 \text {; Orto- } \\
\text { grafia Castellano, I } 896 \text {. }\end{array}$ \\
\hline I & H I S P A I C N O T E S \\
\hline
\end{tabular}




\section{E D E L M A N N}

\section{FEDERICO EDELMANN Y PINTO}

\section{Educator.}

Federico Edeliann y Pinto was born in Havana on the twenty-sixth of May, I869. He was educated at the Colegio of Belén in Havana. After studying also at the School of Painting and Sculpture in Havana, he was appointed in 1892 Protessor of Spanish Language and Literature by the New York City Board of Education. In this capacity he taught at the Evening High School of New York City, and in 1898 he became Professor in the same branches at the De Witt Clinton High School. Both of these positions he filled until 1905,' when he was placed in charge of the chair of English at the Institute of Havana, a position won after competition. From I 889 to 1892 he was employed on the staff of Frank Leslie's

\section{A N D M O N G R A P S}




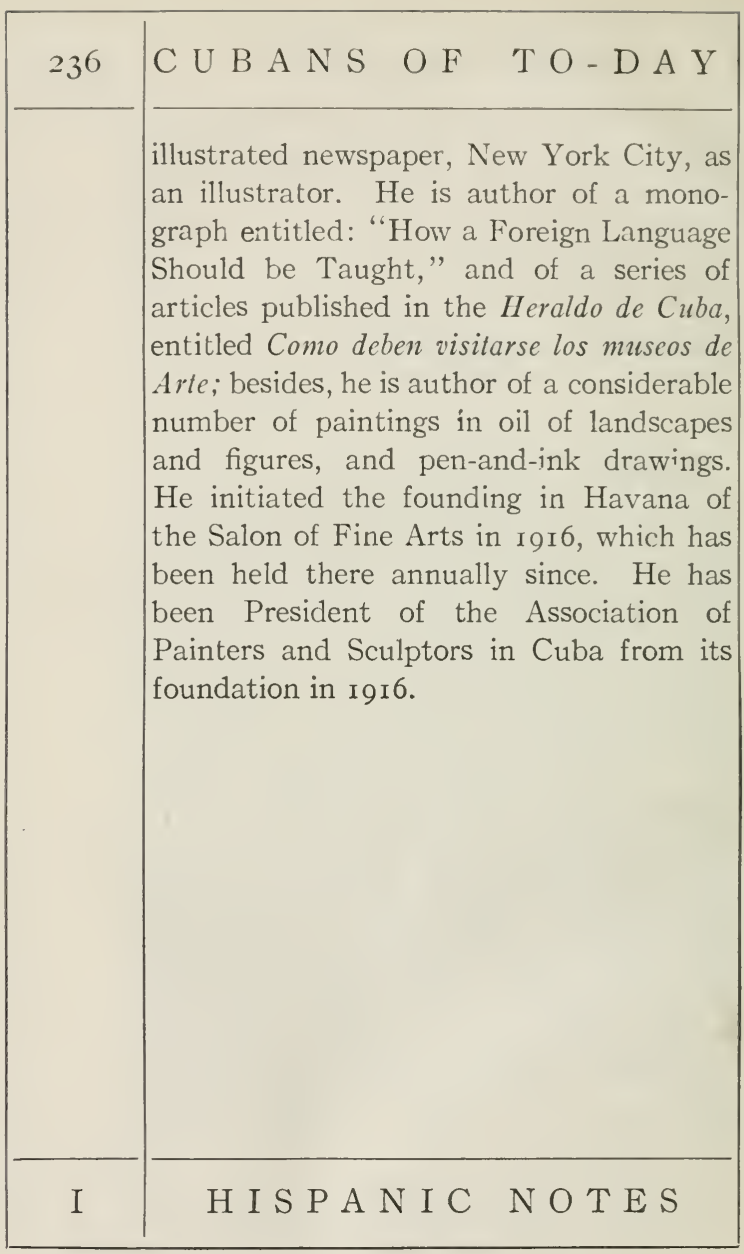




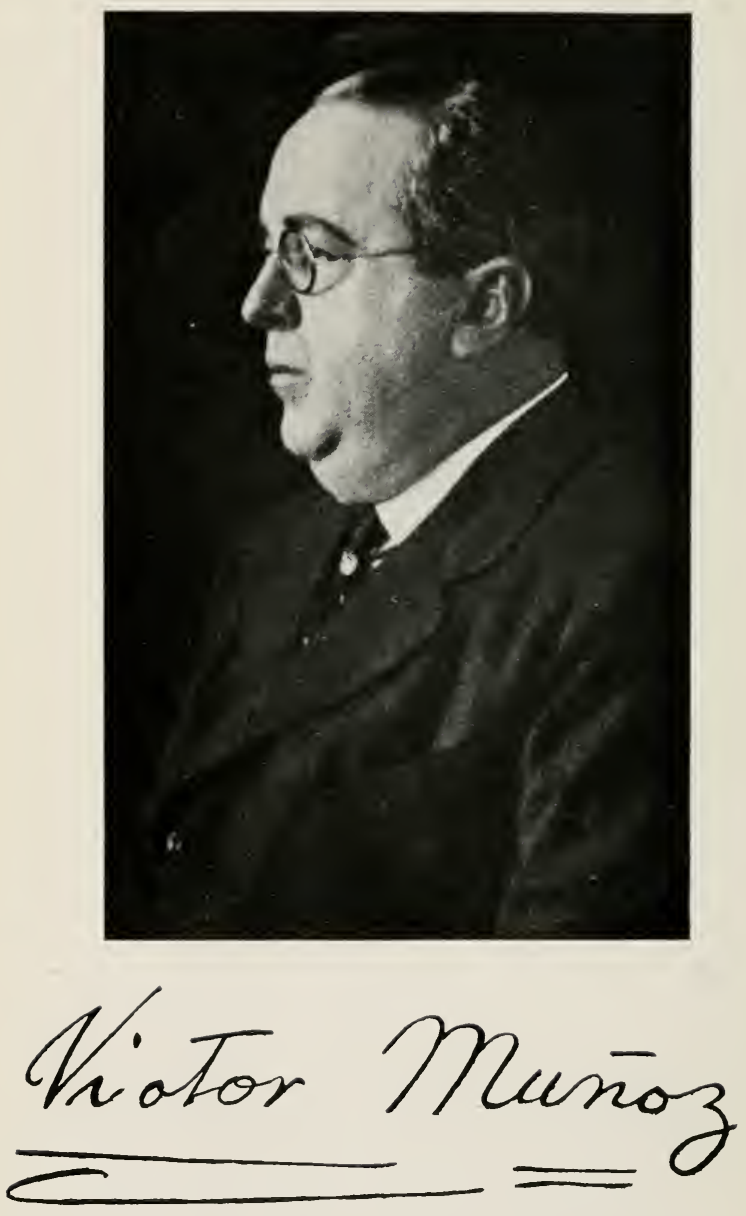


\section{U N O Z \\ VICTOR MUÑOZ}

Journalist.

VICTOR MuÑos was born at Havana in I 873 . He came in his early youth, in 1890 , under the influence of the revolutionary spirit of the day, abandoned his studies, emigrated to the United States, and established himself in Florida, where he soon engaged in journalist work in the Spanish publications issued in Tampa and Key West in favor of Cuban independence. In 1899 he returned to Havana and took up the profession of journalism, to which he has devoted himself ever since. He is a journalist, not a political editor of the type so long familiar in Spanish America, and has familiarized himself practically with all the various departments of journalistic activity. He began his caleer in Havana as reporter of La Discusión and after two

\section{A N D M O N O G R A P S}




\begin{tabular}{|c|c|}
\hline 238 & C U B A N O F T O-D A Y \\
\hline & $\begin{array}{l}\text { years became associated with El Mundo. } \\
\text { In this paper he was in charge of the sport- } \\
\text { ins page and also of the Washington corre- } \\
\text { spondence. His journalistic ideals are } \\
\text { based upon American models, which he } \\
\text { has studied directly in the newspaper } \\
\text { offices of New York. Even the terminology } \\
\text { of American slang he has transplanted to } \\
\text { Havana journalism. Lately, without giving } \\
\text { up his interest in the records of sport, he } \\
\text { has developed in El Mundo a special sec- } \\
\text { tion called "Round About the Capital," } \\
\text { which gives the Cuban reader information } \\
\text { in regard to American social and political } \\
\text { life. His purpose in this department must } \\
\text { be regarded as educational as well as enter- } \\
\text { taining. The picture presented in El } \\
\text { Mundo of the life in the United States is } \\
\text { derived from a careful reading of the } \\
\text { principal representatives of the American } \\
\text { press. An idea of the aims of this type of } \\
\text { his journalistic work can be derived from a } \\
\text { selection published from it, called Junto } \\
\text { al Capitolio. This publication will soon } \\
\text { be followed by another book, a realistic } \\
\text { novel, called Sangre Africana. }\end{array}$ \\
\hline I & H I S P A I C NOTES \\
\hline
\end{tabular}





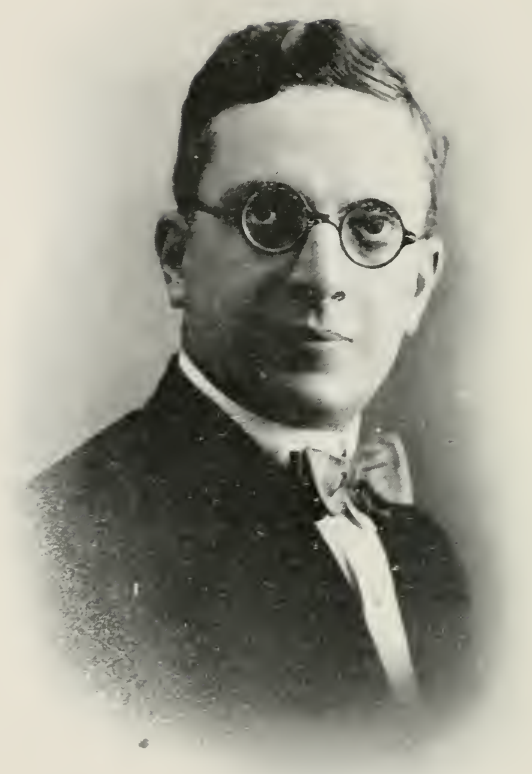

Dr. Brimugotiproms 


\section{R A M O S}

DOMINGO F. RAMOS Y DELGADO

Physician.

Domingo F. Ramos y Delgado was born in Pinar del Rio on the ninth of September, I884. His education was received at the University of Havana, where he took the degrees of Doctor of Medicine, 1905, and Doctor of Science, 1906. In both these schools he was a gold medallist, an honor which enabled him to pursue graduate studies in New York and Paris hospitals. Among the scientific posts held by him may be mentioned the directorship of the clinical laboratory of Hospital No. I, the directorship of the library and press section of the Sanitary Commission, Chief of the Department of Infantile Hygiene, Chief of the Department of Homiculture in the Commission of Hygiene, Chief of the Department of Milk Analysis, and

\section{A N D M O N O G R A P H S}




\begin{tabular}{|c|c|}
\hline 240 & C U B A N S O F TO-D A Y \\
\hline & $\begin{array}{l}\text { Member of the Investigating Laboratory } \\
\text { of the Department of Sanitation. He has } \\
\text { also served as assistant in the Museum of } \\
\text { Natural History of the Havana University, } \\
\text { as interne associate and medical interne } \\
\text { of the Mercedes Hospital, and as delegate } \\
\text { of the Cuban government to the Third } \\
\text { International Congress for the Protection } \\
\text { of Children, I9I I. In I I } 7 \text { he was named } \\
\text { Assistant Professor in the Medical Depart- } \\
\text { ment of Havana University. At the } \\
\text { present time he is attached as doctor to } \\
\text { the Calixto García Hospital and is ob- } \\
\text { stetrician and pediatrician of the Mercedes } \\
\text { Hospital. He is the author of many } \\
\text { scientific articles and in ccllaboration with } \\
\text { Professor Eusebio Hernández has pub- } \\
\text { lished a work entitled Homicultura, pre- } \\
\text { sented to the Third International Congress } \\
\text { mentioned above. Acting in association } \\
\text { with Dr. Hernández he introduced into } \\
\text { Cuba the principles of infantile hygiene, } \\
\text { and took part recently in founding hygienic } \\
\text { departments for the protection of children, } \\
\text { such as milk analysis and the distribution } \\
\text { of modified milk for poor children. In }\end{array}$ \\
\hline I & H I S P A N I C N O T E S \\
\hline
\end{tabular}




\section{R A M O S}

addition to this milk laboratory he has established a similar one in the Bluhme Ramos Laboratory for the well-to-do classes. 



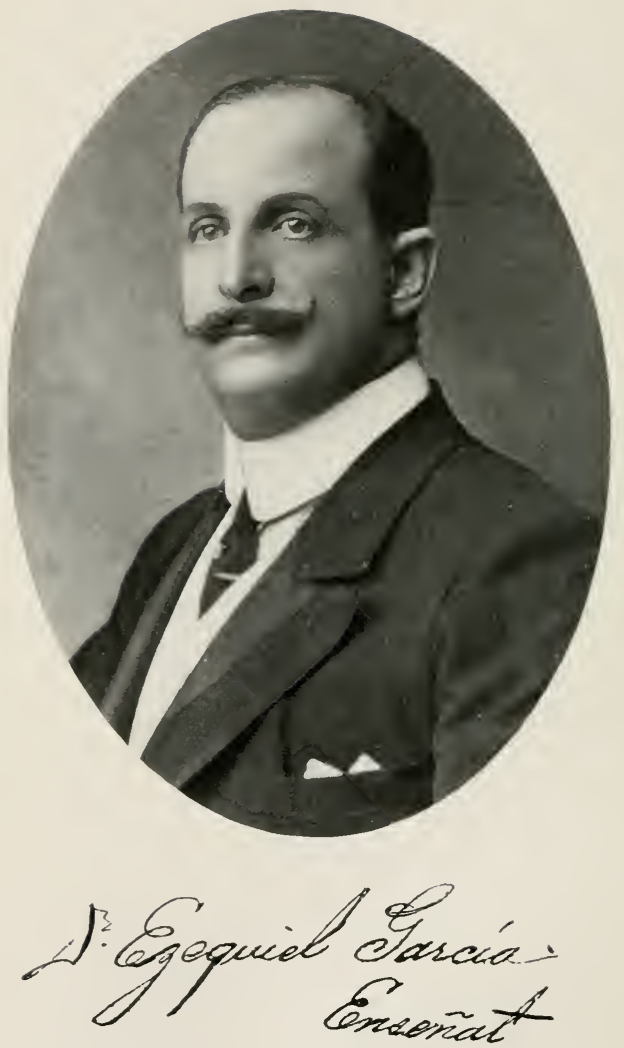


\section{GAR C ÍA E N E N A T}

\section{EZEQUIEL GARCÍA ENSEÑAT}

Educator; public man.

Ezequiel García Enseñat was born in Havana on the twenty-third of March, I862. His advanced studies were pursued in the University of Havana, in which he graduated in law and afteiwards as Doctor of Letters. He soon became known as a writer in the field of literature and journalism but took no part in public life while Cuba was a Spanish colony. For some time he remained away from the Island and traveled in Europe, residing for a considerable period in Paris, where he devoted himself to the study of literature, history, and art, and contributed to Cuban reviews and papers and also those of other countries. During the War of Independence he was secretary of the committee representing the Cuban Revolutionary party, and also

\section{H I S P A N I C N O T E S}




\begin{tabular}{|c|c|}
\hline 244 & C U B A N O F T O - D A Y \\
\hline & $\begin{array}{l}\text { edited the separatist publication, La Ré- } \\
\text { publique Cubaine. On his return to Cuba } \\
\text { he was named professor of one of the chairs } \\
\text { of history, and when the university was } \\
\text { reorganized he obtained competitively an } \\
\text { associate professorship of literature. On } \\
\text { his return to Cuba he began to take an } \\
\text { active part in political life and allied himself } \\
\text { with the Progressive party. He became } \\
\text { editor of the Patria, was a frequent speaker } \\
\text { on the political platform, and in roos he } \\
\text { became editor in charge of El Liberal. } \\
\text { In the Cuban Legislature he represented } \\
\text { the Province of Havana and in this body } \\
\text { he was made Chairman of the Committee } \\
\text { on Public Instruction. Among other legis- } \\
\text { lative measures, his name is associated } \\
\text { with the present educational code of the } \\
\text { Island. As a parliamentary speaker he is } \\
\text { kncwn for his championship of advanced } \\
\text { standards in administrative departments. } \\
\text { In r9I3 he became Secretary of Public } \\
\text { Instruction and Fine Arts, and remained } \\
\text { a member of the Cabinet until the end of } \\
\text { I9I7. In this capacity may be mentioned } \\
\text { his work in behalf of education, illustrated }\end{array}$ \\
\hline I & H I P A N I N O T E S \\
\hline
\end{tabular}




\section{E N S E N A T}

by his reorganization of the program of study, especially in primary schools. More than a thousand country schools were established under his régime, and the system of itinerant school teachers is due to him. In addition to this he promoted the organization of the first four normal schools in the republic. He is a member of the Academy of History of Cuba and is known as a writer on art and as a lecturer. At the present time he is Minister of $\mathrm{Cuba}$ in Mexico.

\section{A N D M O N O G R A P H S}





\section{MANUEL MENCÍA Y GARCÍA}

Physician; man of science.

Manuel Mencía y García was born in Sancti Spiritus, Cuba, on the seventh of December, I884. His early education was received in his native city and he prepared for and received the Bachelor's degree in the Institute of Matanzas. He then entered the University of Havana and followed in his studies the two special lines of his interest, winning first the degree of Doctor of Medicine and later that of Doctor of Natural Sciences.

He continues his pursuit of the Natural Sciences as Secretary of the section of Anthropology of the Felipe Poey Association of the National University.

He began the practice of medicine in his native city as partner of Dr. Rudesino García Rijo, serving in the hospital, the

H I S P A N I C N O T E S 


\begin{tabular}{|c|c|}
\hline 248 & C U B A N O F T O - D A Y \\
\hline & $\begin{array}{l}\text { prison infirmary, the public dispensary and, } \\
\text { during the American Provisional Govern- } \\
\text { ment, was chief of the Board of Health. } \\
\text { In I } 909 \text { he went to Havana as head of } \\
\text { Hospital Number One (now Hospital } \\
\text { Calixto García), but resigned to take a } \\
\text { similar position with the Casa de Bene- } \\
\text { ficencia y Maternidad; in this capacity he } \\
\text { represented the Cuban government at the } \\
\text { International Congress on Infantile Dis- } \\
\text { eases convened in Berlin in I } 1 \text { I and, after } \\
\text { studying asylums and hospitals in the } \\
\text { United States and throughout Europe, } \\
\text { reformed according to the most advanced } \\
\text { standards the hospital in his charge. } \\
\text { Politically Dr. Mencía is a Liberal and } \\
\text { in I } 9 \text { I } 6 \text { as elected to represent the Prov- } \\
\text { ince of Havana in the National House of } \\
\text { Representatives. }\end{array}$ \\
\hline - & $=$ \\
\hline I & H I S P N I C NOTES \\
\hline
\end{tabular}




\section{G O N Z Á L E Z A L C O R A}

\section{LEANDRO GONZÁLEZ ALCORTA}

\section{Teacher; patriot; writer.}

Leandro González Alcorta was born on the thirteenth of March, I86I, in the Province of Pinar del Rio. In 1883 he accepted the call of the recently created Institute of that Province to join its teaching force and became its Secretary.

The Cuban struggle for independence soon claimed his attention and he allied himself enthusiastically with its propagandists. When troubles were at their height in 1895 he was forced to emigrate to Spain where in the very stronghold of the enemy he proclaimed the wrongs of the colony through the columns of $\mathrm{LaPaz}$, a paper which he founded for the purpose. He was arrested and imprisoned, but later being provisionally released, escaped to the United States and thence went to Mexico

\section{A N D M O N G R A P H S}




\begin{tabular}{|c|c|}
\hline 250 & C U B A N S O F TO-D A Y \\
\hline & $\begin{array}{l}\text { where he remained until peace was con- } \\
\text { cluded in I } 899 \text {. } \\
\text { He then returned to his native province } \\
\text { and succeeded in reopening the Provincial } \\
\text { Institute of which he again became Direc- } \\
\text { tor. In this capacity he has worked many } \\
\text { years for the betterment of the locality, } \\
\text { having established in the school a public } \\
\text { library and free training classes for pros- } \\
\text { pective men and women teachers. He } \\
\text { established in I9I I and maintained for } \\
\text { three years a weekly periodical Region y } \\
\text { Patria. He continues in the Provincial } \\
\text { Institute of Pinar del Rio filling two pro- } \\
\text { fessorships, that of Philosophy and Letters } \\
\text { and that of Spanish Language and Litera- } \\
\text { ture. } \\
\text { Dr. González Alcorta has written and } \\
\text { published various pamphlets, chiefly of a } \\
\text { political nature; his thesis for the degree of } \\
\text { Doctor of Philosophy and Letters prepared } \\
\text { in I9oI was upon Causes of the Cuban War } \\
\text { for Independence. }\end{array}$ \\
\hline I & H I S A N I C NOTES \\
\hline
\end{tabular}





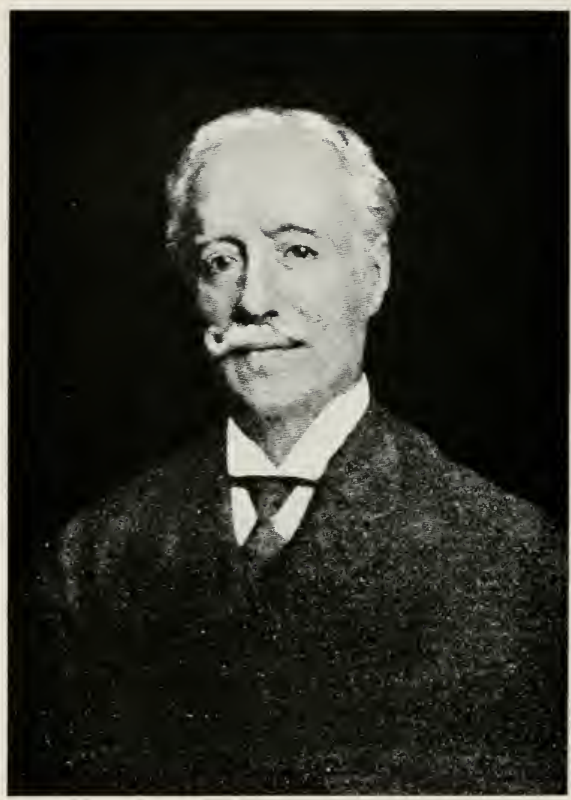

Luis Montané 


\section{O N T A N É}

\section{LUÍS MONTANÉ}

Physician; man of science.

Luís Montané was born in Havana on the seventh of April, I849, and educated in France. He received in Paris in 1874 the degree of Doctor of Medicine, his thesis upon Estudio anatomico del Craneo de los Microcefalos being awarded a prize. Throughout his undergraduate years he devoted special attention to anthropology, coming under the tutelage of the eminent scholars Broca, Hamy, and de Quatrefages. At this time he was chosen as a titular member of La Sociedad de Antropología of Paris.

Upon the completion of his medical education Dr. Montané returned to $\mathrm{Ha}$ vana where he has won distinction in his profession and has held very close his connection with anthropological research.

\section{A N D M O N O G R A P S}




\begin{tabular}{|c|c|}
\hline 252 & C U B A N S O F T O - D A Y \\
\hline & $\begin{array}{l}\text { He has served as visiting physician to the } \\
\text { Hospital of S.S. Felipe y Santiago; dean } \\
\text { of the faculty of Sciences and Letters of } \\
\text { the University of Havana; professor of } \\
\text { Anthropology in the same university. } \\
\text { He is a member of the Academia de Cien- } \\
\text { cias and has acted as its general secretary; } \\
\text { was one of the founders and president of } \\
\text { the Sociedad de Antropologia of the Island } \\
\text { of Cuba; founder and vice-president of the } \\
\text { Sociedad de Estudios Clinicos of Havana; } \\
\text { creator and organizer of the anthropologi- } \\
\text { cal museum which bears his name; member } \\
\text { of the Ateneo, Liceo de la Habana, and } \\
\text { Sociedad "Poey." } \\
\text { He was delegate of the government of } \\
\text { the Republic of Cuba to the scientific Con- } \\
\text { gresses at Monaco, Turin, Paris, Buenos } \\
\text { Aires, and Washington. Under the aus- } \\
\text { pices of the Academy of Sciences Dr. } \\
\text { Montané has carried into effect various } \\
\text { anthropological missions to the interior of } \\
\text { Cuba. } \\
\text { Many of the lectures and papers which } \\
\text { he has prepared for scientific and literary } \\
\text { organizations have found their way to the }\end{array}$ \\
\hline I & H I S P N I C N O T E S \\
\hline
\end{tabular}




\section{O N T A N É}

press. Notable among these writings are those bearing upon scientific research in the Island: La Infancia de la Humanidad, Sepulturas Indias, Cubanas, Un Chimpancé Cubano. He also has made a study of the psychology of the noted Cuban scientist, Felipe Poey.

Dr. Montané holds the following honorary titles and decorations: Caballero de la Legión de Honor, Oficial de Instrucción Pública, Medalla de la campaña FrancoPrusiana (I870), Medalla (cruz de Guerra civil) de la reconnaisance francesa (I9I8), Insignia de la Cruz Roja francesa. 




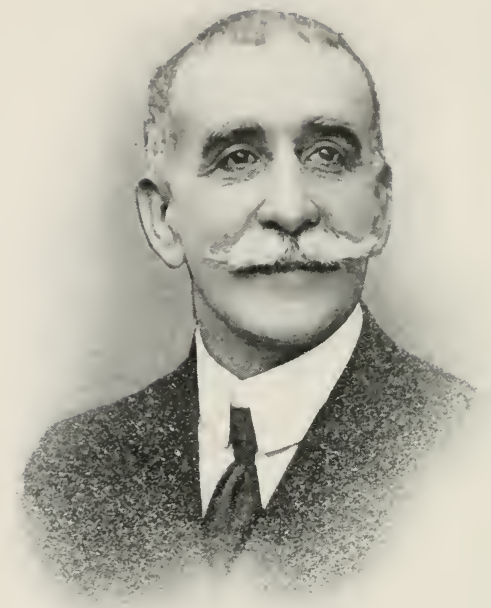

Dr. Mamultengherto 


\section{P É R E Z B E A T O}

\section{MANUEL PÉREZ BEATO}

Teacher; physician; author.

Manuel Pérez Beato was born in Cádiz, Spain, on the fifth of March, I857. His studies were pursued in Cádiz until the fourth year of his medical course which he completed in Havana in 1882 , obtaining the degree of Licentiate and later that of Doctor of Medicine. Upon his graduation he won by competition an appointment as interne in the Civil Hospital of Havana. Through success in later competitions he won places as assistant in the Department of Physics and Chemistry in the Escuela Profesional of the Island of Cuba and as librarian in the same school, and later as assistant in the physical and meteorological observatory of the Island of Cuba. The greater part of his mature life has been devoted to the Escuela de Artes y 


\begin{tabular}{|c|c|}
\hline 256 & C U B A N O F T O - D A Y \\
\hline & $\begin{array}{l}\text { Oficios in Havana, where he has served } \\
\text { for thirty-six years as Professor of Indus- } \\
\text { trial Chemistry, at the same time acting } \\
\text { as Secretary of the school for sixteen years } \\
\text { and for seventeen years as its Vice-presi- } \\
\text { dent. } \\
\text { During recent years Dr. Pérez has been } \\
\text { prominent among students of Cuban } \\
\text { history. He has been since its foundation } \\
\text { in I9Io a member of the Academia de la } \\
\text { Historia de Cuba and since I9I } 8 \text { has been } \\
\text { the librarian of that oiganization. His } \\
\text { later writings have been mostly of a his- } \\
\text { toricai nature: El Curioso Americano, } \\
\text { Revista de Historia de Cuba; Bibliografia } \\
\text { Comentada Sobre los Escritos publicados en } \\
\text { Cuba, relativos alQuijote, I9o5; Inscripciones } \\
\text { Cubanas de los siglos XVI, XVII, XVIII, } \\
\text { I9I } 5 \text {. } \\
\text { His earlier writings were upon medical } \\
\text { topics: Algunos tratamientos empleados en } \\
\text { la curación de la fiebre amarilla (Thesis for } \\
\text { the doctorate); Historia de la vacuna y } \\
\text { progresos alcanzados en este ramo de la } \\
\text { administracion en la isla de Cuba (I } 896 \text { ). } \\
\text { In addition to these works he has pub- }\end{array}$ \\
\hline I & H I P A N I C N T E S \\
\hline
\end{tabular}




\section{PÉ R E Z B E A T O}

lished in different magazines a variety of articles upon history, medicine, and criminology. He has ready for publication: Topografía médica de la Habana, Cuba, Cuatro siglos de Historia, Bibliografía médica Cubana. 




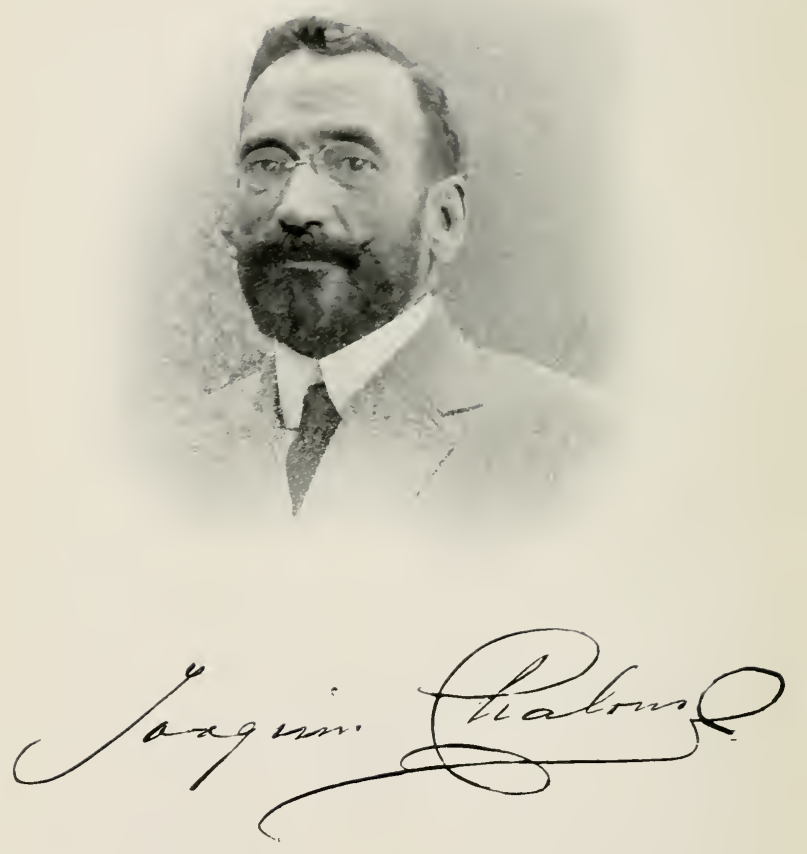




\section{H A L O N S}

\section{JOAQUÍN CHALONS}

\section{Civil engineer.}

Joaquín Chalons was born in Santiago de Cuba, on the twenty-fourth of August, I 864 , and received his early education and his Bachelor's degree in the Colegio "Santiago." In 1882 he entered the Academia de Ingenieros at Guadalajara, Spain, where five years of study brought him the title Engineer. He devoted the next three years to field work upon the Pyrenean border, then returned to Cuba as Captain of Engineers and was appointed subhead of the engineering offices of the city of Santiago.

At the outbreak of the war for Cuban Independence ( 1895 ) he returned to Spain and took a position with the Southern Railway lines of that country.

When the war was over he returned to

\section{H I S P A I C NOTE S}




\begin{tabular}{|c|c|}
\hline 260 & C U B A N S O F T O-D A Y \\
\hline & $\begin{array}{l}\text { Santiago as engineer of the Steel Ore Co., } \\
\text { and in I9oo joined the local Department } \\
\text { of Public Works as assistant engineer. } \\
\text { After several minor promotions he became } \\
\text { chief engineer of the Department of Public } \\
\text { Works of the Province of Oriente. He soon } \\
\text { attained the rank of Chief Engineer of the } \\
\text { First Class and under the national govern- } \\
\text { ment filled successively the offices of } \\
\text { Director General and Inspector General of } \\
\text { Railways. } \\
\text { Following a two-years' interim marked } \\
\text { by the American Provisional Government, } \\
\text { during which he devoted himself to private } \\
\text { practice of his profession chiefly as techni- } \\
\text { cal director of a company engaged in the } \\
\text { urbanization and extension of Santiago, } \\
\text { he was returned to the Department of } \\
\text { Public Works. After a few months, as } \\
\text { head of that department in his native } \\
\text { province, he was attached to the National } \\
\text { Department of Public Works as secretary } \\
\text { (Igog-I9I I). } \\
\text { For the following two years, I } 9 \text { I } 2-\text { I9I3, } \\
\text { he remained in Havana as the consulting } \\
\text { engineer of the General Contracting Co. }\end{array}$ \\
\hline I & H I S A N I C N O T E S \\
\hline
\end{tabular}




\section{H A L O N S}

26 I

and of the "Compañia de los Puertos de Cuba" as well as member of the Harbors Board; he then returned to Santiago where he practices his profession.

$\mathrm{He}$ is a member of the National Academy of Arts and Letters. 




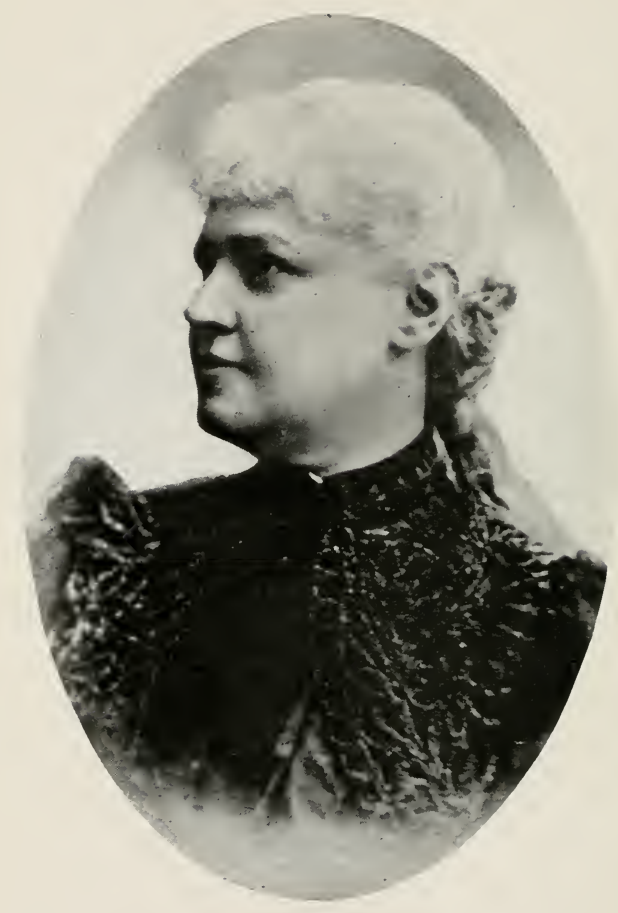

Surcha Pactilla delourálar 


\section{E G O N S A L E S}

AURELIA CASTILLO DE GONSALES

Traveler; author.

Aurelia Castillo, daughter of Pedro Castillo y Betancourt and María Castillo y Castillo, was born in the Province of Puerto Príncipe (now Camagüey), Cuba, on the twenty-seventh of January, I842. Her parents found it impossible to give her the educational advantages they desired, and after her tenth year her intellectual development was left to the Fates which supplied her with reading matter.

In May, I874, she was married to Francisco Gonsales del Hoyo, Major of Infantry in the Spanish Army. A year later she accompanied her husband to Spain when he was expelled from the Island by the Spanish Brigadier Ampudia [because of his vehement condemnation of the execution of the Cuban patriot, Dr. An-

\section{H I S P A N I C N T E S}




\begin{tabular}{|c|c|}
\hline 264 & C U B A N O F T O - D A Y \\
\hline & $\begin{array}{l}\text { tonio L. Luaces]. The family made its } \\
\text { home at various times in Santander, in } \\
\text { Madrid, and in Almería, the husband } \\
\text { engaged in preparing El Pueblo de Cama- } \\
\text { gïey while Doña Aurelia wrote Hicoten- } \\
\text { catle, Doña Marina, and Moctezuma. } \\
\text { Returning to Cuba, Doña Aurelia de } \\
\text { Gonsales settled with her husband in } \\
\text { Guanabacoa and wrote her: Adios de } \\
\text { Victor Hugo which won in I885 the first } \\
\text { prize in a literary contest. The following } \\
\text { year in a similar competition her Biografia } \\
\text { de G. G. Avellaneda received honorable } \\
\text { mention. She attended the Paris Exposi- } \\
\text { tion in I } 889 \text { and recorded her impressions } \\
\text { for a Havana journal, El Pais. The } \\
\text { Revista Cubana published subsequent } \\
\text { letters from Italy and Switzerland and a } \\
\text { poem entitled Pompeya. Later all this } \\
\text { correspondence was collected and pub- } \\
\text { lished under the title Un Paseo por Europa } \\
\text { (I89I). } \\
\text { After traveling in Mexico she visited } \\
\text { the United States and attended the Colum- } \\
\text { bian Exposition in I893 again acting as } \\
\text { correspondent for El Pais; this series of }\end{array}$ \\
\hline I & H I S P N I C N O T E S \\
\hline
\end{tabular}




\section{E G O N S A L E S}

letters composed the volume $U n$ Paseo por A mérica, issued in 1895 .

Upon the sudden death of her husband, the twenty-fourth of March, I895, she determined to write no more since the main incentive was gone.

By the edict of General Weyler she was again expelled from $\mathrm{Cuba}$ in 1896 and chose for her place of residence Santa Cruz de Tenerife and afte1wards Barcelona. Returning to Cuba at the close of the Spanish régime, and finding her former home in Guanabacoa in ruins her emotions forced her to break her resolution and write. Her verses Ruinas were soon followed by another poem, Expulsada, which expressed her feelings upon being obliged to abandon her home as the result of attack and robbery with threats of death.

Upon the reëstablishment of the Republic in I902 Sra Castillo de Gonsales turned again to her pen; she prepared two small volumes of verses, Trozos Guerreros and $A$ poteosis, which appeared the following year. She made visits to Italy and to France in $1904^{-5}$ and 1909 respectively;

\section{A N D M O N O G R A P H S}




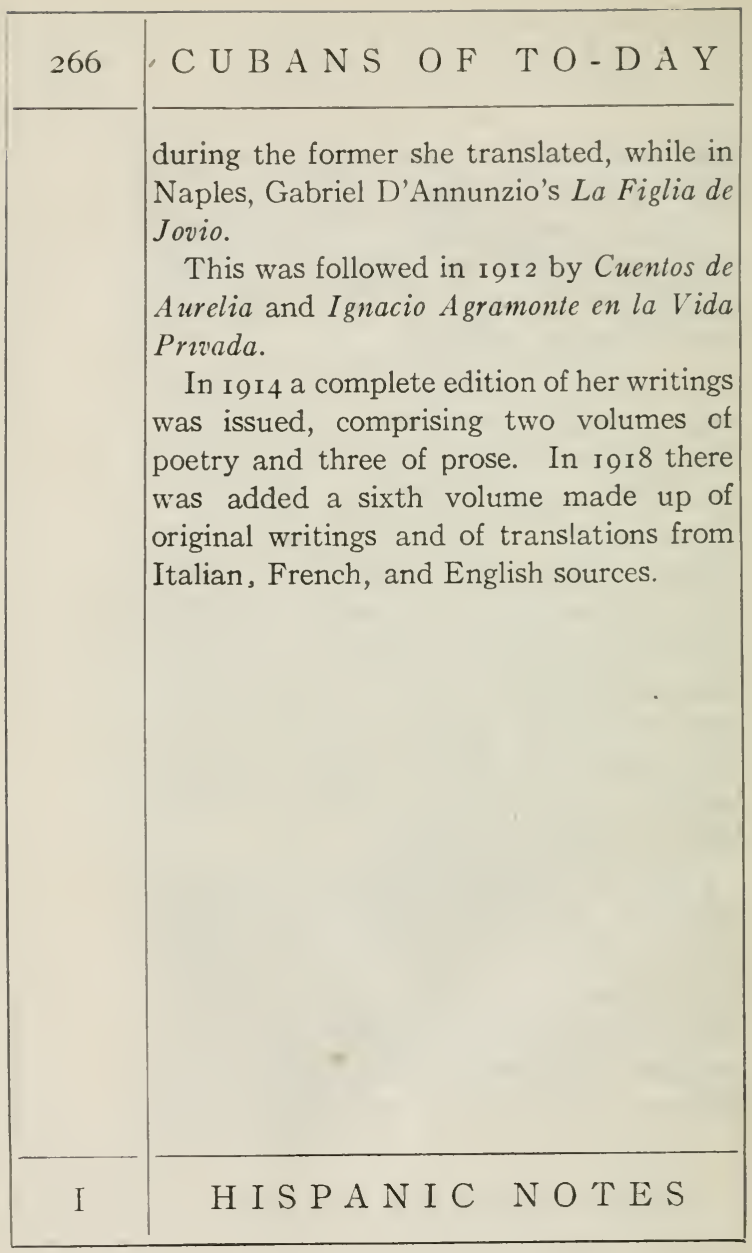





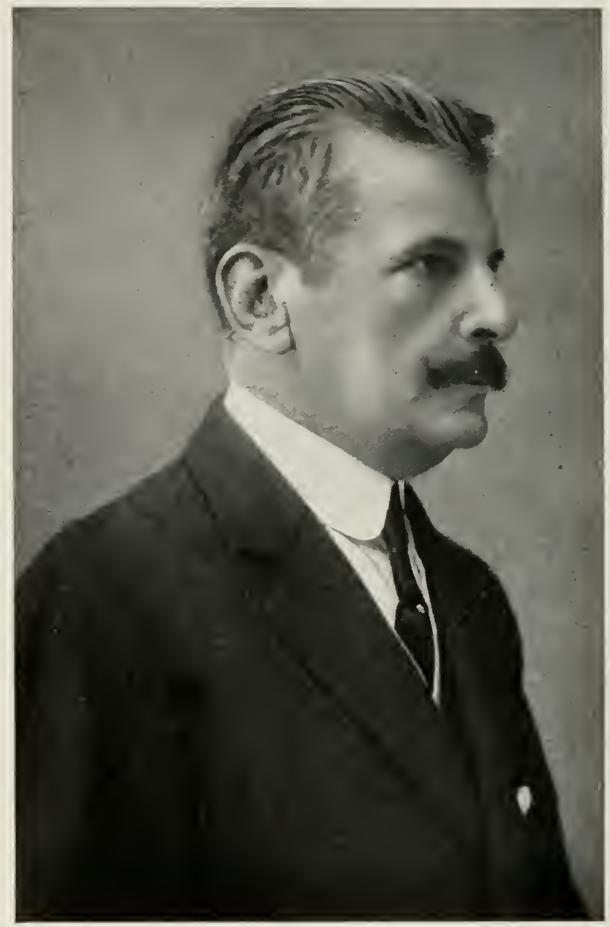

Aral weuretiob astillo Wuany 


\section{DEMETRIO CASTILLO DUANY}

Soldier; man of affairs; administrator.

Demetrio Castillo Duany was born in Santiago de Cuba on the seventeenth of November, 1856 , into one of the leading families of the eastern region of $\mathrm{Cuba}$ and went for education to France. After spending some years at the Lycée of Bordeaux he went on to the United States where he gave himself to the study of English and entered an established business house. In 1878 , at the age of twenty-two, he returned to Santiago de Cuba to take charge of the interests of his mother. A year later the outbreak of the "little war" obliged him to emigrate to the United States where he remained until ${ }_{1} 88_{5}$.

The outbreak of the War of Independence in 1895 found him ready for the final

A N D MONOGR A P H S 


\begin{tabular}{|c|c|}
\hline 268 & C U B A N O F T O - D A Y \\
\hline & $\begin{array}{l}\text { struggle and he devoted himself to it with- } \\
\text { out reserve. He joined the Revolutionary } \\
\text { forces under Victoriano Garzón, was soon } \\
\text { transferred to the staff of José Maceo and } \\
\text { saw much arduous service under that re- } \\
\text { doubtable chief. His valor and enterprise } \\
\text { brought him rapid advancement. He } \\
\text { became Lieutenant Colonel after the } \\
\text { actions of Yerba de Guinea and la Curia } \\
\text { and became Colonel after the battles at } \\
\text { El Triunfo and Sao del Indio. Three days } \\
\text { before the fatal encounter of Loma de } \\
\text { Gato in which Maceo lost his life he pro- } \\
\text { moted Duany to the rank of Brigadier } \\
\text { General. } \\
\text { When the United States entered the } \\
\text { war against Spain, General García selected } \\
\text { Brigadier General Duany to confer with } \\
\text { the American commanders and arrange } \\
\text { for coöperation with them. In fulfillment } \\
\text { of this commission General Duany con- } \\
\text { ferred with Admiral Sampson on board } \\
\text { the battleship New York to concert plans } \\
\text { for the landing of American troops and to } \\
\text { provide for joint action with the Cuban } \\
\text { forces. Under his command the Cubans }\end{array}$ \\
\hline I & H I S A N I C NOTES \\
\hline
\end{tabular}


captured Siboney and thus reduced the risk of the disembarkation of the American force. He continued to coopperate with the Americans throughout the remainder of the war.

When hostilities ceased he turned to politics. In 1898 he was named Governor of Santiago de Cuba and was later appointed Civil Governor of the Eastern Province under the American Intervention. He was one of the founders of the Republican party in Oriente which later merged with the Liberal party. In I 906 he was associated with the Revolutionary Committee and was arrested and imprisoned until the arrival of the American commissioners who released him. Soon thereafter Governor Magoon appointed him Chief of the Penitentiary of the Republic. In consequence of the Revolution of I9I6-I7 he retired from office and resumed the life of a private citizen.

\section{A N D M O N O G R A P H S}






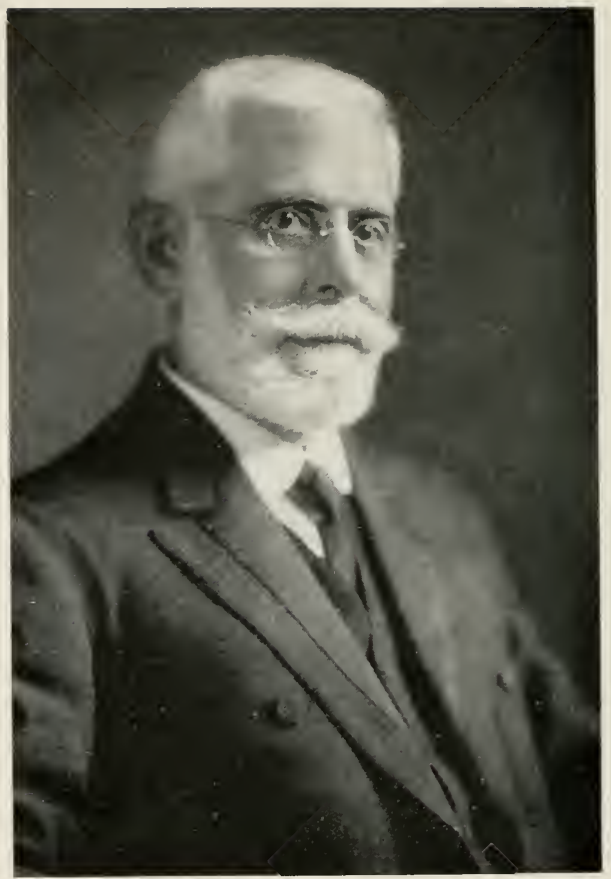

By permission of

Harris-Ewing, photographers (Washington, D. C.)
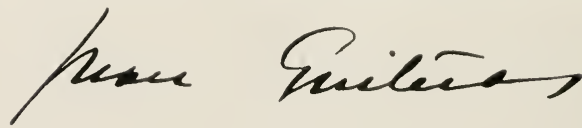


\section{G U I T E R A S}

\section{JUAN GUITERAS}

Physician; author; man of science.

Juan Guiteras was born in the city of Matanzas on the fourth of January, I 852 , the son of Eusebio Guiteras and Josefa Gener, both members of families active in the higher life of Cuba. At the age of seven Guiteras was enrolled in the Colegio "La Empresa" founded by his father and his Uncle Antonio who was at the time at the head of the school. From this institution he graduated Bachelor in Arts in 1867 . At the University of Havana he came under the influence of Don Felipe Poey, the foremost Cuban man of science of his time. Guiteras studied Natural History under him for the preparatory course in Medicine. He matriculated for the first year at the University of Havana, but in 1869 moved 


\begin{tabular}{|c|c|}
\hline 272 & C U B A N S O F T O - D A Y \\
\hline & $\begin{array}{l}\text { to Philadelphia with his parents who were } \\
\text { obliged to emigrate on account of the sym- } \\
\text { pathies of the family with the revolution- } \\
\text { ary movement for the independence of } \\
\text { Cuba. Guiteras then entered upon the } \\
\text { study of Medicine and graduated from the } \\
\text { University of Pennsylvania in I } 873 \text {, taking } \\
\text { first prize for his thesis on the Development } \\
\text { of the Skcleton as Influenced by Functional } \\
\text { Activities. } \\
\text { He completed a term of service as in- } \\
\text { terne in the Philadelphia Hospital, I } 873- \\
74 \text {, and was Visiting Physician to the same, } \\
\text { and clinical lecturer in Medicine from I } 876 \\
\text { to I } 879 \text {. He soon won marked distinction } \\
\text { in his special field of Pathology; he was } \\
\text { selected by the American Government to } \\
\text { study yellow fever in Havana in I } 879 \text {; in } \\
\text { the following year he was appointed Phy- } \\
\text { sician in the United States Marine Hospi- } \\
\text { tal Service; in I } 886 \text { he was made Professor } \\
\text { of Medicine in the University of Charles- } \\
\text { ton, S. C. He took a course in Pathology } \\
\text { at Frankfort, Germany, under Weigert } \\
\text { in I } 889 \text {, and in the same year was called } \\
\text { to the Chair of Pathology by his Alma }\end{array}$ \\
\hline I & H I S P N I C N O T E S \\
\hline
\end{tabular}




\section{G U I T E R A S}

Mater, the University of Pennsylvania.

$\mathrm{He}$ was selected in $\mathrm{I} 890$ by this University to investigate and report upon Koch's discovery of tuberculine. Whilst in Berlin he took a course on the Pathology of the Blood with Ehrlich, and laboratory courses with Israel, Pfeiffer, Jürgens, and Günther.

At the outbreak of the war for the Independence of Cuba, in I 895, Dr. Guiteras, then in the United States, gave his best efforts to obtain recognition of Cuban belligerency by the American Government, and on the formation of the Cuban Republic he devoted himself to strengthening the foundations of the new state, particularly laboring to give Cuba a sound and scientific national hygiene. In 1900 he founded the Review of Tropical Medicine. As colaborer with Dr. Finlay and his associates Reed, Carroll, Lazear, and Agramonte he shared in the final demonstration of the transmission of yellow fever by the mosquito. Since 1909, as Director of Sanitation of Cuba, he has contributed largely to keeping the Republic free from epidemic diseases and reducing the liabil-

\section{A N D $\mathrm{M} \mathrm{O} \mathrm{NOG} \mathrm{R} \mathrm{P} \mathrm{H} \mathrm{S}$}




\begin{tabular}{|c|c|}
\hline 274 & C U B A N S O F T O - D A Y \\
\hline & $\begin{array}{l}\text { ity to those of endemic origin. In I9I6 Dr. } \\
\text { Guiteras was appointed in the International } \\
\text { Health Commission of the Rockefeller } \\
\text { Foundation to study yellow fever in South } \\
\text { America, and has continued these inves- } \\
\text { tigations up to the present year. } \\
\text { He is Professor of General Pathology } \\
\text { and Tropical Diseases in the University of } \\
\text { Havana; Director of Health; President of } \\
\text { the National Board of Health; Member } \\
\text { of the Board for Infectious Diseases; } \\
\text { Member of the Academy of Sciences and } \\
\text { of the Sociedad de Estudios Clinicos of Ha- } \\
\text { vana; Honorary Member of the Association } \\
\text { of American Physicians; of the College of } \\
\text { Physicians of Philadelphia; of the American } \\
\text { Society of Tropical Medicine, and of the } \\
\text { Academy of Medicine of Caracas. } \\
\text { Among the most important contribu- } \\
\text { tions of Dr. Guiteras to Medical Science } \\
\text { the following may be mentioned: he dis- } \\
\text { covered the filaria Bancrofti in the United } \\
\text { States, I } 886 \text {; he demonstrated the impor- } \\
\text { tance of mild cases in the propagation of } \\
\text { infectious diseases, especially in connection } \\
\text { with the yellow fever of children in the }\end{array}$ \\
\hline I & H I S P N I C N OTES \\
\hline
\end{tabular}




\section{G`U I T E R A S}

endemic zone, 1887 ; in his teachings at the University of Pennsylvania he recognized the importance of functional disturbances in the development of structural changes, and endeavored to establish pathology on a physiological rather than an anatomical basis, 1889-99; he introduced in America the modern methods in Tropical Pathology, founding the first chair and the first journal on this specialty on the Continent in 1900; he discovered the existence of ankylostomiasis in Cuba; he contributed to the extinction of yellow fever, and established the importance of hydrocyanic fumigations in the extinction of plague.

Dr. Guiteras has edited the Selected Papers of Dr. Carlos J. Finlay, published in Spanish and English by the Cuban Government in I912, and has contributed to scientific journals numerous articles on his specialty of 'Tropical Medicine, most of which are highly technical. Among them are: Notes on Pathology for Students of the University of Pennsylvania; "Experimental Yellow Fever" (Havana, I901), American Medicine; Recent Discover-

A N D M O NOGRAP H S 


\section{C UBA N S OF TO-D A Y}

ies on Malaria and the Mosquito, I900; Chappa, Aceopatia mutilante, r904; Cartas sobre el Cólera (Habana, I9II); "Insect Borne Diseases," Proceedings of the Second Pan-American Scientific Congress, vol. ix., rgr6. 


\section{MANUEL GUTIÉRREZ QUIRÓS}

\section{IIan of affairs; official.}

Manuel Gutiérrez Quirós was born in Santa Clara on the twelfth of February, I 856 , and began his education at the $\mathrm{Co}$ legio "Santo Domingo" in his native town whence he went in I 868 to the Colegio "E1 Salvador, "then under the direction of the well-known author and educator Señor José Maria Zayas.

As a result of the revolutionary activities of his father and the consequent confiscation of all his property by the Spanish Government, Gutiérrez was thrown upon his own resources while yet quite young. At the age of nineteen he became a teacher, but shortly afterwards gave up the profession to enter business, by which he had acquired some capital when in 1897 , during the Revolution, being President of the

\section{A N D M O N O G R A P S}




\section{C U B A N S O F T O-D A Y}

Revolutionary Board of Sagua la Grande, he was arrested and lodged for a period of eight months in the prison of the Cabaña Fort.

On being released he went to Jamaica where he remained until the end of the war. Thereupon he came back to Cuba and set himself to restore his shattered fortunes, in which he was successful.

Señor Gutiérrez has taken an active part in politics. As a friend and co-religionist of General José Miguel Gómez he became Representative for Santa Clara, later Mayor of Sagua la Grande, and also Minister of Hacienda in the Cabinet of President Gómez.

He has maintained an active interest in literature and has published a book of poems. 


\section{A R B O N E L L}

\section{JOSÉ MANUEL CARBONELL}

Soldier; author; orator.

José Manuel Carbonell y Rivero was born in July, I880, in Alquizar, Province of Havana. When he was an infant his parents moved to the United States where he obtained his early education. From his boyhood he was a revolutionist and a disciple of José Martí, "the liberator." When the War of Independence broke out Carbonell, then fifteen years old, joined one of the expeditions fitted out in the United States and remained in the field for a time. Later he returned to Tampa, Florida, and served with Pastor Moinelo, Carlos Boissier, Octavio García Campos, and Fernando de Zayas in the campaign of propaganda, founding and editing the magazine, $E l$ expedicionario, and contributing to various other periodicals.

A N D M O N O G R A P S 


\begin{tabular}{|c|c|}
\hline 280 & C U B A N S O F T O - D A Y \\
\hline & $\begin{array}{l}\text { At the end of the war he came to Havana, } \\
\text { resumed his studies in the Institute, and } \\
\text { ultimately obtained the degree of Doctor of } \\
\text { Civil Laws in the University. He began } \\
\text { to be known also as a writer of verse and a } \\
\text { public speaker. When the Republic was } \\
\text { constituted in I } 902 \text { Carbonell, and his inti- } \\
\text { mate friend, José Maria Collantes, organized } \\
\text { a great celebration in honor of Martí. } \\
\text { President Palma presided and the oration } \\
\text { of Carbonell was the event of the occasion. } \\
\text { Since that time he has spoken many times } \\
\text { at the Ateneo of which he was the origina- } \\
\text { tor and which he served as secretary for } \\
\text { two years. His most notable work as an } \\
\text { orator was dane in the campaign for the } \\
\text { election of General José Miguel Gómez as } \\
\text { President. Togetherwith Señores Mendieta, } \\
\text { Ferrara, and Villuendas he toured the coun- } \\
\text { try, organizing and inspiring the masses. } \\
\text { When the Revolution of Igo6 broke out } \\
\text { Carbonell joined it; in fact was one of the } \\
\text { first to take the field after a fiery speech } \\
\text { in which he used the phrase, often since } \\
\text { repeated, "hay que sacar los collins (ma- } \\
\text { chetes) de sus vainas!" For his services }\end{array}$ \\
\hline I & H I S A N I C NOTES \\
\hline
\end{tabular}




\section{A R B O N E L L}

in this brief revolution he was rewarded with the rank of Brigadier General.

Since that time he has given much time to poetry and has both recited and published numerous poems which have been received with popular approval. Together with his brother Nestor and Sr. Félix Callejas, he founded the magazine Letras. $\mathrm{He}$ has also held various positions in the field of education-Chief of Section of General Superintendents; Secretary of the Committee of Superintendents; Provincial Superintendent of Havana, etc., etc.

In I9ro he was Cuban Delegate to the Fourth Pan-American Conference held in Buenos-Aires; in I9I I he was Cuban Delegate at the Coronation of King George V. $\mathrm{He}$ is President of the Section of Literature of the National Academy of Arts and Sciences; President of the Geographical Society of Cuba; Compiler of the works of Jesús Castellanos and Enrique Hernández Miyares.

$\mathrm{He}$ is author of: Patria, Poems; Penachos y Mi libro de amor, Poems; Discursos y Conferencias; Páginas literarias; Oyendo a mi padre.

\section{A N D M O N O R A P H S}





\begin{tabular}{l} 
R E Q U E I J O \\
\hline EMILIO ALAMILLA REQUEIJO \\
EMILIO ALAMILLA REQUEIJo was born \\
on the twenty-sixth of January, I872, in \\
Havana, where he gained his early educa- \\
tion in the Colegio of Belén, completed \\
the courses for the Bachelor's degree in \\
the Central Institute, and later entered the \\
University to study the Physico-Chemical \\
Sciences and Medicine. There also he \\
obtained the degree of Doctor of Medicine \\
in I895. \\
Dr. Alamilla graduated at the time of the \\
War of Independence but because of the \\
imprisonment of his political associate, Dr. \\
José A. González Lanuza, he took refuge \\
in the United States where he remained \\
until the war was over, practicing his pro- \\
fession in various hospitals of Atlanta \\
(Gecrgia) and New York. \\
H I S P A N I C N O T E S
\end{tabular}




\begin{tabular}{|c|c|}
\hline 284 & C U B A N O F T O-D A Y \\
\hline & $\begin{array}{l}\text { In I } 903 \text { he set up, in coöperation with } \\
\text { Drs. Carlos Desvernine and Martinez } \\
\text { Mesa, the first Institute of Radiotherapy } \\
\text { and Electrotherapy that had been seen in } \\
\text { Cuba. In I } 908 \text { he was appointed Professor } \\
\text { of Physics in the Institute of Havana and } \\
\text { when, under the plan of Varona, the edu- } \\
\text { cational system was reformed, he entered } \\
\text { the competitive examination for the Chair } \\
\text { of Physics and Chemistry in the Institute, } \\
\text { was successful, and has continued to occupy } \\
\text { this post. } \\
\text { In I } 9 \text { Io he was appointed Director of the } \\
\text { Department of Electrotherapy and Radio- } \\
\text { therapy in the Centro Gallego (Gallician } \\
\text { Club). } \\
\text { Dr. Alamilla has contributed occasional } \\
\text { articles to the medical press, among which } \\
\text { are: Tratamiento del pénfigo por los Rayos } \\
\text { Finsen; Las radiodermitis, I } 905 \text {. }\end{array}$ \\
\hline I & H I S A N I C N O T E S \\
\hline
\end{tabular}




\begin{tabular}{l} 
A G U A Y O \\
\hline \\
ALFREDO M. AGUAYO \\
ALFREDo M. AGUAYo Y SÁNCHEz was \\
born in Porto Rico on the twenty-eighth \\
of March, IS66. While he was still a child \\
his family moved to Havana where he \\
gained his education, obtaining the de- \\
grees of Licentiate in Law and Doctor in \\
Pedagogy. He was appointed Superin- \\
tendent of Schools for the Province of \\
Havana and later became Professor of \\
Pedagogical Psychology, History of Peda- \\
gogy and School Hygiene in the University \\
of Havana. \\
Dr. Aguayo founded, and for a number \\
of years edited, the Magazine of Education \\
of Havana, and in I9I 28 established the \\
Laboratory of Child Study (Paidologia) \\
in the University. \\
He has written much, both as contribu- \\
A N D M O N O G R A P H S
\end{tabular}




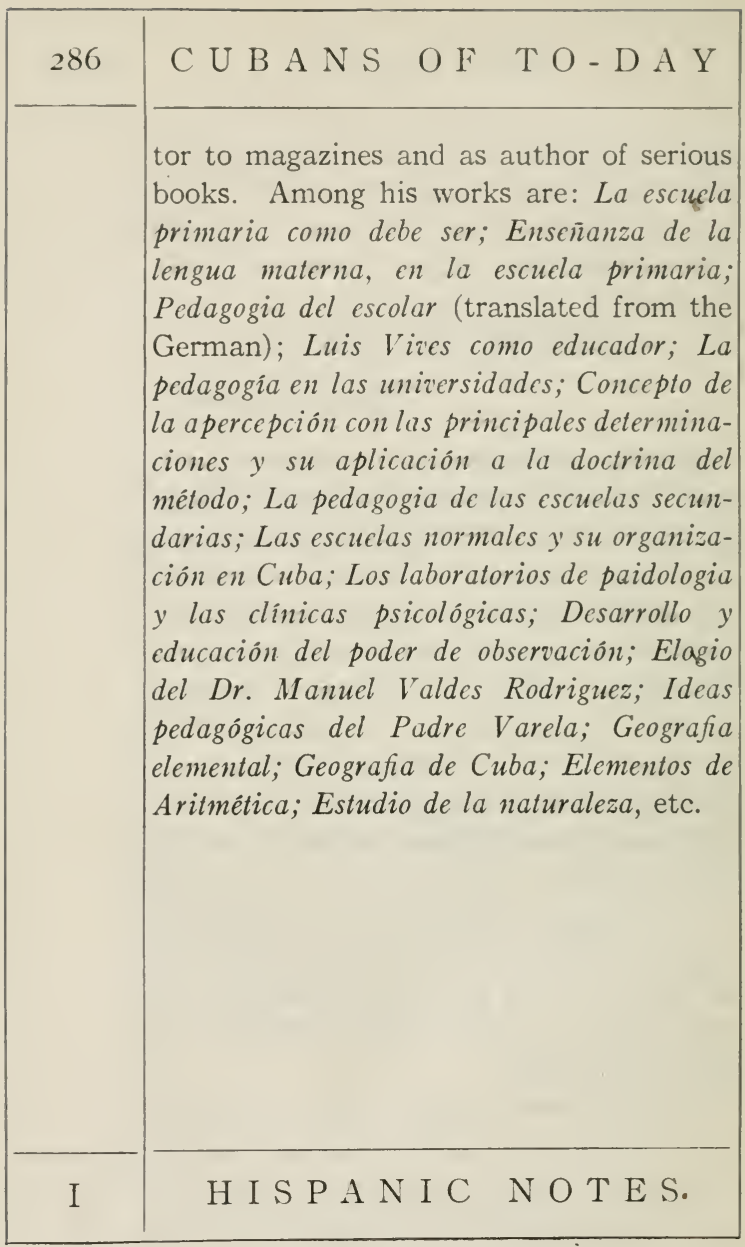




\section{O N T A G Ú}

\section{GUILLERMO DE MONTAGÚ}

Lawyer; official; author.

Guillermo de Montagú was born in San Juan y Martínez, Province of Pinar del Rio, Cuba, on the twelfth of December, I 88I. His early education was obtained in Barcelona, Spain, whither his family moved in his infancy, but they returned to Cuba in 1890 and he entered the Institute of Pinar del Rio where he completed the courses for the Bachelor's degree, thereafter continuing in the University of $\mathrm{Ha}$ vana where he obtained the degree of Doctor of Laws in 1905.

Some years earlier, in $190 \mathrm{I}$, while he was still a student, he began to write articles on legal subjects for the Magazini of Law (Revista del Derecho) of Havana, his topics being "El Protectorado"; "El hipnotismo en Derecho Penal"; "La Premeditación";

\section{A N D M O N O G R A P H S}




\begin{tabular}{|c|c|}
\hline 288 & C U B A N S O F TO-DAY \\
\hline & 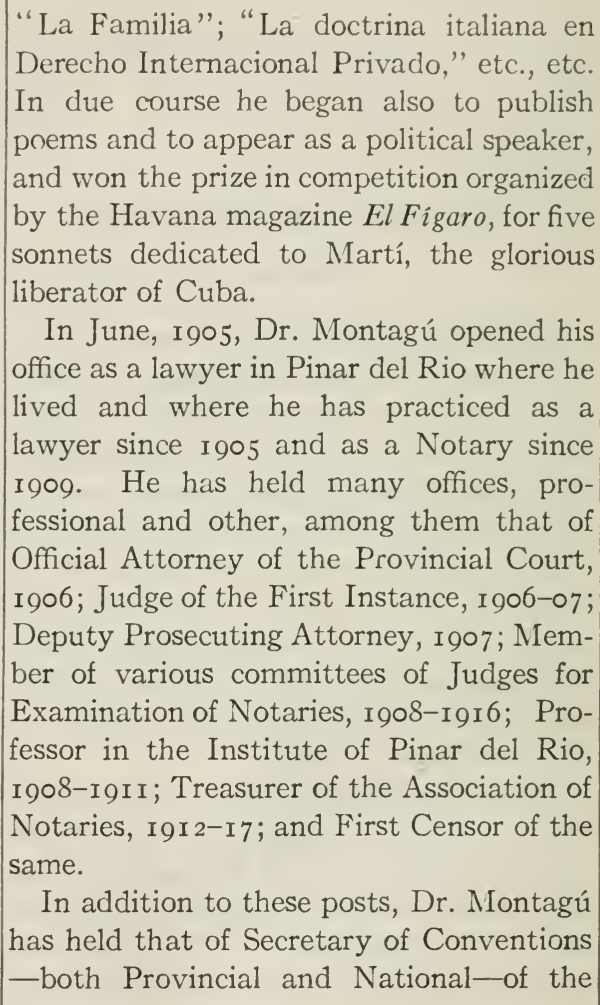 \\
\hline I & H I S P N I C NOTES \\
\hline
\end{tabular}




\section{O N T G Ú}

Liberal Party; president of the Patriotic Association (Asociación Patria) and Representative in the Provincial Legislature, I9ro.

Along with his professional activities, he has had a productive literary career. In 1908 he won the first prize in a poetical contest in the National Theater. In roro he gave an address and read verses in commemoration of the distinguished Cuban author Jesús Castellanos. In IgI I on a visit to Spain he gave various lectures and addresses in the Ateneos of Barcelona and Madrid.

He has contributed to many magazines and reviews and has published the following works: Poesías (1906); A la Patria (I908); Iris (I909); Monografías de la Revista de Derecho (г $90 \mathrm{I})$; Cirilo Villaverde: estudio de su vida y obras (r9o9); Martin Pérez, Novela (I9ro); La Fuga (I9r 2); Notas y A puntes para un sistema de legislación agraria (I9I3); Consideraciones acerca de la Ley que señala el origén y rige el desenvolvimiento de la humanidad (г918).

A N D M O NOG R P H S 




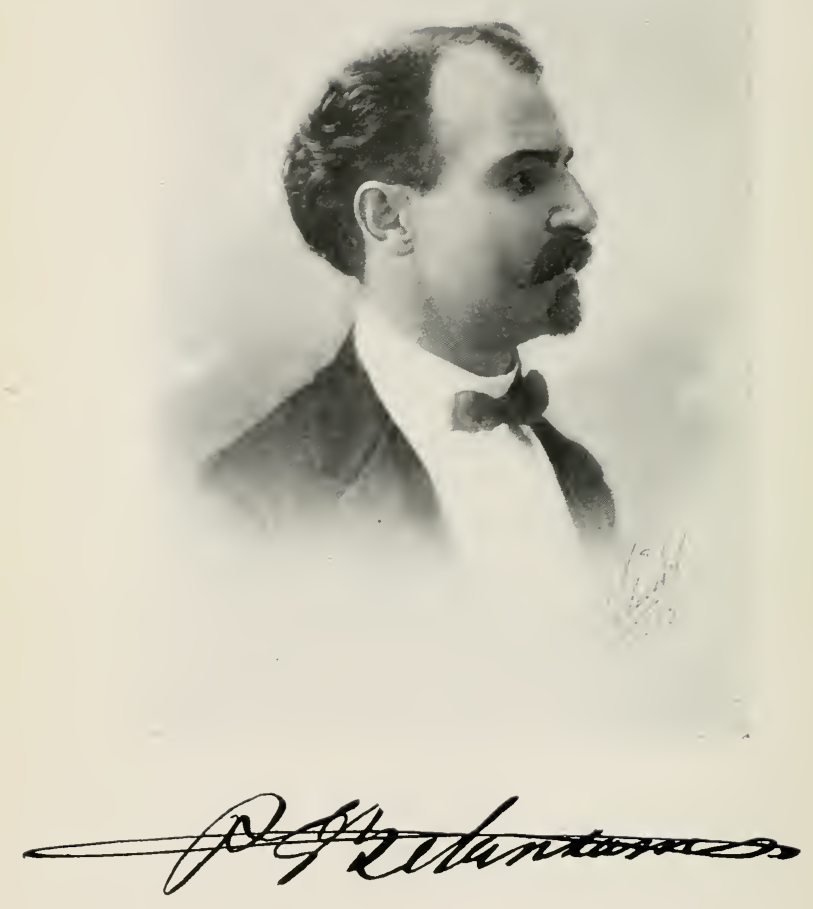




\begin{tabular}{|c|c|}
\hline B E T A N C O U R T & $29 \mathrm{I}$ \\
\hline $\begin{array}{l}\text { PEDRO E. BETANCOURT } \\
\text { Soldier; official. } \\
\text { PEDRo E. BETANCOURT Y Dovalos was } \\
\text { born in I } 858 \text { and baptized in Seiba Mocha, } \\
\text { Province of Matanzas. Having chosen } \\
\text { Medicine for his profession he studied } \\
\text { first in Philadelphia and later in Madrid } \\
\text { where he graduated in } 88 \text { r. He returned } \\
\text { to Matanzas to practice his profession, but } \\
\text { when the War of Independence broke out } \\
\text { in I } 895 \text { he was one of the first to take part } \\
\text { in it. As President of the Revolutionary } \\
\text { Club of the Western part of the Island he } \\
\text { was charged with the selection and organi- } \\
\text { zation of the revolutionary forces of the } \\
\text { Province of Matanzas and was. one of the } \\
\text { members of the ill-fated force that took } \\
\text { up arms in Matanzas on the twenty-fourth } \\
\text { of February, I } 895 \text {. When this force was } \\
\text { defeated and scattered Betancourt was }\end{array}$ & \\
\hline H I S P A I C N O T E S & I \\
\hline
\end{tabular}




\begin{tabular}{|c|c|}
\hline 292 & $\mathrm{C} U \mathrm{U}$ A N S O F $\mathrm{TO}-\mathrm{DA} \mathrm{Y}$ \\
\hline & $\begin{array}{l}\text { captured, imprisoned for a time in the } \\
\text { Castle of San Severino, later in Havana } \\
\text { and finally exiled to Spain. There he en- } \\
\text { countered General Calixto García with } \\
\text { whose assistance he succeeded in escaping } \\
\text { to France. Once in Paris he joined with } \\
\text { the famous Dr. Betances to execute the } \\
\text { commissions affecting France and England } \\
\text { which had been entrusted to him by Gen- } \\
\text { eral García. These fulfilled, he went on to } \\
\text { New York where he joined the Revolution- } \\
\text { ary Committee working for the war. He } \\
\text { served in an expedition organized by Gen- } \\
\text { eral Francisco Carrillo which was detained } \\
\text { in Wilmington (Delaware) by the United } \\
\text { States authorities. The members of the } \\
\text { expedition were placed on trial, acquitted, } \\
\text { and set at liberty; whereupon Betancourt } \\
\text { joined three other expeditions one after } \\
\text { the other, all of which were stopped in the } \\
\text { same way by the American authorities. } \\
\text { In a fourth expedition Betancourt and } \\
\text { his companions were taken prisoners in the } \\
\text { Bahamas by the British Cruiser Partridge } \\
\text { and imprisoned in Nassau where again they } \\
\text { were tried, acquitted, and set at liberty. }\end{array}$ \\
\hline I & H I S P A I C NOTES \\
\hline
\end{tabular}




\section{B E T A N C O U R T}

Once more Betancourt returned to New York and on the next attempt succeeded in landing on the coast of Cuba under the direction of General García.

During the rest of the war he fought in Matanzas, under General Lacret, and at its close was at the head of the revolutionary forces in that province with the rank of Major General.

After the war he was appointed Civil Governor of Matanzas; later Member of the Constituent Convention and also one of those designated by the Assembly to discuss with President McKinley the actual significance of the Platt Amendment.

He was elected Senator in the first Legislature of Cuba, but later retired from public life to devote himself to agricultural interests.

\section{A N D MO NOGR A P H S}






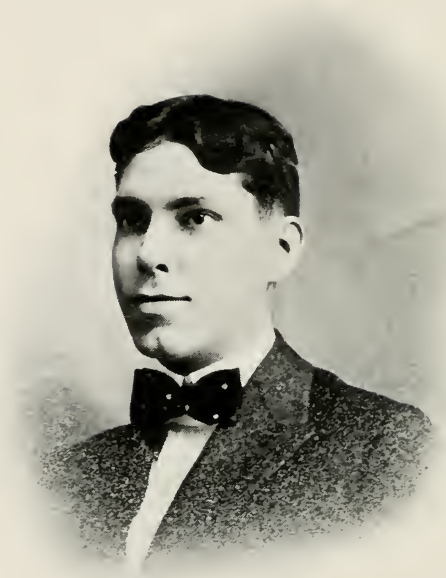

Gutonio

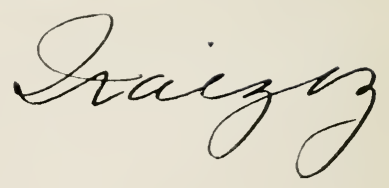




\section{R A I Z O Z}

ANTONIO IRAIZOZ Y DEL VILLAR Journalist; author.

Antonio Iraizoz y del Villar was born on the fourteenth of June, I890, in Havana, where he received his education and where he has had his career. He studied at the Colegio "La Gran Antilla" and completed the course leading to the degree of Bachelor of Arts and Sciences. Obtaining also the degree of public teacher he entered the profession and taught in the schools for five years. Perceiving, however, that his true vocation lay in journalism, he served on the editorial staffs of several Havana papers, including La Discusión, La Prensa, and La Lucha and later became editor-in-chief of Patria. In r9I3 he became editor-in-chief of La Noche, an important evening paper, and has continued at that post.

\section{H I S P A I C N O T E S}




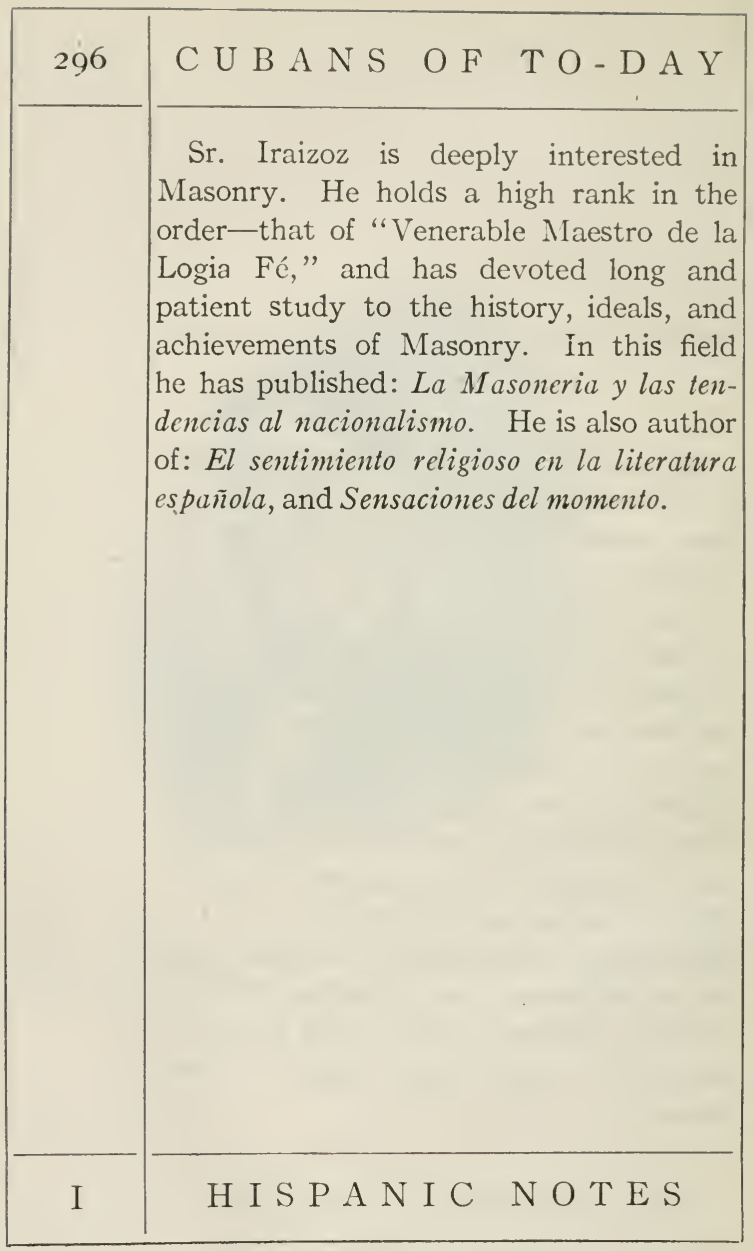




\section{LUIS ORTEGA Y BOLAÑOS}

\section{Physician; teacher.}

Luis Ortega y Bolaños was born on the sixteenth of July, 1872 , in the city of Cienfuegos and there, in the Colegio of the Jesuit Fathers he received his early education. Later he went to Havana where he entered the University and gained the degree of Licentiate in Medicine in 1896 and that of Doctor in 1899 .

When the Spanish-American War broke out he removed to Mexico where he remained, practicing his profession, until peace was signed when he returned to Cuba.

He served as Interne in the Hospital of Nuestra Señora de las Mercedes, and later as Head Interne for ten years. In 1906 he entered the competitive examination for the post of Professor of Clinical Medicine

\section{A N D M O N O G R A H S}




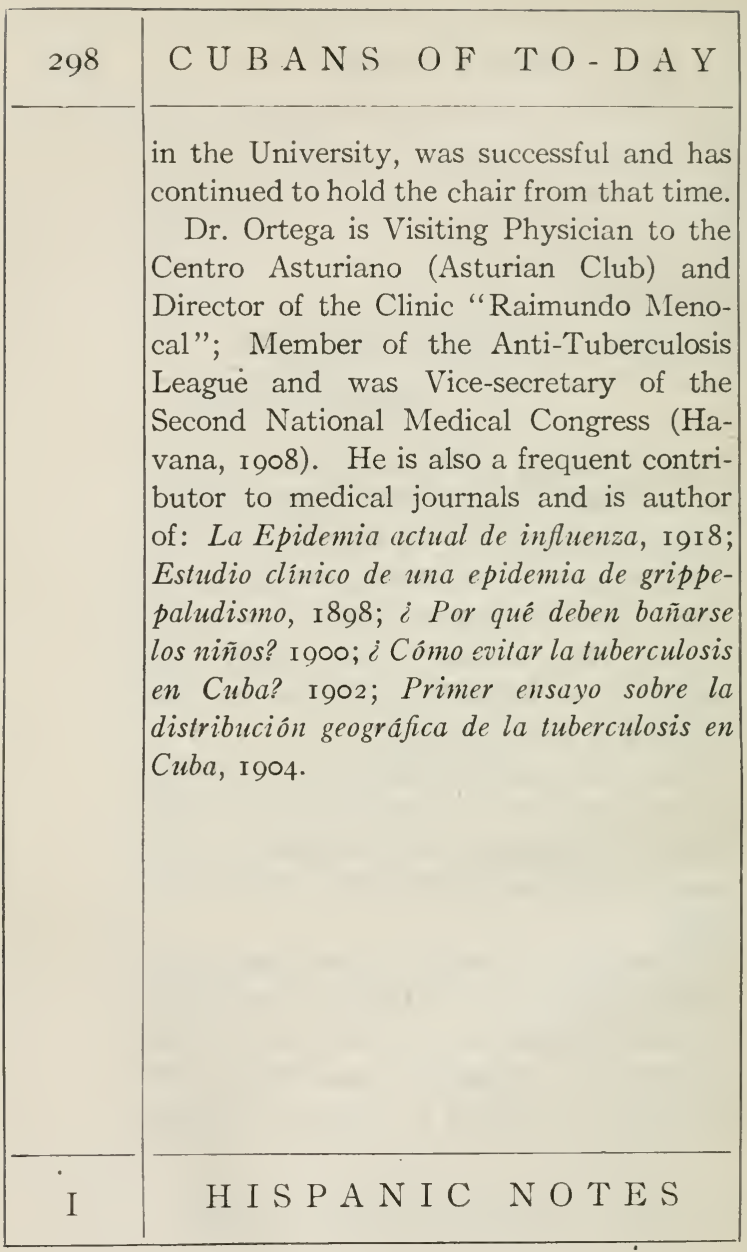



<smiles>CCCCCC1CCCCC1</smiles> 


\section{E L C U E T O}

\section{JOSÉ A. DEL CUETO}

Jurist; teacher; Chief Justice of Cuba.

José A. del Cueto was born in the year I 854 in the city of Havana, but pursued his legal studies abroad at the Central University of Madrid where he obtained the degrees of Licentiate in Administrative Law, as well as in Philosophy and Letters, and Doctor in Civil and Canon Law. He finished his course of study in 1875 and was given the title of Advocate as an extraordinary distinction. Afterwards he won, in competitive examination, the post of Professor of Mercantile Law, in the University of Havana which he retained for thirty years.

He was a Member of the Autonomist party which labored in vain to secure for Cuba her own government without severing the relation with Spain. In the last

\section{A N D M O N O R A P H S}




$300\left|\begin{array}{l}\text { C U B A N S O F T O - D A Y } \\ \hline \begin{array}{l}\text { years of the nineteenth century when the } \\ \text { Spanish Government-at too late a date- } \\ \text { consented to set up an Autonomous govern- } \\ \text { ment, he went as Deputy to the Spanish } \\ \text { Cortes and was also President of the In- } \\ \text { sular House of Representatives during the } \\ \text { brief experiment of the Autonomist Gov- } \\ \text { ernment. } \\ \text { Señor Cueto has served as Dean of the } \\ \text { Bar Association (Colegio de Abogados) of } \\ \text { Havana, and Dean of the Law School. } \\ \text { On the ninth of June, I I } 7 \text {, he was ap- } \\ \text { pointed President of the Supreme Court of } \\ \text { Cuba. Thereupon he resigned his position } \\ \text { as Professor in the University but was } \\ \text { made Honorary Professor, being the first } \\ \text { to be honored with this title. }\end{array} \\ \hline \text { H I S P A N I C N O T E S } \\ \hline \text { - }\end{array}\right|$




\section{A S A R I E. G O}

\section{ARTURO GARCÍA CASARIEGO}

\section{Physician; teacher.}

Arturo García Casariego was born in Cifuentes in the year I 885. He chose the medical career at an early age and pursued his education for the profession in Spain, Paris, London, and New York. He gained his degree with distinction of Doctor of Medicine at the University of Havana in r906 and served as Student-externe and Student-interne in the Mercedes Hospital; Assistant and afterwards Professor in the Faculty of Medicine of the University; Chief of the Laboratory and Professor of the Faculty of Hospital Surgeons; Physician of the "Covadonga" Infirmary as well as of the "Tamayo" Dispensary.

While he was still a student he was one of the founders of the magazine of the School of Medicine and has since served

\section{A N D M O N O G A P H S}




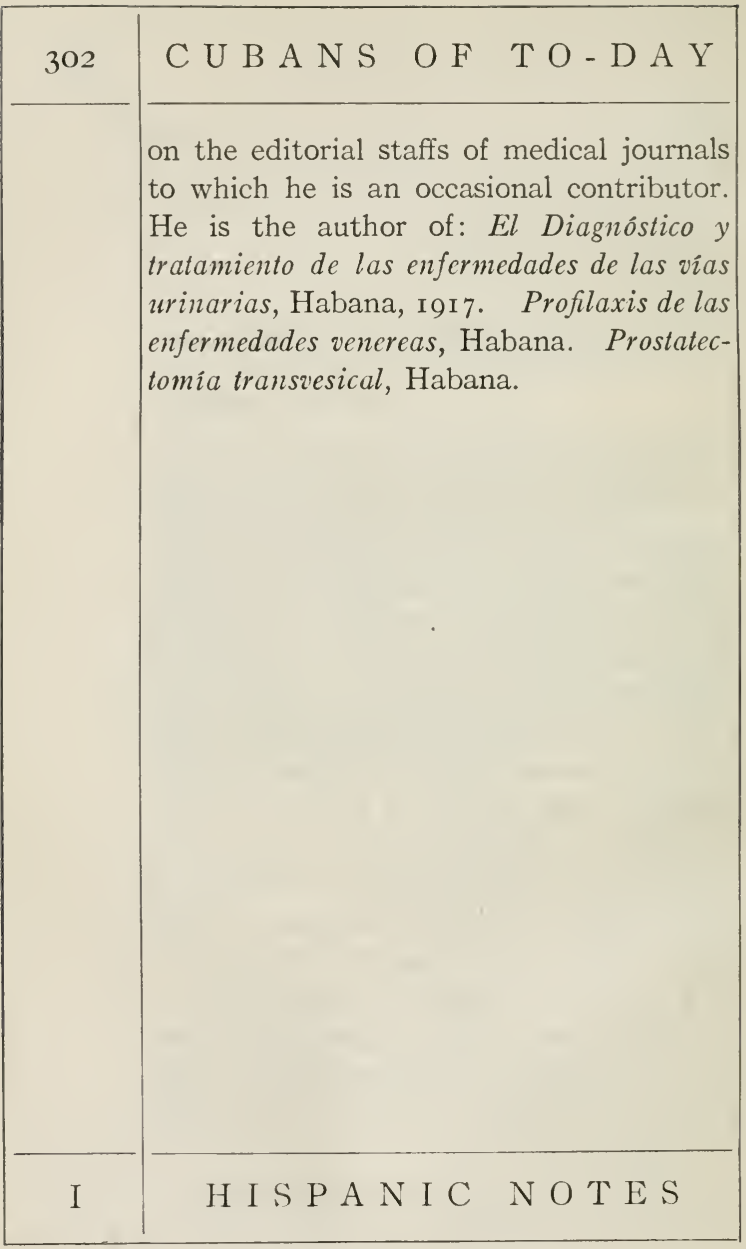




\section{H E N A R E S}

FRANCISCO HENARES Y BRIEGA

Engineer; teacher; illustrator.

Francisco Henares y Briega was born in the year 1872 in Seville, Spain, and was chiefly educated in Spanish schools and colleges, at Zaragoza, at Madrid, and also at Barcelona where he studied drawing and painting in the Academy of Fine Arts.

Later he entered the University of Havana and obtained the degrees of Doctor of Sciences and Doctor of Pharmacy, Agricultural Engineering and Sugar Production.

In 1900 he won, in competitive examination, the chair of Sugar-making, and its derived industries, Industrial Chemistry and Agricultural Chemistry.

Dr. Henares is a member of the National Academy of Arts and Letters, and its

\section{A N D MONOGRAPH S}




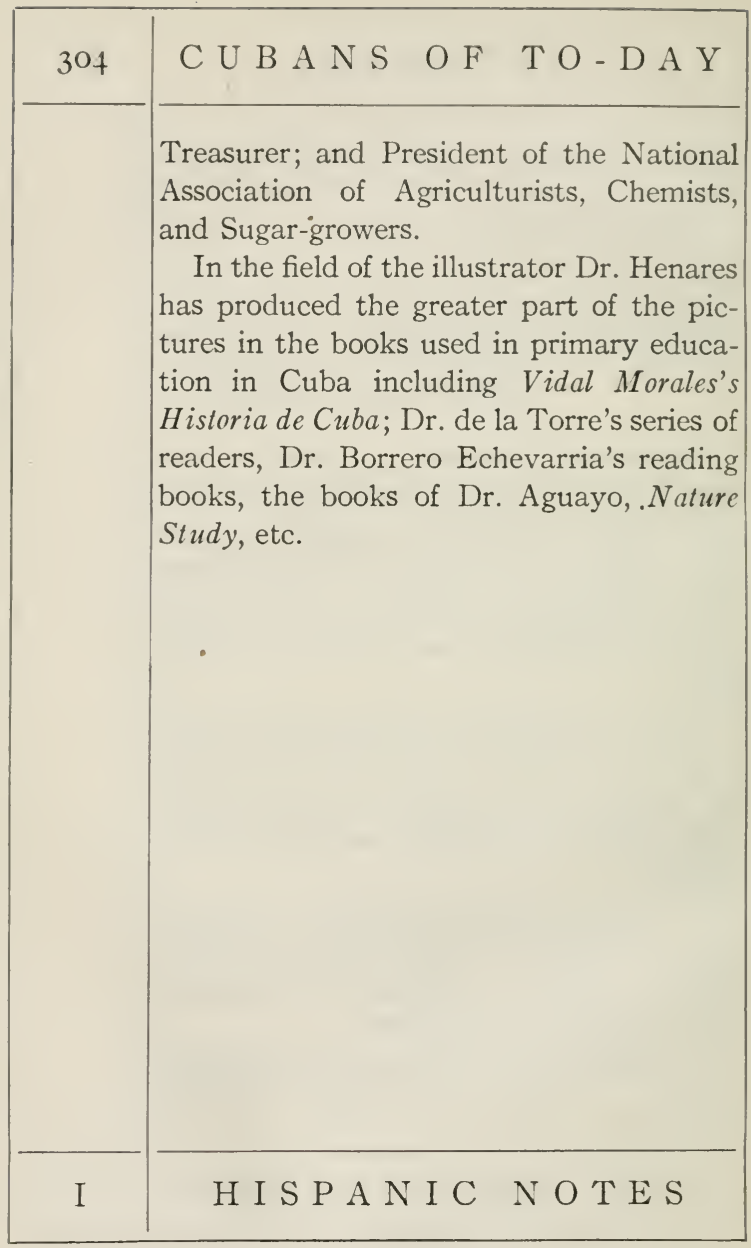





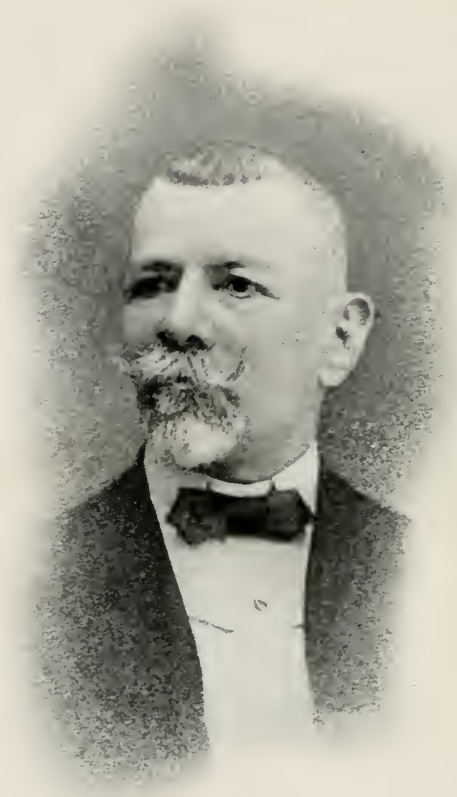

Gabriel Casuso 


\section{A S U S O}

\section{GABRIEL CASUSO}

Physician; educator; Rector of the University of Havana.

Gabriel Casuso was born in Matanzas in $185^{\circ}$. He was educated partly in $\mathrm{Ha}$ vana, partly in Madrid, and partly in Paris. He devoted himself to Medicine and graduated in Medicine in Madrid, in Surgery in Paris, and in Dental Surgery at the University of Havana where he received the Doctor's degree.

He took part in the Ten Years' War (1868-78), serving for five years with the Cuban forces.

By competitive examination he won the chair of Obstetrics and Gynecology in the Medical School and concerned himself solely with university education and his profession until the War of Independence broke out, when he was seized by the

\section{A N D M O N O R A P H S}




\begin{tabular}{|c|c|}
\hline 306 & $\mathrm{CUBANS}$ O F TO-DA Y \\
\hline & $\begin{array}{l}\text { Spanish authorities, imprisoned and de- } \\
\text { ported, being unable to return to Cuba } \\
\text { until peace was concluded. } \\
\text { On his return he resumed his university } \\
\text { relations and was elected three successive } \\
\text { times Dean of the Faculty of Medicine } \\
\text { and Pharmacy. } \\
\text { In I9 I he was elected Rector of the } \\
\text { University and in I9I } 8 \text { reëlected to this } \\
\text { post. } \\
\text { During the Presidency of Tomás Es- } \\
\text { trada Palma Dr. Casuso held the position } \\
\text { of Secretary of Agriculture. } \\
\text { He has been editor of the professional } \\
\text { journal Progreso Médico, to which and to } \\
\text { other medical periodicals he has contri- } \\
\text { buted a great number of articles particu- } \\
\text { larly upon prophylaxis. } \\
\text { In I } 88 \text { I he published an article entitled } \\
\text { Cirugia antiséptica, and from that time } \\
\text { on continued to labor for the populariza- } \\
\text { tion of prophylaxis and the use of anti- } \\
\text { septics. }\end{array}$ \\
\hline I & H I S P A I C N O T E S \\
\hline
\end{tabular}


ENRIQUE SALADRIGAS Y LUNAR

$$
\text { Physician; teacher. }
$$

Enrique Saladrigas y Lunar was born on the twenty-third of December, I864, in Havana where he was educated privately until he entered the University. Here he obtained the degrees of Licentiate in Medicine in 1888 and of Doctor in 1896.

Dr. Saladrigas has been a teacher and a scholar all his life. As early as I 892 he was Honorary Professor of Medicine. A few years later he became Free Professor of General Pathology and in due course, by the path of competitive examinations, he won the positions of First Auxiliary Professor and then of full Professor of Clinical Medicine.

Meantime he continued actively in the practice of his profession and served as Interne in the Mercedes Hospital, Visiting

A N D M O N G R A P S 


\begin{tabular}{|c|c|}
\hline 308 & C U B A N S O F TO-D A Y \\
\hline & $\begin{array}{l}\text { Physician (I896), and Surgeon in } 1905 \text { - } \\
\text { Later he was Physician to Hospital Num- } \\
\text { ber One and Inspector of Public Health. } \\
\text { Dr. Saladrigas is a member of various } \\
\text { scientific associations and is editor-in- } \\
\text { chief of the medical journal el Progreso } \\
\text { Médico. } \\
\text { He is a frequent contributor to the medi- } \\
\text { cal press and is author of: Consideraciones } \\
\text { generales sobre la disenteria observada en la } \\
\text { Isla de Cuba en la epidemia actual (Diciem- } \\
\text { bre de I } 807 \text { ), Habana, I } 898 ; \text { Pericarditis de } \\
\text { origen agudo, I } 898 ; \text { Los tuberculosos taqui- } \\
\text { cárdicos, I } 899 ; \text { Parálisis atrófica escapulo } \\
\text { humeral, I9oo; Lecciones clinicas sobre la } \\
\text { aorta; Consideraciones generales acerca de } \\
\text { la tuberculosis pulmonar y su tratamiento; } \\
\text { Sueroterapia; Estudios clinicos de la neu- } \\
\text { mococcia y estretococcia; Estudios clinicos } \\
\text { de todas las afecciones cardiacas; Estudios } \\
\text { clinicos sobre la nefritis; El papel de las } \\
\text { sanguijuelas en las inflamaciones; Amputa- } \\
\text { ciones, Apendiceptomia; Cancer del recto- } \\
\text { Operaciones; Uretrotomias; Nefrectomias, } \\
\text { etc. }\end{array}$ \\
\hline I & H I S P A I C NOTES \\
\hline
\end{tabular}





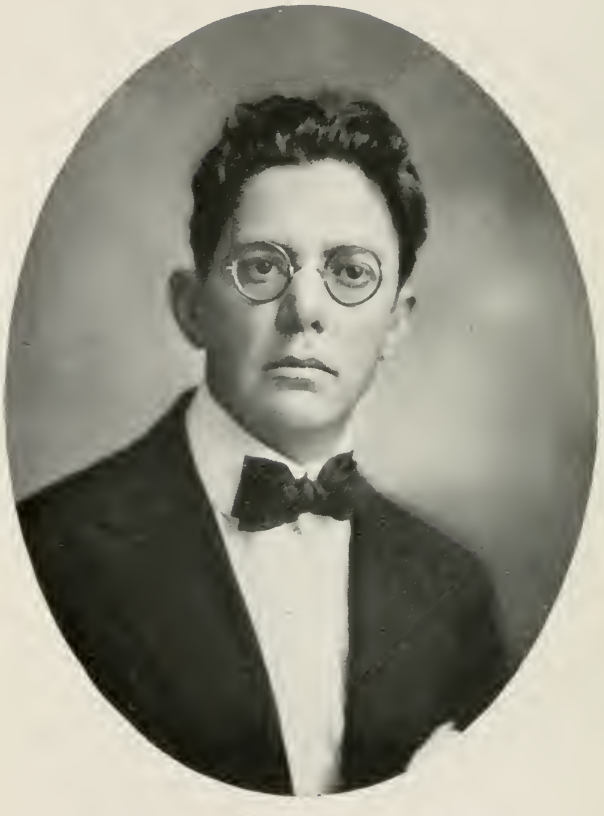

Garlos Oniguel de beopecles g ortu. 


\section{E S P E D E S}

CARLOS MIGUEL DE CÉSPEDES

Lawyer; financier; politician.

Carlos Miguel de Céspedes y Ortiz was born on the sixth of August, I88I, in Matanzas where he passed through the earlier stages of education, thence passing to Santa Clara where'he took the courses necessary for the Bachelor's degree in the Institute and finally entering the University of Havana where he graduated as Doctor of Civil and Public Law while he was still a minor.

On account of his youth he accepted a post as Clerk in the Department of Justice where he continued until I905 when he resigned to practice his profession in association with Dr. José Manuel Cortina.

In I 909 he was appointed Consulting Attorney to the Department of Public Works. In IgI I he took part in organizing

\section{A N D MONOGRAPHS}




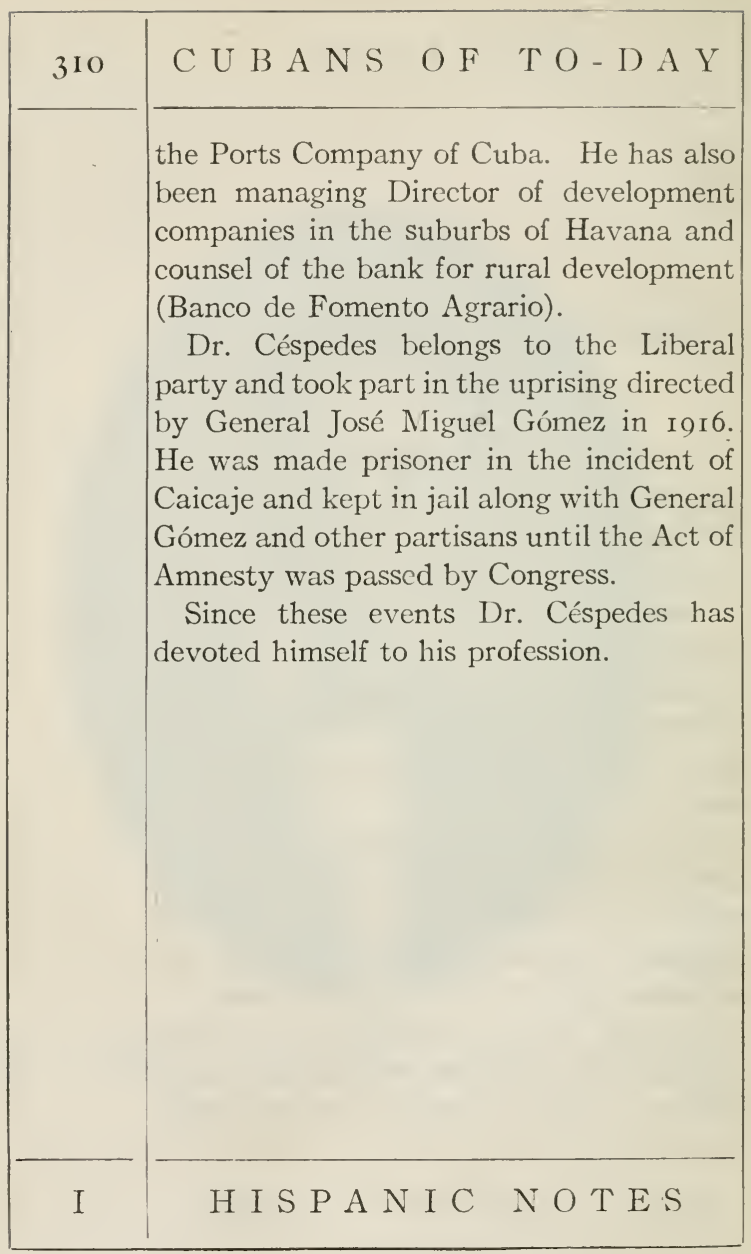


GUSTAVO SÁNCHEZ GALARRAGA

$$
\text { Poet. }
$$

Gustavo Sánchez Galarraga was born on the second of February, I893, in the city of Havana and there received his education, first at the Colegio Belén maintained by the Jesuit Fathers and later, to the completion of the course for the Bachelor's degree, by himself.

He has been President of the society "Fomento del Teatro Nacional" as also of the Section of Literature in the Ateneo of Havana. In I9I5 he was crowned by the National Academy of Arts and Letters for a poem and in I9 8 he received a similar honor for another poem inspired by the World War.

He is the author of: La Fuente matinal (Poems); Lámpara votiva (Poem); La barca sonora (Poems); El jardin de Mar-

\section{A N D M O N O G R P H S}




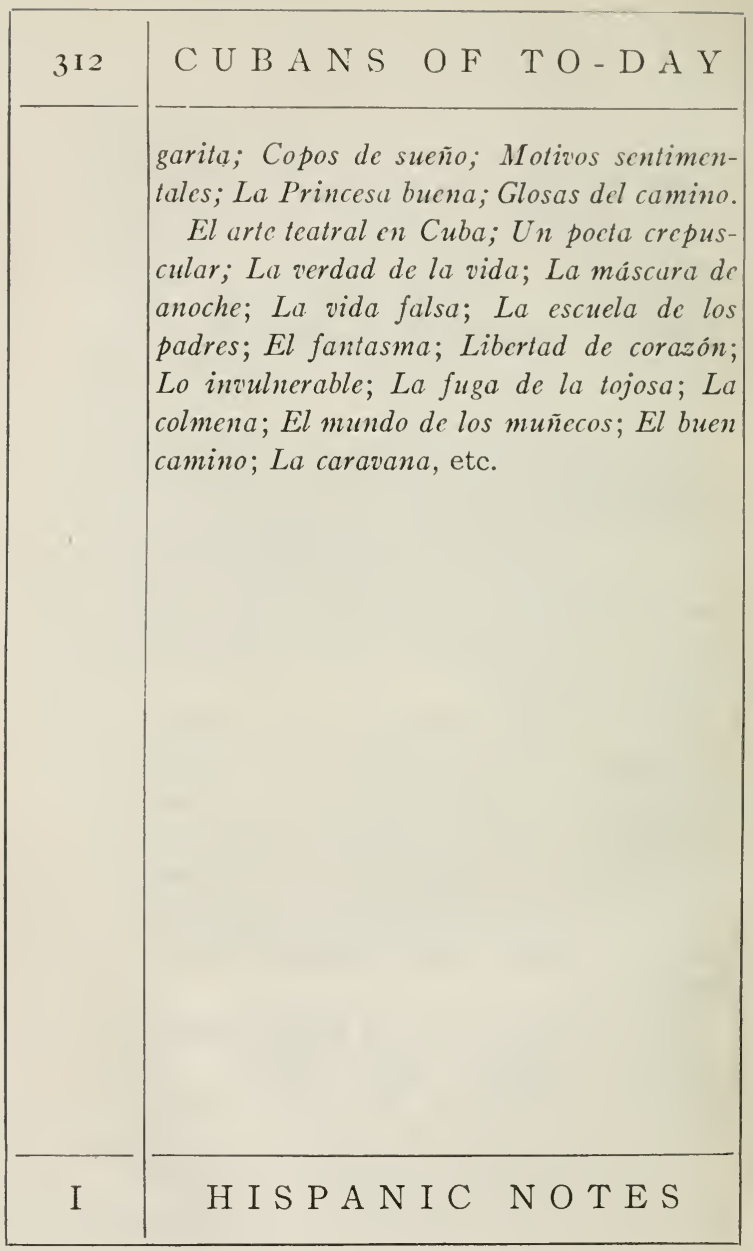





$$
8
$$




\begin{tabular}{l} 
S A N G U I L Y \\
\hline MANUEL SANGUILY \\
Soldier; author; adminis- \\
trator. \\
MANUEL SANG UIL Y Y GARRIT was born \\
on the twenty-sixth of March, I848, in Ha- \\
vana and had the good fortune to enter the \\
Colegio "El Salvador" while the famous \\
educator, Dr. José de la Luz Caballero was \\
at its head. Later he began the study of \\
the law at the University, but the Ten \\
Years' War (I868-78) supervening, he \\
left the academic life for the field. The \\
Peace of Zanjón (I878) found him in New \\
York where he had been sent in I877 by the \\
Revolutionary Government with the rank \\
of Colonel to act as Secretary to his brother, \\
Major General Julio Sanguily. \\
When peace was made he went to Spain \\
and in I879 completed his law studies in \\
the University of Madrid, returning in \\
I880 to enter the office of Dr. Antonio \\
A N D M O N O G R A P H S
\end{tabular} \mid




\begin{tabular}{|c|c|}
\hline 314 & C U B A N S O F T - D A Y \\
\hline & $\begin{array}{l}\text { González de Mendoza in Havana. There } \\
\text { he served as clerk, but was not able to } \\
\text { practice in his own name because he was } \\
\text { unwilling to take the oath. (of loyalty) } \\
\text { required in the Courts as a prerequisite. } \\
\text { Afterwards he got his living for a time by } \\
\text { giving lessons in private houses, but turned } \\
\text { his attention to literature acting as the sole } \\
\text { editor of Dr. Enrique J. Varona's magazine, } \\
\text { the Revista Cubana, and later of Hojas } \\
\text { Literarias which he founded in I } 893 \text {. } \\
\text { During the War of Independence, I895- } \\
98 \text {, Colonel Sanguily emigrated with his } \\
\text { family to the United States, returning at its } \\
\text { close to act as a member of the Assembly } \\
\text { of Santa Cruz which appointed him to the } \\
\text { Commission which went, with Major } \\
\text { General Calixto García at its head, to } \\
\text { Washington to obtain aid for the Cuban } \\
\text { forces so that they might have the means } \\
\text { of existence when they disbanded. In } \\
\text { I9or he began his career as a public man } \\
\text { when he was made a member of the Con- } \\
\text { stitutional Convention for the Province of } \\
\text { Havana. Later he held the offices of } \\
\text { Director of the Institute of Havana; Sena- }\end{array}$ \\
\hline I & H I S P N I C N O T E S \\
\hline
\end{tabular}




\section{S A N G U I L Y}

tor for the Province of Natanzas; President of the Senate; Delegate to the Second International Peace Conference at The Hague (1907); Secretary of State in the Cabinet of President Gómez; Inspector General of the Armed Forces of Cuba, and Director of the Military Academy.

Colonel Sanguily is the author of many articles, as also many orations and addresses-for he enjoys a distinguished reputation as an orator-and among his publications are some which gained a wide reading: Los Caribes de la Isla, Havana, I884; Un insurrecto Cubano en la Corte, Havana, I888; Céspedes y Martí, New York, 1905; Cuba y la Furia Española, New York; Victoria de las Tunas, New York, I897; José de la Luz Caballero. 

D E C A S T R O

RAFAEL FERNÁNDEZ DE CASTRO

Sugar planter; man of affairs.

Rafael Fernández de Castro was born in Regla, a suburb of Havana, in I856, and after passing through the higher grades of school at the Colegio Belén, he there took his B.A. degree in $\mathrm{I} 873$. He then went to Seville and Madrid, graduating in those famous universities as Doctor of Philosophy and Letters.

Returning to $\mathrm{Cuba}$ in $\mathrm{I} 878$ he practiced his profession as a lawyer and in 1880 was appointed Auxiliary Professor in the University of Havana. In $\mathbf{1} 882$, after a competitive examination, he was appointed to the Chair of Universal History.

His first experience in politics was in I 88I as Provincial Deputy for the District of Járuco in the Province of Havana. In r 886 he was elected Deputy to the Spanish

\section{H I S P A I C NOTES}




\begin{tabular}{|c|c|}
\hline 318 & $\mathrm{CUBANS} O \mathrm{OF} \mathrm{TO}-\mathrm{DAY}$ \\
\hline & $\begin{array}{l}\text { Cortes for the Province of Santa Clara, a } \\
\text { post which he held until I } 890 \text { and was re- } \\
\text { elected in I } 893 \text { for the Province of Havana. } \\
\text { Between these two periods, namely in } \\
\text { I } 89 \text { I, he was the representative in Madrid } \\
\text { of the Planters' Association of the Island } \\
\text { of Cuba upon the Commission that was } \\
\text { appointed by the Spanish Government for } \\
\text { the purpose of securing economic data } \\
\text { concerning its colonies. } \\
\text { During the War of Independence, de } \\
\text { Castro withdrew entirely frcm political } \\
\text { affairs, but when the Spanish Government, } \\
\text { in I } 898 \text {, decreed autonomy for Cuba, he } \\
\text { returned to public life and helped in the } \\
\text { organization of the new system, being } \\
\text { elected a representative in the Cuban } \\
\text { House. } \\
\text { At the beginning of the war between } \\
\text { Spain and the United States, he was named } \\
\text { Civil Governor of the Province of Havana, } \\
\text { a difficult task. While the Island was being } \\
\text { blockaded by the American Navy he made } \\
\text { tremendous and successful efforts to avoid } \\
\text { rioting in the Capital and to assist those } \\
\text { who were suffering from hunger. He or- }\end{array}$ \\
\hline I & H I P A N I NOTES \\
\hline
\end{tabular}




\section{E C A S T R O}

ganized the free kitchens at which over seventy-five thousand people were fed each day. His work at that difficult period earned him the praise of Miss Clara Barton, the Spanish Government decorated him with the Gran Cruz de Beneficencia for his services and the Municipal Council of Havana presented him with a medal commemorative of the Blockade. That body also desired to erect a statue in his honor in the San Juan de Diós or the Paula Park, both of which he had caused to be rebuilt. Dr. de Castro accepted the medal, but refused to allow any statue to be erected to him, or to permit either of the parks to be named after him. He based his objections on the fact that such honors should be posthumous.

In 1899 he delivered the City of Havana to General William Ludlow, coincident with the delivery of the Island to General Brooke by General Castellanos in compliance with the provisions of the Treaty of Paris, Dr. de Castro then retired to private life. Since that time he has devoted himself to the development of the

A N D M O NOGR A P H S 


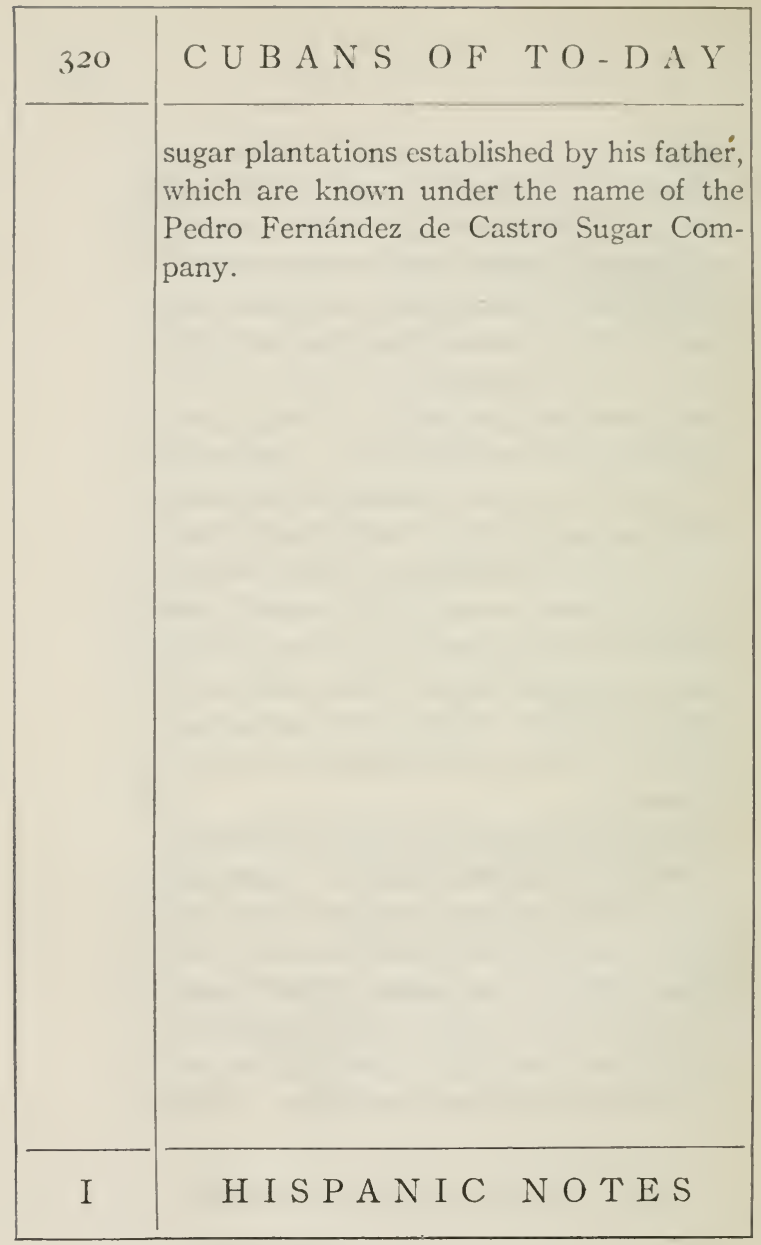





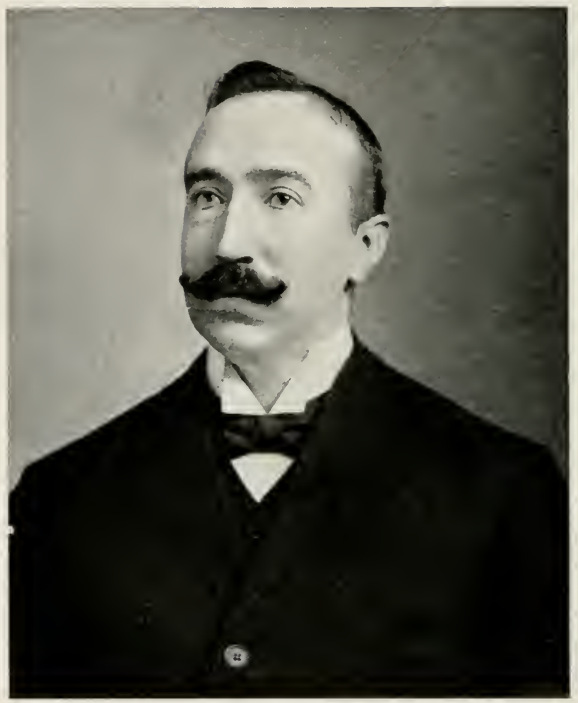

Victorino Trelles 


\section{VICTORINO TRELLES}

\section{Physician; teacher.}

Victorino Trelles Esturba was born in Buenos Aires, Argentina, on the eighth of November, I870, but at an early age came to Cuba and was educated in $\mathrm{Ha}$ vana. In 1885 , he entered the Institute; in 1888 he gained the standing of Perito Mercantil, in the following year that of Professor Mercantil, and in I89 graduated as Bachelor. In the same year he entered the University where in 1897 he obtained the degree of Licentiate in Physico-Mathematical Sciences and in the following year that of Licentiate in Medicine and Surgery. In 1899 he was made Doctor in PhysicoMathematical Sciences, and in 1900 was appointed Auxiliary Professor of Science. In the same year in competitive examination he won the rank of Auxiliary Professor,

\section{A N D M ONOG R A H S}




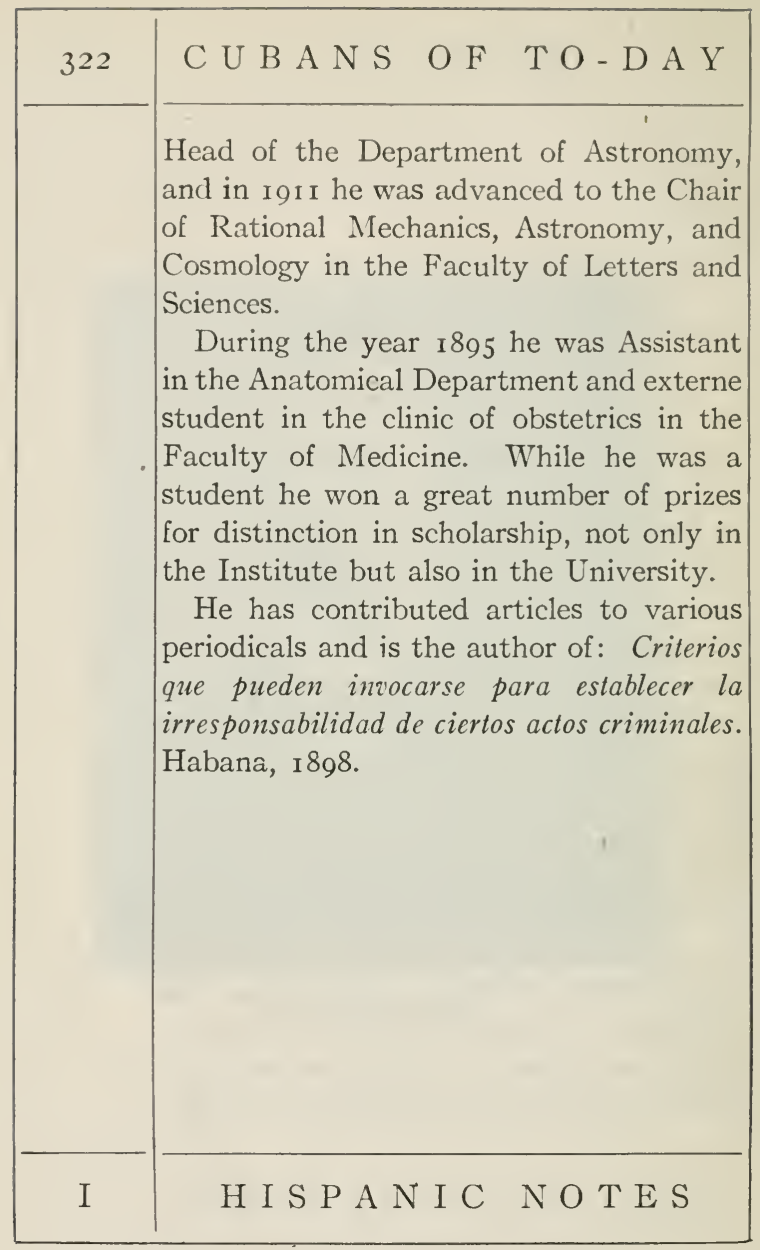




\begin{tabular}{|c|c|}
\hline F E R N Á N D E Z & 323 \\
\hline $\begin{array}{l}\text { WIFREDO FERNÁNDEZ } \\
\text { Journalist; public man. } \\
\text { WIFREDO FERNÁNDEZ Y VEGA was born } \\
\text { in Consolación del Sur, Pinar del Rio, on } \\
\text { the eleventh of October, I88 r, and gained } \\
\text { his early education in his native town at } \\
\text { the Colegio "La Unión" where he com- } \\
\text { pleted the courses for the Bachelor's degree. } \\
\text { At the close of the War of Independence } \\
\text { in r } 898 \text { he went to Spain, but in I } 900 \text { he } \\
\text { returned to Cuba, settled in Havana and } \\
\text { entered upon the career of a journalist. } \\
\text { While he was still a student he had served } \\
\text { on the staff of more than one newspaper } \\
\text { and now at the age of eighteen he became } \\
\text { one of the editors of El Comercio where he } \\
\text { devoted himself so vigorously to his duties } \\
\text { that three years later, on attaining his } \\
\text { majority, he was made Editor-in-Chief } \\
\text { which position he has maintained. Mean- }\end{array}$ & \\
\hline A N D MONOGRA P H S & I \\
\hline
\end{tabular}




\begin{tabular}{|c|c|}
\hline 324 & C U B A N O F T O - D A Y \\
\hline & $\begin{array}{l}\text { time he has continued to contribute to the } \\
\text { various literary magazines of Cuba. } \\
\text { In I9Io he was elected Representative } \\
\text { for his native province and has served on } \\
\text { the important Committees of Estimates } \\
\text { and Public Works. He is a member of the } \\
\text { Conservative party and a member of the } \\
\text { Executive Committee of the organization. } \\
\text { He has introduced several bills of impor- } \\
\text { tance, among which was that for the crea- } \\
\text { tion of a Statistical Committee of Social } \\
\text { and Economic Reforms. He is a fighting } \\
\text { journalist and President of the Press } \\
\text { Association. } \\
\text { Sr. Fernández is the author of: El pueblo } \\
\text { cubano es virtucso; La responsabilidad de sus } \\
\text { clases directoras. Habana, I9o9; Los pre- } \\
\text { supuestos de I9I. a I9Ia. Habana, I9II; } \\
\text { Cuba. Cielo, dicha y esperanza de todos. } \\
\text { Habana, I9II; ¿Cuba es la Patria del "Poco } \\
\text { más o menos"' Ni protectorado, ni Reprib- } \\
\text { lica. Habana, I9I3; Articulos y discursos. } \\
\text { Habana, I9I4; Defensadel CongresoCubano. } \\
\text { Habana, I9I } 5 \text {; Problemas cubanos. Ha- } \\
\text { bana, I9I6. }\end{array}$ \\
\hline & - \\
\hline I & H I S P A I C NOTES \\
\hline
\end{tabular}





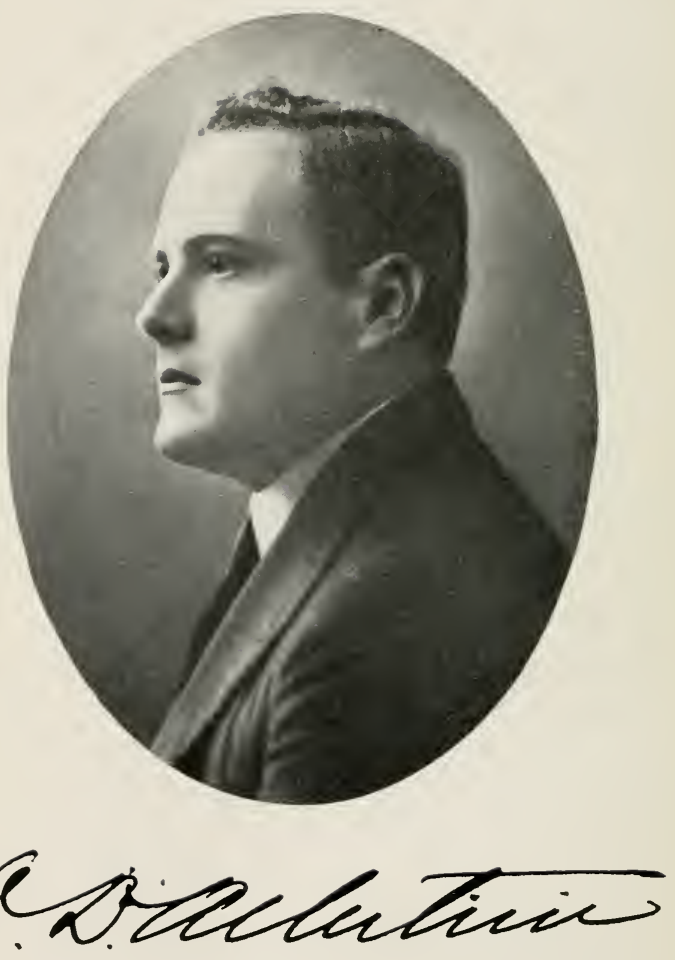




\section{A L B E R T I N I}

OSCAR DÍAZ ALBERTINI

\section{Lawyer; official.}

Oscar díaz Albertini y de Cárdenas was born on the twelfth of February, 1887 , in the city of Havana where, except for a short stay in the United States, he has lived and where he gained his education. He obtained the degree of Doctor in Civil Law at the University of Havana on the second of June, I9II, having previously won that of Bachelor of Letters and Sciences.

On leaving the University, Dr. Albertini entered the law office of the distinguished lawyers and statesmen, Dortors Lanuza and Desvernine, where he continued to practice until the duties of public office engrossed his time.

On the third of June, Ior3, he was appointed Chief Clerk of Provincial and

A N D MONOGR A P H S 


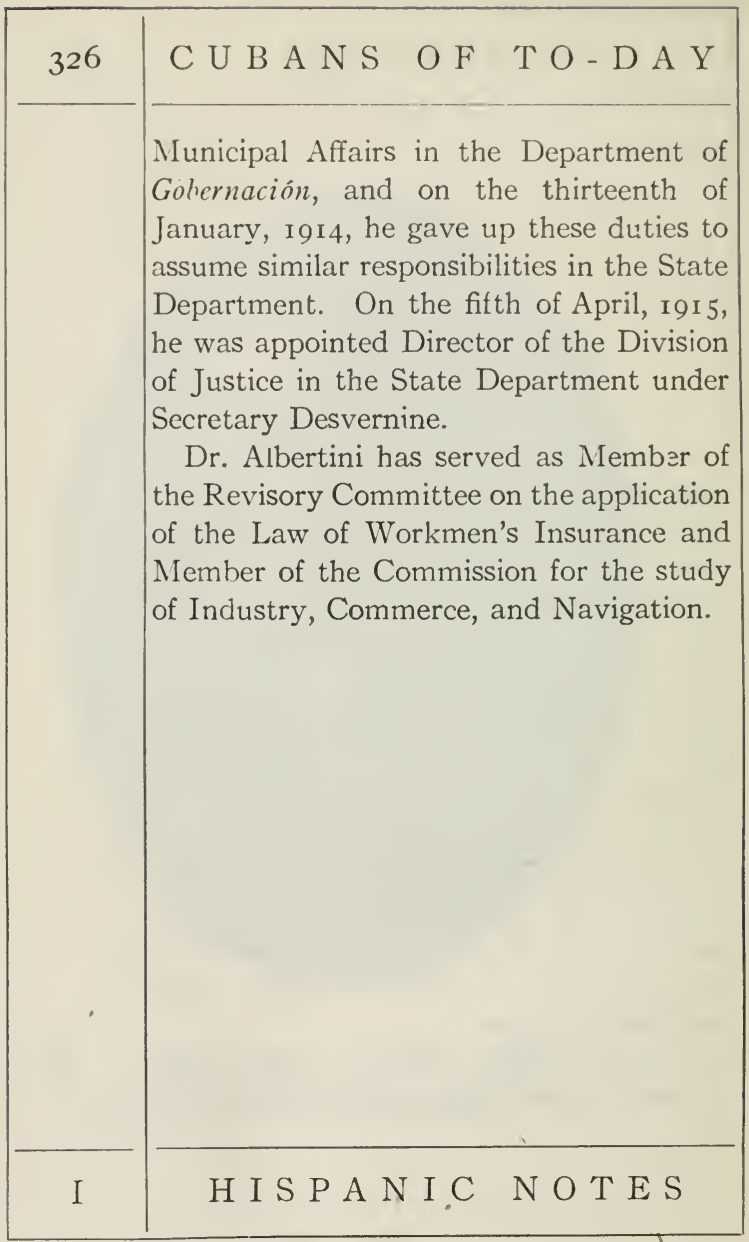




\title{
D E C A R R I Ó N
}

MIGUEL DE CARRIÓN Y CÁRDENAS

\author{
Physician; surgeon; teach- \\ er; writer.
}

Miguel de Carrión y Cárdenas was born on the ninth of April, I875, in Havana, and there gained his early education; but when he was twenty, in I 895 , he left Cuba for the United States where he remained for some years.

On his return to $\mathrm{Cuba}$ he gave himself for some years to a literary career and it was not until 1907 that he resumed his formal studies and gained the degree of Doctor in Medicine in the University of Havana. Meantime he continued to serve as a journalist and in ror 2 was a member of the staff of $E l D i a$, and editor-in-chief of $\mathrm{El} \mathrm{Sol}$. Later he joined the staff of $\mathrm{La}$ Lucha on which he has continued as editorial writer.

\section{A N D M O N O G R A P H S}




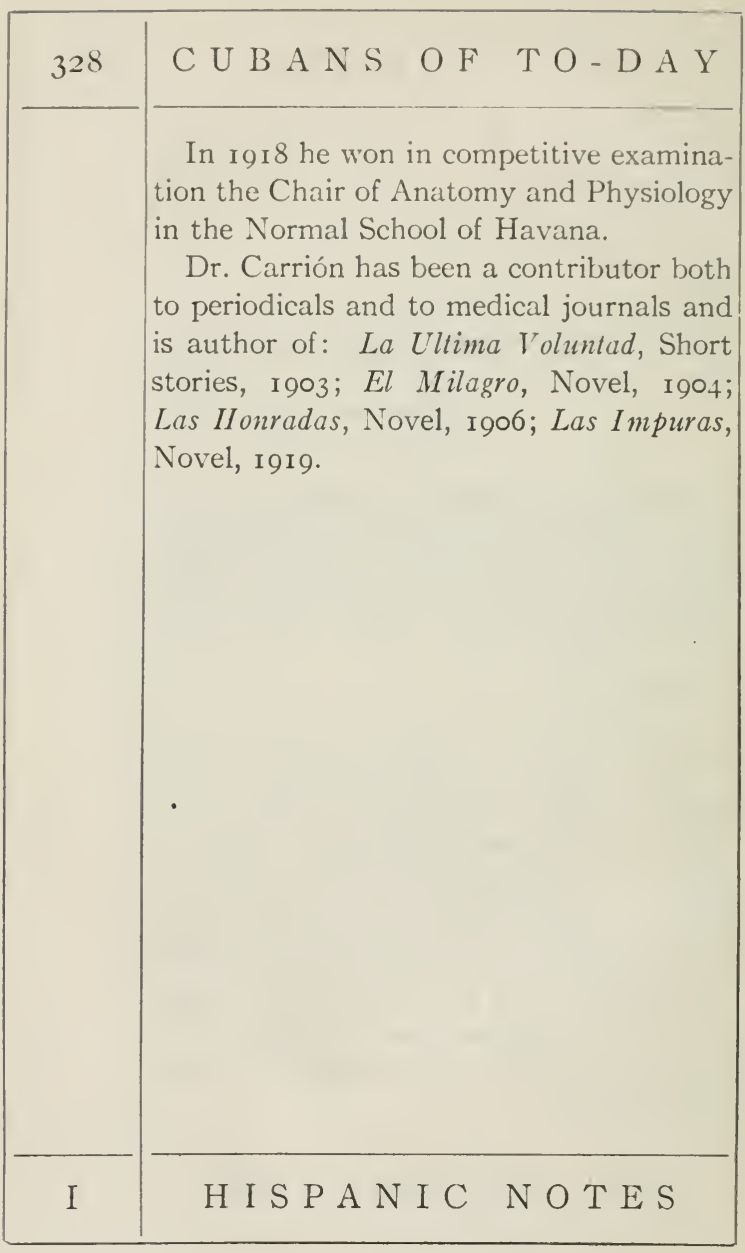




\section{S E G U Í}

\section{DOMINGO HERNANDO SEGUÍ}

Physician.

Domingo Hernando Seguí was born on the sixth of January, 1862 , in the city of Havana and there he received his education in the Colegio of Belén maintained by the Jesuit Fathers and in the University of Havana. He holds the three degrees of Doctor in Medicine, Doctor in Pharmacy, and Doctor in Natural Sciences and is Professor of Medicine and Pharmacy in the University.

Dr. Segui is a member of the Academy of Sciences of Havana.

In I9ro he founded the Revista de Enfermedades de garganta, nariz y oidos which he maintained and published for three years, contributing many articles to its pages. $\mathrm{He}$ has also written much in other medical

\section{A N D M O N O G R A P H S}




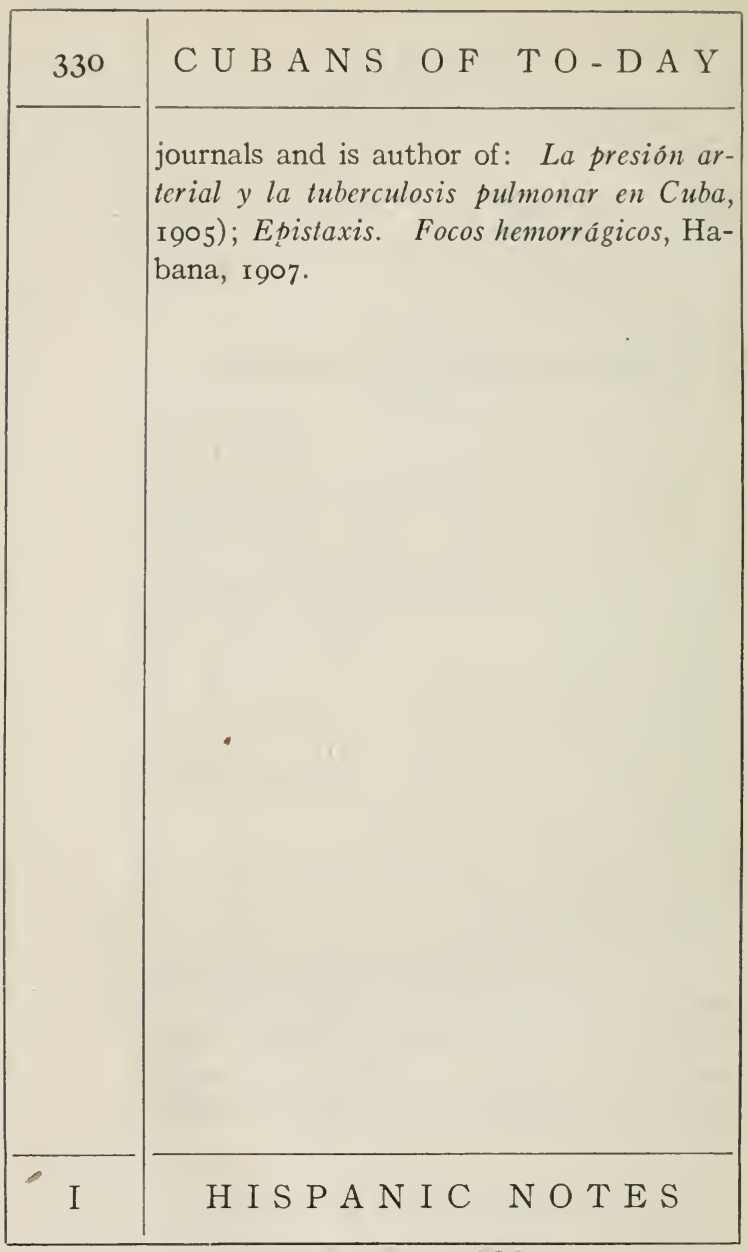




\begin{tabular}{|c|c|}
\hline A V E R H F F & $33 \mathrm{I}$ \\
\hline $\begin{array}{l}\text { OCTAVIO AVERHOFF Y PLA } \\
\text { Lawyer; teacher. } \\
\text { OCTAVIo AVERHOFF Y PLA was born on } \\
\text { the fifth of March, I876, in Havana, where } \\
\text { he was educated and has passed his life. } \\
\text { His early education was obtained in El } \\
\text { Progreso the private school of primary and } \\
\text { secondary education maintained by the } \\
\text { distinguished scholar and naturalist, Dr. } \\
\text { Carlos de la Torre. Later Averhoff at- } \\
\text { tended the University of Havana and there } \\
\text { he obtained the degree of Doctor of Laws } \\
\text { in the year I } 896 \text {, before he was yet twenty } \\
\text { years old. In the following year he was } \\
\text { appointed Professor in the University and } \\
\text { in I } 902 \text { he won in competitive examination } \\
\text { the chair of Roman Law. } \\
\text { Meanwhile he has continued to practice } \\
\text { his profession on which he entered in r } 899, \\
\text { as soon as he had reached the age prescribed } \\
\text { by law. }\end{array}$ & \\
\hline A N D M O N O R A P H S & I \\
\hline
\end{tabular}






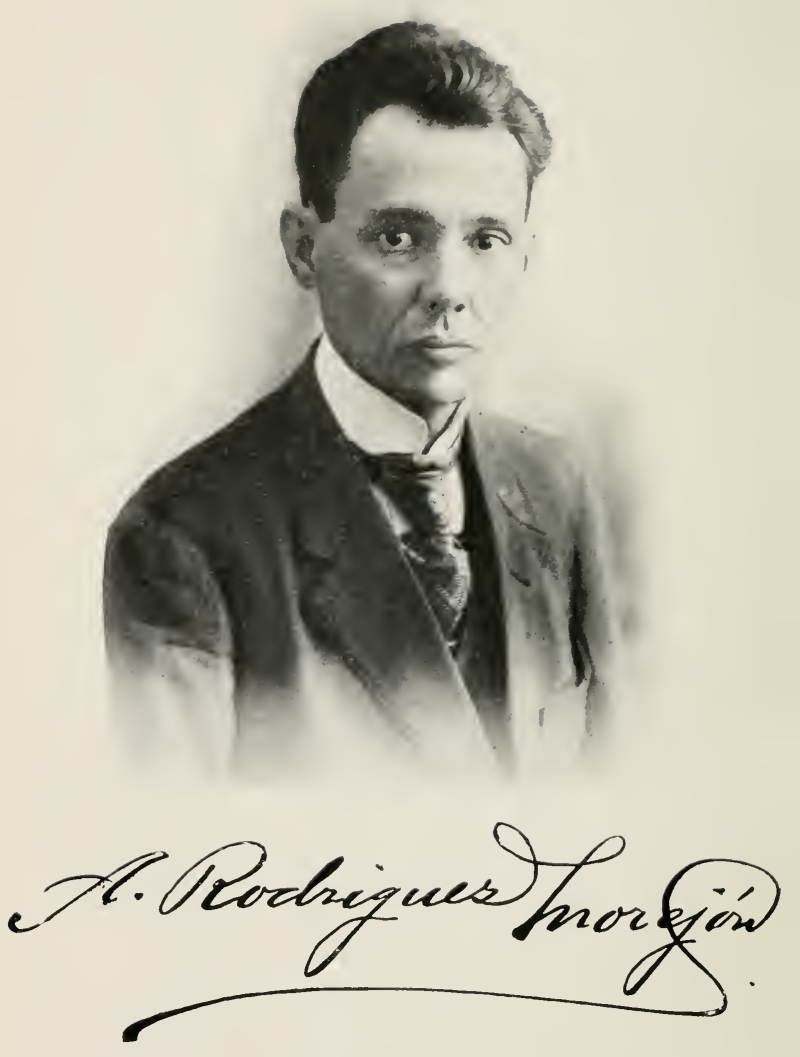




\section{O R E J Ó N}

\section{ALFREDO RODRÍGUEZ MOREJÓN}

\section{Teacher; mathematician;}

writer.

Alfredo Rodríguez Morejón was born on the twenty-eighth of November, 1874 , in the city of Havana where he grew up, was educated and has lived all his life. $\mathrm{He}$ attended the private school "San Francisco de Paula" of which Dr. Claudio Mimó was the head and thence went to the University. He holds the following degrees: Bachelor of Sciences and Arts (I8S9); Licentiate in Physico-Mathematical Sciences (I895); Doctor in PhysicoMathematical Sciences (I9ro); Architect (IOII).

In 1900 he became a teacher in the public schools and in the same year he was appointed Professor of Mathematics in the School of Arts and Crafts of Havana where he continued until I9r5. In that year he

\section{H I S P A N I C N O T E S}




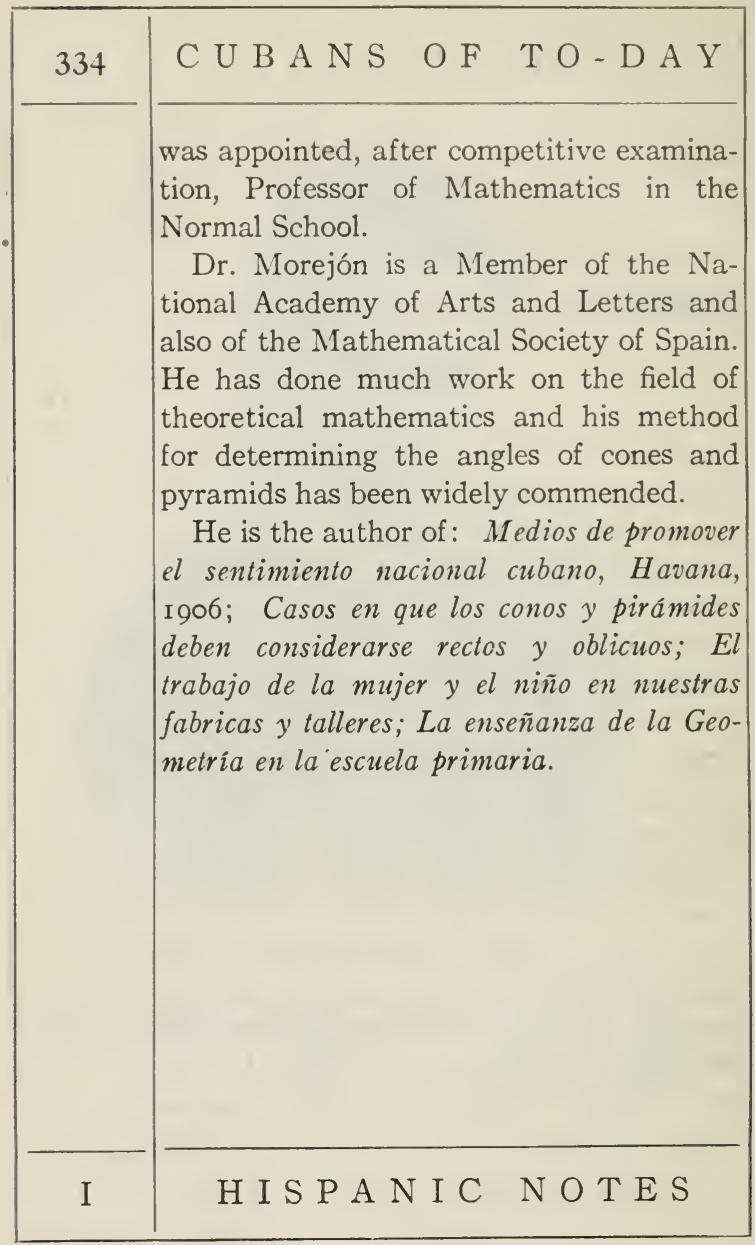




\section{RAMIRO GUERRA Y SÁNCHEZ}

Teacher; writer.

Ramiro Guerra y Sánchez was born on the thirty-first of January, I880, in the town of Batabanó, Province of Havana, Cuba. His early education was gained in his native place whence he went to Havana to continue his studies in the Institute which, however, were interrupted by the War of Independence (I895-8).

In 1900 he began to teach and in the summer of that year accompanied the group of Cuban teachers who went to Harvard University (U. S. A.) for a special course. Later he resumed the regular academic studies at the University of Havana and obtained the degree of Doctor in Pedagogy in I9IO.

From I 900 to I 906 Señor Guerra taught and directed a school which still bears his

\section{A N D M O N O R A P H S}




\begin{tabular}{|c|c|}
\hline 336 & C U B A N O F T O - D A Y \\
\hline & $\begin{array}{l}\text { name in Batabanó. In I } 906 \text { he entered the } \\
\text { ranks of teachers in Havana and was pro- } \\
\text { moted to the position of Principal of the } \\
\text { Practice School attached to the School of } \\
\text { Pedagogy of the University of Havana. } \\
\text { Later for three years he was Professor of } \\
\text { Methods in the Summer Normal School } \\
\text { of Havana. In I9I } 3 \text { he was appointed } \\
\text { Provincial Superintendent of Schools for } \\
\text { the Province of Pinar del Rio. In I } 9 \text { I he } \\
\text { won in competitive examination the Pro- } \\
\text { fessorship of Pedagogical Studies in the } \\
\text { Normal School of Havana which had just } \\
\text { been founded, and the Board of Protessors } \\
\text { elected him Director of the School- thus } \\
\text { placing him at the head of the first institu- } \\
\text { tion of its kind established in Cuba after } \\
\text { the fall of the Spanish rule. } \\
\text { Since I } 904 \text { Dr. Guerra has given much } \\
\text { time and labor to the magazine of educa- } \\
\text { tion Cuba Pedagógica published in Havana, } \\
\text { and has contributed to its pages many } \\
\text { articles on Methods, Psychology, School } \\
\text { Management, History of Education, etc. } \\
\text { He is the author of the courses of study in } \\
\text { Drawing, Nature Study, and Agriculture }\end{array}$ \\
\hline I & H I S P A I C N O T E S \\
\hline
\end{tabular}




\section{G U E R R A}

in the elementary schools and had charge of revising the plan of education for the primary schools of Cuba.

$\mathrm{He}$ is a member of various societies and of the "Comisión de construcciones escolares de Cuba."

Besides his numerous contributions to periodicals, Dr. Guerra has written various books some of which have been adopted as text-books: La Lección en la Escuela Primaria, La Patria en la Escuela, El Padre Varela educador, José Antonio Saco y la educación nacional, Fines de la educación nacional, Del conocimiento de si mismo, El Cardenal Cisnéros y el principio de autoridad en una nación, etc. 



\section{H A C Ó N}

JOSÉ MARÍA CHACÓN Y CALVO

Scholar; author; diplomat.

José María Chacón y Calvo was born in Santa Maria del Rosario, Province of Havana, on the twenty-seventh of October, I893, and was educated in Havana where he took his early studies in the school of the Jesuits-Belén,-continued in the Institute, where he completed the courses for the Bachelor's degree and entered the University where he obtained the two degrees of Doctor in Civil Law, in I9I3, and Doctor of Philosophy and Letters in I9I 5 .

His youthful inclination was toward letters and he began early to contribute to the magazines in Havana-the Figaro, Cuba Contemporanea, and the Magazine of the Faculty of Letters and Sciences. In Igr6 he organized, on the occasion of the

H I S P A N I C N T E S 


\begin{tabular}{|c|c|}
\hline 340 & C U B A N O F T O - D A Y \\
\hline & $\begin{array}{l}\text { tercentenary celebration, a series of ad- } \\
\text { dresses on Cervantes. He was also one of } \\
\text { the founders of the Sociedad Filomatica } \\
\text { Cubana, and he was President of the } \\
\text { Section of Literature of the Ateneo of } \\
\text { Havana and Director of the Socicdad de } \\
\text { Conferencias. } \\
\text { In May, I9I 8, he was appointed Second } \\
\text { Secretary of the Cuban Legation at Mad- } \\
\text { rid where he has continued his literary } \\
\text { work, contributing to the Magazine of } \\
\text { Spanish Philology (Madrid), and sharing in } \\
\text { the work of the Club for Historical Studies. } \\
\text { He is a member of the group of lecturers } \\
\text { who deal with literary topics in the Ateneo } \\
\text { of Madrid, having for his subject the } \\
\text { Figuras del Romanceros. His works are } \\
\text { included in Professor Fitzmaurice Kelly's } \\
\text { Bibliography of Spanish Literature and } \\
\text { have been found worthy of treatment in } \\
\text { the Magazine of Spanish Philology. } \\
\text { Among his works are: Origenes de la } \\
\text { Poesia en Cuba; Romances tradicionales en } \\
\text { Cuba (contribution to Cuban folk-lore); } \\
\text { Gertrudis Gómez de Avellaneda; Jose Maria } \\
\text { Herédia; Vida Universitaria de Herédia; }\end{array}$ \\
\hline I & H I S P N I C NOTES \\
\hline
\end{tabular}




\section{H A C Ó N}

Cervantes y el Romancero; Los Cancioneros gallego-portugueses y Bernaldino Ribeiro.

In preparation: La Poesia cubana en el siglo XIX. Antologia crítica; Ensayos sentimentales; Hermanito menor; Tabla de variantes de las poesias líricas de la Avellaneda.

\section{A N D M O N O G R P H S}





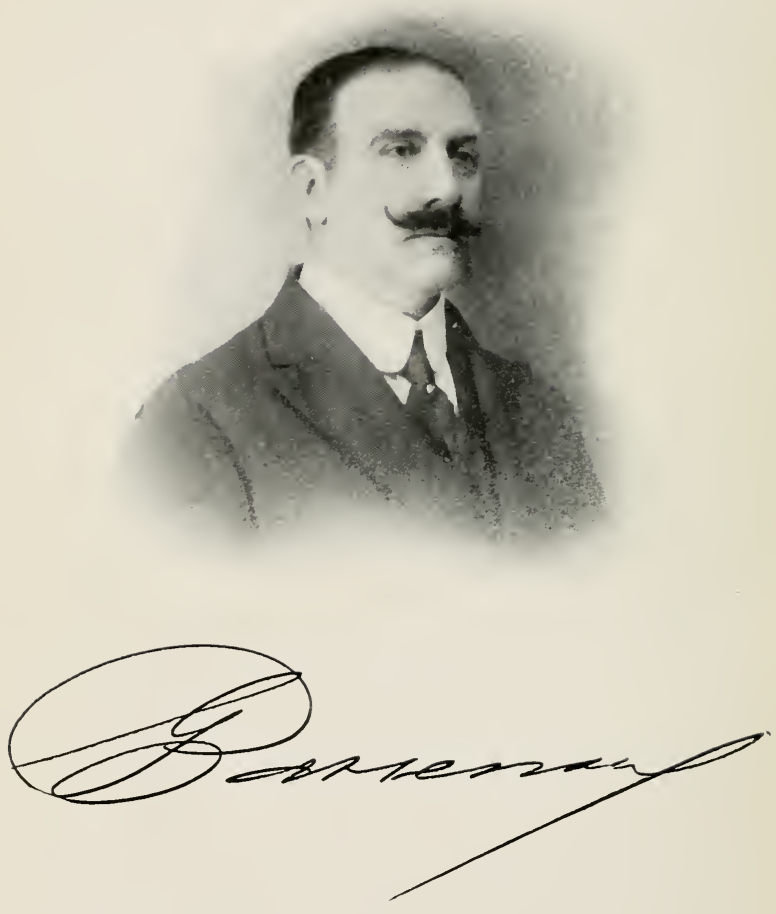


\section{P A T T E R S O N}

\section{GUILLERMO PATTERSON Y JÁUREGUI}

Government official.

Guillermo Patterson y Jáuregui was born in 1870 , in Havana, and there he obtained his education, first in the Church schools, later in the Institute where he gained the degree of Bachelor of Letters and Sciences and, finally, in the University where he was made Licentiate in Civil and Canon Law.

He has spent much of his life in the public service and has fulfilled a number of missions for the Cuban Government in foreign countries. Among the offices which he has held are those of Consul General at Liverpool, Commercial Representative at Madrid, Chief of the Department of Information and Chancery, Director of Registry and, finally, Sub-secretary of the Department of State, which office he now holds.

\section{H I S P A N I C N T E S}



JOSÉ B. CORNIDE

\section{Doctor; legislator.}

José B. Cornide was born in Santa Clara on the thirteenth of December, 1859. After passing the early stages of education in his native town, he went to the Colegio of Esculapius in Guanabacoa where he completed the studies requisite for the Bachelor's degree in 1878 . Then he entered the University at Havana to fit himself for a career in the practice of Medicine. He obtained the degree of Licentiate in 1883 and fulfilled the intellectual requirements leading to the Doctor's degree, but the expenses attending the ceremony of granting the degree (Investidura) prevented him from obtaining it.

Returning then to Santa Clara, Cornide began the practice of his profession, meantime devoting himself to the various prob-

H I S P A I C N O T E S 


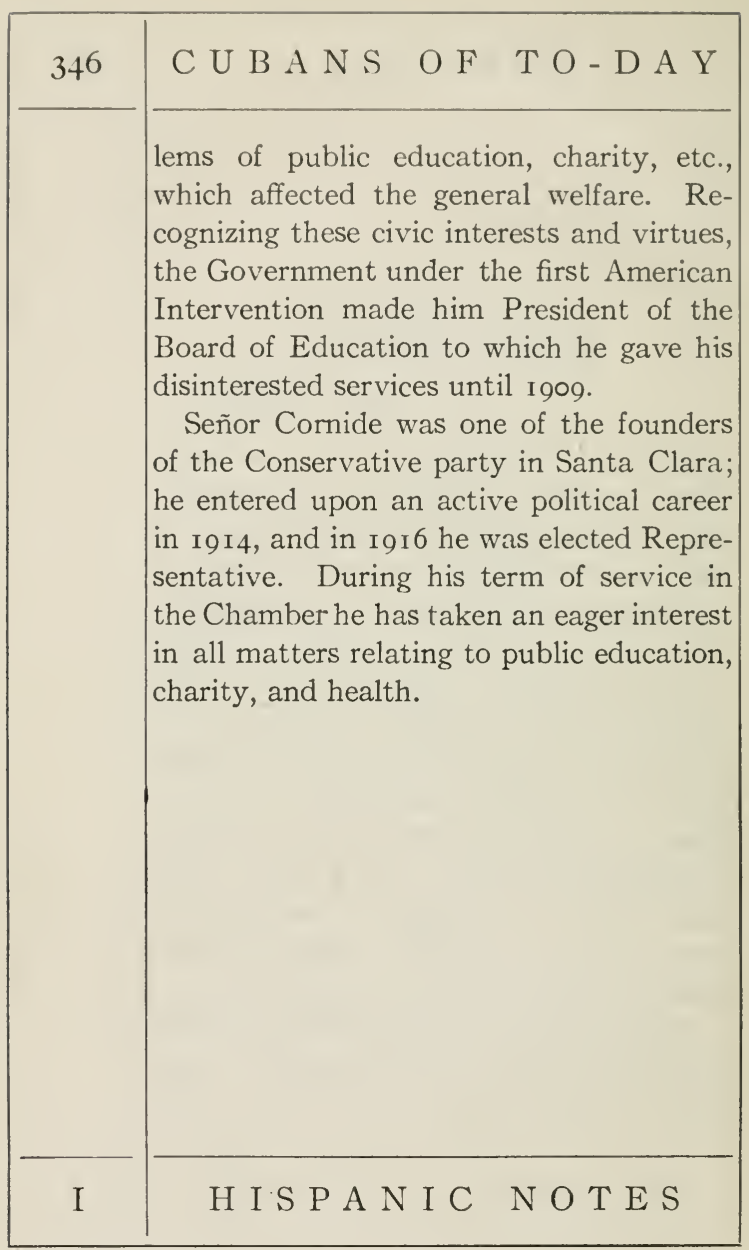




\section{ALCIDES BETANCOURT}

Journalist; man of affairs; senator.

Alcides Betancourt was born in the city of Camaguey on the twenty-first of December, I865, and was educated in $\mathrm{Ha}-$ vana, but went at a later date to New York to obtain special instruction in commercial subjects.

When the War of Independence broke out, in $\mathrm{I} 895$, he was appointed correspondent of the New York Herald in Camagüey, and later, held a similar post in Havana. In consequence of the news he sent to his paper he was expelled from Cuba (I897) by General Weyler, whereupon he went to New York and continued to write for the Herald there until the United States declared war on Spain, when he became war correspondent writing despatches from the front.

During the American Intervention he

\section{A N D M O N O G R A P S}




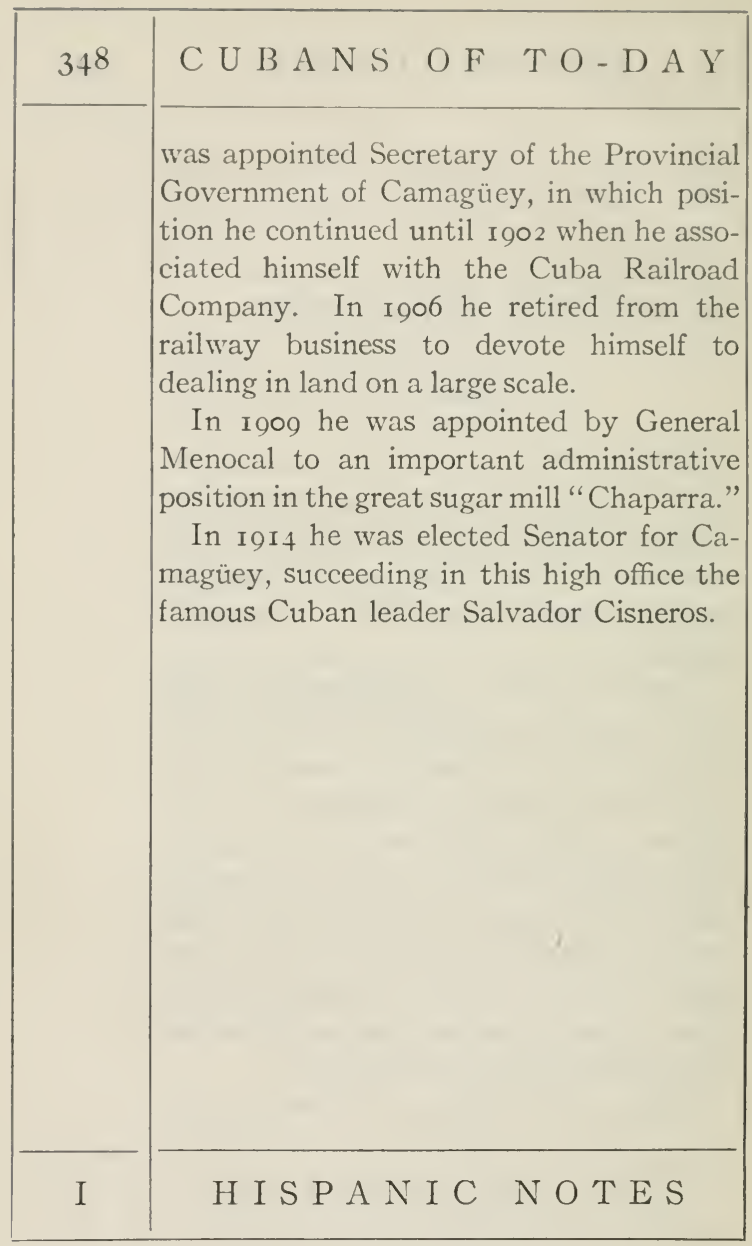




\section{GUSTAVO G. DUPLESSIS}

Physician; teacher; surgeon .

Gustavo G. Duplessis y Aizpurua was born on the twelfth of October, I864, in the city of Havana, but obtained his early education in the Church schools at Guanabacoa, later returning to Havana where he entered the University and obtained his degree as Doctor of Medicine when he was scarcely twenty years of age, in 1884 . Sometime later, being desirous of extending his knowledge and obtaining a wider experience in his profession, he went to Paris, there entered the University and obtained a second degree of Doctor of Medicine in I 893, meantime obtaining invaluable training and experience through a term of services as Interne and Externe in the hospitals.

In 1893 , he returned to Havana, entered 


\begin{tabular}{|c|c|}
\hline $35^{\circ}$ & C U B A N S O F T O - D A Y \\
\hline & $\begin{array}{l}\text { at once on the practice of medicine and } \\
\text { surgery, and has enjoyed a career of dis- } \\
\text { tinguished success. } \\
\text { In I } 895 \text { he was appointed Physician and } \\
\text { Surgeon of the Hospital (Quinta) of the } \\
\text { Association of Clerks (Dependientes) which } \\
\text { has a membership of over thirty thousand. } \\
\text { In I } 899 \text { he was appointed Professor of } \\
\text { Clinical Surgery in the University and } \\
\text { occupied the Chair until I } 90 \text { I. He was } \\
\text { then made Surgical Director of the Hospi- } \\
\text { tal (Casa de Salud) of the Canary Islands } \\
\text { Association with its forty thousand } \\
\text { members. } \\
\text { Dr. Duplessis is a Member of the } \\
\text { Academy of Medicine and of the Society } \\
\text { for Clinical Studies. He has published } \\
\text { frequent articles in the medical press upon } \\
\text { professional subjects. }\end{array}$ \\
\hline I & H I S P N I C N O T E S \\
\hline
\end{tabular}




\section{ANTONIO BRAVO CORREOSO}

Lawyer; public man; administrator.

Antonio Bravo Correoso was born in Santiago de Cuba in 1874 . After obtaining his early education at the Colegio of "Santiago" in his native town he went on to Havana, there completing the course for the Bachelor's degree and entering the University to pursue studies in Philosophy, Letters, and Law. In the year I 886 he obtained the degree of Licentiate in Philosophy and Letters, and a year later that in the Law.

Correoso returned to his birthplace to accept the position of Professor in the Provincial Instituce of Santiago, and continued to teach until the Revolutionary War broke out in I895. He had been a prominent member of the old Reform party and Provincial Deputy for it; naturally, therefore, when the war came he devoted himself

\section{A N D M O N O G R A P H S}




\begin{tabular}{|c|c|}
\hline $35^{2}$ & C U B A N S O F T O - D A Y \\
\hline & $\begin{array}{l}\text { to the Cuban cause and became a marked } \\
\text { man. He was one of the first whom the } \\
\text { Spanish General Martínez Campos caused } \\
\text { to be seized and imprisoned. He was taken } \\
\text { to the Cabaña Fortress in Havana; from } \\
\text { there transported to Spain, and placed in } \\
\text { prison first at Santander and later at Mad- } \\
\text { rid. He escaped from custody, made his } \\
\text { way to Italy, thence to Paris, and later to } \\
\text { New York, meantime spreading in all the } \\
\text { cities which he visited the story of Cuba's } \\
\text { struggle for liberty. } \\
\text { When the war was won and the Cuban } \\
\text { Republic was constituted, Correoso was } \\
\text { elected Member of the Constitutional } \\
\text { Convention for Santiago and was made } \\
\text { Secretary of the Commission charged with } \\
\text { drafting the Constitution. In I9o } 2 \text { he was } \\
\text { elected Senator and reëlected in I } 906 \text {; he } \\
\text { was first Vice-president of this body. From } \\
\text { the end of the war until the second Ameri- } \\
\text { can Intervention he was President of the } \\
\text { political party to which he belonged in } \\
\text { Santiago, but since that time he has taken } \\
\text { little part in politics, preferring to devote } \\
\text { himself to the practice of his profession. }\end{array}$ \\
\hline I & H I S A N I C NOTES \\
\hline
\end{tabular}




\section{A R A G Ó N}

\section{ERNESTO A. DE ARAGÓN}

\section{Physician.}

Ernesto A. de Aragón y Muñoz was born in the town of Marianao on the ninth of January, r868. His early education was obtained in Havana where he attended Colegios, continued in the Institute where he completed the course for the Bachelor's degree and also in the University which granted him the degree of Licentiate in Pharmacy in r889. He became Assistant Professor in this subject in 1894 and also pursued his medical studies obtaining the degree of Licentiate in Medicine in 1895 .

The political events of $\mathrm{r} 895$ in Cuba obliged Dr. de Aragón to withdraw to the United States where he continued the study of his profession as assistant in the Lying-In Hospital in New York and at the same time coopperated with his com-

\section{A N D M O N O G R A P H S}




\begin{tabular}{|c|c|}
\hline 354 & C U B A N S F T O - D A Y \\
\hline & $\begin{array}{l}\text { patriots who were lending effective aid to } \\
\text { the Revolution by means of political clubs } \\
\text { organized in New York and other cities. } \\
\text { After spending some time in New York } \\
\text { Dr. de Aragón removed to Jacksonville, } \\
\text { Florida, where he practiced his profession } \\
\text { until the end of the war and the success of } \\
\text { the Revolution in Cuba when he returned } \\
\text { to Havana. } \\
\text { In I9oo he obtained the degree of Doctor } \\
\text { in Medicine from the University of Havana } \\
\text { and in the same year was made Head of } \\
\text { the Clinic of Obstetrics in the School of } \\
\text { Medicine in Mercedes Hospital. In I9o2 } \\
\text { he was appointed Chief Inspector of the } \\
\text { Health Department. He is also Vice- } \\
\text { president of the Society of Clinical Studies } \\
\text { and Financial Secretary of the Medical } \\
\text { College of Cuba. } \\
\text { Dr. de Aragón is a contributor to medical } \\
\text { journals; has acted as editor of Medical } \\
\text { Progress and collaborated on the Manual } \\
\text { of Practical Sanitation issued by the De- } \\
\text { partment of Health in I } 905 \text {. }\end{array}$ \\
\hline I & H I S P A I C N O T E S \\
\hline
\end{tabular}





$$
\text { farefurnery }
$$




\section{E L A G U A R D I A}

CRISTÓBAL DE LA GUARDIA

Lawyer; official.

Cristóbal de la Guardia was born on the eighteenth of July, I859, in the town of Guanabacoa, Havana Province. There, in the Church schools, he took his early education and continued thereafter in the colleges of Havana and the University where he studied law, obtaining the degree of Licentiate in Law in 1880.

In addition to the practice of his profession Señor de la Guardia has held various public offices and occupied positions of importance, among them being: Secretary of the Board of Patrons of the Hospital for the Insane of Cuba; Counsel of the Board of Aldermen of Havana; Consulting Attorney of the Board of Aldermen of Guanabacoa; Senator for the Province of Havana and Secretary of Justice in the Cabinet of President Menocal.

\section{A N D M O N O G R A P H S}




\section{U B A N OF T O-D A Y}

De la Guardia is the author of articles, addresses, and reports on legal subjects some of which have been highly regarded and one of which was described by an eminent authority as "the most important document which had been published since Cuba became free." This was his, Informe del Secretario de Justicia, $\mathrm{Ha}$ bana, I9I5. Among his other publications are: Para el Pueblo, Habana, r9oo. Porqué soy liberal, Habana, I903. In na reforma que no se hara, Habana, 1905. 



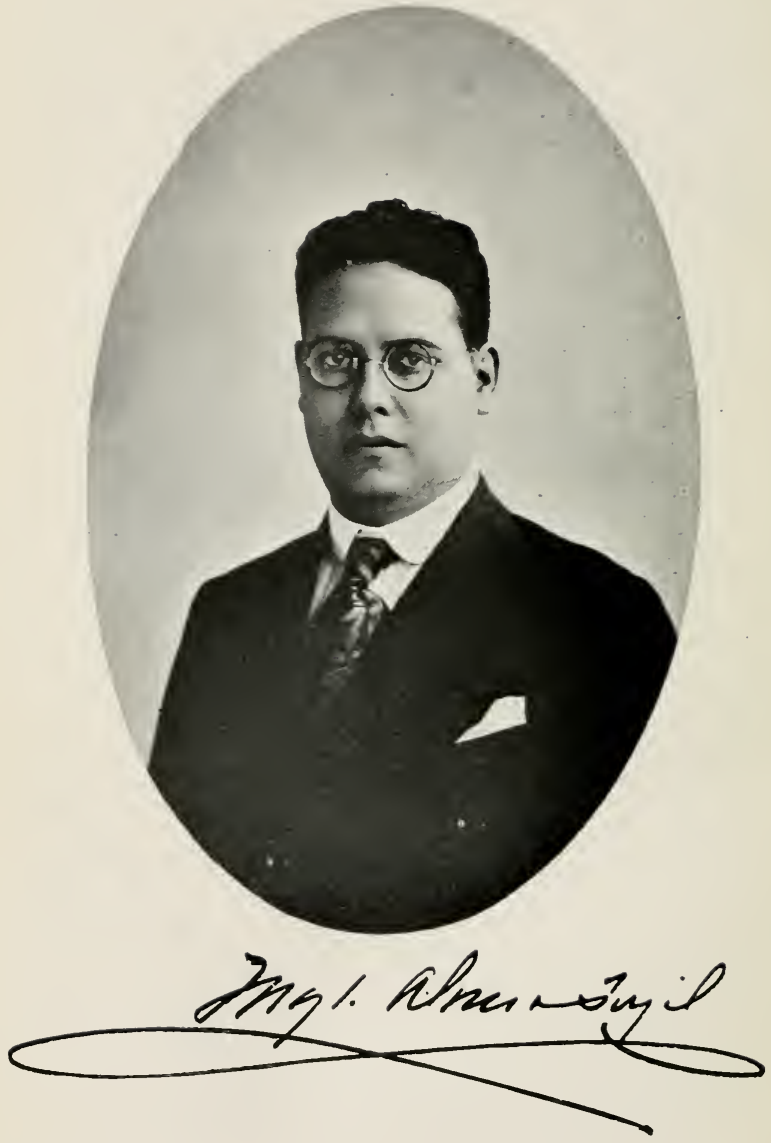


PUJOL

MIGUEL ALONSO PUJOL

Lawyer; publicist.

Miguel Alonso Pujol was born on the seventeenth of July, I892, the son of Señor Gustavo Alonso Castañeda and Señora Teresa Pujol y Tristá. He gained his education largely in Brazil where he graduated from the National Institute of Science of Rio Janeiro in 1907 with the degree of Doctor of Civil Law.

Since he returned to Havana Dr. Pujol has taken an active part in public affairs, contributing to various periodicals including El Mundo, El Triunfo, La Discusión, La Lucha, etc., and recently he has become the editor of Lá Semana Judicial, a magazine devoted to legal and social questions.

In rgro he obtained the degree of Doctor of Civil Laws in the University of Havana. Dr. Pujol is a member of the National

A N D M O N O G R A P H S 


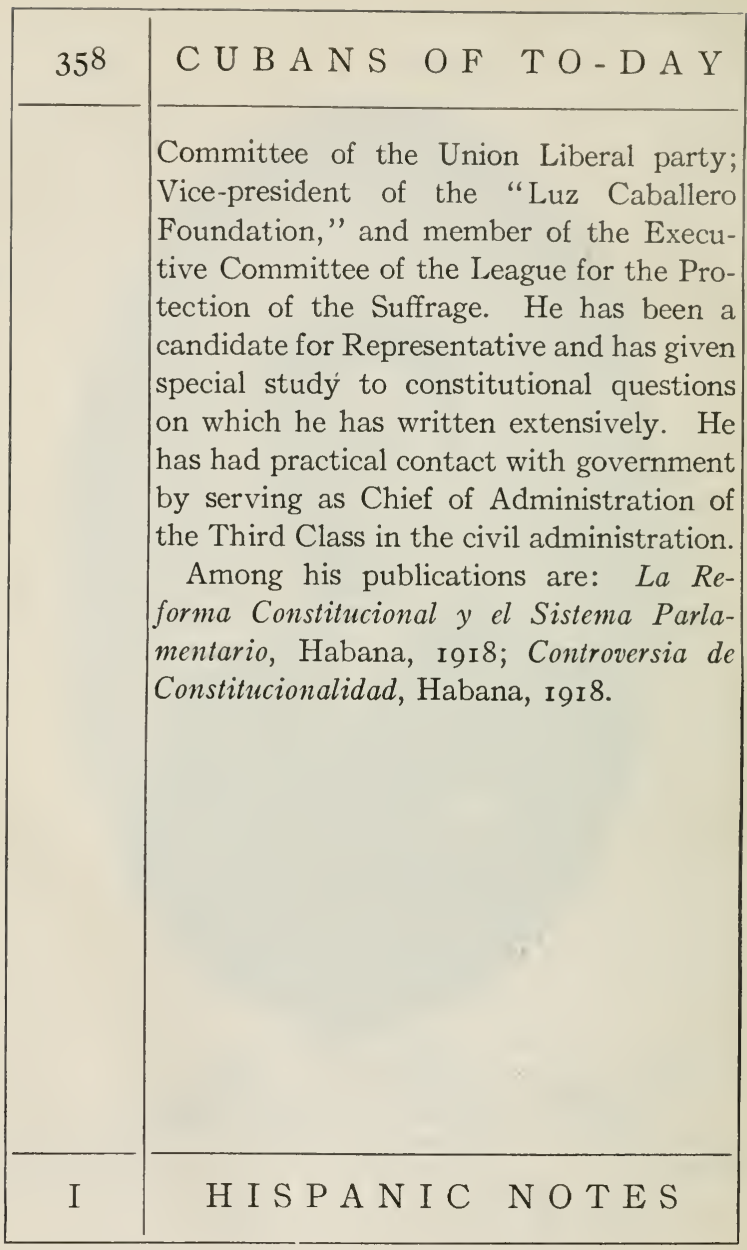




\begin{tabular}{|c|}
\hline LAINÉ \\
\hline HONORÉ F. LAINÉ \\
HonoRÉ F. LAINÉ y GAREScHÉ was born \\
on the tenth of October, I864, in Macurijes, \\
Province of Matanzas. He was educated \\
chiefly in the United States, at Georgetown \\
College, Washington, D. C., and the Ameri- \\
can Veterinary College of New York where \\
he gained the degree of Doctor in Veteri- \\
nary Medicine in I885. \\
From I899 to I905 Dr. Lainé was Veter- \\
inary Inspector of the Port of Havana and \\
from I905 to I907 Veterinary of the Higher \\
Board of Health. \\
In I907 he won in competitive examina- \\
tion the post of professor in the University \\
of Havana in charge of instruction in In- \\
spection of Domestic Animals, Inspection \\
of Meats, Police Sanitation, and Veter- \\
inary Legislation. \\
\hline A N D M O N O G R A P H S
\end{tabular}




\section{C U B A N S O F T O-D A Y}

In 1893 he invented the first mechanical transporter of sugar cane to be installed in Cuba, which was set up in Colonia Santo Domingo, Crimea, Province of Matanzas. 


\section{R U I Z}

\section{MANUEL RUIZ Y RODRÍGUEZ}

Ecciesiastic; author; Bishop of Pinar del Rio.

Manuel Ruiz y Rodríguez was born in Corralillo, Province of Santa Clara, on the eleventh of December, I874. He gained his early education in Havana where he entered the Seminary in 1887 and continued until he graduated as Bachelor of Theology. Later he went to the United States ard continued his studies in the Catholic University of America, at Washington, D. C., where he obtained the Aegree of Licentiate in Theology. He was enabled to take all his courses of study by the generosity of Father Manuel Gonzáiez Cuervo.

In 1897 he was ordained and in 1900 he was sent as chaplain to the teachers who went to Boston in that year.

During his career in the church the

\section{A N D M O N O G R A P S}




\begin{tabular}{|l|l}
\hline C U B A N S O F T O - D A Y \\
\hline $\begin{array}{l}\text { Reverend Father has filled various official } \\
\text { posts, including that of Secretary to the } \\
\text { Chapter of the Cathedral of Havana; Chap- } \\
\text { lain of the Choir; Secretary of the Records } \\
\text { (Sumario); Secretary and Prosecutor of the } \\
\text { Bishops of Havana and Cienfuegos; Curate } \\
\text { and Vicar of Sagua la Grande; Curate of } \\
\text { Cruces, Lajas, and Cienfuegos; Adminis- } \\
\text { trator of the House of Correction, and pro- } \\
\text { fessor of the four courses in Latin and the } \\
\text { Humanities in the Seminary ot Havana. } \\
\text { In I907 Father Ruiz was appointed } \\
\text { Bishop of Pinar del Rio. He was desig- } \\
\text { nated in April, I go7, consecrated in Cien- } \\
\text { fuegos on the eleventh of June, and took } \\
\text { possession of his charge on the tenth of July } \\
\text { of the same year, where he continues. } \\
\text { He is the author of various Pastoral } \\
\text { Letters, has translated The Heart of Jesus } \\
\text { of Nazareth, and is the author of Liras y } \\
\text { Estrofas, poems published under the pseu- } \\
\text { donym "Lucas del Cigarral," and a volume } \\
\text { Impresiones de un Viaje a Tierra Santa. }\end{array}$ \\
\hline H I S P A N I C N O T E S \\
\hline
\end{tabular}





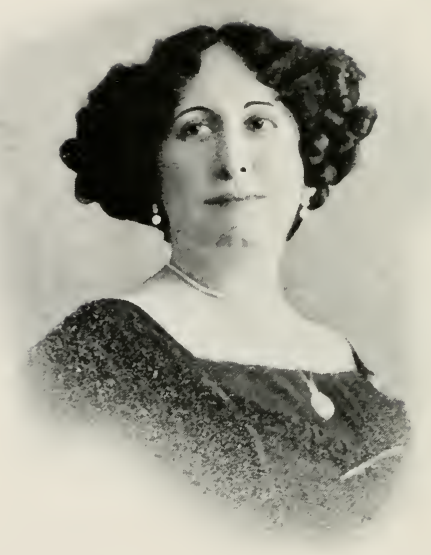

Carmela Nieto de Herrera 


\section{A R M E A N I E T O}

\section{CARMELA NIETO DE HERRERA}

Writer; journalist.

Señora Carmela Nieto de Herrera was born in Havana on the sixth of March, I 879 , but received most of her education abroad; first in the United States and later in Madrid (Spain) where her father, Don Mariano Nieto Mujica, held the rank of Brigadier General in the Spanish Army. There she completed the courses leading to the degree of Bachelor, gaining also various prizes for distinction.

In 1904 she began to write in El Figaro of Havana and soon afterwards was placed in charge of the Home Department of $\mathrm{El}$ Mundo. Later she founded and conducted in the same paper a section devoted to "Questions-moral and general" in which she dealt with matters of belief, affection, and good counsel. 


\begin{tabular}{|c|c|}
\hline C U B A N S O F T O - D A Y \\
\hline $\begin{array}{l}\text { In I go6 she was elected member of the } \\
\text { Board of Charity and Correction; first } \\
\text { officer of the Library and Press division of } \\
\text { the Bulletin of Health of Cuba. } \\
\text { In I907 she was appointed member, } \\
\text { with voice and vote, of the Board of Health } \\
\text { of Havana - being the only woman who has } \\
\text { held any of these positions in Cuba up to } \\
\text { this time. She is a member of the Red } \\
\text { Cross. She is also a member of the Sec- } \\
\text { tion of Public Instruction of Cuba, and } \\
\text { through her writings a general, unofficial } \\
\text { adviser of many students, boys and girls. } \\
\text { Señora Nieto de Herrera is the only } \\
\text { woman journalist in Cuba and is the author } \\
\text { of a great number of articles, sketches, and } \\
\text { stories which have appeared in newspapers } \\
\text { and magazines. }\end{array}$ \\
\hline I I S P A N I C N O T E S
\end{tabular} \mid





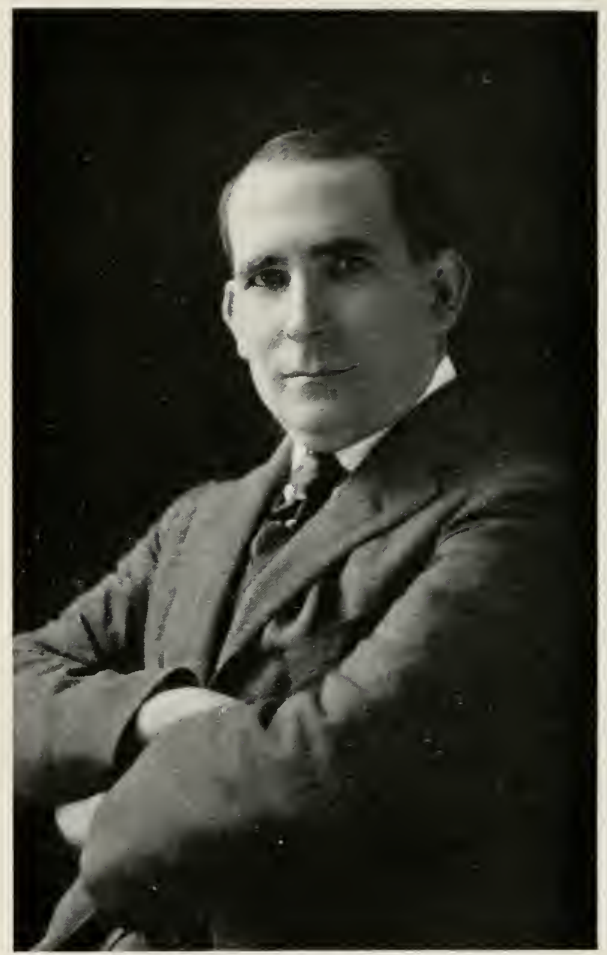

By permission of Hall's Studios, photographers (N.Y.)

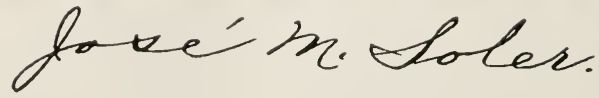




\section{S O L E R}

\section{JOSÉ M. SOLER FERNÁNDEZ}

\section{Teacher of art.}

José M. Soler Fernández was born in Villaclara, Cuba, in the year 1873 . When he was twenty he entered the School of Painting and Sculpture of Madrid where he continued five years, and won gold medals for excellence in his studies and honorable mention in the Exposition of Fine Arts of Madrid in I896. From I90I to 1904 he studied in the University of $\mathrm{Ha}$ vana where he obtained the degrees of Bachelor and of Doctor in Pedagogy (I904). In the same year he won the silver medal for a text-book on the subject of art at the Exposition held in St. Louis.

Meantime he had entered upon his career as teacher of art. In I90I he was Professor of Drawing in the Summer Schools at Cienfuegos; in 1902 in those of

\section{A N D M O N O G R A P H S}




\begin{tabular}{|c|c|}
\hline 366 & C U B A N S O F TO-D A Y \\
\hline & $\begin{array}{l}\text { Santiago de las Vegas, Güines, and Havana. } \\
\text { In Igo6 he was Professor ad interim of } \\
\text { Perspective, Anatomy, and the History of } \\
\text { Art in the School of Painting of Havana. } \\
\text { In I9I5 he was appointed Professor of } \\
\text { Drawing and Modeling in the Normal } \\
\text { School of Havana, and in I9I6 he gained by } \\
\text { competitive examination the position of } \\
\text { Auxiliary to the Chair of Drawing in the } \\
\text { School of Pedagogy. } \\
\text { In I9I } 7 \text { Dr. Soler was elected Member } \\
\text { of the National Academy of Arts and } \\
\text { Letters and in I9I9 he was elected Presi- } \\
\text { dent of the University Pedagogical Asso- } \\
\text { ciation of Havana. } \\
\text { The work of Dr. Soler in his various } \\
\text { classes since I90 I has been directed to } \\
\text { setting up new ideas and new methods in } \\
\text { Drawing, Modeling, and Chirography and } \\
\text { to combating the traditional forms and } \\
\text { methods based on antique doctrines. }\end{array}$ \\
\hline I & H I S P A I C NOTE S \\
\hline
\end{tabular}




\section{O N T O R I}

ARTURO MONTORI DE CÉSPEDES Teacher; writer.

Arturo Montori de CÉspedes was born in the year 1878 in Havana. He was educated partly in Spain, at the Institutes of Zaragoza and Barcelona, and partly in Havana where he gained the degree of Doctor in Pedagogy at the University.

On leaving the University he entered upon his profession as teacher and became Master in the public schools of Batabanó in 1902; Master in the schools of Havana, by competitive examination, in 1904, and Director of Schools Nos. I 3 and 43 , in Havana, I907 to 1909. In I909 he became Inspector of the District Schools of Bejucal, and in I9Io, Professor of the Normal School of Havana. In I 9 I 5 he was elected to the Faculty of the Normal School and in I9I 7 became its Director.

\section{A N D M O N O G R A P S}




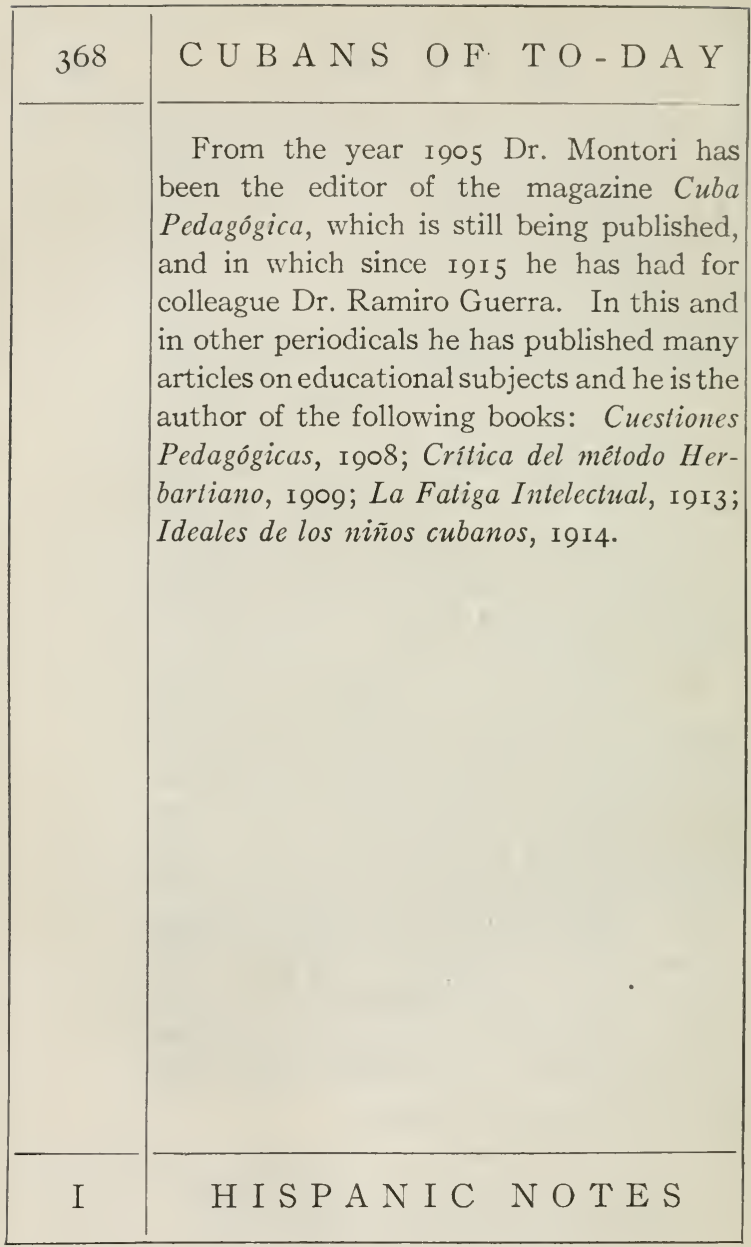





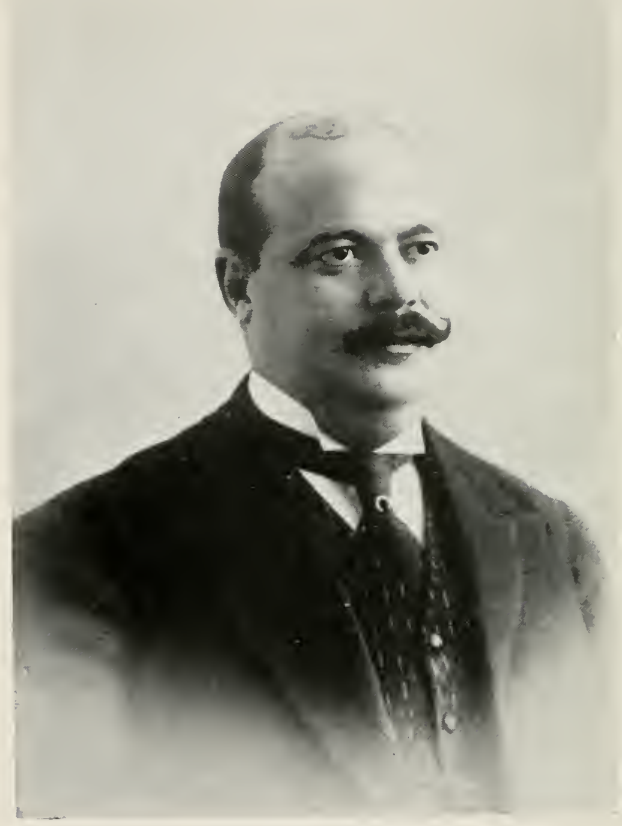

Ernesto Asbert 


\begin{tabular}{|} 
A S B E R T \\
\hline ERNESTO ASBERT \\
Soldier; man of affairs; \\
administrator. \\
ERNESTo AsBERT was born in the town \\
of Consolación del Sur in the Province of \\
Pinar del Rio on the first of May, I873, and \\
took the early courses leading to the \\
Bachelor's degree in the private Colegio of \\
the Society "La Unión" in his native place. \\
But the student's life made an indifferent \\
appeal to his energetic nature and he left \\
books to devote himself to business. \\
When the Revolution broke out in r895 \\
Asbert prepared to take part in it and on \\
January 9, I896, joined the forces of Col. \\
Antonio Nuñez with the rank of Captain. \\
During the remainder of the war he fought \\
under the command of the Commander- \\
in-chief Máximo Gór.ez, under that of \\
General Antonio Maceo, and for part of \\
the time under that of General Adolfo del \\
\hline A N D M O N O G R A P H S
\end{tabular}




\begin{tabular}{|c|c|}
\hline 370 & C U B A N S O F T O - D A Y \\
\hline & $\begin{array}{l}\text { Castillo, the scene of his activities being } \\
\text { the Province of Havana, where he obtained } \\
\text { his promotion to the rank of Colonel on the } \\
\text { 24th of August, I } 898 \text {. } \\
\text { With the close of the war he turned his } \\
\text { attention to politics. His first office was that } \\
\text { of Chief of Municipal Police for Güines. } \\
\text { At the same time he served also as Secre- } \\
\text { tary of the Liquidating Commissions (Com- } \\
\text { mission for settling soldiers' claims) of the } \\
\text { Fifth Corps of the Army. In I } 904 \text { Col. } \\
\text { Asbert was elected Member of the Council } \\
\text { for the Province of Havana, and in I9o } 8 \text { he } \\
\text { was elected Governor of the Province of } \\
\text { Havana, in which post he was active in } \\
\text { improving roads, bridges, and all means of } \\
\text { communication so as to increase the traffic } \\
\text { and add to the resources of all parts of the } \\
\text { province. } \\
\text { Some years ago the Congress of Cuba } \\
\text { passed a special act of amnesty designed, } \\
\text { it was said, to clear Gen. Asbert's name } \\
\text { and exculpate him from the charge of } \\
\text { manslaughter on which he had been tried. } \\
\text { Gen. Asbert has interested himself in } \\
\text { publications: he was the founder of the }\end{array}$ \\
\hline I & H I S P A I C N O T E S \\
\hline
\end{tabular}




\section{A S B E R T}

newspaper $E l$ Independiente of Güines and has had a share in establishing and developing some of the papers of the Capital. 



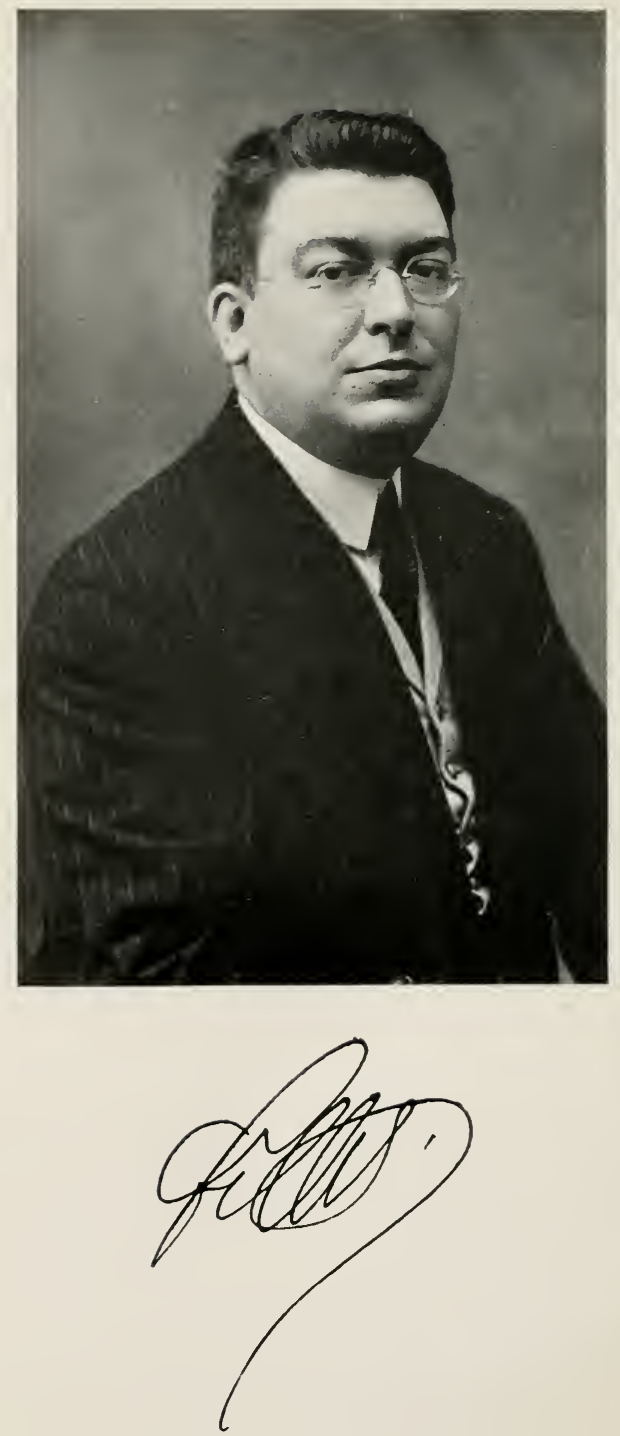
FERNANDO ORTIZ Y FERNÁNDEZ Lawyer; criminologist; author.

FERnANDo Ortiz y FERnÁndez was born in Havana on the sixteenth of July, r88r, of a Spanish father and a Cuban mother. He prepared for his Bachelorate in Menorca, Spain, and commenced in Havana the study of law from which he was graduated in Barcelona in 1900 . In Igor he received the degree of Doctor of Laws from the Central University of Madrid and was made Doctor of Civil Law (I902) and Doctor of Public Law (I906) by the University of Havana.

From I 902 until I906 he was Cuba's consular representative in Italy and Spain after which he served for two years as Public Prosecutor in Havana; he then became Professor of Public Law in the University of Havana, which position he resigned in I9 6

\section{H I S P A N I C N T E S}




\begin{tabular}{|c|c|}
\hline 374 & C U B A N O F T O - D A Y \\
\hline & $\begin{array}{l}\text { upon his election for a seven-year term } \\
\text { to the Cuban House of Representatives. } \\
\text { Dr. Ortiz is a profound student ot Cuban } \\
\text { history, ethnology, and psychology, es- } \\
\text { pecially as related to the negro. He is a } \\
\text { member of the following scientific organi- } \\
\text { zations: American Institute of Criminal } \\
\text { Law and Criminology, American Sociolo- } \\
\text { gical Association, American Academy of } \\
\text { Political and Social Sciences, Societé Gén- } \\
\text { érale des Prisons, Academia de la Historia } \\
\text { de Venezuela, Academia de la Historia de } \\
\text { Cuba, Sociedad Economica de Amigos del } \\
\text { Pais, Sociedad Cubana de Derecho Inter- } \\
\text { nacional. In I9I8 he was made a Corre- } \\
\text { sponding member of the Hispanic Society } \\
\text { of America. } \\
\text { His published works include: Base para } \\
\text { un estudio sobre la llamada reparación civil } \\
\text { (Doctor's thesis), Madrid, I } 90 \text {; Las sim- } \\
\text { patias de Italia por los Mambises cubanos, } \\
\text { "Documentos para la historia de la inde- } \\
\text { pendencia de Cuba," Marsella, I905; La } \\
\text { Criminalita dei negri in Cuba, Turin, I } 905 \text {; } \\
\text { Il Suicidio Tra } i \text { Negri, Turin, I906; Super- } \\
\text { stizione criminose in Cuba, Turin, I906; }\end{array}$ \\
\hline I & H I P A N I N O T E S \\
\hline
\end{tabular}


Hampa Afro-Cubana, Los Negros Brujus, Madrid, r9o6; La inmigración desde el punto de vista criminológico, Habana, I 906; Para la agonografia española, Habana, I908; Los Mambises Italianos, Habana, I909; La reconquista de América, Paris, Ollendorf, I9I ; Historia de Santiago de Cuba, Habana, I9г 2; La identificación dactiloscopica, Habana, I9r3; Entre cubanos, Ollendorf, Paris, I9I 4; Seamos Hoy como fueron A yer, Habana, I9I 4; Hampa Afro-Cubana, Los Negros Esclavos, Habana, I9 6; Bases para la organización Internacional de la Solidaridad de los Estados ante el delincuente, Habana, I9I 7 .

\section{A N D M O N O G R A P H S}






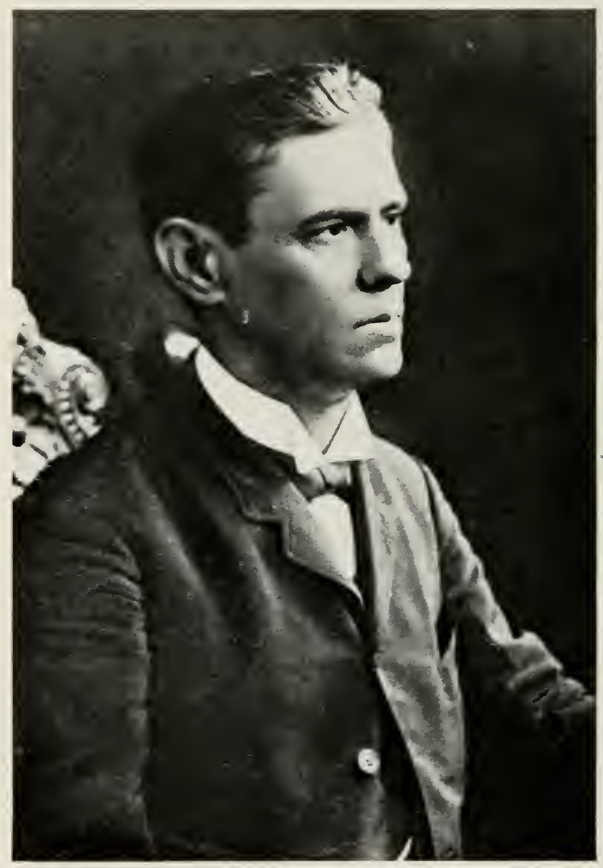

Alfredo Zayas y Alfonso 


\section{ALFREDO ZAYAS}

Lawyer; writer; orator; Vice-president of the $R e$ public of Cuba, I909-I9I3.

Alfredo Zayas y Alfonso was born on the twenty-first of February, I86I, in the city of Havana where his whole life has been spent. His early education was obtained in the colegio of Madame Boblag and the more famous colegio "E1 Salvador" founded by Luz Caballero which was then under the charge of his father, Juan Bruno Zayas. In I 882 at the age of twenty-one he received the degree of Licenciado en Derecho from the University of Havana and entered upon the practice of the law. Like most Cubans of his generation he shared in the revolutionary activities of the time; he was a member of the Autonomist party, a contributor of propagandist articles to various newspapers, editor of a literary magazine,

\section{H I S P A I C NOTES}




\begin{tabular}{|c|c|}
\hline 378 & C U B A N S O F T O - D A Y \\
\hline & $\begin{array}{l}\text { and representative of the Revolutionary } \\
\text { party in Havana. His part in the revolu- } \\
\text { tionary program resulted in his arrest and } \\
\text { imprisonment in I } 896 \text { and his exile in I } 897 \text {. } \\
\text { With the triumph of the Revolution in } \\
\text { I } 898 \text {, he returned to political life in which } \\
\text { he has since been active. He has held many } \\
\text { offices. As early as I } 889 \text { he was Prosecuting } \\
\text { Attorney; in I } 89 \text { I Municipal Judge; in I } 90 \text { I } \\
\text { acting Mayor of Havana and Member of } \\
\text { the Council; in I } 905 \text { he was made Senator } \\
\text { for the Province of Havana and chosen } \\
\text { President of the Senate; in I9o6 he was } \\
\text { President of the Revolutionary Committee; } \\
\text { in I } 907 \text { he was chosen member of the Com- } \\
\text { mittee of Consultation to deal with matters } \\
\text { affecting Cuba and the United States and } \\
\text { in I } 908 \text { he was elected Vice-president of the } \\
\text { Republic. } \\
\text { The literary interests of Dr. Zayas have } \\
\text { been many and varied. He has been a } \\
\text { frequent contributor to the press and to } \\
\text { magazines on political and historical sub- } \\
\text { jects; he was for six years Librarian of the } \\
\text { Sociedad Económica de Amigos del Pais } \\
\text { and for many years its President. His }\end{array}$ \\
\hline I & H I P A N I C N OTE S \\
\hline
\end{tabular}




\section{Z A Y A S}

published works include $E l$ presbitero don José Agustin Caballero y su vida y sus obras, г89г. Cuba Autonómica. Lexicografía Antillana, Habana, I9ı. 



\section{J U S T Í Z}

\section{FRANCISCO CARRERA JÚSTIZ}

Lawyer; teacher; expert in municipal affairs.

Fraxcisco Carrera Jústiz was born in Guanabacoa, Province of Havana, on the thirtieth of August, I857. He gained his early education in the church schools of his native town but for his later studies went to the University of Havana where he obtained the degree of Doctor of Civil and Public Law.

Dr. Jústiz has found his chief interest in the field of municipal government and has devoted himself to its problems. He won in competition the position of professor in the law faculty of the University and he has founded a magazine entitled Revista Municipal y de Intereses Económicas in which he deals with city government. $\mathrm{He}$ is also a founder of the Association for

\section{H I S P A N I C N O T E S}




\begin{tabular}{|c|c|}
\hline 382 & C U B A N S F T O - D A Y \\
\hline & $\begin{array}{l}\text { Municipal Good Government and has deliv- } \\
\text { ered at the Ateneo and elsewhere an exten- } \\
\text { sive series of lectures on the subject. } \\
\text { He is a member of the Academy of } \\
\text { Sciences of Havana; honorary member of } \\
\text { the Royal Academy of Jurisprudence of } \\
\text { Spain; President of the Association of Doc- } \\
\text { tors of Public Law, and President of the } \\
\text { Committee on Social Problems in the Na- } \\
\text { tional Workmen's Congress. } \\
\text { Dr. Jústiz has also seen service as a diplo- } \\
\text { mat, having been Minister of Cuba to } \\
\text { Spain, to the United States, to Holland, } \\
\text { and to Mexico. He is the author of many } \\
\text { articles and of the following works: } \\
\text { Exposicion, del Derecho Civil Español y } \\
\text { sus Leyes Especiales para Cuba; Ayunta- } \\
\text { mientos Cubanos; Breve estudio sobre la ex- } \\
\text { cepcional importancia que presentan en Cuba } \\
\text { los asuntos municipales; Una Sociología } \\
\text { Municipal; Notas sobre progreso municipal } \\
\text { cientifico, Al Congreso Cubano. La Con- } \\
\text { stitucion de Cuba y el problema municipal; } \\
\text { Estudios de Filosofia Politica. El Sufragio } \\
\text { Universal, Estudios de Filosofia Politico. } \\
\text { Los Estados Norte Americanos desde el }\end{array}$ \\
\hline I & H I S P A I C N O T E S \\
\hline
\end{tabular}




\section{J U S T Í Z}

punto de vista de su Gobierno Municipal, Las ciudades del siglo $X X$ y los Monopolios de Sevicios Públicos. El Socialismo Municipal; El Municipio y la Cuestión de Razas; El Municipio y los Extrajeros. Los españoles en Cuba; El Municipio y las clases obreras; Los árboles y la cultura Civica; Estudios de Economía Social. A los Centros Regionales; Pro Raza. A la Asociación de Dependientes de la Habana, como factor Sociológico en la Civilización de Cuba; La Ciencia Civica en su relación con la mujer y con la Democracia; Introduciones a la Historia de las Instituciones Locales de Cuba. Programa de las Asignaturas de Gobierno Municipal y de Historia de las Instituciones Locales de Cuba; Estudio de Sociología Politica: Conservadores y Liberales; Estudios Politicos Sociales. Orientaciones necesarias. Cuba y Panamá. Proyecto de Reforma de la Facultad de Derecho; El panamericanismo. La Independencia de las Colonias. Europeas y en América, El Estado Moderno y la Acción Politica. El Ideal Social, La Reforma Electoral, La Guerra y las Ciudades, Importancia Internacional del problema

\section{A N D M O N O G R A P H S}




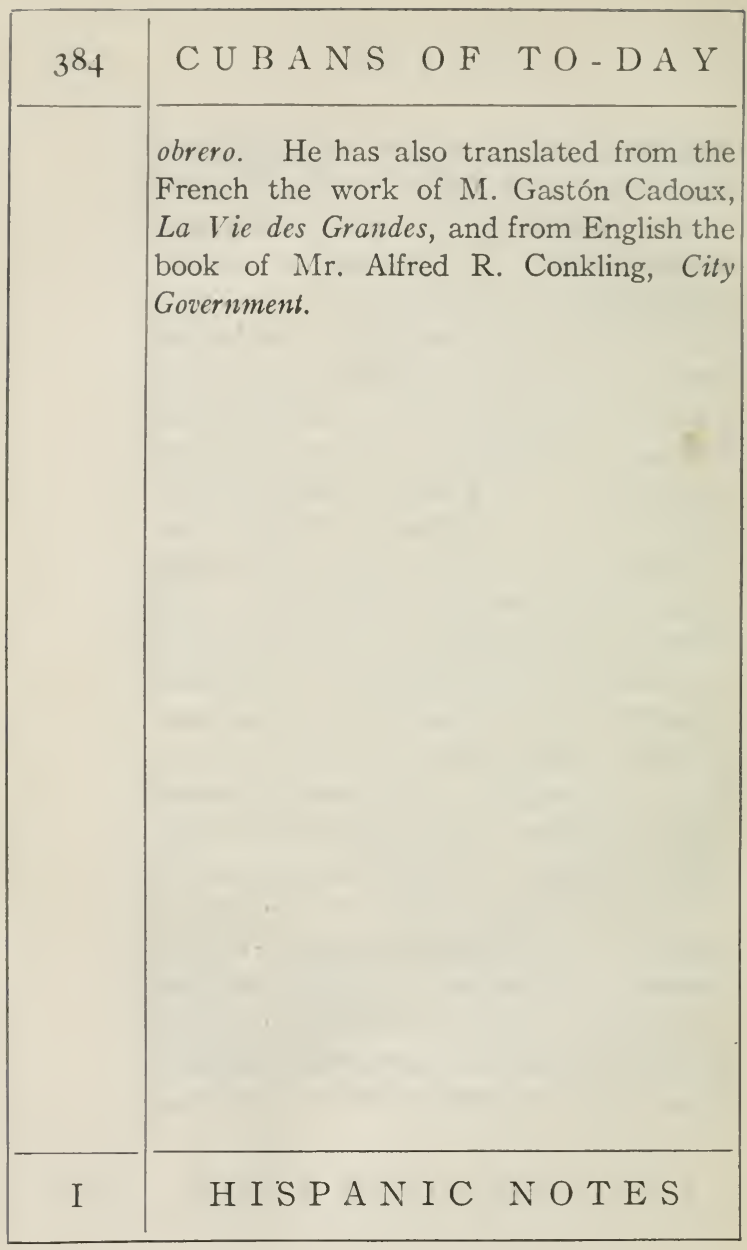




$$
3
$$




\section{I L L A L Ó N}

JOSÉ RAMÓN VILLALÓN Y SÁNCHEZ

Engineer; soldier; teacher; administrator; Secretary of Public Works of Cuba

José Ramón Villalón y SÁNchez was born in Santiago de Cuba on the twentyfifth of March. He was educated abroad, in Spain and the United States; he obtained the degree in Civil Engineering at Lehigh University in I889, and returned to Cuba where he pursued his profession, sharing in the development of the iron industry and of the railroads then rapidly growing. On the outbreak of the Revolution he joined the forces of General Maceo with whom he served as Chief of Staff and won the rank of Lieutenant-Colonel.

He was elected as Delegate to the General Assembly of the Revolutionary Army to meet at Santa Cruz del Sur, Camagüey, by the sixth Army Corps (Pinar del Rio).

\section{A N D M O N O G R A P H S}




\begin{tabular}{|c|c|}
\hline 386 & C U B A N S O F TO-D A Y \\
\hline & $\begin{array}{l}\text { At the Assembly he was elected a member } \\
\text { of the Commission that went to confer with } \\
\text { President McKinley, the Commission be- } \\
\text { ing composed of General Calixto García, } \\
\text { President; Colonel José R. Villalón, Secre- } \\
\text { tary; Major General José Miguel Gómez, } \\
\text { Col. Manuel Sanguily and Doctor José A. } \\
\text { González Lanuza. At the return of the } \\
\text { Commission from the U. S. and after the } \\
\text { dissolution of the General Assembly at } \\
\text { the end of the war, Villalón served as assist- } \\
\text { ant Engineer under the then Major W. M. } \\
\text { Black in charge of the State Department } \\
\text { at Havana; later he was appointed Chief } \\
\text { Engineer of Matanzas and Santa Clara, } \\
\text { etc., etc. } \\
\text { In I902, at the expiration of the Amer- } \\
\text { ican Intervention, Col. Villalón accepted } \\
\text { the professorship of Higher Algebra and } \\
\text { Calculus at the University ot Havana till } \\
\text { May } 20, \text { I } 9 \text { I } 3 \text {, when President Menocal ap- } \\
\text { pointed him Secretary of Public Works, a } \\
\text { position which he still occupies. } \\
\text { He is a member of the American Society } \\
\text { of Civil Engineers, of the American In- } \\
\text { stitute of Mining Engineers, of the Acad- }\end{array}$ \\
\hline I & H I S A N I C NOTES \\
\hline
\end{tabular}




\section{I L L A L Ó N}

emy of Sciences of the Island of Cuba, of the American Academy of Political and Social Science, of the Cuban Society of Engineers, and has represented his country as a Delegate to the International Engineering Congress held at San Francisco, and to the Second Scientific, Pan-American Congress held at Washington. 



\section{P R E S N O}

\section{JOSÉ ANTONIO PRESNO}

Physician; surgeon; teacher.

José Antonio Presno y Bastiony was born in Regla, Cuba, on the nineteenth of March, I876. He had his early education in the Church Schools of Guanabacoa where he gained the degree of Bachelor with distinction. Later he entered the University, matriculating in the Medical School with special credit in the examinations.

In 1893 he won the post of Assistant in Dissection in the Mercedes Hospital. In I 896 he founded the Revista de Medicina $y$ Cirugia de la Habana and gained the degree of Licentiate in Medicine; in the following year he was made Doctor in Medicine and became assistant Instructor in Surgical Anatomy and operations. In 1898 , at the request of the Faculty, he was appointed by Dr. Francisco Zayas, Secretary of Public

H I S P A N I C N O T E S 


\begin{tabular}{|c|c|}
\hline 390 & C U B A N S O F TO - D A Y \\
\hline & $\begin{array}{l}\text { Instruction, to be Assistant Professor Ex- } \\
\text { traordinary. From I } 898 \text { to I } 899 \text { he was } \\
\text { entrusted by the Faculty with the vacant } \\
\text { chair of Descriptive Anatomy. In I } 900 \\
\text { the Faculty of Medicine elected him Auxil- } \\
\text { iary Professor and he won in the same year, } \\
\text { by competitive examination, the post of } \\
\text { Head Professor of Anatomy. } \\
\text { In I902 Dr. Presno was elected a member } \\
\text { of the Academy of Sciences and Surgeon of } \\
\text { Hospital "Number One." In I } 903 \text { he was } \\
\text { made Surgeon of the Centro Asturiano } \\
\text { (Asturian Club); Secretary of the Section } \\
\text { of Anatomy in the Third Pan-American } \\
\text { Medical Congress held in Havana, and Vice- } \\
\text { president of the Medical Press of Cuba. } \\
\text { In I904 he was chosen by the organizing } \\
\text { Committee of the Second Latin-American } \\
\text { Congress to represent Cuba. In I } 905 \text { he } \\
\text { was elected General Secretary of the First } \\
\text { National Medical Congress of Cuba. In } \\
\text { I } 906 \text { he was appointed by the organizing } \\
\text { Committee of the Third Latin-American } \\
\text { Medical Congress to represent Cuba, etc. } \\
\text { In I } 9 \text { I } 7 \text { he was Vice-president of the Fourth } \\
\text { Medical Congress of Cuba. }\end{array}$ \\
\hline $\mathrm{I}$ & H I P A N I C N O T E S \\
\hline
\end{tabular}




\section{P R E S N O}

He is President of the Sociedad de Estudios Clinicos of Havana, Vice-president of the Academy of Medical Sciences and President-elect of the Fifth Medical Congress of Cuba.

Dr. Presno is a contributor to the medical. press, for which he has written a great number of articles during the past quarter century. Among his publications are: Tratamiento de los aneurismas externos, etc., Havana, r897; La situación topográfica del apéndice cecal, Havana, I901, etc.

\section{A N D M O N O G R P H S}





\section{P É R E Z M I RÓ}

ABRAHAM PÉREZ MIRÓ

Physician.

AbrahaM PÉrez Miró was born on the sixteenth of March, I857, in the town of Marianao, Province of Havana, and received his early education at the hands of Professor Pedro del Campo who came from Santander (Spain) for the purpose. Later he entered the Colegio directed by Dr. Alonso Delgado in El Cerro and after taking part of the courses required for the Bachelor's degree, went in I 868 to Spain where he entered the Colegio of Escolapios in Villacarriedo, Santander. Thence he went to Valladolid where he took the examinations for admission to the study of Medicine and gained the degree of Licentiate in Medicine in 1877 . The next stage he accomplished at Madrid where he served as

H I S P A N I C N O T E S 


\begin{tabular}{|c|c|}
\hline 394 & C U B A N S OF TO-DAY \\
\hline & $\begin{array}{l}\text { assistant to Dr. Olavide in the Hospital of } \\
\text { San Juan de Dios. } \\
\text { In December, I } 878 \text {, he returned to Cuba } \\
\text { where he has occupied the following posi- } \\
\text { tions: Physician of San Felipe de San- } \\
\text { tiago Hospital; Physician of Mercedes } \\
\text { Hospital; Physician of "Number One" } \\
\text { Hospital; of The Beneficencias, Francesa } \\
\text { and Montañesa; Emergency Surgeon of the } \\
\text { United Railways of Havana; Physician of } \\
\text { the Covadonga and Purisima Concepción } \\
\text { sanatoriums; Head of the Therapeutic } \\
\text { Laboratory of the University. } \\
\text { He has also taught in the University as } \\
\text { Professor of Therapeutics and Pharmacol- } \\
\text { ogy and as Professor of Therapeutics in } \\
\text { the Dental school. } \\
\text { He is a member of the Society of Clin- } \\
\text { ical Studies of Havana and of the Society } \\
\text { of Cervantes of Valladolid (Spain). } \\
\text { Dr. Miró is the inventor of the method in } \\
\text { Therapeutics of using topical application } \\
\text { of serum and microbinous vaccine to the } \\
\text { gastro-intestinal tract. His articles de- } \\
\text { scribing the method have been translated } \\
\text { into English and widely reproduced with }\end{array}$ \\
\hline I & H I S A N I C NOTES \\
\hline
\end{tabular}




\section{P É R E Z M I R Ó}

notes crediting him with priority in the use of this valuable method which has been adopted in other countries.

Dr. Miró is a contributor to professional journals in Cuba and elsewhere and is author of many articles including: Elogio funebre del Dr. Federico Horstman, Elogio funebre del Profesor Rafael Cowley, A paratos para fractura de las extremidades. 



\section{S A L A Z A R}

SALVADOR SALAZAR

Lawyer; teacher; writer.

Salvador Salazar y RoIg was born in Colón, Province of Matanzas, Cuba, on the thirtieth of June, I892. His early education was obtained in the Institute of Havana where he was granted his Bachelor's degree, with special distinction, I9ıо.

Continuing in the University he gained degrees with distinction as follows: Doctor of Public Law, I9I3, Doctor of Philosophy and Letters in I9I4, and Doctor of Civil Law in r9r4, winning in addition numerous prizes for scholarship and the special award of the "Carrera Jústiz" prize for work in the History of Local $\mathrm{Cu}$ ban Institutions.

In I9I 5 he was elected by the Faculty of Letters and Sciences in the University as Substitute Professor to fill during the ab-

H I S P A N I C N O T E S 


\begin{tabular}{|c|c|}
\hline $39^{8}$ & C U B A N O F T O - D A Y \\
\hline - & $\begin{array}{l}\text { sence of their holders, the Chairs of the His- } \\
\text { tory of America and the rest of the world; } \\
\text { and that of the History of Spanish Litera- } \\
\text { ture and the Modern Foreign Languages. } \\
\text { In the same year, on the organization of } \\
\text { the Normal Schools for Teachers of Cuba } \\
\text { he was appointed by the school of Letters } \\
\text { and Philosophy as a member of various } \\
\text { Committees of judges in the contests for } \\
\text { professorships in the normal schools. } \\
\text { On various occasions in I } 9 \text { I } 5 \text { and I } 77 \\
\text { he has been charged by his Faculty to serve } \\
\text { as lecturer in the popular courses known as } \\
\text { University Extension courses. } \\
\text { In I } 9 \text { I he won after a keen competition } \\
\text { the Chair of History of Philosophy in the } \\
\text { University a position which he continues } \\
\text { to occupy. The Faculty of Letters and } \\
\text { Sciences appointed him in the same year } \\
\text { Editor in Chief of the Magazine of the } \\
\text { Faculty. } \\
\text { He has acted as Honorary Delegate to } \\
\text { the First National Labor Congress in Cuba; } \\
\text { Member of the Centro Catalan of Havana; } \\
\text { Member of the Board of Directors of the } \\
\text { Cuban Society of International Law; Mem- }\end{array}$ \\
\hline I & H I S P A I C N O T E S \\
\hline
\end{tabular}




\section{S A L A Z A R}

ber of the Ateneo; of the Asociacion de Doctores en Derecho Público, of the Graduados en Filosofía y Letras, of the Liga Nacional de Instrucción Pública, of the Sociedad Unión of the Teatro Cubano, of the "Compañia Cubana de Publicaciones" which proposes to publish an edition of the Cuban classics.

Dr. Salazar is the author of: Lope de Rueda y su Teatro (I9II); Por las mubes, novel (I9I2); Ternuras, verses (I9I 2); Por la fuerza del amor and La verdadera aristocracia, comedies (I9I3); Literatura $\mathrm{Cu}$ bana, El clasicismo en Cuba (г19); Rafael Maria Mendive (I915); La cesión de los bienes del Estado (г19); Milanés, Luaces y la Avellaneda (г16); Las libertades catalanas (I9I7); El reposo como elemento estético (I9I7); El Vampiro, novel (I9I7); El porvenir de la A mérica latina (rgr8); José Martí (I9I8); El 7 I (I9I8); El porvenir de las pequenas nacionalidades (19I8); Los muertos mandan ... (I9I8); La mujer en la guerra (19I8).

\section{A N D M O N O G R A P H S}





\section{A N G U L O}

\section{MANUEL RAFAEL ANGULO}

\section{Lawyer; man of affairs.}

Manuel Rafael Angulo was born on the twenty-seventh of April, I855, in Matanzas where he received his early education and at the age of fifteen won the Bachelor's degree. He then entered the University of Havana to study law and continued his studies for a time in Spain, but returned to Havana to practice his profession.

In his youth he took an active part in politics, as a member of the Central Committee of the Autonomist party. During the War of Independence he founded the periodical $C u b a$ in New York which appeared in two editions-Spanish and Englist-both of which he edited. When, a little later, an Autonomist government was set up in Cuba he was made its representa-

H I S P A N I C N O T E S 


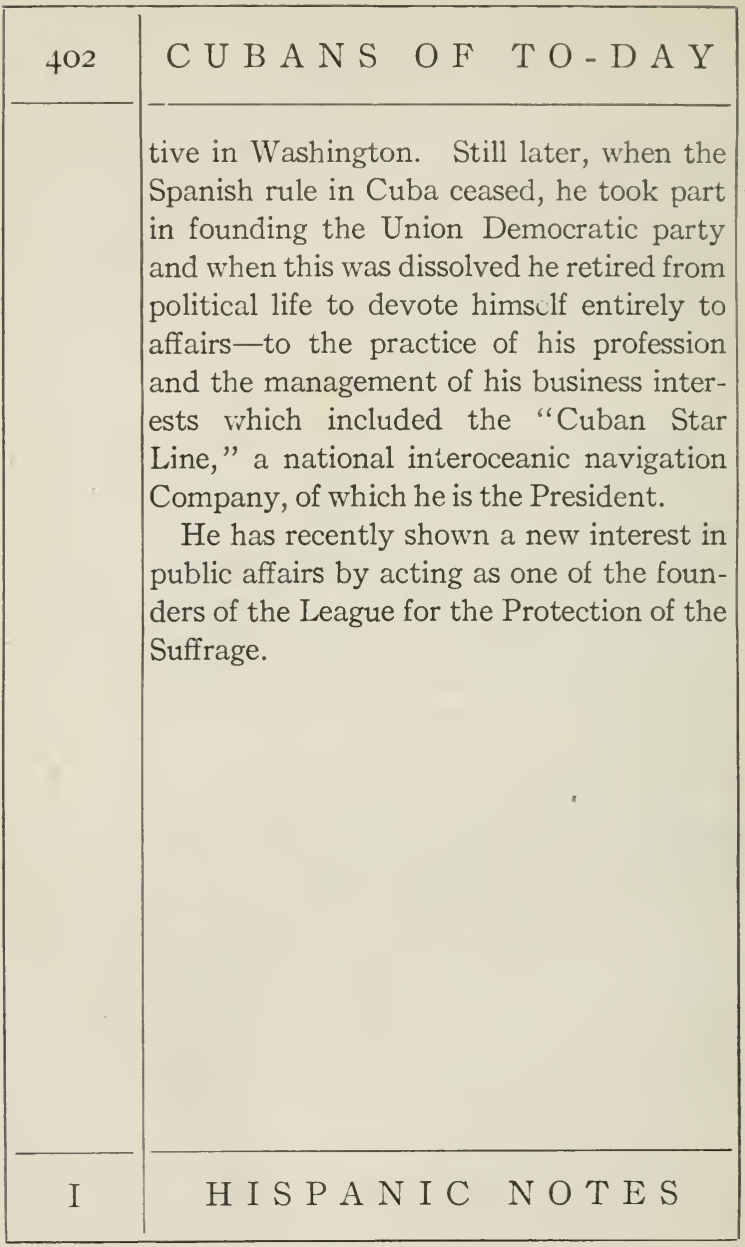





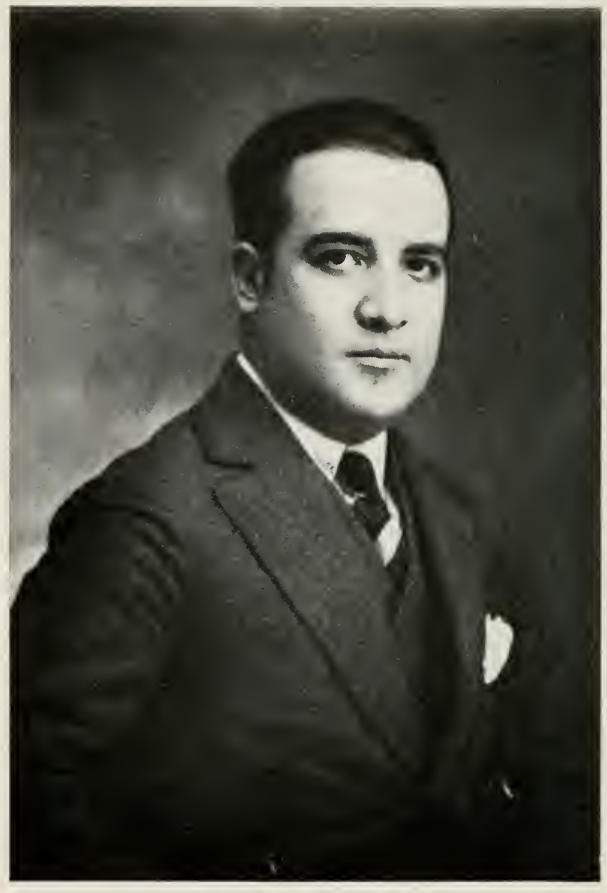

Conrado Walter Massaguer y Dias 
CONRADO WALTER MASSAGUER Artist; editor; manager.

Conrado Walter Massaguer y Díaz was born in Cárdenas, Cuba, on the third of May, I889. When he was seven years old his parents, to escape Spanish persecution, moved to Mexico taking him and his brother. There he attended school in the Literary Institute of Mérida, Yucatan, but soon after moved to the United States where he entered St. John's School, Ossining, N. Y., and later the New York Military Academy at Cornwall. There in I 908 he began drawing caricatures for the school paper. In 1907 he was drawing for the Yacatecan paper La Campana and was soon contributing to other papers in Yucatan, The Diario Yucateco, Artes $y$ Letras, La Arcadia, and Frou Frou.

In I 908 his family returned to Cuba and

\section{A N D M O N O G R A P S}




\begin{tabular}{|c|c|}
\hline 404 & C U B A N S O F T O - D A Y \\
\hline & $\begin{array}{l}\text { he became a contributor to El Figaro, } \\
\text { Letras, Cuba y América, El Triunfo, Don } \\
\text { Pancho, El Choteo, El Mundo, La Prensa, } \\
\text { Ultima Hora and La Lucha. } \\
\text { In I9I he held an exhibition of carica- } \\
\text { tures in the Ateneo of Havana and in I9I } 2 \\
\text { was made President of the section of } \\
\text { Fiestas of the Ateneo. In I9I } 2 \text { he paid a } \\
\text { visit to New York where he made his dé- } \\
\text { but in the New York A merican with cari- } \\
\text { catures of Broadway and accompanying } \\
\text { comment. In I9I3 the health of his family } \\
\text { obliged him to return to Havana where he } \\
\text { founded the Grafico of which he is Vice- } \\
\text { president and which he edited until I9r6. } \\
\text { In I9I6 he founded the magazine Social } \\
\text { of which he is Editor, and in the same year } \\
\text { he founded the Institute of Graphic Arts } \\
\text { of Havana of which he is President. In } \\
\text { I } 9 \text { I } 8 \text { he was appointed a member of the } \\
\text { Committee on the Fourth Liberty Loan } \\
\text { and in the same year he was elected to } \\
\text { the Board of management of the Club de } \\
\text { Pintures y Escultores. } \\
\text { When Cuba entered the war he made an } \\
\text { energetic Pro-allied campaign in caricature }\end{array}$ \\
\hline I & H I S P A I C NOTES \\
\hline
\end{tabular}




\section{A S S A G U E R}

and text in his papers, and lent active aid to the loan and to the Red Cross.

In I9I9 he produced the first number of Pulgarcito, a magazine for children. $\mathrm{He}$ is at work on preparations for the celebration of the Centenary of Havana to be held in December, I9I9.

$\mathrm{He}$ is a member of the Union and Rotary clubs as well as of various clubs of a purely social character. 




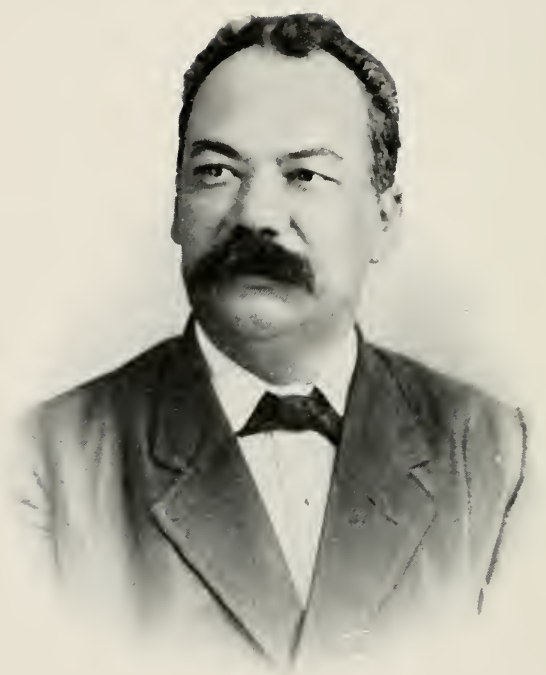

José A. Rodríguez García 


\section{R O D R Í G E Z G A R C Í A}

JOSÉ A RODRÍGUEZ GARCÍA

Teacher; writer.

José A. Rodríguez García was born in Matanzas on the twenty-second of February, I864. He removed to Havana where he was taught in private schools and in due course won his degree of Bachelor.

In $188_{2}$ he was appointed auxiliary Professor in the School of Arts and Crafts. In the following year he became Professor of Mathematics and later, on the reorganization of the plan of education, he was entrusted with the courses in Grammar, Geography, History, Accounting, and Economy. During the seventeen years of his service as Professor in the School of Arts and Crafts he continued his study of Philosophy and Letters and Law. He obtained his degree of Licentiate and later that of Doctor in Philosophy and Let-

\section{H I S P A I C NOTE S}




\begin{tabular}{|c|c|}
\hline 408 & C U B A N S O F T O - D A Y \\
\hline & $\begin{array}{l}\text { ters but did not complete the course in } \\
\text { Law. } \\
\text { In I } 900 \text { he was appointed Professor of } \\
\text { Grammar in the Institute of Matanzas, } \\
\text { and somewhat later entered the competi- } \\
\text { tion for the Chair of Grammar, Didactic } \\
\text { Literature, and the History of Spanish } \\
\text { Literature in the Institute of Havana. } \\
\text { In this he was successful and has since been } \\
\text { Professor in the Capital. } \\
\text { Dr. Rodriguez García has also taken an } \\
\text { active part in journalism. He has been a } \\
\text { member of the staff of El Dia and also of } \\
\text { La Noche and has published several maga- } \\
\text { zines. In I } 887 \text { he issued Cuba Intelectual; } \\
\text { in I } 898 \text { Los Domingos Literarios; in Ioo4 } \\
\text { El Teatro Cubano; and in I } 907 \text { a second time } \\
\text { Cuba Intelectual. } \\
\text { He has also written books in a number of } \\
\text { different fields-Law, History, Geography, } \\
\text { Philology, Mathematics, Literature, Gram- } \\
\text { mar, etc. } \\
\text { Among his publications are: Programa } \\
\text { de nociones de Gramática Castellana, Ha- } \\
\text { vana, I } 904 \text {; Enseñanza gradual de la Lengua } \\
\text { Castellana, Havana, I896; Programa de }\end{array}$ \\
\hline I & H I S P A N C N O T E S \\
\hline
\end{tabular}




\section{R O D R Í U E Z G A R C Í A}

principios de Gramática Castellana, Havana, I896; Principios de Ortografia, Havana, I896; Principios de Geografia, Havana, I 897; Gramatiquerias, Havana, I898; Ensayo de un Programa para la enseñanza gradual de la Gramática Castellana, Havana, I899; Bibliografia de la Gramática y Lexicugrafía Castellana, etc., 2 vols., Havana, I903-I9I3; Literatura Preceptiva, Havana, ı9ı4; De la Avellaneda, Havana, I9I4. 



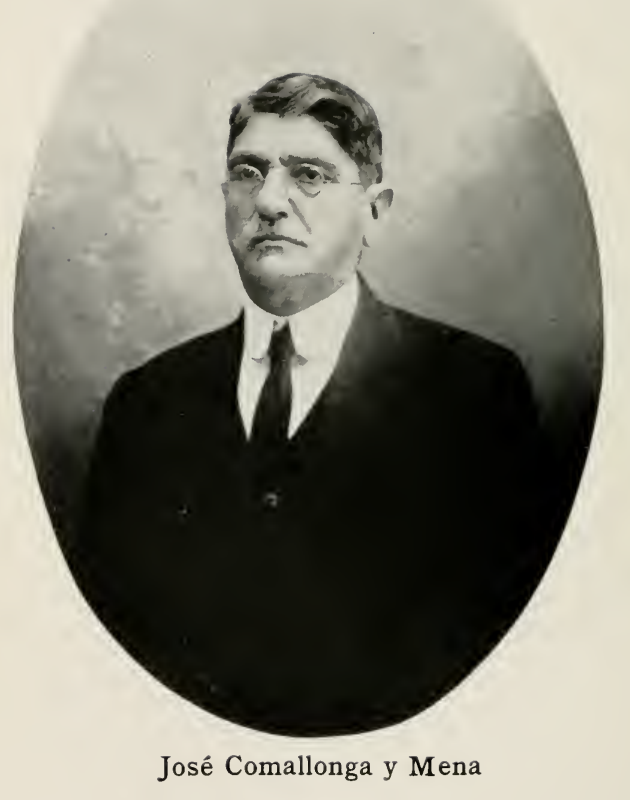




\section{O M A L L O N G A}

JOSÉ COMALLONGA Y MENA

Agriculturist ; teacher ; writer.

José Comallonga y Mena was born in Guantánamo, Province of Oriente, in the year I 865. Although he came of a family fairly well off, when he was fifteen he left home rather than adopt the commercial views of his family and go into business.

From the time he was fifteen until he was eighteen he lived a wandering life, marked by hardships and poverty, which led him into many parts of the Island. Under these unfavorable conditions, without the knowledge of his family or any aid or influence from any source, he entered a competition, set up by the now extinct Provincial Assembly of Santa Clara, for a scholarship at the Moré School of Agriculture, and notwithstanding the odds against him, won the prize. He then got to Havana 


\begin{tabular}{|c|c|}
\hline 412 & C U B A N S O F T O - D A Y \\
\hline & $\begin{array}{l}\text { as best he could and devoted his full ener- } \\
\text { gies to the study of Agronomical Engineer- } \\
\text { ing in which he gained his degree in I } 888 \text {. } \\
\text { Thereupon he paid a long deferred visit to } \\
\text { his home with his degree and with the satis- } \\
\text { faction of owing his success solely to his } \\
\text { own resolution and resources. } \\
\text { During the period of his study for his } \\
\text { degree he got his living by writing for news- } \\
\text { papers, making reports, and other jobs. } \\
\text { At this time he published a book of verses, } \\
\text { collecting those which he had written for } \\
\text { El Figaro and La Habana Elegante some of } \\
\text { which have since appeared in the anthology } \\
\text { of Cuban poetry entitled Arpas Cubanas. } \\
\text { On completing his studies Comallonga } \\
\text { devoted himself to what was then a new } \\
\text { science in Cuba-that of the Chemistry of } \\
\text { Sugar-making-and during fourteen years } \\
\text { served as expert for the leading sugar mills } \\
\text { of the island, seven of which he spent at } \\
\text { the Central Constancia which from I } 890 \text { to } \\
\text { I } 895 \text { had the reputation of being the first } \\
\text { sugar mill in the world. } \\
\text { When the Independence of Cuba was } \\
\text { declared he took an active interest in ob- }\end{array}$ \\
\hline I & H I S P A I C N O T E S \\
\hline
\end{tabular}




\section{O M A L L O N G A}

taining recognition for the academic degrees which had been granted by the School of Moré and as result of his labors secured the validation of his own degrees by the University. Thereupon he presented himself in competitive examination for a professorship in the School of Agronomy in the University, but failed to win it. A little later he entered a new competition for the chair of Agriculture in the Provincial Institute of Oriente Province, which he won. After four years he entered a new competition for the chair of Agriculture in the Institute of Santa Clara, in which he was successful notwithstanding that among his rivals was the famous Cuban authority on agriculture Don Juan Bautista Jiménez.

At this time he was appointed by the government of President Estrada Palma, although he was a political opponent, Commissioner to study the Naudet system, upon which he published a pamphlet designed to prevent the landowners from loss and injury by adopting the new method.

In 1907 he entered a competition for the

A N D M O NOGRAPHS 


\begin{tabular}{|c|c|}
\hline 414 & C U B A N O F T O - D A Y \\
\hline & $\begin{array}{l}\text { Professorship of Rural Economy, etc., in } \\
\text { which he was successful and which he now } \\
\text { occupies. } \\
\text { He was appointed at the same time by } \\
\text { President Gómez, Director General of } \\
\text { Agriculture, and in this position he set up } \\
\text { the six model Agricultural schools which } \\
\text { Cuba has and in which I } 80 \text { children of rural } \\
\text { Cuba are annually taught, clothed, and fed } \\
\text { by the state. } \\
\text { Under the administration of General } \\
\text { Gómez (I9o8-r } 2 \text { ) Comallonga was also ap- } \\
\text { pointed Commissioner of theCuban Govern- } \\
\text { ment to study agricultural instruction in } \\
\text { France,Belgium,Switzerland, andtheUnited } \\
\text { States, publishing a report on his return. } \\
\text { He set up in the Department of Agriculture } \\
\text { the Government agronomical service and } \\
\text { the National Agricultural Laboratory. At } \\
\text { the end of General Gómez's term of office } \\
\text { Comallonga retired from public service to } \\
\text { resume his chair at the University. } \\
\text { In I } 915 \text { he was appointed by President } \\
\text { Menocal, Delegate to the Second Pan- } \\
\text { American Scientific Congress, held in } \\
\text { Washington; President Menocal also in- }\end{array}$ \\
\hline I & H I S P A N I C \\
\hline
\end{tabular}




\section{O M A L L O N G A}

vited Comallonga, in collaboration with Dr. Francisco Henares, to direct the publication of a Portfolio of the Sugar Industry said to be the most sumptuous publication yet produced in Cuba.

He has published: Manual del quimico y maestro de azícar cubano, Habana, I897; Memorandum, Teoria de los Triple Efectos, Santiago de Cuba, r903; La Industria azucarera en Cuba, Habana, I9o6; Por la cultura agrícola, Villaclara, I908; La Feria y el Dr. Sacc, Habana, I9I r ; Acciones Agricolas de algunos Gobiernos europeos, Habana, I9I I ; La instrucción agrícola en Cuba, Habana, I913; Lecturas agricolas para los niños, Habana, I9I4; Portfolio de la industria azucarera, Habana, I915; (and in collaboration with Senorita Ortiz), Tratado de enseñanza de economía doméstica y agricultura, Habana, r9r8.

\section{A N D M O N O G R A P H S}





\section{E N O C A L}

\section{JUAN MANUEL MENOCAL}

Lawyer; soldicr; magistrate.

Juan Manuel Menocal y Fernández DE Castro was born in Matanzas in 1870 , and began his studies in his birthplace where he took the courses leading to the Bachelor's degree in the Institute and was awarded the title after examination. Thence he went to Havana, entered the University, and was made Advocate in I894.

He had practiced his profession only a year when the War of Independence broke out and he joined the revolutionists. $\mathrm{He}$ was a member of the expedition under the command of General Collazo which landed on the beach of Varadero, Hicacos Peninsula, Matanzas, in March, I896, and he continued in the service, fighting in the provinces of Matanzas, Las Villas, and Ha-

H IS P A N I C N O T E S 


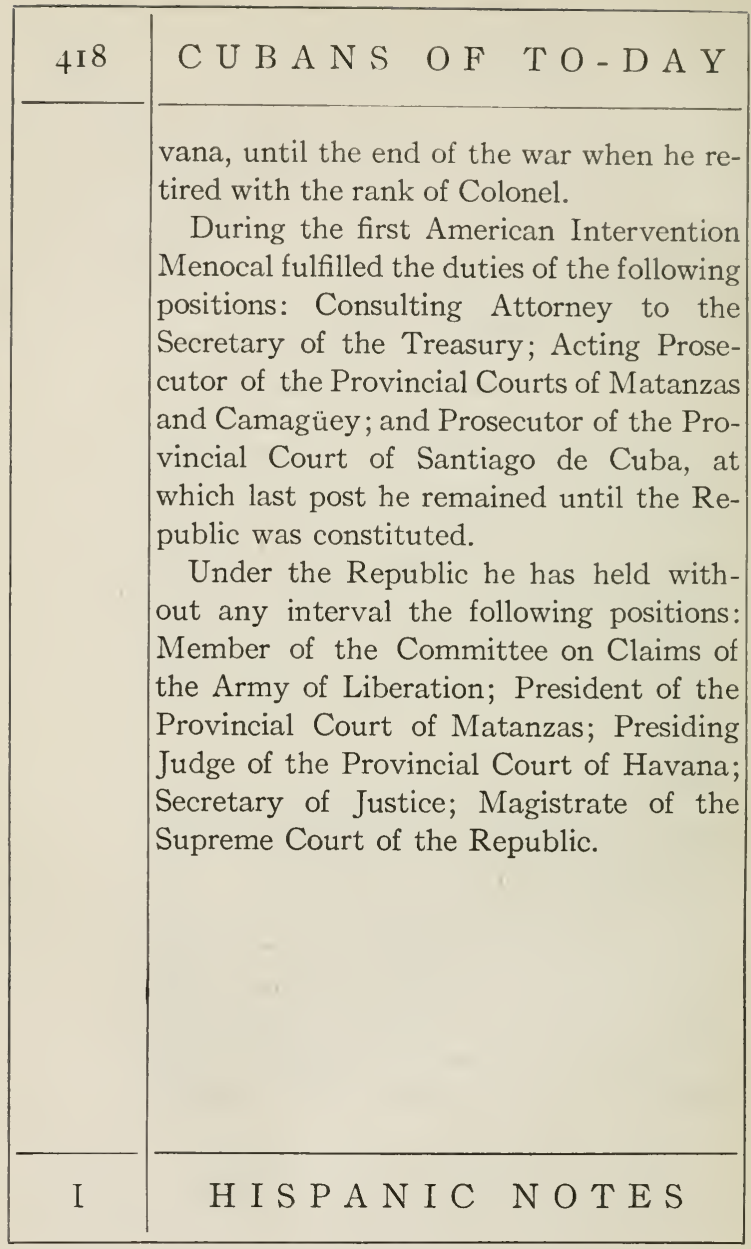




\section{G U I R A L}

\section{RODOLFO GUIRAL}

Oculist.

Rodolfo Guiral y Viondi was born on the eleventh of February, I874, in Guanabacoa and there, in the church schools, he obtained his education as far as the Bachelor's degree. He then entered the University of Havana, began the study of Medicine, and obtained his degree as Doctor in 1898 .

In the practice of his profession he has devoted himself to ophthalmology, in which he has had an exceptionally wide range of experience both in public and private practice.

In 1908 he was appointed head of the Doctor Enrique López Eye Clinic and retained that post for four and a half years. He was then appointed oculist of the Hospital of Guanabacoa, remaining at this

\section{A N D M O N O G A P H S}




\begin{tabular}{|c|c|}
\hline+20 & C U B A N S O F T O - I A Y \\
\hline & $\begin{array}{l}\text { post three years. In Igor he was made } \\
\text { oculist of the Centro Balcar (Balearic Is- } \\
\text { lands Club); and resigned in Igo6 when } \\
\text { he became oculist of the Centro de De- } \\
\text { pendientes (Clerks Club), which position } \\
\text { he later resigned. } \\
\text { In I } 908 \text { he established a clinic of his } \\
\text { own which bears his name. Meantime at } \\
\text { one period or another he has been oculist } \\
\text { to all the societies for mutual help in Ha- } \\
\text { vana and on occasion has been attending } \\
\text { all of them at the same time. } \\
\text { Dr. Guiral has contributed to the pro- } \\
\text { gress of his profession by various studies } \\
\text { and experiments; he has completed a. set } \\
\text { of slides for stereoscopic use containing } \\
\text { four hundred slides which exhibit the whole } \\
\text { of the surgery of the eye, and has set } \\
\text { up a complete laboratory of photomicro- } \\
\text { graphy, the only one in Cuba. } \\
\text { He is the inventor of the treatment for } \\
\text { the care of Oftalmia blenorragica in children } \\
\text { which has proved successful in I, } 200 \text { cases. } \\
\text { He is also the inventor of the operation } \\
\text { called Diverticulo canaliculotomia and of the } \\
\text { special instrument for this operation. He }\end{array}$ \\
\hline I & H I S P N I C NOTES \\
\hline
\end{tabular}




\section{G U I R A L}

has, moreover, effected a modification in Professor Elliot's operation for trepanning by which the trepanning of the eye in glaucoma is harmless. Dr. Guiral has held no political office, but during the War of Independence he served on the Revolutionary Committee of his native city.

$\mathrm{He}$ has been Secretary of the Board of Judges in competitive examinations for the Chair of Ophthalmology in the University.

He has published: La Oftalmia purulenta, Havana, г9г3; Diagnóstico diferencial de la conjuntivitis granulosa, etc., Havana, r9r3; Clinica quirúrgica estereoscópica de los ojos (with $35^{\circ}$ stereoscopic photographs), Havana, r9ı6; Nociones de Oftalmología necesaria al médico general, Havana, r9i6; La antisepsia en Cirugía ocular, I918.

\section{A N D MONOGRAPH s}





\section{FRANCISCO DEL RIO}

Physician; teacher.

Francisco del Rio y FerRer was born in Havana on the twenty-seventh of December, I880, but was educated chiefly in Spain. He won the degree of Bachelor at the Institute of Granada in 1897; then, going to Seville, he studied at the University and graduated as Doctor of Veterinary Medicine in 1905 . In the following year he gained the same degree in the University of Havana, which also granted him the degree of Doctor of Pharmacy in I913 and that of Doctor of Medicine and Surgery in I9I 8.

In 1904 he was appointed Assistant in the Faculty of the Veterinary School of Córdoba (Spain). In 1906 the Board of Health of Havana made him Veterinary Inspector. In 1907 he was appointed

H I S P A I C N O T E S 


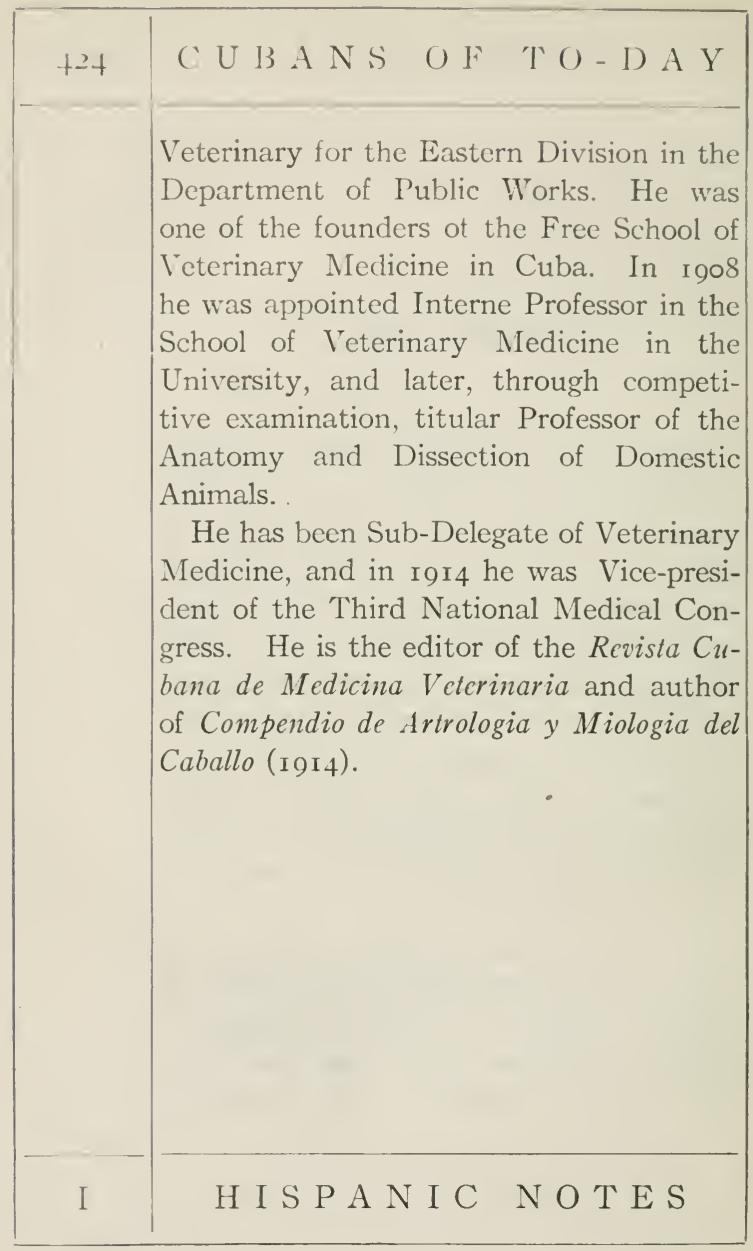





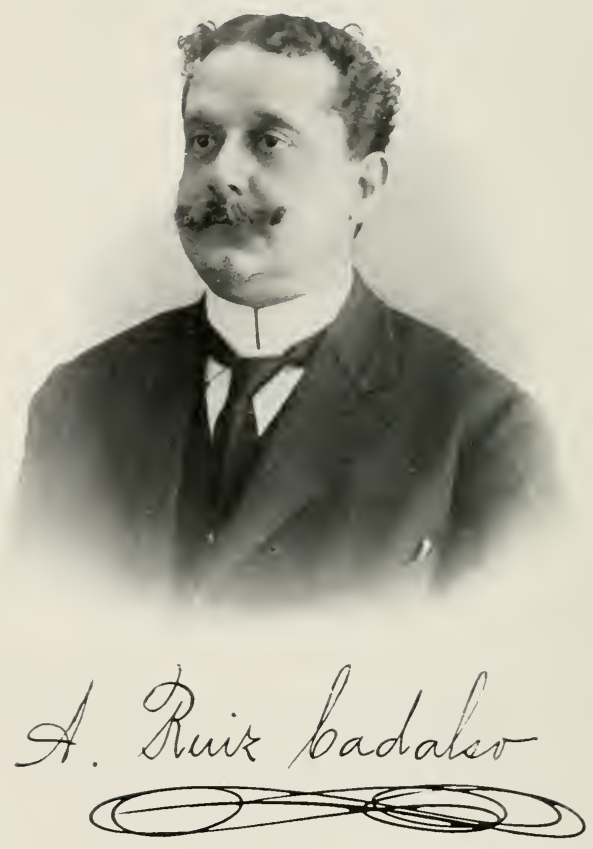




\section{A D A L S O}

\section{ALEJANDRO RUIZ CADALSO}

Engineer; architect; teacher.

Alejandro Ruiz. Cadalso was born on the twenty-fourth of April, r872, in Havana, and there he gained his education in the Institute, where he obtained the degree of Bachelor; in the Professional School where he won the titles of Agrimensor and Maestro de Obras, and in the University where he was made Doctor of Physico-Mathematics and Civil Engineer.

In 1898 he was appointed Auxiliary Professor of the Professional School and in I 9०0, through competitive examination, he won the chair of Surveying, Topography, and Measuration. When the Academy of Arts and Letters was organized he was made a charter Member.

He made the survey for the Municipal Terminal, executing for it the first geodeti-

A N D M O N O G R A P H S 


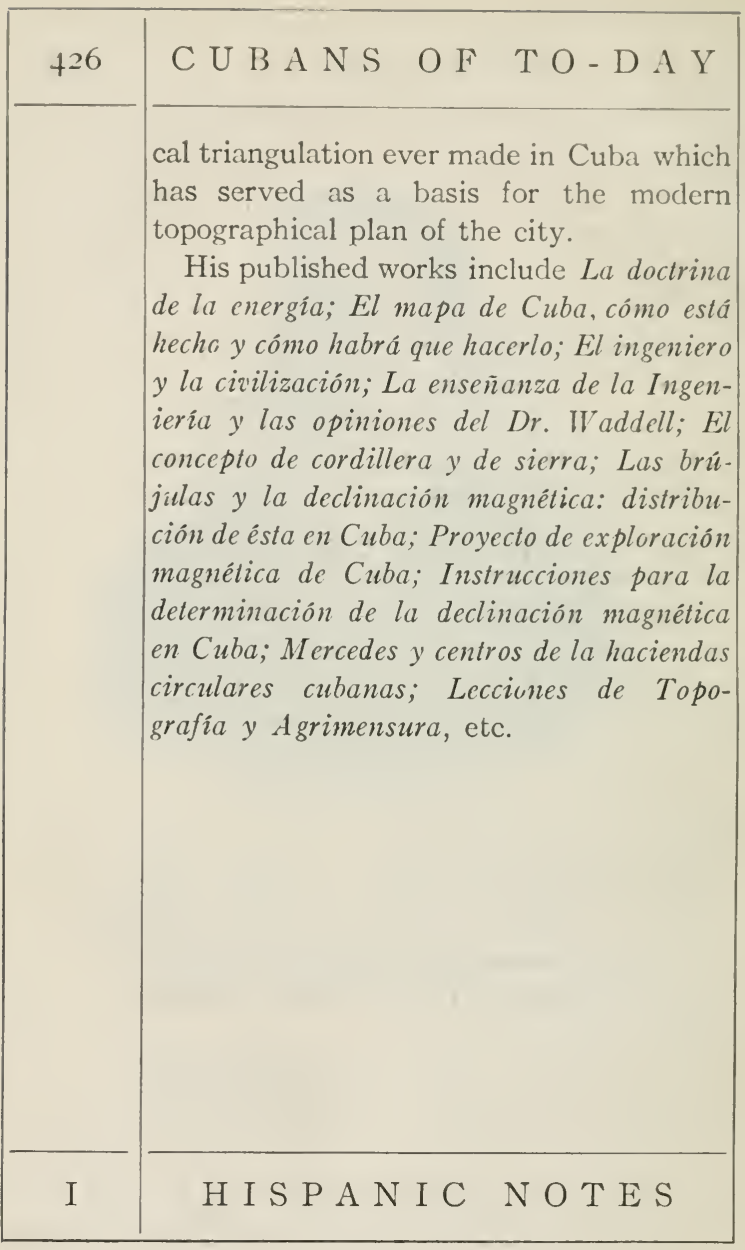




\section{B R O U W E R}

\section{JULIO E. BROUWER}

Veterinary; surgeon; scientist.

Julio E. Brouwer y Etchecopar was born on the twentieth of December, I879, in the city of Matanzas, Cuba, but he was educated in France. His early studies were taken at the St. Bernard College of the La Salle brotherhood in Bayonne; later he entered the Lycée of Bordeaux in which he gained his degree of Bachelor of Letters, and Mathematics at the University in I899. In the same year he was admitted, after a competition, to the Veterinary School of Alfort where he continued three years, and then passed on to the school of Toulouse where he obtained his degree of Veterinary in 1905 .

On his return to Cuba he was made Veterinary of the General Board or Health and took charge at the same time of the Laboratory of Epizooty. On the establishment by Congress of the Agricultural

\section{A N D M O N O G R P H S}




\begin{tabular}{|l|l|}
\hline 428 & $\begin{array}{l}\text { C U B A N S O F T O - D A Y } \\
\text { Stations, Dr. Brouwer was made I Irector } \\
\text { of the Camaguey Station. In I 907 he was } \\
\text { appointed, after competitive examination, } \\
\text { Veterinary Lieutenant in the Rural Guard. } \\
\text { He was one of the founders of the Free } \\
\text { Veterinary School afterwards incorporated } \\
\text { into the University. In I9o8 he was ap- } \\
\text { pointed, after competitive examination, } \\
\text { titular Professor of Pathology, Surgery, } \\
\text { Clinical Surgery, Operations, and Theory } \\
\text { and Practice of Farriery and Horseshoeing. } \\
\text { When the Training School for Horseman- } \\
\text { ship was organized for the officers of the } \\
\text { Rural Guard, Dr. Brouwer was made } \\
\text { Foundation Protessor of the institution } \\
\text { and for two yeals lectured on Military } \\
\text { Horsemanship. } \\
\text { In the exercise of his profession he } \\
\text { founded the first Clinic for dogs in Cuba, } \\
\text { and was one of the tounders of the Pasteur } \\
\text { Laboratory of Havana of serums and vac- } \\
\text { cines and is its Director. He was also the } \\
\text { organizer of the first Dog Show in Cuba. } \\
\text { He is the author of Hipologia Militar, } \\
\text { which was made the textbook in the mili- } \\
\text { tary Academy. }\end{array}$ \\
\hline H I S P A N I C N O T E S \\
\hline
\end{tabular}





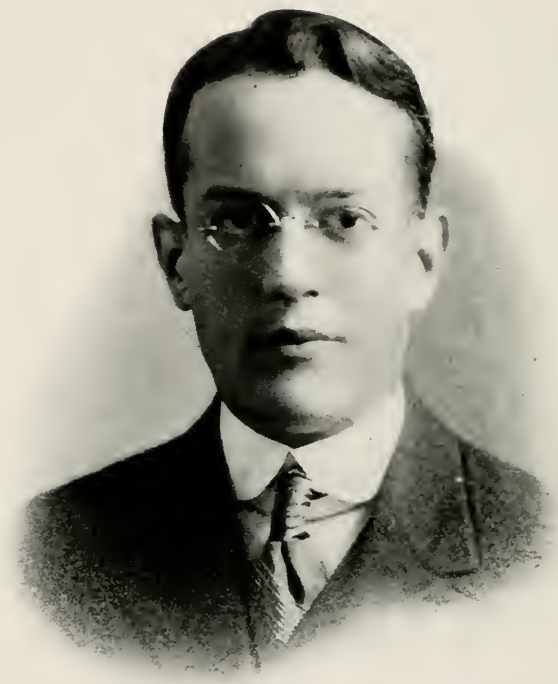

Ricardo M. Aleman 


\section{A L E M Á N}

\section{RICARDO M. ALEMÁN}

Lawyer; teacher; writer.

Ricardo M. Alemán y Martin was born in Havana on the twenty-first of August, I89r. After taking his early studies in the Institute of Havana he went to New York where he studied for a time in the "La Salle Institute," but returned to Havana to complete his course and obtained the degree of Doctor of Civil Laws in June, I9I4.

$\mathrm{He}$ is one of the original members of the Cuban Society of International Law and was Vice Secretary of the First National JuridicalCongress which met in December, r 9 I 6.

In I9I 7 he was elected Fourth Deputy of the Board of Governors of the Bar Association (Colegio de Abogados) of Havana and in I9r 8 he was chosen First Deputy of the board.

\section{A N D MONOGRAPHS}




\begin{tabular}{|c|c|}
\hline 430 & $\mathrm{C} U \mathrm{BAN}$ A O F TO $\mathrm{T}$ - D A Y \\
\hline & 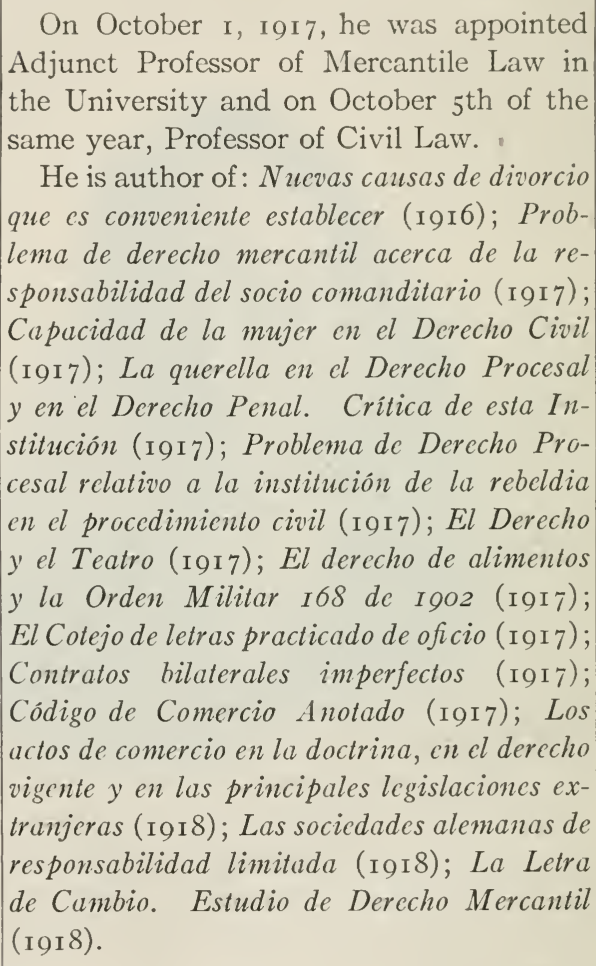 \\
\hline I & H I P A N I C N O T E S \\
\hline
\end{tabular}




\section{R E M O S}

\section{JUAN J. REMOS}

Critic; writer; lecturer.

Juan J. Remos y Rubio was born on the eighth of April, I896, in Santiago de Cuba, where he began his schooling. In October, I908, he entered the Institute of Havana, for which special permission was required because he had not reached the required age for admission. He gained the Bacheor's degree in $19 \mathrm{I} 2$ and in the following year entered the University where he completed the required course for the Doctor's degree in two years.

In I 9 I I, while he was still a student, he founded the Sociedad de conferencias Demostenes, and in 1913 the Sociedad de Estudios Artisticos, in which he has taken an active part and is one of the three Directors, the others being Doctors Sergio Cuevas Zequeira and José Cosculluela. On

\section{A N D M O N O G R A P H S}




\section{$+32$

C U B A N S O F T O-D A Y

the reorganization of the Ateneo of Havana in June, I9 15, Dr. Remos was made Secretary of the Fine Arts section and initiated a series of great popular concerts.

In 1917, on being elected President of the section, he developed an extensive plan for lectures, concerts, meetings, and interchange of ideas with other Latin-Americans.

In September, I9 1 5, he was made Sccretary of the Falcón Conservatory of Music.

In I9I4 he founded the magazine Arte which gained a large measure of success. In I9I5 he was appointed Professor of Spanish Language and Literature in the "English College" of Marianao and in I9I 7 he won in competitive examination the post of first auxiliary Professor of Spanish Grammar and Literature in the Institute of Havana.

Dr. Remos has contributed to the principal periodicals of Cuba and has published the following works: Curso de Historia de la Literatura Castellana (2 vols.); Introducción al Teatro de Schiller; Movimicnto intelectual de Cuba en el siglo XX; La cuestión de oriente y sus relaciones con los estados de

\section{H I S P A N I C NOTES}


Europa (doctor's thesis); Cursos abreviados de Filosofía Historia y Literatura Musicales; Adaris (drama); 27 de Novicmbre y Certámenes artísticos (addresses), La toma de la Bastilla, Meyerbeer, Francia bajo Luis $X I V$, Donizetti, El arte materialista de Fidias y el arte espiritualista de Miguel Angel y Las célebres obras literarias en música (lectures). 




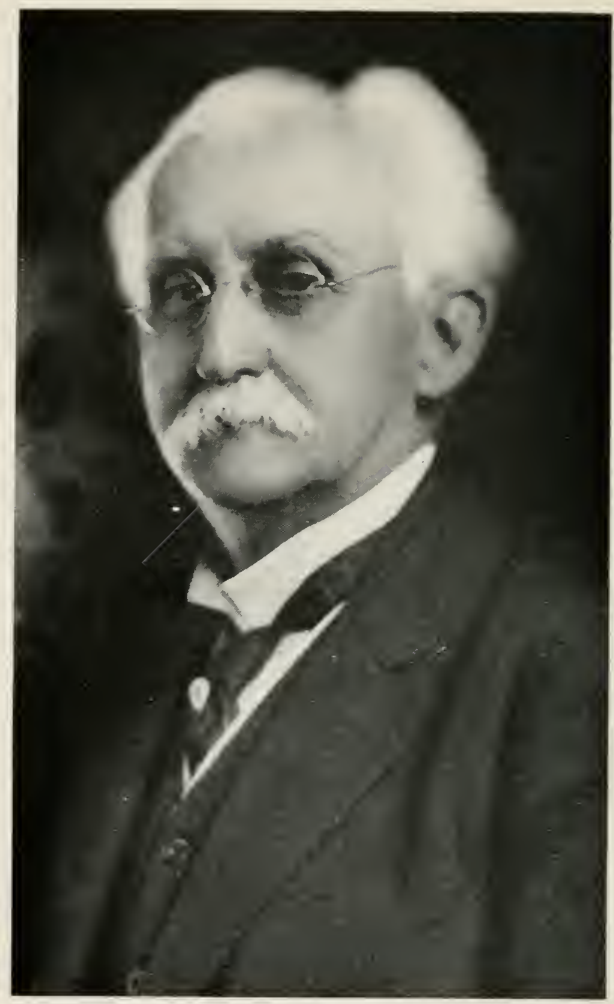

By permission of Harris-Ewing, photographers (Washington, D. C.)

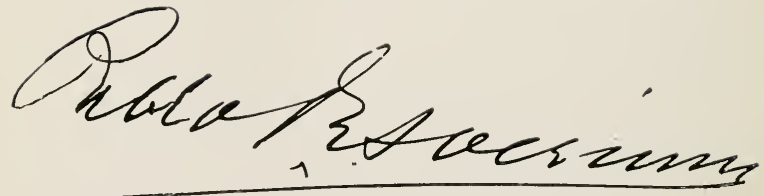




\begin{tabular}{|} 
D E S V E R N I N E \\
\hline PABLO DESVERNINE \\
Scholar; teacher; diplo- \\
matist; Secretary of State \\
in the Republic of Cuba, \\
ThE Premier in President Menocal's \\
Cabinet has had the fortune to run a long \\
and distinguished career almost wholly in \\
the city where he was born and grew up. \\
Except tor two comparatively brief periods \\
spent in the United States, the first at \\
Columbia University where as a student \\
he obtained the degree of LL.B. and the \\
second in Washington where he represented \\
his country as its Minister, his life has \\
been passed in Havana where he was born \\
in the year I 854. \\
He studied at the University of Havana \\
and practiced law in the Havana courts. \\
In I899 he was appointed by General \\
Brooke, the American Military Governor, \\
\hline H I S P A N I C N O T E S
\end{tabular}




\begin{tabular}{|c|c|}
\hline 436 & 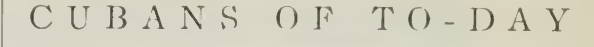 \\
\hline & $\begin{array}{l}\text { to be Chief of the Cabinet to the general } \\
\text { satisfaction of the people. In the follow- } \\
\text { ing year he was made Professor of Civil } \\
\text { Law in the University where he has con- } \\
\text { tinued to teach with occasional interrup- } \\
\text { tions. In I9I I he was made President of } \\
\text { the Exposition of Agriculture, Industry, } \\
\text { Art, and Labor. In I9I3 President Men- } \\
\text { ocal appointed him Envoy Extraordinary } \\
\text { and Minister Plenipotentiary to Washing- } \\
\text { ton, then as now the most important and } \\
\text { responsible diplomatic post to a Cuban. } \\
\text { In I } 94 \text { he was made Secretary of State. } \\
\text { Author: "Special Report of the Secre- } \\
\text { tary of Finance to General John R. Brooke, } \\
\text { U. S. A., Governor General of Cuba. Ha- } \\
\text { vana, I899. El Derecho y la Sociologia, } \\
\text { Habana, I9oo; Conferencia sobre el prob- } \\
\text { lema monetario de Cuba. Habana, I904; } \\
\text { Discurso leido en la apertura del curso aca- } \\
\text { démico de I9Io a I9II. Universidad de la } \\
\text { Habana, I9Io. }\end{array}$ \\
\hline I & H I S P N I C NOTES \\
\hline
\end{tabular}



7. 11. Cerambuin 


\section{A R A M B U R U}

JOAQUIN N. ARAMBURU

Journalist; educator; auhor.

Johquin N. Aramburu was born in Guanajay, Province of Pinar del Rio, on the tenth of September, I 855. He was educated at home, and in the public schools of his native town; never has attended college or university, but has increased his scanty early equipment by constant reading and the regular work of journalisnı. To this he has devoted his lite, having been, during his career of forty years, the founder of eight papers and an editor of no fewer than twenty. For the past fifteen years he has been on the staff of the Diario $d c$ la Marina. Besides his services to Cuban papers he has been correspondent of several European periodicals.

Of public offices Señor Aramburu has held but one-that of Secretary of the

\section{A N D M O N O G R P H S}




\begin{tabular}{|c|c|}
\hline 438 & $\mathrm{C}$ U B A N S O F TO - D A Y \\
\hline & 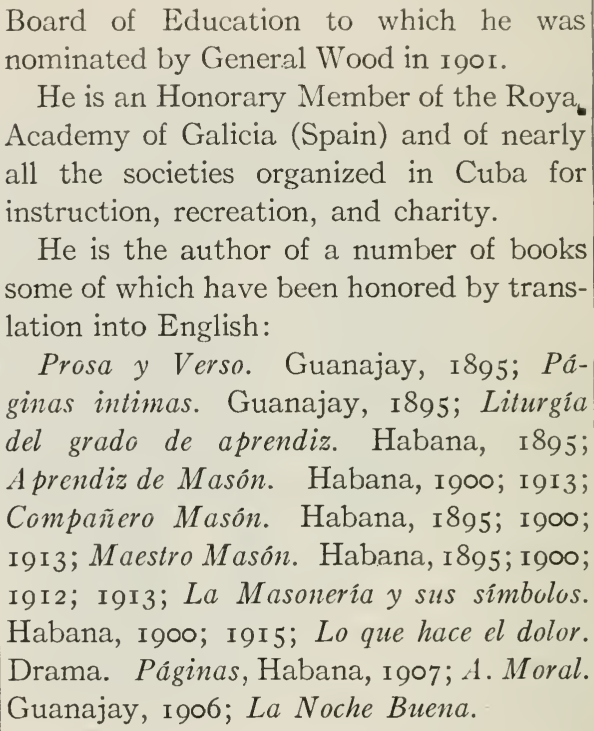 \\
\hline & . \\
\hline I & H I P A N I C N O T E S \\
\hline
\end{tabular}




\section{SANTIAGO GARCÍA CAÑIZARES}

\section{Physician; public man.}

Santiago García Cañlzares was born on the seventh of July, I862, in Sancti Spiritus, the birthplace of his mother; his father was a Spanish army officer. He prepared for the Bachelor's degree in the Jesuit College of Sancti Spiritus and in I 878 entered the University of Havana where he obtained the Licentiate in Medicine in $\mathrm{r} 884$ and the Doctorate in $\mathrm{I} 886$.

$\mathrm{He}$ began the practice of his profession in the Isle of Pines and continued it in his native city where, besides serving on the Board of Education and the Board of Hospital Patrons, he edited a periodical $L a$ Igualdad. He held the position of Director of Coast Sanitation until I 895 when, at the outbreak of the War of Independence, he joined the revolutionaries.

\section{A N D M O NOGRAP H S}




\begin{tabular}{|c|c|}
\hline 440 & C UBANS OF TO-DAY \\
\hline & $\begin{array}{l}\text { In the same year he was elected to re- } \\
\text { present the Fourth Army Corps in the } \\
\text { Constitutional Assembly where Cuban } \\
\text { independence was declared and the con- } \\
\text { stitution signed. By unanimous vote of } \\
\text { that Assembly he was chosen Secretary of } \\
\text { the Interior of the Revolutionary govern- } \\
\text { ment, and performed the duties of that } \\
\text { office during the two years of the constitu- } \\
\text { tional régime. From I } 897 \text { until the end } \\
\text { of the war he held the rank of Colonel in } \\
\text { the Sanitary Service. } \\
\text { Following this, as Mayor of Sancti } \\
\text { Spiritus he organized departments of health } \\
\text { and education, established orphanages } \\
\text { and other philanthropies. } \\
\text { In Igor the Republican party of which } \\
\text { he was one of the founders, elected him to } \\
\text { represent the Province of Santa Clara in } \\
\text { the Cuban House of Representatives where } \\
\text { he served several terms as president. } \\
\text { He has always been an earnest and active } \\
\text { partizan; in Congress he has worked for the } \\
\text { extension and regulation of charities and } \\
\text { has been the author of various bills looking } \\
\text { toward public betterment. }\end{array}$ \\
\hline I & H I P A N I C NOTES \\
\hline
\end{tabular}




\section{J O S É G. V I L L A}

JOSÉ G. VILLA

Writer; teacher.

JosÉ G. VILLA was born on the thirteenth of January, 1850 , in Matanzas and obtained his education in his native place. He first studied Pharmacy, later turned to technical and practical Electricity and at last to teaching, in which he gained a place as Professor of primary instruction and English in a mercantile Academy.

Sr. Villa has written much both in prose and verse for many periodicals, many of his contributions appearing in the Havana magazine Cuba y América. He has also edited and published periodicals of his own which have had more or less success, for example, El Ramo de Acacia, a masonic paper; El Pajaro Sirvidango, a furtive paper issued during the period of freedom of the press in 1869; El Consuelo de los Pobres,

\section{A N D M O N O G R A P H S}




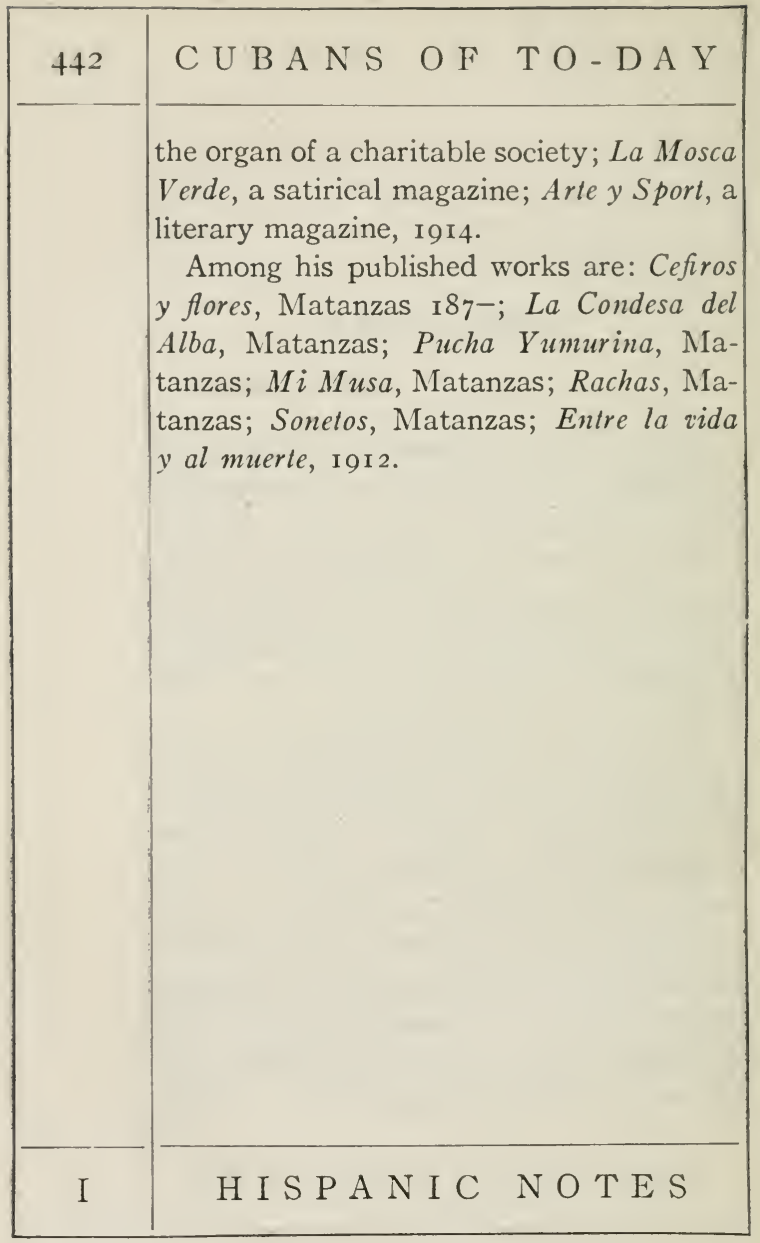




\section{I G U E L}

PABLO MIGUEL Y MERINO

Teacher; mathematician.

Pablo Miguel y Merino was born in Havana on the twentieth of September, 1887. He attended the Colegio de Belen (1898-1903) and the University of Deusto, Bilbao (Spain) (1903-1904), then, entering the University at Havana, took his major work in mathematics. In Igog he was graduated with the degree of Doctor in Physical Science, Mathematics, Civil Engineering, and Architecture.

During his student days, Dr. Miguel began work in the University as instructor in astronomy, later being appointed to an adjunct professorship and in I9I 2 to a full professorship in which capacity he now serves (I9I9).

He is the author of a book on the Elements of Higher Algebra.

\section{A N D M O N O G R A P H S}




ofemistockengetan coust 


\section{B E T A N COUR T}

TEMÍSTOCLES BETANCOURT Y CASTILLO

Lawyer, Magistrate.

Temístocles Betancourt y Castillo was born at Camagüey on the fifteenth of May, I873, where he was educated and from where he proceeded to the University of Havana, in which he graduated in law. During the Spanish régime, as well as the period of intervention, and afterwards under the Republic, he has served in various public positions, beginning with District Attorney for Camagüey and occupied in succession the following posts: Court Officer of the Provincial Court of Camagüey, Judge of the First Instance, etc., of Moron; Judge of Instruction, etc., of Pinar del Rio; Secretary of the Provincial Court of Santa Clara; Prosecuting Attorney of Provincial Court of Oriente; Magistrate

\section{H I S P A I C NOTES}




\begin{tabular}{|c|c|}
\hline $44^{6}$ & $-\mathrm{C} U \mathrm{BANS} O \mathrm{O}$ F T $\mathrm{O}-\mathrm{DA} \mathrm{Y}$ \\
\hline & $\begin{array}{l}\text { of the Provincial Court of Camagücy and } \\
\text { Presiding Judge of the same court. He } \\
\text { was made Public Master of the first and } \\
\text { second grade because of special services } \\
\text { and is on the Board of Examiners in Cama- } \\
\text { güey and Ciego de Avila. } \\
\text { He occupies the post of Official Lecturer } \\
\text { in the summer normal schools and is in } \\
\text { charge of the courses on Geography and } \\
\text { Civic Instruction. He is an honorary } \\
\text { member of the Association of Masters in } \\
\text { Law, at Camaguey, a member of the Veter- } \\
\text { ans' Association and of the Nautical Club } \\
\text { at Moron, and he holds the post of lecturer } \\
\text { for the above Association of Masters in } \\
\text { Law. He is active as managing member } \\
\text { and secretary of the board of directors of } \\
\text { the Puerta Principe and Nuevigas Railway. } \\
\text { He has also held the chair of Geography } \\
\text { and Universal History in the Provin- } \\
\text { cial Institute at Camagüey. He is the } \\
\text { author of a work with notes on the Organic } \\
\text { Law of Judicial Powers, and a treatise on } \\
\text { Extenuating Circumstances in the Penal } \\
\text { Code. He has published articles on Meth- } \\
\text { odology, Natural Sciences, Geography, }\end{array}$ \\
\hline I & H I S P N I C NOTES \\
\hline
\end{tabular}




\section{B E T A N C O U R T}

and Physiology, and two pamphlets on Episodes in the War of Independence up to the arrival in Cuba of the First President of the Republic. He has contributed as a writer of scientific and literary articles, to many Cuban magazines, his contributions ranging from the field of poetry to the field of agriculture. In party politics he is a member of the old National party and is often heard on the public platform of his own city.

\section{A N D M O NOGRAP H S}






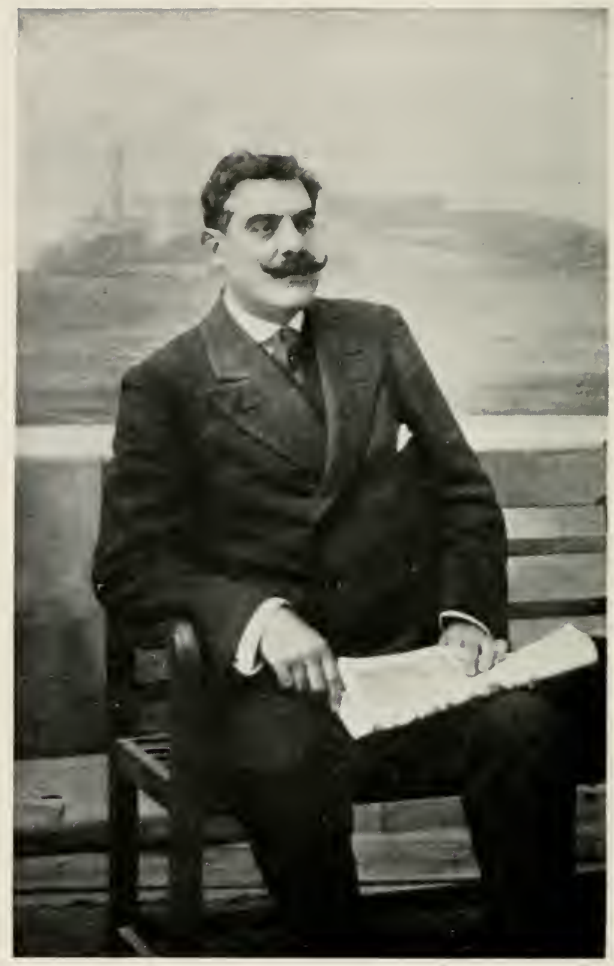

Emilio Bobadilla ("Fray Candil") 


\begin{tabular}{|c|c|}
\hline B O B A D I L L A & 449 \\
\hline $\begin{array}{l}\text { EMILIO DE BOBADILLA } \\
\text { (Fray Candil) } \\
\text { Critic; poet; novelist. } \\
\text { Emilio DE BoBADILLA, widely known by } \\
\text { the pseudonym Fray Candil, was born in } \\
\text { the city of Cárdenas, Cuba, in I } 872 \text {. His } \\
\text { father, Don José Sixto de Bobadilla, a } \\
\text { descendant of the Spanish Knight, Fran- } \\
\text { cisco de Bobadilla who carried Columbus } \\
\text { to Spain in chains in I } 500 \text {, was an attorney } \\
\text { well known in Havana in his day and a pro- } \\
\text { fessor in the Law Department of the Uni- } \\
\text { versity. He desired that his son should } \\
\text { study law and succeed to his practice and } \\
\text { prestige; but the boy's bent was totally } \\
\text { different. } \\
\text { As a youth of fifteen or sixteen, a student } \\
\text { in the University of Havana, young Boba- } \\
\text { dilla felt an irresistible attraction toward } \\
\text { literature as a career; and began writing }\end{array}$ & \\
\hline H I S P A I C NOTES & I \\
\hline
\end{tabular}




\begin{tabular}{|l|l|}
\hline 40 & $\begin{array}{l}\text { C U B A N S O F T O - D A Y } \\
\text { for the local papers and reviews under the } \\
\text { name which he afterwards made famous. } \\
\text { From the first he gave indications of a } \\
\text { vein of satire and keen critical ability, } \\
\text { which made it evident to himself and his } \\
\text { family that he must devote himself to } \\
\text { letters. The intellectual poverty and the } \\
\text { narrow social atmosphere ot the oppressed } \\
\text { colony were odious to the young man and } \\
\text { upon the death of his father he sailed for } \\
\text { Spain. At twenty years of age he arrived } \\
\text { in Madrid, the metropolis of his race and } \\
\text { his tongue, where he was already known in } \\
\text { journalistic circles through his work for } \\
\text { Cuban and South American periodicals. } \\
\text { He at once entered the Central Univer- } \\
\text { sity of Madrid and completed his legal } \\
\text { studies but with his mind fixed always on } \\
\text { literature. He collaborated in the work } \\
\text { of El Imparcial and other Madrid papers } \\
\text { soon becoming recognized as a critic of } \\
\text { power, discernment, and independence. } \\
\text { His fearless sincerity naturally won him } \\
\text { enemies, but in the Spanish speaking world } \\
\text { he is known as one of the critics of the } \\
\text { day. A duel which he had with the famous }\end{array}$ \\
\hline H I S P A N I C N O T E S \\
\hline
\end{tabular}




\section{B O B A D I L L A}

critic and satirist Clarin, in which the latter was wounded, produced a sensation in Madrid.

Bobadilla is a scholar: he is acquainted with several languages and with nearly all European countries. Upon a visit to the Scandinavian countries he was cordially treated by the public and was entertained several days by the celebrated Björnson at his home, Anlestad.

Bobadilla's novels are: Novelas en germen; A fuego lento (a tale which is to tropical life what some of Kipling's are to the jungle); En la noche dormida (a pathological study); En pos de la paz (word painting of events in the Lower Pyrenees); Viajando por España (with a prologue by Pérez Galdos); Sintiendome vivir (the intimate spiritual life of the author). His books of literary criticism are: Capiritazos; Solfeo; Triquitraques; Con la capucha vuelta; Grafomonos de América; Bulevar arriba, Bulevar abajo; El padre Coloma y la aristocracia.

Poetical works: Vortice (a collection of poems various of which have been trans-

\section{A N D M O N O G R A P H S}




\begin{tabular}{|c|c|}
\hline 452 & C U B A N S O F T O - D A Y \\
\hline & $\begin{array}{l}\text { lated into English, Italian, and French); } \\
\text { Fiebres (short poems, much admired and } \\
\text { imitated in Latin America, the best known } \\
\text { of which are entitled Bogota and A Velaz- } \\
\text { quez. Although one by one Fray Candil's } \\
\text { sonnets make their first appearance in La } \\
\text { Esfera (Madrid) he contributes constantly } \\
\text { to many South American and European } \\
\text { reviews incliding Le Figaro and Le Gil } \\
\text { Blas, La Revue de Revues and La Renais- } \\
\text { sance latine. His work is received with } \\
\text { great respect by the critics: Azotin } \\
\text { affirms that "Fray Candil has taught Spain } \\
\text { to think and to feel"; Gómez de Baquero, } \\
\text { "Fray Candil has the melancholy and } \\
\text { sobriety of Anatole France, the aggressive- } \\
\text { ness of Octave Mirbeau, the scientific seri- } \\
\text { ousness of Taine and the roguishness of } \\
\text { Henri Lavedan"; the London Athenceum } \\
\text { proclaims him"the first of Spanish critics." } \\
\text { At present, I9I9, Bobadilla makes his } \\
\text { home in Biarritz, France, where he is } \\
\text { serving as Consul from Cuba. }\end{array}$ \\
\hline I & H I S A N I C N O T E S \\
\hline
\end{tabular}




\section{B U S T O Y D L G D O}

NEMESIO BUSTO Y DELGADO

Lawyer; judge.

Nemesio Busto y Delgado was born in the village of Recreo, now called Máximo Gómez, on the nineteenth of December, 1865. At the Colegio "El Progreso" in the City of Cárdenas he prepared for the Bachelor's degree which he received in 1882; six years later he was granted the Licentiate in Law by the University of Havana.

He has occupied in Cárdenas the office of Judge of the Primary Court of Claims and Mandates, Correctional and Municipal, and was President of the Board ot Education until December, I910.

In 1910 he was the candidate of the Liberal party, and was elected to represent the Province of Matanzas in the

A N D MONOGRAPHS 


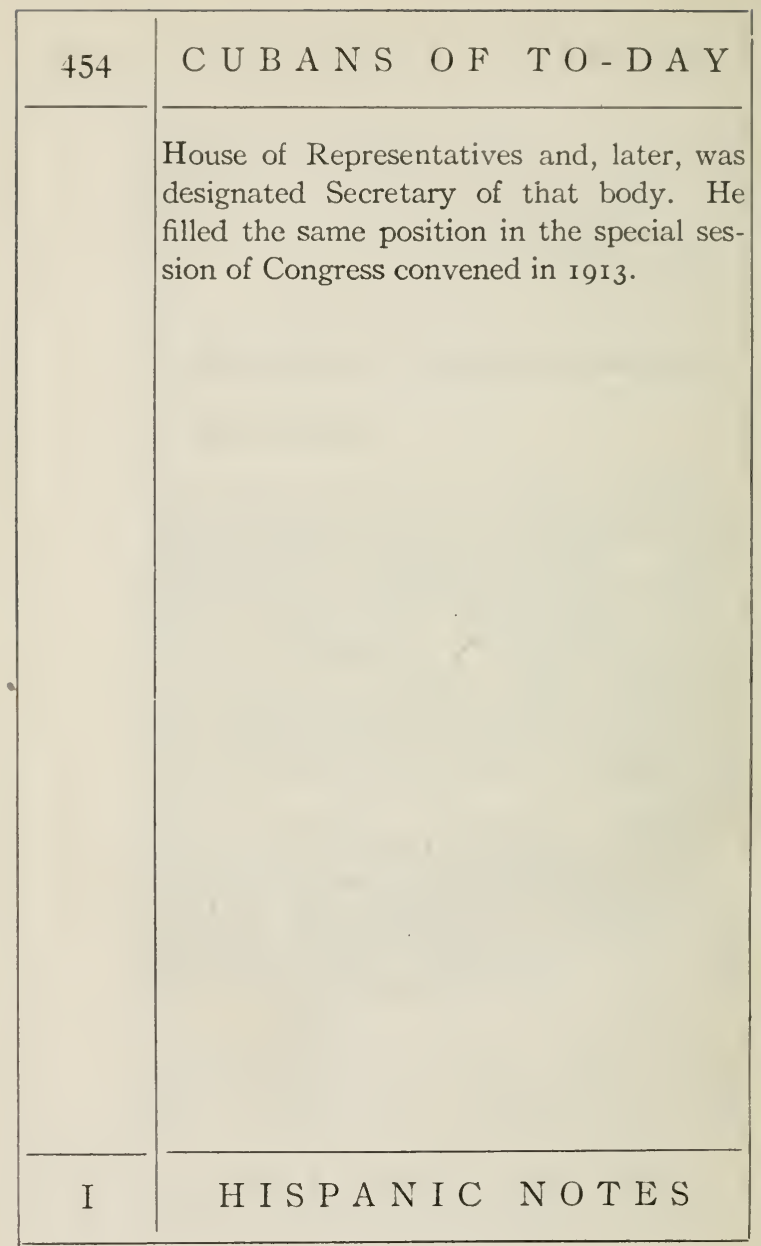




\begin{tabular}{|c|c|}
\hline B Y R N E & 455 \\
\hline $\begin{array}{l}\text { BONIFACIO BYRNE } \\
\text { Poet; journalist. } \\
\text { BoNifACIO BYRNE was born in Pueblo } \\
\text { Nuevo a suburb of Matanzas on the third } \\
\text { of March, I } 86 \text { I. At seven years of age he } \\
\text { entered the Colegio "El Porvenir" in } \\
\text { Matanzas where he came under the influ- } \\
\text { ence of Antonio Luis Moreno, the director } \\
\text { of the school. Pupil until i } 875 \text {, and after- } \\
\text { wards teacher in this institution, the in- } \\
\text { spiration and guidance of Moreno, added } \\
\text { to that master's illuminating teaching of } \\
\text { the poets, led young Byrne to choose poetry } \\
\text { as his vocation. Aside from Moreno, the } \\
\text { model and mentor of Byrne's early days } \\
\text { was the poet Nicanor A. Gonzales. } \\
\text { Byrne's first appearance in print was in } \\
\text { his seventeenth year, when some of his } \\
\text { verses were published in a Matanzas } \\
\text { weekly, La Primavera. }\end{array}$ & f \\
\hline A N D MONOGRA P H S & I \\
\hline
\end{tabular}




\begin{tabular}{|c|c|}
\hline $45^{6}$ & C U B A N O F T O - D A Y \\
\hline & $\begin{array}{l}\text { His first essay in the journalistic field } \\
\text { was as annalist of the "Ateneo" society, } \\
\text { being associated with the veteran writer } \\
\text { Fernando Romero Fajardo who was its } \\
\text { Director. } \\
\text { He later joined the editorial staff of } E l \\
\text { Pueblo in Matanzas, and was director } \\
\text { successively of La Mañana, La Juventud } \\
\text { Liberal and El Obrero; twice he was editor } \\
\text { of El Diario (Matanzas) and did special } \\
\text { articles for El Imparcial and La Regionn. } \\
\text { In I895, when rebellious Cuba was being } \\
\text { disciplined by Spain, Byrne's caustic and } \\
\text { enthusiastic pen attracted a dangerous de- } \\
\text { gree of attention; his separatist propaganda } \\
\text { led to the suppression of his paper, El } \\
\text { Diario de Matanzas. Byrne was arrested } \\
\text { and tried; defended by Nicholás Heredia, } \\
\text { a writer of note, his trial deteriorated into } \\
\text { a picturesque political wrangle, in which } \\
\text { the President of the Tribunal frequently } \\
\text { obstructed the defense with interruptions. } \\
\text { Byrne was sentenced to six months' im- } \\
\text { prisonment but escaped serving through a } \\
\text { proclamation of amnesty. } \\
\text { At this juncture Byrne emigrated to }\end{array}$ \\
\hline I & H I S P A I C NOTES \\
\hline
\end{tabular}




\section{B Y R N E}

Tampa, Florida, where he remained three years. Here he continued to work for Cuban independence largely through the columns of El Expedicionario, a small paper which he directed, and through his contributions to the Cuban periodicals Patria, El Porvenir, Cacarajicara, El Continente Americano, and $C u b a$. He also collaborated in the Album Patriotic which El Figaro published in 1899 . He was secretary, in Tampa, of the club Pedro Betancourt.

Upon his return to the island of Cuba, after the close of the Spanish-American War, Byrne acted for a short time as editor of La Discusión, but in April, I 899, resigned to accept an appointment under the provincial government of Matanzas; later, being appointed secretary of that government, he retained the position for ten years, until I9I 2.

During a part of this period he directed in Matanzas the periodical Yucayo, which he continues in I9I9, serving also as Secretary to the Superintendent of Schools of the Province. He has been President of the Press Club and of the Club of "Emi-

\section{A N D M O N O G R A P H S}




\begin{tabular}{|c|c|}
\hline $45^{8}$ & C U B A N S O F T O - D A Y \\
\hline & $\begin{array}{l}\text { grados" in Matanzas. He is a member of } \\
\text { the Cuban Academy of Arts and Letters } \\
\text { and an Associate (Correspondent ) Fellow } \\
\text { of the Academy of the Republic of San } \\
\text { Salvador. } \\
\text { Byrne has not been without honors in } \\
\text { his own city: The Council has declared } \\
\text { him an Eminent Son of the City of Matan- } \\
\text { zas, and a street has been named in his } \\
\text { honor. A commemorative stone tablet has } \\
\text { been placed in the house in which he was } \\
\text { born, at the expense of the Association of } \\
\text { Students of the Institute in the same place. } \\
\text { In I } 9 \text { I } \text {, during a second visit to the } \\
\text { Great Republic of the North, Byrne wrote } \\
\text { a book of verses entitled La Nacion Mara- } \\
\text { villosa, a tribute of admiration to the } \\
\text { country of Washington. This has not yet } \\
\text { appeared. } \\
\text { His published writings are the following: } \\
\text { Volumes of poetry: Excéntricas (Phila- } \\
\text { delphia, I } 893 \text { ); Efigies (Philadelphia, I } 897 \text { ); } \\
\text { Lira y Espada (I9o I); Poemas (I } 903 \text { ); En } \\
\text { Medio del Camino (I } 9 \text { I } 4 \text { ). } \\
\text { Several of his dramatic works have been } \\
\text { produced with success: El Anónimo; Rayo }\end{array}$ \\
\hline I & H I S P A N I C N O T E S \\
\hline
\end{tabular}




\section{B Y R N E}

de Sol; El Legado; Varón en Puerta; El Espiritu de Martí.

He has been successful in numerous literary competitions, having been awarded the first prizes in Matanzas at the quatrocentenary of the discovery of America, and in Havana. His sonnets and patriotic poems presented at Juegos Florales throughout $\mathrm{Cuba}$ and in Spain have brought him many prizes.

\section{A N D M O NOGR A P H S}


1 


\section{A L L E J A S}

FELIX CALLEJAS

Poet; journalist.

Felix Callejas was born of Cuban parents at Bogotá, Colombia, on the eighteenth of May, I878. His first studies were pursued in the Colegio of Belén and the Institute of Havana. He began his literary career in the field of poetry, where his success as a verse writer soon attracted notice. His first volume of poetry, $V i$ braciones, won enthusiastic welcome from the public. Among the noticeable poems in this volume are "Noche de Baile," "Cuadro de Sombres," "Cieno y Alma," "Præmium," and "Entre llamas." In his later verse may be mentioned "Armas y espigas," which won the first prize in a competition taken part in by the leading poets of Cuba. The sonnet form is especially affected by this writer and many of his sonnets are

H I S P A N I N O T E S 


\begin{tabular}{|c|c|}
\hline 462 & C U B A N S O F T O - D A Y \\
\hline & $\begin{array}{l}\text { distinguished for elevation of thought and } \\
\text { beatty of expression. Endowed with ver- } \\
\text { satility of talent, Callejas has used various } \\
\text { forms of literary expression, ranging from } \\
\text { poetry to humorous essays. He was the } \\
\text { founder and editor of the educational review } \\
\text { Cuba Pedagógica and edited for a number of } \\
\text { years the child's magazine called Primavera. } \\
\text { He has contributed also in prose and verse } \\
\text { to the principal literary publications of his } \\
\text { country. In I9 } 2 \text { he took up journalistic } \\
\text { work as editor of the Prensa or Havana, } \\
\text { in which he inaugurated a humorous sec- } \\
\text { tion, which soon attracted popular notice } \\
\text { throughout the country. His humor and } \\
\text { his irony are directed to encourage all ele- } \\
\text { ments of social progress and it was through } \\
\text { his championship that the system of giving } \\
\text { free luncheons to public school scholars } \\
\text { was introduced in Cuba. A selection of } \\
\text { humorous articles was published in I } 9 \text { I } 4 \text {, } \\
\text { under the title Arreglando } \text { el } M \text { undo, a book } \\
\text { which won popular approval. } \\
\text { Callejas is also distinguished as an } \\
\text { educator, in which capacity he has lectured } \\
\text { on grammar in Normal schools in Havana, }\end{array}$ \\
\hline I & H I P A N I NOTES \\
\hline
\end{tabular}




\section{A L L E J A S}

and has occupied important technical positions in the Office of Public Instruction and Fine Arts. $\mathrm{He}$ is a member of the $\mathrm{Na}$ tional Academy of Arts and Letters, in which he has served as general treasurer and vice-president of the section of literature. At the present time, although not giving up his work in daily journalism, he is editor of the Review of Agriculture, Commerce and Labor, an official publication of the Cuban Government.

\section{A N D M O NOGR A P H S}





\section{A N I Z A R E S}

\section{FELIPE GARCÍA CAÑIZARES}

\section{Physician; teacher.}

Felipe García Cañizares was born in Sancti Spiritus on the fourteenth of July, I 872 . He obtained his early education in his native city, and afterwards proceeded to Havana and Madrid. In 1892 he became a member of the hospital staff of San Francisco de Paulo, and in November of that year, after a competitive examination, he was appointed assistant in Dissection in the medical faculty of the University of Havana. From 1893 to 1896 he was in charge of the chair of Mathematics, Physics, Chemistry and Natural History in the Real Concilia Seminary of Havana. In I 895 he was appointed, after a competition, a member with first honors of the "Weiss" Obstetrical Clinic, and later in the same year associate professor of Technical

H I S P A I C NOTES 


\begin{tabular}{|c|c|}
\hline 466 & C U B A N S O F TO-D A Y \\
\hline & $\begin{array}{l}\text { Anatomy, in the Preparatory School of } \\
\text { Medicine at Havana. He obtained his } \\
\text { degree of Licentiate in medicine with } \\
\text { first-class honors and afterwards the degree } \\
\text { of Doctor of Natural Sciences. At the } \\
\text { close of I } 895 \text { he proceeded to Europe and } \\
\text { graduated as Doctor of Medicine at the } \\
\text { Central Faculty of Madrid. From this } \\
\text { city he went on to Paris to specialize in } \\
\text { the study of botany, syphilitic diseases, } \\
\text { and diseases of the skin. He continued to } \\
\text { Manila and this trip was wrongly inter- } \\
\text { preted as involving him in questions of } \\
\text { Cuban politics. He was tried by a court } \\
\text { martial and was sent to Barcelona. After } \\
\text { a month he was freed and he then went to } \\
\text { France and from there to Venezuela, where } \\
\text { he practiced his profession until he returned } \\
\text { to Cuba in I9oo. He was nominated after } \\
\text { a competition to the chair of Natural His- } \\
\text { tory in the Institute of Havana, and also } \\
\text { assumed charge of the Botanical Garden } \\
\text { and Museum of the Institute. }\end{array}$ \\
\hline I & H I S P A I C N O T E S \\
\hline
\end{tabular}


MANUEL ARTEAGA

Manuel Arteaga was born in Camagüey on the twenty-eighth of December, 1879. In 1892 he went to Venezuela to pursue his studies at the University of Caracas where he followed courses in civil law and theology. After being ordained he was appointed to the position of foreign curate and vicar at Cumana and later was named Canon with the title of Doctor in the Cathedral of Guayana. While at Cumana he took charge of the decoration of the Church of Santa Ines and was also given supervision of the restoration of the parish church at Benita in Venezuela, which had been destroyed by the earthquake of 1900 . This work under his direction was entirely successful. In r9 10 he was sent to the Eucharistic Congress of Madrid as a representative of the Archdio-

$$
\text { A N D MONOGRAPHS }
$$




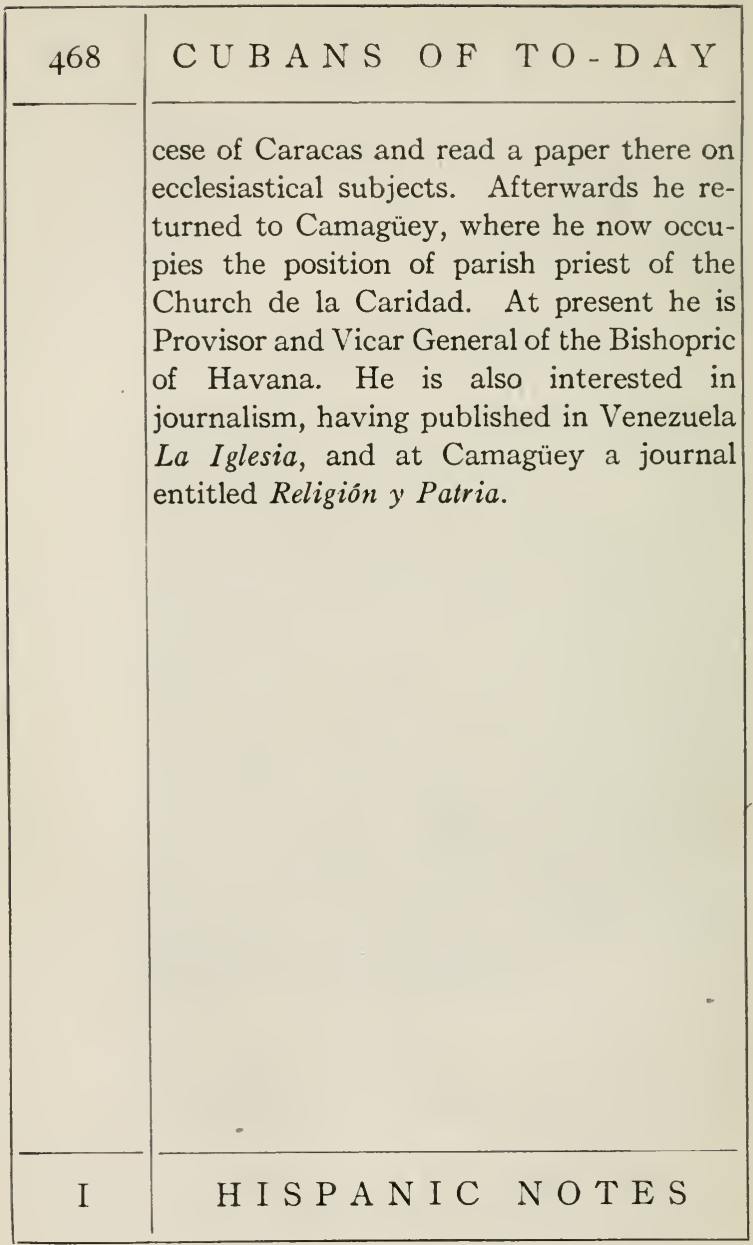




\section{A R T A Y A}

ENRIQUE HERNÁNDEZ CARTAYA

Lawyer; teacher.

Enrique Hernández Cartaya was born on the twenty-sixth of January, I877, in the city of Havana. His elementary and secondary studies were pursued at the Colegio of San José and at the Institute of Havana, where he received his Bachelor's degree in I 89I, with honors. Entering the University of Havana he took courses in law, philosophy, and letters. In the first subject he won prizes in all of his assigned subjects and took the degrees of Licentiate of Laws and Doctor of Laws with first honors. In the faculty of philosophy and letters he received various prizes, became Licentiate and received the public investiture of Doctor in I897. He was appointed assistant supernumerary professor in the Faculty of Philosophy and Letters and was

\section{A N D M O N O R A P H S}




\begin{tabular}{|c|c|}
\hline 470 & C U B A N O F T O - D A Y \\
\hline & $\begin{array}{l}\text { engaged in the teaching of Spanish liter- } \\
\text { ature and metaphysics from I } 897 \text { to I } 898 \text {. } \\
\text { In this year after receiving the degree of } \\
\text { Doctor of Laws he was nominated by the } \\
\text { faculty as assistant professor in the Law } \\
\text { School. In I9oo, after competition, he ob- } \\
\text { tained the chair of Assistant Professor in } \\
\text { the School of Public Law. In this capacity } \\
\text { he has taken charge of the work from I } 900 \\
\text { to I9o4 in political economy and juris- } \\
\text { prudence. In I9o4 he was advanced to } \\
\text { the position of Titular Professor of Ad- } \\
\text { ministrative Law, a position which he holds } \\
\text { at the present time. He is also a member } \\
\text { of the University Council, the governing } \\
\text { body of the University of Havana. } \\
\text { He was a legal member of the extinct } \\
\text { Superior Committee of Especial Hygiene, } \\
\text { a member of the Commission for Social } \\
\text { Service, a part of the Department of Jus- } \\
\text { tice, a member of the Commission nomi- } \\
\text { nated by the President of the Republic to } \\
\text { inquire into the increase in budgetary } \\
\text { items, a member of the Cuban Section of } \\
\text { the Supreme International Commission } \\
\text { for Uniform Legislation in Financial Mat- }\end{array}$ \\
\hline I & H I P A N I N O T E S \\
\hline
\end{tabular}




\section{A R T A Y A}

ters, in which capacity he prepared a questionnaire submitted to the Central Council at Washington on bills of exchange, a work which secured the approval of Secretary McAdoo. He is ex-officio member of the Central Electoral Committee, founded in I908, and during eleven years he has been actively concerned in all of the electoral cases and questions arising in the Island of Cuba. In 1906 he was named as a Counselor by President Palma, and in this capacity was a member of the Commission known under the name of "Cabildo de Altura." At this time he was nominated by this Commission to be Acting Alcalde of the Fifth District of Havana, which takes in an extensive zone in the city. He has been entrusted with various civic duties, among others that of acting as a member of the boards of judges in the open competitions held at the Institute and the University of Havana. For twenty years he has been actively engaged in law practice and has been a member of the governing body of the Havana bar. At present he is Vice-president of the Cuban Society of International

\section{A N D M O N O G R A P H S}




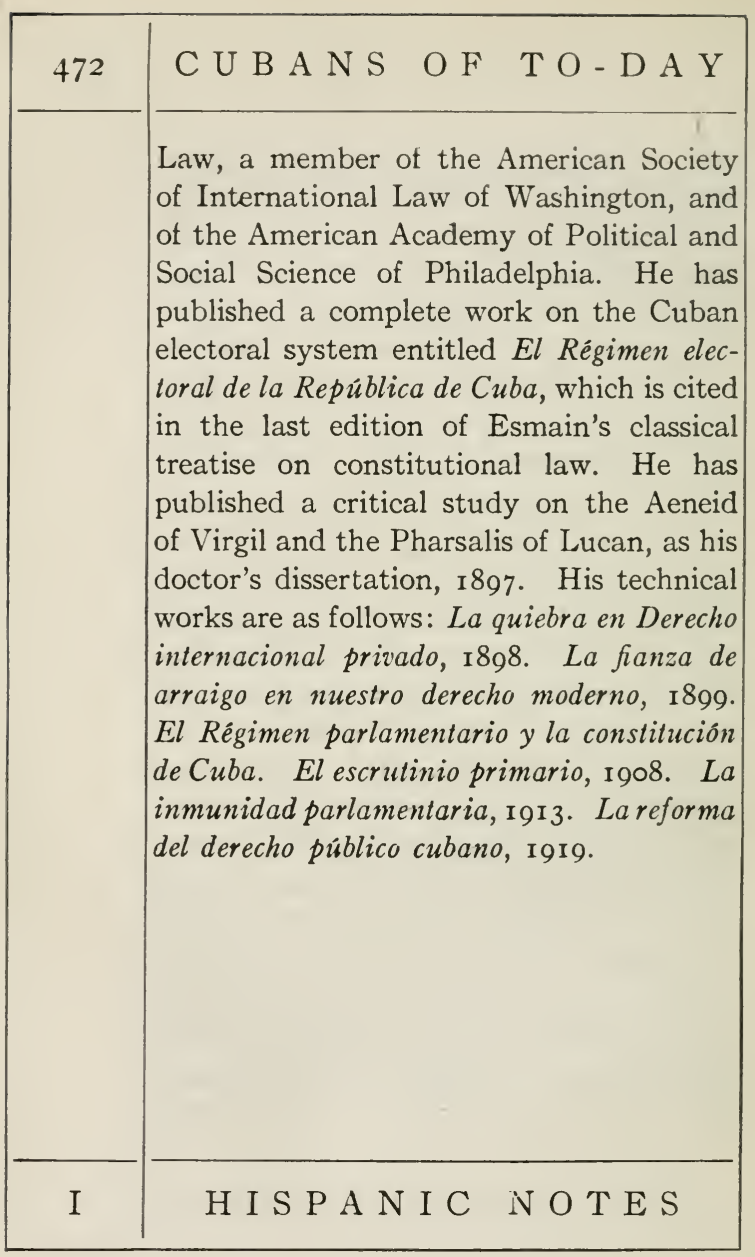




\begin{tabular}{|l|}
\hline M E N O C A L \\
\hline ARMANDO MENOCAL \\
ARMANDo MENocAL was born in Havana \\
in I866. His early education in Cuba was \\
supplemented by the study of art in Spain. \\
In I888, he was appointed professor in \\
the School of Painting and Sculpture of \\
Havana, the appointment being renewed in \\
I899. \\
He has at sundry times served as judge \\
in competitions of painting, and was official \\
representative from Cuba to the Paris \\
Exposition in I9oo. He was elected in \\
I9I 2 to membership in the Academy of \\
Arts and Letters (Cuba). \\
Menocal has for many years been a \\
painter of portraits and of genre and histori- \\
cal pictures; he has more recently turned \\
his attention to fresco. His decorations \\
for the auditorium of the University and \\
A N D M O N O G R A P H S
\end{tabular}




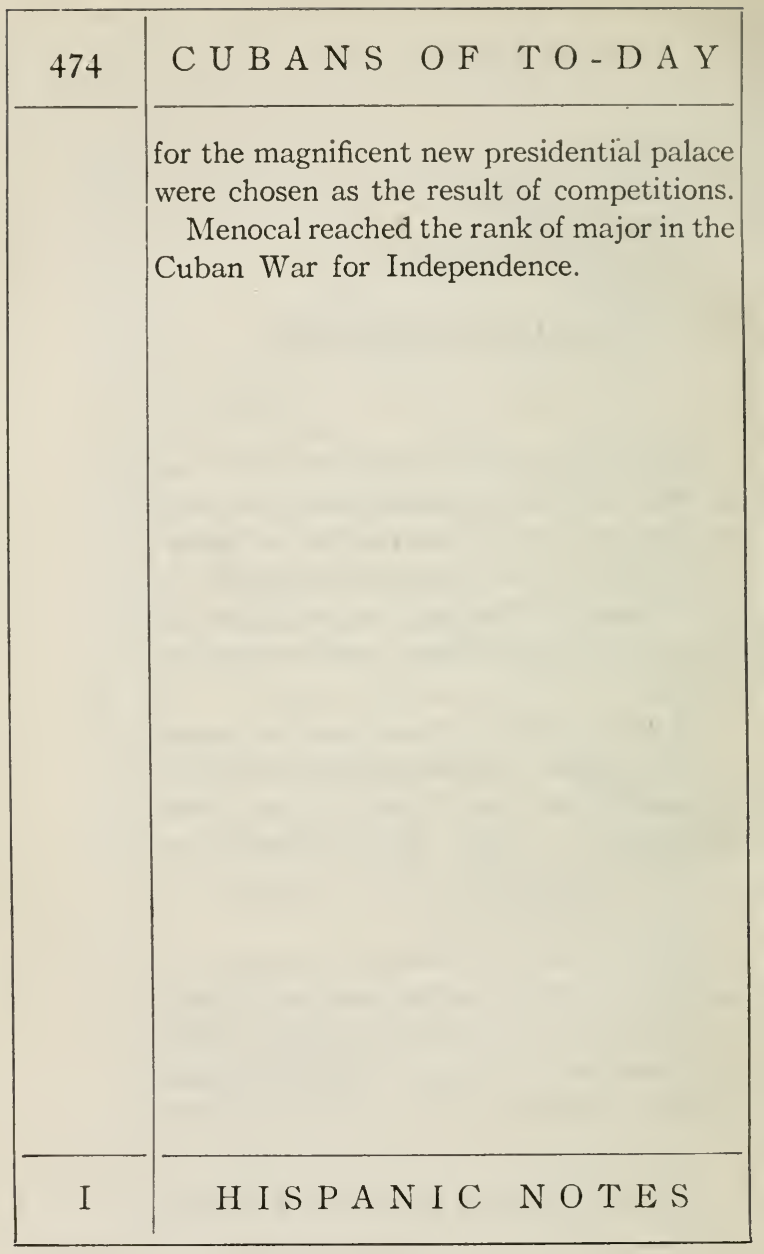





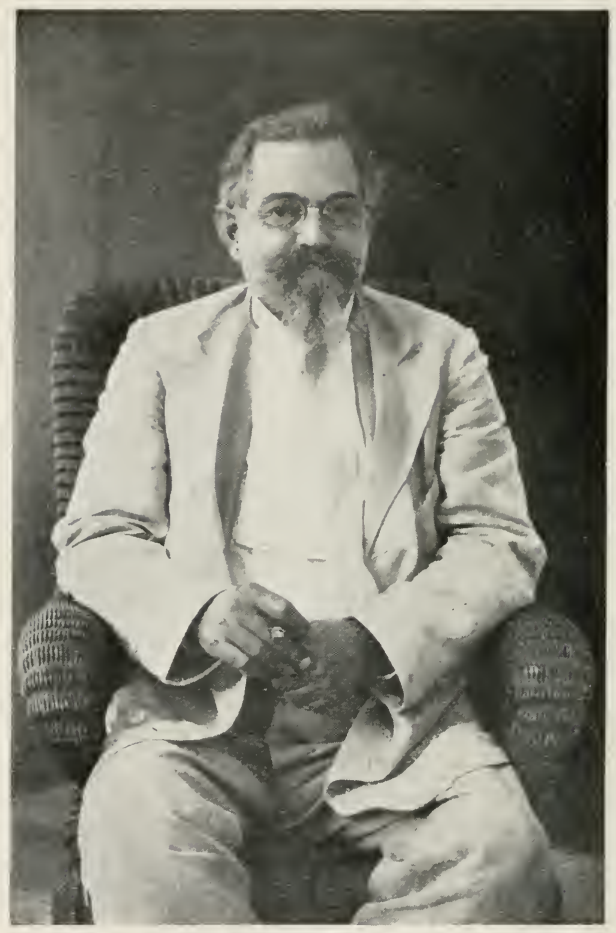

Enrique Collazo y Tejada 


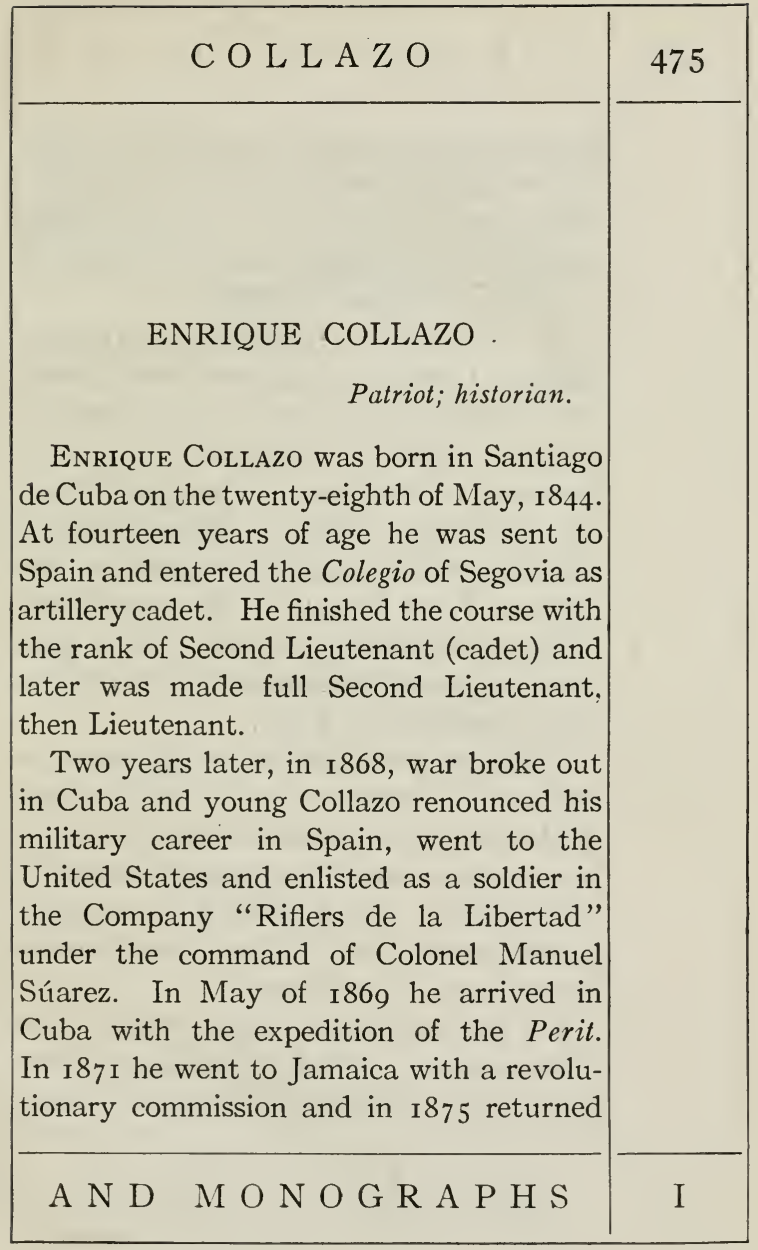




\begin{tabular}{|l|l|}
\hline 476 & \begin{tabular}{l} 
C U B A N S O F T O - D A Y \\
\hline to Cuba in the steamer Octavia as a mem- \\
ber of the expedition under Pio Rosado. \\
Thereafter he remained in the Revolution \\
as Major in Camaguiey until the signing of \\
the Pact of Zanjón in I878. \\
He then went to Jamaica with General \\
Máximo Gómez and together with Gómez \\
and Martí signed on the 2oth of January, \\
I895 the order of revolt for the 24th of \\
February of that year. The year follow- \\
ing, in March, I896, he disembarked in \\
Veradero with an expedition carried by the \\
steamer Three Friends. He commanded \\
different brigades in the war and in I897 \\
was designated Representative for Oriente \\
to the Assembly of Yaya. \\
Upon the formation of the Republic he \\
was made Representative for the Province \\
of Havana; at the close of his term of office \\
he was designated Comptroller General of \\
the Republic, which position he occupied \\
several years as also that of voting member \\
of the Junta de Protestas. \\
He has published various works upon \\
Cuban history: Desde Yara hasta el Zan- \\
jon (I893); Episodios de la Guerra (I899);
\end{tabular} \\
\hline I & \begin{tabular}{l} 
H I S P A N I C N O T E S \\
\hline
\end{tabular} \\
\hline
\end{tabular}




\section{O L L A Z O}

(ìn collaboration with Alboro Catá), Cuba Independiente (I900); Los Americanos en Cuba (I905-06); Cuba Intervenida (I910); Cuba Heróica (I9I2) and various pamphlets such as La Revolución de Agosto (1906). 




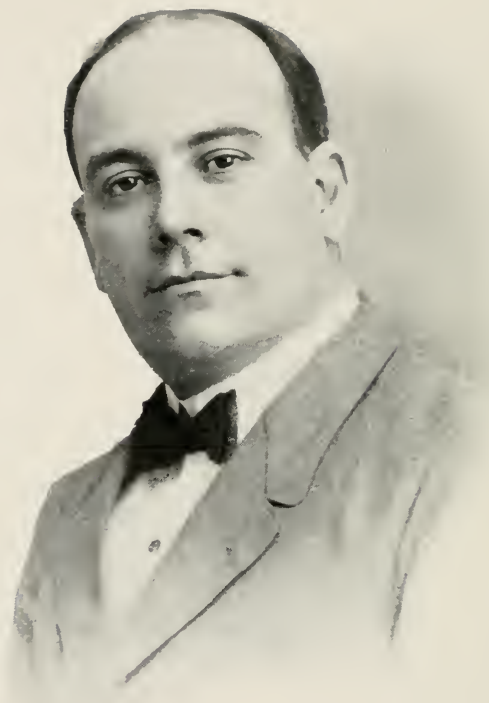

Armando de Córdoba 


\section{E C Ó R D O V A}

\section{ARMANDO DE CÓRDOVA Y QUESADA}

Physician; specialist.

Armando de Córdova y Quesada was born in Havana in 1880 and educated in the Institute and the University of Havana, obtaining from the latter the degree of Doctor of Medicine.

He has served Hospital Number One as Chief of Laboratory and for five years was medical interne. $\mathrm{He}$ has been a voting member of the National Board of Health and Philanthropy and specialist in nervous diseases at the Quinta de Dependientes.

As the result of competitions, Dr. Cordova has been assistant in Histology and Pathological Anatomy and has filled various other positions in the National University, reaching in 1907 the one which he now holds (I9I9): that of Professor of

\section{H I S P A N I C N O T E S}




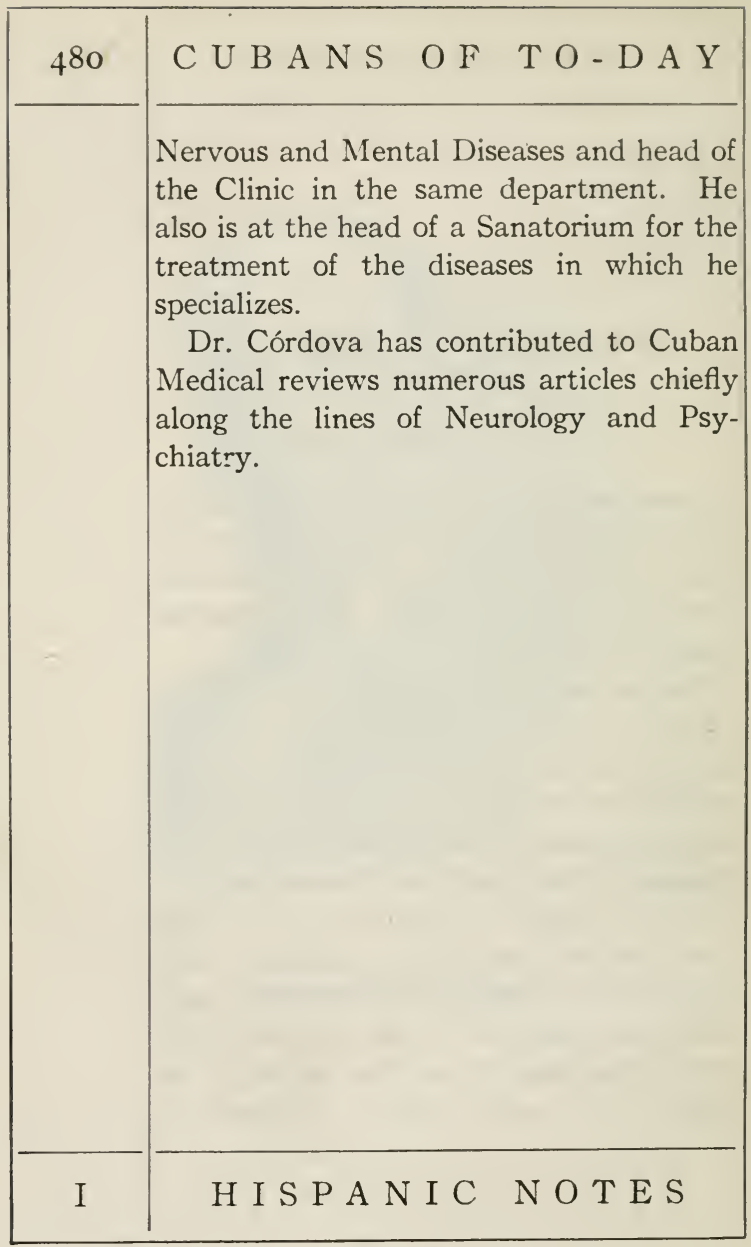




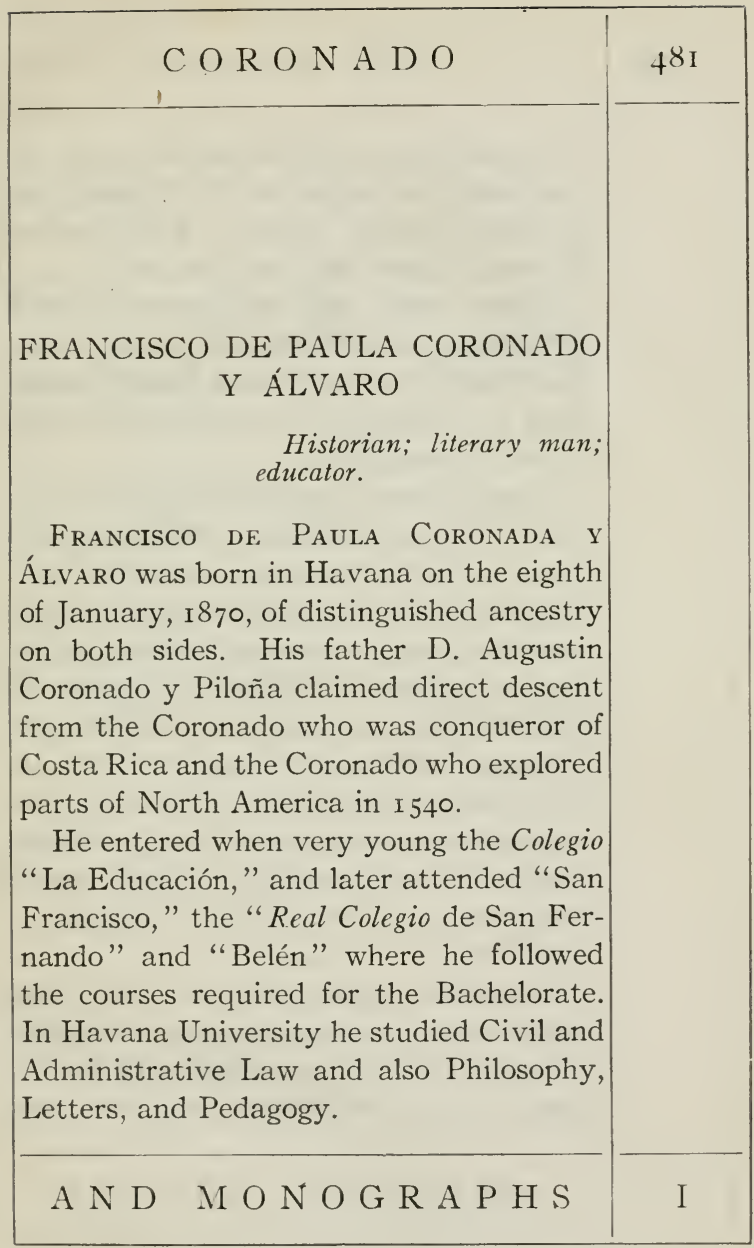




\begin{tabular}{|c|c|}
\hline 482 & C U B A N S O F TO-D A Y \\
\hline & $\begin{array}{l}\text { At seventeen he began to write for } \\
\text { La Republica, a Havana daily paper, and } \\
\text { to teach Spanish grammar and literature } \\
\text { in the "Círculo de Trabajadores." } \\
\text { From about I } 887 \text { he devoted himself } \\
\text { definitely to literature, history, and teach- } \\
\text { ing despite the traditional family profes- } \\
\text { sion, Law, for which he studied but which } \\
\text { he never practiced. } \\
\text { From } 889 \text { to I } 895 \text { his writing was in the } \\
\text { line of literary criticism. Sometimes over } \\
\text { his own name, sometimes using the pseu- } \\
\text { donym César de Madrid, he made constant } \\
\text { contributions to various Havana dailies, } \\
\text { to the reviews, La Habana Elegante, El } \\
\text { Figaro, El Hogar, El Pitcher, Gil Blas and } \\
\text { to some foreign periodicals as well. In } \\
\text { the Figaro he maintained for several years } \\
\text { a special column of wit and satire with the } \\
\text { caption "Cosas" in which he signed himself } \\
\text { variously as Don Pánfilo, Panfilón or } \\
\text { Panfilito. } \\
\text { Upon the organization of the Cuban } \\
\text { Revolutionary party in I } 892 \text {, Coronado } \\
\text { joined it and also was allied with the pa- } \\
\text { triotic "junta" of Havana until I } 896 \text { when }\end{array}$ \\
\hline I & H I S P A I C N O T E S \\
\hline
\end{tabular}




\section{O R O N A D}

he was forced to emigrate to escape the persecutions of the Spanish authorities. Settling in New York he allied himself with various revolutionary clubs and edited Patria, the official organ of the Revolution in foreign parts. He collaborated also in El Porvenir, Cuba y América, and Cuba y Puerto Rico, all published in New York. In $\mathrm{I} 897$, in association with Enrique Hernándes Meyares, he founded $\mathrm{Ca}$ carajicara but soon withdrew from it.

In 1898 , Coronado was free to return to educational and literary work which he has continued with a single interim of two years, $1902-4$, when he was Secretary of the Cuban legation in Mexico. He has been member of the Havana Board of Education (I899), school inspector for the Province of Havana (1900), member and secretary of the board of judges for the scholastic contests in the secondary schools of the Provinces of Matanzas and Santa Clara (I900), Provincial Superintendent of the schools of Camagüey (I900-1902), Provincial Superintendent of the schools of Havana (I904-I909), Secretary of the Na-

\section{A N D M O N O R A P H S}




\begin{tabular}{|c|c|}
\hline $4^{84}$ & $\mathrm{CUBANS}$ O F T O - D A Y \\
\hline & $\begin{array}{l}\text { tional Council of Librarians of Cuba (I9Io- } \\
\text { I9I3), member of the board of judges in } \\
\text { competitions for the chair of Pedagogy in } \\
\text { the University of Havana (I9I6). } \\
\text { Coronado directed the first lay school in } \\
\text { Cuba, that established by the Circulo de } \\
\text { Trabajadores in I889; he first taught pa- } \\
\text { triotic history in night classes for laborers; } \\
\text { he early gave courses of lectures upon na- } \\
\text { tional history to the teachers of the Island. } \\
\text { While connected with the Department of } \\
\text { Public Instruction he codified and edited } \\
\text { the first courses of study used in the ele- } \\
\text { mentary schools, established examinations } \\
\text { for teachers, and organized the system of } \\
\text { common school inspection. } \\
\text { He is a member of the following societies: } \\
\text { Association of Painters and Sculptors; } \\
\text { Cuban Theatrical Society; Fundación Luz } \\
\text { Caballero; National Association of Revolu- } \\
\text { tionary Emigrés; Cuban Society of Inter- } \\
\text { national Law; Ateneo of Havana (one of } \\
\text { the Board of Governors); Academy of } \\
\text { History of Cuba (Secretary). } \\
\text { Leading periodicals of Latin America } \\
\text { frequently publish poems from Coronado's }\end{array}$ \\
\hline I & H I S P N I C N O T E S \\
\hline
\end{tabular}


pen under the pseudonyms "Marcelo Du Quesne" and "El Caballero de la Blanca Luna." He also has delivered many addresses of which the most notable are: Luz Caballero (1908); Los Evangelios apócrifos (I9I I); Villaespesa y la poesía española contemporánea (I9I2).

$\mathrm{He}$ is author of pamphlets bearing the following titles: Frutos coloniales (Havana, I89I); Primera campaña (Havana, I 892); En mis trece (Havana, I893); Debilidades femininas (Havana, I 894); A morios, short stories (Havana, 1895); Sangre, short stories (New York, I896); A puntes para la vida de General Maceo (N. Y., I897); Crimenes de España en Cuba (N. Y., I898); Datos para una biografía del Gen. Calixto García Iñiguez (Havana, I899); La toma de Cárdenas en 1850 (Havana, I900); La enseñanza en Camagiiey, Igoo-Igor (Havana, 1902); and Las Pediciones de Plácido (Havana, i 9o9). 



\section{E L F Í N}

\section{MANUEL DELFÍN}

Physician; charity worker.

Manuel Delfín y Zamora was born in Baracoa, Province of Oriente, Cuba, on the twenty-eighth of February, I849, and began his education in the local public schools. Although in very modest circumstances his family determined to give him educational advantages. Accordingly he was sent to school in Santiago and later to the Colegio de Belén in Havana where he took many prizes for scholarship.

During these years, struggling with poverty, young Delfín tutored in private families and even worked as a servant. He finally entered a private Colegio as pupilteacher but unhappy conditions forced him to leave. Returning to Baracoa, he taught for two years in the public schools, then entered upon a pharmaceutical course in the University of Havana.

H I S P A N I C N O T E S 


\begin{tabular}{|c|c|}
\hline+88 & $\mathrm{C} U \mathrm{BANS} O \mathrm{OF}$ T O $-\mathrm{DAY}$ \\
\hline & $\begin{array}{l}\text { Early in the seventies, Cuba being most } \\
\text { dangerous for a youth who was not cir- } \\
\text { cumspect in speech about governmental } \\
\text { affairs, the family sent young Delfin to } \\
\text { Spain to continue his education. From the } \\
\text { Central University in Madrid he won the } \\
\text { degree of Licentiate in Pharmacy, then } \\
\text { gave himself to the study of medicine. At } \\
\text { the conclusion of this course he returned to } \\
\text { Cuba, making his home in Vuelta Abajo } \\
\text { where he founded and managed a paper } \\
\text { called El Vegucro. Active in the Autono- } \\
\text { mist party he became its unsuccessful can- } \\
\text { didate for membership in the colonial } \\
\text { congress. He became involved in some } \\
\text { political difficulties and was imprisoned; } \\
\text { liberated, he resumed his professional } \\
\text { practice but later moved to Havana. } \\
\text { In Havana, after many hardships, he } \\
\text { became established as chemist in a medical } \\
\text { and surgical laboratory. During this } \\
\text { period he was a pioneer, in Cuba, of medico- } \\
\text { legal investigations. He was Secretary to } \\
\text { the Board of Philanthropies and for three } \\
\text { years issued a review entitled La Higicne. } \\
\text { He established dispensaries, said to have }\end{array}$ \\
\hline I & H I S P N I C N O T E S \\
\hline
\end{tabular}




\section{E L F Í N}

been the first in Cuba, first in Matanzas and later in Santa Clara and Havana. During the enforcement of Gen. Weyler's re-concentration decree, he maintained dispensaries among the fugitives.

Aroused to the necessities of the poor, especially women and children, he founded "La Casa del Pobre," whose object was to care for the poor in their homes; later, about I9I 5 , he succeeded in inducing the public to institute "La Granja de Niños Pobres" and house it satisfactorily. This asylum, directed by Dr. Delfín, cares for about a hundred poor children. 


4. Anquel ispinosa y Olernandes 


\section{MIGUEL ESPINOSA HERNÁNDEZ}

Miguel Espinosa Hernández was born on the Canary Islands on the fourth of April, I869. His father, Miguel B. Espinosa, was a well-known Cuban medical man and publicist. His early studies were pursued in the Santa Cruz Institute at Teneriffe. From there he proceeded to the University of Havana. As a young man he devoted himself to journalism and in politics affiliated himselt with the Liberal and Autonomist party. In the year 1898 , he was elected a deputy to the Spanish Cortes by the Autonomist party. From the foundation of the Conservative party he has acted as a zealous adherent promoting its principles in two newspapers, $E l$ Nuero País, and Cuba. In 1908 he was elected Representative for the Province of Las Villas. In igr I he founded the 


\section{UBANS OF TO-DAY}

Journal El V'ia ot which he is now Managing Editor. In I 9 I 2 he was again elected Representative for Las Villas Province, and secured a further election in November, I 9 I 6. 


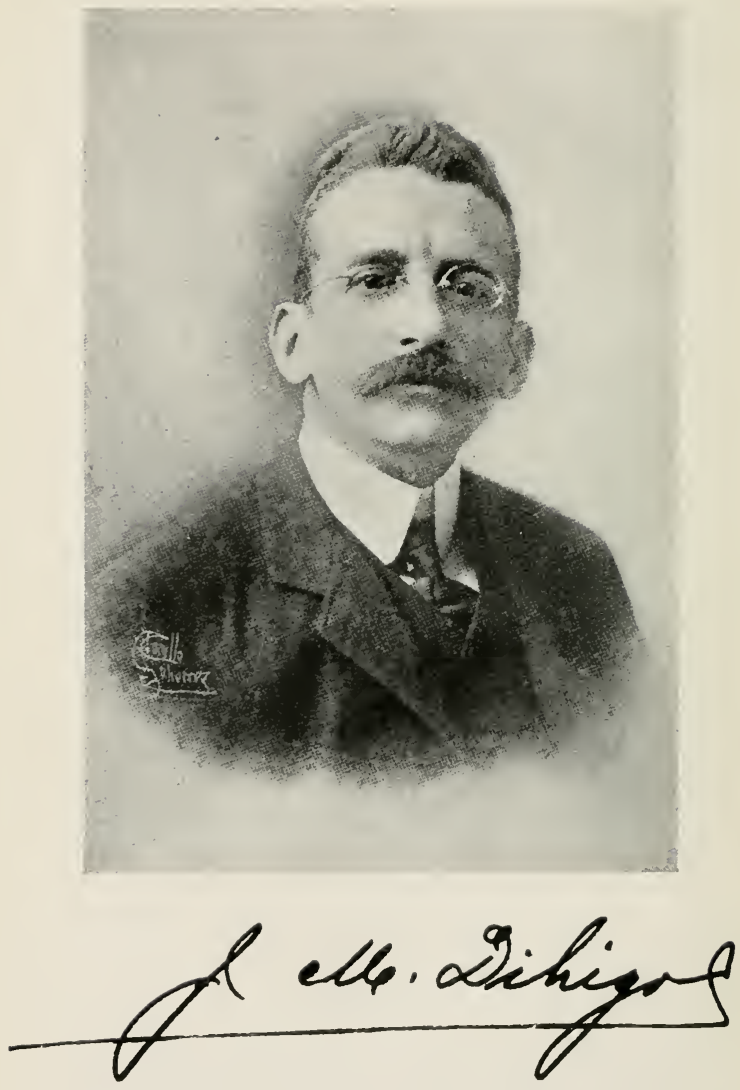


\section{I H I G O}

\section{JUAN MIGUEL DIHIGO}

\section{Teacher; linguist.}

Juan Miguel Dihigo y Mestre was born in Havana on the eighth of May, I866. He received his secondary education in the Colegio de "Belén," a Jesuit school, where through his conduct and application he won many prizes. During these school days he was winner in a competition in the English Language in which the students of the several secondary schools of the city were included. Upon terminating his studies for the Bachelorate in 1882 he entered the University of Havana and pursued simultaneously the courses in Philosophy and Letters and in Law, receiving the Licentiate in both departments in I884, the Doctorate of Philosophy and Letters in $\mathbf{1} 888$, and that of Civil and Canon Law in 1898 .

\section{A N D M O N O G R P H S}




\begin{tabular}{|c|c|}
\hline 494 & C U B A N S O F T O - D A Y \\
\hline & $\begin{array}{l}\text { In I } 89 \text { I he had begun serving as assistant } \\
\text { in Greek, and soon after receiving his Doc- } \\
\text { torate in Law he was given the chair of } \\
\text { Greek in the University ( } 1899 \text { ), at the same } \\
\text { time being Professor of the History of Peda- } \\
\text { gogy. At present (I9I9) he is serving the } \\
\text { University as Professor, by competition, } \\
\text { of Linguistics and Philology. In I9or he } \\
\text { was appointed Secretary of the Depart- } \\
\text { ment of Science and Letters of whose } \\
\text { official Review he became Director in I } 9 \text { I } 4 \\
\text { this organ having been founded by the } \\
\text { joint labors of Dr. Dihigo and Dr. Arístides } \\
\text { Mestre. } \\
\text { He founded in the University the Labora- } \\
\text { tory of Experimental Phonetics which } \\
\text { bears his name and, in association with } \\
\text { Dr. Mestre, an annual series of University } \\
\text { Extension lectures. Some of these lec- } \\
\text { tures he has himself delivered, all on more } \\
\text { or less popular subjects: "Influence of } \\
\text { Analogy in Language"; "Roosevelt's In- } \\
\text { fluence upon English Spe.ling"; "The Bible } \\
\text { from the Linguistic Point of View"; Popu- } \\
\text { lar Speech in Literature"; "How to Know a } \\
\text { Country's History from its Money." }\end{array}$ \\
\hline I & H I S P N I C NOTES \\
\hline
\end{tabular}




\section{I H I G O}

$\mathrm{He}$ has rendered other diverse and distinctive services to the University of Havana, including the editing of the University Statutes, and the delivery of the address of welcome to Dr. Rafael Altamira, delegate from the Spanish University of Oviedo.

Not only in the University Extension work has Dr. Dihigo contributed to the education of the masses. It was to him that was assigned the task of reorganizing and reforming the secondary schools of the Republic; he organized with Drs. Alfredo Zayas and Julio San Martín the first municipal School Board of Havana and for many years worked with that group either as Secretary, President, or member, improving and systematizing the public schools of the city which he visited and studied personally; he was at times member of the examining board for teachers; chairman of a committee which studied the rural school-house question; lecturer in summer Normal Institutes for teachers.

The Teachers' Club of Havana, as an

\section{A N D M O N O G R P H S}




\begin{tabular}{|c|c|}
\hline+96 & C U B A N S O F T O - D A Y \\
\hline & $\begin{array}{l}\text { expression of gratitude for Dr. Dihigo's } \\
\text { efforts in behalf of primary education, pre- } \\
\text { sented to the Board of Education his por- } \\
\text { trait in oils to be hung in the Board rooms. } \\
\text { In Public School No. } 37 \text { of the city there } \\
\text { has been established, in recognition of their } \\
\text { honored patron, the Republica Escolar Juan } \\
\text { Miguel Dihigo. } \\
\text { Although known in other lines of useful- } \\
\text { ness it is chiefly as a linguist that Dr. } \\
\text { Dihigo has gained his reputation. He has } \\
\text { long been a student of the Indo-European } \\
\text { tongues and of those of the Semitic group, } \\
\text { especially Hebrew and Arabic. His lin- } \\
\text { guistic works have been recognized by } \\
\text { foreign laborers in the same field, by Man- } \\
\text { oury, Regnaud, Lebègue, Cejador, Fay, } \\
\text { Wheeler, Meyer Lübke, Boisacq, Lenz, } \\
\text { Sayce, De Gregorio, Rozenvalle, Meillet. } \\
\text { He is frequently consulted upon matters } \\
\text { of doubt in relation to language. } \\
\text { He is a member of the French Associa- } \\
\text { tion for the encouragement of the study of } \\
\text { Greek, of the Society of Linguists in Paris, } \\
\text { of the Geographical Society of Mexico, of } \\
\text { the Cuban Academy of History, and in r } 8 \text { I }\end{array}$ \\
\hline I & H I S P N I C N O T E S \\
\hline
\end{tabular}




\section{I H I G O}

he was elected Corresponding Member of the Hispanic Society of America.

Dr. Dihigo has many times been delegate to foreign congresses and celebrations: official representative of the University of Havana on the occasion of the third Centenary of the University of Oviedo, Spain; official delegate from the University and from the Cuban Government to the first Centenary celebration in Mexico; official University and governmental delegate at the I6th Congress of Orientalists convened in Athens in I 912 ; delegate at the Jubilee of the National University of Greece in the same year.

Although several times offered governmental appointments, Dr. Dihigo has not found their acceptance consistent with his many duties, but he did for a time act as member of the Havana City Council. During that term he corrected, by request of the Council, errors that had been noticed in the Latin inscription upon a stone tablet in the Templete. $\mathrm{He}$ is a member of the Literary Section of the Aleneo.

In I 894 Dihigo came under the surveil-

A N D MONOGRAPHS 


\begin{tabular}{|c|c|}
\hline+98 & C U B A N S O F TO-DAY \\
\hline & 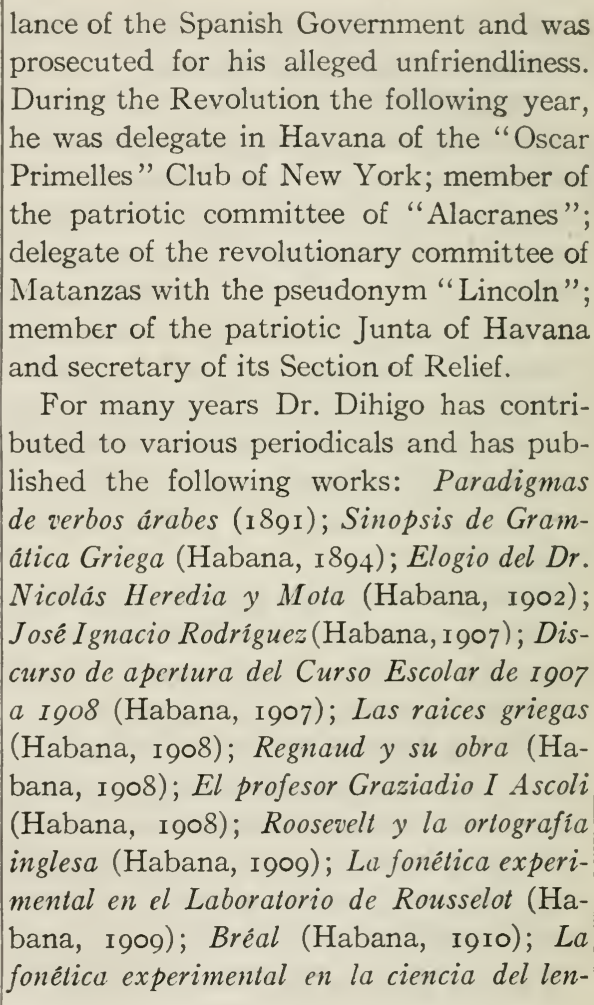 \\
\hline I & H I S P A I C NOTES \\
\hline
\end{tabular}


guaje (Habana, I9II); Rufino J. Cuervo (Habana, I9I I); L'enseignement de la langue grecque à Cuba (Athènes, I912); $E l$ Congreso de orientalista y el Jubileo de la Universidad de Grecia (Habana, I912); Elogio del Dr. Ramón Meza y Suârez Inclán (Habana, I912); Reparos etimológicos al Diccionario de la lengua castellana; Voces derivadas del griego (Habana, I9 I2); La Biblia desde el punto de visto lingüístico (Habana, I9I3); Las clases populares y la extensión universitaria (Habana, I9I4); El habla popular al través de la Literatura cubana (Habana, I915); Rafael Maria Merchán (Habana, I9I5); Poey en su aspecto literario y lingiiístico (Habana, I9I5); La Universidad de la Habana (Habana, I9I5); El movimiento lingïistico en Cuba (Habana, I9r6); Hacia el viejo Oriente (Habana, I917).

A N D M O N O G A P H S 





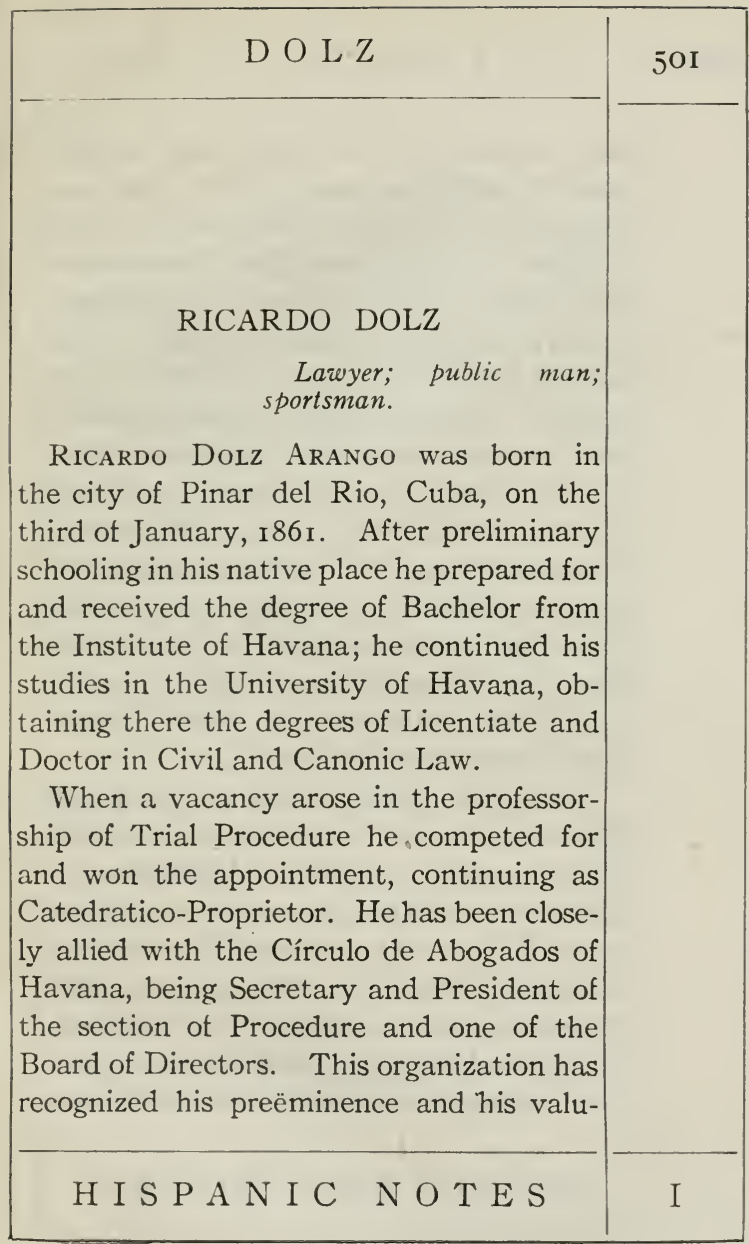




\begin{tabular}{|c|c|}
\hline 502 & C U B A N S F T O - D A Y \\
\hline - & $\begin{array}{l}\text { able service by awarding him several } \\
\text { medals including two of gold. He is a } \\
\text { member of the Board of Governors of the } \\
\text { Colegio de Abogados (Bar Association) } \\
\text { and formerly was president of the Ateneo. } \\
\text { Dr. Dolz early entered political life, } \\
\text { allying himself with the partisans of au- } \\
\text { tonomy. His first public appearance in a } \\
\text { political rôle was at the theater of Santa } \\
\text { Clara during an unsuccessful candidacy } \\
\text { for deputyship to the Cortes. He was sub- } \\
\text { sequently elected to a similar position dur- } \\
\text { ing the period of autonomy, but declined } \\
\text { the office and enigrated to New York } \\
\text { where he was secretary of the Cuban Re- } \\
\text { volutionary committee of which Enrique } \\
\text { José Varona was President. } \\
\text { Since the establishement of the Island } \\
\text { Republic, Dr. Dolz has been connected in } \\
\text { official capacities with the Moderate, the } \\
\text { Republican, and the Conservative parties in } \\
\text { turn. He formerly represented theProvince } \\
\text { of Pinar del Rio and now represents Cama- } \\
\text { güey in the Senate of which he is President. } \\
\text { His legal writings, some of which have } \\
\text { been adopted as textbooks in Spanish and }\end{array}$ \\
\hline I & H I S A N I C NOTES \\
\hline
\end{tabular}


other universities, are as follows: Prescripción de las acciones civiles; El código civil y el Notariado; La seguridad social y la liberatad individual; Las abintestatas $y$ el juicio ejccutivo; Proclama de derecho procesal. He is author of an interpretation of a portion of the Cuban constitution known as the "Quorum Dolz" which has been sanctioned by the Supreme Court. In connection with his professional and public life he has contributed widely to periodicals and for a time was director of a newspaper, Patria. As president of the National Conservative party he was in charge of the party's campaign in which General Menocal was elected President.

What time he can take from weightier matters, Dr. Dolz devotes to sports-to horses, of which he owns some fine thoroughbreds, to fencing, and to marksmanship. He was one of a trio of sportsmen who introduced the first airplane, a Bleriot, into the Island, and continues his interest in aeronautics as Vice-president of the Aero-club of Cuba. He also is a member of the Union Club of Havana.

\section{A N D M O N O R A P H S}



FERNANDO SÁNCHEZ DE FUENTES

Orator; teacher; economist; writer.

Fernando Sánchez de Fuentes was born in Havana on the twenty-second of December, I87 I, son of Eugenio Sanchez de Fuentes and Josefina Pelaez y Cardiff. With both his Bachelorate (Colegio La Gran Antilla, I887) and his Licentiate (University of Havana, r89r) he received prizes for the highest scholarship.

Upon attaining the degree of Doctor of Philosophy and Letters he was appointed Assistant Professor in that department of the University (I 894) and was reappointed in r9or. At about this latter date he took up the study of law and completed it with the doctor's degree in I904. Soon afterwards he was successful in competitive examinations for a position in the Faculty

H I S P A N I N O T E S 


\begin{tabular}{|l|l|}
\hline 506 & $\begin{array}{l}\text { C U B A N S O F T O - D A Y } \\
\text { of Law of the same University where he } \\
\text { now (I9I9) is Titular Professor of Mercan- } \\
\text { tile and Civil Law and Secretary of that } \\
\text { faculty. } \\
\text { Dr. Sanchez de Fuentes was a member of } \\
\text { the delegation from Cuba at the Second } \\
\text { Peace Conference at The Hague, and repre- } \\
\text { sented the Law Faculty and the Cuban } \\
\text { Society of International Law at the Second } \\
\text { Scientific Congress at Washington; he was } \\
\text { Envoy Extraordinary of the Republic of } \\
\text { Cuba to the Mexican Centenary Celebra- } \\
\text { tion, and assisted in preparing the exhibits } \\
\text { for the Fourth Pan-American Conference. } \\
\text { He is a member of the American Society } \\
\text { of International Law, of the Instituto } \\
\text { A mericano de Derecho Internacional, of } \\
\text { the International Council of the World's } \\
\text { Court League, of the Academy of Political } \\
\text { Science in the City of New York, and hon- } \\
\text { orary member of the Bar Association of } \\
\text { Lima, Peru. He has been decorated by the } \\
\text { Venezuelan Government with the Cross } \\
\text { of the Order of the Liberator. } \\
\text { As Representative in the lower House of } \\
\text { Congress he served upon the Committee }\end{array}$ \\
\hline H I S P A N I C N O T E S \\
\hline
\end{tabular}


of Foreign Relations and was Chairman of the Committee on Justice and Legal Codes; he was member of the committee which formulated the existing currency system and of the joint committee which prepared the Law for Economic Defense. He gave final form to the lav organizing the Diplomatic and Consular Service, as also to the Workman's Liability Law which, after having been presented ten years before, was finally perfected and passed under his sponsorship.

Two other important parliamentary labors of Dr. Sánchez de Fuentes are the bill-the first he introduced-by which the National University received a considerable appropriation for improvements, and one by which the Penal Code was reformed in conformity to modern standards.

Upon the occasion of the tobacco crisis of $1915^{-16}$, he was one of a special commission appointed by the House of Representatives to study the situation. The results of these investigations were collected and form the subject-matter of Ponencia, a volume whose editing was as-

\section{A N D M O NOGR A P H S}




\section{C U B A S O F T O- D A Y}

signed to Sánchez de Fuentes. It contains studies upon the agricultural problems of the country, tariff and revenue reforms, partition of lands, the lowering of the cost of living, etc., also the text of a bill recommended by the committee providing for the establishment of Agricultural Credits.

Dr. Sánchez de Fuentes' published writings are: El Teatro moderno; Las Nuevas Tendencias del Derecho Civil; La Segunda Conferencia de la Paz de la Haya; La Ley Orgánica del Poder Judicial y las leyes procesales; Por La Libertad y El Derecho, and various articles and addresses upon professional subjects. 



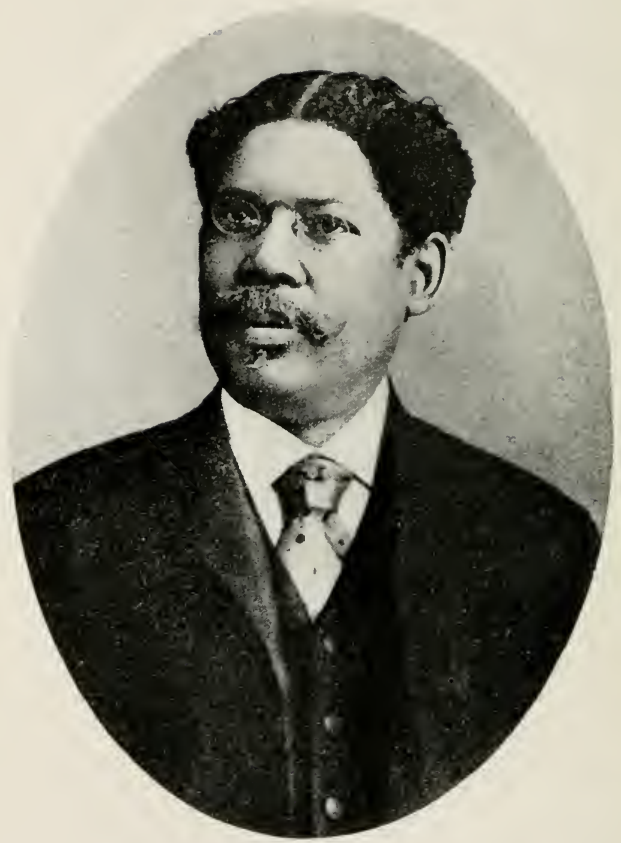

Juan Gualberto Gómez 


\section{GÓ M E Z}

\section{JUAN GUALBERTO GÓMEZ}

Journalist; pvblic man.

Juan Gualberto Gómez was born at the sugar plantation "El Vellocino," Province of Matanzas, on the twelfth of July, I 854 . From an early age he was active in the campaigns for the liberty of Cuba, writing on the subject for various papers.

He later went to Paris and entered the Escuela Central de Ingenieros, but having to earn his living he went into newspaper work on the editorial staff of $L^{\prime}$ Evenement. Later he travelled as a teacher through the French Antilles and from there to Mexico; then, going to Havana, he went into the offices of $L a$ Discusion as editor.

Subsequently he spent nearly ten years in Madrid, the first part of that time being

\section{A N D M O N O G R P H S}




\begin{tabular}{|c|c|}
\hline 510 & C U BANS OF TO-DAY \\
\hline & 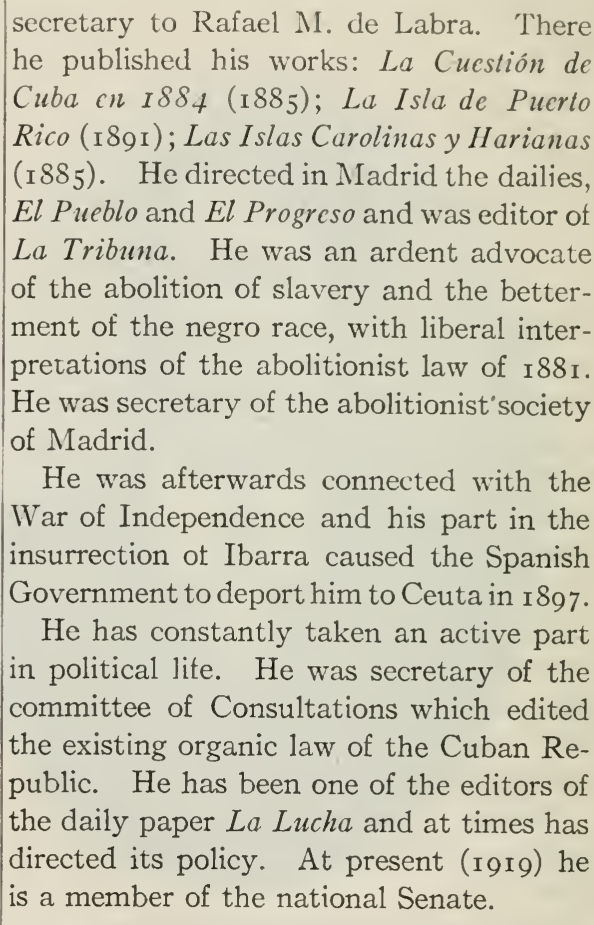 \\
\hline I & H I S P A I C N O T E S \\
\hline
\end{tabular}




\title{
MENDOZA GUERRA
}

\section{PEDRO MENDOZA GUERRA}

\author{
Teacher; journalist; public \\ man.
}

Pedro Mendoza Guerra was born in Pamplona, Spain, in September, I862. While very young his family migrated to Havana where he was educated in the Colegio de Belén, winning there the degree of Bachelor. He early became imbued with a desire to help his adopted country in her struggle for freedom, and the Third Corps of the Army of Liberation, in which he held the rank of Colonel, sent him as its representative to the assembly of la Yaya.

In 1896 he was appointed Governor of Camagüey, and was for a time mayor of the City of Camagüey after the establishment of the Republic. In I902 he was elected to represent that province in the

\section{A N D M O N O G R A H S}




\begin{tabular}{|c|c|}
\hline 512 & C U B A N S O F T O - D A Y \\
\hline & $\begin{array}{l}\text { lower house of Congress where he was for } \\
\text { a time Vice-president and presiding mem- } \\
\text { ber of several committees. In I9o7 he } \\
\text { was made Inspector of Census for the } \\
\text { Province of Havana. } \\
\text { The Cuban Government has sent Colonel } \\
\text { Mendoza upon various toreign missions: } \\
\text { to eastern Uruguay to adjust some na- } \\
\text { tional affairs, to Santo Domingo as Min- } \\
\text { ister, to Washington, and Seattle as } \\
\text { delegate to international congresses. } \\
\text { He has been allied with educational mat- } \\
\text { ters of the country having occupied at one } \\
\text { time the position of sub-secretary of Pub- } \\
\text { lic Instruction and Fine Arts. He has } \\
\text { been teacher of Latin, Spanish, and Uni- } \\
\text { versal History in the Colegios "San Miguel } \\
\text { Arcangel" and "Hernández Mederos" } \\
\text { (Havana) and Progreso (Cárdenas). At } \\
\text { a pedagogical congress at the National } \\
\text { University he delivered an address upon } \\
\text { the educational differences between El } \\
\text { Niño Cubano y el Niño Americano. } \\
\text { He is the author of Laz Razas (a study } \\
\text { in comparative ethnology and sociology) } \\
\text { thirty-nine chapters of which were pub- }\end{array}$ \\
\hline I & H I P A N I N O T E S \\
\hline
\end{tabular}




\section{E N D Z A G U E R R A}

lished in La Cuna de América; and also of Semblanzas de Políticos and Cancionero Heróico.

Besides being a collaborator in numerous periodicals in various parts of the country, he established and directed La Rerolución in Cienfuegos and Las Dos Repúblicas in Camagüey; he was for a time director of El Partido Liberal in Havana. $\mathrm{He}$ is a member of the Academy of History of Cuba. 



\section{G U T I É R R E Z}

GUSTTAVO GUTIÉRREZ Y SÁNCHEZ

Lawyer; teacher.

Gustavo Gutiérrez y SÁnchez was born in Camajuani in the Province of Santa Clara, Cuba, on the twenty-second of September, I895. His mother was a native of the same province, his father of Spanish birth. After some primary instruction at home he was sent to the Colegio of Belén in Havana and later to St. Ann's Military Academy in New York where he acquired a knowledge of English. Returning to Cuba he received his secondary education in the Institute of Havana whence he entered the University where he was graduated as Dcctor of Civil Law in I9I6, and a year later attained the degree of Doctor of Public Law, in both cases receiving the highest honors.

Dr. Gutiérrez acted in a secretarial

\section{H I S P A N I NOTES}




\begin{tabular}{|c|c|}
\hline $5^{16}$ & C U B A N S O F T O - D A Y \\
\hline & $\begin{array}{l}\text { capacity with the First National Legal } \\
\text { Congress of Cuba and with the Board of Di- } \\
\text { rectors of the American Institute of Inter- } \\
\text { national Law in session at Havana; through } \\
\text { competitive examinations he has been made } \\
\text { Assistant Professor of International Public } \\
\text { Law in the University of Havana and, dur- } \\
\text { ing the absence of the titular professor, } \\
\text { Dr. Bustamente, at the Peace Congress in } \\
\text { Paris (I9I9), is the acting head of his } \\
\text { department. } \\
\text { Following is the list of scientific soci- } \\
\text { eties of which he is a member: Colegio de } \\
\text { Abogados de la Habana; Sociedad Cubana } \\
\text { de Derecho Internacional (secretary since } \\
\text { its foundation); American Academy of } \\
\text { Political and Social Sciences; American } \\
\text { Society of International Law; National } \\
\text { Geographic Society; Organisation Centrale } \\
\text { pour une paix durable de la Haye. } \\
\text { As a public speaker he has dealt with } \\
\text { such subjects as La Destrucción de Polonia; } \\
\text { La emancipacion de Grecia; La nacionalidad } \\
\text { en la familia cubana; Cuba contemporánea. } \\
\text { Aside from various papers on historical } \\
\text { and political subjects which, after appear- }\end{array}$ \\
\hline$i$ & H I P A N I NOTES \\
\hline
\end{tabular}




\section{G U T I É R R E Z}

ing in Cuba Contemporanea and other periodicals, have been collected and published in the Anual of the Sociedad de Derecho Internacional, Dr. Gutiérrez has published a volume upon La Neutralidad y la Beligerancia de la República de Cuba durante la Guerra Actual, and in collaboration with Dr. Cesar Salaya a work (404 pp.) entitled 1 puntes de Derecho Internacional Público. He has in preparation works upon La liga de las Naciones; El régimen nacionalista cubano; $L a$ obligación de nointervenir; $L a$ situación internacional de Cuba and A puntes de Derecho Internacional Privado. 



\section{A P E N A}

ANTONIO MARIA VALDÉS DAPENA Physician; teacher.

Anțonio Maria Valdés Dapena was born in the village of Regla in the Province of Havana in 1879. He was educated in his native place and pursued secondary studies in the Institute of Havana, where he obtained the degree of Bachelor of Arts in 1895 and Doctor of Medicine in 1901 . Since then he has held the following positions: Assistant, after competition, in the Chair of Therapeuties and Pharmacy in the University of Havana; in I908 Assistant head ad interim of the laboratory of Therapeutics and Pharmacy of the University of Havana. In the same year, he was designated by the Titular professor to do the work of the Chair of Pharmacy. In October of the same year he was appointed, after a competition, to be Assist-

\section{H I S P A N I C N O T E S}




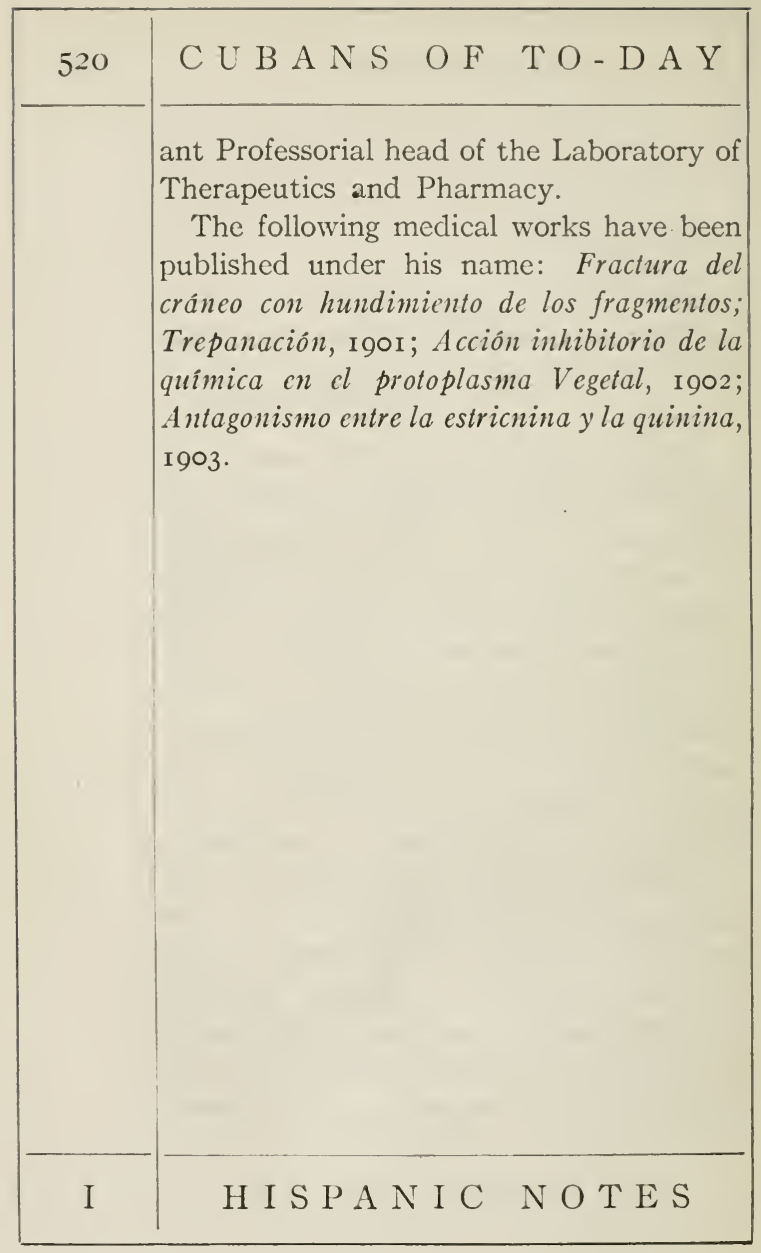




\section{A C H A D O}

GERARDO MACHADO Y MORALES

\section{Business man; official.}

Gerardo Machado y Morales was born in Santa Clara, Cuba, on the twentyninth of September, r87 r, and was educated in the same province, receiving the Bachelor's degree in $\mathrm{r} 884$.

He then joined his father in agricultural pursuits and together they enlisted in the Revolutionary force organized by Casallas, young Machado receiving the rank of Second Lieutenant. He soon joined the guard of General Suárez and later, promoted to a captaincy, was assigned to the guard of Gen. Juan B. Zayas. At the close of the war he was in command of the Santa Clara brigade with the rank of Brigadier General.

Upon the organization of the Rural Guard he was appointed Chief of the Dis-

A N D MO NO G R A P H S 


\begin{tabular}{|c|c|}
\hline 522 & C UBA NS OF TO-DAY \\
\hline & $\begin{array}{l}\text { trict of Santa Clara and Trinidad, but } \\
\text { resigned shortly to go into the tobacco } \\
\text { business, founding the firm Ramos, Ma- } \\
\text { chado y Cia with which he remains as a } \\
\text { silent partner. } \\
\text { General Machado devotes himself chiefly } \\
\text { to public activities. In the first popular } \\
\text { elections he was chosen Mayor of Santa } \\
\text { Clara which office he occupied until the } \\
\text { proclamation of the Republic. He was } \\
\text { subsequently appointed to the command of } \\
\text { the Twelfth Regiment but, desiring to } \\
\text { throw himself into the campaign of the } \\
\text { Liberal party. for the election of General } \\
\text { José Miguel Gómez, he severed his con- } \\
\text { nection with the military. He attended to } \\
\text { private business until his nomination for } \\
\text { the governorship of Santa Clara Province } \\
\text { in I9o8. In December, I } 909 \text {, he was ap- } \\
\text { pointed secretary of the Provincial Gov- } \\
\text { ernment and occupied that position for } \\
\text { seventeen months. } \\
\text { Under the presidency of Gen. Gómez, } \\
\text { Gen. Machado was in command of the } \\
\text { armed forces. }\end{array}$ \\
\hline I & H I P A N I C N O TES \\
\hline
\end{tabular}




\section{LORENZO FRAU MARSAL}

\section{Journalist; author.}

Lorenzo FraU Marsal was born in Igualada, on the third of April, I $88_{5}$. After a public school education he entered the University of Havana and pursued courses in philosophy and literature, then took up the study of law and obtained the degrees of Doctor of Civil and Public Law.

$\mathrm{He}$ was appointed assistant director of the journal of the House of Representatives in Igro and has devoted his time largely to journalistic work as editor or director of various periodicals including $P a y-P a y$, La Ilustración, Graphic Press of Cuba; Biblioteca América; Diario de la Marina; La Opinión; and El Noticiero. The last two are daily papers of Liberal affiliation.

His writings show much diversity of interest; they are: La Babel de Hierro

\section{A N D M O N O G A P H S}




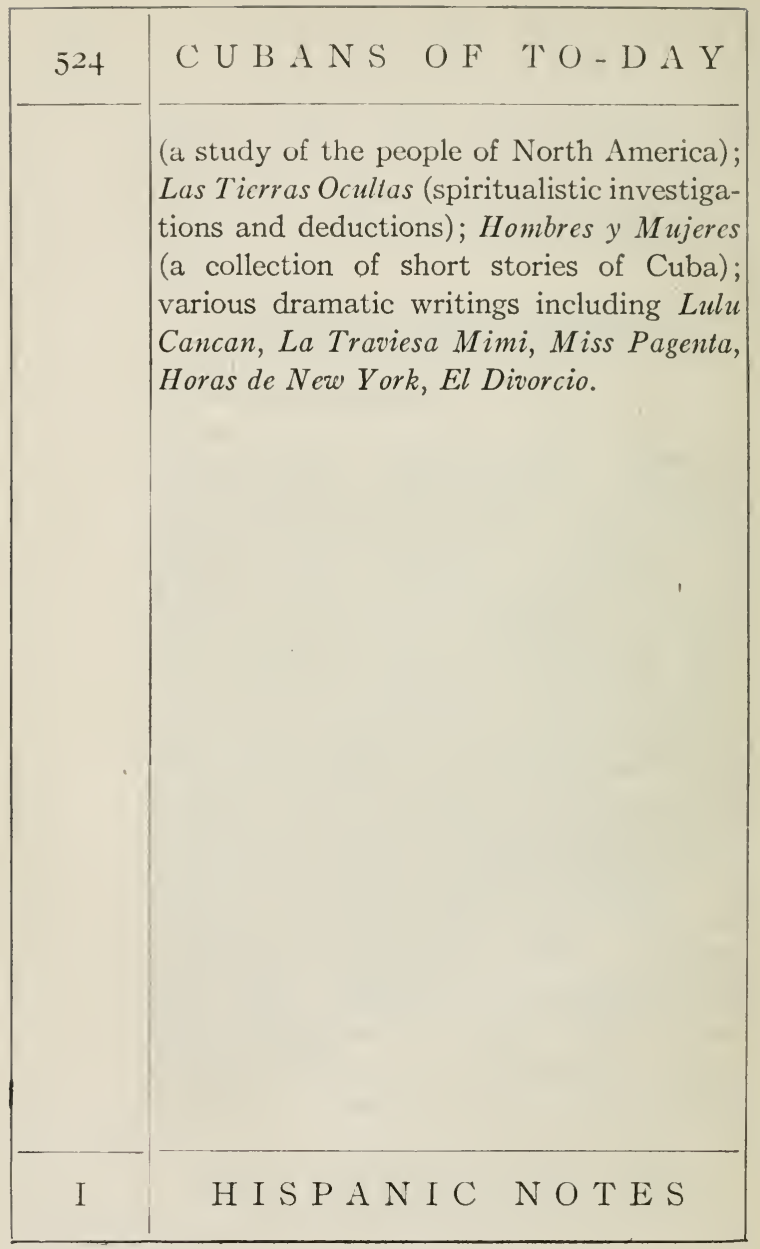




\section{FER NÁNDEZ MASCARÓ}

\section{GUILLERMO FERNÁNDEZ MASCARÓ}

Physician; educator; public man.

Guillermo Fernández Mascaró was born in Puerto Rico in 1872 of cultured and well-to-do parents, his father being a writer of some note. His academic education in San Juan de. Puerto Rico was followed by scientific study in the University of Havana where he obtained the degree of Licentiate in Physico-Chemical Science in 1892. As a student in the School of Medicine and Surgery of the same University he was winner in many competitions and was graduated with the highest honors in 1895 , receiving the degree of Doctor of Medicine and Surgery.

Although of foreign birth, Mascaró, during his student days became one of the

\section{A N D. M O N OGR A P H S}




\begin{tabular}{|c|c|}
\hline 526 & C U B A N S O F T O-D A Y \\
\hline & $\begin{array}{l}\text { leaders and spokesmen of the anti-Spanish } \\
\text { movement, and the moment he was free } \\
\text { from the University he hastened to join } \\
\text { the Army of Liberation of Cuba. Being } \\
\text { appointed to the sanitary service, he at- } \\
\text { tained the rank of Colonel and continued } \\
\text { active until the close of the Spanish-Amer- } \\
\text { ican war. } \\
\text { After a short period devoted partially } \\
\text { to private practice of his profession and } \\
\text { partially to the duties of public and hos- } \\
\text { pital physician, Dr. Mascaró turned his } \\
\text { attention largely to educational work. } \\
\text { Upon appointment of Governor General } \\
\text { Wood in r9oo, he took charge of the reor- } \\
\text { ganization of the Provincial Institute of } \\
\text { Santiago where he served also as professor } \\
\text { of physics and chemistry. He has con- } \\
\text { tinued his connection with this school, } \\
\text { being reconfirmed as director, and has con- } \\
\text { tributed to the cause of education many } \\
\text { scholarly articles of which the following } \\
\text { may be cited: Resumen de los progresos más } \\
\text { recientes en las ciencias fisico-biologicas; } \\
\text { Ideas dominantes en el actual desenvolvimi- } \\
\text { ento de la segunda ensenanza; Educacion }\end{array}$ \\
\hline I & H I S P N I C N OTES \\
\hline
\end{tabular}


física; Necesidad de una educación nacional y patriótica para la juventud cubana; Vulgarización de las ciencias y las letras como medio de educación popular; La educación en sus aspectos artístico, filosófico, cívico y moral; Relaciones entre la educación religiosa y moral.

Closely connected with Dr. Mascaró's labors for general education and for public health has been his political activity; he was one of the founders of the Republican party which has twice elected him to the National House of Representatives and in I9I 7 to the governorship of the Province of Oriente.

\section{A N D $M O N O G R A P H S$}






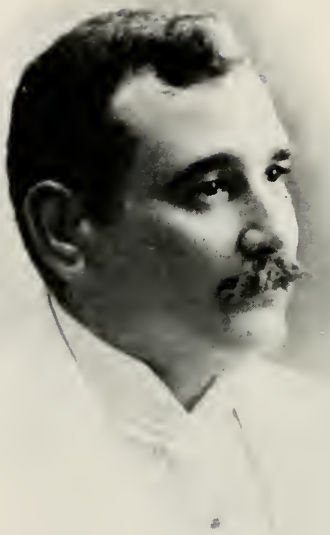

Carlos Mendieta 


\section{CARLOS MENDIETA}

\section{Journalist; soldier; public man.}

Carlos Mendieta was born on the fourth of November, I873, at La Matilde, the sugar plantation of his family, in the vicinity of San Antonio de las Vueltas, Province of Santa Clara, Cuba. His education was begun with private tutors in his home but was continued in the Colegios "Belén" and "El Mesias" in Havana and in the Institute of Santa Clara. From the last named school he received the Bachelor's degree in 1895 , then entered the University of Havana to prepare for the medical profession.

Early in January, I896, he abandoned his studies and went to the family sugar plantation "Central America" situated in San Diego de Nuñez, Province of Pinar del

H I S P A I C N O T E S 


\begin{tabular}{|c|c|}
\hline 530 & C U B A N S O F T O - D A Y \\
\hline & $\begin{array}{l}\text { Rio, there to throw himself into the Revo- } \\
\text { lutionary movement. From his own } \\
\text { allowance he armed and equipped a com- } \\
\text { pany of one hundred and twenty-five men } \\
\text { with whom he joined the Army of Libera- } \\
\text { tion. Before the close of the War of Inde- } \\
\text { pendence he had attained the rank of } \\
\text { Colonel. Upon the formation of the Rural } \\
\text { Guard during the first American Interven- } \\
\text { tion he was made Captain but resioned the } \\
\text { post to continue his medical studies in the } \\
\text { University of Havana. Here he was grad- } \\
\text { uated in I9oI with the degree of Doctor of } \\
\text { Medicine. } \\
\text { In December, following his graduation, } \\
\text { he was elected Representative from the } \\
\text { Province of Santa Clara for the first and } \\
\text { second congressional periods. During the } \\
\text { Provisional Government he occupied the } \\
\text { position of Inspector of Health of the } \\
\text { Republic. In I } 908 \text { he was again elected to } \\
\text { represent the Province of Santa Clara in } \\
\text { the lower House of Congress for four years, } \\
\text { and was returned in I9I } 2 \text { for four years } \\
\text { more. } \\
\text { Meanwhile, in I II, he was elected by a }\end{array}$ \\
\hline I & H I S P N I C N O T E S \\
\hline
\end{tabular}


parliamentary majority of his party to the presidency of the Commission of Agriculture, Industry, and Commerce, and two years later, by the same majority, he was made President of the Commission of Legal Acts, Authorization, Procedures, etc.

In I9I 6 he was the nominee for National Vice-president of the Liberal party of which he is a prominent member. $\mathrm{He}$ is now (Iоrg) Director of the Heraldo de Cuba. 



\section{PEDRO CALVO Y CASTELLANOS}

\section{Dental surgeon; writer.}

Pedro Calvo y Castellanos was born in Güines, $\mathrm{Cuba}$, in 1859 . He received his early education in Havana then studied some years in the United States. He holds the degrees of Doctor of Medicine and Doctor of Dental Surgery from the Pennsylvania College of Dental Surgery and the University of Philadelphia; also the degree of Doctor of Dental Surgery from the Universities of Mexico and Havana.

$\mathrm{He}$ has been one of the leaders in the dental profession in his native country; was active in the organization of the Dental Society in Havana of which he became president, as well as associate editor of its official organ Anales de la Sociedad Odontológica; he was founder and director of

\section{H I S P A N I C N O T E S}




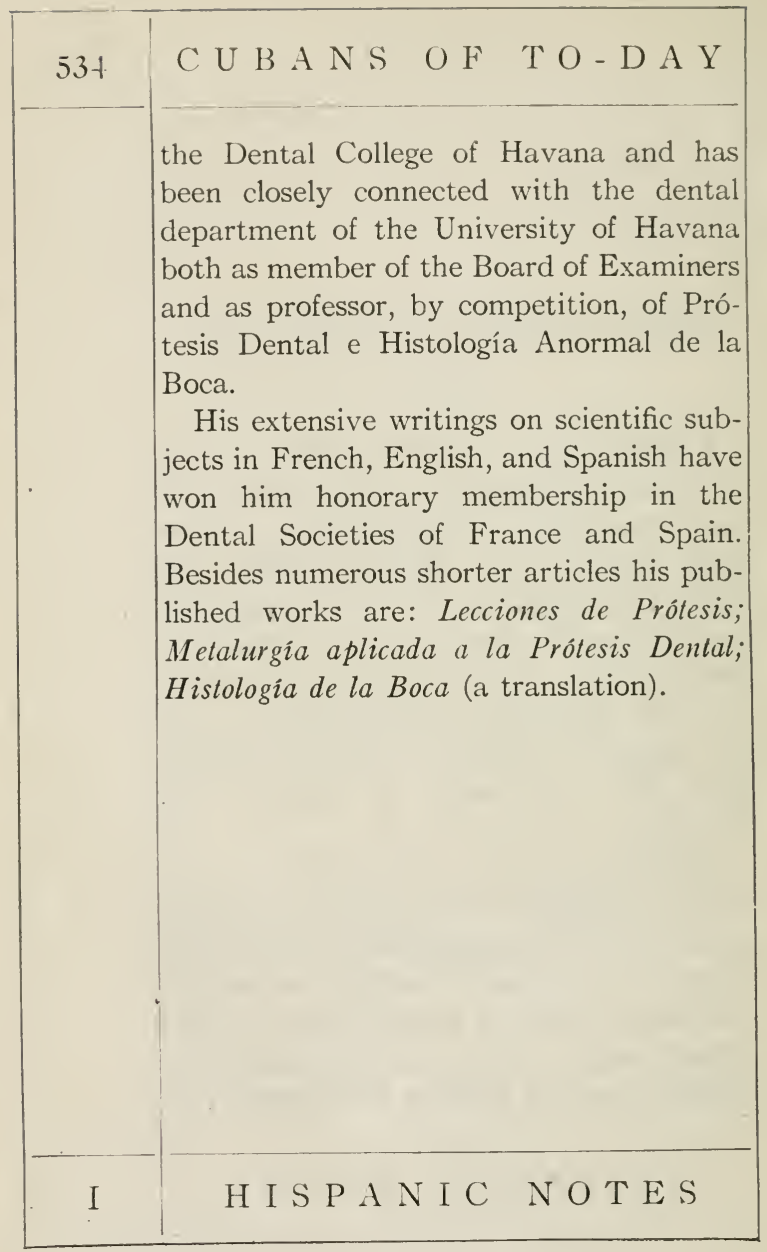




\section{B A R R A Q U É}

JESÚS MARÍA BARRAQUÉ Y ADUÉ Lawyer; cabinet member.

Jesús María Barraqué y Adué was born on the twenty-eighth of December, r868, at Havana. His early and secondary education were received in the Provincial Schools of Guanabacoa, after which he entered upon the legal course in the University of Havana. He was graduated as Licentiate in Civil and Canon Law on the twenty-first of June, I889, his special preparation having been as advocate.

After many years devoted to the private practice of his profession he was chosen in I9I I to the important position of Secretary of Justice of the Republic of Cuba, one of the departments of the President's Cabinet. He was dean of the Colegio de Abogados of Havana in r9r3.

\section{A N D M O N O G R A P H S}





\section{E S T R E}

\section{ARÍSTIDES MESTRE}

Man of science; teacher; author.

Arístides Mestre y Hevia was born in Havana, on the twenty-eighth of November, I 865, his parents being Dr. Antonio Mestre y Domínguez, one of Cuba's most eminent sons, scientist and man of letters, and Dolores Hevia y Romay. He obtained the degree of Bachelor at the Jesuit Colegio de Belén in 1880 . He won the highest honors in his class on that occasion and also at the granting of the Licentiate in Medicine (I886), the Licentiate in Physico-Chemical Science (I886), the Licentiate in Natural Sciences ( 1887 ), and the Doctorate in Medicine (1895) from the University of Havana.

During his student days, young Mestre had been much under the influence and inspiration of Dr. Felipe Poey, the eminent

H I S P A N I C N O T E S 


\begin{tabular}{|c|c|}
\hline 538 & $\mathrm{C} U \mathrm{~B}$ A N S O F T O- D A Y \\
\hline & $\begin{array}{l}\text { naturalist who then headed the faculty of } \\
\text { sciences in the University. On Dr. Poey's } \\
\text { recommendation he was appointed by royal } \\
\text { order in I } 888 \text { to an adjunct professorship } \\
\text { in natural science, a position which he re- } \\
\text { signed in I } 895 \text {. Upon the death of Poey } \\
\text { in I } 89 \text { I his professorship, zoölogy of verte- } \\
\text { brates, also was given to Mestre. } \\
\text { In I } 895 \text {, Dr. Mestre started on his first } \\
\text { trip abroad for scientific study. He spent } \\
\text { some time in New York and Toronto and } \\
\text { matriculated in the University of Pennsyl- } \\
\text { vania. Then, sojourning in Mexico, he } \\
\text { divided his time between medical work and } \\
\text { revolutionary propaganda. The govern- } \\
\text { ment of the State of Monterey put him in } \\
\text { charge of a lazaretto established to com- } \\
\text { bat the yellow fever epidemic. Already he } \\
\text { had begun specializing in nervous diseases } \\
\text { and he now was entrusted with that depart- } \\
\text { ment in the Monterey hospital. } \\
\text { The War for Independence won, Dr. } \\
\text { Mestre in I } 898 \text { set out for Europe by way } \\
\text { of the United States and spent some months } \\
\text { in Paris attending the famous clinics up- } \\
\text { on mental and nervous disorders, Bicêtre, }\end{array}$ \\
\hline I & H I S P A I C NOTE S \\
\hline
\end{tabular}




\section{E S T R E}

Salpêtrière, Santa Ana, etc., as well as studying institutions devoted to the care of abnormal children, following summer courses in natural history, and taking lessons in anthropology. Returning to New York he continued the same lines of study at the Vanderbilt Polyclinic, at hospitals, and the Museum of Natural History. At the end of 1899 he reached Havana.

In conformity with the order of the American Provisional Governor, he gave in I900-1904 free courses in anthropology and in nervous and mental diseases at the National Museum, with related laboratory practice. During the same years he delivered many addresses in hospitals, in the Normal School, the Summer School, and the Institute for Secondary Education.

As the result of competition in I904, Dr. Mestre was named Assistant Professor of the School of Sciences with the additional duties of Curator of the Poey Museum, which positions he continues to occupy (I9I9). To his efforts is due the erection of the Hall of Natural Sciences and the

\section{A N D M O NOGR A P H S}




\begin{tabular}{|c|c|}
\hline 540 & C U B A N S OF TO-DA Y \\
\hline & $\begin{array}{l}\text { Biological Laboratory. He has substituted } \\
\text { for Dr. Dihigo, Secretary of the Faculty of } \\
\text { Letters and Sciences, and has collaborated } \\
\text { with him in founding the Review, organ } \\
\text { of that faculty (1905), and in editing a } \\
\text { biography of Dr. José Manuel Mestre by } \\
\text { Dr. José Ignacio Rodríguez which has } \\
\text { important bearing on Cuban political } \\
\text { evolution. } \\
\text { In I9o9 he represented his University at } \\
\text { the Inaugural of President Lowell of Har- } \\
\text { vard and in I I } 4 \text { received leave to visit the } \\
\text { maritime biological museums of Europe. } \\
\text { This trip was interrupted by the outbreak } \\
\text { of the European war and he hastened home. } \\
\text { Mestre's first appearance in print was } \\
\text { with a translation of a French article on } \\
\text { Hygiene in r88. Since then, aside from } \\
\text { the Doctor's theses and an incalculable } \\
\text { number of articles in newspapers, the } \\
\text { medical journals of Cuba have published, } \\
\text { and foreign journals have to an extent cited } \\
\text { or reproduced, the following articles: Ten- } \\
\text { dencias a que obedece la Higiens actual } \\
\text { (I } 886 \text { ); Hipnotismo. Irresponsabilidad de } \\
\text { los actos que se sugieren y realizan durante }\end{array}$ \\
\hline I & H I S P A I C NOTES \\
\hline
\end{tabular}


ese estado (I 886); La politica moderna y la ciencia antropológica. El problema de la colonizaciôn (1887); ¿ Deben los anfibios conslituir un orden entre ios reptiles, o bien una clase intermediaria entre los reptiles y los peces? (I887); Elogio del Sr. Felipe Poey (I89I); De las relaciones entre los diversos cstados patológicos, consideradas en la serie ancestral y hereditaria (1893); La Antropología en Cuba (1894); Primera observación de acromegalia recogida en Cuba (I895); La enseñanza de las ciencias Naturales en París (1899); La enseñanza de la Antropología en París (1900); Sobre la creación de un departamento para la educación médica de los niños defectuosos en sus facultades intelectuales y morales (1902); Osteoartropatía hipertrofiante pnéumica (I902); Epilcpsia progresiva (1903); Informe sobre el estado mental de una procesada (1903); Elogio del Dr. José I. Torralbas (1904); La Biología y el programa de su enseñanza (1905); Las inteligencias anómalas y el problema de su educación (I905); La imitación como factor de defensa en el reino animal (1906); Los nidos de las aves y su filosofía

\section{A N D M O N O G R A P H S}




\begin{tabular}{|c|c|}
\hline $5+2$ & C U B A N S OF TO-DAY \\
\hline & 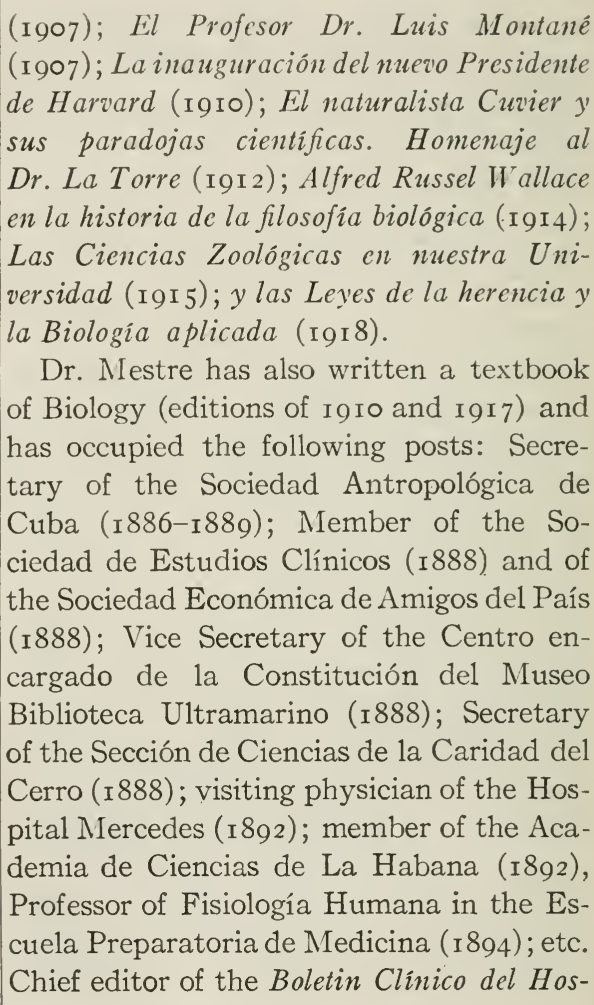 \\
\hline I & H I S P A I C NOTES \\
\hline
\end{tabular}




\section{E S T R E}

pital Number One (1903) and of the Archivos de Medicina Mental (I910); Secretary of the Sección de Enfermedades Nerviosas y Mentales del Tercer Congreso Pan Americano (I90I) and of the Sociedad de Psiquiatria y Neuropatología (I9I I); member of the Séptimo Congreso Internacional de Zoología (I907); charter member of the Sociedad de Medicina Tropical (I908); Charter member of the Sociedad Cubana de Historia Natural Felipe Poey (I9I3) of which he is at present Secretary General; Director of the Sección de Bíología and chief editor of the Memorias, its official organ; member of the American Genetic Association, of Washington (1918). 



M I R O
JOSÉ MIRO Y ARGENTER
Soldier; journalist.
JosÉ MiRO Y ARGENTER was born near
Barcelona on the fifth of March, I857.
He continued his education as far as
fulfilling the requirements for the degree
of Bachelor of Arts.
During the War for Independence, he
was Chief of Staff of Lieutenant General
Antonio Maceo and himself reached the
rank of General. The archives of the
Army of Liberation were consigned to his
keeping.
Following his military career he took an
active interest in journalism. He founded
and directed in Holguin La Doctrina, in
Manzanillo El Liberal and La Democracia,
and in Havana, Vida Militar. He con-
tributes to various periodicals and is the
author of the following pamphlets: La
H I S P A I C N O T E S




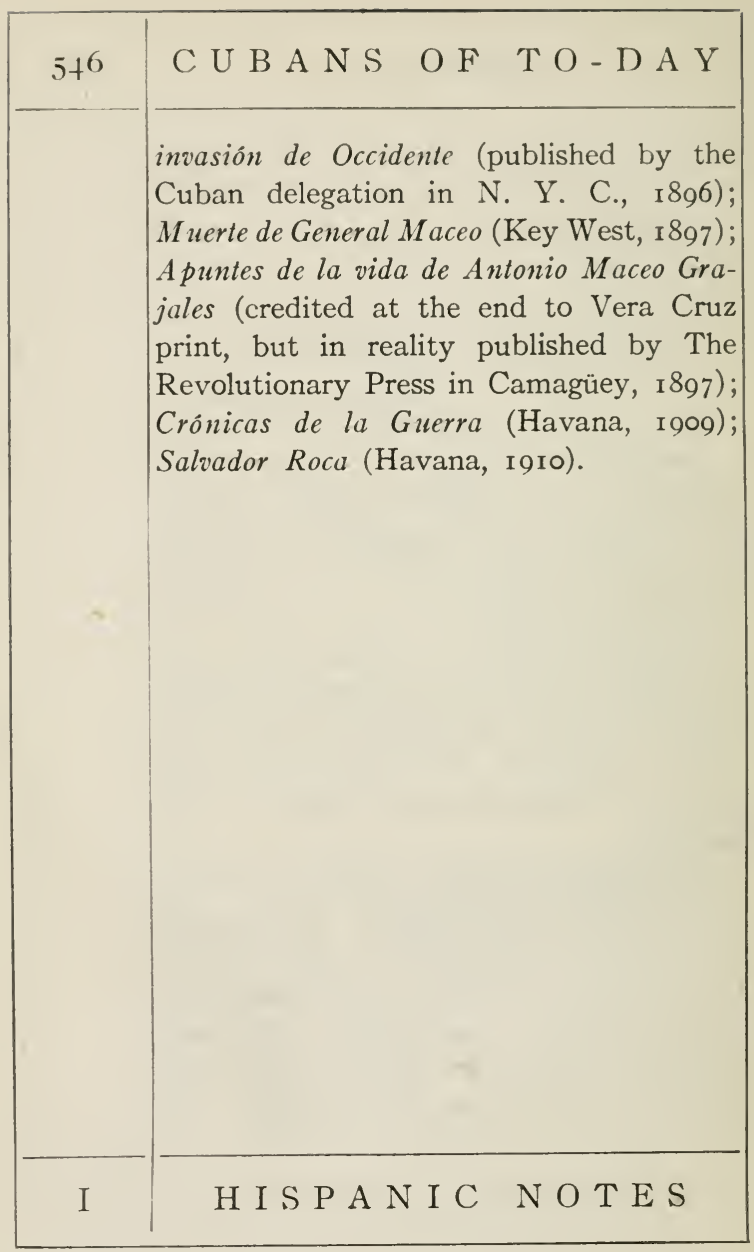




\section{MANUEL RIVERO Y GANDARA}

\section{Agriculturist; public man.}

Manuel Rivero y Gandara was born in the city of Cienfuegos, Province of Santa Clara, Cuba, on the third day of January, I874. He received his primary schooling in the Colegio "San Carlos" and prepared for the Bachelorate in the Colegio of "Monserrat," Cienfuegos, and the Institute of Secondary Education in Santa Clara, the degree being granted him in the latter school in the year $\mathrm{I} 890$.

He pursued in the University of Deusto (Bilbao, Spain) the studies preparatory to entrance in the famous Polytechnic School of Madrid in which institution, as well as the special School of Roads, Canals, and Ports, he was a student.

Since his return to Cuba he has devoted himself to agriculture and to public life.

A N D M O N O R A P H S 


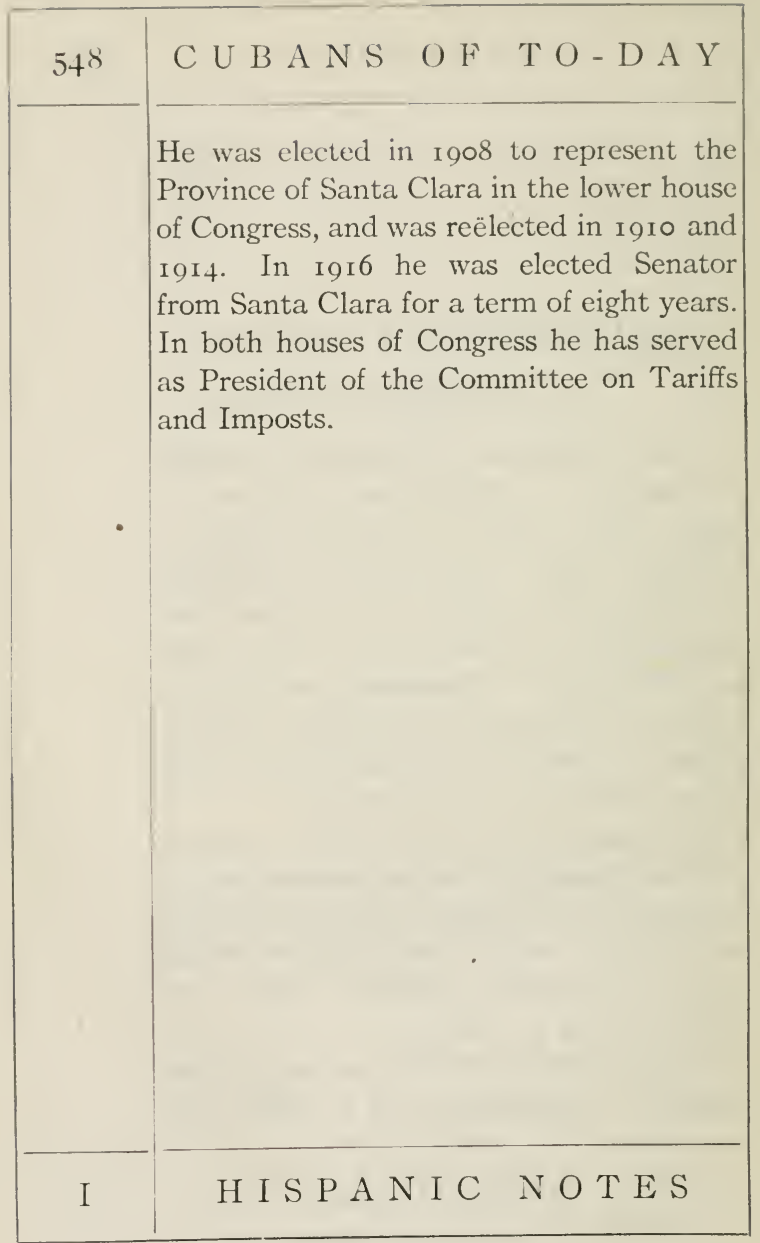




\section{O N T A L V O}

RAFAEL MONTALVO

Business man; soldier; public man.

Rafael Montalvo was born in Havana in 1875 and attended the Colegio Casado until attaining the Bachelorate. He then entered the University of Havana to study pharmacy, but the War of Independence cut short his studies.

Soon after the outbreak of the Revolution he joined the forces of General José Maceo under whom he fought until he was made Aide to General Antonio Maceo, with whom he served during a portion of the campaign. He then was transferred to the orders of General Calixto García taking part in the famous combat of Victoria de las Tunas. He was promoted to be Chief of the Regiment Carlos M. de Céspedes with which he fought near Bayamo; later,

\section{A N D M O N O G R A P S}




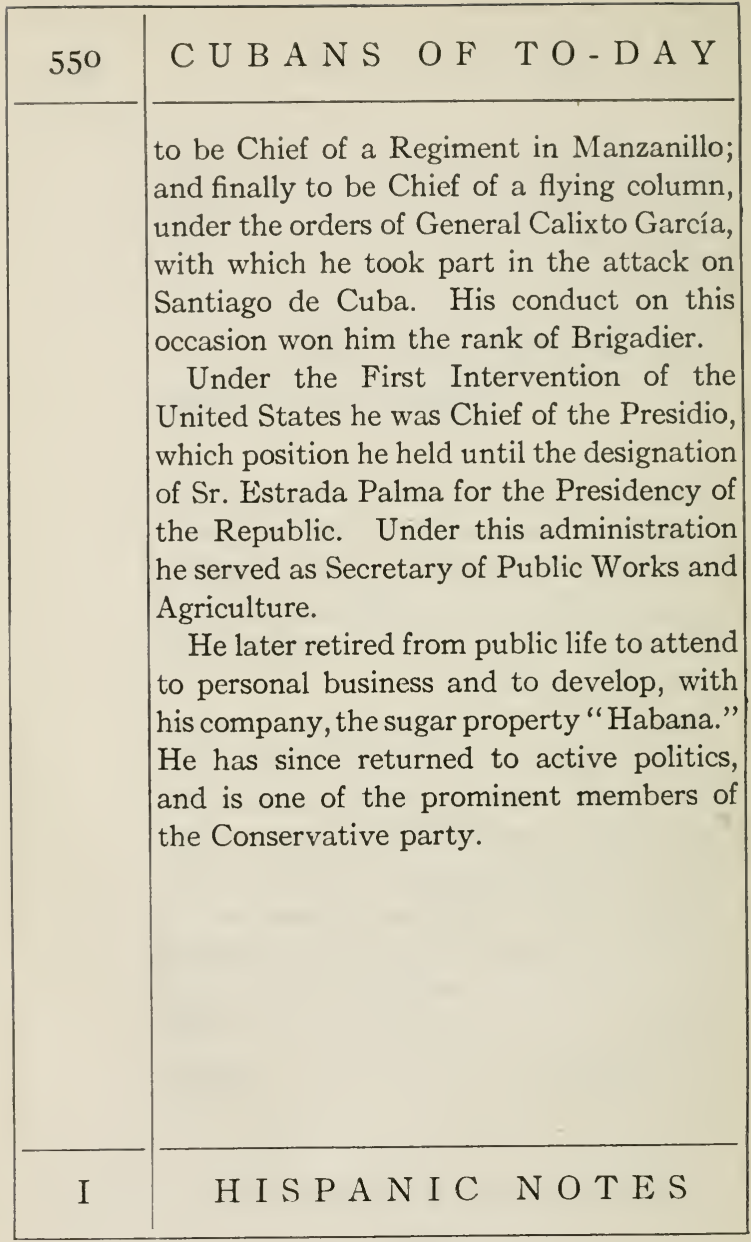




\begin{tabular}{l} 
P A S A L O D O S \\
\hline \\
DAMASO PASALODOS \\
DAMASo PASALODos was born in Cien- \\
fuegos in the Province of Santa Clara, \\
Cuba, on the first of June, I872. He re- \\
ceived his early education at the Jesuit \\
Colegio, "Nuestra Señora de Monserrate," \\
reaching the grade of Bachelor, then passed \\
to the University of Havana to undertake \\
the study of law; here he was graduated in \\
I892 with the degree of Licentiate. \\
He immediately entered public lite and \\
occupied various elective and appointive \\
offices: \\
Under the Spanish dominion, - Commis- \\
sioner of the "Fiscal" of His Majesty \\
for the Audiencia Territorial of Cien- \\
fuegos; Managing Secretary of the Board \\
of Charities of the Province of Santa Clara; \\
Register of Properties for Cienfuegos. \\
A N D M O N O G R A P H S
\end{tabular}




\begin{tabular}{|c|c|}
\hline $55^{2}$ & C U B A N S O F T O - D A Y \\
\hline & $\begin{array}{l}\text { During the first American Intervention, } \\
\text { - Secretary of the Mayoralty of Cien- } \\
\text { fuegos; member of the Cienfuegos City } \\
\text { Council; sub-director of the Registry and } \\
\text { Notary. } \\
\text { Under the first Republic,-Register of } \\
\text { Properties for the city of Trinidad during } \\
\text { two periods covering several years; Regis- } \\
\text { trar for Bejucal, near Havana, to which city } \\
\text { he was transferred upon his own solicitation. } \\
\text { After the reconstruction of the Republic, } \\
\text {-Director of the Registry and Notary } \\
\text { tor five months-during the Presidency of } \\
\text { General Gómez-then called by the na- } \\
\text { tional government to become Secretary to } \\
\text { the President, which position he occupied } \\
\text { two and a half years. Upon the creation } \\
\text { of the Registry of Properties del Oriente } \\
\text { de la Habana he was designated as its chief } \\
\text { and so remained until I9I } 7 \text {, at the same } \\
\text { time attending to private law practice in } \\
\text { Cienfuegos as well as in Bejucal, Trinidad, } \\
\text { and Havana. } \\
\text { Pasalodos' first political affiliation was } \\
\text { with the Reformista party of Duquesne, } \\
\text { Amblard, Conde de la Mortera, etc. He }\end{array}$ \\
\hline I & H I S P N I C NOTES \\
\hline
\end{tabular}




\section{P A S A L O D O S}

was Secretary of this group in Cienfuegos until it was merged with the Autonomists. With the political readjustment that accompanied American Intervention, he was instrumental in the formation of the Republican party in company with Alemán, Monteagudo, Machado, and the afterwards President José Miguel Gómez.

Beside contributing to various newspapers, including the Diario de la Marina and El Triunfo, he has written a number of pamphlets of an administrative order and in his official capacity the presidential reports. 



\section{P E R E D A}

\section{JOSÉ PEREDA}

Physician and surgeon.

José Pereda y Galvez was born on the twenty-sixth of January, ${ } \delta_{72}$, in Consolación del Sur, Province of Pinar del Río, whence after having fulfilled the requirements of the Bachelorate he moved to Havana and matriculated in the Medical Department of the National University.

His special leaning was toward anatomy and surgery to which he devoted his entire time as student and instructor.

In 1894 , he received the title Doctor of Medicine and immediately began in $\mathrm{Ha}$ vana the practice of the profession and also the institution of the "Escuela Libre de Medicina," a private medical school into whose teaching force he drew some of Cuba's most prominent physicians.

At the outbreak of the War for Inde-

H I S P N I C NOTES 


\begin{tabular}{|c|c|}
\hline 556 & C U B A N O $\mathrm{F}$ T O - D A Y \\
\hline & $\begin{array}{l}\text { pendence in I } 895 \text {, he offered his professional } \\
\text { services to the Army of Libcration, but } \\
\text { being without private means of support for } \\
\text { his family he was permitted to serve in the } \\
\text { vicinity of Havana and to devote a portion } \\
\text { of his time to personal affairs. The war } \\
\text { terminated, he returned to his surgical } \\
\text { practice in the several hospitals of the } \\
\text { city and in the "Quinta del Rey." } \\
\text { In I9o6 he founded his clinic "San } \\
\text { Rafael." Throughout the Revolution } \\
\text { which broke out the same year, he gave his } \\
\text { services in city and country and used his } \\
\text { clinic as an army hospital. He had in } \\
\text { his care the Commander-in-Chief, General } \\
\text { Máximo Gómez and, refusing to accept } \\
\text { any emolument for that service, the City } \\
\text { Council of Havana proclaimed him an } \\
\text { "adopted son of that city and capital." } \\
\text { In Igo8 the Liberal party elected him to } \\
\text { represent the Province of Havana in the } \\
\text { lower house of Congress where he was } \\
\text { placed at the head of the Committee of } \\
\text { Health and Philanthropy; but he resigned } \\
\text { to accept President Gómez's appointment } \\
\text { as Surgeon General of the army with the }\end{array}$ \\
\hline I & H I P A N I C NOTES \\
\hline
\end{tabular}




\section{P E R E D A}

rank of Lieutenant Colonel. This position he held until August, I9I3.

In I9I3 under a commission from the Government he left Cuba upon an extended tour of inspection and observation among the leading hospitals of America and Europe.

At various sessions of the Pan-American Medical Congress, Dr. Pereda has presented addresses upon the following subjects: Cinco casos de resección o sea en el cráneo; Consolidación viciosa en una fractura del fémur; Talla hipogástrica por cuerpo extraño; Un caso excepcional de uretrotomia externa.

$\mathrm{He}$ is author of pamphlets as follows: Anastomosis de las arterias del cerebro (I892); Las localizaciones cerebrales y la trepanación; Modalidades de la artritis blenorrágica (1896); Contribución al estudio del peritoneo tuberculoso (1906); Ictero apendicular; Diversas etiologías (I906); Estudio comparativo entre la seda y el catgut, paraligaduras en las operaciones abdominales (I908); La apendicitis y el ovario escleroquístico derecho (r9o9); Un caso de tuberculosis genital (I9I I); Hojas clinicas (I912).

\section{A N D M O N O G R A P S}






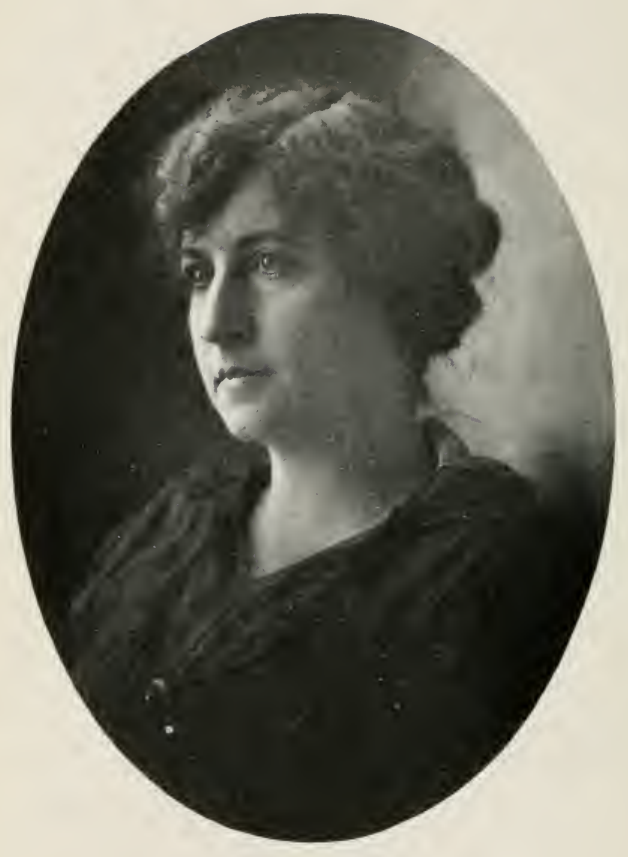

10 arolina Ponect y de Cárdenas. 


\section{CAROLINA PONCET Y DE CÁRDENAS}

\section{A uthor; teacher.}

Carolina Poncet y de Cárdenas was born in the village of Guanabacoa in the outskirts of Havana and belongs to an ancient and distinguished Cuban family, her uncle being the well-known literary man José M. de Cárdenas y Rodríguez. After finishing her elementary studies she pursued courses in the normal school for school teachers in Havana and secured the degree of Mistress of Elementary and Superior Primary Education. As her family was ruined economically during the War of Independence, she was obliged to put her pedagogical training into practice at an early age. She took part in the reorganization in Cuba of primary education, becoming head-mistress of a public school in Havana.

\section{H I S P A N I C N O T E S}




\begin{tabular}{|c|c|}
\hline 560 & C U B A N S O F T O - D A Y \\
\hline - & $\begin{array}{l}\text { She has held the position of teacher in the } \\
\text { vocational school and often lectured in the } \\
\text { summer normal schools in the Cuban capi- } \\
\text { tal. In I9 Io she won the first prize in the } \\
\text { Province of Havana at an official competi- } \\
\text { tion open to public school teachers. After } \\
\text { she had followed advanced studies in the } \\
\text { University of Havana for several years, she } \\
\text { received the degree of Doctor of Pedagogy, } \\
\text { I 9o9, and Doctor of Philosophy and Letters } \\
\text { in I9I3. In I9I } 5 \text {, when the new normal } \\
\text { schools of the republic were founded, she } \\
\text { obtained after competition in Havana the } \\
\text { chair of grammar, composition, elocution, } \\
\text { Spanish and Cuban literature in the normal } \\
\text { school, a position which she now occupies, } \\
\text { having been at the same time the first } \\
\text { superintendent of this school. She has } \\
\text { published a monograph, El Romance en } \\
\text { Cuba, which obtained the prize in the liter- } \\
\text { ary competition of the National Academy of } \\
\text { Arts and Letters in I } 9 \text { I3, and also an edu- } \\
\text { cational book, Lecciones de Lenguaje, which } \\
\text { was rewarded with an especial silver medal } \\
\text { at the St. Louis Exposition and adopted as } \\
\text { a textbook in the public schools of Cuba. }\end{array}$ \\
\hline I & H I S P A I C N O TES \\
\hline
\end{tabular}




\section{P O N C E T}

She has prepared for publication a biography of Joaquin Lorenzo Luaces, a critical study of his works, which was rewarded with a prize at a competition held under the auspices of the Bar Association (Colegio de Abogados) in Havana in 1910. 



\section{R E C I O}

ENRIQUE RECIO Y AGUERO

Soldier; surveyor; public man.

Enrique Recio y Aguero was born on the twenty-second of March, I877, in Callao, Peru. His parents were Cubans and in the early childhood of the boy returned to their native island where he received his early education, obtaining the degree of Bachelor in Camagüey in 1894 .

Upon the outbreak of the War for Independence in 1895 , at that time a student in the University of Havana, he followed the example of his father and joined the Army of Liberation as soldier in the Fourth Cavalry troop "Agramonte." Wounded in the first attack on Cascorro, he was promoted to a second-lieutenancy. In the course of the war, he suffered several subsequent wounds one of which left his right

H I S P A N I N O T E S 


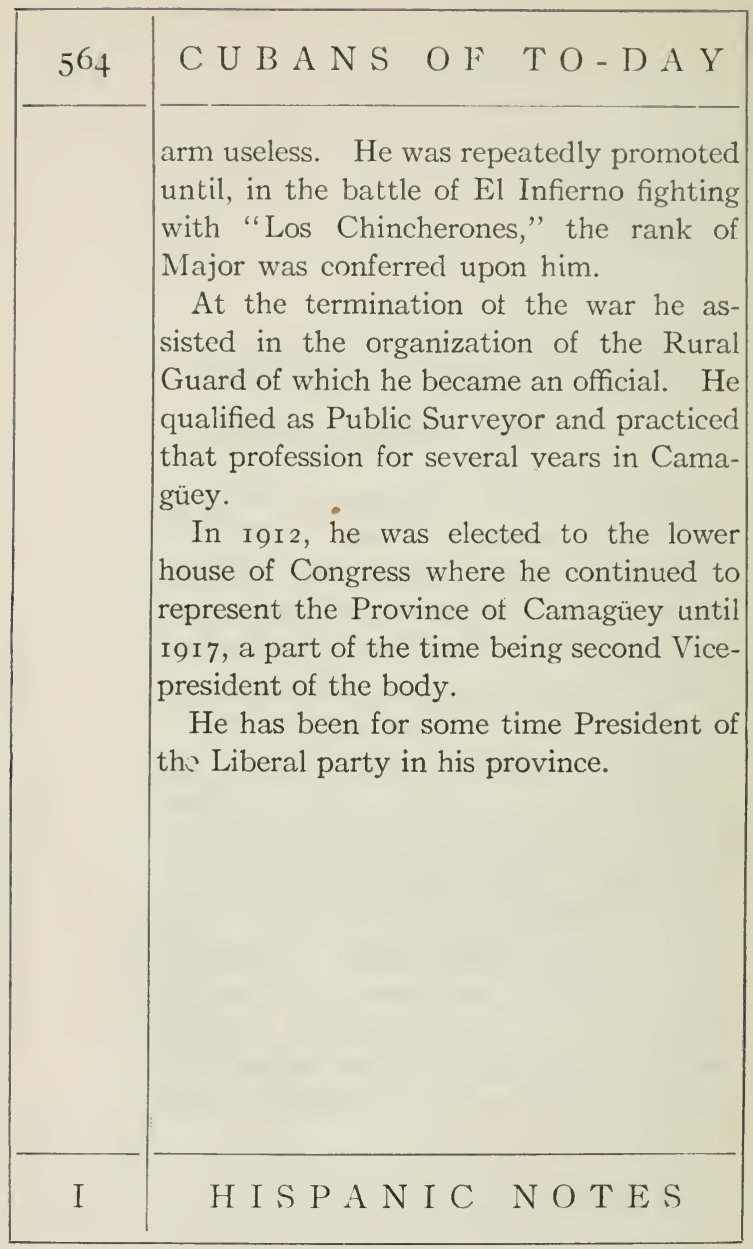




\section{G A R C Í A M O N}

\section{RAMÓN GARCÍA MON}

\section{Physician.}

RaMón García Mon was born in Vivero, Spain, in I 868, and moved to Cuba in $\mathrm{I} 88 \mathrm{I}$. $\mathrm{He}$ received his education in $\mathrm{Cuba}$, fulfilling the requirements for the degree of Bachelor. He devoted himself to the study of sciences, obtaining the Doctorate in 1892 and a year later was graduated as Doctor of Medicine. Soon thereafter he was named Professor of the Institute of Santa Clara, but resigned that he might practice his profession.

He was appointed assistant secretary of the Colegio Médico of Cuba and member of the Society for Clinical Research of Havana. In I9I4 he was offered the position of Director of the "Purísima Concepción," the sanatorium of the Association of Commercial Assistants. He also is the physician of the Spanish Legation, and "Caballero" of the Royal and Distinguished Spanish Order of Carlos III.

\section{A N D M O N O G A P H S}





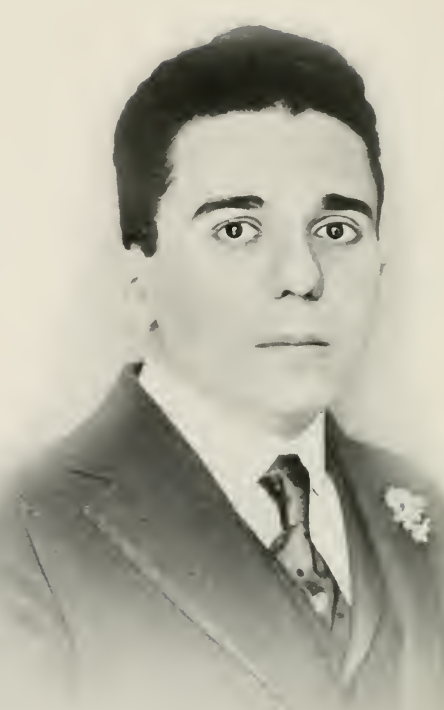

Emilio Roig de Senchsenring. 
EMILIO ROIG DE LEUCHSENRING

\section{Lawyer; writer.}

Emilio RoIG DE LeUChSENRING was born on the twenty-third of August, I889, in Havana where he pursued his studies first of all in the Jesuit College of Belén and then at the University of Havana, where he graduated in law (I9I6), a profession which he now pursues along with that of journalist and writer. He was corresponding secretary of the first National Law Congress held at Havana in I9I6 and edited the publication of the proceedings of this congress. At the present time he is corresponding secretary of the codification committee named by the above congress to prepare a new paragraphed edition of the civil code. From I908 to I9Io he was editor of the Revista de Derecho. $\mathrm{He}$ is head of the editorial staff of the Grafico

\section{H I S P A I C NOTES}




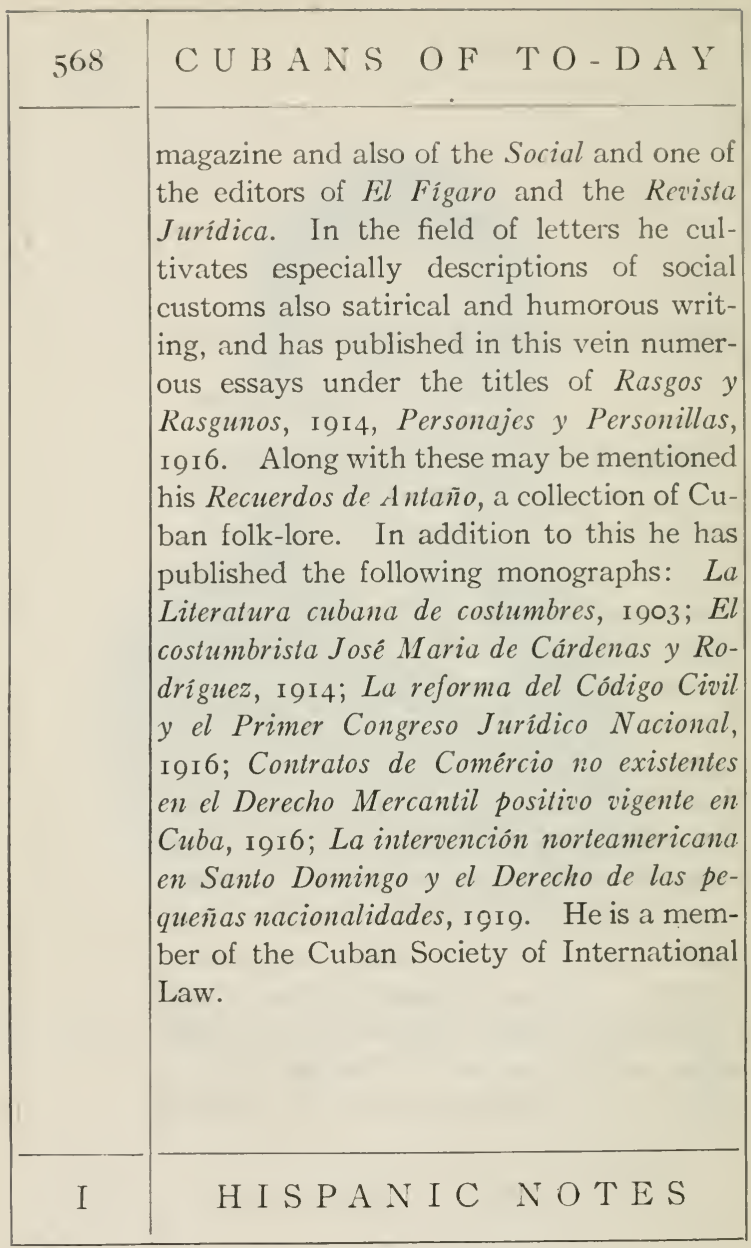




\section{E R O J A S}

ALBERTO DE ROJAS Y CRUZA'T

Business man; patriot; official.

Alberto de Rojas y Cruzat was born in Cárdenas, Cuba, on the second of April, I868. He fulfilled the requirements for the degree of Bachelor at the Colegio "La Gran Antilla" in Havana, then entered the law department of the University in that city where he remained until, at the end of the third year, he was called to take charge of his father's sugar plantation near his native town.

Throughout the War for Cuban Independence he was representative of the Revolutionaries in Cárdenas, where he was arrested and imprisoned and his sugar properties destroyed. Shortly after General Blanco succeeded Weyler, Rojas was freed.

During the American Intervention he belonged to the City Council of Cárdenas

\section{A N D MONOGRA P H S}




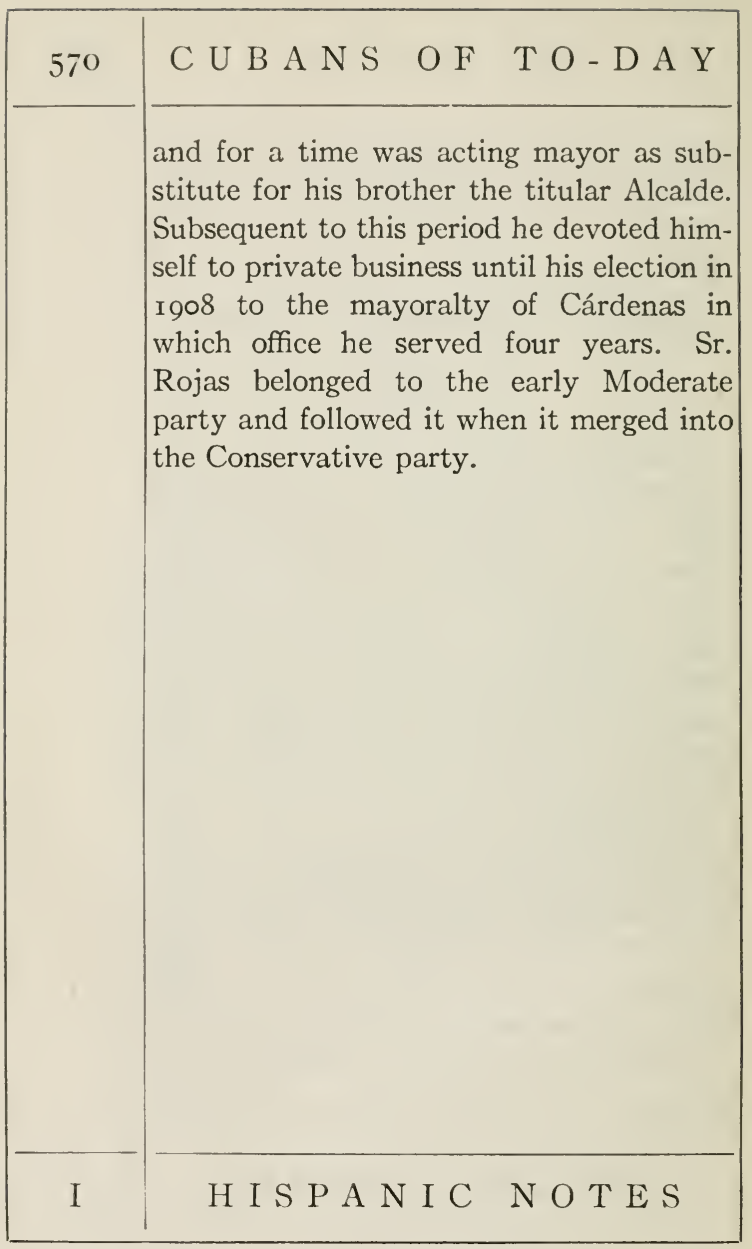


FRANCISCO CABRERA SAAVEDRA Physician; public man.

Francisco Cabrera SaAvedra was bórn in the Canary Islands in I $85^{\circ}$. While very young he moved to Cuba where his parents' circumstances were such that they could afford for him only the most elementary education.

Seeing in him a promising student, the Council of Caibarien, where he lived, granted him a pension to enable him to study in the Normal School of Guanabacoa. Here he received the title Teacher in 1868 .

He then went to the United States and later to Santa Cruz de la Palma where in one year he fulfilled the requirements for the Bachelorate. Going to Madrid he took up the study of Medicine and was graduated as Licentiate in 1875 .

\section{A N D M O N O G R A P S}




\begin{tabular}{|c|l|}
\hline 572 & $\begin{array}{l}\text { C U B A N S O F T O - D A Y } \\
\text { In a brilliant competition in which he } \\
\text { stood at the head of } 2 \text { I } 4 \text { aspirants, he ob- } \\
\text { tained a place in the sanitary corps of the } \\
\text { army. On his return to Cuba, he soon } \\
\text { retired from the military service, entered } \\
\text { the University, and obtained the degree of } \\
\text { Doctor of Medicine. } \\
\text { Thereupon he began the practice of his } \\
\text { profession in which he has won a creditable } \\
\text { position and has been elected President of } \\
\text { the Colegio Medico of Cuba. He has also } \\
\text { served as Medical Inspector of Special } \\
\text { Hygiene, member of the City Council and } \\
\text { inspector of the Sanitary Service of that } \\
\text { body. In addition to these offices he has } \\
\text { held those of president of the Railway ot } \\
\text { Caibarien and Delegate for Havana to the } \\
\text { Spanish Cortes. } \\
\text { Since I898, Dr. Cabrera Saavedra has } \\
\text { taken little part in public life, but has de- } \\
\text { voted himself to medical practice and his } \\
\text { personal affairs. }\end{array}$ \\
\hline I & \begin{tabular}{l} 
H I S P A N I C N O T E S \\
\hline
\end{tabular} \mid \\
\hline
\end{tabular}


ENRIQUE ROIG Y FORTESAAVEDRA Lawyer; public man.

Enrique Roig y Fortesaavedra was born on the twenty-ninth of June, I 872 , in the city of Havana, where he pursued all of his studies, first at the Colegio of Belén and then at the University of Havana, at which he received the title of Advocate. Since his graduation he has devoted himself to the practice of law, along with that of notary public. He was a member of the Provincial Council of Havana. In November, 1908, he was elected Representative by the Liberal party in the Province of Havana, and was reëlected in I9ı and in I9I4. His term expires in April, I9I9. During the Fifth Congressional period he was president of the Committee on Foreign Relations and in I9I 3 he was reëlected to the same position.

\section{A N D MONOGRAPH S}




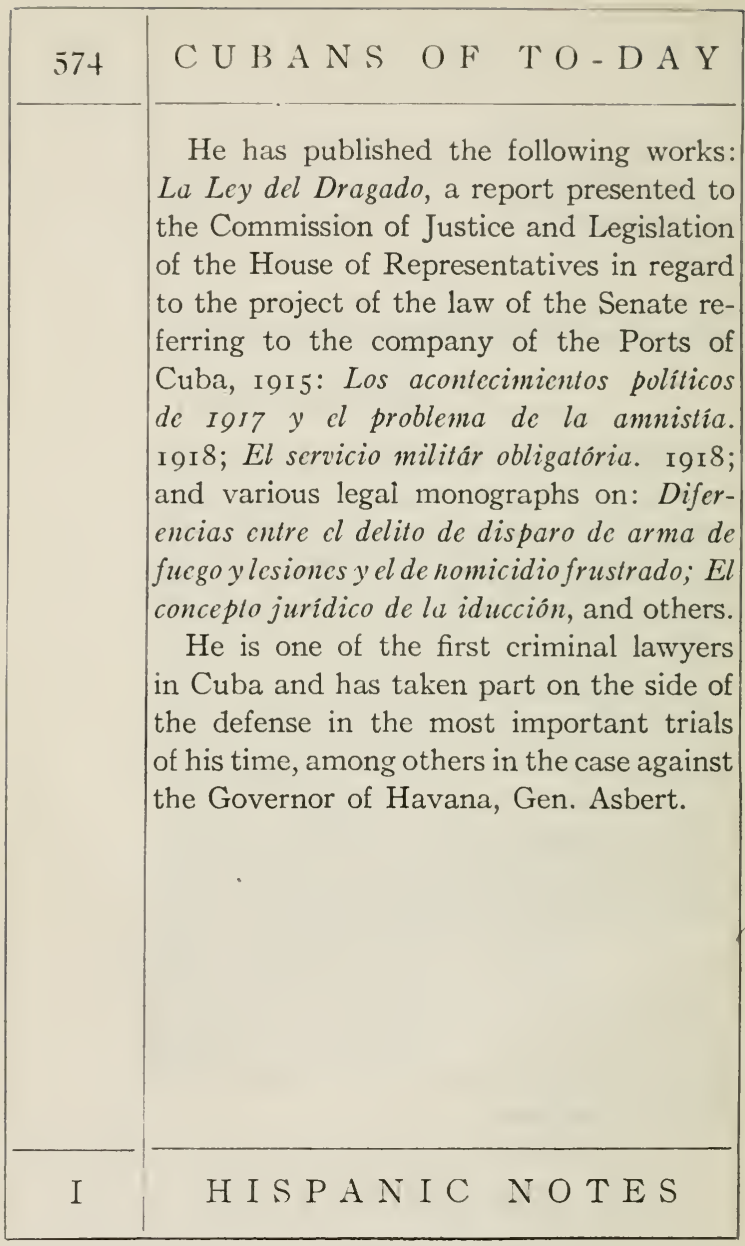




\section{E S A T O}

\section{LUÍS DE SATO Y SAGARRA}

\section{Scholar; teacher.}

Luís de Sato y Sagarra was born in Ponce, Puerto Rico, on the twenty-seventh of December, 1893. After a short residence in Spain, he went to Santiago de Cuba, where he pursued his first studies at the Colegio Séminario, and at the Colegio Inglés. Later he entered the Colegio de Belén, Havana, where he secured the degree of Bachelor of Letters and Sciences in July, I9Ir. From here he proceeded to the University where he studied law and philosophy. In I9I6 he was graduated as Doctor of Civil Law and in I9I 7 took the degree of Doctor of Philosophy and Letters. After being nominated to a fellowship in the University he took up graduate studies at Columbia University, New York, as a candidate for the degree of Master of Arts

\section{A N D M O N O G R A P H S}




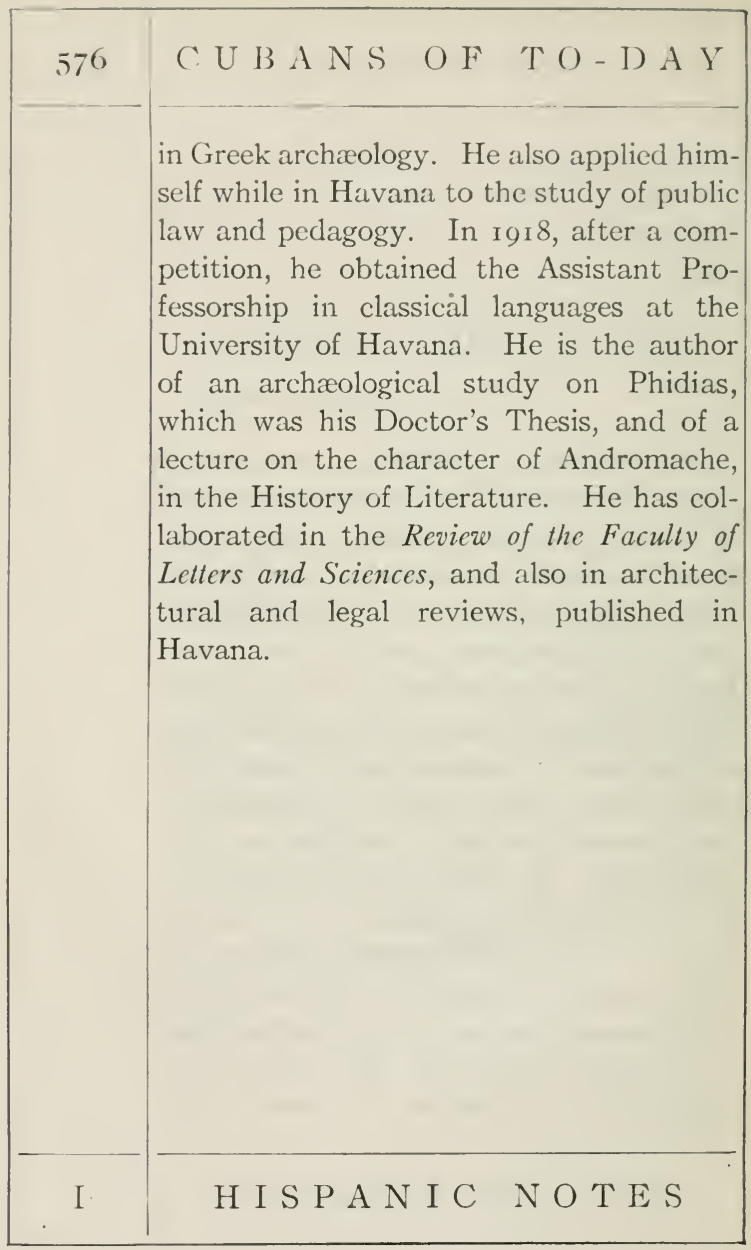




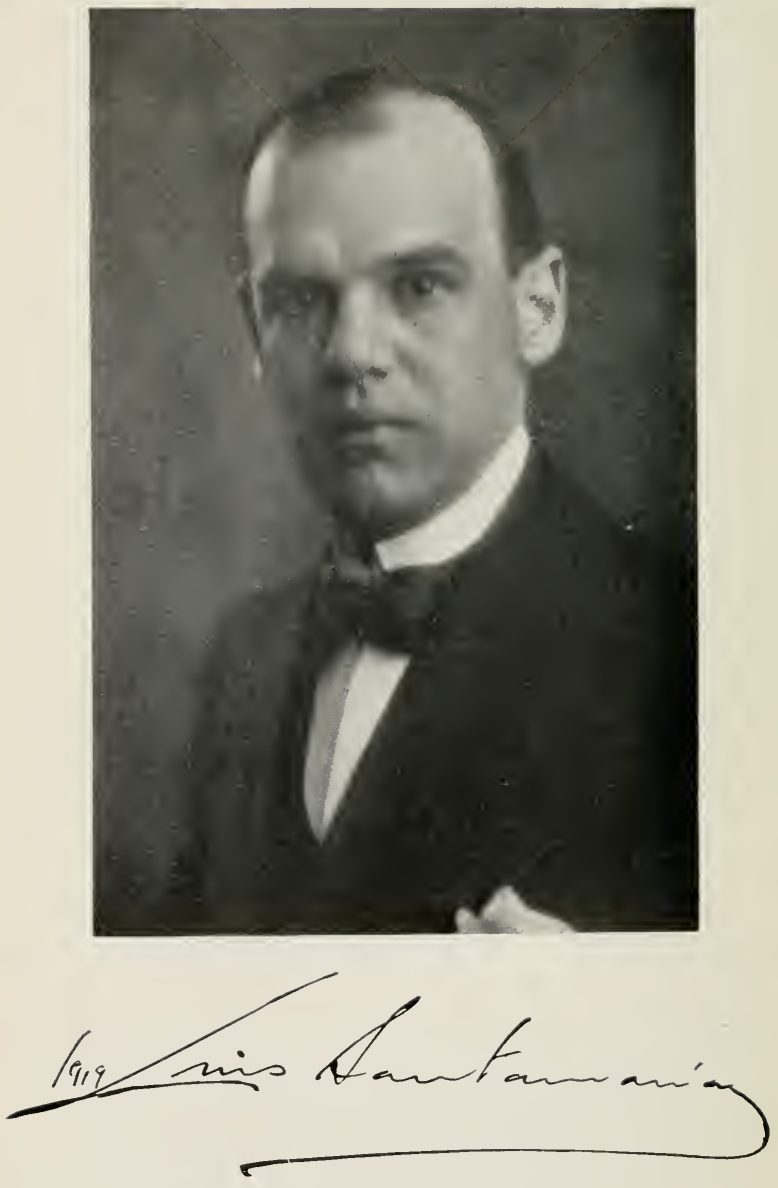


\section{S A N T A M A R I A}

LUÍS SANTAMARIA

\section{Lavover; diplomat.}

Luís Santamaria was born in Cuba in the city of Pinar del Rio on the fourteenth of June, I886. He was educated at the Institute of his native place and also at the University of Havana, where he obtained the degree of Bachelor of Letters and Sciences. He also graduated as land surveyor and land inspector and Doctor of Civil Law. He was Master in Bankruptcy twice and exercised during one year the said profession. For one year he was employed in the Secretary's office of the Senate of the Cuban Republic. He served two years as Second Secretary of the Cuban Legation in Mexico and afterwards was promoted to the rank of First Secretary and then for eight years was Chargé d'Affaires at the

\section{A N D MONOGRAPHS}




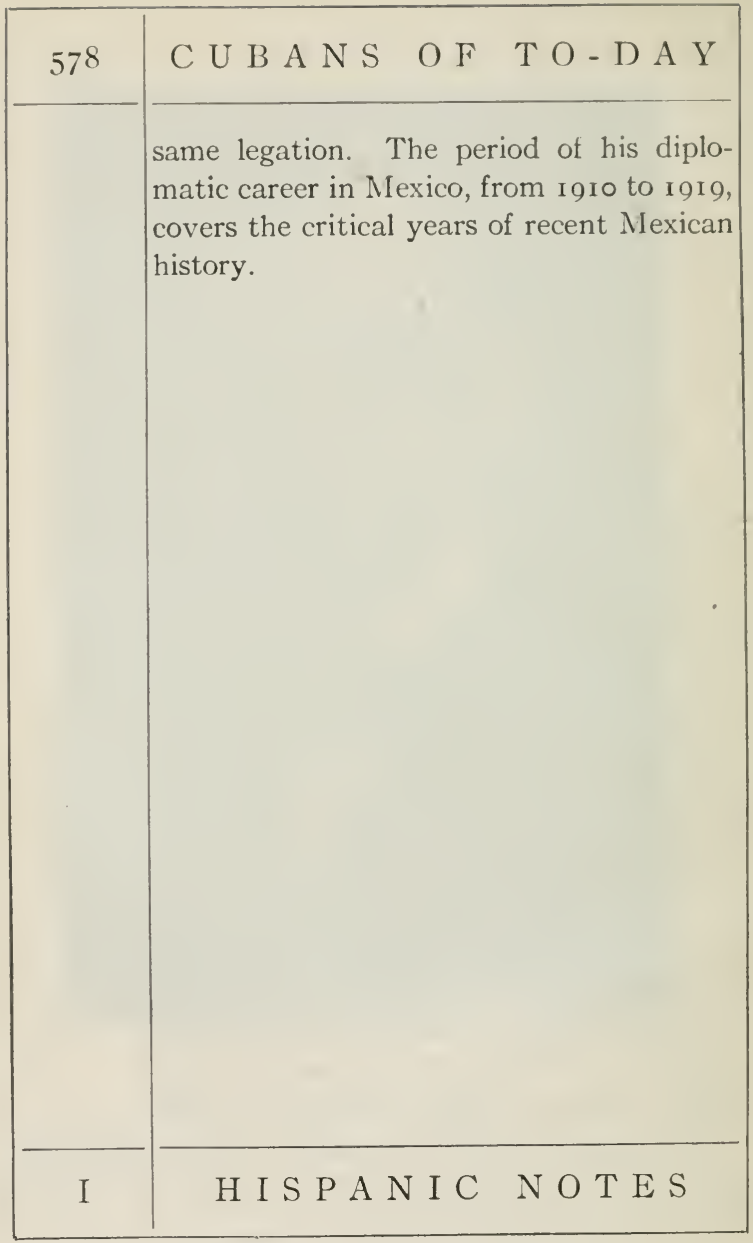





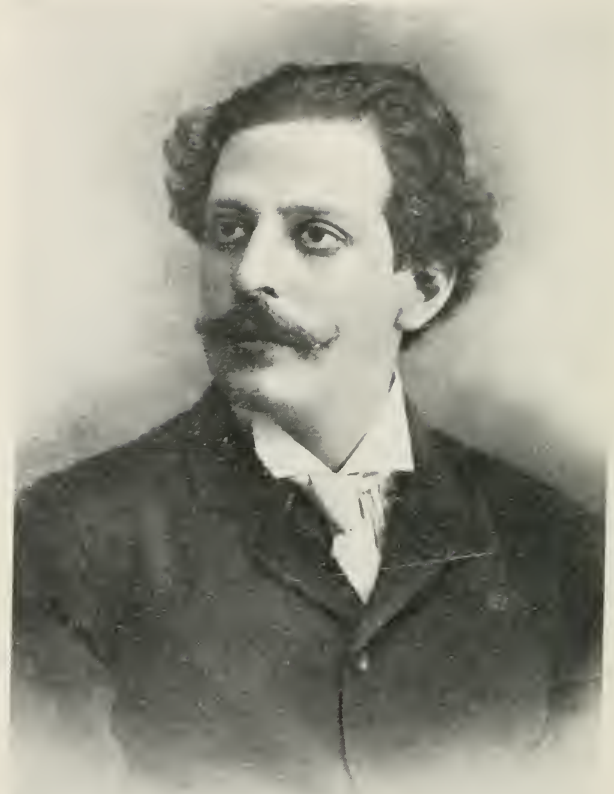

Manuel Márquez Sterling 


\section{M ÁR Q E Z S T E R L I N G}

MANUEL MÁRQUEZ STERLING Y LORET DE MOLA thor.

Manuel Márquez Sterling y Loret DE Mola was born in Lima, Peru, at the Cuban Legation in that city on the 28 th of August, I 872 . He comes of distinguished Cuban parentage, being in both lines of descent associated with illustrious and ancient families in the town of Camaguiey. His father, Manuel Márquez Sterling, took part in the War of Separation in 1868 , and was sent to South America to secure the recognition and protection of Cuban patriots in South American countries. After Peru had recognized the independence of Cuba, his father remained there for some time, representing as Minister Plenipotentiary the Cuban President Carlos Man-

\section{A N D M O N O R A P H S}




\begin{tabular}{|c|c|}
\hline $5^{80}$ & C U B A N S OF TO-DAY \\
\hline t & $\begin{array}{l}\text { uel de Céspedes. Márquez pursued courses } \\
\text { in the University of Havana, but the war } \\
\text { of I } 895 \text { prevented him from completing his } \\
\text { studies. During his youth he traveled in } \\
\text { Europe and the United States. After the } \\
\text { war was ended and Cuba had become in- } \\
\text { dependent he was intrusted with impor- } \\
\text { tant public duties. He was Secretary to } \\
\text { the Cuban patriot, Gonzalo de Quesada, at } \\
\text { Washington, during the negotiations for the } \\
\text { establishment of the republic. In I } 900 \text { he } \\
\text { was member of the Commission sent by } \\
\text { Cuba to the Paris Exposition. After this } \\
\text { date he devoted himself to journalism until } \\
\text { I9o7, when he was nominated Chargé } \\
\text { d'Affaires in Buenos Ayres. In I } 900 \text { he } \\
\text { became Resident Minister at Rio de } \\
\text { Janeiro; in I I I Minister Plenipotentiary } \\
\text { in Peru, and in I9I } 2 \text { Minister Plenipoten- } \\
\text { tiary in Mexico. He was in Mexico at the } \\
\text { time of the tragic end of President Madero } \\
\text { and with other diplomats tried to save his } \\
\text { life. These efforts failed, but he was able } \\
\text { to place the widow, the father, and the sis- } \\
\text { ters of the President and the President's } \\
\text { brother, Ernesto Madero, safe on board the }\end{array}$ \\
\hline I & H I S P N I C NOTES \\
\hline
\end{tabular}




\section{M ÁR Q U E Z S T E R L I N G}

cruiser $C u b a$, which was anchored in the port of Vera Cruz.

He soon retired from the diplomatic career and founded the journal, Heraldo de Cuba, which achieved great success. After this paper had passed into the hands of Dr. Orestes Ferrara he founded his present organ, "La Nación," which supports the Liberal party. In I9I 8 he was nominated as a candidate for the Chamber of Deputies, but refused after learning that the election would be tainted by fraud. In the line of literature he has written many books. The best known of these are Ideas y sensaciones, Hombres de pro, Alrededor de nuestra Psicología, Psicología profana, Burla burlando, La Diplomacia en neustra Historia, Los ultimos dias del Presidente Madero, a volume of more than seven hundred pages, a large edition of which was exhausted in one month. He is a member of the National Academy of Arts and Letters. 



\section{S U Á R E Z}

\section{ANTONIO PARDO SUÁREZ}

\section{Journalist; proletarian.}

Antonio Pardo SuÁrez was born on the thirtieth of March, I87I, in Havana. After primary instruction in the Colegio of Estebán Borrero Echevarría, his education was continued in the Colegios "Santiago Apostol" and "San Francisco de Paula" and the Institute of Havana.

He then entered the factory "Por Larrañaga" as grader of tobaccos. He later entered the field of journalism serving as editor of $L a$ Republica, La Epoca, and $E l$ Nuevo Criollo successively, and is at present (I9I9) Director of Regeneracion a weekly paper devoted to the interests of the laboring classes.

During the War of Independence, the persecutions of which he was the object forced him to emigrate. He took up his

\section{H I S P A N I C NOTES}




\begin{tabular}{|c|l|}
\hline 584 & $\begin{array}{l}\text { C U B A N S O F T O - D A Y } \\
\text { residence in Vera Cruz (Mexico) where he } \\
\text { served the cause of the Revolution through } \\
\text { various clubs, returning to Cuba only after } \\
\text { the American Intervention. } \\
\text { In I908, he became the candidate of the } \\
\text { Conservative party, and was elected Repre- } \\
\text { sentative from the Province of Havana and } \\
\text { was reëlected in I9I 2. In April, I9I I, he } \\
\text { was chosen Secretary of the House of Re- } \\
\text { presentatives and continued in that office } \\
\text { during the four legislatures of the fifth } \\
\text { Congressional period. } \\
\text { In April, I9I 5, he was made Chairman } \\
\text { of the Committee on Agriculture, Industry, } \\
\text { and Commerce. In the same month he } \\
\text { was elected Vice-president of the House of } \\
\text { Representatives for the seventh Congres- } \\
\text { sional period, by virtue of which office he } \\
\text { occupied the Presidency for two months in } \\
\text { I9I7. }\end{array}$ \\
\hline H I S P A N I C N O T E S \\
\hline
\end{tabular} \mid




\section{VARELA Z E Q E I R A}

JOSÉ VARELA ZEQUEIRA

Physician; teacher; poet.

José VARELA ZequeIra was born in Nuevitas, Province of Puerto Príncipe, Cuba, on the nineteenth of March, 1859 . His secondary education was received in Spain and in Havana after which he entered the University of Havana and began the study of medicine. In 1887 he received the degree of Licentiate.

In the early days of his medical career he was visiting physician of the hospitals "La Benéfica" and "Mercedes" and chief of the clinic of the latter. In 1894 he founded in Havana a Preparatory Medical School which he directed.

In 1897 he went to Costa Rica where he was quarantine doctor at Puerto Limón and edited the medical journal Gaceta Médica de Costa Rica.

\section{A N D M O NOGR A P H S}




\begin{tabular}{|c|c|}
\hline $5^{86}$ & C U B A N S OF TO-D A Y \\
\hline & $\begin{array}{l}\text { Returning to Cuba in I } 899 \text {, he was at } \\
\text { first Vice-Director and later Director and } \\
\text { Surgeon of the hospital "La Benéfica." } \\
\text { In I } 900 \text { the University of Havana con- } \\
\text { ferred upon him the degree of Doctor of } \\
\text { Medicine and Surgery and appointed him } \\
\text { to a professorship in the faculty of Dissec- } \\
\text { tion. Later he became, by competition, } \\
\text { Adjunct Professor of Anatomy and in the } \\
\text { following year was promoted to the titular } \\
\text { professorship, which position he continues } \\
\text { to hold. } \\
\text { In I } 900 \text { Dr. Varela was delegate to the } \\
\text { Third Pan-American Medical Congress and } \\
\text { Secretary of the section of General Sur- } \\
\text { gery. In I } 903 \text { he was appointed a member } \\
\text { of the National Board of Health. } \\
\text { Aside from his profession, two of Dr. } \\
\text { Varela Zequeira's interests have been } \\
\text { poetry and anthropology. He has spe- } \\
\text { cialized in political verse and was one of the } \\
\text { founders of the Anthropological Society } \\
\text { of Cuba. } \\
\text { He is also Vice-president of the "Colegio } \\
\text { Médico de Cuba," member of the Society } \\
\text { for Clinical Research of Havana, and cor- }\end{array}$ \\
\hline I & H I S P N I C NOTES \\
\hline
\end{tabular}




\section{A R E L A E Q U E I R A}

responding member of the Academy of Medicine of Rio Janeiro, Brazil.

$\mathrm{He}$ is the author of numerous articles in medical publications of $\mathrm{Cuba}$ and Costa Rica, among which are: Teoria Celular (I878); La Adaptación (I880); La Gula ( 1883 ); Diagnóstico diferencial (г 886); Carácter actual de los Estudios Antropológicos (I889); Puramyoclonus múltiplex (189o); Resección completa del maxilar superior, Congreso francés de Cirugía (1893); Estadística de opcraciones practicadas en el Hospital "Mercedes," años I894: I895 y I896 (I896); Notas Clinicas (I897); Técnica de la cura operatoria de la hernia inguinal (1900); Estadistica de las operaciones practicadas en la Casa de Salud "La Benéfica," del Centro Gallego (1902); Las Casas de Salud de la Habana (I902); Mecanismo de la Muerte en Garrote (1903); Sifilis. Blenorragia. Lepra (1905); Hernía inguinal conteniendo el apéndice (1905); Elogio del Doctor Federico Horstmann y Cantos (I906).

A N D MONOGRAPHS 



\section{T A R A F A}

JOSÉ TARAFA

Business man.

José TARAFA was born in Matanzas, $\mathrm{Cuba}$, in $\mathbf{1} 869$. His early education was received in Havana, after which he continued his education in the United States.

Upon his return to Cuba he went into the sugar business, but at the outbreak of the War for Independence enlisted in the insurrectionist forces. Fighting under Generals Máximo Gómez, Monteagudo, and Vega he won several promotions; reaching the rank of Colonel.

At the termination of the war he once more turned his attention to financial affairs especially as related to sugar. Through the great experience acquired in re-organizing several sugar enterprises and the successful outcome of his efforts, he has come to be considered an expert in the

\section{H I S P A N I C N O T E S}




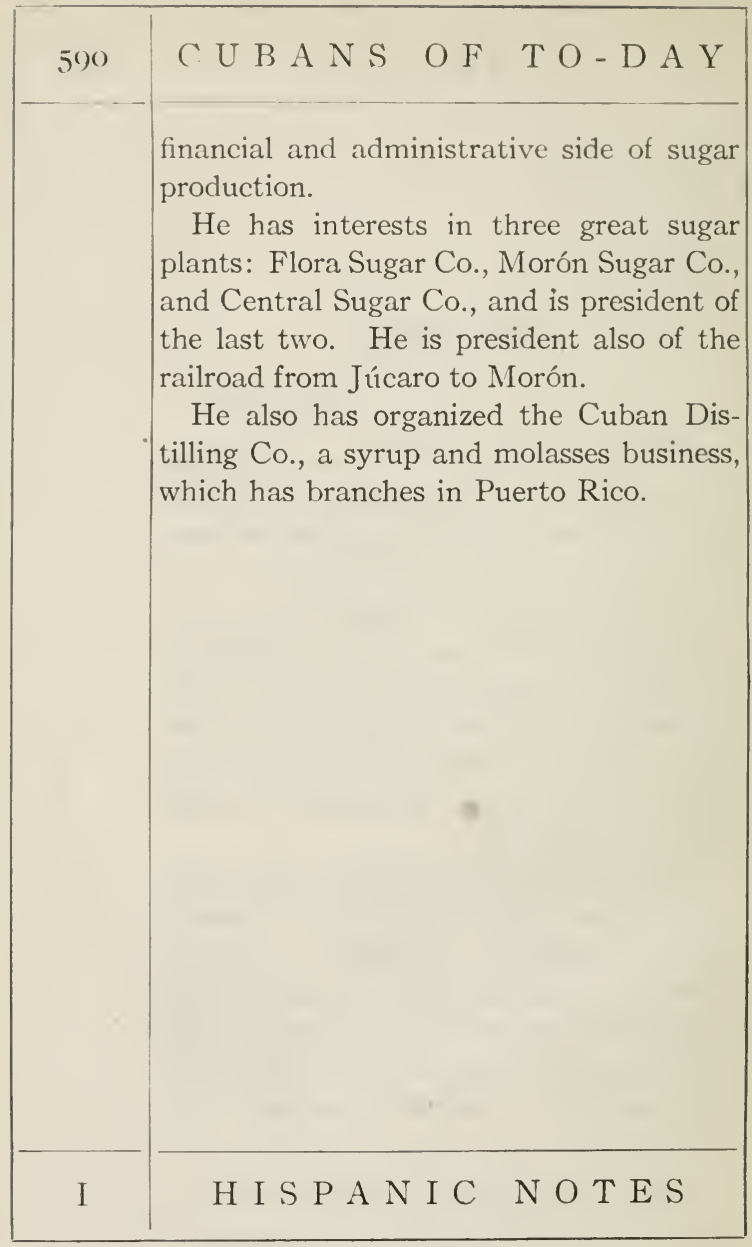




\section{I L L A L Ó N}

\section{MANUEL VILLALÓN}

\section{Lawyer; public man.}

Manuel Villadón was born in Cienfuegos on the twenty-second of December, I877. After receiving the degree of Bachelor in his native city he matriculated in the University of Havana where he was graduated in 1898 with the degree of Doctor of Laws.

Upon his graduation he was named municipal judge for the city of Cienfuegos and also acted ad interim as judge of the Primary Court of Claims and Mandates. In the political turmoil which was specially violent in Cienfuegos at the beginning of the American Intervention, he was appointed by General Wood to study questions of electoral legality and to assist in remedying the situation.

$\mathrm{He}$ has served as Register of Deeds of

A N D M O N O G A P H S 


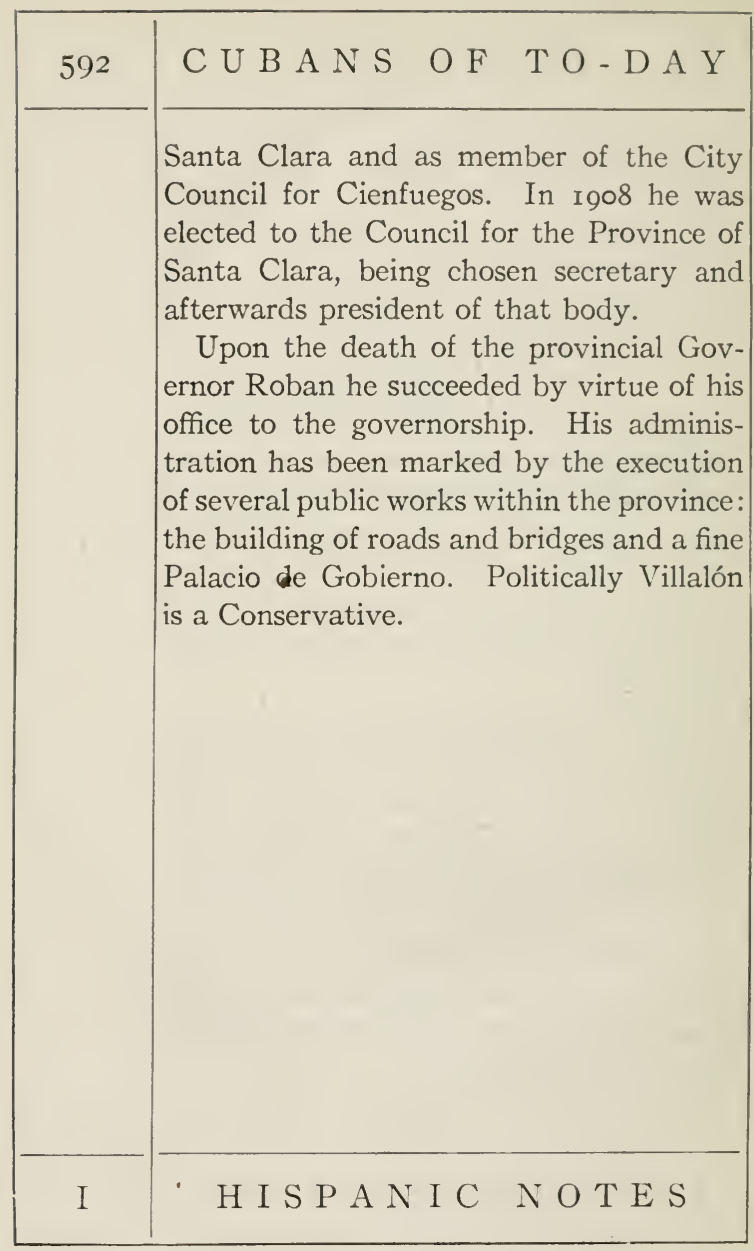




\section{T O R R I E N T E}

RICARDO DE LA TORRIENTE

Painter; illustrator; cartoonist.

Ricardo DE LA Torriente Y TORRIENTE was born at Matanzas, Cuba, on the eighth of January, I867. He was educated in Bordeaux, France, and in the leading schools of Spain. After receiving the degree of Bachelor of Arts he returned to Cuba and devoted himself to artistic iabors.

At the time of General Weyler's reconcentration decree Torriente emigrated to New York. He became associated with well-known American cartoonists and was for five years cartoonist for New York daily papers-the Journal, the Herald, and the World.

In 1900 he returned to Havana and became professor in the National School of Painting and Sculpture, which position he

\section{A N D M ONOG R A H S}




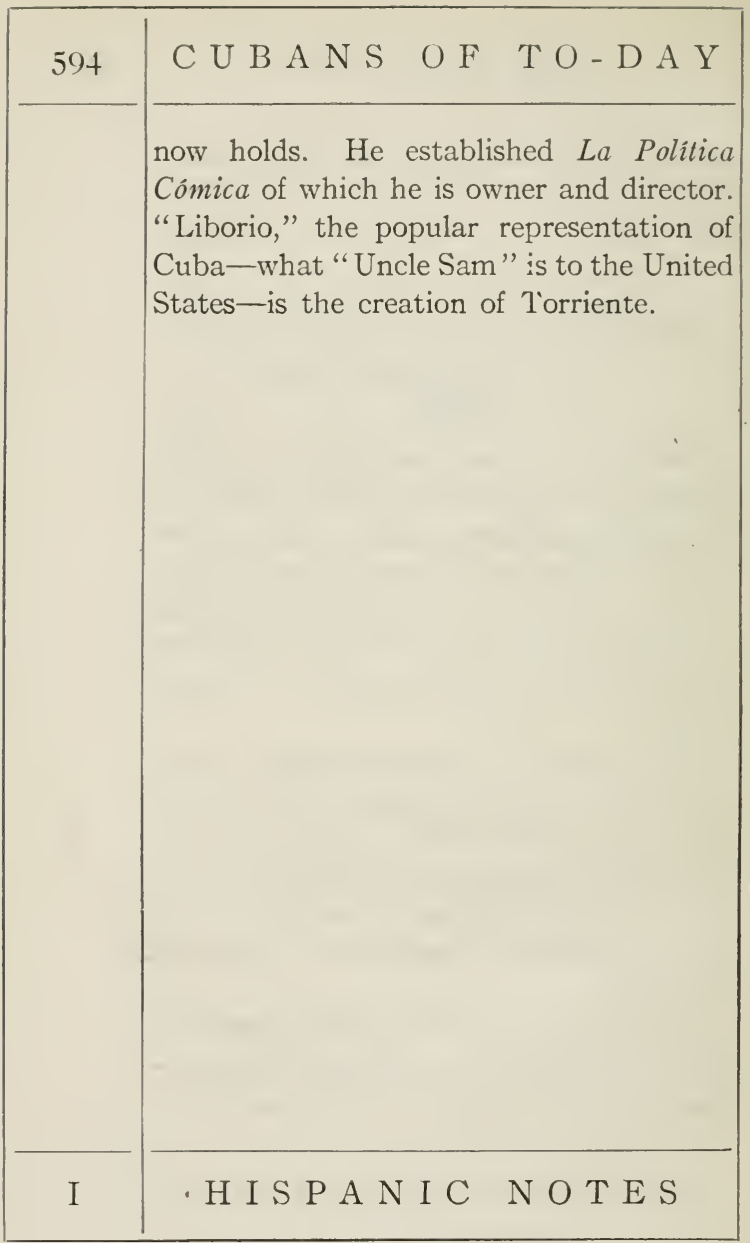


REGIS DU REPAIRE DE TRUFFIN Business man; club man.

Regis du Repaire de Truffin, generally called in Cuba Regino Truffin, was born in the Province of Santa Clara, Cuba, in the year 1857 . He was educated in Paris in the Colegio de "Sainte Barbe" obtaining the degree of Bachelor. He retained the citizenship of his father who was French.

At the close of his course of study in France he returned to Cuba where, under the firm name R. Truffin \& Cía, he devoted himself to business enterprises, especially to the export of molasses and crude sugars. This business was transferred after twentytwo years to the "Cuba Distilling Co." He built up also the large sugar plantations "Mercedes" and "San Juan Bautista."

During an interim in his business ac-

\section{A N D MONOG R A P H S}




\section{U B A N S O F T - D A Y}

tivities, Truffin served as Cuban Consul in Russia, appointed in 1892 . The Russian Government conferred upon him the Cross of Santa Ana and the Order of Saint Stanislas.

Returning to commercial life he has been Vice-president of the Cuba Cane Sugar Corporation; President of the Manatí Sugar Co., and President of the Companía Cubana de Jarcia. Furthermore, he has been President of the French Chamber of Commerce of Havana, President of the Union Club, and President of the Yacht Club of that city.

\section{H I S P A I C NOTES}




\section{JAIME VALLE Y DIAZ}

Artist; draughtsman.

JAIME VAlle Y Diaz was born in Barcelona in the year $188_{5}$ and was educated at the church schools where he obtained the Bachelor's degree. In Havana he has acted as supervisor of Modeling and Drawing in the public schools of the city and as Artistic Director of the Bureau of Publicity and Graphic Arts. He has served also as art editor of the Cuban paper, La Discusión. He is the author of the artistic posters which obtained the first prize in all competitions held in Cuba up to the present year (I9I9). These competitions, it may be mentioned, were nine in number. He is responsible for almost all the drawings and posters published by the Bureau of Publicity and Graphic Arts in Havana, and of a great number of title-pages, illustrations 


\section{UBANSOF TU-DAY}

and caricatures contributed to the leading papers and magazines of Havana. He has the reputation of being one of the best draughtsmen in Cuba at the present time. His poster work is noticeable for its firmness of treatment, its distinction of form and its beauty of coloring. 



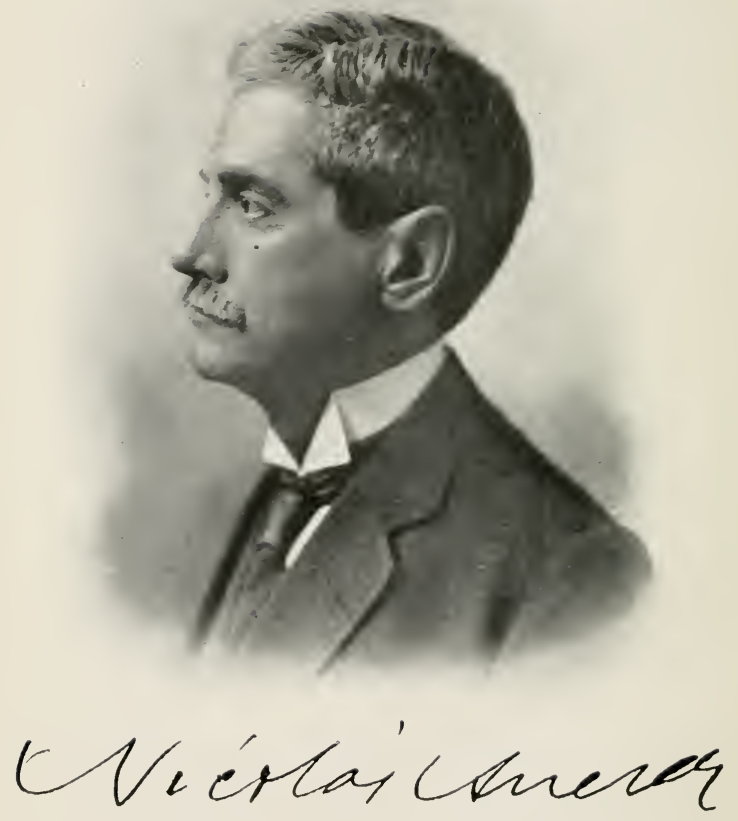




\section{A L B E R D I}

\section{NICOLÁS ALBERDI}

Doctor; soldier; official.

Nicolás Alberdi was born in Sagua la Grande, Province of Santa Clara, Cuba, in the year i 865. At the age of ten he was taken to Spain to continue his education in Seville and in 1883 he returned to Cuba, entered the University of Havana and in I 892 obtained the degree of Doctor in Medicine.

Following his graduation Doctor Alberdi settled in Cifuentes to practice his profession and continued there until the Revolutionary War broke out in 1895 , whereupon he joined General José Luís Roban in the organization of the military forces of Santa Clara and was appointed to a command. He later joined the Medical Corps, being chief health officer first of the brigade of Juan Bruno Zayas and later of the Fourth 


\begin{tabular}{|c|c|}
\hline 600 & C U B A N S OF TO-DAY \\
\hline & $\begin{array}{l}\text { Corps of the Army of Liberation. By the } \\
\text { Fourth Corps he was elected to the As- } \\
\text { sembly of Yaya and there chosen Subsecre- } \\
\text { tary of Foreign Relations, later becoming } \\
\text { Secretary. He retired at the close of the } \\
\text { war with the rank of Colonel. } \\
\text { He has held important appointments } \\
\text { both civil and medical. During the Amer- } \\
\text { ican Intervention he was made Director of } \\
\text { the Civil Hospital of Sagua la Grande; in } \\
\text { I } 90 \text { I he was appointed Health Officer for } \\
\text { the Province of Santa Clara; during the } \\
\text { first Cuban Government he was elected } \\
\text { Member and President of the Council of } \\
\text { the Province of Santa Clara and Governor } \\
\text { pro tem of the Province, and in January, } \\
\text { I go9, he was appointed Secretary of Gov- } \\
\text { ernment (Gobernación) in the cabinet of } \\
\text { President José Miguel Gómez. In I I } 3 \\
\text { he was elected Senator for the full period } \\
\text { of eight years on the Fusion ticket. He is } \\
\text { chairman of the Committee on Sanitation. }\end{array}$ \\
\hline & 1 \\
\hline I & H I S P N I C N O T E S \\
\hline
\end{tabular}




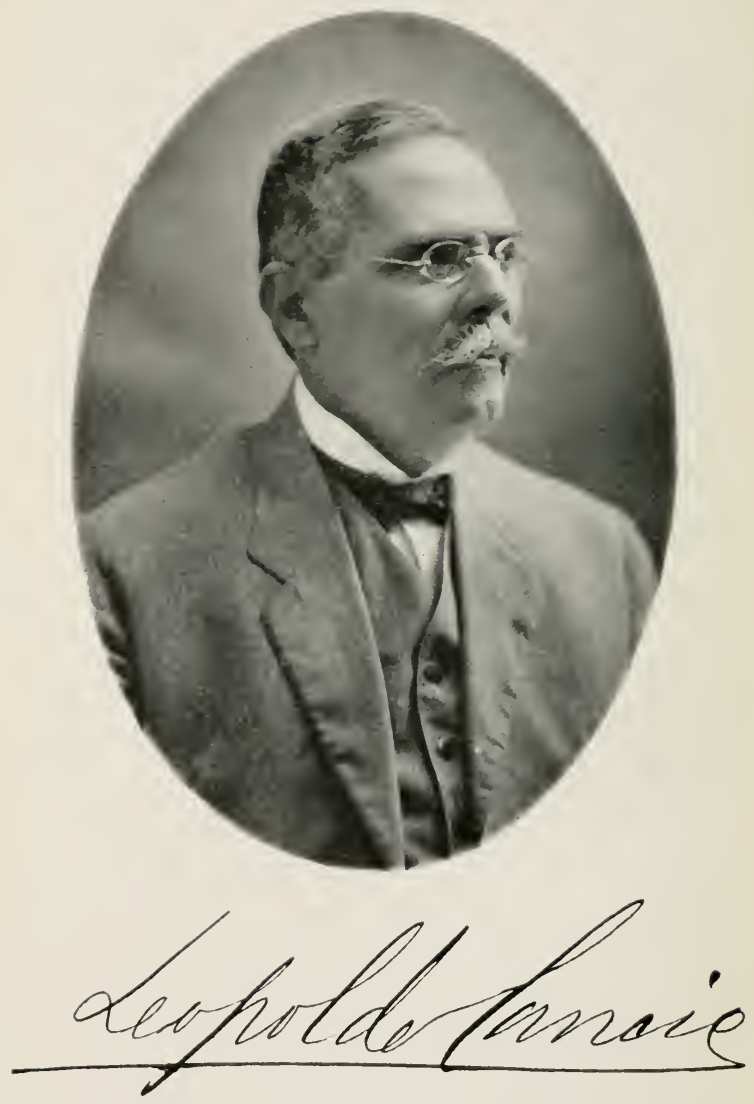




\begin{tabular}{|c|c|}
\hline $\mathrm{CANCIO}$ & 601 \\
\hline $\begin{array}{l}\text { LEOPOLDO CANCIO Y LUNA } \\
\text { Economist; publicist; fin- } \\
\text { ancier; Secretary of the } \\
\text { Creasury of the Republic of }\end{array}$ & \\
\hline A N D MONOGRA P H S & I \\
\hline
\end{tabular}




\begin{tabular}{|c|c|}
\hline 602 & C UBANS OF TO-I A Y \\
\hline & $\begin{array}{l}\text { which he had helped to organize. To fur- } \\
\text { ther the purposes of the party new periodi- } \\
\text { cals sprang up, El Triunfo, El Pais, and } \\
\text { later La Union on all of which Dr. Cancio } \\
\text { served as editor. He later withdrew from } \\
\text { the Autonomist party; but not desiring to } \\
\text { join the revolutionary conspirators, sepa- } \\
\text { rated entirely from political activity, shut- } \\
\text { ting himself up in his house. } \\
\text { Nevertheless when, upon the American } \\
\text { Intervention, a new government was or- } \\
\text { ganized Dr. Cancio's talents were recog- } \\
\text { nized and his services required. He served } \\
\text { in the Treasury Department under the } \\
\text { direction of General Brooke and also under } \\
\text { the administration of General Wood. } \\
\text { Shortly after the first Cuban government } \\
\text { was formed under the Presidency of Tomás } \\
\text { Estrada Palma in I } 902 \text {, Dr. Cancio was } \\
\text { appointed substitute Secretary of Govern- } \\
\text { ment in which capacity he acted a year and } \\
\text { a half. At about this time he was instru- } \\
\text { mental in removing serious obstacles to } \\
\text { the negotiation of the Treaty of Recipro- } \\
\text { city with the United States; in recognition } \\
\text { of this service he was placed in charge of }\end{array}$ \\
\hline I & H I S P A I C N O T E S \\
\hline
\end{tabular}




\section{A N C I O}

Public Instruction. This post he resigned, however, because of political differences with the President and entered upon an active campaign of opposition using the columns of the review Cuba y América and coöperating with Dr. Emilio Nuñez in founding the Conservative party, upon the success of which Dr. Cancio became President of the Provincial Assembly and Delegate to the National Assembly. In I9I3, when the Conservative party won a complete triumph, Dr. Cancio was appointed Secretary of the Treasury in President Menocal's cabinet.

He has headed many committees designated to study the financial problems of the country and for many years has been censor of the economic Society, Amigos del Pais. He is contributor to periodicals and reviews upon economic and financial subjects and is the author of numerous pamphlets among which is La Moneda y la Circulacion, published in I 900 under the auspices or the University of Havana where he is professor of Political Economy and Finance.

\section{A N D MO NOG R A P H}






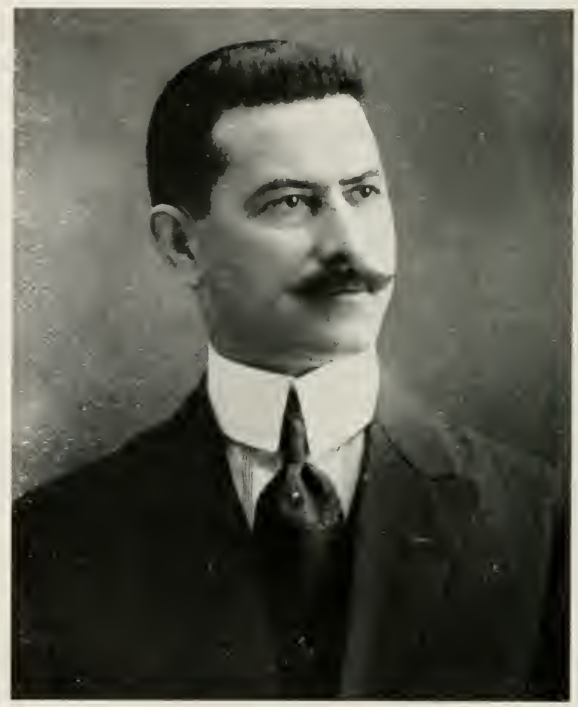

Rafael A. Fernández 


\section{F É R N Á N D E Z}

\section{RAFAEL, ANTONIO FERNÁNDEZ}

\section{Educator.}

Rafael Antonio Fernández was born in the Asturias in Spain at the town of Belmont, in 1877 . He was educated privately at Surgidere de Batabanó, Cuba. At the University of Havana he obtained the degree of Doctor of Pedagogy. In Batabanó from I 9 I o to I 9 I 5 he was director of a primary school called José Alonzo Delgado. $\mathrm{He}$ was pedagogical instructor of the Aguacate District in the Province of Havana in 1915 , and in 1915 became provincial instructor of primary instruction in the Province of Pinar del Rio. After competition he was nominated to the chair of Associate Protessor of Pedagogical Studies in the Normal School for Schoolteachers in Havana, rgr6. In the same year he was named by the Department of Public

\section{H I S P A N I C NOTES}




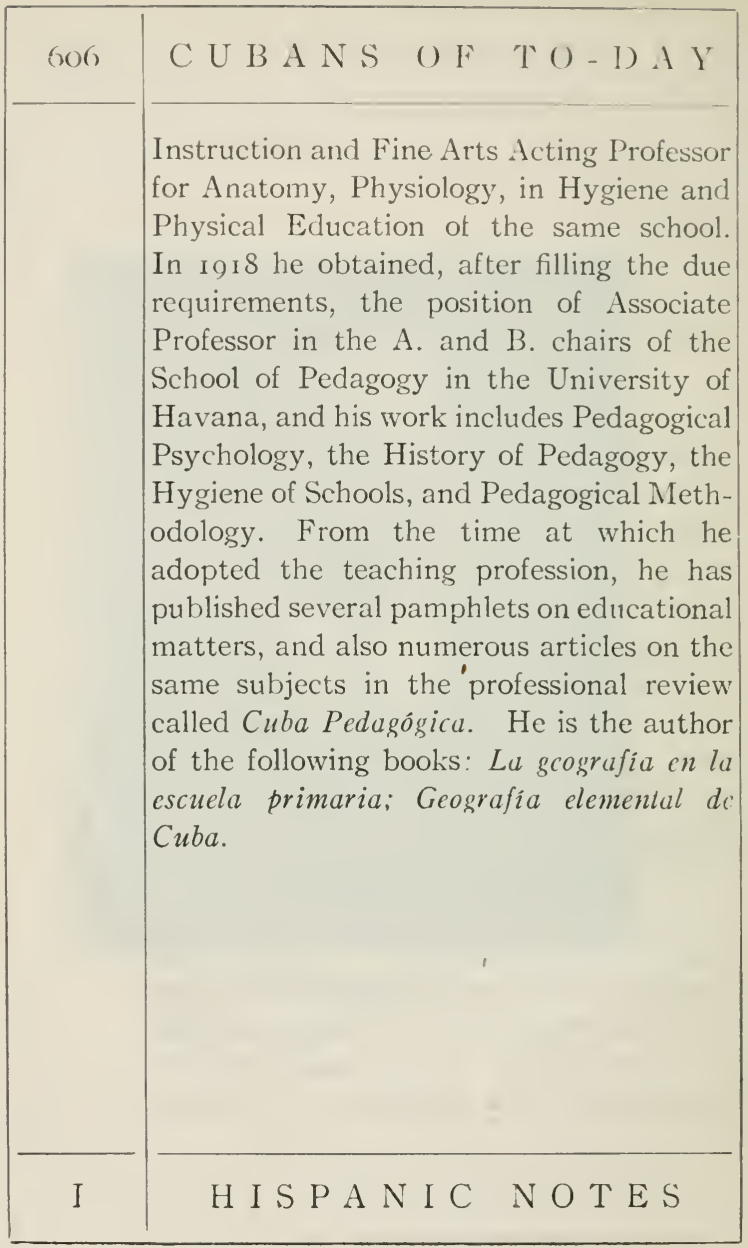





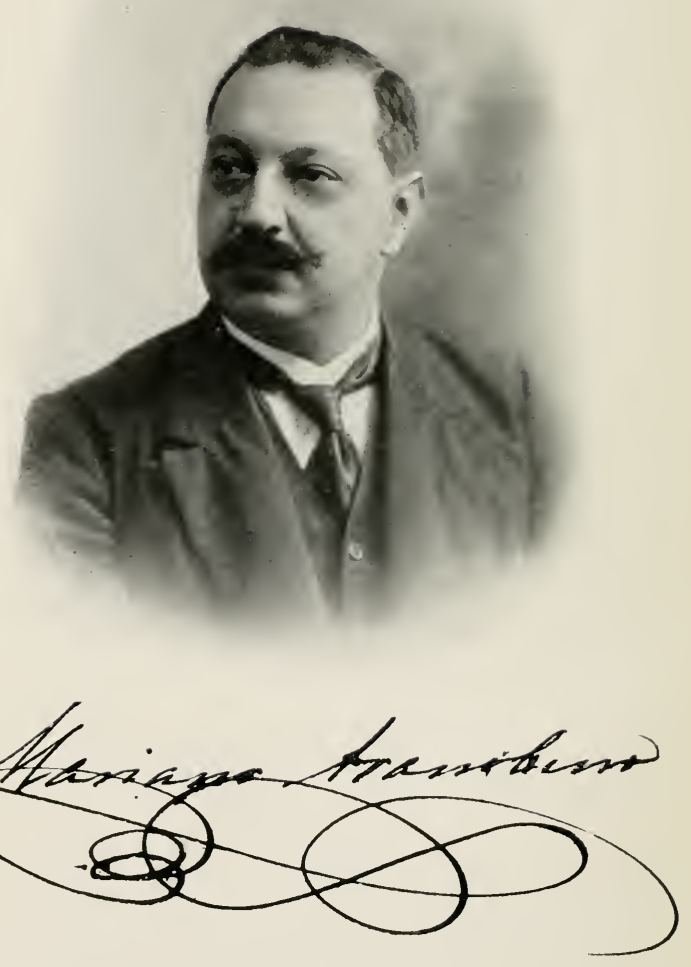




\section{A R A M B U R O}

\section{MARIANO ARAMBURO}

Jurist; man of letters; public speaker.

Mariano Aramburo y Machado was born in Puerto Principe (now Camagüey) on the thirtieth of November, I 870 , and obtained his early education in his native city at the Colegio of Esculapius, where he completed the course for the Bachelor's degree in I886. In the same year he went to Spain, entered the University of Saragossa and pursued simultaneously the courses leading to two degrees - that in Philosophy and Letters and that in Law,-both of which he obtained as Licentiate in 1890 . A year later he passed on to the University of Madrid and there obtained the degree ot Doctor likewise in both faculties.

For some years he remained in Madrid devoting himself to intellectual pursuits,

\section{A N D MONOGRAPH S}




\begin{tabular}{|c|c|}
\hline 608 & C U B A N S OF TO-DA Y \\
\hline & $\begin{array}{l}\text { contributing to important magazines and } \\
\text { discursos oratorios before the Royal Acad- } \\
\text { emy of Jurisprudence, the Ateneo and } \\
\text { other learned societies. In I } 898 \text {, he re- } \\
\text { turned to Cuba but remained only three } \\
\text { years, retracing his steps to Spain in I9oI, } \\
\text { where he devoted himself to literary criti- } \\
\text { cism. } \\
\text { At the end of I9o6 he again resumed his } \\
\text { residence in Cuba and in I9o9, when Gen- } \\
\text { eral José Miguel Gómez was elected Presi- } \\
\text { dent, Señor Aramburo was appointed } \\
\text { Minister to Chile-a post which he filled } \\
\text { until I9I3. Under the Gómez administra- } \\
\text { tion he arbitrated, in association with a } \\
\text { Spanish appointee, a complaint of judicial } \\
\text { injustice to a Spanish subject; the findings } \\
\text { are given in his pamphlet Proyecto de laudo } \\
\text { o votc particular (I9I 7). His other writ- } \\
\text { ings are: Personalidad literaria de doña } \\
\text { Gertrudis Gómez de Avellaneda (I898); } \\
\text { Origén, desarrollo y decadencia de la tragedia } \\
\text { griega (I89o); Estudio de las causas que } \\
\text { determinan, modifican y extinguen la capaci- } \\
\text { dad civil (I894); Impresiones y juicios } \\
\text { (I9or); Monógrafas oratorios (I9o6); Liter- }\end{array}$ \\
\hline I & H I S A N I C NOTES \\
\hline
\end{tabular}


atura crítica (1909); Arte de bién vivir (1915); Doctrinas jurídicas (I9I6); and Bases para el Código cívil cubano (rgr6).

$\mathrm{He}$ belonged to the directorate of the Democratic Union party; is academician of the Real de Jurisprudencia y Legislación, Madrid; honorary President of the Academia Jurídico-Literaria Arogonesa; President of the Sección de Ciencias Morales y Politicos of the Ateneo, Havana; honorary member of the Real Hispano-Americana, Cádiz; Corresponding member of the Instituto de la Orden de Abogados Brasileños, of the Academia Nacional de Historia de Colombia and of the Real Academia de Ciencias Morales y Políticas, Madrid. 



\section{AR'TURO HEVIA Y DIAZ}

Lawyer; magistrate.

Arturo Hevia y Diaz was born on the fifth of November, $\mathrm{I}_{86}$, in the city of Havana, and there gained his education; first in the Colegios of Belén and San Elias, where he completed the courses for the Bachelor's degree in 1880 , and later in the University where he took the law course and obtained the degree of Doctor of Laws in 1885 .

In addition to the practice of his profession, Dr. Hevia has held various official positions. He has served as judge of the lower courts in Colón and in the city of Havana; special Prosecuting Attorney in the Provincial court of Havana, and Magistrate in the same court. In 1908 he was Member and Secretary of the Legislative Committee to revise the Penal Code and

H I S P A N I C N O T E S 


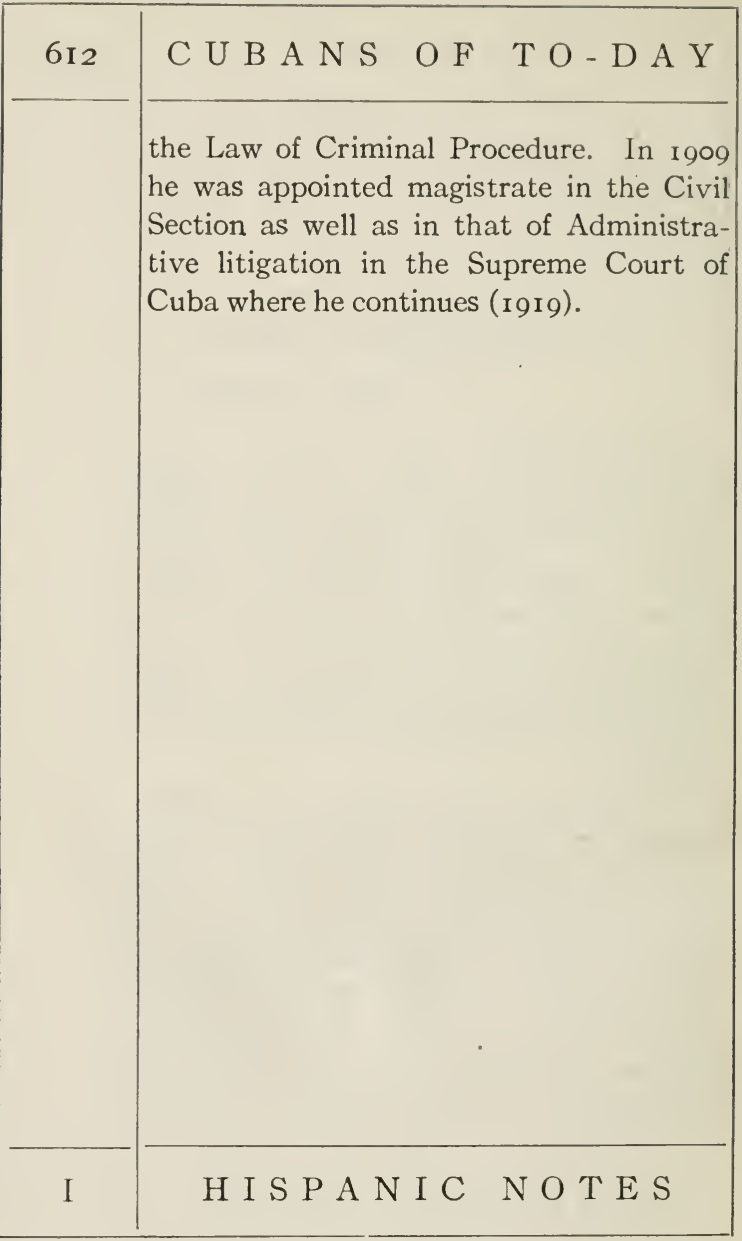


SANTIAGO DE LA HUERTA

Physician; teacher.

Santiago de la Huerta y Ponce de LEON was born in Cuba, City of Matanzas, on the sixth of April, I870. He received his secondary and technical education in $\mathrm{Ha}$ vana, first at the Colegio Gran Antilla, and then at the University. He took the degree of Bachelor of Arts in I886, was made a I.icentiate in Natural Sciences with first honors in 1890 , Doctor of Natural Sciences, with first honors, in $\mathrm{r} 89 \mathrm{I}$, and became $\mathrm{Li}$ centiate in Medicine and Surgery in 1892 . From I 890 to 1897 he was Assistant Curator in the Museum of Natural History of Havana University. In 1893 he was named, after competition, to be Associate Professor in the Santa Clara Institute of Secondary Education. In $\mathrm{I} 894$ he was made Associate Professor in the Free

\section{A N D M O N O G R A P S}




\begin{tabular}{|c|c|}
\hline 614 & C U B A N O F T O-D A Y \\
\hline & $\begin{array}{l}\text { School of Medicine of Havana, in the de- } \\
\text { partment of General and Medical Pathol- } \\
\text { ogy, and in the same year took charge of } \\
\text { the course in Histology at the same school. } \\
\text { In I } 895 \text { he became titular professor of Medi- } \\
\text { cal Natural History in the same school. } \\
\text { From I } 896 \text { to I } 898 \text { he was acting professor } \\
\text { of Natural History, including Mineralogy, } \\
\text { Botany, and Zoölogy at the University of } \\
\text { Havana. In I } 898 \text { to I } 899 \text { he held the chair } \\
\text { of Stratigraphic Paleontology in the same } \\
\text { faculty, that is, the Scientific Faculty of } \\
\text { the University. In I } 899 \text { he was titular pro- } \\
\text { fessor of Mineralogy and Crystallography. } \\
\text { From I } 900 \text { to date he has acted as titular } \\
\text { professor, after a competition, in Chair "I" } \\
\text { in the School of Sciences. From I } 900 \text { to } \\
\text { I } 90 \text { I he gave courses in Natural History } \\
\text { in the Normal Summer School. In I } 902 \\
\text { and I } 903 \text { he gave similar courses in geog- } \\
\text { raphy. In I } 906 \text { he was a delegate of the } \\
\text { Cuban Government to the "X" section } \\
\text { of the Geological Congress held in Mexico } \\
\text { and was nominated Vice-president of this } \\
\text { Congress. } \\
\text { In I } 907 \text { he was made Vocal of the Ex- }\end{array}$ \\
\hline I & H I P A N I C N O T E S \\
\hline
\end{tabular}




\section{H U E R T A}

ecutive Committee of the Conference on Charity and Corrections of Cienfuegos. In I 908 he held a similar position at Cárdenas. He was named by election in 1913 substitute member in the Faculty of Letters and Sciences of the University Council, in which position he served three years. In 1915 he became a Foundation Member of the Society of Natural History "Felipe Poey." In I9I 5 he was elected director of the Geological Section of this society and has served in that position four years. In I9I6 he became titular member of the University Council, elected by the Faculty of Letters and Sciences, and has served as such up to the present date.

\section{A N D M O N O G A P H S}






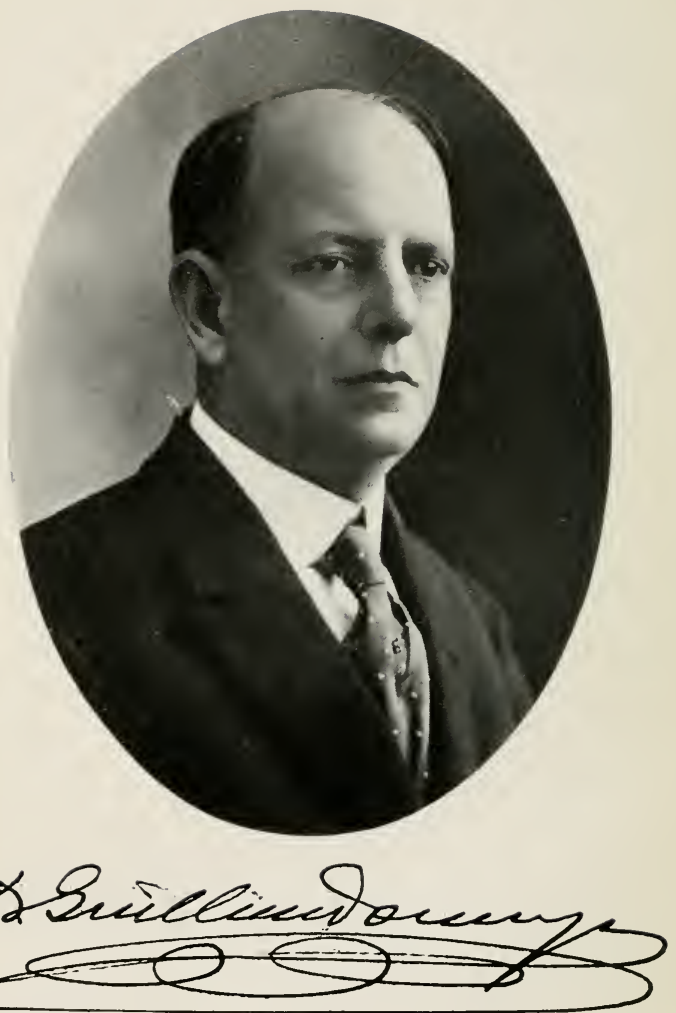




\section{O M Í N G U E Z}

\section{7}

\section{GUILLERMO DOMÍNGGUEZ ROLDÁN}

Teacher; writer; lawyer; public speaker.

Guillermo Domínguez Roldán was born in Havana, December I 2, I868, was educated in the same city; was graduated from the University of Havana at nineteen with the degree of Doctor of Philosophy and Letters and two years later received the Doctorate in Law, in both cases being the recipient of class honors.

At twenty years of age he entered a competition conducted in Madrid for the Professorship in Hebrew in the University of Havana and won. He taught Hebrew and other ancient languages for a time with the rank of Assistant Professor and was Secretary of the Faculty of Philosophy and Letters, but in rgor succeeded Dr. Nicolás Heredia in the chairs of History of Spanish

\section{H I S P A N I N O T E S}




\begin{tabular}{|c|c|}
\hline 618 & C U B A N S O F TO-DA Y \\
\hline & $\begin{array}{l}\text { Literature and Modern Foreign Literature, } \\
\text { which posts he still occupies. He has been } \\
\text { member of the University Council, and at- } \\
\text { tained this and all other appointments by } \\
\text { competition. } \\
\text { Dr. Domínguez Roldán is Vice-president } \\
\text { of the National Academy of Arts and } \\
\text { Letters; President of the Section of Litera- } \\
\text { ture of the "Amigos del País" before which } \\
\text { organization as well as before the Ateneo, } \\
\text { the Fundación Luz Caballero, and the Uni- } \\
\text { versity he has delivered numerous addresses } \\
\text { on literary and educational subjects. } \\
\text { Outside numerous articles and stories } \\
\text { contributed to magazines he has written } \\
\text { Lugar que ocupa Cervantes cn las letras } \\
\text { Castillanos (I905); España como del En- } \\
\text { tranjero (I905); La Literatura Cubana, } \\
\text { necesidad de su enseñanza (I9I 5); Elogio } \\
\text { Funebre del Dr. Luis Padró (I9I8). } \\
\text { As lawyer he has been City Attorney and } \\
\text { has kept up his private practice especially } \\
\text { as attorney for insurance companies. He } \\
\text { has made a special study of Insurance, } \\
\text { owns and edits an Insurance periodical, } \\
\text { Revista de Seguros, and has written pam- }\end{array}$ \\
\hline I & H I P A N I C N T E S \\
\hline
\end{tabular}




\section{O M Í N G U E Z}

phlets on Estudio del Contrato de seguro por derecho comercial terrestre y marítimo and Poliza tipo francesa de Seguros contra incendio.

Politically Dr. Domínguez Roldán has always been a Conservative and was by that party elected to the City Council (I906-I9I3). 




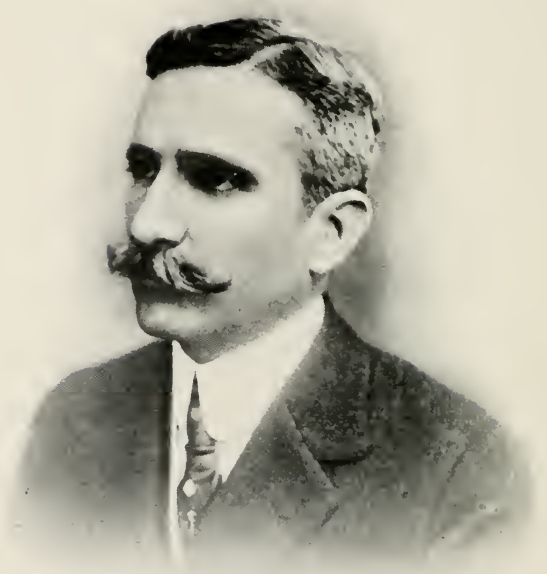

Aurelio Hevia y Alcalde 
AURELIO HEVIA

Lawyer; soldier; publicist; administrator; Secretary of Government (i. e., Army, Navy, Railways and Police) in the Republic of Cuba.

Aurelio Hevia y Alcaide was born in Havana on the twenty-fifth of October, I866, and after a preliminary course of study entered the law office of Señor Antonio Govín, where he was introduced to the practice of the law.

When the Revolution broke out in 1895 Dr. Hevia enlisted in the army where he won his way upward step by step to the rank of Colonel. In 1898 he was a member of the Assembly of Santa Cruz del Sur by which he was designated a member of the commission which visited the United States to treat with President McKinley in regard to the claims of the Cuban Army

H I S P A I C N O T E S 


\begin{tabular}{|c|c|}
\hline 622 & C U B A N S F TO-DA Y \\
\hline & $\begin{array}{l}\text { for back pay. In I } 899 \text { he was a member } \\
\text { of the Constituent Assembly. In I } 900 \text { he } \\
\text { was named by General Brooke Chief of the } \\
\text { section of State in the Secretaryship of } \\
\text { State and Government, a post in which he } \\
\text { was continued by General Wood. In I } 902 \\
\text { when President Tomás Estrada Palma } \\
\text { came into office Dr. Hevia became Sub- } \\
\text { secretary of State where he had to do with } \\
\text { organizing the diplomatic and consular } \\
\text { service of Cuba and with negotiating the } \\
\text { treaties which the infant Republic entered } \\
\text { into with the various Powers. } \\
\text { When the. second Intervention became } \\
\text { imminent Dr. Hevia opposed it to his ut- } \\
\text { most and on its occurrence withdrew to pri- } \\
\text { vate life only to resume his interest in pub- } \\
\text { lic affairs with the candidacy of his friend } \\
\text { General Menocal for the Presidency in } \\
\text { I } 909 \text {. Into that campaign he threw him- } \\
\text { self with ardor, and although unsuccessful } \\
\text { he gained experience which enabled him to } \\
\text { contribute to General Menocal's success } \\
\text { in the notable campaign of I } 9 \text { I } 3 \text {. Elected } \\
\text { then to the Presidency, General Menocal } \\
\text { designated Dr. Hevia Secretary of Gov- }\end{array}$ \\
\hline I & H I S P N I C NOTES \\
\hline
\end{tabular}




\section{H E V I A}

ernment, which post he occupied until I9I 8.

While Secretary he introduced important prison reforms including the abolition of corporal punishment and commutation of sentence for good behavior; secured the regulation of the manufacture, sale, and storage of explosives; dictated improvements in mail and telegraphs; aided in suppressing brigandage; supported Army and Navy reforms and the retirement provision for both branches of the service.

\section{A N D MONOGRAPHS}






$$
y
$$




\section{C Á R D E N A S}

\section{JULIO DE CÁRDENAS}

\section{Lawyer; magistrate.}

Julio de Cárdenas y Rodríguez was born in Matanzas on the twelfth of April, I 849 , and began his education in the famous Colegio of "San Francisco de Asis," which was then conducted by D. José Alonso y Delgado. Thence he passed to the University of Havana and completed the studies for his degree in the Law, which he began at once to practice in the office of Dr. Antonio González de Mendoza.

In addition to his long practice of the profession, extending over nearly half a century, Dr. Cárdenas has seen important and varied service as a judge. In May, I894, he was appointed Municipal Judge for the District of Pilar in Havana; in 1899 , General Brooke, the first Military Governor of Cuba, appointed him Presiding Judge

\section{H I S P A I C NOTES}




\section{6 \\ C U B A N OF TO-DA}

over the Criminal Section of the Provincial Court of Havana and in I9oI General Wood appointed him Presiding Judge of the Provincial Courts of Santa Clara, a post which he found it inconvenient to accept. In I 906 the City Council of Havana elected him Mayor and Chairman of the Council and in 1908 he was chosen by popular vote on the Conservative ticket to the same office under the new laws. Besides these regular appointments and elections, Dr. Cárdenas has filled from time to time temporary posts on the bench, thus extending the period of his service as a magistrate. After completing his term of office as Mayor in I9I 3 he was appointed Attorney General of the Republic which office he held until he retired with a pension in 1918 . He then resumed the practice of law. 


\section{LANDA Y GONZALES}

MARIA DE LOS ANGELES LANDA Y GONZALES

Scholar; teacher.

Señorita Maria de Los Angeles LANDA Y Gonzales was born in Colón, Province of Matanzas, on the second of August, I865, where she received her early education. Later she attended the University of Havana where she won the title of Mistress, I 898, and Doctor of Pedagogy (1906). She was appointed Superintendent and Mistress of Public School, No. 8 , in the City of Havana in 1899 , and in rgrg she became Superintendent of the first home school founded in the Republic of Cuba. This position she secured from the Department of Public Instruction and Fine Arts on the grounds of the preparation by her of the project for the Home School, which met the approval of this department. She has been instrumental in founding boards of examiners to act in filling the chairs of

A N D MO NOGRAPH S 


\begin{tabular}{|c|c|}
\hline 628 & C U B A N S O F T O - D A Y \\
\hline & $\begin{array}{l}\text { the Normal School. In School No. 8, at } \\
\text { Havana, she founded an Alumnæ Associa- } \\
\text { tion for the purpose of increasing the esprit } \\
\text { de corps among its graduates. Many of } \\
\text { the students instructed under her have } \\
\text { taken prominent places in the teaching } \\
\text { force of the republic. She was the founder } \\
\text { of the night school held in the building of } \\
\text { School No. 8, and because of her work, in- } \\
\text { dustry, and success she has been formally } \\
\text { recognized by the Board of Education in } \\
\text { Havana which conferred upon School No. } \\
8 \text { her name, and it is now called the Angela } \\
\text { Landa School. She has been able through } \\
\text { the Alumnæ Association founded by her } \\
\text { to increase the interest of the graduates } \\
\text { by holding regularly literary exercises, at } \\
\text { which addresses are given by experienced } \\
\text { persons. This association, called the "Sun- } \\
\text { shine Association," conferred upon her a } \\
\text { gold medal as a reward for her labors in } \\
\text { behalf of the good of humanity. The } \\
\text { thesis offered by her in obtaining the degree } \\
\text { of Doctor of Pedagogy has the following } \\
\text { title: "Como afecta el concepto de } \\
\text { evolución al estudio de la moralidad." }\end{array}$ \\
\hline I & H I P A N I C NOTES \\
\hline
\end{tabular}




\section{H E R R Y M A N}

\section{MANUEL HERRYMAN GIL}

Soldier; official.

Manuel Herryanan Gil was born in the city of Manzanillo, in the Province of Oriente, on the fifteenth of April, I879. In March, I 895 , although he was only fifteen years old, he took part in the revolution that had its center at his native place, and he first operated in the Eastern Province, under the direction of Generals Bartolomé Masó and Amador Guerra. Later he acted under the orders of Lieutenant General Antonio Maceo, during the invasion of this province and he became Aide-de-Camp of Maceo. He was a member of the Sixth Corps of the Army of Liberation, having gained distinctive honors, and was a member of the Staffs of Generals Vidal Ducasé and Pedro Diaz. At the end of the revolution he had obtained the rank of Major.

A N D MONOGRAPHS 


\section{$630 \mathrm{C}$ U B A N O F TO-DA}

He took part in all the actions of the War of Invasion, namely: Paralejo, Cacarajicara, Montezuelo, Ceja del Negro, Tumas de Estorino, La Madama, etc.

During the Presidency of Tomás Estrada Palma he occupied positions of trust in the Bureau of Internal Revenue, being attached in this capacity to the Department of Finance. After the termination of the war and since then he has applied himself to agriculture. When General Menocal became President of the Republic in I9I 2 he was appointed Provincial Inspector of Internal Revenue for the Province of Pinar del Rio, a post which he resigned in February, I9I 7 , in order to take possession of the office of Civil Governor, to which he was elected at the election held in November, I9I 6. 
MARIO G. LEBREDO Y ARANGO

$$
\text { Physician; teacher. }
$$

Mario G. Lebredo y Arango was born in Havana on the twenty-seventh of April, I866. He was educated in Havana and also studied in Paris at the Lycée Henri Quatre. He also practiced in Paris hospitals. From the University of Havana he has received the degree of Doctor of Medicine and Surgery and also Doctor in the Physico-Chemical Sciences. In 1902 he was appointed Resident Physician in Las Animas Hospital, Havana, which is devoted to the treatment of contagious diseases. Shortly afterwards he was appointed Vice-superintendent of the same hospital. Later on he became Director of the Laboratory of Scientific Investigation and finally chief of the section of Epidemiology and the laboratories of the Depart-

A N D M O N G R A P S 


\begin{tabular}{|c|c|}
\hline 632 & C U B A N S O F T O - D A Y \\
\hline & $\begin{array}{l}\text { ment of Hygiene. He was also substitute } \\
\text { member in the Commission for Infectious } \\
\text { Diseases. He is ex-director in the Biological } \\
\text { Section of the Felipe Poey Cuban Society of } \\
\text { Natural History. He was head of the cam- } \\
\text { paigns conducted in various regions of the } \\
\text { Island against the yellow fever epidemic. } \\
\text { He was given a special commission by the } \\
\text { Department of Hygiene for epidemiological } \\
\text { works for such diseases as yellow fever, } \\
\text { paludism, bubonic plague, poliomyelitis, } \\
\text { and typhoid fever. He organized the bac- } \\
\text { teriological service for the diagnostic study } \\
\text { of the human and murine plague during } \\
\text { the epidemic which took place in I } 9 \text { I. He } \\
\text { was delegated officially to go abroad at dif- } \\
\text { ferent times to study epidemic conditions: } \\
\text { to New Orleans for the bubonic plague; to } \\
\text { Merida for the yellow fever; to Vera Cruz } \\
\text { and Tampico on suspected cases of cholera } \\
\text { and yellow fever; to Puerto Rico for yel- } \\
\text { low fever. He was a delegate from Cuba } \\
\text { to the Paris Tuberculosis Congress in I } 905 \text {; } \\
\text { to the American Public Health Association } \\
\text { in Colorado in I } 9 \text { I } 2 \text { to the Tuberculosis } \\
\text { Congress held in Washington in I } 908 \text {; to }\end{array}$ \\
\hline I & H I S P A I C N O T E S \\
\hline
\end{tabular}




\section{E B R E D O}

the International Congress of Hygiene and Demography held at Washington in 1912; to the second Pan-American Scientific Congress held in Washington in 1915.

$\mathrm{He}$ was in charge of the reports on Sanitary Subjects in the second and third National Congresses of Cuba. He was a member of the Yellow Fever Commission at Guayaquil, Ecuador, July to September, I9I8, appointed by the Rocketeller Institute. $\mathrm{He}$ is the author of reports and pamphlets on medical subjects from the point of view of original investigation in the field of epidemiology, embracing such questions as filaria, malaria, poliomyelitis, inquilostomiasis; in collaboration with Dr. Arthur Coca, New York, he has made a study of cancer. $\mathrm{He}$ is the author of monographs on the anatomy of the mosquito, and on the transmission of the nocturnal filaria by the mosquito. $\mathrm{He}$ is the author of a memoir rewarded with the "Nicolás Gutiérrez" prize of the Academy of Medical and Physico-Natural Sciences of Havana on Intestinal Parasitism in Cuba principally inquilostomiasis.

\section{A N D M O N O R A P H S}





\section{L Ó P E Z D E L V A L L E}

JOSÉ ANTONIO LÓPEZ DEL VALLE

- Doctor; health officer.

José Antonio López del Valle was born in Havana on the sixth of November, I 875 , and was educated by his mother. At the age of twelve he was pupil-teacher in a private school; at the age of fourteen he was assistant-professor in a public school of the Monserrate ward, and at fifteen he was student-interne in the Hospital Aldecoa. Aided by the maternal counsels, López del Valle continued his arduous course; he obtained the degree of Licentiate in 1897 and that of Doctor of Medicine and Surgery in 1903 .

After seven years at the Hospital of Aldecoa in which he held the most important posts, he accepted the position of Physician of the Emergency Station and Home Relief Staff (Casa de Socorro y 


\begin{tabular}{|c|c|}
\hline 636 & C U B A N O F TO-DA Y \\
\hline & $\begin{array}{l}\text { Asistencia Domiciliaria). But in } 1898 \text { at } \\
\text { the end of the War of Independence he } \\
\text { found an opportunity under the American } \\
\text { Intervention of entering the field of Public } \\
\text { Health and Sanitation to which he has } \\
\text { devoted himself without respite ever since } \\
\text { and in which he has held successively many } \\
\text { offices: Local Inspector; District Inspector; } \\
\text { Disinfection Officer; Inspector-General of } \\
\text { the Department; Secretary of the Local } \\
\text { Board of Health of Havana; Executive } \\
\text { Head of the Department of Health, etc. } \\
\text { As health officer Dr. López del Valle has } \\
\text { contributed to the public health by many } \\
\text { practical suggestions and regulations look- } \\
\text { ing to the reduction of means of contagion } \\
\text { and infection. In association with Drs. } \\
\text { Furbusch and Jacobsen he had an active } \\
\text { part in founding the first dispensary for } \\
\text { ailments of the lungs. And he was instru- } \\
\text { mental in having Arbor Day adopted as a } \\
\text { holiday. } \\
\text { Among his publications are: El Departa- } \\
\text { mento de Sanidad de la Habana, su organ- } \\
\text { izacion, procedimientos y marcha (I9o5), La } \\
\text { nacionalizacion de las servicios de Sanidad }\end{array}$ \\
\hline I & H I P A N I C NOTES \\
\hline
\end{tabular}




\section{LÓ P E Z D E L V A L L E}

(1908); Lecciones populares sobre tuberculosis (r9ro); Desenvolvimiento de la Sanidad y la Beneficencia en Cuba (I914); Plan de campaña contra la peste bubonica (I9I5); La Fiebre A marilla, Casos atípicos; Instrucciones Populares contra la Grippe; El Paludismo-Notas para la propaganda sanitaria; Fiebre Tifoidea-Profilaxis $y$ marcha de esta infección; Los establicimientos públicos desde el punto de vista sanitario; Campaña contra las moscas; Las casas de vecindad-estudio de esas viviendas y mejoras de carácter higiénico que deben introducirse en las mismas; Las Escuelas públicas de la Habana; Abastecimiento de agua. 



\section{N U N E Z}

\section{EMILIO NUÑEZ}

Soldier; administrator; Vice-president of the Republic since IOI7.

EMILIo NuÑEZ y RodRÍGUEZ was born on the plantation called "San Francisco" near Sagua la Grande on the twenty-seventh of December, 1855 . His youth was spent in the midst of revolutionary agitation and he became a revolutionist by force both of heredity and of environment. He had hardly obtained his Bachelor's degree at the Institute of Havana when the Revolution of ' $68-$ ' 78 broke out-the first act of the great struggle-and he joined the fighters. Figuring in the "Guerra Chiquita," he is said to have been the last Cuban leader to come to terms with the Spanish. From that time until the final success in 1898 , he never ceased his revolutionary activities, either fighting in the

\section{H I S P A N I C N O T E S}




\begin{tabular}{|c|c|}
\hline 640 & C U B A N S O F T O - D A Y \\
\hline & $\begin{array}{l}\text { field or directing agitation in Cuba or } \\
\text { the United States. He gained the rank of } \\
\text { Colonel as an aide to General Martí in } \\
\text { charge of the Department of Expeditions } \\
\text { obtaining and transporting to the revolu- } \\
\text { tionists in the field, supplies, arms, and } \\
\text { munitions and by his vigorous prosecution } \\
\text { of these important duties gained in I } 895 \\
\text { the rank of General at the head of the } \\
\text { Department of Expeditions. } \\
\text { Meantime General Nuñez had obtained } \\
\text { his degree in dental medicine and was } \\
\text { practicing his profession in Philadelphia. } \\
\text { Sometime before the close of the Revolu- } \\
\text { tion he returned to Cuba and became the } \\
\text { Representative in the Assembly of Santa } \\
\text { Cruz del Sur of the Fourth Corps of the } \\
\text { Army of Liberation. Upon the dissolu- } \\
\text { tion of the Assembly of Representatives of } \\
\text { the Army, in I899, he was appointed by } \\
\text { General Brooke, Military Governor under } \\
\text { the American Intervention, to go to Phila- } \\
\text { delphia to represent Cuba in the Com- } \\
\text { mercial Congress. In the same year he } \\
\text { was elected a member of the Constituent } \\
\text { Convention for the Province of Havana }\end{array}$ \\
\hline I & H I S P N I C NOTES \\
\hline
\end{tabular}


and took an active part in its deliberations. In 1900 he was appointed Governor of the Province of Havana under the American Intervention - to which office at the close of the Intervention he was elected without opposition by the popular vote.

One of the most notable achievements of General Nuñez in public affairs was his part in the organization of the Veterans of the Revolution into an influential political body, by which his services were recognized in his election as President of the National Council of Veterans - an office to which he has been twice reëlected.

Upon General Menocal's accession to the Presidency in I9I3, General Nuñez was appointed Secretary of Agriculture, Commerce, and Labor; in the general elections of 1916 he was elected Vice-president of the Republic, which post he now holds (I9I9).

\section{A N D M O N O G R P H S}





\section{BENIGNO SOUZA}

Physician; surgeon.

Benigno SouzA Y Rodríguez was born in the village of Macurijes, Province of Matanzas, on the twenty-first of May, I 873 .

His early education, up to the completion of the course for the Bachelor's degree, was obtained in Havana at the Colegic "El Progreso" then under the direction of the distinguished scholar Dr. Carlos de la Torre, whence he went to the University and gained the degree of Doctor in Medicine in the year 1900 , at the age of twentyseven.

While a student at the University he had won in open competition the post of assistant in Dissection. For six years after graduation, Dr. Souza held the position of Interne Physician in Hospital Number One in Havana; then he became Head Physi-

H I S P A N I N O T E S 


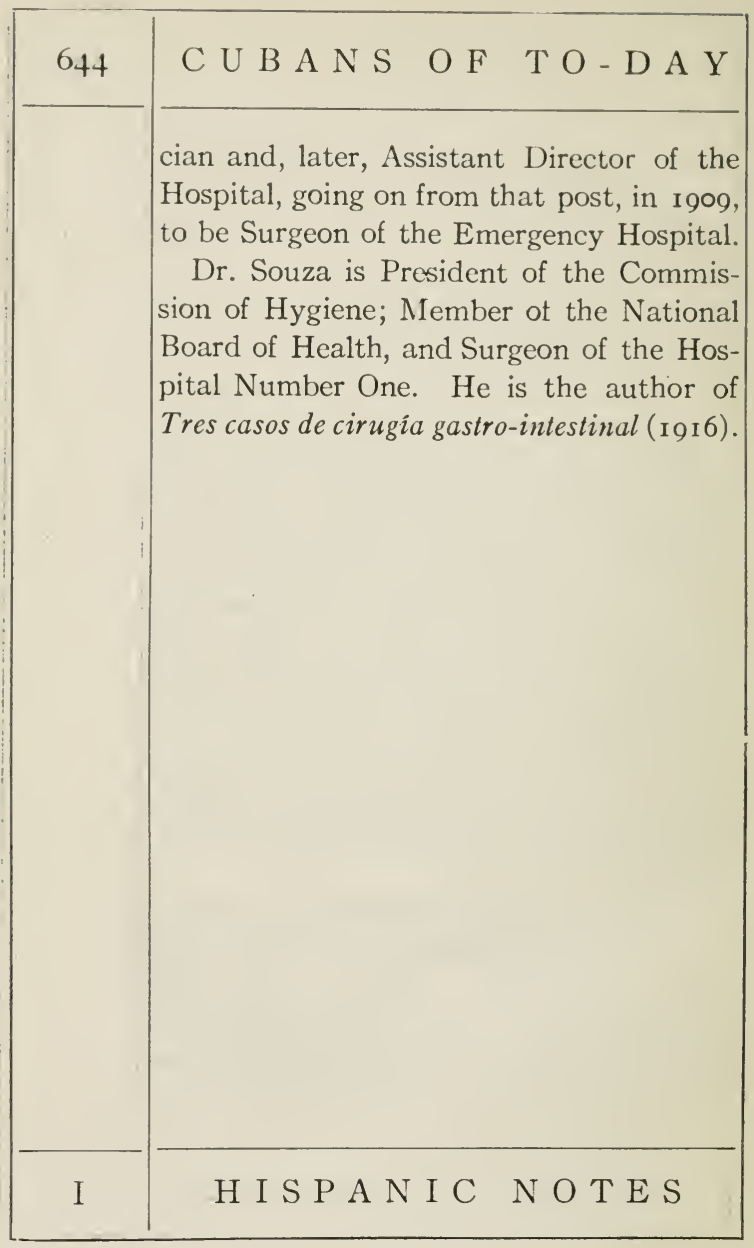




\section{E R O J A S}

CARLOS M. DE ROJAS

Soldier; official; man of affairs.

Carlos de Rojas was born on the fourteenth of March, I862, in Cárdenas. Here he gained his early education, going on to the Colegio of Esculapius in Guanabacoa where he completed the course required for the Bachelor's degree and proceeded to the University. After two years' study of law, de Rojas left the University to visit the United States and spent a year at Harvard University where he had the privilege of studying under the poet Longfellow.

On leaving the United States de Rojas went to Santo Domingo where he devoted himself to business, but in $\mathrm{I}_{8} 8_{3}$ he returned to Cuba and settled in Cárdenas to develop certain special business interests. In 1884 . he was made Vice Consul for the Dominican

\section{A N D M O N O G R A P H S}




\begin{tabular}{|c|c|}
\hline 646 & C U B A N O F T O-D A Y \\
\hline & $\begin{array}{l}\text { Republic in Cárdenas and, in I } 89 \text { I, Vice } \\
\text { Consul for the Republic of Argentina. The } \\
\text { latter position he retained until I } 896 \text {. He } \\
\text { then joined the revolutionary forces under } \\
\text { General Lacret and fought through the } \\
\text { war, gaining promotion step by step by } \\
\text { valor in combat until at the close of hos- } \\
\text { tilities he had been made General of a } \\
\text { Division and in I } 897 \text { had won the rank of } \\
\text { Brigadier General. } \\
\text { During the first American Intervention } \\
\text { de Rojas was appointed Alcalde of Cár- } \\
\text { denas and continued in the same office by } \\
\text { elcction of his fellow citizens. During his } \\
\text { incumbency of the office the Library and } \\
\text { Museum of Cárdenas was founded. } \\
\text { In Ioo3 he was appointed Colonel of the } \\
\text { Rural Guard; in I } 905 \text {, Chief of Corps of } \\
\text { Artillery; in I } 908 \text {, on the reorganization of } \\
\text { the Army, he was given command of the } \\
\text { Second Regiment of Infantry, and in I9Io } \\
\text { he was made Inspector of the Armed Forces } \\
\text { of the Republic with the rank of Brigadier } \\
\text { General. In I9I3 he was appointed Min- } \\
\text { ister to Peru, but he did not take possession } \\
\text { of the post. }\end{array}$ \\
\hline I & H I P A N I C N OTE S \\
\hline
\end{tabular}




\section{T H E Y E}

CARLOS THEYE Y SHOSTE

Scientist; teacher.

Carlos Theye y Shoste was born at Havana on the twenty-third of October, I853. He was educated at Paris, where he obtained the degree of Bachelor of Sciences at the Sorbonne, in 1871 . He also completed courses at the École Centrale in Paris, obtaining the degree of Engineer in Chemistry, and he received at Barcelona, in Spain, the degree of Industrial Engineer. He was instructor in Chemistry at the École Centrale of Paris, and in $\mathrm{I}_{8} 8_{2}$ became Professor of Physics and Chemistry at the Havana School of Agriculture. In I $8 S_{5}$ he was named Professor of Chemistry at the University of Havana, a position which he holds at the present day. In r 904 he was a member of the Commission appointed by the Cuban Government in

A N D MONOGRAPH S 


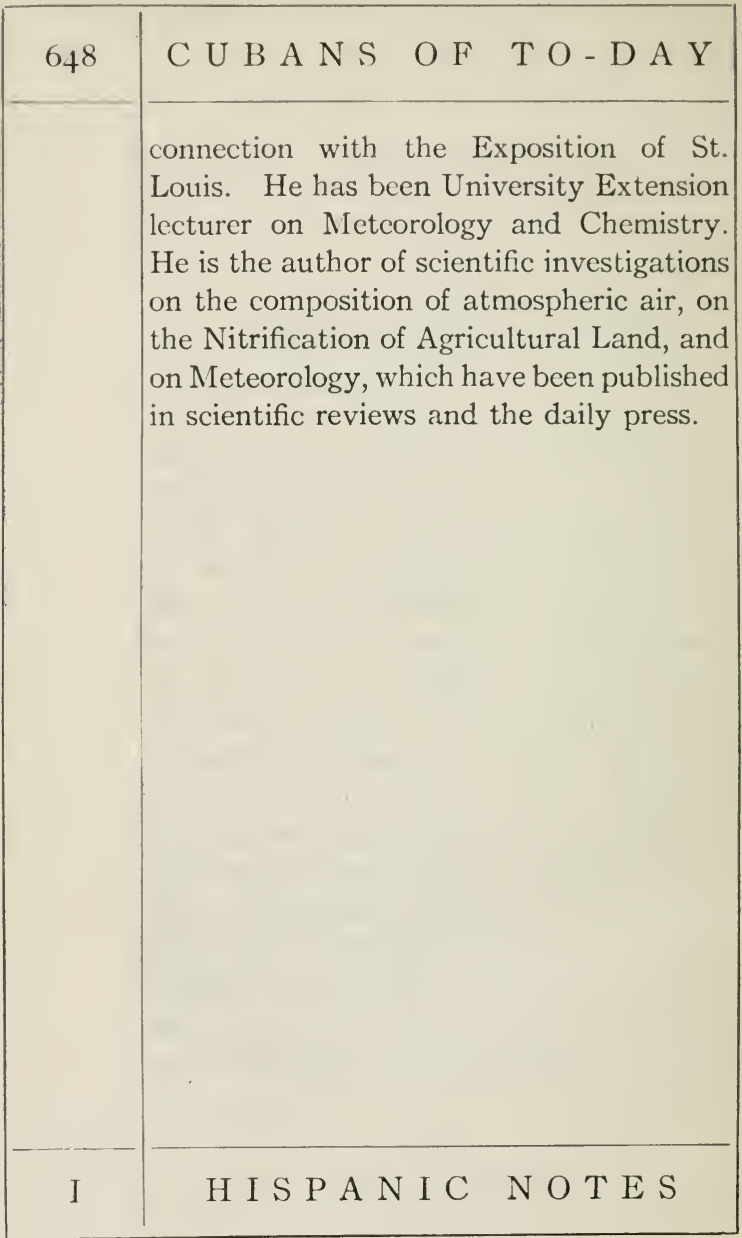





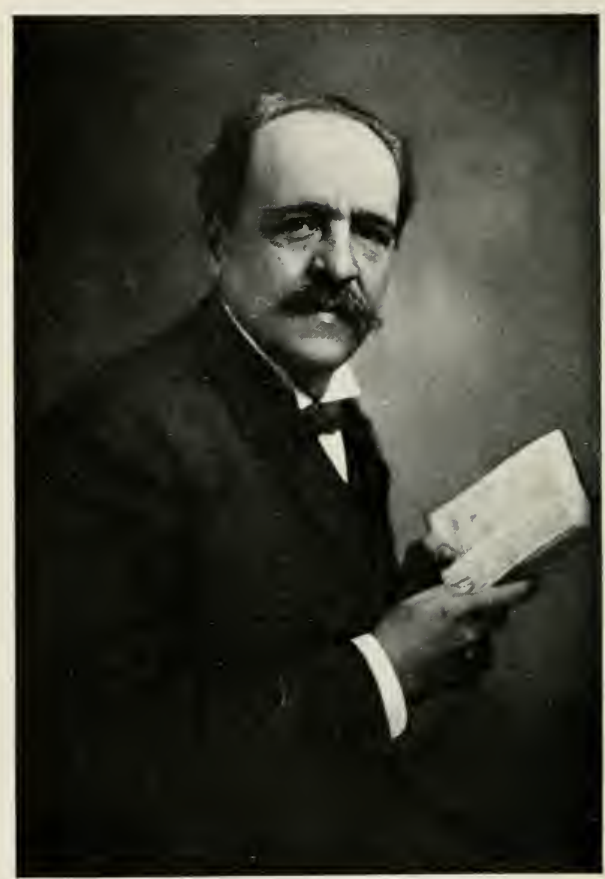

Published by permission of The Campbell Studio ( $\mathrm{N}$. Y.)

farlos de la Tane y thesta. 


\section{E L A T O R R E}

\section{CARLOS DE LA TORRE}

Naturclist; teacher; author.

CARlos de LA TORRE was born in Matanzas, on the fifteenth of May, I858, and after early education at "Las Normales" and the Colegio "La Empresa" of Matanzas, completed the requirements for the Bachelor's degree at the Institute of Havana in 1876 , then entered the National University where his brilliant scholarship won him many prizes and where, in $188 \mathrm{I}$, he received the Licentiate in Medicine, in Pharmacy, and in Natural Sciences. The degree of Doctor of Natural Science he obtained at the Central University of Madrid two years later, with a thesis upon Distribución geográfica de la fauna malacológica terrestre de Cuba.

His vocation for Natural History was furthered by the learned Francisco Ximeno,

A N D MO NOG R A P S 


\begin{tabular}{|c|c|}
\hline 650 & C U B A N S OF TO - D $A Y$ \\
\hline & $\begin{array}{l}\text { of Matanzas, who opened to young de la } \\
\text { Torre his museum and fine library, and by } \\
\text { his teachers Ramón Forns, Rafael Arango, } \\
\text { and Juan Gundlach. He also acknowledges } \\
\text { a great debt to Felipe Poey in whose in- } \\
\text { spiring society he worked and whom he } \\
\text { succeeded in the chair of Zoögraphy in the } \\
\text { University of Havana. Before the end of } \\
\text { his twentieth year he had discovered two } \\
\text { new species of mollusk which were named } \\
\text { in his honor Cylindrella Torrei, Arango, } \\
\text { I } 876 \text {, and Cyclostoma Torreianum, Gund- } \\
\text { lach, I } 878 \text {. } \\
\text { Simultaneously with his enthusiasm for } \\
\text { natural science grew his interest in teach- } \\
\text { ing. He taught in "Los Normales" and } \\
\text { "San Carlos" (Matanzas) and "La Gran } \\
\text { Antilla" and "El Progreso" (Havana) } \\
\text { and was one of the founders of the School of } \\
\text { Arts and Crafts in Havana. As the result of } \\
\text { competitive tests he was appointed in I } 880 \\
\text { Assistant in Natural and Physico-Chemi- } \\
\text { cal Sciences at the Institute of Havana, } \\
\text { and, in I } 883 \text {, Professor of Natural History } \\
\text { and Physiology in the Institute of Porto } \\
\text { Rico, which latter position he filled one }\end{array}$ \\
\hline I & H I P A N I C NOTES \\
\hline
\end{tabular}




\section{E L A T O R R E}

year then returned to take the professorships of Comparative Anatomy and of Zoögraphy of Mollusks and Zoöphites in the University of Havana.

In I $\$ 86$ he joined the Anthropological Society of Cuba and in $I 889$ the Academy of Sciences, on the latter occasion delivering a learned discourse on Consideraciones anatómicas solve los huesos de la cabeza del manjuari. Before the same Academy in I 890 , he presented an Informe sotre la enfermedad de los cocoteros, and a year later a report, illustrated with many archæological objects there discovered, of his Excursion antropológica a las cavernas de Maisi (Oriente), from which he had just returned.

In $\mathrm{I}_{93}$ he was appointed "Judge of Awards" in the section of Mineralogy and Geology of the Chicago Columbian Exposition. In I 895 he opened the scholastic year at the University of Havana with an address on Clasificación de los animales obseriados por Colón y los primeros exploradores de Cuba.

Persecutions by the Spanish colonial government moved him to leave the coun-

A N D MONOGRA PHS 


\begin{tabular}{|c|c|}
\hline 652 & C U B A N S OF TO-DA Y \\
\hline · & $\begin{array}{l}\text { try at the outbreak of the War for Inde- } \\
\text { pendence. He went first to Mexico where } \\
\text { he served as Professor of Natural Science } \\
\text { in Chihuahua, then to Paris where, after } \\
\text { studying in the University and the College } \\
\text { of France, he was, in I } 897 \text {, admitted to } \\
\text { membership in the Société Zoologique of } \\
\text { France. } \\
\text { Upon returning to Cuba in I898, his } \\
\text { university post of which he had been de- } \\
\text { prived by order of General Weyler was, by } \\
\text { the Government of the American Inter- } \\
\text { vention, restored to him. He has contin- } \\
\text { ued active service in the University, being } \\
\text { now (I9I9) Professor of Biology, Zoölogy, } \\
\text { and Zoögraphy. } \\
\text { Upon his return to Cuba Dr. de la Torre } \\
\text { entered political life and was active in } \\
\text { founding and organizing the Nationalist } \\
\text { party, by which he was elected to the City } \\
\text { Cuuncil (I9oo-Igo2). General Wood ap- } \\
\text { pointed him to the Mayoralty which posi- } \\
\text { tion he was occupying upon the inaugura- } \\
\text { tion of the Republic in I9o2. He then was } \\
\text { elected Representative for the Province of } \\
\text { Havana for four years, and in I9o5 the }\end{array}$ \\
\hline I & H I S A N I C NOTES \\
\hline
\end{tabular}




\section{E L A T O R R E}

House chose him for presiding officer. In the same year he retired from public life to devote himself to scientific pursuits.

When the Government of the American Intervention designated Supt. Frye and Lieut. Hanna to organize the Cuban public school system (1 899), Dr. de la Torre was an able coöperator: he enlisted the aid of his distinguished countrymen, Aguayo, Borrero Echevarría, Vidal Morales, and others, and prepared the Manual para los examines de maestros which soon was followed by Libros de lectura y lenguaje, La Geografía de Cuba, La Historia de Cuba, La Instrucción Moral y Cívica.

In 1900 he was delegate for the Province of Havana at the Paris Exposition; in 1904, Commissioner of Public Instruction at the Exposition of St. Louis; in 1906, delegate to the Tenth International Geological Congress in session in Mexico; in 1910 , he represented the Government of Cuba at the Eighth International Zoölogical Congress at Gratz.

In 1909 he proved the existence of Jurassic strata in the western part of Cuba and

A N D MONOGRAPH S 


\begin{tabular}{|c|c|}
\hline $65+$ & ('U B A N S U F T $\mathrm{T}-1$ - A $\mathrm{Y}$ \\
\hline & $\begin{array}{l}\text { in IgIo found Pleistocene fossils in the } \\
\text { central region of the island, restoring a } \\
\text { Megalocnus rodens, discoveries which were } \\
\text { submitted to the judgment of the Eleventh } \\
\text { Geological Congress at Stockholm in I9 I I. } \\
\text { The Cuban Government has committed } \\
\text { to de la Torre the revision and publication } \\
\text { of Ictiologia cubana by the illustrious natu- } \\
\text { ralist Poey, a work in which Dr. Cañizares } \\
\text { is collaborating. } \\
\text { The Academy of Science of Havana in } \\
\text { I I I raised him to the category of member } \\
\text { "de mérito." He has been since I9o I } \\
\text { corresponding member of the Academy of } \\
\text { Science of Philadelphia and since I9I I } \\
\text { corresponding member of the Spanish } \\
\text { Academy of Science, and life member of the } \\
\text { Museum of Natural History of New York. } \\
\text { In I I } 2 \text { Harvard University conferred } \\
\text { upon him the honorary title Doctor of Sci- } \\
\text { ence, characterizing him as "statesman and } \\
\text { naturalist, first in the knowledge of mol- } \\
\text { lusks of the Gulf of Mexico, discoverer of } \\
\text { fossils which haverevolutionized the geolog- } \\
\text { ical history of Cuba." In recognition of } \\
\text { this honor to their co-worker the University }\end{array}$ \\
\hline [ & H I S P A I C N O T E S \\
\hline
\end{tabular}




\section{E L A T O R R E}

of Havana gave a great celebration in I9I3; the Academy of Science hung his portrait in the Salon de Sesiones; Matanzas, his native city, declared him a "favorite son" and had a gold medal made in his honor; the Institute of Matanzas gave a festival and hung his portrait in the Auditorium. In 19I8 Dr. de la Torre was elected corresponding member of The Hispanic Society of America. 



\section{S E G U R A}

\section{ANDRÉS SEGURA Y CABRERA}

Lawyer; public man; writer.

Andrés Segura y CABrera was born on the twenty-third of October, I864, in the city of Havana, of Cuban parentage. $\mathrm{He}$ pursued his secondary studies in Havana, taking the degree of Bachelor of Arts in I $88_{3}$, and then entered what was then the Royal University of Letters at Havana, where he pursued legal studies. In r 888 he was graduated as Licentiate in Civil and Canon Law, and immediately after graduation began to practice his profession. In 1897 he received the degree of Doctor of Jurisprudence and in 1898 the title of Notary Public. In the year 1900 , he was graduated as Public Expert Land Surveyor and Taxer of Lands in the professional school of the Island of Cuba, which later

H I S P A N I C N O T E S 


\begin{tabular}{|l|l|}
\hline 658 & $\begin{array}{l}\text { C U B A N S O F T O - D A Y } \\
\text { on was incorporated in the Engineering } \\
\text { Institute of the University. In I So5 he } \\
\text { graduated as Mercantile Professor in the } \\
\text { Havana School of Commerce, an institu- } \\
\text { tion affiliated with the Institute. After } \\
\text { being duly authorized by the Secretary of } \\
\text { Public Instruction and after having given } \\
\text { proof in the University of his training in } \\
\text { Paleography, he began the exercise also of } \\
\text { expert caligraph and paleograph and expert } \\
\text { chirograph. } \\
\text { During the course of his public career he } \\
\text { has filled the following positions: Assist- } \\
\text { ant Reporter and Administrative Judicial } \\
\text { Instructor in the Bureau of Public Works; } \\
\text { and acted in the same capacity in the } \\
\text { Bureau of Agriculture, Commerce, and } \\
\text { Labor; ex-municipal Judge of the Town of } \\
\text { Regla; ex-secretary in the office of the } \\
\text { Civil Section in the Havana Court and in } \\
\text { the local Tribunal of Administrative Cases } \\
\text { in the Island of Cuba; Clerk of the Depart- } \\
\text { ment of Records and Judicial Archives in } \\
\text { the Department of Finance; President of } \\
\text { the National Association of Land Surveyors } \\
\text { in the Republic of Cuba; of the Buenos } \\
\text { I H I S P A I C N O T E S }\end{array}$ \\
\hline Hen
\end{tabular}




\section{S E G U R A}

Aires Latin-American Scientific Congress; of the Perpignan Agricultural Scientific and Literary Society of the Pirenés-Orientales; of the New York Society of Medical Jurisprudence; of the Caracas Academy of National History; Corresponding Member of the Association of Medical experts attached to the Courts of the State of Yucatan; Corresponding Member of the Barcelona Economic Society, called Amigos del País; of the Economic Society of Havana, called Amigos del País; of the Economic Society of Porto Rico; of the Association of Sugar Manufacturers and Distillers in Cuba; of the Society of Electricians in Havana; founder and ex-director of the Colegio "El Salvador" in Havana; member of the National Touring Club of Spain; author of various works on legal matters and land taxation; as the author of these works the holder of a prize given by the Paris Exposition of 1900 ; founder and ex-director of La Revista Decenal de Jurisprudencia y Noticias; El Mundo Judicial; of the review Los Sports; editor of the Consultorio de la Discusion; ex-editor of the

\section{A N D MONOGRA PH S}




\begin{tabular}{|c|c|}
\hline 660 & C U B A N S O F T O-D A Y \\
\hline & 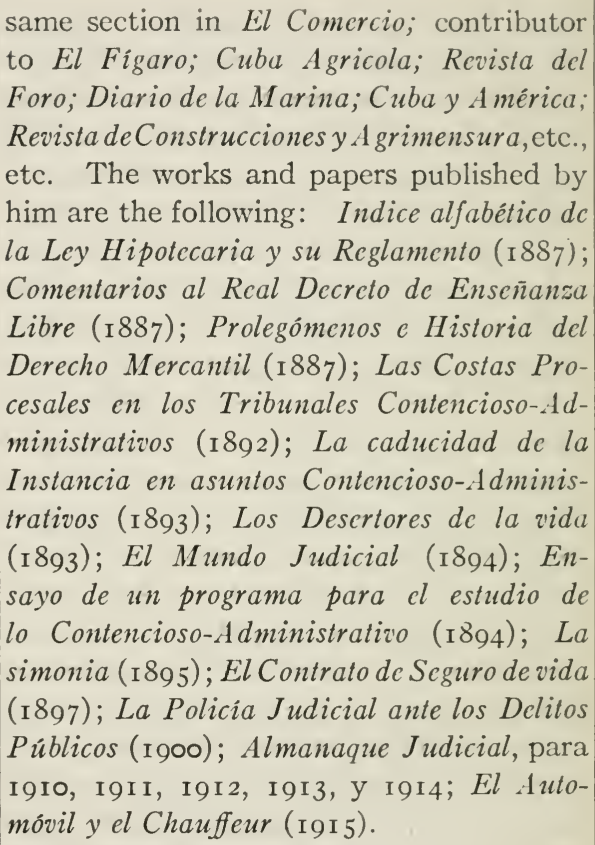 \\
\hline I & H I S P A I C N O T E S \\
\hline
\end{tabular}





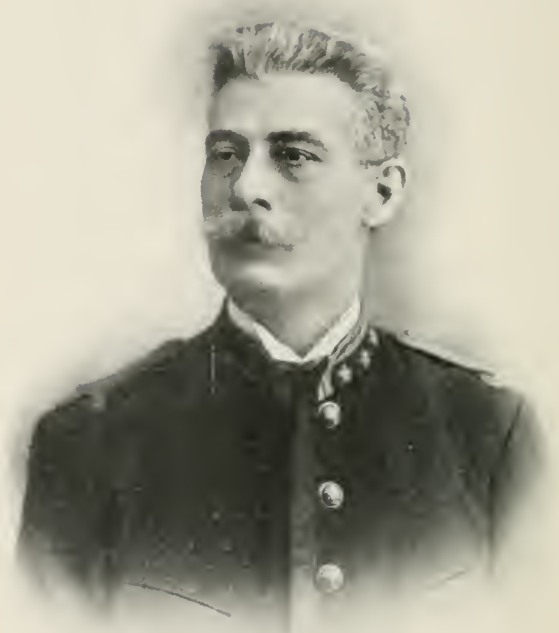

Gnl. Eusebio Hernandez 


\section{H E R N Á N D E Z}

\section{EUSEBIO HERNÁNDEZ}

Soldier; physician.

Eusebio Hernández was born in the year $I_{5} 8$, in the town of Colón, Province of Matanzas, and received his education in Madrid where he obtained the degree of Doctor of Medicine which was afterwards confirmed at Tegucigalpa, the capital of Honduras, and also at Havana. At a later date he pursued special studies in obstetrics in Paris.

In 1879 he interrupted his studies at Madrid to take part in the revolution known as the "Little War" (La Guerra Chiquita) which had its origin in an uprising organized abroad and brought to pass in Santiago on August 26th of that year. In this enterprise he held the rank of Captain and in the same year he was promoted, in consideration of his services to the

\section{A N D MONOGRAPH S}




\begin{tabular}{|c|c|}
\hline 662 & C UBANS OF TO-DAY \\
\hline & $\begin{array}{l}\text { revolution where he coöperated with José } \\
\text { Maceo, Emilio Nuñez, José Martí and other } \\
\text { leaders, to the rank of Major. } \\
\text { In I } 880 \text { he was obligcd by the persistent } \\
\text { persecution of the Spanish authorities to } \\
\text { leave Cuba, and he sailed to New York } \\
\text { where he joined the revolutionary leader } \\
\text { Calixto García. With a group of revolu- } \\
\text { tionists including Carlos Roloff and José } \\
\text { María Aguirre he went to Kingston, Ja- } \\
\text { maica, to organize an expedition directed to } \\
\text { Santa Clara. The "Little War" came, how- } \\
\text { ever, to an unsuccessful end and he turned } \\
\text { for a time to journalism, contributing to } \\
\text { the Deber of Kingston and La República and } \\
\text { El Yara of Key West, acting also as secre- } \\
\text { tary to Antonio Maceo. In the following } \\
\text { year Hernández went with a group of } \\
\text { revolutionaries to Honduras and there } \\
\text { continued his journalistic work in La. Paz, } \\
\text { El Yara, and El Renacimiento. } \\
\text { In I } 883 \text { he was appointed Professor in } \\
\text { the School of Medicine of Tegucigalpa and } \\
\text { there continued his labors as a revolution- } \\
\text { ist, serving as envoy of Generals Antonio } \\
\text { Maceo and Máximo Gómez to the govern- }\end{array}$ \\
\hline I & H I S P A I C N O TE S \\
\hline
\end{tabular}




\section{H E R N Á N D E Z}

ments of Honduras, Guatemala, and San Salvador. These labors finished he went to Europe to resume his medical studies, but continued his relations with the revolutionary group and took an active part in the Revolution of $1895^{-8}$.

Hernández maintained an equal loyalty to his profession and served in many capacities in his special field of obstetrics. He was interne in the clinic of Bandelacque in Paris; assistant to Professor Segond in the same clinic; Professor of Obstetrics in the Free School of Medicine of Havana; Professor of Obstetrics in the clinic of the University of Havana; chairman of the Board of Patrons of the Hospital of San Lazaro, etc., etc. $\mathrm{He}$ is also author of many articles in his special field of medicine.

On the political side, Hernández has played a prominent part, having been Chief of his political party and its candidate for high office. He was Vice-president from I 908 to I9I2; President of the Historical Assembly, and in I9I 2 was candidate for Vice-president but was defeated.

\section{A N D M O N O G R A P H S}



JOSÉ LÓPEZ RODRIGUEZ

$$
\begin{aligned}
& \text { Merchant; planter; } \\
& \text { financier. }
\end{aligned}
$$

José López Rodriguez was born in Spain but emigrated to seek his fortune in Cuba before he was twenty. He arrived in Havana without money or friends or education, penniless and illiterate. In spite of these hindrances, López Rodriguez has won great success and has become one of the most widely known and reputed to be one of the richest men in Cuba.

He began his business career as a dealer in books and though he has since extended his interests into many fields,-printing, manufacturing, contracting, farming, sugar planting, real estate, banking, etc.,-he has retained his early interest and still has one of the leading book-stores of Havana and in fact of Cuba.

\section{H I S P A N I NOTE S}




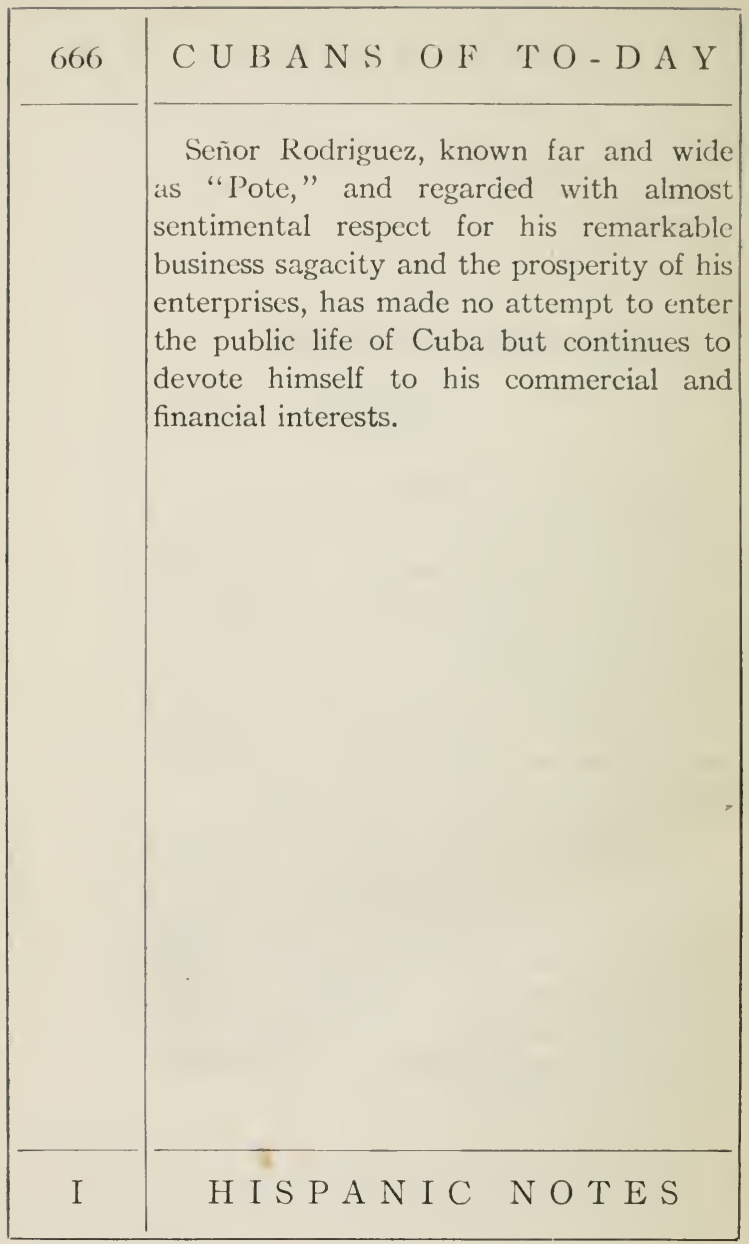





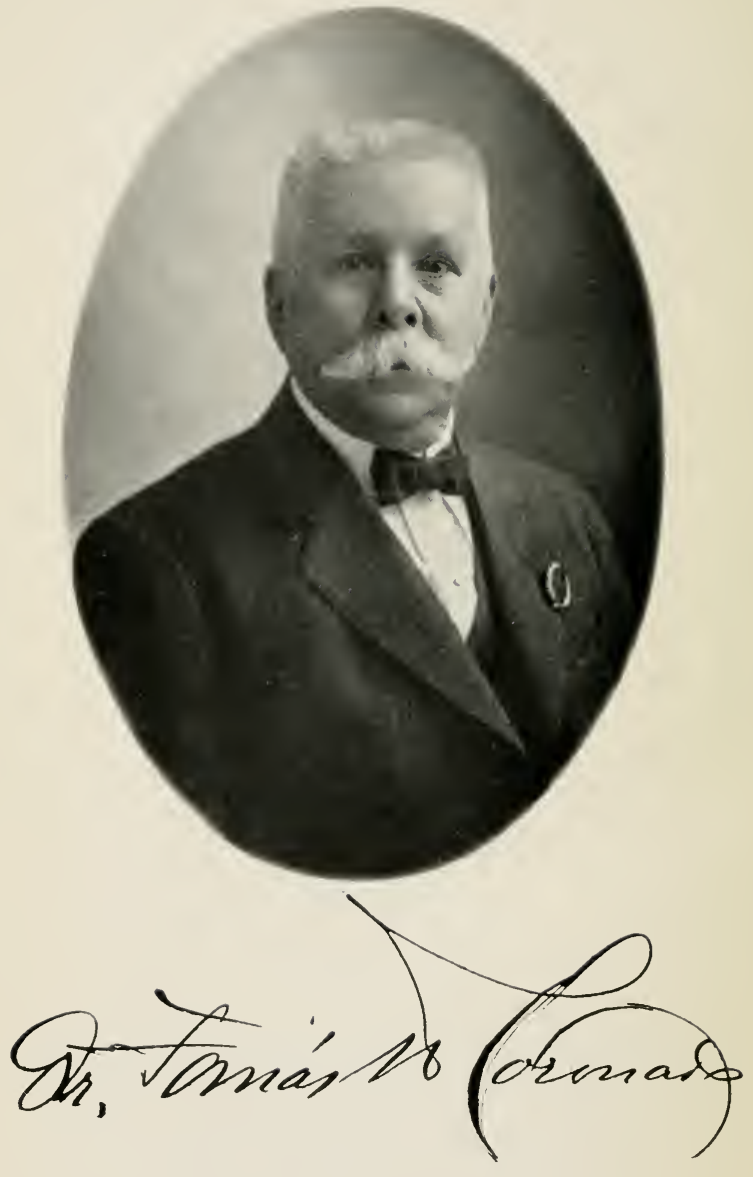




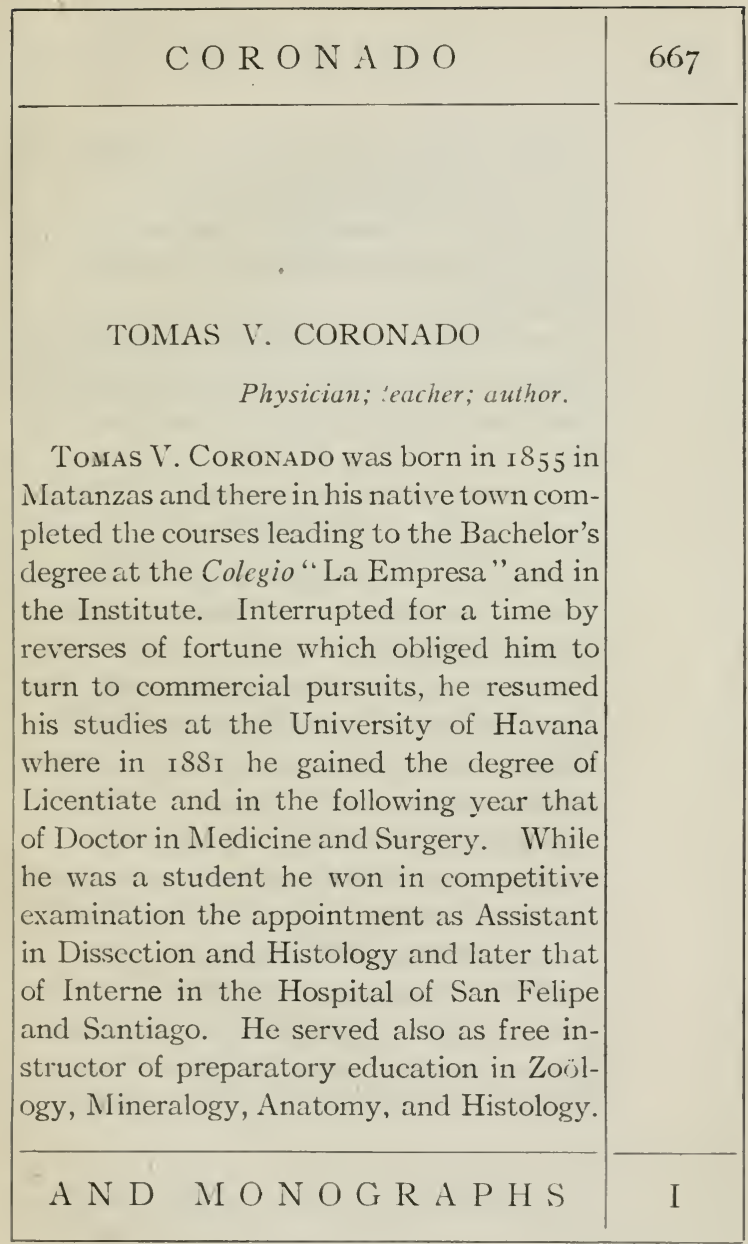




\begin{tabular}{|c|c|}
\hline 668 & C U B A N OF TO-DAY \\
\hline & $\begin{array}{l}\text { From } 1882 \text { to I } 893 \text { he was a member of } \\
\text { the Board of Health of Cabanas. } \\
\text { In I } 888 \text { he founded a free station for } \\
\text { vaccination in the district of San Diego in } \\
\text { Vuelta Abajo. } \\
\text { In I } 896 \text { he was Delegate representing } \\
\text { Cuba and Porto Rico to the Second Pan- } \\
\text { American Medical Congress, held in Mex- } \\
\text { ico. } \\
\text { In I } 899 \text { he aided in founding the Medico- } \\
\text { pharmaceutical Association of Cuba and } \\
\text { served as its Secretary; in the following } \\
\text { year he became its Vice-president and in } \\
\text { I } 90 \text { its President. } \\
\text { In i } 899 \text { he was appointed auxiliary pro- } \\
\text { fessor in the Faculty of Sciences in the Uni- } \\
\text { versity. In I } 900 \text { he received the degrees } \\
\text { of Licentiate and Doctor in Physico- } \\
\text { Chemical Science and Pharmacy and in the } \\
\text { same year won the position, by competi- } \\
\text { tive examination, of auxiliary Professor of } \\
\text { Hygiene and Legal Medicine. } \\
\text { Dr. Coronado has held many honorary } \\
\text { positions and is member of many societies. } \\
\text { He is a member of the National Board of } \\
\text { Health; he has served as Vice-president of }\end{array}$ \\
\hline I & H I P A N I C NOTES \\
\hline
\end{tabular}




\section{O R O N A D O}

the Academy of Sciences and as President of the Society for Clinical Studies.

In 1918, after being auxiliary Professor of Hygiene and Legal Medicine for seventeen years, he became titular Professor. $\mathrm{He}$ has devoted himself chiefly for a number of years to Hygiene and Medicine, and has in preparation a work on Hygicne and Sanitary Legislation in Cuba. His published works are very numerous and include: Prescntación á la Academia de preparaciones de filarias sanguinis hominis, I879; Pleuresía con derrame, mucrte, I88I; Hemato-quiluria de los países cálidos, I882; Tratamiento de las fiebres palúdicas sin quinina, I888; Botón de Biskra, I888; Envenenamiento autoctono $\mathrm{cn}$ cl paludismo, I888; Ayuda forceps, I888; Cuerpo extraño en la articulación peronco-tibial superior. I888; Impotencia temporal, I888; $\mathrm{El}$ microbio del paludismo, I889; Orquitis paludicas, I 889; Cuerpos de Laveran, su confirmación, I889; ¿ Pneumonía palúdica? I889; Contestación al Dr. Roig, I889; Crítica cicntifica, I889; Tétanos traumático, su tratamiento, I889; Erupcioncs medica-

\section{A N D MONUGR A P H S}




\begin{tabular}{|c|c|}
\hline 670 & C U B A N S O F T O - D A Y \\
\hline & 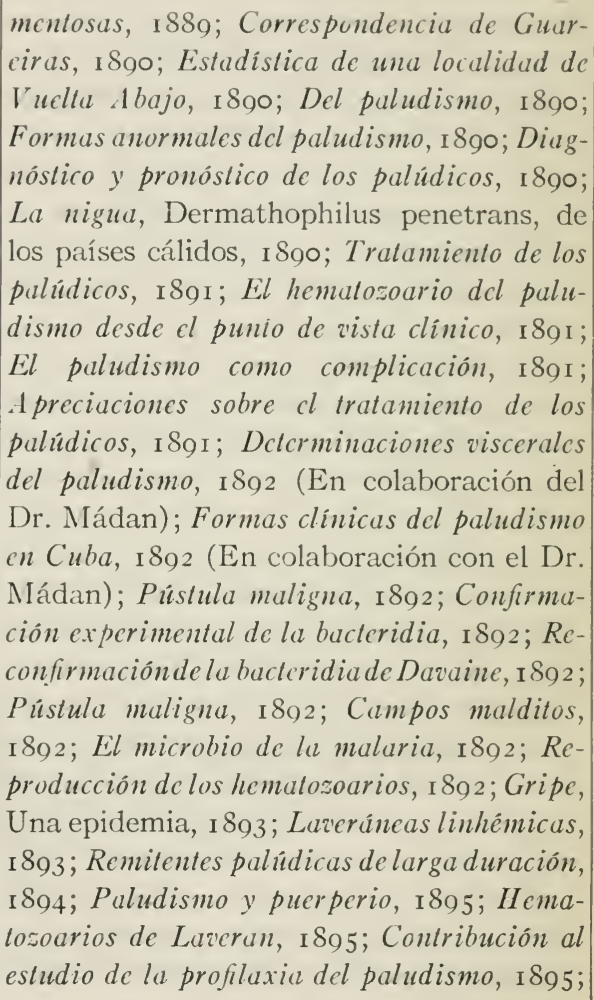 \\
\hline I & H I S P A I C NOTES \\
\hline
\end{tabular}


Observaciones clinicas de la difteria, I 896; Laveráneas en las aguas del Cerro, I896.

Fiebre amarilla, I896; Suero diagnóstico en la tifoidea, ז896; El microbio de la gripe, I896; Pústula maligna, I896; Las fiebres hipertérmicas, I896; Pirexias en la Isla de Cuba (Libro, en colaboración con el Dr. Mádan, premiado por la Academia de Ciencias, 1896); El dengue en la Habana, I897; El paludismo es contagioso, r897; Trasmisión del paludismo, I897; Fiebres altas de origen gripal, 1897; El paludismo es trasmisible, I897; La fiebre amarilla.en los cubanos, I897; Unidad del paludismo, r897; Disenterías gripales, I 898 ; A preciaciones sobre el tratamiento clinico del paludismo, I 898; Feto hemectro-melico con hidrocefalia $y$ enteroceles, I898; Gripe, I898; Nuero método para diagnosticar la gripe, 1898 ; Enterocolitis gripales, I899; El Dr. Mádan como clinico, I899; Pústula maligna, curación, I 899; Nuestras fiebres, г899; Reseña de los trabajos realizados en el último bienio, I 899; Medicación cacodílica, I900; Crítica del plan de enscñanza del Sr. Varona, I900; Protestas al nuevo plan de estudios universi-

\section{A N D M O NOGRA P H S}




\begin{tabular}{|c|c|}
\hline 672 & C U B A N S OF TO-DAY \\
\hline & 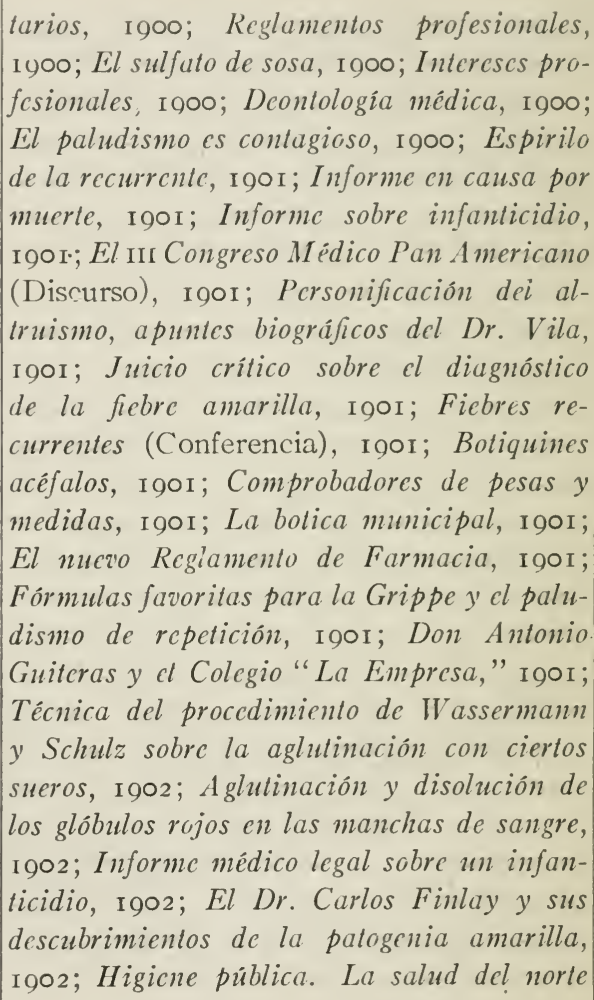 \\
\hline I & H I S P N I C NOTES \\
\hline
\end{tabular}




\section{O R O N A D O}

americano en Cuba, I902; Reconstrucción de las viviendas en los distritos rurales, 1902 ; ¿Placeres imbéciles? Higicne de los sports, I903; Informe Médico legal cn causa por estupro, r904; Etiología y Profilaxis del paludismo en Cuba, I905; Psicología de los Simuladores (Discurso), I905; Informe médico legal en causa por duelo, I905; Conferencia sobre el diagnóstico de la fiebre a marilla, I 905; El Tetuán en la Habana, 1906; Nuestros parques y paseos en el porvenir, 1906; Un modesto Colegio en el porvenir, г906; La nueva Cátedra de enfermedades mentales y nerviosas, I906; Un sanatorio ideal en las lomas del Cuzco, I006; Higiene escolar para los maestros.

\section{A N D MONOGRAPHS}





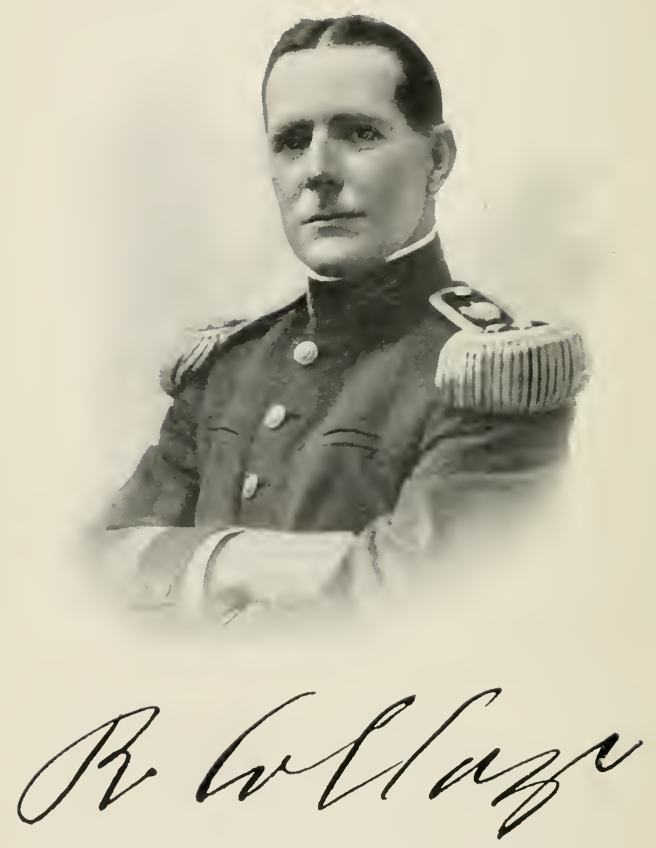


\section{R OSE N D O C O L L A Z O}

ROSENDO COLLAZO

Soldier.

Rosendo Collazo y García was born on the Hacienda "San José," in the district of Mangas, Province of Pinar del Rio on the first of March, 1875, and obtained his education in the provincial Institute of Pinar del Rio.

He joined the Revolutionary Army in 1895 and thus entered the military profession to which he has devoted his life. His first command was that of Captain in the forces of Brigadier General Torres and Colonel Nuñez who were coöperating with Generals Gómez and Maceo. He obtained promotion to the rank of Lieut. Colonel by conspicuous gallantry in the action of "Galope" on March I 7, I896, and in May I4, I898, won the rank of Colonel in the battle of "Flor de Mayo" at Güines.

\section{H I S P A N I C N O T E S}




\begin{tabular}{|c|c|}
\hline 676 & C U B A N O F TO-DAY \\
\hline & $\begin{array}{l}\text { He saw much active service and took } \\
\text { part in a great number of combats small } \\
\text { and great, among them "Guano Prieto," } \\
\text { "Caiman," "Mulatin," "Potrero de Men- } \\
\text { doza," "Batabanó," "Canja de Prieto," } \\
\text { "Ufón," "La Lima," "Adjovin" and } \\
\text { "Venecia." } \\
\text { When the war closed he was appointed } \\
\text { Inspector of Police for Havana (Fifth Zone) } \\
\text { and fulfilled the duties of this post until } \\
\text { I9o3 when he was made First Lieutenant } \\
\text { in the Rural Guard. In I9o5 when a } \\
\text { revolution was attempted in the district of } \\
\text { Alquizar he was called upon at the sugges- } \\
\text { tion of President Palma to assume com- } \\
\text { mand in the zone of disturbance, where he } \\
\text { speedily restored order, taking a great } \\
\text { number of the rebels prisoners and com- } \\
\text { pelling the surrender of their leaders. This } \\
\text { and his success in dealing with the threat- } \\
\text { ened revolution of August, I } 906 \text {, secured } \\
\text { him promotion to the rank of Captain. } \\
\text { In these and other actions it has been } \\
\text { chiefly as an organizer and as an expert in } \\
\text { the use of machine guns that Major Collazo } \\
\text { - rank granted him in I } 9 \text { I } 2 \text { - has gained his }\end{array}$ \\
\hline I & H I S P A I C NOTES \\
\hline
\end{tabular}




\section{R O S E N D O C O L L A Z O}

successes. To this weapon he has given special study and attention making it the subject of various articles for publication.

In the year I9I2 Major Collazo was placed in command of the operations of the so-called "War of the races," or negro uprising in the Cobro district where he took personal charge and had part in numerous skirmishes as well as engagements of a larger scope including those at "Santa Elena," “La Yaya," "Trinchera," "Gran Colima," "Loma de Gato," "Barraquerra," etc., etc.-operations which he brought to a successful termination.

$\mathrm{He}$ was appointed in this year Paymaster General of the Army.

In I9I 3 he was promoted to the rank of Lieutenant Colonel and in I9r 5 to that of Colonel. In I9I 7 when a revolution was threatened he was in command of the troops who captured the city of Sancti Spiritus and sometime later seized General Gómez and staff-thus putting an end to the rising.

He has always maintained an active interest in sports, particularly in polo in

\section{A N D M O NOGRAPHS}




\section{C UBA N S OF TO-D A Y}

which he has been Captain of the Artillery team and has won two years in succession the trophy offered by the President. $\mathrm{He}$ has also written occasional articles on military subjects, particularly in his special field of the Machine Gun and its uses. 


\section{I $\mathrm{N} \mathrm{D} \mathrm{E} \mathrm{X}$}

\section{INDEX}

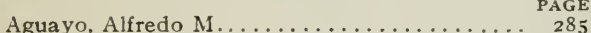

Alamilla Requeij, Emilio...................... 283

Alberdi, Nicolás..................... 599

Albertini y de Cárdenas, Oscar Díaz......... 325

Alcorta, Leandro González.............. 249

Alemán, Ricardo M.................. 429

André Alvarado, Armando................ 163

Angulo, Manuel Rafael................ 40 I

A ragón, Adolfo de................... I I I

Aragón y Muñoz, Ernesto A. de........... 353

Aramburo, Mariano.................. 607

Aramburu, Joaquín N................. 437

Arango, Francisco de .................. 95

Armas, Rodolfo Rodriguez de............. I 59

A rocha y Llaneras, Gustavo F.............. 231

Arteaga, Manuel................... 467

A sbert, Ernesto..................... 369

A verhoff y Pla, Octavio............... 331

Baralt, Blanche Zacharie de........... I69

Baralt, Luis A ................... I 89

Baralt, Jr., Luis A ................... 7 I

Barraqué y Adué, Jesís María.............. 535

Barreras Fernández, Alberto................. 149

Betancourt Manduley, Alcides............. 347

Betancourt Manduley, Arturo............ 87

Betancourt y Castillo, Temístocles.......... 445

Betancourt y Dovalos, Pedro E............. $29 \mathrm{I}$

Blanck. Hul ert de..................... II5

Bobadilla, Emilio de................... 449

Brouwer, Julio E.................... 427

Brull, Mariano.......................... 109

Bustamante, Antonio Sánchez de......... 127

Bustamante, Mario MI uñoz............ 157

Busto y Delgado, Nemesio.................. 453

Byrne, Bonifacio.................... 455

\section{A N D MONOGRAPH S}




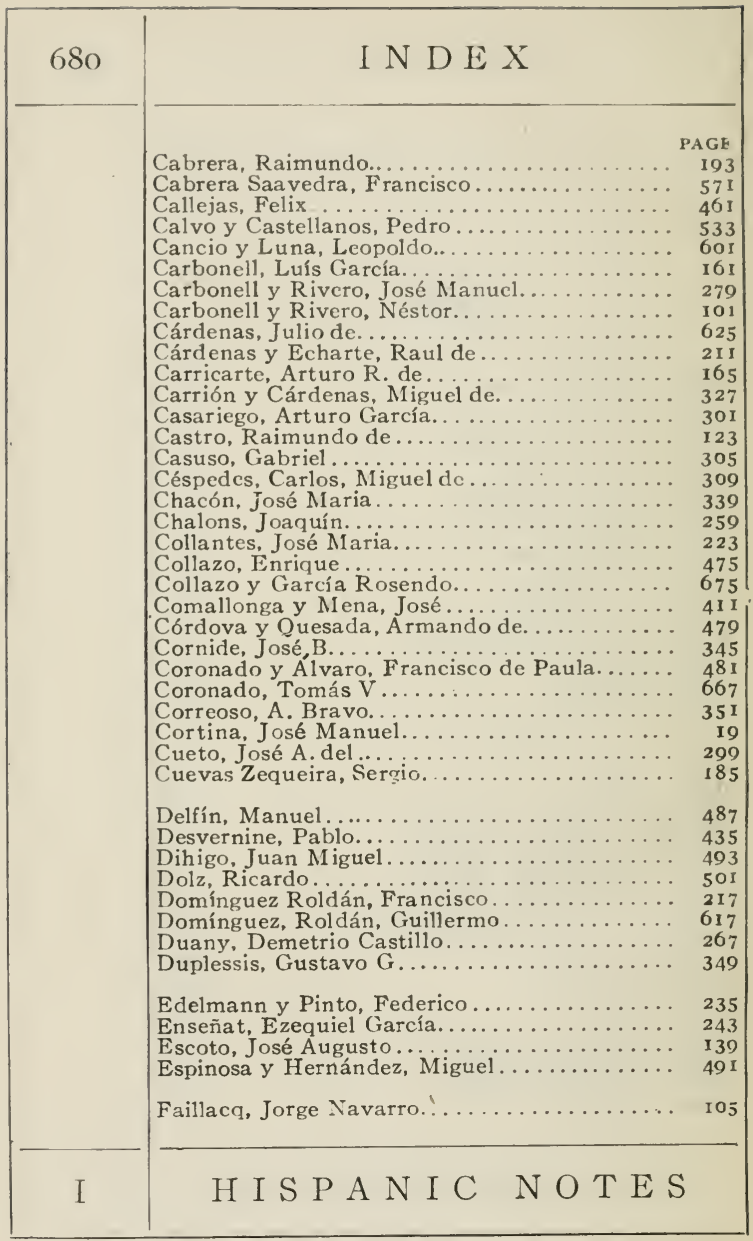


Fernández Mascaró, Guillermo........ PAGE

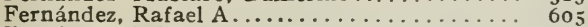

Fernández, Wifredo................... 323

Fernández de Castro, Rafael .................... 3 I 7

Figarola Caneda, Domingo.............. 91

Figueredo y Socarras, Fernando.............. 23

Figueroa y Martí, Leopoldo.............. 5 I

Finlay, Carlos E.................. 22 I

Frau Marsal, Lorenzo................. 523

Freyre de Andrade, Fernando............ I8 I

García Cañizares, Felipe............... $44_{5}$

García Cañizares, Santiago.............. 439

García Mon, Ramón.................... 565

Garmendia y Rodríguez, Miguel............. 233

Gómez, José Miguel ... . . . . . . . . . . . . . . I3 I

Gómez, Juan Gualberto... . . . . . . . . . . . 509

Gonsales, Aurelia Castillo de............. ${ }_{2} 63$

González Benard, Alfredo............... 13

González Sarrain, Felipe............... 107

Guardia, Cristóbal de la................ 355

Guerra, Pedro Mendoza................. 5 II

Guerra y Sánchez, Ramiro.............. 335

Guiral, Rodnlfo.................. 419

Guiteras, Juan. . . . . . . . . . . . . . . . 27 I

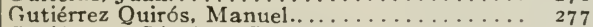

Gutiérrez y Sánchez, Gustavo............. 5 I 5

Henares y Briega, Francisco............ 303

Henriquez Ureña, Max.................... 97

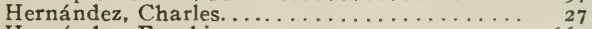

Hernández, Eusebio..................... 66

Hernández Cartaya, Enrique............. 469

Herrera, Julio Blanco ................. I 55

Herryman Gil, Manuel................ 629

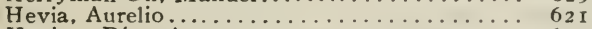

Hevia y Díaz, Arturo................. 6 I I

Huerta, Santiago de la.................. 623

Tglesia y Santos, Alvaro de la........... 59

Iraizoz y del Villar, Antonio............. 295

Jorrin, Leonardo Sorzano..... . . . . . . . . 73

Tústiz, Francisco Carrera.................... $38{ }_{3}$

Jústiz, Tomás Juan de ................ I $_{53}$

\section{A N D M O N G R A P H S}




\begin{tabular}{|c|c|c|}
\hline 682 & I N D E X & \\
\hline & 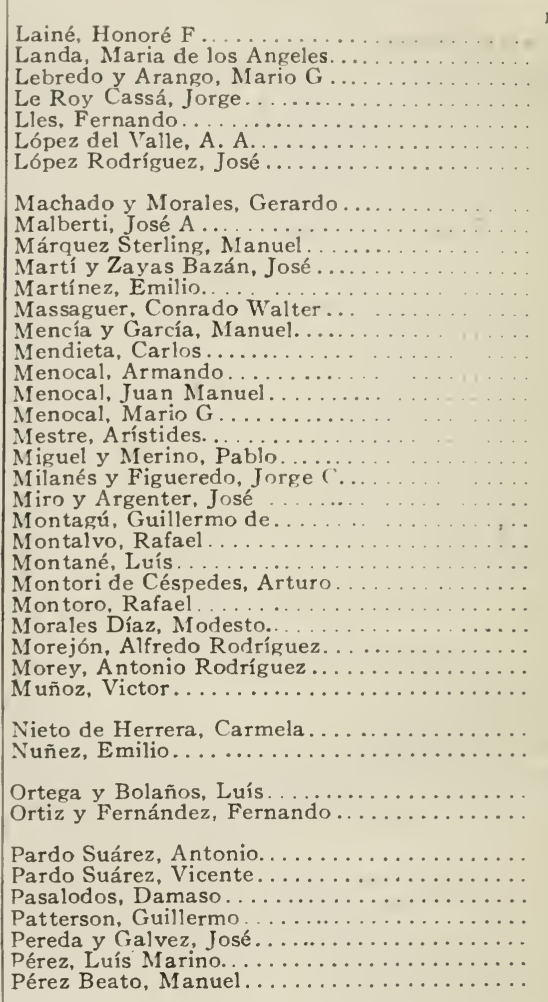 & $\begin{array}{r}P A G E \\
359 \\
627 \\
631 \\
119 \\
137 \\
635 \\
665 \\
\\
521 \\
67 \\
579 \\
213 \\
39 \\
403 \\
247 \\
529 \\
473 \\
417 \\
1 \\
537 \\
413 \\
63 \\
545 \\
287 \\
549 \\
251 \\
367 \\
77 \\
171 \\
333 \\
117 \\
237 \\
363 \\
639 \\
639 \\
297 \\
373 \\
583 \\
58 \\
15 \\
551 \\
343 \\
555 \\
227 \\
255\end{array}$ \\
\hline I & H I P A N I C NOTES & \\
\hline
\end{tabular}




\section{N D E X}

\section{3}

Pérez Miró, Abraham .................... 393

Pérez-Vento y Nin, Rafael............... I 47

Pichardo, José Antonio . . ............... 6. 6 I

Pino, Gustavo....................... 33

Plasencia, Leonel. ................... 49

Poncet y de Cárdenas, Carolina............ 559

Presno, José Antonio... . . . . . . . . . . . . . 389

Pujol, M. Alonso................. 357

Ramos y Delgado, Domingo F............. 239

Recio y Aguero, Enrique.................. 563

Remos, Juan J...................... 431

Rio, Francisco del .................... 423

Rivero, Nicolás.................... 75

Rivero y Gandara, Manuel ................ 547

Roberts, Hugo..................... 177

Rodríguez García, José A... . . . . . . . . . . 407

Rodríguez Lendián, Evelio.............. 43

Roig y Fortesaavedra, Enrique........... 573

Roig y Leuchsenring, Emilio............... 567

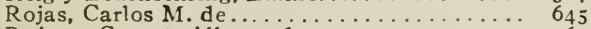

Rojas y Cruzat, Alberto de............... 569

Romanach, Leopoldo................. I 75

Ruiz Cadalso, Alejandro............... 425

Ruiz y Rodríguez, Manuel.............. 36

Saladrigas y Lunar, Enrique... . . . . . . . . . 307

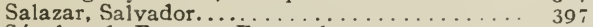

Sánchez de Fuentes, Fernando............. 505

Sánchez Galarraga, Gustavo............ 3 I I

Sanguily, Manuel.................. 313

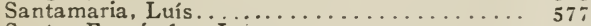

Santos Fernández, Juan.................... I 43

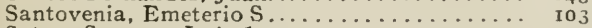

Sato y Sagarra, Luís de................. 575

Seguí, Domingo Hernando................. 329

Segura y Cabrera, Andrés.............. 65 .

Soler, Fernández José M .............. 365

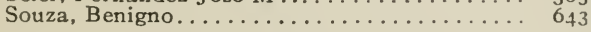

Tamayo y Figueredo, Diego............. 35

Tarafa. José. . . . . . . . . . . . . . . . . . 580

Ti6 Lola R. y Ponce de Leon de............. 209

Theye y Shoste, Carlos.................. 647

Torre, Carlos de la .................... 649

Torriente, Cosme de la.................. 79

\section{A N D MONOG R A H S}




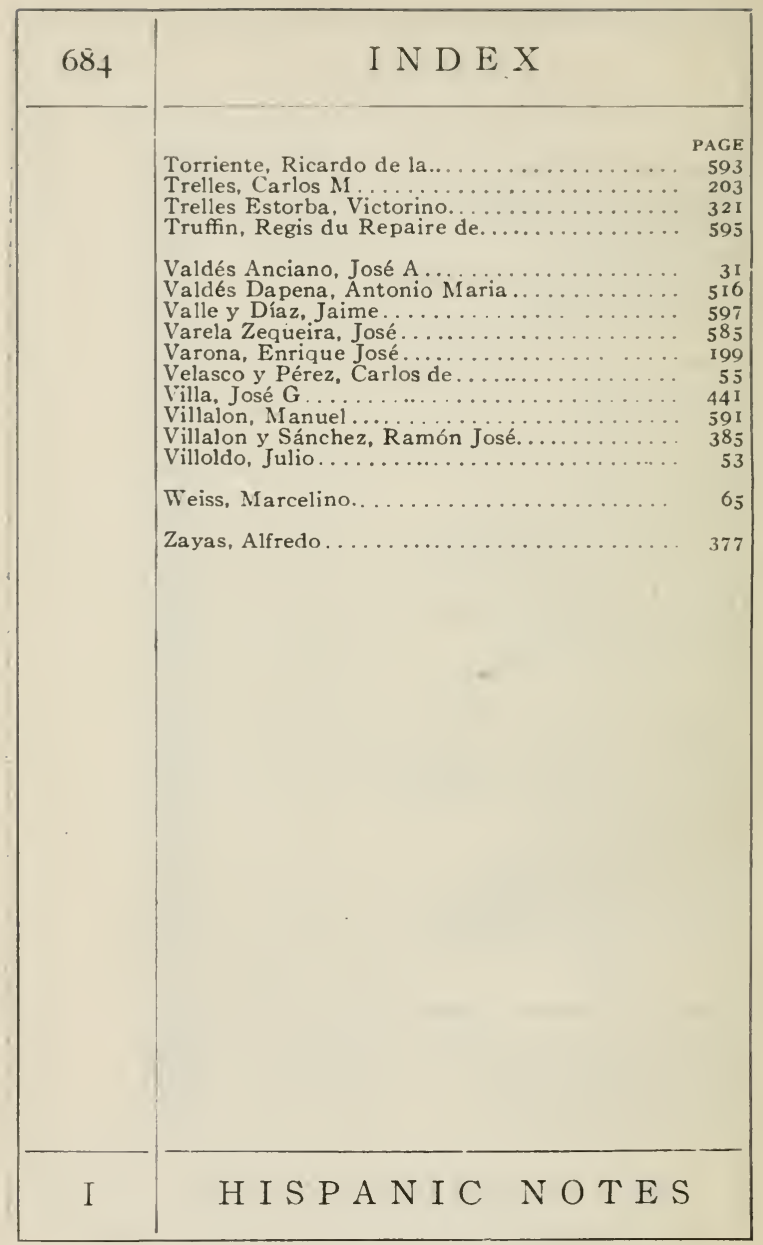








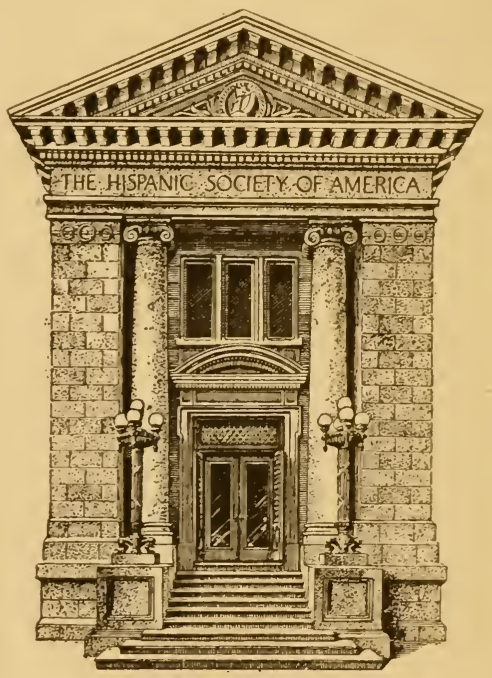

H I S P A I C SOCI E T Y 


\section{A M E R I C A S E R I E S}
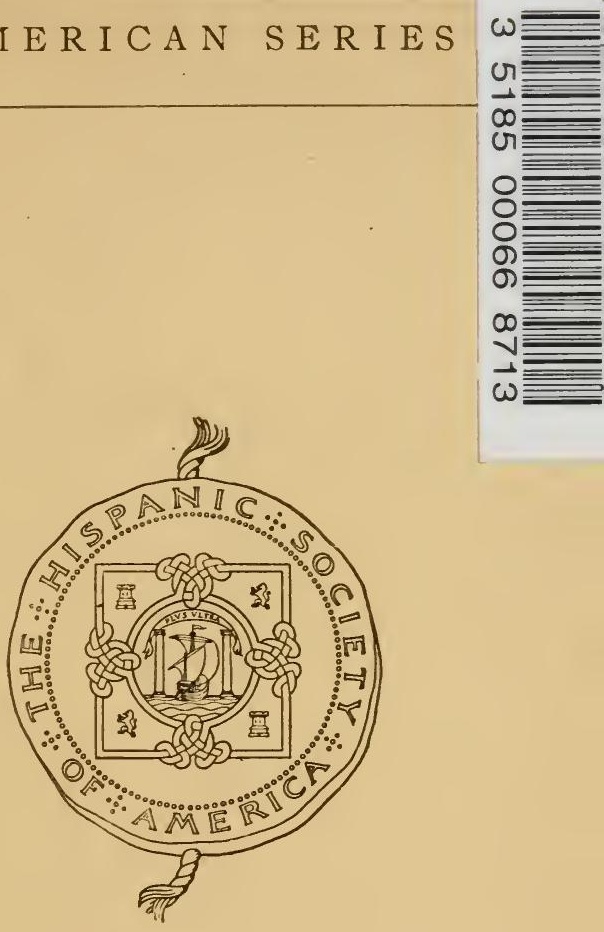


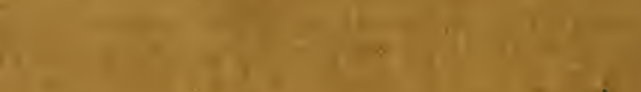

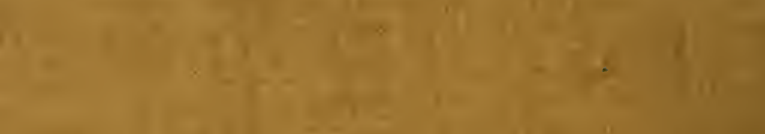

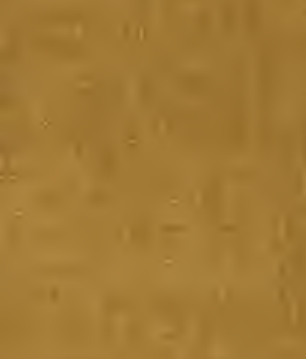

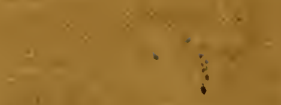

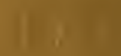
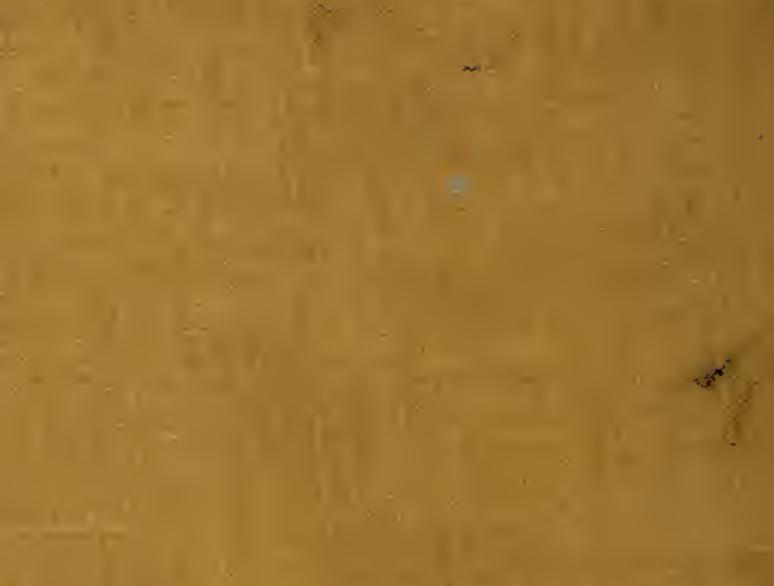

$\tan =-$

$\therefore$

1.

$+x-7$<smiles>C1CCCCC1</smiles>

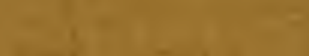

$=$

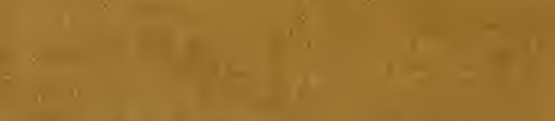

$$
\begin{aligned}
& \text { + } 1
\end{aligned}
$$

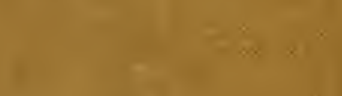

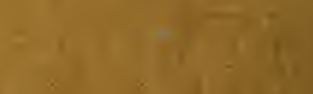

$$
\begin{aligned}
& -8 \times 3 x=
\end{aligned}
$$

